GEOLOGICAL SURVEY OF NEW JERSEY.

HENRY B. KÜMMEL, STATE GEOLOGIST.

REPORT ON PALEONTOLOGY.

VOLUME III.

\title{
The Paleozolc Faunaj.
}

BY

¿TIJART WELLER, PA.D.

TRENTO:, N. J.:

The John L. Murphy pubhishing Co, Printexs.

1903. 


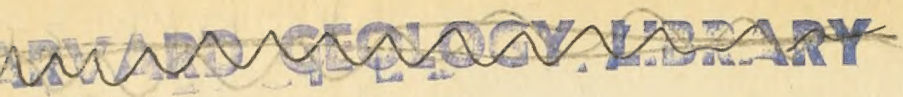

\section{HARVARD UNIVERSITY.}

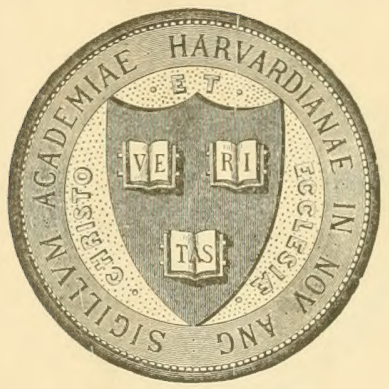

LIBRARY

OF THE

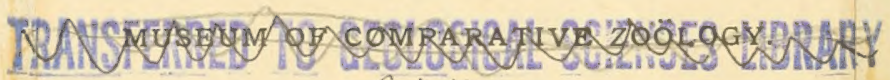
21,140

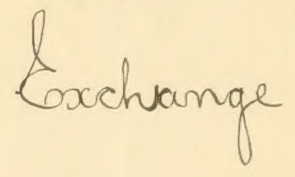

Gune 11.1903 

GEOLOGICAL SURVEY OF NEW JERSEY.

HENRY B. KÜMMEL, STATE GEOLOGIST.

\section{REPORT ON PALEONTOLOGY.}

VOLUME III.

\section{The Paleozoic Faunas.}

BY

STUART WELLER, PH.D.

TRENTON, N. J.:

The John L. Murphy Publishing Co., Printers.

$1 \overline{903 .}$ 


$$
\begin{aligned}
& \text { Mrafigle }
\end{aligned}
$$

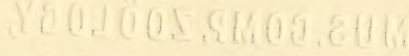

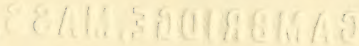




\section{Contents.}

BoARD OF MANAgERS...............

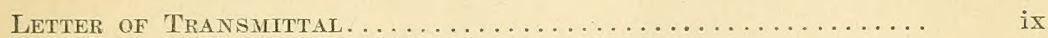

Preface $\ldots \ldots \ldots \ldots \ldots \ldots \ldots \ldots \ldots \ldots \ldots \ldots \ldots \ldots \ldots \ldots \ldots \ldots \ldots \ldots \ldots \ldots$

INTRODUCTION $\ldots \ldots \ldots \ldots \ldots \ldots \ldots \ldots \ldots \ldots \ldots \ldots \ldots \ldots \ldots \ldots \ldots$

PART I.--Stratigraphic Paleontology.

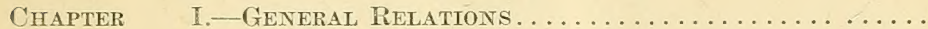

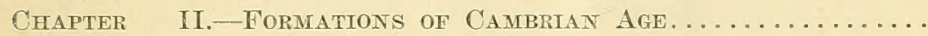

Hardyston quartzite $\ldots \ldots \ldots \ldots \ldots \ldots \ldots \ldots$

Kittatinny limestone $\ldots \ldots \ldots \ldots \ldots \ldots \ldots$

$10-14$

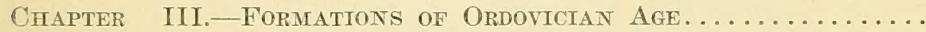

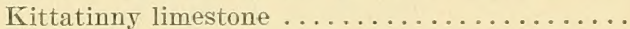

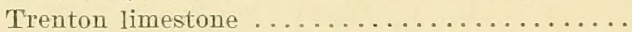

The Jacksonbur' section.............

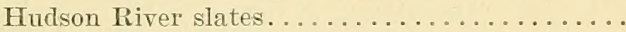

Chapter IV.-Formations of Silurian Age............

Shawangunk-Green Pond conglomerate. .....

Medina-Longwood sandstone ............

Nearpass section $\ldots \ldots \ldots \ldots \ldots \ldots \ldots \ldots$

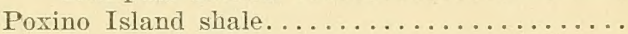

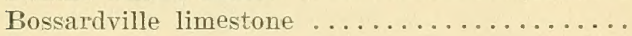

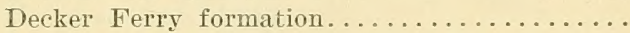

Correlation of Decker Ferry faunas......

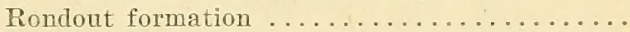

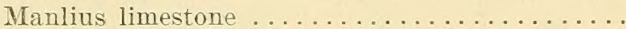

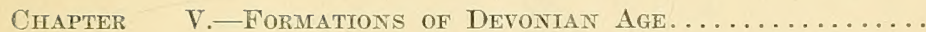

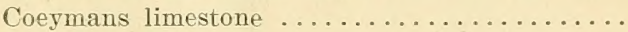

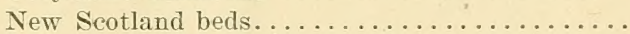

Stormville sandstone ................. 91

Becraft limestone .................. 91

Kingston beds ................... 93

Oriskany formation ............... 93

The Dalmanites dentatus zone......... 94

The Orbiculoidea jervensis zone......... 97

The Spirifer murchisoni zone.......... 99

Esopus grit . . . . . . . . . . . . . . . 102

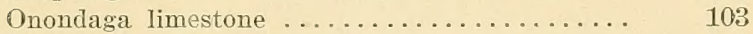

Newfoundland grit .................. 104

Monroe shales .................... 106

Bellvale flags .................... 107

Skunnemunk conglomerate ............ 108 
PART II.-Descriptive Paleontology.

PAGE.

Chapter VI.-Faunas of Cambrian Age............. 111-122

Chapter VII.-Faunas of Ordoviotan Age............. 123-216

Description of species in the Beekmantown fauna,

Description of species in the Trenton faunas....

Description of species from the Hudson River formation $\ldots \ldots \ldots \ldots \ldots \ldots \ldots \ldots \ldots \ldots \ldots \ldots \ldots \ldots$

Chapter VIII.-Faunas of Silurian Age..............

Description of species in the Decker Ferry fauna,

Description of species in the Rondout fauna....

Description of species in the Manlius limestone

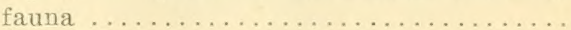

Description of species in the Coeymans limestone fauna $\ldots \ldots \ldots \ldots \ldots \ldots \ldots \ldots$.

Description of species in the New Scotland-Becraft fauna . . . . . . . . . . . . .

Description of species in the Lower Oriskany or

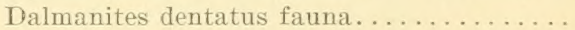

Description of species in the Middle and Upper Oriskany faunas . . . . . . . . . . . .

Description of species in the Onondaga limestone fauna . . . . . . . . . . . . . . .

Description of species in the Newfoundland grit,

Description of species in the Monroe shale and Bellvale flags .................. 


\section{Illustrations.}

\begin{tabular}{|c|c|}
\hline Plates & I.-III.-Cambrian fossils. \\
\hline PLATES & IV.-V.-Beekmantown fossils. \\
\hline Plates & VI.-XV.-Trenton fossils. \\
\hline Plate & XVI.-Hudson River fossils. \\
\hline Plates & XVII.-XXII.-Decker Ferry fossils. \\
\hline Plate & XXIII.-Rondout fossils. \\
\hline Plates & XXIV.-XXV.-Manlius fossils. \\
\hline PLates & XXVI.-XXXII.-Coeymans fossils. \\
\hline PLATeS & XXXIII.-XL.-New Scotland-Becraft fossils. \\
\hline PIates & XLI.-XLIV.-Lower Oriskany fossils. \\
\hline Plates & XLV.-L.-Oriskany fossils. \\
\hline Plate & LI.-Onondaga fossils. \\
\hline Plate & LII.-Newfoundland fossils. \\
\hline Plate & LIII.-Hamilton fossil \\
\hline
\end{tabular}





\section{Board of Managers}

His Excellency FRANKLIN MURPHY, Governor, and ex-officio

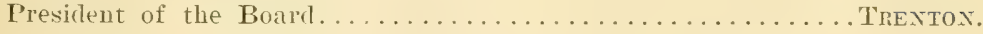

Member-at-Lai'ge.

JOHN C. SMIOCK. Trenton.

I. Congressional District.

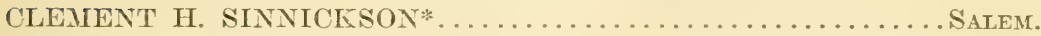
VACANCY.

II. Congressional District.

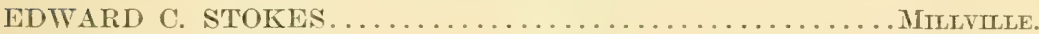

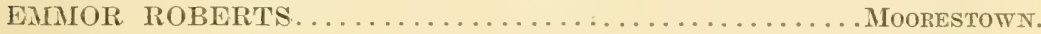

III. Congressional District.

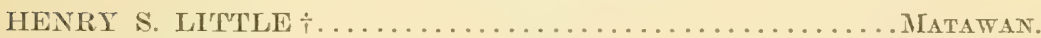

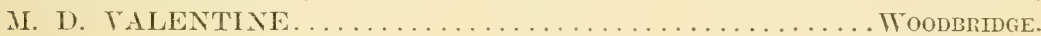

IV. Congressional District.

WASHINGTON A. ROEBLING. . . . . . . . . . . . . TRENTON.

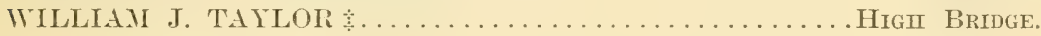

V. Conglessional District.

FREDERTCK A. CANFIELD . . . . . . . . . . . . . . . DotER.

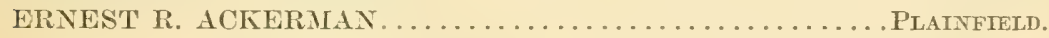

VI. Congressional District.

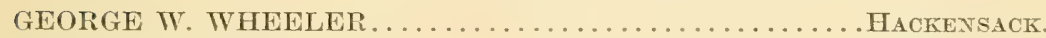
WILLIAM F. HALL........................ POMPTON LAKES.

*Mr. Sinnickson resigned December 2d, 1902.

† Mr. Little resigned February 25th, 1903.

$\ddagger$ Mr. Taylor died February 17 th, 19 C3. 
TII. Congressional District.

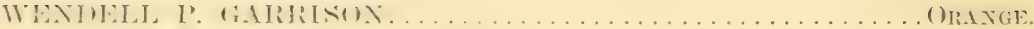

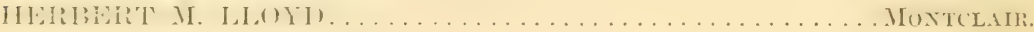

TIII. Congressional District.

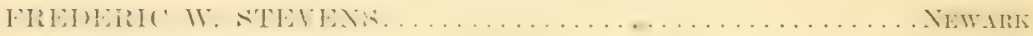

HARRISON TAN DUYXE. . . . . . . . . . . . . . NEWARE

IX. Congressional District.

JOSEPH D. BEDLE. .............................. CITY. VACANCY**

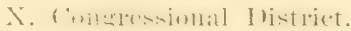

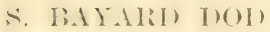

IFOHOKEX. VACANCY.

* Mr. George G. Tenuant elected to fill this vacancy February 25th, 1903. 
To His Excellency Frantin Murphy, Governor of the State of New Jersey and ex-officio President of the Board of Managers of the Geological Survey:

SrR-I have the honor to submit a report upon the Paleozoic Paleontology of New Jersey, with the request that it be printed as an Appendix to my Annual Report for the year 1902.

Yours respectfully,

HENRY B. KÜMMEL,

State Geologist.

Trenton, N. J., November 29th, 1902.

(ix) 



\section{Preface.}

The report upon the fossils of the Paleozoic formations of New Jersey forms Volume III. of the Paleontology Reports of the State Geological Survey. The previous reports of this seriesTolume I., The Brachiopoda and Lamellibranchiata of the Raritan Clays and Greensand Marls, by R. P. Whitfield; and Volume II., The Gasteropoda and Cephalopoda of the Raritan Clays and Greensand ILarls, by the same author-were prepared and published in co-operation with the United States Geological Survey. They appear, also, as United States Geological Survey Monographs IX. and XVIII., respectively. Although this report-Volume III.was written and published under the direction of the present State Geologist, it is proper to state that the field work was commenced and carried on in 1899 and 1900, while Professor John C. Smock was State Geologist.

The Paleontology Reports are distributed to libraries, geologists and other surveys. Volume III. will be sent upon request, also, to those especially interested in this subject. A few copies of Volumes I. and II. of this series are still undistributed, and libraries are urged to notify the State Geologist of gaps in their sets of survey reports. The reports are distributed without cost, except that transportation charges are paid by the recipient.

The subject matter of the Paleontology Reports is of a more specialized nature than of some of the volumes of the Final Report series-i. e., the Report on the Physical Geography of the State, Volume IV.; and on Glacial Geology, Volume V.; nor is it of such direct economic ralue as the Report on Water-supply, Volume III. ; and the Report on the Clay Industrv, now in preparation. Nerertheless, a knowledge of the fossils contained in the rocks of the State is of no little importance. The age of the formations, their correct stratigraphical position, and the conditions under which they originated, are, in part, to be determined by 
a study of their fossil contents. Colrect inferences as to their economic value and the ready and accurate determination of their

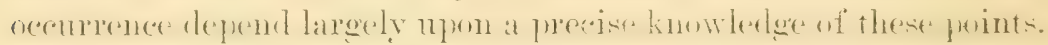

A striking example of this indirect economic value of paleontological studies was seen in connection with these rery investigations. Very early in the work it, was found that the earthy limestone, so extensively used in the ricinity of Phillipsburg for the

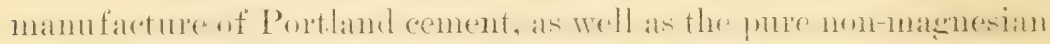
limestone used with the cement rock to increase the percentage of lime, belonged to the Trenton formation, and was readily recognized by the fossils it contained. It was foumd to occupy a definite

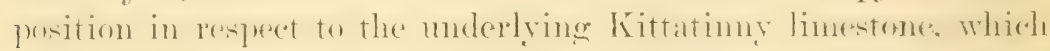
was highly magnesian and of no value for Portland cement, and

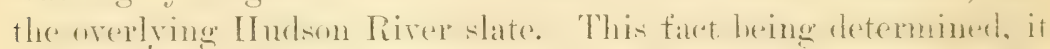
was a comparatively rapid and easy matter to trace the boundaries of the formation and so determine the location of these beds. It was at once possible to eliminate a large area from the field of investigation, with great saving both of time and moner. In fact,

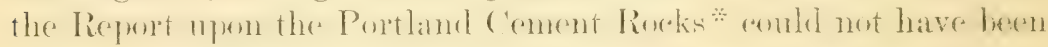
prepared, without the expenditure of a mnch greater sum tham was involved, if it had been necessary to examine the whole area of Paleozoic rocks with as much detail as was given to a few comparatively narrow zones.

But even if the study of these famas were totally unproductive of any economic results, direct or indirect, nevertheless, their inrestigation is a legitimate part of the Survey work. It is worthy the honor and name of the State to foster "science for seience's sake," and to earry on inrestigations which add something to the sum of human knowledge. When it is remembered that these fossils are the remains of living forms - some of them the highest forms of life of their time-and that from these lowly forms has come, through countless rears, the grand culmination of the life of to-day, a new interest is aroused. They cease to be mere bits of stone, curious but meaningless, and become instead the touchstones to the past.

\section{HENRY B. KÜMMEL.}

*Ann. Rep. for 1900. 


\section{A REPORT}

ON THE

\section{Paleozoic Paleontology}

NEW JERSEY.

By STUART Weller, Pir.D. 



\section{Introduction.}

The present report on the Paleozoic Paleontology of New Jersey consists of two parts. Part I. covers the Stratigraphic Paleontology. The several geologic formations recognized in the State are described, lists of their included fossils are given and the characteristics of their fossil faunas are discussed with a view of establishing correlations between the Paleozoic formations of New Jersey and those of other regions. The detailed geographic distribution of the formations and their geologic structure are not considered in the present report, but many facts of distribution and structure lave been given in a report upon "Portland Cement," published in the Annual Report of the state Geologist for 1900, and in a report upon "The Rocks of the Green Pond Mountain Region," in the Annual Report for 1901.

Part II. of the report is devoted to Descriptive Paleontology. In this part the fauna of each formation is taken up in detail, each one of its species being fully described and illustrated on the accompanying plates. This part includes the descriptions of many species previonsly described elsewhere, as well as the descriptions of a considerable number of new species here published for the first time. With the descriptions of old species one or more references to the literature of the species are always given, but no attempt at a complete bibliography has been made. The references usually selected are those which will direct the reader to additional illustrations which will be helpful in the identification of the species. For a complete bibliography of the Brachiopoda, to which class of organisms a large number of the species described in the present rolume belong, the reacler is directed to Bulletin No. $8 \%$ of the United States Geological Survey, entitled "A Synopsis of American Fossil Brachiopoda, including Bibliography and Synonymy," by Charles Schuchert. Those readers who desire a full discussion of the characteristics of the various Branches, Classes, Orders and Families of the fossil organisms described are referred to any one of the sereral text-books of paleontology, the best one for 
American students being Eastman's translation of "Zittel's Text-Bonk of Paleontology," published by Macmillan \& Company.

Most of the drawings accompanying Part II. have been preprared by Miss Mildred L. Marvin. A few have been made by Miss Annio L. Weller and Mr. D. F. Higgins, and the writer himself has contributed a small number. 


\section{PART I.}

Stratigraphic Paleontology. 



\section{CHAPTER I.}

\section{GENERAL PEIATIONS.}

The Paleozoic rocks of New Jersey fall naturally into three geographic divisions. The first of these is the Delaware valley area, lying to the northwest of the Kittatinny mountain, between the crest of the mountain and the Delaware river; the second area is the Kittatinny valley, lying between the Kittatimy mountain on the northwest and the crystalline highlands on the southeast; the third dirision includes several smaller outlying areas within the region occupied br the Pre-cambrian crystalline rocks, which are entirely surrounded by the crystalline rocks or by the crystalline rocks on one side and the Triassic sandstones on the other. The areas of palcozoic sedimentary strata within the crystalline highlands occupy the valleys of the Musconeteong and Pohatcong rivers, the ralley of the south Branch of the Raritan river from Califon northeastwardly to beyond German Valley, and the area known as the Green Pond mountain region, which extends from near Port Oram northeastwardly to the New York State line at Greenwood lake, having its greatest width a little south of Newfoundland. Between the German Valley and the Green Pond mountain regions there are several additional, much smaller areas. On the border between the crystalline highlands and the red Triassic santstones there is a small area extending northeast for a short distance from the Delaware river at a point about two miles south of Riegelsville, another at Little Fork, another of considerable extent extending from Pattenburg eastwardly to beyond Clinton. There is a small area about Pottersville and another larger one extending northeastwardly from Peapack. With the exception of the Green Pond montain region, the geologic formations of all of these ontlying areas are essentially the same as those in the Kittatinny valley. but in the Green Pond mountain regions seceral conspicunus geologic formations occu which are seen nowhere else in the State.

The geologic formations of the Delaware valley area are all of Silurian and Deronian age, covering a perior extending from the time 
of cleposition of the Shawangunk conglomerate. which was the beginning of silurian time, to that of the Onondaga limestone, which represents the first half of middle Deronian time. In the Kittatinny valley and in all of the outlying areas. except the Green Pond mountain region. the formations are of (ambrian and Ordovician age. The greatest range of geologic formations occurs in the Green Pond mountain region, where there are ('ambrian strata as old as any in the Kittatimny valley, and Deronian stata younger than any in the Delaware valley.

In the following table the geologic formations of Paleozoic age in New Jersey have been alranged in sequence, and in the following fagess their paleontologic wharaters will be discussed in order, beginning with the oldest and procededing to the youngest. In the table the furmations of the Delaware valley arra are placed in one column, those of the Kittatimny valley and all of the outlying areas, except the Green Pond mountain region, in another, and those of the Green Pond mountain region in a third column. 


\begin{tabular}{|c|c|c|}
\hline DeLaWARE Valley. & Kittatinny VaLley. & $\begin{array}{l}\text { Green Pond MoUntain } \\
\text { Region. }\end{array}$ \\
\hline Cambrian. & $\begin{array}{l}\text { Cambrian. } \\
\text { Hardyston quartzite. } \\
\text { Kiltatinny li mest on e } \\
\text { (part). }\end{array}$ & $\begin{array}{l}\text { Cambrian. } \\
\text { Hardyston quartzite. } \\
\text { Kittatinny limestone. }\end{array}$ \\
\hline Ordovician. & $\begin{array}{l}\text { Ordovician. } \\
\text { Kittatinny li mest on e } \\
\text { (part). } \\
\text { Trenton limestone. } \\
\text { Hudson River slate. }\end{array}$ & Ordovician. \\
\hline $\begin{array}{l}\text { Silurian. } \\
\text { Shawangunk conglomer- } \\
\text { ate. } \\
\text { Medina sandstone. } \\
\text { Poxino Island shale. } \\
\text { Bossardville limestone. } \\
\text { Decker Ferry formation. } \\
\text { Rondout formation. } \\
\text { Manlius limestone. }\end{array}$ & Silurian. & $\begin{array}{l}\text { Siluriun. } \\
\text { Green Pond Mountain } \\
\text { conglomerate. } \\
\text { Longwood shale. } \\
\text { Decker Ferry formation. }\end{array}$ \\
\hline $\begin{array}{l}\text { Devonian. } \\
\text { Coeyman's limestone. } \\
\text { New Scotland beds. } \\
\text { Stormville sandstone. } \\
\text { Becraft limestone. } \\
\text { Kingston beds. } \\
\text { Oriskany formation. } \\
\text { Esopus grit. } \\
\text { Onondaga limestone. }\end{array}$ & Devonian. & $\begin{array}{l}\text { Newfoundland grit. } \\
\text { Monroe shales. } \\
\text { Bellvale flags. } \\
\text { Skunnemunk conglom- } \\
\text { erate. }\end{array}$ \\
\hline
\end{tabular}

The names used for the formations in New Jersey have in most kases been adopted either from New York or from Pennsylvania, into which States the New Jersey formations extend, and where they have been more or less carefully studied and described in the literature. 


\title{
CHAPTER II.
}

\section{FORMATIONS OF CAMBRIAN AGE.}

\author{
IIARDTSTON QUARTZITE.
}

Wherever the sedimentary Paleozoic strata lie normally against the pre-cambrian crystalline rocks without faulting, both in the Kittatinny valley and in the outlying atreas, the berinning of the sedimentaly series is a rock with exceedingly rariable lithologic characteristics, but always highly siliceous. In some localities it is a quartzite, sometimes it is a conglomerate, often an arliose, and in its upper layers it becomes more and more calcareous, with some shaley beds. This formation is known in New Jersey as the Hardyston quartzite. It was first named the Hardystonville quartzite by Wolft and Brooks,; but an abbreviation of the name to Hardyston seems desirable. The same formation extends into Pennsylrania, where it is known as the Chiques sandstone, $\uparrow$ and similar beds extend southward along the Appalachians.

In New Jersey the thickness of the formation is as rariable as its physical characters. Wolff and Brooks qave its thickness as ranging from "thirty feet to a foot or less," but their observations were restricted to the region about Franklin Fumace. In other parts of its outcrop the conglomeritic phase of the formation is known to equal or even exceed 200 feet.

The age of the formation has been well established as Cambrian. In the enrly reports of the survey, without fossil evidence, it was correlated with the Potsdam sandstone of New York, $\S$ but later, Beecher $\|$ first found fossils in the formation at Hardystonville, belonging to the Trilohite genus Olenellus, which established its age as lower Cambrian. It a later date Foerste discovered additional fossil localitics,

\footnotetext{
* Eighteenth Ann. Rep. U. S. Geol. Surv., pt. II., p. 442.

† Penn. Geol. Surv., Summary, Final Report, vol. I., p. 165.

$\ddagger$ Loc. cit.

₹ Geol. N. J., 1868, p. 71.

I Ann. Rep. State Geol. N. J. for 1890, p. 49.

If Am. Jour. Sci. (3), rol. XLVI, p. 438.
} 
Otenellus always being the most conspicuous form. During the field. investigations carried on for the preparation of the present report, fossils have been found (1) at various points along the line between Hardystonville and Frankille Furnace, $(2)$ at the southern end of Iliff's pond, north of Andorer, (3) at the foot of the mountain east of Tranquility, (4) in the railroad cut just north of Oxford Furnace and (5) in the railroal cut at Washington. Aside from some more or less indefinite worm burrows, all of the fossils detected have beren trilobites, referable to a single species of Olenellus, which has been identified as o. thompsoni. Except at the localities near Franklin Furnace and Hardystonville, where sereral nearly perfect heads of Olenellus have been found, all of the specimens are in fragmentary condition. Wherever they occur the specimens of trilobites have always been found in the decomposed portions of the more calcareous beds of the formations. In the process of weathering the calcareous portion of these beds is removed by solution, leaving a more or less friable. rusty brown sandstone. The tests of the trilobites are removed with the other calcareous matter, loring cavities, along which the rock easily splits: lut in the unweathered portions of the rock the fossils have in no case ban detected, although they must be present in greater or less abundane. Field observations have led to the conclusion that whenerer the decrmposed beds of the Hardyston quartzite present a rusty brown appearance, with a rather fine-grained, arenaceous texture, fragments of Olenellus may be detected in greater or less abundance if careful search is made.

The formation accurs in the Green Pond mountain region, and its upper calcareous portion or the limestones immediately supcrjacent to it have afforded fragments of Otenellus." At the time of its deposition the formation was doubtless continuous across the present erystalline highlands, from the Green Pond mountain region to the Kittatinny valley.

ПITTATINNY LIMESTONE.

Lying conformably upon the Hardyston quartzite there is a great thickness of limestone in large part dolomitic and rarely fosiliferons. The division between the quartzite below and this limestone is not a sharp one, the siliceous Hardyston beds becoming more and more calcareous in their composition, through strata of arenaceous lime-

* Walcott, Am. Jour. Sci. (3), vol. XLVII., p. 309. 
stone or calcareous sandstone and shales. This limestone formation has a great thicklless, which is estimated at from 2,700 to 3,000 feet. It is designated the Kittatinny limestone* because it is the great limeston formation of the Kittatinny ralley, where it occupies extensive areas. It is also present in all of the outlying areas. Like the Hardyston quartzite, this limestone formation was doubtless at one time continuous across the area now occupied by the crystalline highlands, and has been eroded. It is continuous across Pennsylvania, where it has been described as the Great Valley limestone, No. II., $\uparrow$ and across Maryland and the eastern part of West Virginia into Virgrinia, where it is known as the Shenandoah limestone. ${ }_{+}^{+}$The formation also extends northward from New Jersey into New York.

The fossil fauna of the Kittatimny limestone, so far as it is known, is not an extensive one. Although organic remains have been found at hut few localities, they are sufficient to establish the age of the formation as Cambrian for the most part. At one locality, near the summit of the formation, however, a fauna indicating the early Ordovician age of the beds containing it has been collected.

The largest fauna of Cambrian age which has been discovered in the formation is that from O'Domnell and MacManniman's quarry, at. Newton (Iocality $136 \mathrm{~A}$ ), where the following species have been collected :

Foraminifera? genus and sp. undet.

Lingulella stoneana Whitf.

Orthis newtonensis $\mathrm{n}$. $\mathrm{sp}$.

Microdiscus? sp. undet.

Olenellus? sp. undet.

Ptychoparia newtonensis n. sp.

Ptychoparia 2 sp. undet.

Anomocare parvula n. sp.

Dikelocephalus newtonensis $\mathrm{n}$. $\mathrm{sp}$.

'This fauna is of much interest because of its similarity to some of the upper Cambrian faunas of the so-called Potsdam sandstone of th. Tpper Mississippi valley. The species described as Dikelocephalus newtonensis is the most abundant member of the fauna and is closely allial to $D$. pe pinensis from Minnesota. Lingulella stoneana, which

\footnotetext{
* That portion of it near Franklin Furnace was called the Wallkill limestone by Wolff and Brooks, Eighteenth Ann. Rep. U. S. Geol. Surv., pt. II., p. 443.

+ Penn. Geol. Surv, Summary, Final Report, rol. I., p. 298.

\$Md. Geol. Surv., vol. I., p. 178.
} 
is not associated with the other species, but occurs in a bed a few feet higher in position, is a Wisconsin form, of peculiar type, which is now recognized for the first time from the east. The association with a welldefined species of Dikelocephalus, of the species which has here been referred to the genus Olenellus, would be of much greater interest if the identification could be made with certainty, but, in any case, it suggests the possibility of a much longer range for the genus Olenellus: in geologic time than has been ascribed to it. This genus is usually considered as particularly characteristic of the very lowest Cumbrian strata, but here it seems to be associated with a fauna which bears unmistakable marks of upper Cambrian age.

In A. J. Graey's quarry (Locality $136 \mathrm{C}$ ), just south of Newton, ai few imperfect specimens of the brachiopod, described as Orthis newtonensis, have been detected; and again, the same species has been found in an abandoned quarry north of Andover, near the Delaware. Lackawanna and Western railroad, west of Long pond (Locality $158 \mathrm{C}$ ). In neither of these localities have any trilobites been found associated with the brachiopods.

About one-half mile north of Blairstown (Locality $175 \mathrm{~A}$ ), in an abandoned quarry, a bed about one foot in thickness was found to contain many fragments of trilobites, and the following species hare: been identified:

Agraulos saratogensis Walc.

Ptychoparia blairi n. sp.

Ptychoparia calcifera Walc.?

of these species one is described for the first time in the present report, the other two being identified with species described by Walcott from the upper Cambrian limestones of Saratoga county, New York.

One other fossiliferous locality in the Cambrian portion of the Kittatinny limestone has been found in Robinson Brothers' quarry; south of Carpentersville (Locality $3+1 \mathrm{~A}$ ). This locality is situater in one of the outlying areas of the limestone, occupying the valley of the Pohatcong river; only one species, Solenopleura jerseyensis Weller, has been found, which was described for the first time from this locality.

The position of these rarious fossiliferous beds of the Kittatinny limestone, in the formation as a whole, cannot be determined with certainty, but it may probably be stated, with a degree of safety, that

\footnotetext{
* In the Annual Report of the State Geologist for 1899 this species is doubtfully. referred to the genus Liostracus.
} 
all of these fosiliferous localities, with the exception of that near Carpentersville, are in the upper portion of the formation. The Carpentersille locality is probably somewhere in the lower third of the entire series. So far as the fossils afford any definite evidence, the age of all is ny rer Cambrian. To middle ('ambrian faunas have hwen recognized, although the Olenellus fauna of the Hardyston ufuartzite is ustally considered to be of lower Cambrian age, and a middle Cambrian fauna would naturally tre expected to oceur somewhere in the formation. 


\title{
CHAPTER III.
}

\section{FORMATIONS OF ORDOVICIAN AGE.}

\author{
KITTATINAY LIMLESTONE.
}

The top of the Kittatinny limestone in New Jersey is not a continuous horizon, as there is an erosion interval between it and the Trenton limestone, the next succeeding formation. At many localities the highest beds are doubtless Cambrian in age. but the remnants of heds bearing a younger fauna than that characterized by Diketocephalus are present in at least one locality. These strata seem not to be separated by any physical break from those bearing the Cambrian fauna, and the deposition was doubtless continuous from early Cambrian time until after the opening of the Ordovician, as usually understood. The single locality in the Kittatinny limestone which ha: afforded this early Ordorician fauna is in the railroad cut of the Delaware branch of the Tew York, Susquehanna and Westeru railroad at Columbia (Locality $210 \mathrm{~A}$ ). The limestone at this point is somewhat thinner bedded than usual for the formation, the beds being: frequently separated by thin, shaley partings. Similar strata occur along the railroad at Hainesburg, near the top of the formation, and they, too, may be of Ordorician age, although no fossils have been found at that locality. At Columbia the Trenton limestone outerop: only a short distance up the hillside from the railroad cut where the fossils occur, so that the position of the fauna near the top of the Tittatinny limestone formation is assured. The following species of fossils have been recognized:

Dalmanella wemplei Cleland.

Dalmanella electra (Bill.).

Syntrophia lateralis (Whitf.).

Cyrtolites sinuatus H. \& W.

Bellerophon sp. undet.

Raphistoma columbiana n. sp.

Liospira sp. undet.

Ophileta? sp. undet. 
Eccytiomphalus subelliptica n. sp.

Polygyrata sinistra n. sp.

Platyceras? columbiana n. sp.

Cyrtoceras sp. undet.

Isotelus canatis (Whitf.).

Illanurus columbiana n. sp).

Bathyurus? sp. undet.

This fauna contrasts sharply with the C'ambrian fauna of the Kittalimm limestone, by reason of the predominance of gastropods, a charareristic in which the fama agrees with that of the Beekmantown limestone of New York in most of its localities.

of the species identified with already-described forms, two, syntriIhia lateralis and Isotelus crmulis, oecur in the beds of Beekmantown age at Fort Cassin, on Iake Champlain. One species, Dalmanellu clectra, was described from the Levis heds of similar age on the St. Lawrence river. near Montreal. Dalmanella wemplei was describer? irom the same horizon at Fort Hunter, Tew Sork, in the Mohawh valley: this species, however, is closely allied to, and perhaps should he (onsidered as irlentical with, D. maclendi (Whitf.), from the typical Beekmantown limestone at Beekmantown, New York. Illcnume rolumbiana, also, occurs at Fort Hunter, New York, but has been lescribed from there muler another mame. Cyrtolites sinuatus was ariginally iescribes from the Pogonip limestone of Nevada. Aside from these speries, which are identical with forms in the Beekmantown limestone of New York and Canada, all of the new species described have their nearest allies in the same fauna, and there can be no question whaterer as to the correctness of the correlation of the beds at Columbia with the Beekmantown limestone of New York.

TRENTON IAIESTONE.

In the Kittatinny valley and in most of the outlying areas, aside frum the Green Pond mountain region, two conspicuous rock formatims are met with. One of these is the great magnesian limestone? wris already described under the name Kittatinny limestone, and the other is the Hudson River slate, whose outcrop covers a considerably greater area than does the limestone. Wherever the normal siquene from the orreat limestone formation to the slate is present in New Jersey, a much less conspicuous limestone formation may 
always be detected between the two. The average thickness of this formation is from 135 to 150 feet, and although it is a limestone, it is very different in character from the subjacent Kittatinny limestone. Chemically it is a nearly pure calcium carbonate, while the Kittatinny limestone is almost always highly magnesian. It becomes, however, an argillaceous limestone in the transition beds to the overlying shale. It is usually much darker in color than the Kittatinny limestone and almost always contains fossils, although they are frequently fragmentary and poorly preserved. The formation was described by Professor Cook* as the fossiliferous limestone and its Trenton age has long been recognized. It rests unconformably upon the Kittatinny limestone, the two formations being separated by an erosion interval, and in its lower beds it is frequently conglomeritic, the pebbles being from the underlying Kittatinny limestone. In some localities, where it is not conglomeritic at the base, its lower portion consists of fine, clastic material, apparently derived from the underlying Kittatinny limestone. In many localities the formation is apparently absent, the Hudson Rirer slates resting directly against the Kittatinny limestone, but in all these cases its absence is due to overthrust faulting.

A large number of fossil species have been recognized in the formation at its various localities in the State, and a critical study of its faunas shows that it is not strictly equivalent to the typical Trenton limestone of New York, but that it also includes somewhat older beds of the age of the Black River limestone. The entire formation, however, in New Jersey constitutes a single stratigraphic unit, and this unit may be considered as being the equiralent of the Black River and Trenton limestones of New York, although the top of the formation in New Jersey is doubtless lower down in the series than the summit of the typical New York Trenton limestone.

Several distinct faunal zones have been recognized in the formation. The outcrops, however, are usually more or less isolated knolls, and are usually so fully covered with debris that fossils can be collected only from loose fragments of the limestone on the surface. It is also rare to find more than a single faunal zone in any one outcrop. Under these circumstances the determination of the exact succession of the faunal zones has been a problem of some difficulty. The locality selected for a detailed investigation of the succession of fossil faunas in the formation is a hill, 580 + feet in eleration, on the property

* Geol. N. J., 1868, p. 131. 
of Mr. E. J. Hough, just back of the mill at Jacksonburg, near Blairstown (Locality 1it A). At this locality the formation is more than ordinarily fossiliferous and the fosils are hetter preserved than usual. On the lower slope of the hill the Kittatinny limestone is exposed and in the knoll just beyond the slate outcrops, so that the entire thickness of the formation is present. A trench was dug, in order to expose a continuous section of the formation from its contact with the Kittatinny limestoue, through a thicknes of 122 feet. At this point in the section, although the top of the limestone had not been reached, the trench was discontinued, because the rock surface dipped so deeply beneath the surface of the ground that further digging was impracticable. It is probable that fifteen or twenty additional feet of limestone are present in the section hefore it passes into the orerlying Hudson River slates. This section was accurately measured, sixty-one different beds being recognized, from each of which fossils were carefully collected. This Jacksonburg section through the Trenton limestone will be giren first consideration in the discusion of the Trenton faunas, it heing the key to the determination of the faunal succession in this formation in New Jersey.

Locality 174 A.-The Jacksonburg Section.*

$1 \% 4 \mathrm{~A}^{1}$. Fine-grained, buff-colored, shaley beds, the constituent material apparently having been dederived from the underlying Kittatinny limestone.

2 ft. 2 in.

1. Strophomena sp. undet.

(r).

2. Rafinesquina alternata (Emm.) (r).

3. Dalmanella subcquata (Con.) (aa).

4. Ctenodonta jerseyensis $\mathrm{n}$. $\mathrm{sp}$. (r).

5. Ctenodonta sp. undet. (r).

6. Modiolopsis sp. undet. (r).

\%. Undet. pelecypod (r).

8. Helicotoma sp. undet. (r).

9. Lophospira sp. undet. (r).

10. Trilobite fragments undet. (r).

11. Leperditia fabulites (Con.) (a).

* The relative abundance of the species in the rarious beds is indicated by the symbols $(a)$ abundant, $(c)$ common, $(f)$ frequent, $(r)$ rare 
$17 \pm \mathrm{A}^{2}$. Fine-grained, chocolate-colored, shaley beds, simi-

lar to the last in all respects except color.

1 ft. 6 in.

1. Strophomena sp. undet.

(r).

2. Refinesquina alternata (Emm.) (r).

3. Dalmanella subaquata (Con.) (aa).

4. Ctenodonta sp. undet.

(r).

5. Modiolopsis jerseyensis n. sp. $\quad(\mathrm{r})$.

6. Undet. pelecypods (r).

\%. Pterygometopus intermedius Walc. (r).

8. Leperditia fabulites (Con.)

(a).

$174 \mathrm{~A}^{3}$. Chocolate-colored, calcareous band.

1. Dalmanella subaquata (Con.) (a).

2. Lophospira sp. undet. (r).

3. Leperditia fabulites (Con.) (a).

$174 \mathrm{~A}^{4}$. Brownish, calcareous shale.

3 in.

1. Lingula sp. undet.

1 ft. 3 in.

2. Strophomena sp. undet.

(r).

3. Rafinesquina alternata (Emm.)

(r).

4. Dalmanella subrequata (Con.)

(r).

5. Scenidium anthonensis Sard.

6. Ctenodonta sp. undet.

(r).

\%. Cyrtodonta sp. undet.

(r).

8. Modiolopsis sp. undet.

(r).

9. Phragmolites sp. undet.

(r).

10. Helicotoma sp. undet.

(r).

11. Orthoceras sp. undet.

(r).

12. Pterygometopus intermedius Walc.

13. Leperditia fabulites (Con.)

(r).

(a).

$1 \% \pm \mathrm{A}^{5}$. Fine-grained, buff-colored, shaley bed.

1. Dalmanella subcequata (Con.)

1 ft. 6 in.

2. Undet. pelecypod fragments

(a).

3. Undet. gastropod fragments

(c).

4. Orthoceras sp. undet.

(c).

5. Leperditia fabulites (Con.)

(c).

(a). 
$174 \mathrm{~A}^{6}$. Buff or chocolate-colored, shaley beds, similar to the preceding, with some bands of darker limestone.

1. Dalmanella subcquata (Con.) (aa).

2. Ctenodonta nasuta (Hall) (r).

3. Undet. pelecypod fragments (c).

4. Undet. gastropod fragments (c).

5. Ptychopyge jerseyensis n. sp. (r).

6. Leperditia fabulites (Con.) (a).

$174 \mathrm{~A}^{7}$. Hard, fine-grained, dark, bluish-gray limestone. $1 \mathrm{ft.} 8 \mathrm{in.}$

1. Leperditia fabulites (Con.)

(r).

$17+A^{8}$. Fine-grained, buff-colored, shaley beds, with hard, calcareous bands.

$4 \mathrm{ft}$.

1. Modiolopsis sp. undet.

(r).

2. Leperditia fabulites (Con.)

(c).

$174 \mathrm{~A}^{9}$. Soft, fine-grained, bluish-gray limestone.

3 ft. 6 in.

1. Undet. bryozoan

(r).

2. Rafinesquina alternata (Emm.) (r).

3. Dalmanella subrequata (Con.) (r).

4. Camarella inornata n. sp. (r).

5. Modiolopsis sp. undet. (r).

6. Raphistoma peracutum U.\& S. (r).

\%. Undet. gastropod fragments (r).

8. Bumastus trentonensis (Emm.) (r).

9. Pterygometopus intermedius Walc. (r).

10. Leperditia fabulites (Con.) (r).

$174 \mathrm{~A}^{10}$. Soft, fine-grained, brownish or bluish-gray limestone.

1. Phinidictya sp. undet. (c).

2. Phylloporina fenestrata $\mathrm{H}$. (c).

3. Rafinesquina alternata (Emm.) (f).

4. Dalmanella subcquata (Con.) (c).

5. Ctenodonta nasuta (Hall) (r).

6. Modiolopsis sp. undet. (r).

\%. Undet. pelecypod fragments (r).

S. Raphistoma peracutum U. \& S. (c).

$6 \mathrm{ft}$. 
9. Lophospira oweni U. \& S. (r).

10. Isotelus gigas De Kay (f).

11. Bumastus trentonensis (Emm.) (c).

12. Ceraurus pleurexanthemus Green (f).

13. Pseudospharexochus trentonensis Clark ( $\mathrm{r}$ ).

14. Pterygometopus sp. undet. (r).

15. Leperditia fabulites (Con.) (c).

$174 \mathrm{~A}^{11}$. Soft, bluish-gray limestone, similar to the last.

$4 \mathrm{ft}$.
1. Undet. bryozoan
(r).
2. Lingula sp. undet.
(r).
3. Rafinesquina alternata (Emm.)
(a).
4. Dalmanella subaquata (Con.)
(c).
5. Undet. pelecypod fragments
(r).
6. Isotelus gigas De Kay
(r).
\%. Leperditia fabulites (Con.)
(r).

$174 \mathrm{~A}^{12}$. Soft, bluish-gray limestone, similar to the last.

$6 \mathrm{ft}$.

1. Hindia parva Ulr.

(f).

2. Streptelasma corniculum $\mathrm{H}$.

(r).

3. Rhinidictya sp. undet.

(c).

4. Strophomena incurvata (Shep.) (r).

5. Dalmanella subaquata (Con.) (r).

6. Scenidium anthonensis Sard.

(f).

\%. Bumastus trentonensis (Emm.) (r).

8. Leperditia fabutites (Con.) (r).

$174 \mathrm{~A}^{13}$. Hard, bluish-black limestone.

8 ft. 4 in.

1. Romingeria? trentonensis $\mathrm{n}$. sp. $(\mathrm{r})$.

2. Bucania sp. undet. (r).

3. Bumastus trentonensis (Emm.) (c).

4. Pterygometopus sp. undet. (r).

5. Leperditia fabutites (Con.) (c).

$174 \mathrm{~A}^{14}$. Hard, dark gray, granular limestone.

2 ft. 8 in.
1. Crinoid stems
(r).
2. Bumastus trentonensis (Emm.)
(r).

$174 \mathrm{~A}^{15}$. Hard, bluish-black limestone.

$1 \mathrm{ft}$.

1. Leperditia fabulites (Con.)

$(\mathrm{r})$. 
$174 \mathrm{~A}^{16}$. Hard, bluish-black limestone.

1. Pterygometopus sp. undet. (r).

2. Leperditia fabulites (Con.) (c).

$174 \mathrm{~A}^{17}$. Dark, bluish-gray or nearly black, irregularly thin-bedded, knotty limestone.

$15 \mathrm{ft}$.

1. Streptelasma corniculum H. (a).

2. Actinostroma trentonensis $\mathrm{n}$. sp. (c).

3. Crinoid stems (c).

4. Rhinidictya sp. undet. (r).

5. Schizocrania filosa (H.) (r).

6. Strophomena incurvata (Shep.) (r).

\%. Rafinesquina alternata (Emm.) (r).

8. Plectambonites sericeus (Sow.) (f).

9. Orthis tricenaria Con.

10. Dalmanella subcequata (Con.) (c).

11. Dalmanella testudinaria (Dal.) (rr).

12. Dinorthis pectinella (Emm.) (c).

13. Plectorthis plicatella (Hall) (c).

14. Rhynchotrema incequivalvis (Castel.) (a).

15. Zygospira recurvirostris (H.). ( $\mathrm{rr}$ ).

16. Cyrtodonta canadensis Bill. (a).

17. Isotelus gigas De Kay (r).

18. Bumastus trentonensis (Emm.) ( $\mathrm{r})$.

19. Encrinurus trentonensis Walc. (r).

20. Pterygometopus callicephalus (H.) (r).

21. Leperditia sp. undet. (r).

$174 \mathrm{~A}^{18}$. Bluish-gray, granular, highly fossiliferous limestone.

$3 \mathrm{ft}$.

1. Streptelasma comiculum H. (c).

2. Prasopora simulatrix Ulr. (r).

3. Rafinesquina alternata (Emm.) (r).

1. Plectambonites sericeus (Sow.) (a).

5. Orthis tricenaria Con. $\quad(\mathrm{r})$.

6. Plectorthis plicatclla (Hall) (c).

\%. Dalmanella testudinaria (Dal.) (rr).

8. Rhynchotrema inacquivalvis (Castel.) (f).

9. Isotclus gigas De Kay (f).

10. Proetus brevimarginatus n. sp. (r).

11. Pterygometopus callicephatus (H.) (f). 
The following additional species have been collected from a loose slab, probably from this bed:

1. Nyctopora billingsi Nich. (r).

2. Actinostroma trentonensis n. sp. (c).

3. Parastrophia hemiplicata (Hall) (r).

$174 \mathrm{~A}^{19}$. Dark, highly fossiliferous limestone in beds from three to six inches thick.

1. Streptelasma corniculum H. (rx).

2. Plectambonites sericeus (Sow.) (aa).

3. Rhynchotrema incequivalvis (Castel.) (rr).

4. Proetus brevimarginatus $\mathrm{n}$. $\mathrm{sp}$. (rr).

$1^{1 \%}+\mathrm{A}^{20}$. Dark, fossiliferous limestone.

9 in.

1. Strophomena incurvata (Shep.) (r).

2. Plectambonites sericeus (Sow.) (aa).

3. Dalmanella testudinaria (Dal.) (r).

t. Plectorthis plicatella (Hall) (r).

5. Parastrophia hemiplicata (Hall) (c).

6. Bucania punctifrons Emm. (r).

\%. Isotelus gigas De Kay (r).

8. Calymene senaria Con. (r).

$174 \mathrm{~A}^{21}$. Dark limestone, with some highly fossiliferous bands.

1. Lingula sp. undet.

2. Plectambonites sericeus (Sow.) (aа).

3. Dalmanella testudinaria (Dal.) (c).

t. Bucania punctifrons Emm. (r).

5. Proetus brevimarginatus $\mathrm{n}$. $\mathrm{sp} . \quad(\mathrm{r})$.

$1 \% 4 \mathrm{~A}^{22}$. Dark, fossiliferous limestone.

1. Strophomena incurvata (Shep.) (r).

2. Rafinesquina alternata (Emm.) (c).

3. Dalmanella testudinaria (Dal.) (aa).

4. Plectorthis plicatella (Hall) (r).

5. Bucania punctifrons Emm. (r).

6. Hormotoma salteri Ulr. $(\mathrm{r})$.

\%. Isotelus gigas De Kay (c).

8. Proetus latimarginatus n. sp. (f). 
9. Bronteus lunatus Bill.

(r).

10. Calymene senaria Con.

(f).

11. Pterygometopus callicephalus (H.) (f).

$174 \mathrm{~A}^{23}$. Dark, fossiliferous limestone.

$1 \mathrm{ft}$.

1. Prasopora simulatrix Ulr.

(f).

2. Strophomena incurvata (Shep.)

$(\mathrm{r})$.

3. Rafinesquina alternata (Emm.)

4. Dalmanella testudinaria (Dal.)

5. Plectorthis plicatella (Hall)

(r).

6. Bucania punctifrons Emm.

(r).

$\therefore$ Hormotoma salteri Ulr.

$(\mathrm{r})$.

¿. Conularia trentonensis $\mathrm{H}$.

(r).

9. Isotelus gigas De Kay

(f).

10. Proetus latimarginatus n. sp.

(f).

11. Calymene senaria Con.

(r).

12. Pterygometopus callicephalus

$174 \Lambda^{24}$. Hard, bluish-black, fossiliferous limestone.

$1 \mathrm{ft}$.

1. Prasopora simulatrix Ulr.

(f).

?. Strophomena incurvata (Shep.)

(r).

3. Rafinesquina alternata (Emm.)

t. Dalmanella testudinaria. (Dal.)

(c).

$\therefore$ Plectorthis plicatella (Hall)

(r).

(i. Orthoceras tenuistriatum (H.)

(c).

$\therefore$ Isotelus gigas De Kay

$\therefore$ Bathyurus extans (Hall)

(r).

!. Proetus brevimarginatus n. sp.

(r).

11. Plaiymetopus trentonensis (H.)

(r).

11. Calymene scnaria Con.

$\left(l^{2}\right)$.

1‥ Pterygometopus calticephala $\left(\mathrm{H}_{\mathrm{.}}\right)$

(f).

$174 \mathrm{~A}^{25}$. Dark, fossiliferous limestone.

1. Hindia parva Ulr.

2. Prasopora simulatrix Ulr.

3. Strophomena incurvata (Shep.)

4. Rafinesquina alternata (Emm.)

(r).

5. Dalmanella testudinaria (Dal.)

6. Plectorthis plicatella (Hall)

(a).

¿. Ctenodonta sp. undet.

(r).

8. Bucania punctifrons Emm.

(r).

$(\mathrm{r})$.

$1 \mathrm{ft}$. 
9. Conularia trentonensis (Hall) (r).

10. Harpina ottawensis (Bill.) ( $)$.

11. Isotelus gigas De Kay (c).

12. Proetus latimarginatus $\mathrm{n} . \mathrm{sp}$. (r).

13. Pterygometopus callicephalus (Hall) (r).

$174 \mathrm{~A}^{26}$. Dark, fossiliferous limestone.

9 in.

1. Dalmanella testudinaria (Dal.) (a).

2. Plectorthis plicatella (Hall) (f).

3. Ctenodonta sp. undet. (r).

4. Protowarthia cancellata (Hall) (r).

5. Hormotoma salteri Ulr. (r).

6. Harpina ottawensis (Bill.) (r).

\%. Isotelus gigas De Kay (f).

8. Bumastus trentonensis (Emm.) (r).

9. Proetus latimarginatus n. sp. (r).

10. Calymene senaria Con. (r).

$174 \mathrm{~A}^{2 \tau}$. Dark, fossiliferous limestone.

$1 \mathrm{ft.} 2$ in.

1. Prasopora simulatrix Ulr.

(f).

2. Strophomena incurvata (Shep.) (r).

3. Rafinesquina alternata (Emm.) (c).

4. Plectambonites sericeus (Sow.) (f).

5. Dalmanella testudinaria (Dal.) (c).

6. Zygospira recurvirostris Hall (r).

$\therefore$ Modiolopsis faba (Con.) (f).

8. Protowarthia cancellata (Hall). (r).

9. Tetranota bidorsata (Hall) (r).

10. Liospira micula (Hall) (f).

11. Orthoceras tenuistriatum (Hall) (r).

12. Trinucleus concentricus (Eaton) (r).

13. Isotelus gigas De Kay (f).

14. Bumastus trentonensis (Emm.) (r).

15. Calymene senaria Con.

16. Pterygometopus callicephalus (Hall) (f).

$174 \mathrm{~A}^{28}$. Dark limestone, sparsely fossiliferous.

1. Prasopora simulatrix Ulr.

(r).

2. Lingula riciniformis Hall

3. Rafinesquina alternata (Emm.) (r).

4. Plectambonites sericeus (Sow.) (r). 

5. Dalmanella testudinaria (Dal.)
(r).
6. Conularia trentonensis Hall
\%. Bumastus trentonensis (Emm.)
$(\mathrm{r})$.
(r).

$174 \mathrm{~A}^{29}$. Sparsely fossiliferous, dark limestone.

$2 \mathrm{ft}$.

1. Rafinesquina alternata (Emm.) (r).

2. Plectambonites sericeus (Sow.) (c).

3. Dalmanella testudinaria (Dal.) (a).

t. Parastrophia hemiplicata (Hall) (r).

5. Hormotoma salteri Ulr.

6. Isotelus gigas De Kay

(l) .

(f).

$174 \mathrm{~A}^{30}$. Sparsely fossiliferous, dark limestone.

1. Prasopora simulatrix Ulr.

2. Orbiculoidea lamellosa (Hall)

$(\mathrm{r})$.

3. Strophomena incurvata (Shep.)

(r).

4. Rafinesquina alternata (Emm.)

(f).

5. Plectambonites sericeus (Sow.)

(c).

6. Dalmanella testudinaria (Dal.)

(c).

\%. Zygospira recurvirostris (Hall)

(r).

8. Ctenodonta sp. undet.

(r).

9. Modiolopsis faba (Con.)

10. Isotelus gigas De Kay

(r).

(c).

11. Bumastus trentonensis (Emm.) (r).

12. Proctus latimarginatus n. sp.

(i).

10 in.

$174 \mathrm{~A}^{31}$. Dark, fossiliferous limestone.

1. Strophomena incurvata (Shep.) (r).

2. Rafinesquina alternata (Emm.) (f).

3. Plectambonites sericeus (Sow.) (aa).

4. Dalmanella testudinaria (Dal.) (c).

5. Plectorthis plicatella (Hall) (r).

6. Ctenophora sp. undet. (r).

\%. Modiolopsis faba (Con.) (f).

8. Bucania punctifions Emm. (r).

9. Tetranota bidorsata (Hall) (r).

10. Liospira micula (Hall) (r).

11. Hormotoma salteri Ulr. (c).

12. Orthoceras (r).

13. Isotelus gigas De Kay (f).

1 ft. 8 in. 
14. Proetus brevimarginatus n. sp. (r).

15. Calymene senaria Con. (r).

16. Pterygometopus callicephalus (Hall) (r).

$174 \mathrm{~A}^{32}$. Dark, fossiliferous limestone.

1. Lingula sp. undet. (r).

2. Strophomena incurvata (Shep.) (r).

3. Rafinesquina alternata (Emm.) (r).

4. Plectambonites sericeus (Sow.) (aa).

5. Dalmanella testudinaria (Dal.) (c).

6. Zygospira recurvirostris (Hall) (f).

\%. Ctenodonta sp. undet. (r).

8. Modiolopsis faba (Con.) (r').

9. Goniophora carinatus (Hall) (r).

10. Protowarthia cancellata (Hall) (f).

11. Bucania punctifrons Emm. (r).

12. Hormotoma salteri UIr. (c).

13. Orthoceras sp. undet. (f).

14. Bumastus trentonensis (Emm.) (r).

15. Pterygometopus callicephalus (Hall) (f).

$174 \mathrm{~A}^{33}$. Dark, fossiliferous limestone.

$1 \mathrm{ft.} 4 \mathrm{in}$.

1. Prasopora simulatrix Ulr. (r).

2. Strophomena incurvata (Shep.) (r).

3. Rafinesquina alternata (Emm.) (r).

4. Plectambonites sericeus (Sow.) (aа).

5. Dalmanella testudinaria (Dal.) (c).

6. Zygospira recurvirostris (Hall) (f).

\%. Protowarthia cancellata (Hall) (f).

8. Liospira micula (Hall) (r).

9. Hormotoma salteri Ulr. (c).

10. Orthoceras (r).

11. Isotelus gigas De Kay (f).

12. Proetus latimarginatus n. sp. (r).

13. Calymene senaria Con. (1').

$174 \mathrm{~A}^{34}$. Dark, fossiliferous limestone.

6 in.

1. Plectambonites sericeus (Sow.) (aa).

2. Dalmanellu testudinaria (Dal.) (f).

3. Zygospira recurvirostris (Hall) (r).

4. Ctenodonta sp. undet. (r).

10 in. 
5. Modiolopsis faba (Con.)

(r).

6. Goniophora carinatus (Hall)

(r).

\%. Liospira micula (Hall)

(r).

8. Hormotoma salteri Ulr.

(f).

9. Orthoceras sp. undet.

10. Isotelus gigas De Kay

11. Proetus latimarginatus n. sp.

12. Pterygometopus callicephalus (Hall) (r).

$13+\Lambda^{35}$. Dark, fossiliferous limestone.

$1 \mathrm{ft}$.

1. Schizocrania filosa (Hall)

(r).

2. Strophomena incurvata (Shep.)

-3. Rafinesquina alternata (Emm.)

4. Plectambonites sericeus (Sow.)

5. Dalmanella testudinaria (Dal.)

(a).

f. Zygospira recurvirostris (Hall)

7. Modiolopsis faba (Con.)

S. Goniophora carinatus (Hall)

9. Archinacella patelliformis (Hall)

(r).

10. Liospira micula (Hall)

11. Hormotoma salteri Ulr.

(c).

12. Isotelus gigas De Kay

13. Proetus latimarginatus n. sp.

14. Pterygometopus callicephalus (Hall) (r).

$174 \mathrm{~A}^{36}$. Dark, fossiliferous limestone.

$1 \mathrm{ft.} 4$ in.

1. Strophomena incurvata (Shep.)

(c).

$\therefore$ Rafinesquina alternata (Emm.)

(c).

$\therefore$ Plectambonites sericeus (Sow.)

(c).

1. Dalmanella testudinaria (Dal.)

(c).

.. Plectorthis plicatella (Hall)

(r).

(:. Zygospira recurvirostris (Hall)

(f).

i. Modiolopsis depressa n. $\mathrm{sp}$.

(r).

$\therefore$ Whitclla? sp. undet.

(f).

9. Bucania punctifrons Emm.

(r).

11. Tetranota bidorsata (Hall)

(r).

11. Liospira micula (Hall)

(r).

$1 \therefore$ Lophospira mediatis U. \& S.

(r).

1:. Hormotoma salteri Ulr.

(c).

1t. Orthoceras sp. undet.

(r). 
15. Isotelus gigas De Kay

16. Proetus latimarginatus n. sp.

1\%. Pterygometopus callicephalus (Hall) (f).

$174 \mathrm{~A}^{37}$. Dark, fossiliferous limestone.

1 ft. 2 in.

1. Lingula sp. undet. (r).

2. Rafinesquina alternata (Emm.) (c).

3. Plectambonites sericeus (Sow.) (c).

4. Dalmanella testudinaria (Dal.) (c).

5. Harpina ottawensis (Bill.) - (r).

6. Calymene senaria Con. (r).

$174 \mathrm{~A}^{38}$. Thin-bedded, fossiliferous, micaceous shale.

$1 \mathrm{ft}$.

1. Plectambonites sericeus (Sow.) (r).

2. Dalmanella testudinaria (Dal.) (c).

3. Plectorthis plicatella (Hall) (r).

$174 \mathrm{~A}^{39}$. Thin-bedded, shaley limestone, with flakes of mica. $1 \mathrm{ft} .2 \mathrm{in}$.

1. Plectambonites sericeus (Sow.) (r).

2. Dalmanella testudinaria (Dal.) (c).

3. Plectorthis plicatella (Hall) (r).

$174 \mathrm{~A}^{40}$. Dark, fossiliferous limestone, with mica flakes.

$1 \mathrm{ft}$.

1. Strophomena incurvata (Shep.) (r).

2. Rafinesquina alternata (Emm.) (c).

3. Dalmanella testudinaria (Dal.) (f).

4. Plectorthis plicatella (Hall) (f).

5. Zygospira recurvirostris (Hall) . (r).

6. Pterygometopus callicephalus (Hall) (f).

$174 \mathrm{~A}^{41}$. Soft, decomposed, shaley limestone.

6 in.

1. Dalmanella testudinaria (Dal.) (c).

2. Plectorthis plicatella (Hall) (r).

3. Proetus latimarginatus n. sp. (r).

4. Pterygometopus callicephalus (Hall) (r).

$174 \mathrm{~A}^{42}$. Hard, dark, fossiliferous limestone.

6 in.

1. Hindia parva Ulr.

(r).

2. Prasopora simulatrix UIr.

(r).

3. Lingula sp. undet.

(r).

4. Strophomena incurvata (Shep.)

(c). 
5. Rafinesquina alternata (Emm.) (c).

6. Dalmanella testudinaria (Dal.) (c).

\%. Plectorthis plicatella (Hall) (r).

S. Zygospira recurvirostris (Hall) (f).

9. Ctcnodonta sp. undet. (f).

10. Modiolopsis faba (Con.) (r).

11. Bucania punctifrons Emm. (r).

12. Liospira micula (Hall) (r).

13. Lophospira medialis U. \& S. (r).

14. Hormotoma salteri Ulr. (f).

15. Orthoceras sp. undet. (f).

16. Trinucleus concentricus (Eaton) (r).

1\%. Isotelus gigas De Kay (f).

18. Bumastus trentonensis (Emm.) (r).

19. Proetus latimarginatus n. sp. (f).

20. Calymene senaria Con. (r).

21. Pterygometopus callicephalus (Hall) (f).

$1 \% \pm A^{43}$. Dark, sparsely fossiliferous limestone.

11 in.

1. Lingula sp. undet. (r).

2. Strophomena incurvata (Shep.) (r).

3. Dalmanella testudinaria (Dal.) (f).

4. Plectorthis plicatella (Hall) (f).

5. Zygospira recurvirostris (Hall) (f).

6. Bumastus trentonensis (Emm.) (f).

$174 \mathrm{~A}^{44}$. Dark, fossiliferous limestone.

$1 \mathrm{ft}$.

1. Hindia parva Ulr.

2. Prasopora simulatrix Ulr.

(f).

3. Orbiculoidea lamellosa (Hall)

4. Strophomena incurvata (Shep.)

(f).

5. Rafinesquina alternata (Emm.)

6. Plectambonites sericeus (Sow.)

(r).

\%. Dalmanella testudinaria (Dal.)

(c).

8. Zygospira recurvirostris (Hall)

(f).

9. Ctenodonta nasuta (Hall)

(r).

10. Ctenodonta sp. undet.

(f).

11. Modiolopsis faba (Con.)

(r).

12. Whitella subtruncata (Hall)

(c).

13. Orthodesma canaliculata Ulr.

(r).

14. Bucania punctifrons Emm. 
15. Tetranota bidorsata (Hall) (r).

16. Orthoceras sp. undet. (r).

1\%. Trinucleus concentricus (Eaton) (r).

18. Harpina ottawensis (Bill.) (f).

19. Isotelus gigas De Kay (f).

20. Bumastus trentonensis (Emm.) (f).

21. Proetus latimarginatus n. sp. (f).

22. Platymetopus trentonensis (Hall) (r).

23. Calymene senaria Con. (r).

24. Pterygomctopus callicephalus (Hall) (r).

$174 \mathrm{~A}^{45}$. Dark, fossiliferous limestone.

$1 \mathrm{ft} .1$ in.

1. Hindia parva Ulr.

2. Lingula sp. undet.

3. Strophomena incurvata (Shep.) (r).

4. Rafinesquina alternata (Emm.) (r).

5. Plectambonites sericeus (Sow.) (r).

6. Dalmanella testudinaria (Dal.) (f).

\%. Plectorthis plicatella (Hall) (f).

8. Zygospira recurvirostris (Hall) (r).

9. Ctenodonta sp. undet. (r).

10. Cleidophorus neglectus Hall (r).

11. Protowarthia cancellata (Hall) (f).

12. Bucania punctifrons Emm. (f).

13. Eccyliomphalus trentonensis (Hall) (r).

14. Trinucleus concentricus (Eaton) (r).

15. Isotelus gigas De Kay (r).

16. Bumastus trentonensis (Emm.) (f).

17. Proetus latimarginatus n. sp. (r).

18. Cyphaspis trentonensis $\mathrm{n}$. sp. (r).

19. Calymene senaria Con. (f).

20. Pterygometopus callicephalus (Hall) (f).

$174 \mathrm{~A}^{46}$. Dark, fossiliferous limestone.

$1 \mathrm{ft} .6$ in.

1. Strophomena incurvata (Shep.)

2. Dalmanella testudinaria (Dal.) (f).

3. Plectorthis plicatella (Hall) (f).

4. Zygospira recurvirostris (Hall) (f).

5. Ctenodonta sp. undet. (f).

6. Cyrtodonta sp. undet. (r). 
7. Modiolopsis faba Con.

8. Bucania punctifrons Emm.

(f).

9. Protowarthia cancellata (Hall)

(r).

10. Lophospira medialis U. \& S.

11. Conularia trentonensis Hall

12. Trinucleus concentricus (Eaton) (r).

13. Isotelus gigas De Kay

(r).

14. Bumastus trentonensis (Emm.) ( $\mathrm{r}$ ).

15. Proetus latimarginatus $\mathrm{n} . \mathrm{sp} . \quad$ (r).

16. Proetus brevimarginatus $\mathrm{n} . \mathrm{sp}$. (r).

1\%. Calymene senaria Con. (r).

18. Pterygometopus callicephalus (Hall) (r).

$174 \mathrm{~A}^{47}$. Dark, fossiliferous limestone.

8 in.

1. Prasopora simulatrix Ulr.

(f).

2. Rhinidictya sp. undet.

(r).

3. Strophomena incurvata (Shep.) (r).

4. Rafinesquina alternata (Emm.) (r).

5. Plectambonites sericeus (Sow.) (c).

6. Dalmanella testudinaria (Dal.) (c).

\%. Platystrophia biforata (Schl.) (r).

8. Zygospira recurvirostris (Hall) (f).

9. Ctenodonta sp. undet. (r).

10. Modiolopsis faba (Con.) (c).

11. Orthodesma sp. undet. (r).

12. Bucania punctifrons Emm. (f).

13. Protowarthia cancellata (Hall) (f).

14. Tetranota bidorsata (Hall) (f).

15. Cyrtolites ornatus var. minor U. \& S. (r).

16. Liospira micula (Hall) (f).

17. Lophospira medialis U. \& S. (c).

18. Eccyliomphalus trentonensis (Hall) (r).

19. Orthoceras sp. undet. (r).

20. Trinucleus concentricus (Eaton) (r).

21. Isotelus gigas De Kay (f).

22. Proetus latimarginatis n. sp. (f).

23. Platymetopus trentonensis (Hall) ( $\mathrm{r}$ ).

24. Encrinurus trentonensis Walc. (r).

25. Calymene senaria Con. (f).

26. Pterygometopus callicephalus (Hall) (f). 
$174 A^{45}$. Dark, fossiliferous limestone.

1. Rafinesquina alternata (Emm.) (r).

2. Plectumbonites sericeus (Sow.) (c).

3. Dalmanella testudinaria (Dal.) (c).

4. Zygospira recurvirostris (Hall) (f).

5. Ctenodonta nasuta (Hall) (r).

6. Modiolopsis sp. undet. (r).

\%. Bucania punctifrons Emm. (r).

S. Liospira micula (Hall) (f).

9. Lophospira medialis U. \& S. (f).

10. Proetus latimarginatus 11. sp. (f).

11. Calymene senaria Con. (f).

12. Pterygometopus calliceplatus (Hall) (f).

$174 \mathrm{~A}^{49}$. Dark, sparsely fossiliferous limestone.

6 in.

1. Plectambonites sericeus (Sow.) (r).

2. Protowarthia cancellata (Hall) (r).

3. Pterygometopus callicephalus (Hall) (r).

$174 \mathrm{~A}^{50}$. Dark, sparsely fossiliferous limestone.

$\gamma$ in.

1. Plectumbonites sericeus (Sow.) (c).

2. Zygospira recurvirostris (Hall) (r).

3. Modiolopsis faba (Con.) (r).

$174 \mathrm{~A}^{51}$. Dark, sparsely fossiliferous limestone.

$1 \mathrm{ft}$.

1. Rafinesquina alternata (Emm.) (r).

2. Plectambonites sericeus (Sow.) (c).

3. Dalmanella testudinaria (Dal.) (r).

t. Lophospira medialis U. \& S. (r).

5. Calymene senaria Con.

6. Pterygometopus callicephalus (Hall) (r).

$174 \mathrm{~A}^{52}$. Dark, fossiliferous limestone.

$1 \mathrm{ft}$.

1. Rafinesquina alternata (Emm.) (c).

2. Plectumbonites sericeus (Sow.) (c).

3. Dalmanella testudinaria (Dal.) (c).

t. Zygospira recurvirostris (Hall) (f).

5. Ctenodonta sp. undet. (r).

6. Modiolopsis faba Con. (r). 
¿ Protowarthia cancellata (Hall) ( $\mathrm{r}^{\circ}$

๙. Liospira micula. (Hall) (r).

). Bumastus trentonensis (Emm.) (()).

10. Proetus latimarginatus n. sp. (1).

11. Proetus brevimarginatus n. sp. (r).

1 if $\mathrm{A}^{53}$. Dark. fossiliferous limestone.

1 it. 4 in.

1. Rafinesquina alternata (Emm.) (œ).

?. Plectambonites sericeus (Sow.) (1.).

:). Malmanella testudinaria (Dal.) (1).

t. Zygospira recurivostris (Hall) (t).

$\therefore$ Modiolopsis sp. undet. (1).

(i. Bumastus trentonensis (Emm.) (1).

$\therefore$ Proetus latimarginutus n. sp). (r).

19t $\mathrm{A}^{\text {it }}$. Dark. fossiliferous limestone.

sin.

1. Pectambonites sericeus (Sow.) (ai).

$\because$ Datmanella testudinaria (Dal.) (f).

B. Wodiolonsis faba (Con.) (1).

$1 \%+1.1$. Ditk. fossiliferous limestone.

1 fit. 3 in.

1. Pectambonites sericens (Sow.) (c).

$\because$ Malmanella testudinaria (Dal.) (f).

$\therefore$ Yyyospira recumirostris (Hall) (li).

1. Ctenodonta nasuta (Hall) (1).

․ Modiolopsis faba (Con.) (r).

1i. Bucania punctifrons Emm. (r).

¿. Protourarthia cancellata (Hall) (f).

S. Lophospira medialis L. \& S.

?. Orthocerus sp. undet. (I').

10. Proetus latimarginatus $\mathrm{n} . \mathrm{s}$ ). (1').

11. Proetus brevimarginatus n. si). (r).

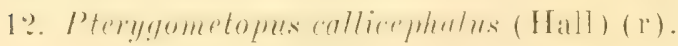

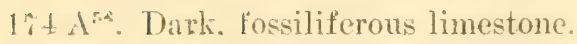

$1 \mathrm{ft} .1$ ill.

1. Rafinesquina alternata (Emm.) (i).

2. Plectumbonites sericews (Sow.) (f).

:. Dalmanella testudinaria (Dal.) (1).

4. Zygospira recuriostris (Hall) (f). 
5. Protowarthia cancellata (Hall) (f).

6. Lophospira mediatis U. \& S. (r).

7. Orthoceres sp. undet. (r).

8. Proetus latimarginatus n. sp. (r).

9. Encrimurus trentonensis Walc. (r).

10. Plerygometopus callicephalus (Hall) (f).

$174 \mathrm{~A}^{57}$. Dark, fossiliferous limestone.

1. Streptelasma corniculum Hall (r).

2. Rhinidictya sp. undet. (1).

3. Strophomena incurvata (Shep.) (r).

4. Rafinesquina alternata (Emm.) (s).

5. Plectambonites sericeus (Sow.) (c).

6. Dalmanella testudinaria (Dal.) (f).

\%. Zygospira recurvirostris (Hall) (c).

8. Ctenodonta sp. undet. (r).

9. Bucania punctifrons Emm. (f).

10. Protowarthia cancellata (Hall) (c).

11. Holopea sp. undet. (r').

12. Orthoceras sp. undet. (f).

13. Isotelus gigas De Kay (r).

14. Proetus latimarginatus n. sp. (f).

15. Platymetopus trentonensis (Hall) ( $\mathrm{r}$ ).

16. Encrinurus trentonensis Walc. (r).

1\%. Calymene senaria Con.

18. Pterygometopus callicephalus ( $\mathrm{H}_{\mathrm{all}}$ ) (t).

$174 \mathrm{~A}^{5 s}$. Dark, fossiliferous limestone.

1. Rafinesquina alternata (Emm.) (r).

2. Plectambonites sericeus (Sow.) (c).

3. Dalmanella testudinaria (Dal.) (c).

4. Zygospira recurvirostris (Hall) (f).

5. Bucania punctifrons Emm. (r).

6. Protowarthia cancellata (Hall) (r).

\%. Lophospira medialis U. \& S. (r).

8. Orthoceras sp. undet. (r).

9. Proetus latimarginatus n. sp. (f).

10. Encrinurus trentonensis Walc. (r).

11. Calymene senaria Con. (r).

12. Pterygometopus callicephalus (Hall) (r). 
$1 \hat{t}+\mathrm{A}^{59}$. Dark, fossiliferous limestone.

11 in.

1. Streptelasma corniculum Hall

(r).

2. Plectambonites sericens (Sow.)

3. Dalmanella testudinaria (Dal.)

4. Zygospira recurvirostiv (Hall)

5. Lophospire medialis U. \& S.

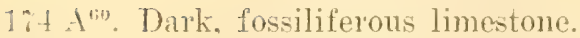

$11 \mathrm{in}$.

1. Hindia parva Ulr.

(f).

2. Rafinesquina alternata (Emm.) (r).

3. Pectambonites scriceus (Sow.) (c).

t. Dalmanella testudinaria (Dal.) (f.)

5. 'zygospira recurvirostris (Hall) (f).

6. Bucania punctifrons Emm. (r).

\% Protowarthia cancellata (Hall) (r).

S. Orthoceras sp. undet. (r).

9. Proetus latimarginatus n. sp. (f).

10. C'alymene senaria Con. (r).

11. Pterygometopus callicephalus (Hall) (f).

$1 \mathrm{\gamma}^{\mathrm{A}} \mathrm{A}^{61}$. Dark, fossiliferous limestone.

1. Rafinesquina alternata (Emm.) (r).

2. P'lectambonites sericeus (Sow.) (c).

3. Dalmanclla testudinaria (Dal.) (f).

4. Kygospira recurvirostris (Hall) (c).

5. (Yeidophorus sp. undet. (r).

6. Modiolopsis faba (Con.) (r).

$\therefore$ Bucania punctifrons Emm. (r).

8. Protowarthia cancellata (Hall) (r).

9. Orthoceras sp. undet. (r).

10. Proetus latimarginatus n. sp. (f).

11. Platymetopus trentonensis (Hall) ( $\mathrm{r}$ ).

12. Ceraurus pleurexanthemus Green (r).

In the accompanying table the data included in the preceding lists are recorded in another mamner. In the first column is given a list of all the species definitely identified from the beds in situ; following this there is a column reserved for each one of the separate beds. 

1. Hindia parva Ulr............................

Streptelasma corniculum

Romingeria? trentonensis $\mathrm{n} . \mathrm{sp}$

5. Actinosiroma trentonensis $\mathbf{n}$. sp.

6. Prasopora simulatrix UI

6. Prasopora simulatrix Ulr.......

8. Lingula riciniformis Hall

9. Schizocrania filosa (Hall)...

10. Schizocranza flosa (Hall)

11. Rafinesquina alternata (Emm.)

13. Plectambonites sericeus (Sow.)

14. Orthis tricenaria Con

15. Plectorthis plicatella (Hall)

16. Plalystrophia biforata (Schl

17. Dinorthis pectinella (Emm.)

18. Dalmanella testudinaria (Dal.)

19. Dalmanella suborquata (Con.)

20. Scenidium anthonensis Sard

21. Camarella inornata n. sp.........

22. Parastrophia hemiplicata (Hall)

24. Zygospira recurrirostris (Hall)

25. Clenodonta nasuia (Hall)

26. Clenodonta jerseyensis n. sp.

28. Cyrtodonta canadensis Bill.

29. Whitella subtruncata (Hall)

30. Modiolopsis faba (Con)

31. Modiolopsis jaba (Con.) ....

32. Modiolopsis jerseyensis n. $\mathrm{sp}$

33. Orthodesma canaliculatum U. U.

34. Goniophora curinatus (Hall)

5. Archinacella patelliformis (Haill)

36. Cyrtolites ornatus var minor U. \&

37. Protowerthin cancellata (Hall)

38. Tetranota bidorsata (Hall)...

39. Bucania punctifrons Emm.

41. Raphistoma peracuita U. \& S

42. Lophospira oweni U. \& S.

43. Liospira micula (Hall)

44. Hormotoma salteri U!r.

45. Eccyliomphalus trentonensis (Con.).

46. Conularia trentonensis Hall.

47. Orthaceras temuistriatum (Hail)

48. Harpina ottawensis (Bill.).............

49. Trimucleus concentricus

51. Ptychopyge jerseyensis n. sp....

52. Bumastus trentonensis (Emm.

53. Proetus latimarginatus n. sp .

55. Proetus brevimarginatus n. sp.

56. Bronteus lunatus Bill.

7. Platymetopus trentonensis (Hall)

58. Entrimurus trentomensis Walc.

59. Calymene senarin Con

60. Craurus pleurexanthemus Green

62. Plerygometopus intermedius (W Clarke

63. Plerygometopus callicephalus (Hall)

61. Leperditia fabulites (Con.)...

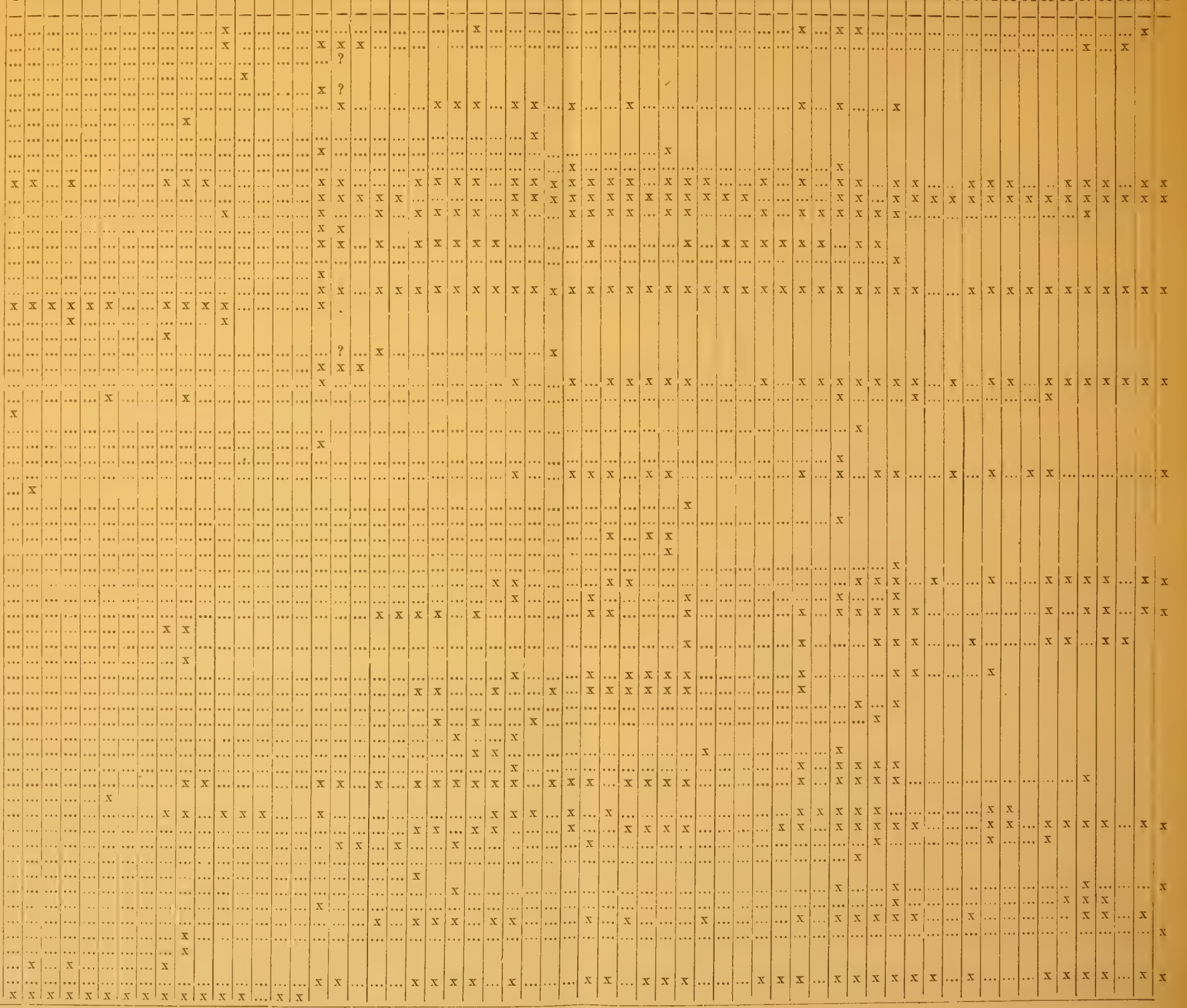


recognized in the Jacksonburg section, the species occurring in each bed being recorded in the column especially reserved for that bed. An examination of the table shows that the first sixteen beds, comprising a thickness of strata of fifty-eight feet and four inches, contain a fauna which is quite distinct from the faumas of the succeeding strata. The most characteristic species of this lower fauna are $\mathrm{Dal}$ munella subaquata and Leperdiliu fubuliles, and the beds containing it may be considered as represuting the Black Rirer limestone of the New York section. The beds from numbers $1 \%$ to 61 , inclusive, represent the Trenton limestone proper, and although there are several subordinate faunal zones recognizable, the beds, as a whole, are especially characterized throughout by Plectambonites sericeus, Datmanella testudinaria, Zygospira recurvirostris and Pterygometopus callicephalus. Only eight species pass from the lower horizon to the upper, and of these only three, Rafinesquina alternata, Isotelus gigas and Bumastus trentonensis, are conspicnous forms in both the lower and the upper faunas. The remaining five species are either comparatively rare, or, if normally members of the lower fauna, as Datmanella subcquata, occur, also, only in the base of the beds carrying the upper fauna; or they are initiated near the summit of the lower beds and become more abundant above.

Within the T'renton limestone proper a basal zone, including beds numbers 17 to 19 , inclusive, is especially characterized by the species Streptelasma corniculum, Actinostroma trentonensis, Orthis tricenaria, Dinorthis pectinella and Rhynchotrema incequivalvis. Just above this basal zone is another, with rather indefinite limits, which bears Parastrophia hemiplicata. The lower beds of the Trenton limestone proper are characterized by the special abundance of Plectambonites sericeus and the rarity of Dalmanella teshdinaria, but higher up the relative abundance of these two species is reversed. Dalmanella usually being the most conspicuous species in the faunas. In the higher beds the Pelecypod, Gastropod and 'Trilobite species become more conspicuous. In a general way the faunas of the section may be separated into three zones-the Black River horizon, the lower Trenton and the upper 'Irenton-the two lower zones being more sharply separated than the two upper ones.

The more or less isolated Trenton faumas which have been collected from other localities in the State can all be placed, in a general way, in one or the other of these three zones recognized in the Jackson- 
burg section, although there must of necessity be more or less mingling of the species from other localitics, because the material has in nearly all cases been collected from loose blocks of limestone on the surface. In the discussion of the 'Trenton faumas from clsewhere in the State they will be arranged geographically, those from the northernmost localities being first described, follower in order by the others, as nearly as possible, towards the sonth.

Locality $79 \mathrm{~A}$. - The northermmost locality from which a good Trenton fama has been secured in New Jersey is about seven-eighths of a mile a little west of north from Beaver Run, west of Hamburg. * At this locality the following species of fossils were collected:

1. Hindia parva Ulr.

?. Prasopora simulatix: Ulr.

3. Monotrypa globosa n. sp).

1. Callopora sp. undet.

r. Rhinidictya sp. undet.

ti. Phylloporina fenesteatu (liall).

i. Crania spe. undet.

s. Schicocmania filose (Hall).

؛. Lingula progne Bill.?

11. Rafinesquina alternata (Emm.).

11. Plectambonites sericeus (Sow.).

1:. Strophomena incurvata (Shep).).

13. Orthis tricenaria Con.

1+. Plectorthis plicatella Hall.

1.). Platystrophia biforata (Schl.).

14. Dalmanella testadinaria (1)al.).

1). Parastrophin hemiplicata (Hall).

1․ Zygospira nicoletti U. \& \&.

1!). Hormotoma salteri Uir.

?0). Comularia trentonensis 11 all.

$\because 1$. Cyrtoceras sp. undet.

․). Isotelus gigas De Kay.

?3. Bumastus trentonensis (Limm.).

-4. Platymetopus trentonensis (Ilail).

2.). Ceraums pleurexanthemus Green.

¿ti. Pterygometopus callicephalus (Hall).

* See locality marked 9, on Map No. 15, p. 69, Ann. Rep. State Geol. for 1900. 
The fossils secured from this locality were all collected from loose blocks of limestone, and doubtless came originally from several different beds. No representatives of the Black River fam occur, however, although both lower and upper Trenton species, such as Orthis tricenaria and Platystrophia biforata. are recorded. The locality is a promising one - the fossils being abundant and well preserved-and a careful study of the section, similar to that made at Jacksonburg, would undoubtedly shed light on the faunal succession in the New Jersey Trenton limestone.

Locality 79 B.-The next locality lies just a quarter of a mile east of Beaver Run, on the westerr side of the fault line, which is there present.* The following' species have been recognized:

1. Prasopora simulatrix Ulr.

2. Plectambonites sericeus (Sow.).

3. Strophomena incurvata (Shep.).

4. Dinorthis pectinella (Emm.).

5. Bumastus trentonensis (Limm.).

(i. C'alymene senaria Con.

This fauma undoubtally represents the lower 'Trenton horizon: The presence of Dinorthis pectinclla and the abundance of Plectambonites sericea, with the absence of Dalmanella testudinaria, are its distinctive lower Trenton features.

Locality 75 A.-Lying about three-fourths of a mile nearly due east from Branchvillef is one of the most interesting fossiliferous Trenton localities in the State, because, in the Hudson River shales, a short distance above the limestone, an interesting graptolite fauna occurs. The Trenton fossils which have been collected at this locality are as follows:

1. Streptelasma conniculum Hall.

2. Nyctopora billingsi Nich.

:Prasopore simulatrix $\mathrm{El}$.

t. Monotrypa sp. undet.

5. Callopora sp. undet.

6. Orbiculoidea lamellosa (IIall).

$\therefore$ Orbiculoidea? sp. undet.

S. Crania sp. undet.

9. Rafinesquina alternata (Emm.).

10. Plectambonites sericeus (Sow.).

* See Map No. 15, indicated in the previous footnote. † See Map No. 7, p. 52, Ann. Rep. State Geol. for 1900. 
11. Strophomena incurvata (Shep.).

12. Dinorthis pectinella (Emm.).

13. Platystrophia biforata (S'chl.).

14. Dalmanella testudinaria (Dal.).

15. Dalmanella subaquata (Con.).

16. Parastrophia hemiplicata (Hall).

17. Rhynchotrema incequivalvis (Castel.).

18. Cyclonema montrealensis Bill.

19. Isotelus gigas De Kay.

20. Calymene senaria Con.

With the single exception of Platystrophia biforata, which has been found in situ elsewhere only near the top of the Trenton limestonc, in the Jacksonburg secton, this entire fauna is strongly lower Trenton in aspect. The limestone at this locality, from which the fossils were collected, is more nearly in situ than in most of the Trenton localities studied, and there is but little doubt that the species all occurred together, in which case it must be assumed that Platystrophia biforata does, at times, but not often, oceur in the lower 'Trenton beds. The fossils were collected from the higher beds exposed at the locality, the lowel strata being highly conglomeritic with pebbles derived from the subjacent Kittatimu limestone. The Hudson River slates outcrop only a short distance abore the limestone stratum bearing the fossils, and it seems probable that the shale deposition began somewhat earlier than usual at this locality.

Locality 114 A.-The next locality is about one-half mile from Swartzwood station, on the west side of the road to Swartzwood.* At this point the lower. Trenton beds have been faulted in between masses of the older Kittatimy limestone, the beds being greatly sheared and the fossils being much distorted. The following species hare been recognized:

1. Receptaculites occidentulis Salter.

2. Streptelusmu comiculum Hall.

:i. Rhinidictya sp). molet.

t. Rafinesquina allernata ( $\mathrm{Emm}$.).

万. Orthis tricenaria (on.

6. Dalmanella suberquatu (con.).

$\therefore$ Modiolopsis sp. undet.

S. Helicotoma sp. undet.

9. Orthoceress. sundet.

* See locality marked 6, on Map No. 8, p. 54, loc. cit. 
10. Isotelus gigas De Kay.

11. Bumastus trentonensis (Emm.).

12. Calymene senaria Con.

13. Pterygometopus callicephalus (Hall).

14. Leperditia fabulites (Con.).

The fossils from this locality are practically in situ. The presence of such species as Streptelasma corniculum, Orthis tricenaria and Plerygometopus calliccphalus, associated with Dalmanella subaquata, Helicotoma sp. and Leperditia fabulites, indicates the position of the beds to be at the top of the Black River horizon or at the very base of the lower Trenton. Receptaculites occidentalis is an interesting species which was not found in the Jacksonburg section, but which occurs frequently in New Jersey, and seems to mark a faunal zone at the very summit of the Black River horizon.

Locality $135 \mathrm{~A}$.- This locality lies about one-fourth of a mile south of the slate quarry at Newton.* The fossils were collected from loose masses of limestone on a barren knoll in the midst of the cultivated fields, and the following species have been identified:

1. Prasopora simulatrix Ulr.

2. Rhinidictya sp. undet.

3. Plectambonites sericeus (Sow.).

4. Plectorthis plicatella (Hall).

5. Dalmanella testudinaria (Dal.).

6. Parastrophia hemiplicata (Hall).

¿. Zygospira recurvirostris (Hall).

8. Tetranota bidorsata (Hall).

9. Bumastus trentonensis ( $\mathrm{Emm}$.).

10. Calymene senaria Con.

11. Pterygometopus callicephalus (Hall).

This fauna indicates the middle portion of the Trenton limestone proper. The extreme basal Trenton species, such as Streptelasma cornicutum, Orthis tricenaria, Dinorthis pectinella and Rhynchotreme incequivalvis, are all absent, but Parastrophia hemiplicata, which characterizes the zone next above, is one of the common species, and is associated with Tetranota bidorsata, which occurs somewhat higher in the Jacksonburg section. From the nature of the locality fossils from more than one bed in the formation have become mingled in the collection.

* Near locality marked 14, Map No. 17, p. 75 , loc. cit. 
Locality 136 B.-One of the best localities in the State to collect from the lower 'Trenton horizon, is just at the north end of Drake's pond, one mile southeast of Newton. The following species have been identified from this locality:

1. Nyctopora billingsi Nich.

2. Prasopora simulatrix Ulr.

3. Rhinidictya sp. undet.

4. Lingulasma galenansis $\mathrm{U}$ \& $\mathrm{S}$.

5. Rafinesquina alternata (Emm.).

6. Plectambonites sericeus (Sow.).

i. Strophomeno incurvate (Shep.).

s. Orthis tricenaria Con.

9. Dinorthis pectinella (Emm.).

10. Platystrophia biforata (Schl.).

11. Datmanella testudinaria (Dal.).

12. Parastrophia hemiplicata (Hall).

13). Cyrtodonta billingsi []r.

14. Isotelus gigas De Kay.

15. Bumastus trentonensis (Emmis.).

16. Platymetopus trentonensis ( $\mathrm{Hall}$ ).

1\%. Calymene senaria Con.

18. Ceraurus pleurexanthemus Green.

19. Pterygometopus callicephalus (Hall).

'This group of species is strictly confined to the lower Trenton horizon, both the Orthis tricenaria and the Parastrophia hemiplicate zones being represented. None of the higher Trenton forms are present.

Locality 1:3\% 1.- This locality lies two miles southeast of Newton and one-half mile northwest of lliff's pond.* 'Two horizons are revognized here, the lower being on the top of the ridge, a short distance from the subjacent Kittatimy limestone beds, while on the lower slope of the hill, towards the northwest, fossils from a somewhat higher horizon were collected. The species identified from the lower bed at this locality are as follows:

1. Streptelasma corniculum Hall.

2. Actinostroma trentonensis n. sp).

3. Lingula sp. undet.

t. Strophomena incuriata (Shep.).

* Locality 24 , on Map No. 17 , p. 75 , loc. cit. 
5. Camarella inomata 1 . sp.

6. Rhynchotrema inaquivalvis (Castel.).

\%. Rhinidictya sp. undet.

S. Ctenodonta nasuta. (Hall).

9. Cyrtodonta? sp. undet.

10. Hormotoma salteri Ull.

11. Orthoceras sp. undet.

12. Bumastus trentonensis (Emm.).

13. Arges tuberculatus n. sp.

14. Calymene senaria Con.

15. Leperditia fabulites (Con.).

16. Leperditella ornata. n. sp.

1\%. Eurychitina oculifera n. sp.

18. Eurychitina jerseyensis 11. sp.

19. Beyrichia sp. undet.

Leperditia fabulites is by far the most abundant species in this fauna, a charactrastic which stamps it as belonging to the Black River horizon; but the presence of such species as Streptelasma rorniculum and Rhynchotrema inaquivalvis suggests that it occurs near the summit of the beds referable to that horizon.

From the higher beds at the same locality the following fauna was secured:

1. Prasopora simulatrix Uh:

2. Monotrypa sp. undet.

3. Rhinidictya sp. undet.

4. Callopora sp. undet.

5. Crania sp. undet.

6. Rafinesquina alteriata (Emm.).

7. Plectambonites sericeus (Sow.).

S. Strophomena incurvata (Shap.).

9. Platystrophia biforata (Schl.).

10. Dalmanella testudinaria (Dal.).

11. Scenidium anthonensis Sard.

12. Parastrophia hemiplicata (Hall).

13. Zygospira recurvirostris (Hall).

14. Orthoceras sp. undet.

15. Isotelus gigas De Kay.

16. Bumastus trentonensis (Emm.).

1\%. Proetus latimarginatus n. sp. 
18. Platymetopus trentonensis (Hall).

19. Encrinumus trentonensis Walc.

20. Calymene senaria Con.

21. Ceraurus pleurexanthemus Green.

22. Pterygometopus callicephatus (Hall).

This fam suggests a lower 'Trenton horizon, but is not from the lowest, or Orthis tricenaria, zone, as none of the species characteristic of that zone have been found, but it is rather from the next succeeding, Parastrophia hemipicata, zone. The rarity of the pelecypod and gastropod elements in the fauna exclude it from the upper Trenton.

Locality $158 \mathrm{~A}$.-Along the same line of outerop as the last locality, and at a point about one and one-fourth miles in a southwesterly direction," another collection was made from the Trenton limestone, and the following species have been identified:

1. Streptelasma corniculum Hall.

2. Prasoporu simulatrix: Ulr.

:. Monotrypa sp. undet.

4. Callopora sp. undet.

5. Rafinesquina alternata (Emm.).

6. Plectambonites sericeus (Sow.).

$\therefore$ Strophomena incurvata (Shep).).

8. Plectorthis plicatella (Hall).

9. Dalmanella testudinaria (Dal.).

10. Parastrophia hemiplicata (Hall).

11. Zygospira recurvirostris (Hall).

12. Bumastus trentonensis (Limm.).

13. Platymetopus trentonensis (Hall).

14. Encrinurus trentonensis Walc.

15. Pterygometopus cullicephalus (Hall).

The horizon here represented is essentially that of the upper fauna in the last locality, viz., the Parastrophia hemiplicata zone of the lower' 'Trenton.

Locality 158 B.-This locality is nearly one-half mile southwest of the last, along the same line of outcrop, and nearly opposite an abandoned slate quarry. The following species were collected:

1. Callopora sp. undet.

2. Rafuesquina alternata (Emm.).

3. Plectambonites sericeus (Sow.).

* See Map No. 17, loc. cit. 
4. Strophomena incurvata (Shep.).

5. Plectorthis plicatella (Hall).

6. Platystrophia biforata (Schl.).

\%. Dalmanella testudinaria (Dal.).

8. Zygospira recurvirostris (Hall).

9. Hormotoma salteri Ulr.

10. Bumastus trentonensis (Emm.).

11. Bronteus lunatus Bill.

This fauna seems to represent nearly the same horizon as the last, but in the absence of Parastrophia hemiplicata, may, perhaps, be considered as having come from a little higher up in the formation.

Locality $15 \%$ A.-This locality is in the roadside just above Mr. Wittingham's house, three miles southwest of Newton.* Thr. Trenton formation at this point is a highly calcareous shale, like that used in the State for the manufacture of Portland cement. The specio identified from here are as follows:

1. Prasopora simulatrix Ulr.

2. Rafinesquina alternata (Emm.).

3. Plectambonites sericeus (Sow.).

4. Strophomena incurvata (Shep.).

5. Dalmanella testudinaria (Dal.).

6. Zygospira recurvirostris (Hall).

\%. Isotelus gigas De Kay.

8. Bumastus trentonensis (Emm.).

9. Proetus latimarginatus n. sp.

10. Pterygometopus callicephalus (Hall).

This fama was collected from beds in situ, and represents a horizor higher in the formation than the Parastrophia hemiplicata zone. It may probably be safely placed in the middle portion of the Trenton limestone as represented in the Jacksonburg section.

Locality $156 \mathrm{~A}$.- This locality is on the same line of outcrop as the last, and about one mile to the southrest. $\uparrow$ The following species have been identified:

1. Receptaculites occidentalis Salter.

2. Streptelasma corniculum Hall.

3. Rhinidictya sp. undet.

4. Lingula sp. undet.

5. Rafinesquina alternata (Emm.).

* See locality 15 , Map No. 18 , p. 80 , Joc. cit.

$\dagger$ Locality A, Map No. 18, p. 80 , loc. cit. 

i. Plectumbonites sericeus (Sow.).
‘. Strophomena incurvata (Shep.).
$\therefore$ Dalmanella testudinaria (Dal.).
?. Dalmanella subequata (Con.).
10. Rhynchotrema incequivalris (Castel.)
11. Oxydiscus sp. undet.
12. IIelicotoma sp. undet.
13. Camaroceras proteiformis (Hall).
14. Isotelus gigas De Kay.
15. Bumastus trentonensis (Emm.).
16. Bumastus elongatus n. sp.
1\%. Platymetopus trentonensis (Hall).
18. Calymene senaria Con.
19. Leperditia fubutites (Con.).

The association of species in this list indicates a mingling of the Blatek River forms. such as Leperditia fululites and Inalmanella subarquata, with those from the lower zone of the Trenton, as Streptelasma comiculum and Rhynchotrema incequivalvis. The specimens were all collected trom loose blocks of limestone, which were doubtless originally derived from the upper Black River and the lower Trenton beds.

Locality 153 A. - This locality lies about two miles southwest of Stillwater and about one-quarter of a mile from Mud pond.* 'Tho following list of species were collected:

1. Receptaculites occidentalis Salter.

?. Streptelasma corniculum Hall.

:). Nyctopora billingsi Nich.

4. Romingeria? trentonensis n. sp.

$\therefore$ Actinostroma trentonensis n. sp.

i. Prasopora simulatrix Tlr.

$\therefore$ Rafinesquina alternata (Emm.).

$\therefore$ Plectambonites sericeus (Sow.).

!) Strophomena incurvata (Shep.).

10. Dinorthis pectinella. (Emm.).

11. Dalmanella testudinaria (Dal.).

1:. Datmanella subcequata (Con.)

1:i. Ctenodonta nasuta (Hall).

14. Hormotoma salteri $\mathrm{Clr}$.

15. Isotelus gigas De Kay.

*Locality A, Map No. 10, p. 60, loc. cit. 
16. Bumastus trentonensis (Emm.).

1\%. Pterygometopus callicephalus (Hall).

18. Leperditia fabulites (Con.).

The strata which have afforded the species recorded in the above list are undoubtedly the higher Black River and the lower Trenton beds, all of the species identified, except such as oceur throughout the Trenton limestone, being characteristic of this horizon.

Locality $153 \mathrm{~B}$.-This locality lies one mile southwest of the last, on the same line of outcrop, * and has fumished the following species, the horizon represented being the same as the last:

1. Receptaculites occidentalis Salter.

2. Streptelasma corniculum Hall.

3. Romingeria? trentonensis $\mathrm{n}$. sp.

4. Actinostroma trentonensis $\mathrm{n}$. sp.

5. Prasopore simulatrix Ulr.

6. Lingula sp. undet.

\%. Plectambonites sericeus (Sow.).

8. Dalmanella testudinariu (Dal.).

9. Dalmanella subaquata (Con.).

10. Rhynchotrema incequivalvis (Castel.).

11. Hormotoma salteri Ulr.

12. Bumastus trentonensis (Emm.).

13. Leperditia fabulites (Con.).

Locality 192 A.-This locality is near Hainesburg, on the hill just east of the station, $\uparrow$ and from it the following species have been identified:

1. Receptaculites occidentalis Salter.

2. Streptelasma corniculum Hall.

3. Romingeria? trentonensis n. sp.

4. Rafinesquina alternata (Emm.).

万. Dinorthis pectinella (Emm.).

6. Dalmanella suboquata (Con.).

i. Camarella inornata $\mathrm{n}$. sp.

$\therefore$ Rhynchotrema inaquivatvis (Castel.)

9. Cyrtodonta canadensis Bill.:

10. Hormotoma salteri Ulr.

11. Bumastus trentonensis (Emm.).

12. Leperditia fabulites (Con.).

* Locality C, Map No. 10, p. 60, loc. cit.

$\dagger$ Locality 7, Map No. 12, p. 64, loc. cit. 
This list is, for the most part, of Black River species, but with a few forms from the lowest Trenton. The horizon of the beds is upper Black River and basal Trenton.

Locality $243 \mathrm{~A}$.- This locality is in a small railway cut and quarry by the side of the Pennsylrania railroad, three-fourths of a mile north of the station at Belvidere." At this point there is only a small exposure of the limestone and the fossils are very poorly preserved, only the following three species being identified:

1. Actinostroma trentonensis n. sp.

2. Orthis tricenaria Con.

3. Bumastus trentonensis (Emm.).

The horizon indicated is the basal portion of the Trenton limestone proper.

Locality 244 A.-Another locality near Belvidere, which has furnished a few fossils, is a highly calcareous shale or slate, outeropping along the Pequest river, about one and one-quarter miles northwest of the town. $\uparrow$ The following species of fossils have been identified:

1. Prasopora simulatrix Ulr.

$\therefore$ Pafinesquina alternata (Emm.).

3. Plectambonites sericeus (Sow.).

t. Dalmanella testudinaria (Dal.)

5. Bumastus trentonensis (Emm.).

Tone of the species recorded from here are distinctive enough to characterize any particular horizon, further than to show it to be higher than the Black river. 'The most abundant species in the fauma is Plectambonites sericens; Dalmanella testudinaria being comparatively rare, a fact which would indicate the horizon to be in the lower portion of the Trenton limestone proper.

Other Localitics.-No collections of fossils capable of specific determination have been made from other localities of the 'Trenton limestone in the State, althongh in all of the areas of the formation indicated on the small maps in the Report of the State Geologist for 1900 , to some of which reference has been made, organic remains of some sort hare been detected. Broken fragments of crinoid stems are almost unirersally present in the limestones of the formation, and may also usually be found, by careful search, in the more calcareous bands of the calcareous shales which represent the higher portion of the formation.

The fossil fammas which have leen recorded in the preceding pages

* See Map No. 23, p. 93, loc. cit.

+ See Map No. 23, p. 93, loc. cit. 
nearly all indicate a lower Trenton or upper Black Rirer horizon, and it may doubtless be stated with safety that the heavier beds of limestone in the formation occupy this horizon. In no other locality in the State, aside from Jacksonburg, so far as has been observed, have the higher beds of the formation been represented by limestones. In most cases these beds seem to be calcareous shales, which rarely outcrop on the surface, and which grade imperceptibly from the limestones below into the typical Hudson river slates above. Sometimes. as on the Pequest river near Belvidere, the depasition of the calcareous shales seems to have begun earlier than usual, even as early as the lower Trenton horizon.

The numerous field observations by Dr. Kümmel indicate that the average thickness of the formation as a whole, from the contact with the Kittatinny limestone below to the transition into the typieal Hudson River slates, varies from 135 to 150 feet in Sussex county, but increases to 300 feet or more at the Delaware river; the relative thickness of the limestones below and the calcareous shales above is, however, probably quite variable-in some localities, as at Jacksonburg, the limestones extending through nearly the entire thickness of the formation, and again, being very thin, as in the neighborhood of Belvidere.

\section{HUDSON RIVER SLATES.}

The Hudson River slates constitute the surface formation over a large portion of the Kittatinny valley and occur, also, in some of the outlying paleozoic areas surrounded by the erystalline rocks. The formation rests conformably upon the Trenton limestone and is not sharply separated from it, there being a gradual gradation from the limestone of the lower formation, through calcareous shales, to the typical slates and arenacenus beds of the Hudson River formation. Because of the great amount of folding and faulting in the region the thickness of the formation has not been determined, but it may probably be safely stated to be several thousands of feet.

The name Hudson Rirer is here used strictly as a formation namu. these beds evidently being continuous with the great mass of contorted slates along the Hudson river in New York State, to which this name was first applied. The transition from the calcareous to the clay and sand sedimentation seems to have taken place earlier in the ancient Ordovician ocean, towards its eastern shore, in the region which is now Eastern New York and Northwestern New Jersey, and probably 
"ximbline southwestwatly along the Appalachians, than at Trenton Halls, in Central New York, where the Trenton limestone was first describul. The time of the lregimning of deposition of the Hudson River slates was previons to the close of the deposition of the typical Irenton limestone, so that the deposition of the lower portion of the Iludinn liver tomation wak contemporaneons with the 'Trenton limestone beds further west. The evidence in New Jersey of this relationship between the Hudson River and the Trenton formations is-first, the much less thichness of the Trenton limestone in New Jerser, where, exclusive of the lower beds of Black River age, it is less than one hundred feet, while at Trenton Falls, New York, it is two hundred and seventy feet and at some other localities very much more; and second, because the fossil faunas in the Trenton limestone of New Jersey, for the most part, represent only the lowest life zones of the formation.

Athough the age of the base of the Hudson River formation can ne determined with some degree of certainty by the faunas of the subjacent 'Trenton limestone, the age of the top of the formation in New.Jersey has not been deternined, because of the extreme rarity of organic remains in the formation. The formation may be the time equivalent, not only of a portion of the Trenton, but also of the Ttica and the Torrain formations of the New York series.

In the typical exposures of the Trenton limestone at Trenton Falls, New Tork, 280 feet have been recognized by Prosser and Cummings* and 268 feet by White, $\dagger$ but neither the bottom nor the top of the formation is exposed at this locality. Dana gives the thickness of the Trunton limestone at Montreal as 600 feet and west of Iahe Ontario as nearly 1,000 feet.

- The thickness of the Utica slate, giren by Dana, is 15 to 35 feet at Glen's Falls, 250 feet in Montgomery county and 30 feet in Lewis county, New York. Walcott|| gives the thickness of the same formation in its typical locality at Utica, New Iork, as over 600 feet. The Lormin shales have a thickness of $\% 00$ feet in Scoharie county, Now Tork, and a similar thickness in Western Canada aceording to D):

*Fifteenth Ann, Rep. N. Y. State Geol, p. 626.

† Fifty-first Ann. Rep. N. Y. State Museum; vol. I., p. 231.

\$ Man. Geol., 4th ed., p. 493.

3. Loc. cit., p. 494.

il Trans. Albany Inst, vol, X., p. I.

Ioc. cit., p. 494. 
If we tabluate the thickness of these several Ordovician formations as they occur in their more typical New York and Canadian exposures, comparing them with the New Jersey section, some such relations

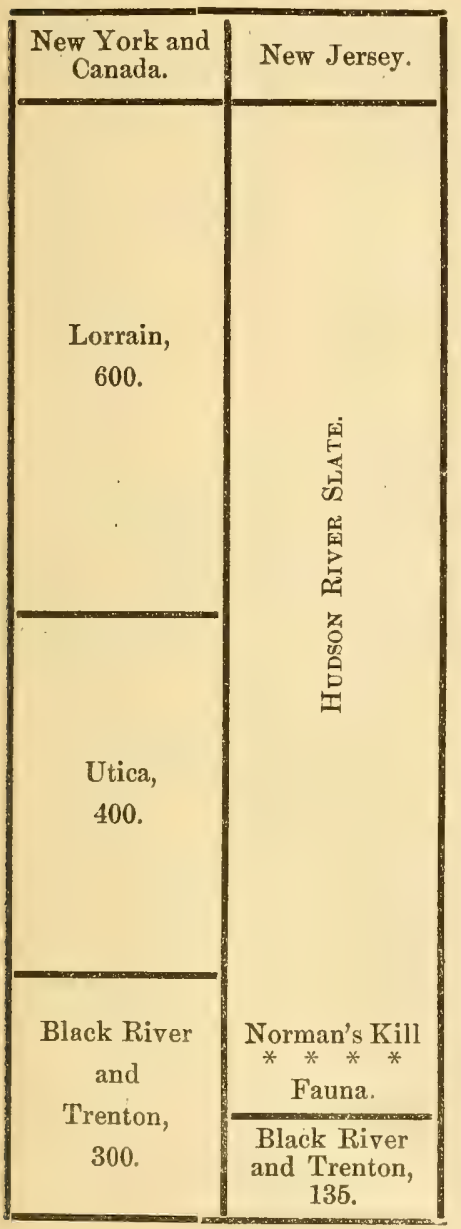

as are exhibited in the accompanying table may be shown. The thickness of the New York and Canadian formations used are somewhat arbitrarily chosen, but in all cases they have been under rather than overestimated. Winchell and Ulrich* have used greater thicknesses for the same formations in a comparison with more western localities. the 'Irenton being estimated as 450 feet, the Utica 460 feet and the Lorrain 825 feet.

The organic remains in the Hudson River formation are exceedingly rare, only three fossil localities having been observed in the State.

Locality 44 A. - This locality is in the flagstone quarry within the limits of the borough of Sussex. At this place the strata are nearly vertical in position and the fossils occur only in a thin bed but a few inches in thickness, which is exposed near the front of the quarry. This bed is a very calcareous sandstone, and is crowded with many specimens of a small variety of Plectambonites sericeus, with a few other species rarely represented. The fossils may be most easily detected in the weathered portions of the rock. The species which have been identified are as follows:

1. Cornulites sp. undet.

2. Plectambonites sericeus (Sow).

3. Plectorthis plicatella (Hall).

4. Dalmanella testudinaria (Dal.).

* Geol. and Nat. Hist. Surv. Minn., vol. III., pt. II., Paleontology, p. Ixxxix. 
None of these species has a very definite, stratigraphic value, as all of them have a long range in the Ordovician strata, so that they indicate nothing beyond the Ordorician age of the stratum in which they oceur.

Locatity 75 B.-This locality is on the hillside, a short distanceabove the Trenton limestone, Loeality $75 \mathrm{~A}$, three-fourths of a mile aast of Branchille. The fossils were collected in a small quarry opening in the slate, and have all been replaced by pyrite, their conclition of preservation being far from satisfactory. The species remornized are as follows: *

1. Diplograptus foliaceus (Murch.).

2. Diplograptus angustifolius (Hall).

3. Lasiograptus mucronatus ( $\mathrm{Hall}$ ).

t. Corynoides calycularis Nich.

\%. Dalmanella testudinaria (Dal.).

All of these graptolite species occur in the Nomman's Kill shate, near. Albany, New York, and all except Diplograptus foliacens, which has as. wide range in the Ordovician formations, are among the characteristic species of the Norman's Kill fauna, and are not known to oceur at any other horizon. The oecurrence of species of this graptolite fauma in New Jersey is of interest, because its exact geologic horizon in. New York has berm a question of much discussion. Different authors have placed the Norman's Kill shale in the Lorrain, the Utica and the Trenton periods of the Ordovician. An able discussion of the whole problem comnected with the Norman's Kill fauma, with a historical review of all earlier opinions, has been presented by Dr. liudolph Ruedemann, of Albany, Now Tork, in a paper entitled "Hudson River Beds Near Albany, and 'Their 'Taxomomic Equiralents." In this paper Dr. Ruedemann has shown that the strata inaring the Norman's Kill graptolite famal are "homotoxial with a? part of the middle or lower T'renton limestone." The occurrence of the fauna at Branchville seems to confirm the observations of Dr. linedemann. The stratum containing the fauna is near the base of the IIudson River formation, at an elevation of from fifty to serentyfire feet above a ledge of limestone, whose fauna is that of the Para-

* The author is greatly indebted to Dr. Rudolph Ruedemann, of Albany, for valuable assistance in the identification of the graptolites from both this locality and frons. the locality near Jutland.

$\dagger$ Bull. N. Y. State Museum, No. 42, vol. VIII. (1901). 
strophia hemiplicata zone (see page 39 ), near the base of the Trenton limestone. The sequence from the Trenton limestone to the Hudson River slates at this locality is normal for New Jersey, and there is no dislocation of the strata between the two exposures. Although no Trenton fauna has been found above the graptolite beds, their position, as indicated by their relationship with the Parastrophia hemiplicata beds below, would seem to be equivalent to about the middle portion of the typical Trenton limestone of Central New York, or even to a position below the middle.

Locality $348 \mathrm{~A}$.- This locality is near Jutland, in the large outlying area of Paleozoic rocks, with the town of Clinton near its centre, and which lies between the Pre-cambrian crystalline rocks on the north and the Triassic sandstone on the south. The fossils were collected in the first railroad cut cast of Jutland, on the Lehigh Valley railroad, about 340 yards east of Jutland station and 92 yards from the contact of the Triassic sandstone with the IIndson River beds. The geologic structure of the neighboring region is very complex, and the position of the fossil-bearing bed in the formation, as a whole, cannot be determined. The fossils collected have been identified as follows, all of them being graptolites:

1. Climacograptus phyllophorus Gurley.

2. Dicranograptus ramosus (Hall).

3. Conograptus gracitis ( Hall).

4. Reteograptus geinitzianus Hall.

Of these species all but Dicranograptus ramosus, which sometimes accurs in the Utica shale, are characteristic of the Norman's Kill fauna, and the bed bearing the fauna undoubtedly belongs near the base of the Hudson River formation. 


\title{
CHAPTER IV.
}

\section{FORMATIONS OF SILURLAN AGE.}

\author{
SHAWANGUNK-GREEN POND CONGLOMERATE.
}

The formation next above the Hudson River slates is best exhibited in the Kittatinny mountain, where it forms the erest of the ridge, dipping away to the northwest. 'The northward extension of this mountain in New York is known as the Shawangunk mountain, and in 18 to this formation wat named the shawangunk grit by Mather." The name Oneida was applied later by Vanuxem, $\uparrow$ in 1842, and has been the usual designation of the formation in New Jersey, but Wather's name has priority, and it seems best to retain it.

The formation consists of beds of coarse quartz conglomerate, the pebbles usually being white or yellowish in color, with a gray or reel matrix. Nowhere in New Jersey has the contact between this formation and the subjacent Hudson River beds been observed, but in the New York, Lake Wrie and Western railroad cut west of Otisville, in New York, the contact is well exposed, and the higher formation is seen to rest unconformably upon the lower. The thickness of the formation in the Kittatinny mountain has been estimated by Dr. $\mathrm{K}$ iummel to be 1.500 to 1,600 feet.

In the Green Pond mountain region a conglomerate very similar to that of the Kittatimy mountain forms the erests of Green Pond, (opperats and kanolis mombains. and restis monformably upun the? subjacent formation, which is sometimes the Kittatinny limestone and sometimes the Pre-cambrian erystalline rocks.

No organic remains have been detected either in the Shawangunk conglomerate of the Kittatinny mountain or in the Green Pond conglomerate, but the identity of the two formations seems to be assured. Both formations are rery similar lithologieally, both rest uneoniormably upon the underlying formations, both are succeeded by similar,

* N. Y. Geol. Surv., Fourth Ann. Rep., pp. 246-255.

† Geol. N. Y., pt. III., p. 75.

+Fifteenth Ann. Rep. N. Y. State Geol. for 1895 , vol. I., plate XX., opposite p. 444 . 
soft, red, arenaceous, more or less shaley, unfossiliferous beds, and in both regions the first fossil fauna, which appears in higher beds lying in a perfectly conformable series with the conglomerate beds, is identical.

The western side of the Green Pond paleozoic area is eut off by profound faults along its entire extent, and it is altogether probable thal. at the time of its deposition, the Green Pond conglomerate was continuous with the Shawangunk conglomerate of the Kittatinny mountain, and that it has been removed by erosion from the intervening Highlands and the Kittatinny valley.

\section{MIEDINA-LONGWOOD SANDSTONE.}

In the Delaware valley this formation cover's a large portion of the northwestern slope of the Kittatinny mountain, and doubtlens occupius the greater portion of the ralley lying west of the Wallpack ridge. although the surface rock is deeply drift-covered in the valley. The formation is a soft sandstone, which is often somewhat shaley and has a deep red color. It is absolutely barren of organic remains. It is impossible to determine its thickness accurately, owing to the indefiniteness in the field of its upper limits and numerous low folds and small faults which affect it. At the Delaware Water Gap 1,645 feet is given by the Pennsylvania Survey * as the thickness of the beds which we class as Medina, with ito feet additional not exposed. but probably belonging here-a total of 2,385 feet. An estimate by Dr. Kümmel, based on its dip and width of outerop near Poxino island, gave 2,305 feet.

This formation has always been referred to the Medina sandstone of the New York series, and although it cannot be considered as loing strictly equivalent to the typical Medina of Western New York, the name may be retained for the present or until the relationship between this formation in the Appalachian province with that in the interior is better understood.

In the Green Pond mountain region Darton thas called the formation overlying the Green Pond conglomerate, which is exactly similas. to the upper part of the Medina of the Delaware valley in its lithologis:

* Second Penn. Geol. Surv., Rep. G. 6, p. 340.

† Bull. Geol. Soc. Am., vol. V., p. 382 (1894). 
characters, the Longwood red shales, and it is possible that, with future studies upon the relationship between this fomation in New Jursey with the typical Medina, it may he found adrisable to use the name Longwoorl to include the beds of both the Green Pond and the Welaware valley region, as they were probably continuous at the time w deposition wrer the crytalline highlands and the Kittatinny valley. In the Green Pond region 19r. Kïmmel has estimated the thickness of the Longwood beds to be over 200 feet.

TIIE NEAHPASS SECTION.

'The formations lying above the Medina sandstone in New Jersey, with the exception of the Devonian formations younger than the Onondaga limestone and the Newfoundland grit, have their most. typical development in the Wallpack ridge. This ridge lies between the Kittatimy mountain and the Delaware river, extending in a northeast-southwest direction from the New York State line to the Wallmack bend in the Delaware river at Flatbrookville. At the north, just worth of the State line, the ridge is transected by the Clove brook. which drains the northern half of the valley between the Wallpack ridge and the Kittatinny mountain, and which empties into the Neversink river at Tri-States, New York, near the junction of the latter stream with the Delaware. The southern half of the valley betwen the ridge and the mountain is drained by Flatbrook. At the mouth of Flathrook, the J) laware river describes the great, sigmodial, Wallpack bend. ("ntting through the. Wallyack ridge, whose more southwestern extension is in the State of Pennsylvania.

'Hh' strita of the Wallpack ridge all dip, with some local exceptions, more or less sterply wo the northwest, so that in passing from the CloveWatbrook valley io the Delaware river younger and younger strata are encounterel. The northwestern slope of the ridge usually approximates more or less alowely to the dip of the strata, so that the complete section is usually exhibited in passing from the valley on the east to a little beyond the crest of the ridge.

Rock exposures are frequent throughout the entire length of the Wallparek ridge, and many of the strata are highly fossiliferous. The bost section for study, howrrer, is at the old William Nearpass quarry ant in the ridges lying heynd. on the farms of Sanford Nearpass and 
John Bigart, about two miles south of the New York State line. This Nearpass section is described in detail at this place, because it will be used as a basis for the descriptions of most of the following formations, with their faunas, of both Silurian and Deronian ages. In this section the actual succession of the beds can be worked out in greater detail than at any other locality on the Wallpack ridge, although in some cases particular beds are better exposed elsewhere. The continuous rock exposure in the Nearpass quarry bluff is about 150 feet, but between the top of this exposure and the main crest of the ridgo there are some $\% 00$ feet of strata which are not continuously exposed but whose harder layers make persistent outcrops.

Locality 2 A.-The Nearpass section, from below upward.

\section{Poxino Island Shate.}

$2 \mathrm{~A}^{1}$. Buff-colored or yellow, calcareous shale or shaley limestone, with dendritic markings along the joints and bedding planes. $1 \mathrm{ft}$.

\section{Bossardville Limestone.}

\& $\mathrm{A}^{2}$. Fine-grained thinly-bedded, gray or blue limestone. At times so thinly bedded as to be essentially a calcareous shale; the thin laminæ being frequently alternately light and dark gray, giving to the rock a banded appearance. $12 \mathrm{ft} .4 \mathrm{in}$.

\section{Decher Ferry Formation.}

\% $\mathrm{A}^{3}$. Highly fossiliferous, earthy, somewhat arenaceous limestone. $2 \mathrm{ft}$.

2 $\mathrm{A}^{4}$. Hard, blue or gray, crystalline limestone, with many fossils. $14 \mathrm{ft} .2 \mathrm{in.}$

2 $\mathrm{A}^{5}$. Fissile, calcareous, earthy shale, with some limestone bands. $6 \mathrm{ft} .9 \mathrm{in}$.

$2 \mathrm{~A}^{6}$. Hard, blue, crystalline limestone, similar to $2 \mathrm{~A}^{3}$. $s$ in. 
$2 \mathrm{~A}^{\top}$. Farthy shale, with bands of crystalline limestone. o in.

$3 \% \mathrm{ft} .4 \mathrm{in}$.

$2 A^{s}$. Rel, crystalline limestone, abundantly fossiliferous. $2 \mathrm{ft} .6 \mathrm{in}$.

$39 \mathrm{ft} .10 \mathrm{in.}$

$21^{9}$. Fissile, earthy shale, with some irregular limestone bands. $9 \mathrm{in.}$

$40 \mathrm{ft} . \mathrm{r}$ in.

$2:{ }^{10}$. Blue, erystalline limestone, with an abundance of fossils. Some beds are Jargely composed of broken crinoid stems. $\% \mathrm{ft} .4 \mathrm{in}$.

$47 \mathrm{ft} .11 \mathrm{in}$.

$\therefore 1^{11}$. Rather thick-bedded, calcareous shale, with thin bands of limestone. $\% \mathrm{ft} .3 \mathrm{in}$.

$55 \mathrm{ft} .2 \mathrm{in.}$

$2 A^{12}$. Thin and often irregularly bedded, coralline limestone, with an abundance of fossils. $6 \mathrm{ft}$.

$61 \mathrm{ft} .2 \mathrm{in}$.

2. $1^{13}$. Blue, crystalline limestone, in beds from six to ten inches thick, separated by shaley seans. Fossils fommon, many ostracodes. I ft.

65 ft. 2 in.

liontout Formation.

$2 \mathrm{~A}^{14}$. Earthy shale, with limestone bands. $3 \mathrm{ft.} 9 \mathrm{in.}$

$68 \mathrm{ft} .11 \mathrm{in.}$

$2 \mathrm{~A}^{15}$. Fine-grained, dark limestone. $6 \mathrm{ft} .4 \mathrm{in}$.

75 ft. 3 in.

$2 A^{16}$. Thin-bedded, calcareous shale. $1 \mathrm{ft} .6 \mathrm{in}$

$76 \mathrm{ft} .9 \mathrm{in}$.

$2 A^{17}$. Hard, fine-grained, blue or gray, brittle limestone. $2 \mathrm{ft} .3 \mathrm{in}$.

2. $1^{\text {in }}$. Thin-bedded, calcareous shale. if $\mathrm{ft} .3 \mathrm{in}$.

$8+\mathrm{ft} .3 \mathrm{in}$.

$\therefore 1^{19}$. Warthy limestone, weathering to a buff color. The "Pethstone" of Professor Cook's report. $5 \mathrm{ft} . \quad 89 \mathrm{ft} .3 \mathrm{in}$.

2. A"2. Thin-bedded, crumpled shale, with some bands of denser limestone. $15 \mathrm{ft}$.

$10+$ ft. 3 in.

\section{Mantius Limestone.}

$3 \mathrm{~A}^{21}$. Hard, bluish-hlack limestone. with some fossils: $2 \mathrm{ft}$.

$106 \mathrm{ft} .3 \mathrm{in.}$

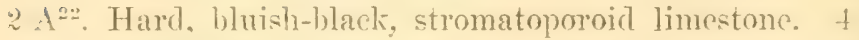

it. 6 in.

$110 \mathrm{ft} .9 \mathrm{in}$. 
$2 \mathrm{~A}^{23}$. Hard, bluish-black limestone, similar to $2 \mathrm{~A}^{21}$.

$1 \mathrm{ft} .6 \mathrm{in}$.

$112 \mathrm{ft} .3$ in.

$2 \mathrm{~A}^{24}$. Hard, bluish-black, semi-crystalline limestone, with many fossils. $5 \mathrm{ft}$.

$2 \mathrm{~A}^{25}$. Hard, nearly black limestone, with bands of fossils. $9 \mathrm{ft} .8 \mathrm{in}$.

$126 \mathrm{ft} .11 \mathrm{in}$.

$2 \mathrm{~A}^{26}$. Hard, fine-grained, knotty, blue limestone, with some bands of fossils. $12 \mathrm{ft}$.

$138 \mathrm{ft} .11 \mathrm{in}$.

Coeymans Limestone.

$2 \mathrm{~A}^{27}$. Coarser-grained, crystalline, gray limestone, with masses of Favosites. $10 \mathrm{ft} .3$ in.

$2 \mathrm{~A}^{28}$. Not exposed. $30 \pm \mathrm{ft}$.

$149 \mathrm{ft}$. 2 in. $180 \mathrm{ft}$

New Scotland Beds.

$2 \mathrm{~A}^{29}$. Hard, cherty limestone, abundantly fossiliferous. Tedge exposed just back of the Sanford Nearpass quarry. $20 \pm \mathrm{ft}$.

200 :ft.

$2 \mathrm{~A}^{30}$. Soft shale, with some limestone bands, mastly unexposed. Fossils numerous in some beds. $140 \pm \mathrm{ft}$. 340 ft.

\section{Becraft Limestone.}

$2 \mathrm{~A}^{31}$. Hard, dark or gray, cherty limestone, continuously exposed for about one-half mile along the crest of a low ridge back of the summit of the Nearpass quarry bluff. Abundantly fossiliferous. $20 \pm \mathrm{ft}$

$360 \mathrm{ft}$.

Kingston Beds.

$2 \mathrm{~A}^{32}$. Unexposed beds, probably more or less shaley.

$$
\mathrm{so} \pm \mathrm{ft} \text {. }
$$




\section{Oristany Formation.}

2 A Hard, more or less siliceous, gray or black limestone, with an abundance of fossils, many of which are trilobite fragments. The "Trilobite bed" of authors. Exposed continuously along the crest of the first high ridge back from the Nearpass quarry bluft. $30 \pm \mathrm{ft}$.

$2 A^{34}$. The Orbiculoidea jervensis bed, exposed in the Nearpass section only on the Werden farm next north of the Sanford Nearpass place, near the private road leading over the hill to the gravel pits. It is dark, siliceous limestone. $20 \pm \mathrm{ft}$. $+90 \mathrm{ft}$.

$2 \Lambda^{95}$. More or less earthy or siliceous limestone, usually unexposed. $120 \pm \mathrm{ft}$.

\section{Esopus Grit.}

$2 \Lambda^{36}$. Exposed in the ridges beyond the Trilobite ridge in the Nearpass section and forming the northwestern slope of the Wallpack ridge. It is a hard, siliceous, irregularly-cleaved slate, which has been greatly sheared, and forms the crest of the Wallpack ridge near the State line and also in Wallpack township. $400 \pm \mathrm{ft}$.

In this section the berls up to and including $2 \mathrm{~A}^{26}$ have been careinlly measurad with a tape line, and are all exposed in the bluff of the William Nearpass quarry. The higher beds do not present a comtimus outcrop, but are exposed at intervals back to the main crest of the ridge west of the quarry, upon the Sanford Nearpass farm and the Werien farm next north. The thickness given for most of thes: high:. loeds has had to be very roughly estimated, as they are exhibited only in isolated outerops for the most part, but the total thichness of thr New sootland beds and the Becraft limestone together has hern ustimated by Dr. Kümmel, as near as possible by numerous observations upon the dip of the strata and the width of the outerop, to lu: 180 feet, and the sum of the thicknesses given for these bedi) $I^{20}$ to $2 \mathrm{~A}^{31}$-is made to equal this amount. In the same manner the total thickness of the Led referred to the Kingston and Oriskany has been estimated at 250 feet. 
POXINO ISLAND SHALE.

The summit of the Medina formation in New Jersey has not been observed, but the lowest formation above that sandstone and having outcrops in the State is a buff or greenish, calcareous shale, irregularly bedded, in layers one inch or less in thickness. In the bottom of the Nearpass section about one foot of this rock is exposed in an excavation which has been made in the talus slope at the foot of the bluff. South of Hainesville is another exposure, where a quantity of the material has been excavated for road-making purposes. Other exposures occur at several points south of Wallpack Centre, but nowhere have fossils of any description been observed.

This formation was first described by I. C White,* from Pennsylvania, in the southwestern extension of the Wallpack ridge, but he observed no outcrops in New Jersey. The base of the formation has not been observed in New Jersey, but in Pennsylvania it is descritrect by White as resting upon a thin limestone formation, which, in turn, rests upon the Medina. It is said to be at least 200 feet in thicknese in Pennsylvania, but only a small fraction of this thickness is exposed anywhere in New Jersey.

BOSSARDVILLE LIMESTONE.

Lying above the Poxino Island shales is a fine-grained, compact, bluish-gray, banded limestone. It is exposed in the Nearpass section, in the excavation already mentioned, where its entire thickness is twelve feet four inches. From this point south to Peter's Valley but few outcrops are to be seen, but between Peter's Valley and Flatbrookville there are many excellent exposures. The thickness of the formation is greatly increased to the south, and although no exact measurements could be made, it is at least 100 feet thick below Wallpack Centre. This formation is without question a northward extension of the limestone in Pennsylvania, designated by Whitef as the Bossardville limestone. It is, also, the formation which was called the "Ribbon limestone" by Professor Cook, $\$$ and which was errone-

* Second Geol. Surv. Penn., Rep. G. 6, p. 145.

† Loc. cit.; p. 141.

$\ddagger$ Geol. of N. J., p. 156 (1868). 
"usly correlated by hin with the "Ribbon limestone" at Rondout, Now York, which is the Manlius or "Tentaculite" limestone lying alinve the Rondout waterline formation. This correlation of the Bostarlville limestone was also adopted by White in his Pennsylrania report. As a matter of fact, the age of the Bossardville limestrme is very much greater than that of the Nanlius limestone at Hendout, although the two formations are somewhat similar in lithologic characters. 'Th" Bossardville limestone itself is entirely barren of fossils, but it is followed by a series of beds which-are highly fossiliferous, containing a well-defined, Silurian fauna.

DECKER FERRY FORMATIOA.

In his report on Pike and Monroe comties, Pennsylvania, White has rescribed three formations succeding the Boswardville limestons. which he designates by the name Decker. Ferry, from the ferry of this name below Flathrookville-the Decker Ferry shate, the Decker Ferry sandstone and the Decker Ferry limestone. The first two of thes formations are closely allied, the so-alled shate being an altermation of thin sandstone beds with thin beds which are more calcareous, rather than a true shale. These two formations of White will here be induderl in a single division, and will be alled the Decker Ferry formation. The Decker Ferry limestone of White is quite distinct, both faunally and lithologically, from the Decker Ferry formation here recognized.

- At Flatbrookville and north to Peter's Valley this entire formation could legitimately be called a sandstone, but with many thin, calcareous bands, especially in the lower portion; but north of Peter's Valley the formation rapidly becomes more and more calcareous, until, in the Nearpass section, the whole formation is, for the most part, limestone, with some thin bands of more or less fissile, greenish shale. Only about two feet at the very base of the formation, immediately on top of the Bossardville limestone, show any indication of being arenaceous, and even this is an earthy limestone, with a small perrentage of siliceous matter, rather than a true sandstone.

In New Jersey the Decher Ferry formation is usually fossiliferous, sometimes highly so, but in many instances the fossils are poorly

* Second Geol. Surv. Penn., Rep. G. 6, pp. 137-141. 
preserved. Near the lime-hiln at Flatbrookville, in a bed a fraction of an inch in thickness, at the very base of the formation, there are numerous specimens of a species of Leperditia, which has been described in the present report as $L$. altoides $\mathrm{n}$. sp. This thin bed may be considered as lying at the contact of the Decker Ferry formation with the Bossardville limestone. In lithologic character it resembles the underlying heds, but is darker colored. It is followed for a few inches by an alternation of fine-grained limestone and more coarsely-grained, crystalline limestone, in layers less than an inch in thickness, the more crystalline lavers containing the typical fossils of the higher Decker Ferry beds.

The only complete exposure of the entire formation is in the Nearpass quarry bluff, and the Decker Ferry section at this locality, with its succession of fossil faunas, will be first described, after which the faunas of the formation from other localities will be discussed.

Locality 2 A.-William Nearpass quarry, two miles south of TriStates, New York.

$2 \mathrm{~A}^{3}$. Highly fossiliferous, earthy, somewhat arenaceous limestone, resting upon the Bossardville limestone.

1. Zaphrentis sp. mndet.

2. Monotrypa corrugata n. sp.

3. Pholidops ovata Hall.

4. Stropheodonta bipartita (Hall).

5. Orthothetes decherensis n. sp.

6. Chonetes jerseyensis Weller.

$\%$ Dalmanella postelegantula n. sp.

S. Rhynchonella decherensis $\mathrm{n}$. sp.

9. Rhynchonella agglomerata n. sp.

10. Atrypa reticularis (Linn.).

11. Reticularia bicostata (Van.).

12. Edmondia? decherensis n. sp.

13. Pterinea sp. undet.

14. Ptychopteria? subquadrata n. sp.

15. Mytilarca obliqua n. sp.

16. Goniophora sp. undet.

1\%. Straparollus sp. undet.

18. Loxonema sp. undet.

19. Orthoceras sp. undet.

20. Proetus? depressus n. sp. 
21. Dalmanites aspinosa 11. sp.

22. Undetermined ostracodes.

$2 \mathrm{~A}^{4}$. Hard, blue or gray, crystalline limestone, with many fossils, which are less perfectly preserved than those in the subjacent bed.

$14 \mathrm{ft} .1 \mathrm{jn}$.

1. Favosites sp. undet.

2. Monotrypa corrugata n. sp.

3. Stropheodonta bipartita (Hall).

4. Orthothetes deckerensis $\mathrm{n}$. sp.

5. Chonetes jerseyensis Weller.

6. Dalmanella postelegantula n. sp.

\%. Rhynchonella deckerensis n. sp.

8. Rhynchonella agglomerata $\mathrm{n}$. sp.

9. Atrypa reticularis (Linn.).

10. Reticularia bicostata (Van.).

11. Cyrtina magnaplicata n. sp.

12. Lichenalia? sp. undet.

13. Ptilodictya sp. undet.

14. Platyceras sp. undet.

$2 \mathrm{~A}^{5}$. Fissile, calcareous, earthy shale, with limestone bands. No fossils observed.

$6 \mathrm{ft} .9 \mathrm{in}$.

$2 \mathrm{~A}^{6}$. Hard, blue, erystalline limestone, similar to $2 \mathrm{~A}^{4}$.

Fossils poorly preserved.

$S$ in.

2. $A^{\top}$. Earthy shale, with bands of erystalline limestone.

Fossils in the limestone.

.) in.

1. Stropheodonta bipartita (Hall).

?. Chonetes jerseyensis Weller.

3. Rhynchonella agglomerata n. sp.

4. Bythocypris nearpassi n. sp.

$2 A^{8}$. Red, crystalline limestone; abundantly fossiliferous.

1. Farosites sp. undet.

2. Cladopora rectitineala $11 . \mathrm{sp}$.

3. Honotrypa corrugata n. sp.

4. Termipora sp. undet.

5. Ptilodictya frondosa n. sp.

6. Lichenatia sp. undet.

\%. Stropheodonta bipartita (Hall).

8. Leptana rhomboidatis (Wilck.).

9. Orthothetes decherensis n. sp. 
10. Chonetes jerseyensis Weller.

11. Orthis flabellites Foerste.

12. Dalmanella postelegantula n. sp.

13. Rhipidomella preoblata n. sp.

14. Pentamerus circularis n. sp.

15. Rhynchonella deckerensis $\mathrm{n}$. sp.

16. Rhynchonella agglomerata $11 . \mathrm{sp}$.

1\%. Atrypa reticularis (Linn.).

18. Spirifer sp. undet.

19. Undetermined pelecypod.

20. Calymene camerata Con.

$2 \mathrm{~A}^{2}$. Fissile, earthy shale, with some irregular limestone bands. No fossils observed.

$2 \mathrm{~A}^{10}$. Blue, more or less crystalline limestone, with an abundance of fossils.

1. Cladopora rectilineata $n$. sp.

2. Escharopora siluriana n. sp.

3. Stropheodonta bipartita (Hall).

4. Orthothetes interstriatus ( $\mathrm{Hall}$ ).

5. Orthothetes decherensis n. sp.

6. Leptæna rhomboidalis (Wilck.).

\%. Dalmanella postelegantula n. sp.

8. Rhynchonella agglomerata n. sp.

9. Atrypa? lamellata Hall.

10. Spirfer vanuxemi var. minor n. var.

11. Whitfieldella? sp. undet.

12. Mytilarca sp. undet.

13. Pterinea emacerata (Con.)?

14. Undetermined pelecypod.

15. Proetus pachydermatus Barrett.

$2 \mathrm{~A}^{11}$. Rather thick-bedded, calcareous shale, with thin limestone bands.

$2 \mathrm{~A}^{12}$. Irregularly bedded, coralline limestone, with an abundance of fossils.

1. Zaphrentis sp. undet.

2. Diphyphyllum integumentum Barrett.

3. Cladopora rectitineata $\mathrm{n}$. sp.

4. Favosites pyriformis (Hall).

5. Prismatophyllum inequalis (Hall).

6. Halysites catenularia (Linn.). 
\%. Stromatopora concentrica Goldf.

8. Monotrypa corrugata n. sp.

9. Spirorbis sp. undet.

10. Photidops ovata Hall.

11. Stropheodonta bipartita (Hall).

- 12. Leptana rhomboidalis (Wilck.).

13. Orthothetes interstriatus (Hall).

14. Rhynchonclla agglomerata $\mathrm{n}$. sp.

15. Wilsonia globosa n. sp.

16. Atrypa? lamellata (Hall).

12. Rhynchospira formosa (Hall).

18. Whitfieldella nucleolata (Hall).

19. Actinopteria reticulata n. sp.

20. Undetermined gastropod.

21. Proetus pachydermatus Barrett.

22. Calymene camerata Con.

23. Beyrichia sussexensis n. sp.

2t. Beyrichia barretti n. sp.

$2 \Lambda^{13}$. Blue, crystalline limestone, in beds from six to ten inches in thickness, with shaley partings between. Fossils common, many ostracodes.

1. Photidops ovata Hall.

$\therefore$ Phynchonella agglomerata n. sp.

:). Atrypa? lamellata Hall.

1. Whitfieldella nucleolata (Hall).

$\therefore$ Actinopteria sp. undet.

i. Undetermined pelecypods.

$\therefore$ Undetermined gastropod.

$\therefore$ Beyrichia perinflata n. sp.

9. Beyrichia jerseyensis 11. il).

10. Beyrichia nearpassi n. sp.

11. Beyrichia sussexensis n. sp).

12. Beyrichia decherensis $\mathrm{n}$. sp.

These faunas of the Decker Ferry formation in the Nearpass section may be readily arranged in several distinct life zones. The fauma, as a whole, including all of the subfaumas from the lowest to the highest, is ciperially waracterized hy Rhymehonelle agglomerata. In all of the fossiliferen herts this suecies is one of the common forms, and in some cases it occurs more abundantly than all other species combined. 
The lower strata of the formation, $2 \mathrm{~A}^{3}$ to $2 \mathrm{~A}^{7}$, inclusive, or all the beds up to the red limestone, are particularly characterized by the species which has been described as Chonetes jerseyensis. All of these beds which are fossiliferous at all, carry essentially the same fauna, and this life zone may be designated as the Chonetes jerseyensis zone.

The second faunal zone is essentially restricted to the red limestone bed $2 \mathrm{~A}^{8}$. The fauna of this bed has a character of its own, distinct from that of either the subjacent or superjacent strata-it being characterized by the large number of specimens of the bryozoan, Ptilodictya frondosa. The name of this species may be used for the designation of this faunal zone. In an earlier, preliminary report on these faunas* the writer identified this species with an Ohio species, Ptilodictya platyphylla Jas., which is, in reality, a member of the genus Phcenopora. but a microscopic study of the specimens has shown this identification to be incorrect, and has shown that the New Jersey specimens helong to an hitherto undescribed species. The earlier designation of this zone, then-Ptilodictya platyphylla zonehas to give way for the name Ptilodictya frondosa zone.

The beds lying above the Ptilodictya frondosia zone, up to and including $2 \mathrm{~A}^{13}$, are not characterized by one homogeneous fauna, althongh they are characterized throughout by the species Atrypa? lamellata and may, therefore, be lesiguated as the Atrypa lamellata zone. There are really three subzones here included-the first, or lower one, having its fauna typically represented in bed $2 \mathrm{~A}^{10}$; the second, in bed $2 \mathrm{~A}^{12}$, which is characterized by the great abundance of corals, and may be called the coralline zone, and the third, in bed $2 A^{13}$, characterized by the abundance of members of the ostracode genus Beyrichia, may be called the Beyrichia zone.

In most cases the Decker Ferry faunas, in whatever localities they have been found in the State, may be definitely referred to one or the other of these faunal zones recognized in the Nearpass section.

Locality $8 \mathrm{~A}$.- On the next farm south of that upon which the Tilliam Tearpass quarry is located, and in a southward continuation of the quarry bluff, the lower Decker Ferry beds are exposed. The following species of fossils have been identified from here:

1. Favosites sp. undet.

2. Monotrypa corrugata n. sp.

*Ann. Rep. State Geol. N. J. for 1899, p. 12. 
3. Stropheodonta bipartita (Hall).

4. Orthothetes deckerensis n. sp.

5. Chonetes jerseyensis Weller.

6. Dalmanella postelegantula n. sp.

\%. Rhynchonella deckerensis $\mathrm{n}$. sp.

8. Rhynchonella agglomerata n. sp.

9. Atrypa reticularis (Linn.).

10. Reticularia bicostata (Van.).

11. Edmondia? deckerensis n. sp.

12. Nucula? sp. undet.

13. Ptychopteria? subquadrata 11. sp.

14. Platyceras sp. undet.

15. Proetus? spinosus 11. sp.

16. Dalmanites aspinosa n. sp.

This fauna belongs in the Chonetes jerseycnsis zone of the formarinn, and is essentially identical with that from bed $2 \mathrm{~A}^{3}$ of the quarry r.tion, and the bed containing it is, perhaps, continuous with $2 \mathrm{~A}^{3}$.

Locality $15 \mathrm{~A}$.- On the farm of Mr. G. N. Cole, one and onefourth miles southeast of Brick House, the red limestone stratum of the Decker Ferry formation is well exposed near the road. No opportunity was afforded to secure a collection of fossils at this locality, but the presence of the characteristic species of the Ptylodictya frondosu zome was observed. I little search would douhtless bring to light ? rood fauna from here, and it is altogether probable that the faunas of the lower and of the higher life zones of the formation could also be detected.

Locality 15 B.-This locality is one and three-fourths miles northeast of Hainesville. At this point the Decker Ferry formation is not so well exposed as in the Nearpass section, and most of the fossils (.)llected were from masses of rock not in situ. The following species have been identified:

1. Monotrypa corrugata $\mathrm{n} . \mathrm{sp}$.

2. Ptilodictya frondosa $\mathrm{n}$. sp.

3. Escharopora siluriana n. sp.

4. Stropheodonta bipartita (Hall).

5. Rhynchonella decherensis $\mathrm{n}$. sp.

6. Rhynchonella agglomerata n. sp.

$\therefore$ Atrypa reticularis (Linn.).

8. Atrypa? lamellata Hall. 
In this list characteristic species from both the Ptilodictya frondosa zone and the Atrypa? lamellata zone are recorded, but they are not mingled in the same beds. The two zones are just as distinctly separated here as in the Nearpass section. Masses of the red limestone, with its typical Ptilodictya frondosa, are scattered about, but most of the loose material, as well as the ledges in situ, evidently belong to beds higher than the red limestone, in the Atrypa? lamellata zone. No evidence of the presence of the Chonetes jerseyensis fauna has been detected, and the lower beds of the formation bearing this fauna are doubtless more deeply drift covered than the others.

Locality 25 B.-In the fields one-half mile southwest of Hainesville many of the Silurian and Devonian formations are more or less well exposed. Towards the east the beds of the Poxino Island shale hare been excavated for road material; west of the exposure of this formation comes a ridge of Bossardrille limestone, and beyond that are exposures of the Decker Ferry formation. From a brownish sandstone, near the base of the formation at this locality, the following species were collected:

1. Monotrypa corrugata $\mathrm{n}$. sp.

2. Stropheodonta bipartita (Hall).

3. Orthothetes deckerensis n. sp.

4. Chonetes jerseyensis Weller.

5. Rhynchonella agglomerata n. sp.

6. Atrypa reticularis (Linn.).

\%. Reticularia bicostata (Van.).

8. Dalmanites sp. undet.

This fama is characteristically that of the Chonetes jerseyensis zone, as might be expected from its low position in the formation. No collections from the other portions of the formation have been made at this locality, but scattered over the surface on the summit of a low hill, the coralline bed was observed with an abundance of reathered coral masses of the same species as those in the Nearpass section. A careful study of the locality would undoubtedly furnish an abundance of excellent Decker Ferry fossils.

Locality 52 A.- In a bluff east of the road to Flatbrookville, and about one and three-fourths miles below Peter's Valley, the Decker Ferry formation is exposed through a thickness of more than righty feet, although the base of the formation is covered. The major portion of the beds at this locality are sandstones, but interstratified with the arenaceous beds there are occasionally thin bands of lime- 
stone, in which fossils occur in a sufficiently perfect state of preservation to be identified. From a thin limestone bed, fifty feet above the base of the exposure at this locality; the following species have been identified:

1. Escharopora siluriana 11. sp.

2. Stropheodonta bipartita (Hall).

3. Rhynchonella agglomerata n. sp.

t. Atrypa? lamellata Hall.

5. Whitfieldella nucleolata (Hall).

From another thin limestone band, twenty-five feet higher than the last, the following species have been identified:

1. Diphyphyllum integuinentum Barrett.

¿. Zaphrentis sp. undet.

3. Orthothetes interstriatus (Hall).

t. Whitfieldella nucleolata (Hall).

5. Leperditia sp. undet.

Both of these small groups of species indicate a horizon in the Alrypa? lamellata zone of the Decker Ferry formation. The lower one. eontaining the bryozon. Escharopora silurana, may be definitely referred to the lower beds of this zone, while the upper one suggests the coralline rone, although the corals are not so abundantly represented as they normally are in this life zone.

Locatity $71 \mathrm{~B}$.- This locality is on the road to Flatbrookville, about three-fourths of a mile below Wallpack Center. The rocks are exposed in ledges along the roadside and in the fields east of the road. The following species have been identified:

1. Monotrypa compata n. sp.

$\therefore$ Orthothetes decherensis $\mathrm{n}$. sp.

3. Chonetes jerseyensis $\mathbb{V}$ eller.

4. Rhynchonella, dectierensis $\mathrm{n}$. sp.

5. Rhynchonella agglomerata n. sp.

6. Atrypa reticularis (Linn.).

This fauna is characteristically that of the lower zone of the Decher Ferry formation, characterized by Chonetes jerseyensis.

Locality $90 \mathrm{~A}$. - This locality lies two and one-half miles below Wallpack Center, near the mill on Flatbrook, and is one of the rery few localities where the formation outcrops east of the stream. The following species have been collected, all of which indicate the chonetes jerseyensis zone of the formation: 
1. Zaphrentis sp. undet.

2. Monotrypa corrugata n. sp.

3. Chonetes jerseyensis Weller.

4. Rhynchonella agglomerata n. sp.

5. Atrypa reticularis (Limn.).

Locality 109 B.- It Flatbrookville, along the creck below the limekiln, the lower beds of the Decker Ferry formation are fincly exposed, and may be seen resting directly upon the Bossardville limestone. At this locality the beds contain a large amount of arenaceous material, but in the more or less calcareous beds intercalated in the sandstone, fossils are abundant, the commonest species heing (honeles jerseyensis. The species which have been identified from here are as follows:

1. Favosites corrugatus n. sp.

2. Monotrypa corrugate n. sp.

3. Stropheodonta bipartita (Hall).

4. Orthothetes decherensis $\mathrm{n}$. sp.

5. Chonetes jerseyensis Weller.

6. Dalmanella postelegantula $\mathrm{n}$. sp.

\%. Rhynchonella decherensis $\mathrm{n}$. sp.

8. Rhynchonella agglomerata 11. sp.

9. Atrypa reticularis (Limn.).

10. Reticularia bicostata (Van.).

11. Whitfieldella? sp. undet.

12. Undetermined ostracode:

At Flatbrookville the only Decker Ferry fauna which has been observed is that of the Chonetes jerseyensis zone, above described. It is possible that the higher faunas might be detected after a careful search, but the higher beds are highly arenaceous, with fossils rarely present or very poorly preserved.

Locality 167 A.-Outside of the Delaware valley the Decker Ferry formation occurs in the Green Pond mountain region, where it overlies the red, arenaceous, Longwood shales. In this region its thickness does not exceed forty or fifty feet. At the period of its deposition the formation was probably continuous across the interval between the Delaware valley and the Green Pond region, thimning out to the east, having since been removed by erosion. The most fossiliferous locality in the Decker Ferry formation of the Green Pond region is on the Cobb property, one and one-half miles south of Newfoundland, and the following species have been identified from there: 
1. Favosites comrugatus n. sp.

2. Monotrypa corrugata n. sp.

3. Chonetes jerseyensis Weller.

4. Orthis flabellites Foerste.

5. Rhynchonella decherensis 12 . si).

6. Rhynchonella agglomcrate 11. sp.

\%. Atrypa reticularis (Jimn.).

8. Dalmanites aspinosa n. sp.

Locality 187 A.-A second locality in the Green Pond region which has furmished fossils from the Decker Ferry formation is in an abandoned quarry at Lpper Longwool. and the following pecius have been identified:

1. Monotrypa corrugata n. sp).

2. Strophcolonta bipartita (Hall).

3. Chonetes jerseyensis Weller.

4. Orthis flabellites Foerste.

5. Rhynchonella decherensis n. sp.

6. Rhynchonella agglomerata n. sp.

\%. Atrypa reticularis (Tinn.).

The faunas at both of these Green Pond localities are typical of the lower or Chonetes jerseyensis zone of the Decker Ferry formation, and the higher fannas have not been anvwhere detected in the region. The only species of the fauna in the (ireen Pond region which dow not occur in the Chonetes jerseyensis zone of the Delaware valley is Orlhis flabellites, which, in the latter region, has been found only in the red limestone bed associated with the Ptilodictya frondosa fauma.

\section{Corretalion of the Declier Ferry Faunas.}

The following complete list of recognized species in all the faunal zones of the Decker Ferry formation will serve as a means of comparicon with other launas of Silurian age in America and elsewhere:

1. Diphyphyllum integumentum Barrett.

2. Prismatophyllum inequatis (Hall).

3. Favosites comugatus 11. sp.

4. Favosites pyriformis (Hall).

). Cladopora rectilineata n. sp.

6. IIalysites catenularia (Linn.).

¿. Monolrypa corrugata n. sp.

S. Plilodictya frondosa n. sp. 
9. Escharopora siluriana 11. sp.

70. Pholidops ovata Hall.

11. Stropheodonta bipartita (Hall).

12. Leptena rhomboidalis (Wilck.).

13. Orthothetes interstriatus (Hall).

i4. Orthothetes deckerensis n. sp.

15. Chonetes jerseyensis Weller.

16. Orthis flabellites Foerste.

$\because$ ¿. Dalmanella postelegantula n. sp.

18. Rhipidomella preoblata n. sp.

19. Pentamerus circularis n. sp.

20. Rhynchonella deckerensis $\mathrm{n}$. $\mathrm{sp}$.

1. Rhynchonella agglomerata n. sp.

22. Wilsonia globosa n. sp.

23. Atrypa reticularis (Linn.).

24. Atrypa? lamellata Hall.

25. Spirifer vanuxemi var. minor $n$. var.

26. Cyrtina magnaplicata n. sp.

2\%. Reticularia bicostata (Van.).

28. Rhynchospira formose Hall.

29. Whitfieldella nucleolata (Hall).

30. Edmondia deckerensis n. sp.

31. Pterinea emacerata (Con.).

32. Pteronites? subplana (Hall).

33. Ptychopteria? subquadrata n. sp.

34. Actinopteria reticulata n. sp.

35. Mytilarca obliqua n. sp.

36. Proetus pachydermatus Barrett.

3\%. Proetus depressus n. sp.

38. Proetus spinosus n. sp.

39. Calymene camerata Con.

40. Dalmanites aspinosa n. sp.

41. Leperditia altoides $\mathrm{n}$. sp.

42. Beyrichia sussexensis n, sp.

43. Beyrichia barretti n. sp.

4. Beyrichia perinflata n. sp.

45. Beyrichia jerseyensis n. sp.

46. Beyrichia nearpassi n. sp.

4: Beyrichia decherensis n. sp.

48. Bythocypris nearpassi n. sp. 
Of this list of forty-eight species, twenty-nine are described for the first time in the present report, and three of those previously described -Miphyphyllum intequmentum Barr., ('honetes jerseyensis Weller and l'outus pachydermatu: Barr.-Came originally from the Deckrr Ferry fauna of New Jersey, and have not been reported elsewhere. This leaves but sixteen species in the fama which may be used for direct comparison with other faunas. Of these sixteen species, sixl'rismutophyllum ineruulis ( Hall), stropheodonte bipartita (Hall), ()rthothetes interstriatus( $\mathrm{Hall}$ ), Atrypa? la melluta Hall, Whitfieldella mucleolata (Hall) and Calymene camerata Con.-were originally rescribed from the Coralline limestone of Eastern New York, and are characteristic of the fauna of that formation. Among these six species are to be found some of the most characteristic species of the Decker Ferry fama of New Tersey. Five of the sixteen species - Frarostes myriformis (Hall), Orthis flubellites Foerste, Reticularia bicostata (Tan.), Pterinea emacerata (Con.) and Pteronites subplana (Hall) - have been described from the Niagaran faunas of the interior of the continent, but of these the two pelecypods are, perhaps, somewhat doubtful, and the identification of Orthis flabllites is not entirely satisfactory. Reticularia bicostata has only been recorded from the extreme eastern extension of the Niagaran strata, in Oneida county, New York, and the beds of the Coralline limestone are known to extend as far west as Herkimer county, which is adjacent to Oneida comnty on the east, and it is possible that careful field work would show the species to be really a member of the Coralline fauna and not of the typical Niagaran fauna; at any rate, the species is not one of the typical Niagaran species of the interior of the continent. The identification of Favosites myriform is is entirely satisfactory, and it scems to be the only really good representative of the Western Niagaran fauna. Three additional species-Halysites catenularia (Limn.), Leptona rhomboidalis (Wilck.) and Atrypa reticularis (Limn.) - occur, also, in the Niagaran faunas of the west, but they are all so cosmopolitan in their distribution that their presence gives little assistance towards a definite correlation of any famm in which they occur. The association of the three species, however, is an excellent indication of the Silurian age of the fauna. Two speciesPhotidops ovata. Hall and Rhynchospira formosa Hall-have been identified with species normally occurring in the Helderbergian fanmas.

The eridence of these sixteen previously-described species, then, points most strongly to the Coralline age of the Decker Ferry fauna, 
and it is believed that the beds containing the upper faunal zone of the formation, characterized by Atrypa? lamellata, may be definitely rorrelated with the Coralline limestone of New York, and that the entire Decker Ferry formation is the southern extension of that formation. 'The coralline age of these beds was first recognized by Dr. S. T. Barrett,* a local geologist of Port Jervis, and to him credit. is due for the first announcement of the presence of strata in the New Jersey section referable to the Coralline limestone of Eastern New York.

Among the species which are unknown except in the Decker Ferry fauna we find forms more or less closely allied to Western Niagaran and to Helderbergian species, but there seem to be sufficient differences in all cases to constitute distinct species. Among the orthids, both Dalmanella postelegantula and Rhipidomella preoblata are intermediate in their characters between Niagaran and Helderbergian species. Rhynchonella deckerensis and Rhynchonella agglomerata are both probably ancestral to Helderbergian species. Wilsonia globost is of a Silurian type, the similar rhynchonelloids of the Helderbergian faunas being members of the genus Uncinulus. The small variety of spirifer vanuxemi, called var. minor, is closely allied to the typical form of the species, which is one of the most characteristic Manlius limestone species.

In his original description of the fauna of the Coralline limestome, Hall $\nmid$ considered these beds in Eastern New York to be the eastward extension of the Niagaran strata in the western portion of the State. The great dissimilarity between the Coralline or Decker Ferry fauna, however, and that of the Niagaran formations further west indicates that the strata containing the two faunas were deposited in two distinct basins of sedimentation, which were either entirely separaterl from each other by a land barrier or their connection was very slight or indirect. The great interior epicontinental sea of Niagaran time is believed to have had its connection with the oceanic waters by a northern passage through the Hudson bay.t The Decker Ferry fauna lived in a sea which has been called the Cumberland basin by Ulrich and Schuchert, \& which occupied a rather long and narrow area in the Appalachian region and had its' oceanic connection with the At-

* Ann. N. Y. Acad. Sci., vol. I, pp. $121-124$ (1878); Am. Jour. Eci. (3), vol. XV., pp. 370-372 (1878).

† Pal N. Y., vol. II., p. 321.

$\ddagger$ Jour Geol., vol. VI., pp. 692-703.

\& Rep. N. Y. State Pal. for 1901, p. 649. 
Intic in the neighborhood of Chesapeake bay. Although deposited in an entirely distinct basin, the Decker Ferry formation, as well as the -nbjacent beds down to the Medina formation. were probably concemporanenus with some portion or the whole of the Niagaran formations of the interior.

The incursion of faunas from the exterior into the Cumberland Jasin culminated with the Helderlergian faumas, and for that reason f'lrich and Sichuchert* have spoken of that chapter in the faunal history of North America, covering the history of the life of the ('mmberland basin, as the Helderhergian invasion. The earliest faunal vidence of this invasion in New Jersey is to be found in the Decher Ferry fomation, but further south, aceording to Drich and Schuchert, there are faunas belonging to this invasion older than the Decker Ferry of New Jersey.

The Decker Ferry fauna is allied to the Silurian faunas of the Alantic province, which extends along the Atlantic border in New Fugland and Eastern Canada, but sufficiently detailed study of these ustern Silurian famnas for detailed comparison with other faunas has never been made.

\section{RONDOUT FORAITIOX.}

In the Nearpass section the thirty-nine feet of strata lying above the Decker Ferry formation are referred to the Rondout formation. The beds consist of more or less earthy shales and limestones, which are usually sparsely fossiliferous, although in some beds qstracode 4.rustaceans belonging to the genus Leperditia are abundant. But a single specimen of a brachiopod has been found in these beds in New Jerey in comnection with the fueld investigations for the preparation of this report.

Locality 2 A.-At the Nearpass quarry the following section of these beds, with the for-ils identifed from them. has been recognized: $\approx \mathrm{A}^{14}$. Earthy shale, with limestone bands.

$3 \mathrm{ft} .9 \mathrm{in}$.

1. Leperditia sp. undet.

$2 \mathrm{~A}^{15}$. Fine-grained, dark limestone.

$6 \mathrm{ft} .4 \mathrm{in}$.

1. Leperditia elongata n. sp.

$2 \mathrm{~A}^{16}$. Thin-bedded, calcareous shale, with no fossils.

1 ft. 6 in.

$2 \mathrm{~A}^{1 \tau}$. Hard, fine-grained, blue or gray, brittle limestone.

2 ft. 3 in.

1. Hyatella lamellosa n. sp.

2. Leperditia gigantea n. sp.

* Loe. cit., p. 648. 
$2 \mathrm{~A}^{18}$. Thin-bedded, calcareous shale.

$5 \mathrm{ft} .3 \mathrm{in}$.

1. Leperditia alta (Con.)?

$2 \mathrm{~A}^{19}$. Earthy limestone, weathering to a buff color. The

"Peth stone" of Professor Cook's report. $5 \mathrm{ft}$.

1. Undetermined foraminifera or ostracodes. $2 \mathrm{~A}^{20}$. Thin-bedded, crumpled shale, with some bands of denser limestone.

$15 \mathrm{ft}$.

1. Leperditia alta (Con.).

This formation occurs at various localities throughout the entire: length of the Wallpack ridge in New Jersey, but it is usually covered in the sections, and no detailed study of it has been made, except at the Nearpass quarry.

The original definition of the Rondout formation by Clark and Schuchert* is not entirely satisfactory. At Rondout, New York, where the typical section of the formation occurs, there are two. cement beds quarried or mined, which are separated by a series of strata which do not possess the necessary properties for the manufacture of cement. Clark and Schuchert seem to have included this. entire series of strata - the lower cement bed, the intermediate beds. and the upper cement bed-in their Rondout formation. The intermediate beds are not abundantly fossiliferous, but a careful search during a short risit to the locality brought to light several species, all of which are characteristic of the Decker Ferry fauna of New Jersey, and it is believed that the strata separating the two cement: beds at Rondout are to be considered as an extension of the Coralline limestone of New Tork and of the Decker Ferry formation of New Jersey. In this case the lower cement bed at Rondout may be directly correlated with the Bossardville limestone of New Jersey, which leares only the upper cement bed to be included under the name Rondout formation, and it is in this restricted sense that the name of the formation is used in the New Jersey section. The beds lying between the Decker Ferry formation below and the Manlius limestone above are believed to be the southern extension of the upper cement bed at Rondout. In its southern extension the cement bed proper has become reduced in thickness, so that in the Nearpass section it is represented only by bed $2 A^{19}$, which was described by Professor Cookt as the "Peth stone," but with the thinning of the cement bed proper, to the south, the associated shales and limestones have become increased in thickness.

\footnotetext{
* Sci. N. S., vol. X., No. 259, pp. 874-878, and Am. Geol., vol. XXV., p. 119.

† Geol. N. J., 1868, p. 159.
} 
The fauna of the Rondout formation, made up almost exclusively of members of the genus Leperditia, is a peculiar one, and must indicate some peculiar conditions of environment, but what these conditions may have been we do not know.

MANLIUS LIMLSTONE.

The Manlius, or "Tentaculite," limestone of the older New York reports is a somewhat thinly-bedded, lnotty, dark blue or almost black limestone. It is the bed which constitutes the quarry stone, and its outcrop may be traced throughout the entire length of the Wallpack ridge in New Jersey by the line of active or abandoned quarries and lime-kilns, its upper portion being the only limestone which is extensively used in this portion of the State for the mamufacture of lime. The total thickness of beds in the Tearpass section referable to the formation is thirty-four feet and eight inches.

The fauma of the Manlius limestone is not a large one. Ostracodes still persist, but associated with them in some beds are several species and many indiriduals of brachiopods, with some gastropods and phecrpods and an occasional cephalopod. Specimens of Tentaculites, which are so abundant in this formation at some localities in New York State, and which gave rise to the older name of the formation, are among the rarest members of the fauna in New Jersey. One of the most characteristic speres of the fauna, although it has not been noticed in the lowest beds, is Spirifer vanuxemi, and the life zont represented hy the Manlins Jimestome may le called the spirifor vanuxemi zone.

Locality 2 A.- In the Nearpass quarry, where this formation has been studied in most detail, several beds have been recognized, as shown in the following section, and from each bed the species enumerated were collected:

$2 A^{21}$. Hard, bluish-black limestone.

1. Stromatoporoid masses.

2. Megambonia aviculoidea Hall.

:). Leperditia alta (Con.).

t. Beyrichia sp. undet.

$2 \mathrm{~A}^{22}$. Hard, bluish-black stromatoporoid limestone. $4 \mathrm{ft} .6 \mathrm{in}$.

1. Stromatoporoid masses.

$\because$ Leperditia alta (Con.).

3. Beyrichia mantionsis $\mathrm{n}$. sp. 
$2 \mathrm{~A}^{23}$. Hard, bluish-black limestone, similar to $2 \mathrm{~A}^{21}$.

$1 \mathrm{ft} .6 \mathrm{in.}$

1. Leperditia alta (Con.).

$2 \mathrm{~A}^{24}$. Hard, bluish-black, semi-crystalline limestone, with many fossils.

1. Stropheodonta varistriata (Con.).

2. Spirifer vanuxemi Hall.

3. Megambonia aviculoidea Hall.

4. Holopea antiqua (Van.).

5. Tentaculites gyracanthus (Eaton).

6. Undetermined cephalopod.

\% Leperditia alta (Con.).

8. Beyrichia kümmeli n. sp.

$2 \mathrm{~A}^{25}$. Hard, nearly black limestone, with bands of fossils.

!) ft. s in.

1. Stropheodonta varistriata (Con.).

2. Centronella? biplicata $\mathrm{n}$. sp.

3. Spirifer vanuxemi Hall.

4. Undetermined pelecypod.

5. Beyrichia smocki n. sp.

$2 A^{26}$. Hard, fine-grained, knotty, blue limestone, with some bands of fossils.

1. Stroplieodonta varistriata (Con.).

2. Rhynchonella sp. undet.

3. Centronella? biplicata n. sp.

4. Spirifer vanuxemi Hall.

ร. Undetermined gastropod.

6. Orthoceras sp. undet.

$\therefore$ Beyrichia montiguensis $11 . \mathrm{sp}$.

No collections of fossils have been made from the Manlius limestone at other localities, but the same species, especially Spirifer vanuxemi, Stropheodonta varistriata and Leperditia alta, have frequently been observed elsewhere. In a former preliminary report on the faunas of the Wallpack ridge * the Manlius limestone was associated with the superjacent Helderbergian formations rather than with the subjacent formations, but the transition from the Rondout to the Manlius is so gradual, both stratigraphically and famally, that it has proved to be difficult to draw a sharp dividino. line at this horizon.

* Ann. Rep. N. J. State Geol, for 1899. 
The conditions which obtained in the region under discussion during the time of deposition of the Rondout formation were peculiar, as is shown by the almost entire absence of all organisms except ostracodes belonging to the genus Leperditia. In the earlier report it was suggested that these ostracode faunas in some way representer? the Eurypterus fauna of the "waterline" formation of Western New York, but it now seems clear that the New Jersey formations of this perion were deposited in a distinct basin, which probably had no rirert connection with the contemporaneous interior sea. It is posible that these Leperditia faunas lived under non-marine, perhap: brackish water conditions, as was formerly suggested, although these (nnditions may have been more or less local, and may not have existed throughout the entire Cumberland basin. At any rate, in that portion of the Cumberland basin which is now included in New. Tersey, the conditions were not favorable during Rondout time for the existences of the typical marine faunas of the period, with an abundance of brachiopods, trilobites, \&c. Brachiopods did exist, however, in thi. portion of the Cumberland basin at this time, though rarely, as is shown by the presence of Hyattella? lamellosa.

In the lower beds of the Manlius limestone there is evidence of environmental conditions similar to those of the Rondout. Leperditir still remains the most common form of life, but associated with this ostracorle are other organisms, especially stromatoporoids, and an occasional pelecypod. In the middle portion of the formation Leperditic is still abundant, but is associated with a brachiopod fauna prolific in individuals, which suggests the recurrence of more typical marine conditions of environment. In the upper beds of the formation Leperditia has entirely disappeared and the fauna has assumed an "ntirely normal marine aspect. In this fama the most characteristic species is Spirifer vanuxemi, which was represented by a varietal form in the Decker Ferry fauna.

The greatest faunal change is to be found in passing from the Vanlius to the Coeymans limestone, and the Coeymans fama represents the first distinctive immigration of an important, typically marine fauna into the northern portion of the Cumberland basin since its occupation by the Decker Ferry faunas. The importance of this immigration seems to be sufficient to be recognized as the hegimning of the period which we call Dewonian time, the Coeymanc fauna being the earliest of the Helderbergian faunas in America, all of which have distinctively Devonian characteristics. 


\title{
CHAPTER V.
}

\section{FORMATIONS OF DEVONIAN AGE.}

\author{
COEYMANS LIMESTONE.
}

The Helderbergian faunas in New Jersey do not differ essentially from those in New York. The same faunal zones are recngnized, and nearly all of the species identified are New York forms, which are in no way different from specimens occurring in the typical Helderbergian localities.

The Coeymans limestone is the first of the Helderbergian formations, and in the Nearpass section it has an estimated thickness of forty foet, though only the lowermost beds are actually exposed. It lies upon the Manlius limestone, in the top of the Tearpass bluff, differing from the subjacent formation in its coarser and more crystalline texture and in its lighter color. Frequently more or less chert is mingled with the limestone. The lithologic transition from the Manlius to the Coeymans limestone is not abrupt, but is accomplished within a thickness of a few feet.

The Coeymans fauna is far more prolific than that of the Manlius limestone, and has an altogether different composition. The most characteristic species of the fauna, wherever it occurs, is Gypidula galeata, and the faunal zone included in the Coermans limestone may be spoken of as the Gypidula galeata zone. In the basal portion of the formation there are frequently numerous masses of the coral, Favosites helderbergia, usually more or less completely silicified, associated with masses of a concentrically laminated stromatoporoid. This coral bed in the Coeymans limestone of New Jersey is doubtless the southern extension of the coralline bed at the base of the same formation in New York.

No complete section of the Coeymans limestone has been exposed in New Jersey, and usually it is the lower portion of the formation which is exposed in the outcrops. If the beds could be studied in detail throughout the entire thickness of the formation several sub- 
ordinate faunal zones might possibly be detected, but the exposures in New Jersey are nowhere sufficiently continuous to afford such a detailed study as it has been possible to make with the lower beds of the Nearpass section.

Locality $2 A^{27}$. - The Coeymans fauna at this locality was collected from the basal ten feet of the formation at the top of the Nearpass quarry bluff. The following species of fossils have been identified:

1. Favosites helderbergice Hall.

2. Stromatopora concentrica Goldf.

3. Ptilodictya lobata n. sp.

4. Lichenalia torta Hall.

5. Monotrypa spherica (Hall).

6. Stropheodonta varistriata (Con.).

7. Strophcodonta planulata Hall.

S. Strophonella punctulifera (Con.).

9. Gypidula galeata (Dal.).

10. Rhynchonella semiplicata (Con.).

11. Rhynchonella transversa Hall.

12. Uncinulus mutabitis (Hall).

13. Atrypa reticularis (Linn.).

14. Spirifer cyclopterus Hall.

15. Meristella lavis (Tan.).

16. Actinopteria communis (Hall).

1\%. Platyceras sp. undet.

18. Tentaculites elongatus Hall.

19. Proetus protuberans Hall.

- 20. Dalmanites pleuroptyx (Green).

Locality 15 C.-At a single locality, one and three-fourths miles northeast of Hainesrille, a fauna has been collected which is believed to belong at the very summit of the Coeymans limestone. A varietal form of Gypidula galeata occurs at this locality, as well as another form of the genus, which seems to be specifically distinct from the shell which occurs in the lower beds. The following species of fossils have bean identified from this locality:

1. Zaphrentis romeri E. \& H.?

2. Favosites helderbergic Hall.

3. Cladopora multiseriata n. sp.

4. Cornulites cingulatus Hall.

5. Lichenalia torta Hall? 
6. Fenestella sp. undet.

\%. Gypidula galeata (Dal.) var.

8. Gypidula angulata n. sp.

9. Rhynchonella altiplicata Hall.

10. Uncinulus pyramidatus (Hall).

11. Rhynchotreta transversa $\mathrm{n}$. sp.

12. Atrypa reticularis (Linn.).

13. Spirifer octocostatus Hall.

14. Spirifer concinnus Hall.

15. Cyrtina sp. undet.

16. Rhynchospira formosa (Hall).

1\%. Meristella loevis (Van.).

18. Nucleospira ventricosa Hall.

19. Rhombopteria clathratus n. sp.

20. Actinopteria communis (Hall).

21. Butimorpha? helderbergce n. sp.

22. Loxonema? sp. undet.

23. Platyceras gibbosum Hall.

The composition of this fauna is quite different from any of those which have been studied from the lower beds of the Coeymans limestone. Its most conspicuous characteristics are-first, the entire absence of the genera Stropheodonta and Strophonella, which are usually among the commonest species of the Coeymans limestone; and second. the increased representation of the genus Spirifer, which is usually rare in the Coeymans fauna. In this last character the fauna approaches that of the superjacent New Scotland beds, where the specie: of Spirifer are among the commonest members of the fauna. Because of the presence of Gypidula, hotrever, and especially of a varietal form of Gypidula galeata, the strata containing this fauna are retained in the Coeymans limestone.

Locality 37 A.-This locality is in the hillside, just abore the large spring, a little orer one-half mile northeast of Peter's Valley. The outcrop is in the lower portion of the Coeymans limestone, all of the higher beds being corered with drift. The Manlius limestone, also, outcrops at this locality, a little lower down the hillside. The species identified from here are as follows:

1. Zaphrentis sp. undet.

2. Lichenalia torta. Hall.

3. Stropheodonta varistriata (Con.). 
4. Strophonella punctulifera (Con.).

5. Gypidula galeata (Dal.).

6. Rhynchonella semiplicata (Con.).

\%. Rhynchonella altiplicata Hall.

8. Uncinulus mutabilis (Hall).

9. Atrypa reticularis (Linn.).

10. Spirifer cyclopterus Hall.

11. Meristella lavis (Van.).

12. Rhynchospira formosa (Hall).

13. Rhombopteria clathratus n. $\mathrm{sp}$.

14. Conocardium sp. undet.

15. Tentaculites elongatus Hall.

16. Dalamanites pleuroptyx (Green).

1\%. Beyrichia sp undet.

This fauma is esentially like that collected from the Coeyman= limestone in the Nearpass section, and is the normal fauna of the Gypidula galeata zone.

Locality : 1 A.-This locality is on the 619-foot hill, three-eighths of a mile northwest of Wallpack Center. The limestone at this point is very cherty, and the following species have been recognized:

1. Strophonella punctulifera (Con.).

2. Leptiena rhomboidalis (Wilck.).

3. Gypidula galeata (Dal.).

4. Atrypa reticularis (Linn.).

5. Spivifer cyclopterus Hall.

Locatity $89 \mathrm{~A}$.- The outcrop from which the fossils at this locality were secured is at the side of the road, one and one-half miles northeast of Flatbrookville. The limestone is a more or less crystalline, dark rock, with normal Gypidula galeata fauna. The following species have been identified:

1. Stropheodonta varistriata (Con.).

?. Stropheodonta planulata Hall.

3. Schizophoria bisinuata n. sp.

4. Gypidula galeata (Dal).

5. Rhynchonella semiplicata (Con.).

6. Uncinulus mutabilis ( $\mathrm{Hall}$ ).

\%. Atrypa reticularis (Linn.).

S. Meristella lavis (Van.). 
Locality 109 A.-Just below Flatbrookville the Coeymans limestone is well developed, and in Elmer Garris' pasture fossils occur abundantly, both in situ and in loose masses of the limestone. The entire fauna collected at this locality is the normal Gypidula galeata fauna, and the following species have been identified:

1. Stropheodonta varistriata (Con.).

2. Stropheodonta varistriata var. arata Hall.

3. Stropheodonta planulata Hall.

4. Stropheodonta indenta (Con.).

5. Strophonella punctulifera (Con.).

6. Orthothetes woolworthana (Hall).

\%. Leptcena rhomboidalis (Wilck.).

8. Schizophoria bisinuata n. sp.

9. Gypidula galeata (Dal.).

10. Rhynchonella altiplicata Hall.

11. Uncinulus mutabilis (Hall).

12. Uncinulus nucleolatus (Hall).

13. Atrypa reticularis (Linn.).

14. Spirifer cyclopterus Hall.

15. Spirifer macropleurus (Con.).

16. Meristella lavis (Van.).

1\%. Rhynchospira formosa (Hall).

18. Lichenalia torta Hall.

19. Fenestella sp. undet.

20. Actinopteria communis (Hall).

21. T'entaculites elongatus Hall.

22. Dalmanites pleuroptyx (Green).

23. Phacops sp: undet.

Of the entire fauna enumerated above, all the species except one, Spirifer macropleurus, were secured in situ from a single bed. МГanr of them have also been collected at the same locality from loose blocks of limestone. A single specimen of Spirifer macropleurus was found, and although not in situ, it was associated in the same block of limestone with Gypidula galeata and other typical Coermans limestone species, so that its presence in the Coeymans limestone cannot be disputed. The specimen does not essentially differ from the New Scotland representatives of the species, except in its somewhat inferior size. 
NEW SCOTLAND BEDS.

The formation following the Coermans limestome in the New Jersey section is twofold. In its lower portion there are twenty feet, more or less, of a very hard, cherty limestone. Above this is a series of one hundred and forty feet, more or less, of calcareous shales. The faluna of the entire formation, including both the cherty limestone and the shale, is a prolitic one, and has much in common throughout, it being especially charactrized by the abundant representation of the genus Spirifer. In a previous preliminary report upon the Wallpack ridge* a hard, cherty limestone, overlying the shales, was in- Huded in the Tew seotland beds, griving the entire formation a threefold character, instead of twofold, as hre recognized. Further study seems to indicate that this upper, rherty limestone represents what has been described as the Becraft limestone of the New York section, although it - lama is intimately allicel to that of the subjacent Tew Scotland bets. This faunal similarity is so great, although there are recognizalse differences, that in the decriptive part of the present report the New Scotland and Becraft faunas are all described together.

Locality $2 A^{29}$. - Nowhere in New Jersey is there a continuous section where the complete sucession of the New scotland beds, with their included faunas, can be studied in detail. The only outcrops arailable for olservation are isolaterl, and such exposures of both the cherty limestome at the hase and the higher shale beds are present in the Nearpass section. From the cherty limestone the species in the following list were collected at an outcrop just back of the quarry and lime-kiln of Mr. Sanford Nearpass:

1. Hindia fibrosa (Roem.).

2. Streptelasma strictum Hall.

3. Icthyocrinus magnaradiatis $\mathrm{n.} \mathrm{sp}$.

4. Pholidops ovata Hall.

5. Stropheodonta beckei Hall.

6. Strophonella punctulifera (Con.).

$\%$ Strophonella levenworthana (Hall).

S. Leptana rhomboidatis (Wilck.).

9. Rhipidomella oblata (Hall).

10. Rhipidomella eminens (Hall).

*Ann. Rep. State Geol. N. J. for 1899. 
11. Dalmanella perelegans (Hall).

12. Dalmanella subcarinata (Hall).

13. Bilobites, varica (Con.).

14. Scenidium insigne (Hall).

15. Uncinulus pyramidatus (Hall).

16. Eatonia medialis (Van.).

1\%. Centronella? subrhomboidea n. sp.

18. Spirifer perlamellosus Hall.

19. Spirifer cyclopterus Hall.

20. Meristella lavis (.Van.).

21. Actinopteria sp. undet.

22. Strophostylus gebhardi (Con.).

23. Phacops logani Hall.

24. Dalamanites pleuroptyx (Green).

Locality $2 A^{30}$.- The higher beds of the upper, shaley member of the New Scotland beds are exposed in the Nearpass section, but not extensively. The following species of fossils have been identified:

1. Streptelasma strictum Hall.

2. Stropheodonta beckei Hall.

3. Strophonella punctulifera (Con.).

4. Leptcena rhomboidalis (Wilck.).

5. Rhipidomella oblata (Hall).

6. Uncinulus vellicatus (Hall).

\%. Eatonia medialis (Van.).

8. Spirifer macropleurus (Con.).

9. Spirifer perlaniellosus Hall.

10. Spirifer cyclopterus Hall.

11. Trematospira multistriata Hall.

12. Nucleospira ventricosa Hall.

13. Anoplotheca concava (Hall).

14. Meristella lavis (Vàn.).

15. Actinopteria sp. undet.

16. Tentaculites elongatus Hall.

1\%. Dalmanites pleuroptyx (Green).

The fauma of the shaley member of the New Scotland beds differs in some respects from that of the lower, cherty limestone, but they have many characters in common. The most notable additions to the shale fauna, species which are almost always present in these beds in the State, are spirifer macroplcurus, Trematospira multistriata and Anoplotheca concava. Another species which may be associated 
with these, but which happens to he absent from the fauna at the locality just describerl, is Atryfrim imbricutu. The presence of Eatonia, of many individuals of Spirifer and some of the same species of

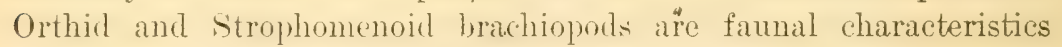
which unite the two members of the New Scotland beds.

Locality 8 A. - This locality is one-half mile northeast from the first cross-road over the Walpack ridge, below the New York State line. It is a small excaration, which has been made in the shales of the New Scotland beds, and fossils are preserved in abundance, the following species having been identified:

1. Stropheodonta beckei Hall.

2. Strophonella punctulifera (Con.).

3. Leptona rhomboidatis (Wilck.).

4. Rhipidomella oblata Hall.

5. Eatonia medialis (Van.).

6. Spirifer macropleurus (Con.).

\%. Spirifer verlamellosus Hall.

S. Spirifer cyclopterus Hall.

9. Atrypina imbricata Hall.

10. Anoplotheca concava (Hall).

11. Meristella lavis (Van.).

'This is the normal famma of the haley member of the New Scotland beds, characterized especially by spirifer macropleurus.

Locality 25 ('-O-One-half mile below Hainesville there are excellent exposures of the New Scotland heds, both the basal, cherty limestone and the higher, shaley beds, and nowhere is there a better opportunity for the collection of fosils. From the lower, werty beds at this locality the following species have been recognized:

1. Hindia fibrosa (Roem.).

$\therefore$ ef. Glossina spatiosa (Hall).

$\therefore$ Stropheodonta beckei Hall.

t. Strophonella punctulifera (Con.).

5. Strophonella levenworthana Hall.

6. Leptena rhomboidatis (Wilck.).

\%. Orthothetes woolworthanus (Hall).

8. Rhipidomella oblata (Hall).

9. Rhipidomella eminens (Hall).

10. Dalmanella perelegans (Hall).

11. Dalmanella subcarinata Hall.

12. Uncimulus vellicatus Hall. 
13. Eatonia medialis (Van.).

14. Eatonia singularis (Van.).

15. Spirifer perlamellosus Hall.

16. Meristella lavis (Van.).

1\%. Actinopteria sp. undet.

18. Cypricardinia sublamellosa Hall.

19. Mytilarca sp. undet.

20. Strophostylus gebhardi (Con.).

21. Loxonema attenuata Hall.

22. Orthoceras sp. undet.

23. Phacops logani Hall.

24. Dalmanites pleuroptyx (Green).

Locality $25 \mathrm{D}$.- This locality is near the last, it being the outcrop of the shaley beds of the New Scotland formation, which are exposed to the west of the cherty limestone outcrops. The following species of fossils have been identified:

1. Stropheodonta bechei Hall.

2. Leptona rhomboidatis (Wilck.).

3. Rhipidomella oblata (Hall).

4. Uncinulus vellicatus (Hall).

5. Eatonia medialis (Van.).

6. Eatonia singularis (Van.).

\%. Spirifer macropleurus (Con.).

8. Spirifer cyclopterus Hall.

9. Trematospira multistriata Hall.

10. Atrypina imbricata Hall.

11. Anoplotheca concava (Hall).

12. Meristella lavis (Van.).

Locality 52 A.-A little over one mile below Peter's Talley, in the side of the road crossing the ridge, an excavation for road material has been made in the shaley beds of the New Scotland formation. Some of the strata at this locality are fossiliferous, and the following species have been identified:

1. Hindia fibrosa (Roem.).

2. Stropheodonta beckei Hall.

3. Strophonella punctuilifera (Con.).

4. Leptcena rhomboidalis (Wilck.).

5. Orthostrophia strophomenoides (Hall).

6. Rhipidomella oblata (Hall).

\%. Eatonia medialis (Van.). 
8. Spirifer macropleurus (Con.).

9. Spirifer perlamellosus Hall.

10. Spirifer cyclopterus Hall.

11. Atrypina imbricata Hall.

12. Trematospira multistriata Hall.

13. Meristella levis (Tan.).

Locality 109 A.-Below Flathrookille, in beds lying above those carrying the Gypidula galcatus famna, but separated from them by the Stormville sandstone, which will be described later, there are calcarcous, shaley heds belonging in the Tew Scotland formation, which are much harder and tougher than is usually the case with the shaley member of this formation. These heds contain numerous fossils, and the following species have been identified:

1. Streptelasma strictum Hall.

2. Stropheodonta bechei Hall.

3. Leptcena rhomboidatis (Wilck.).

4. Orthostrophia strophomenoides (Hall).

5. Rhipidomella oblata Hall.

10. Eatonia medialis (Van.).

\%. Spirifer macropleurus (Con.).

8. Meristelle lavis (Van.).

9. Dalmanites pleuroptyx (Green).

A comparison of the faunas of the New Scotland beds with those emumerater from the Coemans limestone shows several essential differences. In the ('ocymans limestone ciglndula galeatus was always the most conspicuous member of the fauna, except at the very summit of the formation. In the New Scotland beds the species never occurs. In the earlier lanna species of the ()rthir genera and of Spirifer are among the most uncommon forms, but in the New Scotland beds these types of brachiopods are among the most abundant and characteristic members of the fauna. In the New Scotland fauna several genera, Hindia and Eatonia especially, are introduced for the first time, and they are types which have no near allies in the preceding fauna. There are, of course, several members of the New Scotland fauna which oceur, also, in the Commans limetone. or are represented by closely-allied species, but the differences between the two faunas are of such an essential character as to indicate two separate immigrations from the exterior into the Cumberland basin. 
STORMIVILLE SANDSTONE.

This formation is present only in the southern half of the Wallpack ridge in New Jersey, but, according to White, * who named the formation in Pennsylvania, it becomes a more and more conspicuous formation to the south, and gradually replaces the more calcareous and shaley strata until it ocempies the entire interval between the Coeymans limestone and the Oriskany sandstone, becoming continuous with this higher, arenaceous bed.

In New Jersey the formation makes its first appearance just south of Hainesville, where it occurs as a thin, sandy layer at the top of the Coeymans limestone. South of this locality, for some distance, it is not a conspicuous formation, it being too thin a bed and too heavily drift corered to afford noticeable exposures. Below Peter's Valley, however, it becomes more strongly developed, and is frequently met with. A good exposure of it may be seen in the side of the road crossing the Wallpack ridge at. Wallpack Center. At one locality above Wallpack Center the formation contains numerous fossils, but they are all imperfect casts, and cannot be identified with any certainty, though most of them appear to be identical with species which occur in the cherty limestone, the basal member of the New Scotland beds. At Flatbrookville this sandstone occurs, and from the base of the formation specimens of Gypidula galeatus were collected, while beds Jying above it contain a fauna characterized by spirifer macropleurus, which indicates that at this locality the Stormville sandstone has replaced the lower, cherty limestone member of the New Scotland beds.

\section{BECRAFT LIIIESTONE.}

In a preliminary report upon the formations of the Wallpack ridge in New Jersey $\nmid$ a hard, gray, cherty limestone, lying above the shaley nember of the New Scotland beds, was included in that formation, being considered as a third, or higher, member of the New Scotland beds. Further study has led to the conclusion that this limestone represents, and is the southern continuation of, the Becraft limestone of the New York section. It is a rery hard and resistant layer, and

* Second Geol. Surv. Penn., Rep. G. 6, pp. 132, 133.

†Ann. Rep. State Geol. N. J. for 1899. 
back of the Nearpass quarry bluff it forms a continuous outerop for half a mile or more, and is frequently met with further south. The contire thickness of the formation has never been observed, but it is estimated as twenty feet, more or less.

The fauna of the Becraft limestone is closely allied to that of the New scotland beds, many species being common to the two formations, although some forms identified from one formation have not hee'n observed in the other. Because of this conspicuous community of specie's in these two formations, their faumas have not been separated in the descriptive part of the present report, but are all deseribed together.

Locality $21^{\circ 1}$. - The only locality where the fossils of the Becraft limestone have been carefully collected is in the low ridge back of the Nearpass quarry bluff. Fossils are abundant in the formation, wherever it occurs, but they are always so firmly imbedded in the hard, cherty matrix that it is difficult to collect them. In the collections made from the Nearpass section the following species have been identified:

1. Streptelasma strictum Hall.

2. Stropheodonta beckei Hall.

3. Stropheodonta sp. undet.

4. Strophonella punctulifera (Con.).

5. Leptcona rhomboidalis (Wilck.).

6. Rhipidomella oblata (Hall).

\%. Schizophoria multistriata (Hall).

8. Uncinulus vellicatus (Hall).

9. Rhynchotrema formosum (Hall).?

10. Spirifer cyclopterus Hall.

11. Neristella lavis (Van.).

12. Actinopteria sp. undet.

13. Lichas pustulosus Hall.

14. Homalonatus vanuxemi Hall.

15. Phacops logani Hall.

16. Dalmanites pleuroptyx (Green).

1\%. Beyrichia sp. undet.

With the exception of the two trilobites, Lichas pustulosus and Homalonatus vanuxemi, and the brachiopod, Schizophoria multistriata, the species representer in the Becraft limestone fauna are present, also, in the fauna of the New Scotland beds. There is, howerer, some difference in the proportionate number of individuals 
of some species. This is especially noticeable in the case of Leptona rhomboidalis, which has not been a common species in the earlier Helderbergian faunas, but which, in the Becraft limestone, becomes especially abundant.

\section{KINGSTON BEDS.}

Lying above the Becraft limestone, and below the conspicuous trilobite bed at the base of the Oriskany formation, there is a series of strata which have nowhere been exposed. They are probably shaley beds, which are easily disintegrated, and become more or less deeply covered with debris. In the Nearpass section these beds occupy the interval between the outcrops of the resistant subjacent and superjacent beds, in a shallow depression and in the lower, drift-covered portion of the bluff, which is capped by the "trilobite bed." The thickness of the beds at this point is roughly estimated as about 80 feet.

No fossils have been collected from this formation, so that the only basis for the correlation of the beds is their stratigraphical position, which corresponds with that of the Kingston beds of the New York section. In Pennsylvania these same beds have been called the Stormville shales, by White.*

ORISKANY FORMATION.

Lying above the formation which has been referred to the Kingiton beds there is a series of strata having an aggregate thickness estimated at about 170 feet. These beds are, for the most part, siliceous limestones, but at the summit of the formation in the southern half of the Wallpack ridge in New Jersey the higher beds are replaced by sandstones. With the southwestern extension of the formation into Pennsylvania the arenaceous facies becomes more and more conspicuous, the sandstones replacing lower and lower beds until the entire Oriskany formation is a sandstone continuous with the Stormville sandstone or conglomerate, which, in its turn, replaces higher and higher beds in its southwestern extension.

The fauna of the Oriskany beds in New Jersey is not homogeneous

* Second Geol. Surv, Penn., Rep. G. 6, p 131.

† Second Geol. Surr. Penn., Rep. G. 6, p. 133. 
throughout, and three well-defined faunal zones may be recognized, all of them being represented in the Nearpass section. The lowest of thes life zones is especially characterized by Dalmanites dentatus; the second is characterized by Orbiculoided jervensis, and the third by the great abundance of spirifer murchisoni, although this species also occurs in both of the lower zones.

In the descriptive part of the present report the fauna of the Dulmanites dentatus zone has been treated as a unit, there being at least a doubt as to whether it should be included in the Oriskany. The faunas of the two higher zones, on the other hand, have been described all together, as it is believed that no one will question the Oriskany age of both. In the present discussion of the faunas, however, each of these faunal zones will be treated by itself, in order that its characteristics and relationships may be more easily discussed.

\section{The Dalmanites dentatus Zone.}

Locality $2 A^{33}$. - In the Nearpass section the beds bearing the Dulmanites dentatus fama form the crest of the high ridge to the northwest of the Nearpass cuarry. They are a southern extension of the beds which form the crest of the ridge in New York State, east of Tri-States, which has been called "the trilobite ridge" by those who have collected in that region. The species of fossils which have been identified from this locality are as follows:

1. Termipora serpuloides Hall.

2. Orbiculoidea ampla (Hall).

3. Lingula sp. undet.

t. Stropheodonta magnifica (Hall).

5. Stropheodonta sp. undet.

6. Leptcena rhomboidatis (Wilck.).

$\%$ Chonostrophia jervensis Schuchert.

8. Dalmanclla subcarinata (Hall).

9. Dalmanella perelegans (Hall).

10. Rhynchonella bialveata Hall.

11. Rhynchotrema formosum (Hall).

12. Rensseleria subglobosa n. sp.

13. Spirifer murchisoni Castel.

14. Spirifer nearpassi n. sp.

15. Cyrtina rostrata Hall. 
16. Meristella princeps Hall.

1\%. Actinopteria textilis (Hall).

18. Megambonia parva n. sp.

19. Megambonia? sp. undet.

20. Goniophora sp. undet.

21. Platyostoma nearpassi n. sp.

22. Platyceras $2 \mathrm{sp}$. undet.

23. Loxonema jerseyensis n. sp.

2t. Hyolithes centennialis Barrett.

25. Tentaculites acula Hall.?

26. Orthoceras sp. undet.

2\%. Homalonatus vanuxemi Hall.

28. Dalmanites dentatus Barrett.

29. Beyrichia sp. undet.

Locality 53 A.-The beds bearing the Dalmanites dentatus fauna can be traced throughout nearly the entire length of the Walpack ridge in New Jersey, but they are less easily distinguished torard the southern part of the region. At Peter's Valley, opposite the residence of Mrs. Coss, the beds are well exposed and are highly fossiliferous, the following species having been identified from there:

1. Schizocrania superincreta Barrett.

2. Pholidops sp. undet.

3. Stropheodonta magnifica (Hall).

4. Stropheodonta sp. undet.

5. Leptcona rhomboidalis (Wilck.).

6. Anoplia nucleata Hall.

\%. Chonostrophia jervensis Schuchert.

8. Dalmanella subcarinata Hall.

9. Rensselaria subglobosa n. sp.

10. Spirifer murchisoni Castel.

11. Cyrtina rostrata Hall.

12. Meristella princeps Hall.

13. Actinopteria textilis (Hall).

14. Dalmanites dentatus Barrett.

15. Leperditia? sp. undet.

Locality 71 C.-A little over three-fourths of a mile southwest of Wallpack Center the calcareous, trilobite beds are exposed, and the following species have been collected:

1. Dalmanella subcarinata (Hall).

2. Rhynchotrema formosum (Hall). 
3. Rensselaria subglobosa n. sp.

4. Megambonia parva n. sp.

5. Orthoceras sp. iundet.

6. Homalonatus vanuxemi Hall.

\%. Dalmanites dentatus Barrett.

South of the last-described locality the trilobite bed has not been detected in situ, although some of the species of the fauna have been observed. The most characteristic species of the fauna, besides Dalmanites dentatus, are Renssclaria subglobosa and Chonostrophia jerrensis, all three of these species having been originally described from this horizon in New Jersey, and being known nowhere else at present. The constitution of the fauna is peculiar and intersting, both Helderbergian and Oriskany species being associated in the same bed. Clarke* has considered these trilohite beds to be the upper portion. of the Kingston beds, so placing them below the Helderberg-Orishany boundary line. The presence in the fauna, however, of such characteristic Oriskany species as Orbiculoidea ampla, Stropheodonta magnifica, Anoplia nucleata. Exirifer murchisoni and Cyrtina rostrata seems to indicate the Oriskany age of the fauna, although the association with these species of a large number of Helderbergian forms cmphasizes the low position of the fami in the Oriskany. A careful study of the Helderberg and Oriskany faunas in New Jersey has brought out conspicuously the absence of any sharp dividing line between these two horizons, either of a stratigraphic or of a faunal nature. The famal change in pasing from the Coemmans limestone to the New Scotland beds is a much more pronounced one than that in fasing from the Holderbergian to the Oriskany. This mingling of Helkerherg with Oriskany specis is not confined to the Dalmanites dentatus fauna alone, but is a noticeable feature, also, in the next succeeding zone. All of the Oriskany faunas in the Delaware valley region of New Jersey belong, essentially, to the calcareous facies of the formation, and are more or less closely allied to the Oriskany fauna of Becraft mountain, in New York, which has been so well described by Clarke. The Dalmanites dentatus fauna of New Jersey, howerer, is believed to he somewhat older than Clarke's Becraft mountain fauna, the latter corresponding more closty in age with the fauna of the Orbiculoidea jervensis zone in New Jersey.

* Mem. N. Y. State Mus., No. 3, vol. III, p. 16.

† Loc. cit. 
The Orbiculoidea jervensis Zone.

The total thickness of the siliceous limestone beds which bear the Orbiculoidea jervensis fauna are nowhere entirely exposed. The beds, however, are probably not of great thickness, the estimate being twenty feet, but this may be too great. But few outcrops have been observed, and the fauna has been detected only at intervals from the New York State line to about Hainesville. Beyond this point the fauna is either not differentiated from the general Oriskany fauna or the beds are so heavily drift covered as to escape observation.

Locality $2 A^{34}$. The only exposure of the Orbiculoidea jervensis beds detected in the Nearpass section is a very limited one on the Werden farm, just north of the Sanford Nearpass place, near a private road leading over the hill to the gravel pits. It was from here that the type specimens of Orbiculoidea jervensis were originally collected by Dr. Barrett. The following species have been identified from this locality:

1. Orbiculoidea jervensis (Barrett).

2. Chonetes hudsonica Clarke.

3. Spirifer murchisoni Castel.

4. Beachia suessana (Hall).

Locality 7 A.-An outcrop of this zone occurs in the first cross-road over the Wallpack ridge, south of the New York State line, about three miles from the line. The following species have been recognized from this point:

1. Orbiculoidea jervensis (Barrett).

2. Chonetes hudsonica Clarke.

3. Spirifer murchisoni Castel.

4. Actinopteria sp. undet.

Locality 6 A.-By far the best locality observed for collecting the fossils of the Orbiculoidea jervensis zone is along the edge of the woods just south of the second wagon road crossing the Wallpack ridge, about five miles from the New York State line. From this locality the following species have been identified:

1. Trachypora orishania n. sp.

2. Fenestella? sp. undet.

3. Orbiculoidea jervensis (Barrett).

4. Stropheodonta magnifica Hall.

5. Orthothetes sp. undet. 
6. Chonetes hudsonica Clarke.

$\%$ Rhipidomella oblata Hall.

8. Anoplia nucleata Hall.

9. Spirifer murchisoni Castel.

10. Cyrtina varia Clarke.

11. Metaplasia plicata n. sp.

12. Meristella lata Hall.

13. Rhynchonella breviplicata n. sp.

14. Anoplotheca flabellites (Con.).

15. Anoplotheca dichotoma (Hall).

16. Beachia suessana (Hall).

1․ Actinopteria insignis Clarke.

18. Pterinea? sp. undet.

19. Platyostoma desmatum (Clarke).

20. Platyceras sp. undet.

21. Orthoceras sp. undet.

22. Tentaculites elongatus Hall.

23. Dalmanites sp. undet.

24. Phacops sp. undet.

Loculity $25 \mathrm{E}$ - - Whout one-half mile southwest of Hainesville, an outerop of the beds bearing the Orbiculoidea jervensis fauna has heen observed, from which the following species of fossils have been secured:

1. Orbiculoidea jervensis (Barrett).

2. Stropheodonta magnifica Hall.

3. Beachia suessana (Hall).

Although the fauna of this zone still contains an element of the older Helderbergian famms, indicated by the presence of Rhipidomelle oblata, its (omposition is esentially Oriskany, and more espe(ially that facies of the oriskany which has heen described by Clarke** from Becraft mountain, New York. Five species in the New Jersey fauna have been identified with forms originally described by clarke from Becraft mountain, and nine others are common to the two faunas. Of the other eleven species recorded from the New Jersey fauna. seren have not been identifed specifically, but all belong to genera present in the Becraft momntain fauma; three are described as new species in the present report, and one other was originally described from this faunil, and has not ret been observed elsewhere. Although the correspondence between the Becraft mountain fauna

\footnotetext{
* Mem. N. Y. State Mus., No. 3, vol. III.
} 
and this fauna from New Jersey is close, the one species, Orbiculoidea jervensis, which is pre-eminently the most conspicuous member of the famna in New Jersey, has not been recognized by Clarke from Becraft mountain.

\section{The Spirifer murchisoni Zone.}

The larger proportion of the Oriskany beds in New Jersey bears the fauna which is chiefly characterized by Spirifer murchisoni, a species which is also present in the earlier Oriskany faunas, but which only attains a conspicuous position in the fauna of these higher beds. The strata containing this fauna are, for the most part, siliceous limestones, not especially different from those which bear the Orbiculoidea jervensis fauna, but the fauna itself resembles that of the arenaceous, Oriskany beds of New York more closely than the calcareous facies of Becraft mountain. In the southern portion of the Delaware valley region of New Jersey the upper portion of these siliceous limestones is replaced by sandstone, which does not essentially differ, in its lithologic characters, from the typical Oriskany sandstone of New York, and yet, so far as has been observed in this State, there is no essential change in the fauna of these sandstone beds from that of the calcareous beds immediately beneath. The fauna differs in some respects from that of the typical Oriskany sandstone of New York, one of the most conspicuous differences being in the rarity of Spirifer arenosus, which, in New York, is abundantly represented in the Oriskany sandstone. In these New Jersey beds fragments of trilobites may usually be detected, as well as an occasional coral, these being fossils which are among the rarest forms in the New York Oriskany sandstone.

Locality 3 A.- In the Nearpass section the beds bearing the Spirifer murchisoni fauna may be best studied on the Werden farm, north of the Sanford Nearpass place. The beds at this locality are a northward extension of $2 \mathrm{~A}^{35}$, which is too much drift covered to offer an opportunity for making collections. The following species have been identified:

1. Stropheodonta magnifica Hall.

2. Camarotochia barrandii (Hall).

3. Eatonia peculiaris (Con.).

4. Spirifer murchisoni Castel.

5. Cyrtina varia Clarke. 
6. Metaplasia plicata n. sp.

\%. Anoplotheca flabellites (Con.).

8. Meristellá lata (Hall).

9. Actinopteria textilis var. arenaria (Hall).

10. Platyostoma ventricosa Con.

11. Tentaculites elongatus Hall.

12. Dalmanites sp. undet.

Locality $15 \mathrm{D}$.- In the roadside, a little less than one mile south of Brick House, an outcrop of these siliceous limestones may be seen. Fossils are not abundant, only the two following species having been recognized:

1. Spirifer murchisoni Castel.

2. Actinopteria sp. undet.

Locality $25 \mathrm{~F}$.- From a locality one and one-half miles directly north of Layton the following species were collected:

1. Chonostrophia complanata (Hall).

2. Spirifer murchisoni Castel.

3. Meristella lata (Hall).

Locality 37 A.-Three-fourths of a mile west of Layton, on the road to Dingman's, one of the best exposures of these siliceous limestones may be studied. The beds outcrop along the roadside, and they have been excavated more or less in building the road. This is one of the best localities for collecting the fossils of the horizon, and the following species have been recognized:

1. Pholidops arenaria Hall.?

2. Stropheodonta magnifica Hall.

3. Leptcena rhomboidalis Wilck. var. ventricosa (H.).

4. Chonostrophia complanata (Hall).

๖. Anoplia nucleata (Hall).

6. Rhipidomella sp. cf. R. musculosa (Hall).

7. Beachia suessana (Hall).

8. Spirifer arenosus (Con.).

9. Spirifer murchisoni Castel.

10. Cyrtina varia Clarke.

11. Metaplasia pyxidata (Hall).

12. Anoplotheca flabellites (Con.).

13. Meristella lata (Hall).

14. Actinopteria textilis var. arenaria (Hall).

15. Platyostoma ventricosa Con.

16. Dalmanites sp. undet.

1\%. Phacops sp. undet. 
Locality 37 C.-This locality is three-fourths of a mile north of Peter's Valley, in the woods, above the large spring. The stratum from which the fossils were obtained is a sandstone bed, near the top of the Oriskany formation. The fossils are not well preserved, but the following species have been identified:

1. Leptcona rhomboidalis var. ventricosa (Hall).

2. Spirifer murchisoni Castel.

3. Anoplotheca flabellites (Con.).

4. Meristella lata (Hall).

Locality 53 B.-At Peter's Valley, on the hill opposite the residence of Mrs. Coss, weathered masses of the siliceous, Oriskany limestone are strewn over the surface, and the hill itself is doubtlessly constituted of this rock. Some of these loose masses are highly fossiliferous, and the following species have been identified:

1. Edriocrinus sacculus Hall.

2. Pholidops ovata Hall.

3. Stropheodonta magnifica Hall.

4. Leptcena rhomboidalis var. ventricosa (Hall).

э. Hipparionyx proximus (Van.).

6. Chonostrophia complanata (Hall).

\%. Eatonia peculiaris (Con.).

8. Beachia suessana (Hall).

9. Spirifer arenosus (Con.).

10. Spirifer murchisoni Castel.

11. Metaplasia plicata n. sp.

12. Anoplotheca flabellites (Con.).

13. Meristella lata (Hall).

14. Megambonia bellistriata Hall.

15. Platyostoma ventricosa Con.

16. Platyceras tortuosum Hall.

1\%. Tentaculites elongatus Hall.

Locality 70 A.-A short distance southwest of the cross-roads, one and one-half miles southwest of Wallpack Center, the following specie: rere collected from these siliceous limestone beds of the Oriskany:

1. Pholidops arenaria Hall.

2. Anoplotheca flabellites (Con.).

3. Actinopteria textilis var. arenaria (Hall).

4. Platyostoma ventricosa Con.

Locality $88 \mathrm{~A}$.- In the hillside, about one-half mile due east of Flatbrookville, the siliceous limestone, Oriskany beds are exposed, and 
abore them the sandstone facies of the formation. From the calcareous beds at this locality the following species have been identified:

1. Favosites sp. undet.

2. Bryozoa several undet. sp.

3. Photidops ovata Hall.

t. Stropheodonta magnifica Hall.

5. Eatonia peculiaris (Con.).

6. Spirifer murchisoni Castel.

\%. Metaplasia plicata n. sp.

8. Anoplotheca flabellites (Con.).

9. Platyostoma ventricosa Con.

10. Tentaculites elongatus Hall.

11. Dalmanites sp. undet.

ESOPUS GRIT.

This is one of the mo:t persistent formations in the Delaware valley region of Xew . Tersey, and forms the crest of the Wallpack ridge throughout the greater part of its extent in the State. It is a nearly black, gritty, rexistant rock, in which clearage is frequently developed to a high degree. Esually it is difficult to distinguish the bedding planes, because of the slaty cleavage, but when they can be recognized, the fucoid "andagalli" markings are often more or less clearly to be seen. Asile from these indefinite. supposed fucoid or sea-weed markings, fosils are exceedingly rare in the whole formation. A single, imperfect specimen of an inarticulate brachiopod, probably Lingule or Orbiculoidea, has been found in an outerop of this formatinn near Flathrookrille, but no other specimens have been olserved.

In his report on Pike and Montgomery counties, Pennsylvania, White* mentions the presence of fosil brachiopods in this formation, but a careful seareh in New Jersey has failed to bring to light any other than the single sprecimen already mentioned. It is possible that the fossils mentioned by White were secured from the shaley heeds at the base of the superijacent Onondaga limestone, als these beds frequently resemble, in a measure, some of the beds of the Esopus grit, and they are often more or lesis foriliferous. The arerage thickness of the formation has been estimated as about 375 feet.

\footnotetext{
* Second Geol. Surv. Penn., Rep. G. 6, p. 122.
} 
ONONDAGA LIMESTONE.

The Onondaga (Corniferous) limestone proper is restricted to the Delaware valley region of New Jerser, although beds of similar age are represented in the Green Pond region. The formation lies above the Esopus grit, and covers the greater portion of the northwestern slope of the Wallpack ridge. Towards its base the formation is somewhat shaley, and there is apparently a rather gradual transition from the subjacent Esopus grit to the Onondaga limestone. The limestone is a hard, regularly-bedded rock, the beds ranging in thickness from three inches to a foot. Some of them contain large quantities of chert, which give to their weathered surfaces an extremely rough and jagged appearance. Fossils are not abundant in this formation, and those that are present are usually too firmly imbedded in the matrix to be satisfactorily studied.

Locality 2 B.-Along the river road, about two and one-half miles below Tri-States, New York, there are several outcropping ledges of this formation, from which the following species of fossils were collected:

1. Stropheodonta perplana (Con.).

2. Atrypa reticularis (Linn.).

3. Loxonema sp. undet.

Locality $37 \mathrm{D}$.- In a field about three-fourths of a mile northwest of Peter's Talley there are good exposures of the Onondaga limestone, in which some fossils are present. Nost of these are corals, too firmly imbedded in the matrix to be collected, and some crinoid columns; the only species of brachiopod observed was Leptcena rhomboidalis.

Locality $52 \mathrm{~A}$.- One of the best fossil localities which has been observed in the Onondaga limestone of New Jersey is at the side of the river road, one and one-half miles southwest of Peter's Valley. The following species have been identified from there:

1. Fenestella? sp. undet.

2. Stropheodonta perplana (Con.).

3. Chonetes arcuatus Hall.

4. Rhipidomella vanuxemi (Hall).

5. Atrypa reticularis (Linn.).

6. Reticularia fimbriata (Con.).

7. Anoplotheca concava (Hall). 
Locality an B.-Another locality where sereral species of fossils were secured from this formation is at the side of the river road, four miles northeast of Flathrookrille. The following species have been identified from there:

1. Zaphrentis sp. undet.

2. Lingula sp. undet.

3. Leptana rhomboidalis (Wilck).

4. Orthothetes pandora (Bill.).

5. Rhipidomella vanuxemi (Hall).

6. Atrypa reticularis (Linn.).

\%. Spirifer sp. cf. S. varicosus Hall.

8. Anoplotheca concava (Hall).

9. Platyceras sp. undet.

Loculity S9 B.-.On the river loank, two miles northeast of Flatbrookville, the following species were collecterl from the Onondaga limestone:

1. Orthotheles pandora (Bill.).

2. Anoplotheca acutiplicata (Con.).

Locality $8 \mathcal{B}$ B. - In an excavation in the lower, shaley beds of the Onondaga limestone, one-half mile northwest of Flatbrookville, on the river road. several imperfect specimens of anoplotheca acutiplicata were collected.

The entire recognized fauna of the Onondaga limestone in New Jersey is a small one, and it does not afford sufficient characteristics for close correlation. There are none of the recognized species, however, which do not commonly occur in the Onondaga limestone in its more typical localities in New York, and this, together with its stratigraphic relations, makes the correlation of the New Jersey formation under consideration reasonably sure.

\section{IEWFOUNDLAND GRIT.}

The Newfoundland grit is limited in its geographic distribution in New Jersey to the Green Pond mountain region. It is a heavybedded, fine-grained, light-olomed. quartzite conglomerate below, becoming a thinner-bedded sandstone above. It grades upward into the dark, siliceous, Monroe shales, without any line of demarkation. The total thickness of the formation is estimated as about 215 feet. 
The fossils of the formation are nerer well preserved, and in most localities they are rarely met with, only two localities having afforded material sufficiently well preserved for identification.

Locality 87 B.-The fossils from this locality were collected on top of the ridge west of the southern portion of Greenwood lake. They occur in the upper portion of the formation, and the following species have been identified:

1. Orthothetes pandora (Bill).

2. Chonetes arcuata Hall.

3. Amphigenia elongata (Van.).

4. Spirifer macrothyris Hall.

5. Cyrtina hamiltonensis Hall.

6. Anoplotheca acutiplicata (Con.).

\%. Actinopteria decussata Hall.

Locality 145 A.-At Newfoundland, about 300 yards east of Chamberlain's Hotel, the lower beds of this formation outerop in a field. Fossils occur somewhat commonly, but, on account of the matrix in which they are imbedded, it is exceedingly difficult to make a large collection of them. The following species have been identified:

1. Zaphrentis sp. undet.

2. Stropheodonta inequiradiata Hall.

3. Schizophoria sp. ef. S. striatula (Schl.).

4. Amphigenia elongata (Van.).

5. Spirifer macrothyris Hall.

6. Spirifer sp. undet.

\%. Cyrtina hamiltonensis Hall.

8. Pterinea flabella (Con.).

The composition of the fauna of the Newfoundland grit at both of these localities is essentially that of the Onondaga limestone of the New York section. In a former preliminary report upon the Green Pond mountain region* it was stated that the fauna contained a mixture of Oriskany and Onondaga species, but a more careful study of the material has failed to establish a single Oriskany species in the fauna. The specimens formerly identified provisionally as Spirifer arenosus and Spirifer murchisoni ( $=S$. arrectus) prove not to be these species. The presence of horn corals in some abundance is another character of the fauna which tends to disprove its Oriskany relationships. Two species in the fauna, Pterinea flabella and Aclinop-

* Ann. Rep. N. J. State Geol, for 1901, p. 20. 
teria decussata, are, normally, members of the fauna of the Hamilton beds in New York. The deposition of this formation was, without doubt, essentially contemporaneous with the deposition of the Onondaga limestone in the Delaware valley and in New York, it being composed of the arenaceons shore deposits, while the limestone was deposited in somewhat deeper water, at a distance from the shore line, in the same basin of sedimentation.

\section{MIONROE SHALES.}

This formation, like the last, is restricted in its distribution to the Green Pond mountain region. It consists of a series of more or less siliceous or argillaceous shales of a dark color, which have been crushed and sheared to such an extent that the lines of bedding and the organie remains are frequently obliterated. Fossils never oceur in abundance, and those which are found are almost always badly distorted and imperfectly preserved. The estimated thickness of the formation is from 700 to 1,000 feet.

Locality 87 A.-This locality lies one and one-half miles from the southern extremity of (ireenwood lake, at the wide of the road along the west shore of the lake. The following species have been identified:

1. Orthothetes chemungensis (Con.).

2. Chonetes sp. undet.

3. Tropidoleptus carinatus (Con.).?

4. Ambocalia umbonata (Con.).

5. Anoplotheca acutiplicata (Con.).?

6. Stroplestylus sp. undet.

\%. Phacops rana (Green).

8. Dalmaniles sp. cf. D. anchiops (Green).

Locality $106 \mathrm{~A}$.-A short distance southwest of West Milford the two following species were collected:

1. Tropidoleptus carinatus (Con.).

2. Actinopteria sp. undet.

Locality 104 A.-This locality is in the woods, west of the road, a little over one-half mile north of the ('linton reservoir, north of Newfoundland. The following species were collected:

1. Crinoid stems.

2. Chonetes coronatus (Con.)?

3. Camarotochia sappho Hall.? 
Locality 188 A.-Near the roadside at Sylvester's Corners, Woodstock, five and one-half miles southwest of Newfoundland, the following species were collected:

1. Fenestella? sp. undet.

2. Chonetes sp. undet.

3. Camarotrchia sp. undet.

4. Homalonotus dekayi (Green).?

Although the entire known fauna of the Monroe shales, as indicated in the foregoing lists, is not a large one, its characteristics are undoubtedly those of the Hamilton fauna of the New York section. Tropidoleptus carinatus is one of the most characteristic Hamilton species, and its identification in New Jersey can be made without the least doubt. All of the other species recognized are also Hamilton forms, with the exception of Anoplotheca acutiplicata and Dalmanites anchiops, which hare been originally described from the fauna of the Onondaga limestone.

\section{BELLVALE FLAGS.}

This formation is scarcely more than a continuation of the last. The beds are more arenaceous, but there is a gradual gradation from the shale beds below into the dark-colored grits and flagstones. The average thickness of the formation is about 1,800 feet.

Locality 144 A.-Fossils do not commonly occur in the Bellvale flags. but from the material which has been excavated to form the outlet of the Oak Ridge reservoir, near Newfoundland, the following species have been collected:

1. Crinoid stems.

2. Tropidoleptus carinatus (Con.).

3. Spirifer audaculus (Con).?

4. Palceoneito emarginata (Con.).

5. Paracyctus elliptica Hall.?

6. Grammysia sp. undet.

\%. Cyrtonella mitella Hall.

S. Strophostylus sp. undet.

These species constitute the known fauna of the Bellvale flags in New Jersey. They are all Hamilton forms, with none of the characteristic Chemung species of the New York faunas. 


\section{SKUNNEMUNK CONGLOMERATE.}

This conglomerate forms the great mass of the Bearfort mountain in New Jersey, and also of Bellvale mountain, which is its northward continuation in New York. Skunnemunk mountain, lying still further north in New York State, is another great mass of this conglomerate. and has given rise to the name of the formation. The typical beds of the formation are a coarse, purple-red, masive conglomerate, the pebbles of which are sometimes six or sevell inches in diameter. Beds of red sandstone altermate more or les frequently with the conglomerate, and there are nany gradations between the two. No fossils have been detected in the formation, and, as it is the youngest paleozoic formation in New Jersey, its age can only be determined by the underlying beds, which are Hamilton in age. It may be correlated with the upper Devonian of the New York section, but whether it is the exact equivalent of the chemung-Catskill cannot be determined. 
PART II.

Descriptive Paleontology.

(109) 



\section{CHAPTER VI.}

\section{FAUNAS OF CAMBRIAN AGE.}

The Cambrian faunas of New Jersey are restricted to certain layers of the Hardyston quartzite and the Kittatinny limestone. Nowhere in these formations are the fossils abundant, while usually no traces of organisms can be detected, and those that have been found are always fragmentary. In the uppermost beds of the Kittatinny limestone the Cambrian species disappear, and are replaced by a fauna of Beekmantown ( = Calciferous) type, which is usually considered as of early Ordovician age.

The species of the Cambrian faumas will all be considered together, although the different localities which have afforded fossils are doubtless of somewhat different horizons. The only fossil horizon of Cambrian age that can be definitely placed in relation to the others is the Olencllus bearing bed of the Hardyston quartzite, which is always, wherever it has been found, near the base of the sedimentary series in New Jersey, and is at a lower horizon than any of the other beds carrying Cambrian fossils. At this horizon, however, Olenellus thompsoni is the only species which has been identified, although the fragments of some other trilobites may be present; as well as some more or less indefinite worm burrows.

\section{PROTOZOA.}

\section{FORAMINIFERA.}

Plate I., Figs. 1-2.

In the Cambrian fauna at Newton some more or less subglobular bodies, whose diameters range from 4 to $6 \mathrm{~mm}$., have been observed, which are quite plainly organic in their nature. In some cases these 
lodies have a slightly constricted, encircling band, nearer to one extremity than to the other. It is difficult to determine with certainty what thes objects have been, but they suggest the shells of Foraminifera.

\title{
MOLLUSCOIDEA.
}

\author{
BRACHIOPODA.
}

LINGULELLA STONEANA Whitf.

Plate I., Fig. 6.

1882. Lingulella stoneana. Whitf., Geol. Wis., vol. IV., p. 344, pl. 27 , figs. $6-7$.

Description.- Shell suborate to subpentagonal in outline, longer than wide, the beak rather blunt. The surface of both valves marked hy concentric lines of growth, which are usually crowded and much. more conspicuous near the margin, and also by fine, sharply-elevated, somewhat wary ridges, which extend directly across the shell transveriely from margin to margin, being nearly at right angles to the concentric growth lines at the marcin, and becoming parallel with them along the medium line of the shell. The transverse lines become ohiolete towards the anterior portion of the shell, but posteriorly about four or five of them occupy the space of $1 \mathrm{~mm}$. In one specimen, near the centre of the anterior margin of the shell, fine, rounded, radiating strix may be detected.

The dimensions of a nearly perfect valve are: length, $8.33 \mathrm{~mm}$; witth, 5.5 mm. Other fragmentary specimens must have had a length of $10 \mathrm{~mm}$. or more when complete.

Remarks-This species is enpecially characterized by the peculiar transverse markings of the shell, which are entirely independent of the lines of growth. It has heretofore been recorded only from the upper Cambrian strata of Wisconsin, and was first illustrated by Hall * as a variety of Lingulu aurore. In Hall's illustration of the shell the transverse marking do not pass directly across the valve from margin to margin, but they form a rounded angle, directed toward the beak

\footnotetext{
* Sixteenth Rep. N. Y. State Cab. Nat. Hist., pl. 6, figs. 6-8.
} 
at the medium line of the shell. In Thitfield's illustration, however, the lines are shown to pass more directly across the shell, as they do in the New Jersey specimens.

\section{ORTHIS NEWTONENSIS n. sp.}

Plate I., Figs. 3-5.

Description.-Shell biconvex, subquadrangular to subelliptical in outline, the hinge-line a little shorter than the greatest width of the shell. Pedicle valve regularly convex, greatest convexity near the beak in the smaller shells, but further towards the front in the larger individuals; cardinal area of moderate height, flat, sloping backward from the hinge-line at an angle of about $45^{\circ}$. Internally the pedicle valve has a more or less prominent, concave, muscular impression, about one-fourth as wide as the shell and about as long as wide; it is a little elevated above the floor of the valve and is bounded laterally toward the beak by the short, dental plates. In some of the older shells a narrow, mesial, elevated ridge extends forward from the anterior margin of the muscular impression, becoming broader toward the front, lut dying out before reaching the margin of the shell. The brachial valve is less convex than the pedicle; it is depressed along the median line in a shallow, ill-defincd, broadly-rounded sinus, which becomes more conspicuous as it approaches the anterior margin. Internally the muscular impression is much smaller than that of the pedicle valve; it is elevated above the floor of the valve and resembles the impression of the other valve, but is marked by a slight, median ridge. The surface of both ralves is marked by faint, radiating lines, which are visible on the internal casts, but are too imperfectly preserved to properly exhibit their characters. There are apparently about thirty or forty costæ upon a shell of average size, some of which are coarser, with two or three finer ones between.

The dimensions of one of the best-preserved pedicle valves are: length, $7 \mathrm{~mm}$.; width, $8 \mathrm{~mm}$. ; convexity, $2 \mathrm{~mm}$.

Remarks. - This is the commonest species in the fauna at Newton, and occurs, also, at several other localities. It is apparently one of the Orthidæ, but its generic position is not so easily determined. In general form the shell resembles some members of the genus Dalmanella more closely than any others, but the muscular impressions 
are not at all as in that genus. The muscular impression of the pedicle valve has some more or less remote resemblance to that of members of the typical genus Orthis, but the impression in the brachial valve is quite different. Doubtless there are other similar Cambrian Orthids, but for the present, until all the Cambrian brachiopods have been thoroughly investigated, the species may be placed provisionally in the genus Orthis.

\title{
ARTHROPODA.
}

\author{
TRITOBITA.
}

MICRODISCUS? sp. undet.

Plate III., Fig. 11.

A single specimen, too imperfect for identification or clescription, appears to belong either to Microdiscus or Agnostus. The specimen is probably a head, and is nearly scmi-circular in outline, being proportionately much broader than is usually the case with members of the genus Agnostus, for which reason it is placed prorisionally in Microctiscus.

\section{OLENELLUS THOMTSONI (Hall).}

Plate II., Figs. (1)-10.

1859. Otenus thompsoni Hall, Pal. N. Y., rol. III., p. 525, fig. on 1). $\check{6} 2$.

188t. Otenellus thompsoni Whitfield, Bull. Am. MIus. Nat. Hist., rol. I., p. 151, pl. 15, figs. 1-t.

1886. Otenellus thompsoni Walcott, Bull U. S. Geol. Surv., No. 30, p. $16 \%$, pl. 1\%, figs. 1, \%, 4. 9, pl 22, fig. 1, pl. 23, fig. 1. 1890. Otenellus thompsoni Walcott, 10th Anm. Rep. U. S. Geol. Surr., pt. I., p. 635, pl. 82 , figs. 1-1 a, pl. 83, figs. 1-1 b.

Description.-Head, without the genal spines, sub-semi-circular in outline. Glabella elongate, with subparallel sides, depressed convex, marked by four pairs of lateral furrows, of which the anterior pair 
is situated about two-fifths the length of the glabella from the anterior end, the others heing arranged nearly equidistantly from each other; the posterior or occipital furrow is usually the most pronounced, sometimes being almost continuous across the glabella. The eye-lobes are level with the glabella and are separated from it by the rather broad, dorsal furrow. The eyes are elongate, narrowly crescentic in outline, reaching nearly to the posterior margin of the head, with their anterior extremities opposite the anterior, lateral lobes of the glabella. The cheeks slope away from the glabella and the eyes, to the laterial and anterior margins, with a gentle convexity at first, but becoming slightly concave near the margin. The margin bordered by a narrow, scarcely-elevated rim, which is produced at the genal angles into short, rounded spines. Thorax and pygidium not seen.

The dimensions of an average specimen are: length of head along axis, $8 \mathrm{~mm}$; width of head, $13.5 \mathrm{~mm}$. The length of one of the largest heads observed is $22 \mathrm{~mm}$.

Remarks. - This species has been found most abundantly in the .Hardyston quartzite near Franklin Furnace, but it also occurs in the same formation, near Andover, near Oxford Furnace and at Washington, as well as in the Green Pond region, northeast of Newfoundland. No complete individuals have been seen, the portions found usually being more or less perfect heads. Associated with the heads are the fragments of thorasic segments, which doubtless belong to the same species, but no pygidium or posterior spine has been observed. Because of our lack of knowledge of the posterior extremity of this trilobite, it is not possible to identify it with absolute certainty as $O$. thompsoni, but the characters of the head seem to be identical with that species, although the specimens are much smaller, as a rule, than the more typical representatives of the species from Vermont.

oLENELLUS? sp. undet.

Plate III., Fig. 8.

Among the specimens collected at Newton is a single imperfect free cheek of a trilobite, with an exceedingly elongate eve-lobe, which strongly suggests the genus Otenellus. It resembles more closely the similar cheeks of undoubted Olenellus from the Hardyston quartzite 
at Franklin Furnace than any other trilobite. If in the future more perfect specimens of this trilobite should be secured, and its identification as Olenellus should be confirmed, this association of the two genera, Olenellus and Ditielocephulus, in the same fauna would be a remarkable occurrence.

PTYCHOPARIA BLAIRI N. SP).

Plate I., Figs. 10-13.

Description.-Glabellin small, tumid, longer than wide, the sides subparallel, the front regularly rounded and reaching to the anterior margin of the head. It is marked by two pairs of well-defined, lateral furrows, which divide it into three nearly equal parts; the anterior pair of furrows are straight and each one extends, about one-third the distance across the glabella; the second pair are straight at first and then bend backward somewhat abruptly, towards the occipital furrow; in length they about equal the anterior pair. The occipital furrow is well defined and is continuous across the glabella; the occipital segment is rather broad, with the posterior margin parallel with the occipital furrow. The fixed cheeks are only imperfectly known, but are apparently strongly depressed below the glabella, are rather broad behind, becoming narrower anteriorily, and are not continuous around the anterior extremity of the glabella. Free cheeks unknown. Pygidium minute, strongly convex, semi-circular in outline; the axis highly elevated above the plurw, occupying more than one-third the total width, and tapering to the rather sharply-rounded posterior extremity, which reaches to the posterior margin of the pygidium; divided into five segments by four transverse furrows, which become less and less strongly marked posteriorly; the pluræ convex, with a narrow marginal border, divided into four segments.

The dimensions of an arerage-sized head are: length, $2.8 \mathrm{~mm}$; approximate width, $6.5 \mathrm{~mm}$.

Remarks.-This species occurs near Blairstown, and is known only from imperfect specimens of the head and pygidium. The glabella is frequently well presered and is abundant, but in no case have the cheeks been observed in a perfect condition. 
PTYCHOPARIA NEWTONENSIS $\mathrm{n}$. sp.

Plate III., Fig. 10.

Description.-Glabella tumid, subquadrangular in outline, the lateral margins parallel, broadly rounded anteriorly, slightly contracted posteriorly just in front of the occipital furrow; marked by two pairs of lateral furrows, of which the anterior pair is near the centre of the glabella; all the furrows curve backward as they approach the median line of the glabella, and extend about one-third of the distance across it. Occipital furrow well defined; occipital segment with parallel margins, a little narrower than the width of the glabella, Fixed cheeks broad behind, becoming much narrower in front. Palpebral lobes situated at about the middle of the total length of the head. Anterior border not preserved, but apparently rather broad, connecting the fixed cheeks around the front of the glabella. Free cheeks, thorax and pygidium unknown.

The approximate dimensions of the type specimen are: length, 3.5 $\mathrm{mm}$.; width, $4.75 \mathrm{~mm}$.

PTYCHOPARIA CAICTFERA Walcott.?

Plate I., Fig. 14.

1879. Conocephalites calciferus Walc., 32d Rep. N. Y. State Mus. Xiat. Hist., p. 129.

1886. Ptychoparia calcifera Walc., Bull. U. S. Geol. Surv., No. 30, p. 21.

Among the specimens from near Blairstown is a single, fragmentary individual, which may belong to Ptychoparia calcifera Walc., originally described from the upper Cambrian of Saratoga county, New York. Nothing is preserved except the occipital segment of the head, which is produced into a long spine as in that species. 
PTYCHOPARII? sp. undet.

Plate III., Fig. 13.

A single specimen from Newton, which is different from any of the others in the collection, but is too imperfect for identification, may be provisionally referred to the genus Ptychoparia.

The glabella is subelliptical in outline; glabellar furrows obsolete; occipital furrow well defined; axial portion of occipital segment narrower than the width of the glabella in front. Fixed cheeks imperfectly preserved, rather broad behind, becoming narrower anteriorly, and passing into the frontal limb; palpebral lobes small, apparently placed nearly opposite the anterior end of the glabella. Fixed cheeks, thorax and pygidium unknown.

The approximate dimensions of the specimen are: length, 3.5 mm.; width, $5 \mathrm{~mm}$.

PTYCHOPARTA sp. undet.

Plate III., Fig. 9.

This specimen from Newton cannot be identified with any of the described species of the genus I'tychopuria, to which it apparently belongs, but it is altogether too imperfectly preserved to be used as the type of a new species.

The approximate dimensions of the specimen are: length, 8.5 $\mathrm{mm}$; width, $13 \mathrm{~mm}$.

AGRAULOS SARATOGENSIS Walcott.

Plate I., Figs. 7-9.

1890. Agraulos saratogensis Walcott, Proc. U. S. Nat. Mus., vol. XIII., p. 276, pl. 21, fig. 14.

Description.-Head convex, nearly semi-circular in outline. The cranidium irregularly, sulpentagonal in outline, narrowest in front. Glabella molerately convex, longer than wide, the sides converging slightly towards the broadly-rounded anterior; surface smooth, not narked by lateral furrows; occipital furrow moderately well defined, 
rather broad and shallow; occipital segment produced posteriorly at the centre, into a short, blunt protuberance, scarcely to be called a spine, and narrowing towards the sides. Dorsal furrow shallow, but fairly well defined. Fixed cheeks about one-half as wide as the glabella at the posterior margin of the head, narrowing anteriorly and merging into the frontal limb. Palpebral lobes small, situated a little anterior to the middle of the head. The frontal limb one-fourth to one-sixth the length of the head, curved downward to the anterior borders, without any marginal furrow. Free cheeks convex, irregularly triangular in outline, without a marginal furrow or border, with a short, rounded, genal spine. Pygidium sub-semi-circular in outline, strongly convex, marginal furrow slight or entirely obsolete; axial lobe occupying nearly one-half the entire width and reaching to the posterior margin, divided by four transverse furrows, of which the two anterior ones are much the stronger; pluræ crossed by two furrows corresponding to the two anterior ones of the axial lobe.

The approximate dimensions of a large head are: length, $14.5 \mathrm{~mm}$; width, $24 \mathrm{~mm}$.

Remarks.-This species was first described by Walcott from near Saratoga Springs, New York. In the original description mention is made of indistinct, glabellar furrows, but they are not shown in the illustration accompanying the description, and are wholly absent from the New Jersey specimens. The pygidia associated with the New Jersey specimens does not enitirely agree with the description of that portion of the species as it occurs at Saratoga, the transverse furrows being much less conspicuous. Notwithstanding these differences, the specific identity of the specimens from the two localities can scarcely be questioned. Most of the specimens observed are smaller than the one illustrated, some of them being less than $5 \mathrm{~mm}$. in length.

SOLEXOPLEURA JERSEYENSIS Weller.

Plate II., Figs. 1-8.

1899. Liostracus? jerseyensis Weller, Geol. Surv. N. J., Ann. Rep. of State Geol. for 1899, p. 51, pl. 1, figs. 1-8.

Description.-Glabella large and prominent, longer than wide, subquadrangular or subelliptical in outline, marked by two pairs of faint, lateral furrows, of which the anterior pair are transverse in their 
rirection, anch one extending about one-third the width of the glabella, and are sometimes nearly or quite obsolete; the posterior pair are always mrecent, although sometimes nearly obsolete, arching backwards towards the occipital furrow. Occipital segment separated from the glatella by a deep and rather wide occipital furrow, proAuced posteriorly in a broadly-triangular spine, which is slightly attemate towalds the extremity. Fixed cheek hroad hehind, somewhat convex, bending downwart to the lateral margins; the frontal limb bending upward and forming a rather conspicuous; elevated rim in iront. Facial sutures slightly enred inward anteringly and bending outward posteriorly to the posterior margin, their direction being somewhat sigmoidal. Position and form of pelpelsal lobes not definitely shown in the specimens. Pygidium small, much broader than long, obtuscly sulamgular at its posterior extremity: axis prominent and strongly convex, consisting of five segments, with indications of a sixth one posteriorly, its posterior extremity abruptly rounded and reaching to the pesterior margin of the previtium: plura nearly flat, with a slight marginal groove, divided into five segments.

The approximate dimensions of the largest cranidium observed are: length, $6.2 \mathrm{~mm}$; width, $7.5 \mathrm{~mm}$.

Remarks. - The true generic position of this species must remain in doubt until a complete revision of the genera of American Cambrian trilobites has been made. When first described the species was referred to Liostracus. This generic reference, however, was evidently wrong, and is now changed to Solenopleura, which may also eventually prove to be an incorrect reference.

ANOAIOCARE PARTULA 11. Sp.

Plate III., Fig. 12.

Description.-Cranidium convex, broadly subquadrangular in outline, the anterior margin broadly rounded. Glabella tumid, subquadrangular in outline, nearly as broad as long, not marked by lateral furrows, the sides parallel, the anterior extremity truncated. Occipital furrow well defined: margins of onipital segment parallel. Fixed cheeks broad, united anteriorly by a broad frontal limb, with a convex border along its anterior margin, behind which is a broad, concare furrow, becoming convex towards the glabella. Palpebral 
lobes prominent, situated nearly opposite the anterior extremity of the glabella. Free cheeks, thorax and pygidium unknown.

The approximate dimensions of the type specimen are: length, 3.25 $\mathrm{mm}$; width, $4.5 \mathrm{~mm}$.

Remarks. - This species is placed in the genus Anomocare on account of its broad frontal limb, a character which it shares with members of that genus.

DIKELOCEPHALUS NEWTONENSIS $\mathrm{n}$. sp.

Plate III., Figs. 1-7.

Description.-Head convex, sub-semi-circular in outline. Cranidium irregularly subquadrangular in outline. Glabella moderately convex, longer than wide, subquadrangular in outline, the anterior extremity somewhat truncated, the lateral margins converging anteriorly; crossed by three transverse furrows, the first of which is very faint, but extends continuously across the glabella, its lateral extremities directed slightly forward, so that the furrow describes the arc of a circle; the second furrow opposite the palpebral lobes, parallel with the first, but much more deeply impressed; the third, or occipital, furrow is usually nearly straight, but sometimes with its lateral extremities directed slightly forward, about as deeply impressed as the second furrow ; occipital segment depressed, convex, not rising higher than the glabella in front of it. Fixed cheeks less than one-half the width of the glabella, longitudinally convex, moderately depressed below the level of the glabella opposite the palpebral lobes, but more deeply depressed, both anterior and posterior, to this point. Palpebral lobes situated at about the middle of the length of the head. Frontal limb rather narrow, convex at the margin, separated from the anterior extremity of the glabella by a shallow, rounded groove. Free cheeks large, with long genal spines, which are frequently broken off; convex toward the eyes, with a convex marginal border separated from the inner portion of the cheek by a rather broad, concave depression. Pygidium subsemi-circular in outline, its margin entire, about one and one-half times as wide as long; axis prominent, especially posteriorly, tapering gradually to the somewhat sharply-rounded posterior end, crossed by five transverse furrows, which become more and more nearly obsolete posteriorly; 
pluræ convex near the axis, but becoming flattened or broadly concave near the margin, with five, or, in the larger specimens, six, distinct grooved segments.

Remarks. - This is by far the commonest trilobite in the fauna at Newton, it being represented by fragments of a hundred or more individuals in the collection. 'These vary greatly in size, the smallest pygidium being not over $4 \mathrm{~mm}$. in length, while the largest one observed, when complete, could not have been less than $30 \mathrm{~mm}$. in length. The fragments of heads which have been observed also indicate a great variation in size; several fragments which, however, cannot be certainly determined as belonging to this species because of their imperfection, must have been portions of a trilobite head which, when complete, could not have been less than $50 \mathrm{~mm}$. in breadth. All of these fragments of both heads and pygidia which are perfectly enough preserved for generic identification seem to belong to a single species.

Among the free cheeks observed, a considerable variation in the length of the genal spine is exhibited. The longer spines observed must have been equal to the length of the heads of which they were a part, and are extended into a very slender point posteriorly. The shorter spines have blunter, rounded points, and may simply indicate that the terminal portion has been broken away.

The species most closely resembles $D$. pepinensis Owen, from the Potsdam sandstone of Wisconsin, but differs from that specias, especially in the pygidium, which, in D. promensix, is norly semi-elliptical in outline, with a much more pointed axial lobe. The species differs from D. hartii Walc., described from the upper Cambrian limestone of Saratoga county, New York, in the anterior convergence of the sides of the glabella and in the different shape of the prsidium, which, in $D$. hartii, has the anterior margin curving backward laterally to such an extent that the outline of the whole pygidium is nearly elliptical. The axial lobe of the pygidium of $D$. hartii is also much more pointed than in the species unter consideration. The preidium of $D$. newtonensis resembles that of $D$. devinei Bill., but the head is quite different. The pygidium also resembles that of a species illustrated, but not named, by Hall in Foster and Whitney's Report on the Lake Superior I and District, pl. 23, fig. $3 e$. 


\section{CHAPTER VII.}

\section{FAUNAS OF ORDOVICIAN AGE.}

The Ordovician faunas in New Jersey represent two distinct horizons, and the strata containing them are separated by a conspicuous physical break. The oldest Ordovician fauna represents the Beekmantown (= Calciferous) stage of the New York series, and occurs in the rppermost beds of the Kittatimny limestone, with no apparent phrsical hreak separating the strata from those bearing a Cambrian fauna. This fauna has been found. at but a single locality-near Columbia.

The younger Ordovician fauna represents, in general, the 'Trenton stage of the New York series, and occurs in strata which lie unconformably upon the Fittatimny limestone, with a basal conglomerate between them. The limestones bearing the Trenton fauna have a wide distribution through the Kittatinny valley, in the northrestern portion of the State, and are usually more or less fossiliferous, although the fossils are frequently poorly preserved.

These two=Ordovician faunas will be described separately, the first one which occurs in the upper strata of the Kittatinny limestone being the older. 
Description of Species in tile Beekmantown Fauna.

\title{
MOLLUSCOIDEA.
}

\author{
BRACHIOPODA.
}

Datmanelua wemplet Cleland.

Plate IV., Figs. 10-12.

1900. Datmanella (Orthis) wemplei Cleland, Bull. Am. Pal., No. 1:3, 1. 1\%, pl. 1\%, figs. 10-13.

Descriplion.-Shell small, subcumilringular or suhelliptical in outline, a little wider than long, hinge-line a trifle shorter than the greatest width, cardinal extremities angular or a little rounded. Pedicle valve strongly convex, the highest point being posterior to the mildle; beak elevated, projecting beyond the hinge-line; cardinal arat high, slightly arched. Brachial valve less convex than the perlicle, with a meial flattening, which sometimes becomes a shallow sinus towards the front. Surface of each ralve marked by from ten to sixteen stronger, radiating costæ, with finer ones between.

The dimensions of the largest specimen observed, a brachial valve, are: length, $6 \mathrm{~mm}$; width, $8.5 \mathrm{~mm}$. A smaller pedicle valve measures: length, $5 \mathrm{~mm}$.; width, $5.5 \mathrm{~mm}$.

Remarks. - There seems to be no doubt as to the identity of this little shell with $D$. weniplei, described from the Beckmantown beds, near Fort. Hunter, New York. 'It is represented by numerous specimens in the collection, which exhibit considerable variation in outline and surface markings. The proportional length and breadth vary from being nearly equal in some specimens to others in which the breadth is one and two-thirds the length. In all specimens, however, the breadth is the greater dimension. In most of the specimens the presence of stronger, radiating costie, with less conspicuous ones between, can usually be easily recognized, but in some specimens, which apparently belong to the same species, this alternation is not conspicuous. The species is most closely allied to D. maclocdi Whitf., from the Beckmantown limestone at Beekmantown, New York, and 
it is quite possible that the two species should be considered as the same, but the New Jersey specimens scem to differ from that species in being lesis nearly subcircular and in having a proportionally longer hinge-line.

This species occurs most abundantly in a stratum a few feet above that containing Illonurus columbiana, where it is not associated with. any other species, except a minute, coiled shell, a single, imperfect specimen of which has been observed.

DALALANELLA ELECTRA (Bill.).

Plate IV., Fig. 13.

1862. Orthis electra Billings, Pal. Foss., vol. I., p. 79, fig. "72.

Description.- Shell wider than long, subquadrangular or subelliptical in outline, the hinge-line a little shorter than the greatest width, cardinal extremities angular. Pedicle valve moderately convex on the umbo, slightly flattened towards the cardinal extremities; the beak projecting somewhat beyond the cardinal margin; cardinal area narrow, concave above. Brachial valve not seen. Surface marked by about fifty fine, subequal, radiating costæ, which increase by bifurcation.

The dimensions of a nearly perfect pedicle valve are: length, 5.\%5 mim.; width, $7 \mathrm{~mm}$.

Remarks.-This species is not so abundant as the last, and the only specimens observed occur in the bed with Illcenurus, near Columbia. The species may be distinguished from $D$. wenplei by its finer striæ, which do not alternate in size, and by its less convex pedicle valve, which is slightly flattened toward the cardinal angles. 
SYNTROPHIA LATERALIS (Whitf.).

Plate IV., Figs. 14-15.

18s6. Triplesia lateralis Whitficld, Bull. Am. MIus. Nat. Hist., vol. I., p. 303, pl. 24, figs. 2-11.

Description.-Shell subelliptical in outline, hinge-line about twothirds the greatest width, cardinal extremities broadly rounded. Pedicle ralve moderately convex, most prominent on the umbo, slightly flattened toward the cardinal angles; beak rather blunt, projecting beyond the cardinal margin, slightly incurred; mesial sinus broad, shallow and ill-defined, not reaching to the beak. On some exfoliated specimens a dark line, representing the median septum, may be detected extending forward from the beak for several millimeters. Surface marked by fine, concentric lines of growth. Brachial valve not seen.

The dimensions of an arerage specimen are: length, $7.5 \mathrm{~mm}$; width, $11 \mathrm{~mm}$.

Remarks.-None of the New Jersey specimens of this species are very perfectly preserved, and they differ in some minor respects from Whitfield's illustrations of the types of the species from Fort Cassin, but there can scarcely be a doubt as to the identity of the shells from the two localities. The New Jersey specimens are proportionally a little longer than the original illustration of the species, and the mesial sinus of the pedicle valve is a little less angular, but these differences can scarcely be more than individual variations. The shell described as Syntrophia palmata by Cleland from Fort Hunter, New York, is also probably specifically identical with Whitfield's species and the New Jersey specimens. 


\title{
MOLLUSCA.
}

\author{
GASTROPODA.
}

CYRTOLITES SINUATUS $H$. \& $W$.

Plate IV., Fig. 9.

18\%. Cyrtolites sinuatus H. \& W., U. S. Geol. Expl., 40th par., vol. IT., 1. 23\%, pl. 1, figs. 23-24.

Description.-Shell laterally compressed, composed of about two (?) slightly-embracing volutions. Cross-section of the outer volution subtriangular, the dorso-ventral diameter much greater than the lateral. Sides of the outer rolution marked by a broad depression, which produces a conspicuous carination upon the dorsum of the shell for one-half the entire width of the outer volution. At the inner border of this depression the sides of the shell are somewhat abruptly elevated, then are rather narrowly rounded, dropping almost vertically into the umbilicus. The umbilicus large, exposing the inner volutions.

The maximum diameter of the only specimen observed is $8 \mathrm{~mm}$.

Remarks.-The single specimen of this shell which has been observed in the New Jersey collections has only one side exposed. It agrees with the description and illustrations of the typical $C$. sinuatus described from the Pogonip limestone of Nevada, except that the lateral compression of the outer volution is even greater than in the Nevada shell, so that the portion of the shell immediately surrounding the umbilicus stands up conspicuously as a rounded ridge.

BELLEROPHON? sp. undet.

A single, imperfect specimen of a minute species of a Bellerophonlike shell has been observed in this fauna near Columbia. The diameter of the specimen is less than $5 \mathrm{~mm}$. 


\section{RAPHISTOIIA COLUIBIANA 11. sp.}

Plate IV., Figs. 3-5.

Description. - Shell about twice as wide as high, spire slightly elevated, with about three and one-half volutions, which are flat above and rounded below. The periphery sharply rounded, a little raised above the flattened portion of the volution within. On the rounded portion of the outer volution, just below the periphery and parallel with it, is a rather broad, shallow, ill-defined sulcus. Umbilicus small. Surface nearly smooth, the lines of growth being almost obsolete.

The dimensions of the type specimen are: maximum diameter, 13 mm.; height, $6.5 \mathrm{~mm}$.

Remarhs.--In general form this species resembles $R$. staminea Hall, from the Chazy limestone, but the upper portion of the rolution is flatter, the conspicuous lines of growth described in that species are absent and the shell is smaller. In the internal casts the elevation of the periphery is not exhibited, the clevation, as well as the ols-ure sinus below, being the result of a thickening of the shell along that line. Such an elevation of the outer border of the shell is one of the characteristic features of the genus Helicotoma, and it is possible that the species unler discussion should he placerl in that gemus.

LIOSPIRA sp. undet.

A single specimon of a minute, coiled shell, $3 \mathrm{~mm}$. in diameter, with about two complete volutions, may probably be referred to the genus Liospira. Only the low spire of the shell is exhibited, the opposite side being buried in the matrix. The specimen occurs associated with Dalmanella wemplei in a bed a few feet above that in which most of the species were obtained near Columbia. 
OPHILETA? sp. undet.

Among the specimens collected at Columbia are numerous fragmentary examples of a small, depressed, dish-like, coiled shell, with a broad, open umbilicus, which may be a member of the genus Ophileta. The specimens do not exceed $10 \mathrm{~mm}$. in diameter.

ECCYLIOMPHALUS SUBELLIPTICA n. sp.

Plate IV., Fig. 6.

Description.-Shell loosely coiled, consisting of a little more than one volution, which increases gradually in diameter. Cross-section of the tube subelliptical in outline, slightly flattened above, subangular at the inner, upper margin, and rather sharply rounded on the periphery. Shell substance rather thick, nearly smooth or marked by indistinct lines of growth.

The dimensions of an average specimen are: maximum diameter, $27 \mathrm{~mm}$. ; width of outer volution at aperture, $7 \mathrm{~mm}$.; height of same, $5 \mathrm{~mm}$.; distance between the outer and inner volutions at the aperture, $2.75 \mathrm{~mm}$.

Remarks.-In none of the specimens observed is there more than about one and a quarter volutions preserved, but the inner extremity of the shell is always somewhat blunt, so that some of the older portion of the shell may have been removed. The shell resembles $E$. priscus Whitf., from the Beekmantown limestone at Beekmantown, New York, but the size of the volutions increases more gradually, and none of the longitudinal flutings of that shell have been observed. It agrees even more closely with E. multiseptarius Cleland, from strata of similar age near Fort Hunter, New York, but lacks the strongly-concave, transverse septa of that species. 


\section{POLYGYRA'TA n. gen.}

Shell depressed-conical, with many non-embracing volutions, whose cross-sections are rhomboidal. The umbilicus broad and open, its sloping sides subparallel with the sloping sides of the spire. The genus probalsy includes both sinistral and dextral species. Type of the genus $P$. sinistra.

POLYGYRATA SINISTIA 10 . SP.

Plate IV., Figs. 1-2.

Description.-Shell large, sinistral, depressed, conical. Volutions many, slightly elevated at the suture, not at all embracing. Umbilicus broad and open, its sloping sides sulparallel with the sloping sides of the low spire. Cross-section of the rolution rhomboidal, the width being twice the depth.

Maximum diameter of the type specimen, $3 \% \mathrm{~mm}$.

Remarks.-The most perfect specimen of this species in the collection has been used for the construction of the diagrammatic illustrations here prescnted. In the vertical view the sutures actually preserved are represented by the full lines, the broken lines indicating the portion which has been supplied. On one side the specimen is broken in such a manner as to exhibit a cross-section of several volutions, and from this the cross-section of the shell here presented has been constructed.

This species resembles Euomphalus polygyratus Roem., * from the lower Ordovician (?) of Texas, but differs from it in being a sinistral shell and in having the cross-section of the rolutions much broader. The two species described by Meekt from the lower Ordovician of Utah, under the names Raphistoma? rotuliformis and Raphistoma? trochiscus, are also similar shells, but, like $E$. polygyratus, both have dextral spires, and they are much smaller than either the Texas or New Jersey shells. Pleurotomaria hunterensis Cleland, from near Fort Hunter, New York, is another species of this group which resembles the New Jersey shell quite closely, but is coiled in a dextral

* Die Ḱreidebildungen von Texas (1S52), p. 91, pl. XI., figs, $4 a-4 l$.

f U. S. Geol. Expl., 40th par., pp. 18, 19, pl. I., figs. 2-3. 
direction. All these species agree in having the broad, open umbilicus, and it is possible that all should be included in a single genus, which would, in that case, include both sinistral and dextral shells.

\section{PLATYCERAS? COLUTIBIANA n. sp.}

Plate IV., Figs. 7-S.

Description.-Shell laterally compressed, composed of about two. rolutions; apex small. closely incurved, slightly depressed below the general plane of the shell. Outer volution expanding rapidly, sharply carinate along the dorsum; one side gently convex and but slightly elerated abore the apex of the shell; the opposite side much more convex and rounding into a rather broad, open umbilicus. Surface of shell not well preserved, but apparently smooth, save for some inconspicuous lines of growth.

The dimensions of the type specimen are: maximum diameter, 13.5 mm.; length of aperture, $12 \mathrm{~mm}$.; width of same, about $5 \mathrm{~mm}$.

Remarks.-Only two specimens of this species, exhibiting opposite sides of the shell, have been observed, both of which have one side buried in the matrix. There is some question as to the genus in which this species should be placed. In a general way it resembles some species of Raphistoma or of Maclurea, but it differs from any of these in its small number of volutions, the outer one of which expands rapidly. It does not altogether agree with members of the genus Platyceras, but it may be provisionally considered as a muchcompressed species of this genus.

\section{CEPHALOPODA.}

CYRTOCERAS sp. undet.

Plate III., Figs. 7-8.

Only two specimens of cephalopods have been observed in the fauna. One is a weathered, longitudinal section, exhibiting the chamber of habitation and a little more than $10 \mathrm{~mm}$. of the septate portion of the shell. The other is an imperfect fragment of a shell about 8 
$\mathrm{mm}$. in length, whose transverse outline, so far as preserved, is semielliptical. The complete cross-section seems to have been ovate in outline, with the siphuncle near the broader side, though this cannot be certainly determined from the specimen. In this specimen several sutures are preserved, which are $.5 \mathrm{~mm}$. apart. In the specimen exhibiting the longitudinal section the sutures are slightly more distant and the shell is slightly curved. It is not certain that both these specimens belong to the same species, but neither of them is well enough preserved for identification.

\section{ARTHROPODA.}

\section{TRILOBITA.}

\section{ISOTELUS CANALIS Whitf.}

Plate III., Figs. 5-6.

1886. Asaphus canalis Whitf., Bull. Am. Mus. Nat. Hist., vol. I., p. 336, pl. 34, figs. 1-8.

1889. Asaphus canalis Whitf., Bull. Am. Mus. Nat. Hist., vol. II., p. 64 , pls. 11-12.

This species is represented only ly fragments of the free cheeks, genal spines and prgidia. The largest fragmentary free cheek ohserved indicates an individual with a breadth of $50 \mathrm{~mm}$. or more. This specimen, with a fragmentary prgidium of similar size, has been illustrated. The species resembles $I$. gigas of the Trenton limestone, but is proportionally much broader, the head and pygidium being nearly semi-circular in outline. It also differs from $I$. gigas in the presence of well-developed genal spines, in this respect resembling I. megistos. Broken fragments of these spines are the most common portion of the trilobite preserved in the limestone at Columbia. Some of the specimens, with no part of the remaining portion of the free cheeks preserved, are 30 to $40 \mathrm{~mm}$. in length, and the individuals to which these large spines belonged must hare been at least twice as large as the specimens illustrated, as large, in fact, as the nearly complete specimen illustrated by Thitfield from Fort Cassin, on Lake 
Champlain. The specimens from the Trenton limestone of Minnesota, referred provisionally to this species by Clarke, * do not possess the nearly semi-circular head and pygidium of the Fort Cassin and New Jersey specimens, and are probably specifically distinct.

ILLAENURUS COLUMBIANA $n$. sp.

Plate V., Figs. 1-4.

Description.-Head semi-elliptical in outline; glabella subquadrate, strongly convex, occupying the entire width of the cranidium in front of the eye-lobes. The dorsal and occipital furrows nearly obsolete. Fixed cheeks small, subtriangular, restricted to the region back of the eye-lobes. Eye-lobes prominent, centrally located. Facial suture cutting the anterior margin of the head nearly in line with the base of the eye-lobes, passing in a nearly straight line to the anterior margin of the eye-lobe, and, after encircling this lobe, curving gently outward to the posterior margin. Free cheeks about one-third longer than wide, genal angles broadly rounded. On exfoliated specimens an indistinct, flattened rib extends the entire length of the head along its median line. Pygidium semi-elliptical in outline, axis ill-defined, with three or four nearly obsolete segments. Plure smooth, convex, segments obsolete. Surface of test smooth, except near the outer border of the free cheeks, where it is finely pitted, and near the genal angles, where it is marked with fine, raised lines parallel with the border.

The dimensions of a large cranidium are: length, $23 \mathrm{~mm}$; width at eye-lobes, $22 \mathrm{~mm}$. A large pygidium is $13.5 \mathrm{~mm}$. long and $17 \mathrm{~mm}$. wide.

Remarks.-This is one of the commonest species in the Beekmantown fauna near Columbia, and the cranidia occur in all sizes, from 3 or $4 \mathrm{~mm}$. in length to that of the large specimen illustrated, having a length of $23 \mathrm{~mm}$. The pygidia are not so abundant as the cranidia.

Four species of the genus Illcnurus have previously been described: I. quadratus Hall, from the Potsdam sandstone of Wisconsin; $I$. convexus Whitf., from the Lower Magnesian limestone of the same State; I. dia Walcott, from the Upper Cambrian of Texas, and $I$.

* Pal. Minn., pt. II., p. 707. 
eurekensis Walcott, from the Pogonip limestone of Nevada. The New Jersey species attains a larger size than any of the others, judging from their published illustrations. It differs from 1 . quadratus Hall in its less quadrangular cranidium, its proportionally narrower free cheeks and in its much more elongate pygidium. From I. convexus Whitf. it differs in having more prominent eye-lobes, in having a broader cranidium anteriorly and in having a much more elongate pygidium. From $I$. dia Walc. it differs in having a more elongate head, with narrower fixed cheeks in front. From I. eurekensis Wale. it may be distinguished by its more pointed and narrower cranidium anteriorly and by its somewhat narrower free cheeks.

The pygidium described as Asaphus convexus Cleland, from the Beekmantown limestone near Fort Hunter, New York, is evidently the pygidium of $I$. columbiana, and if Whitfield had not already described a member of the genus under the same specific name, Cleland's name would have been adopterl. Asiociated with the prgidium called Asuphus concerus is an imperfect cranidium, which has been briefly describerl and illustrated by ('leland under the name Buthyurus sp.? This cranidium, also, in all probability is an incomplete specimen of our Illcenurus columbiana.

BATHYURUS? sp. undet.

A single specimen of a small, pustulose, trilobite glabella has been detected in the Beckmantown fauna from near Columbia, which hears some resemblance to Buthyurus conicus Bill., as illustrated by Whitfield,* from Beekmantown, New York. The New Jersey specimen is only $3 \mathrm{~mm}$. in length, however, which is about one-third the size of Whitfield's specimens. Another similar species is Bathyurus ellipticus Cleland, $\uparrow$ from beds of similar age near Fort Hunter, New York, but the New Jersey specimen is also smaller than this species.

* Bull. Am. Mus. Nat. Hist, vol. II., p. 61, pl. 13, figs. 15-21.

$\doteqdot$ Bull. Am. Pal., No. 13, p. 17, pl. 16, figs. 5-6. 
Description of Species in the Trenton Fauna.

\title{
COELENTERATA.
}

\author{
SPONGIAE. \\ IIINDIA PARVA Ulrich.
}

Plate VI., Fig. 1.

1859. Hindia parva Ulrich, Am. Geol., vol. III., p. 244.

1895. Hindia parva W. \& S., Pal. Minn., pt. I., p. 79, pl. G, figs. $7-9$.

Description.- "Sponges free, globular in form, with an even, rounded surface. Specimens vary between 5 and $10 \mathrm{~mm}$. in diameter, but in a large proportion of the specimens seen the diameter varies but little from 7 or 8 mm."-Ulrich.

Remarks.-Specimens of a small, globular sponge have been recognized from various localities in the collections of Trenton limestone fossils. 'They agree perfectly in external characters with the original description of Hindia parva, and are also indistinguishable from authentic specimens of that species from Wisconsin. Their condition of preservation is not such as to show the internal structure in thin sections.

\section{RECEPTACULITES OCCIDENTALIS Salter.}

Plate VI., Figs. $2-4$.

1859. Receptaculites occidentalis Salter, Can. Org. Rem., Dec. 1, p. 45 , pl. 10, figs. $1-\%$.

1884. Receptaculites occidentalis Hinde, Quart. Jour. Geol. Soc., Lond., vol. XL., p. 842, pl. 3\%, figs. $3-3 \mathrm{~m}$.

Description.-Sponge forming discoid or flattened, saucer-like expansions, attaining a diameter of $200 \mathrm{~mm}$., and having a thickness varying from $4 \mathrm{~mm}$. at the centre of the disk to $12 \mathrm{~mm}$. at the margin. 
The disk itself composed of vertical rods or spicules, with their extremities expanded and more or less flattened to form the two surfaces of the disk. The shafts of the spicules are cylindrical, about $1 \mathrm{~mm}$. or slightly more in thickness, and separated from each other by interspaces about equal to their own thickness. The arrangement of the terminations of the spicules upon the surface of the disk is in curved, radiating lines, crossing after the manner of the engineturned ormamentation of a watch. The expanded outer extremities of the spicules are rhomboidal in outline, leaving narrow, linear interstices on each side between adjoining spicules. A short distance above the flattened, rhomboidal extremity there are four connecting processes, which join the spicule with each of the adjoining ones. The inner extremities of the spicules are also expanded and joined together to form the inner surface of the disk.

Remarks.-Specimens of this species of Receptaculites are not uncommon in the lower beds of the Trenton limestone in New Jersey. The manner of preservation is always such as to exhibit poorly the structure of the fossil, as they can usually be detected only upon weathered surfaces of the rock, and are usually but fragmentary specimens. The largest specimen observed has a maximum diameter of $100 \mathrm{~mm}$., but it is only a fragment, and, when complete, must have been at least $200 \mathrm{~mm}$. in diameter.

ANTHOZOA.

STREPTELASILA CORNiCULUM Hall.

Plate VI., Figs, 6-7.

1901. Streptelasma comiculum Lambe, Cont. to Can. Pal., vol. IV., pt. II., p. 108, pl. 6, figs. $7-7 \% b$.

Description.- "Corallum simple, elongato-conical, curved, gradually increasing in size from a pointed base until a maximum breadth of about 3 cent. is reached in a length of hetween 6 or 7 cent., average size somewhat smaller. Outer surface marked transversely by accetion ridges of rather variable size and disposition. Epitheca complete, with distinct septal furrows. Calyx moderately deep, with 
steep sides and a convex floor; its depth, measured from the centre of its floor, is equal to rather less than one-third of the height of the corallum. Septa well developed, of two orders-primaries and secondaries-alternating, numbering in all mature individuals from ninety to one hundred and twenty, the primaries reaching the centre, with their inner ends twisted, the secondaries extending but a short distance inward from the wall. The free edges of the septa in the calyx are denticulated. Dissepiments at times having the appearance, in longitudinal sections of the corallum, of true tabulæ, irregular, subordinate to the septa between which they curve upwards convexly toward the centre of the visceral chamber, where they lose their individuality, and form, with the twisted inner ends of the primary septa, an axial area of cellulose structure."-Lambe.

Remarks.-This species occurs more or less abundantly in some strata of the Trenton limestone, but usually the specimens are in a poor condition of preservation. It is the only species of horn coral which has been recognized at this horizon.

\section{NYCTOPORA BILLINGSI Nich.}

Plate VII., Figs. 1-2.

1879. Nyctopora billingsi Nicholson, Pal. Tab. Corals, p. 184, pl. 9, figs. 3-3 $c$.

1899. Nyctopora billingsi Lambe, Cont. Can. Pal., vol. IV., pt. I., p. 49, pl. 2, figs. $1-1 a$.

Description.-Corallum depressed hemispherical, spheroidal or pyriform, attaining a diameter of 40 to $50 \mathrm{~mm}$. Corallites polygonal, 1 to $1.25 \mathrm{~mm}$. in diameter, their walls of moderate thickness, in close contact and entirely coalesced. The septa rather thick, projecting but slightly into the cavity of the corallite, eight to twelve in number. Tabulæ horizontal, complete, two or three in the space of $1 \mathrm{~mm}$. Mural pores minute, circular, arranged in no definite order.

Remarks.-The genus Nyctopora differs only from Columnaria in the presence of mural pores, and only one species of the genus has been described. This species most closely resembles Columnaria halli Nich. in the character of its septa, but the individual corallites are 
much smaller, rarely attaining a diameter of more than $1.25 \mathrm{~mm}$, while in $C$. halli they are usually about $3 \mathrm{~mm}$. in the adult condition. The corallum of $C$. halli also grows to a much larger size than does Nyctopara. The presence of mural pores can only be detected in thin sections of the coral.

\section{ROMINGERIA? TRENTONENSIS $\mathrm{n}$. sp,}

Plate VI., Fig. 5.

Corallum consisting of loosely-spreading and sometimes anastomosing, irregularly subcylindrical, straight or curved branches, 5 to $10 \mathrm{~mm}$. in diameter, each branch being formed by the aggregation of from six to ten of the subcylindrical corallites, which are in lateral contact throughout the greater portion of their length. The individual corallites subeylindrical in form, usually nearly straight, the sides diverging gradually from the initial point, attaining a langth of from 5 to $10 \mathrm{~mm}$. and a breatth of from 2 to $2.5 \mathrm{~mm}$. The axes of the corallites diverge slightly from the axis of the branch of which they form a part, their sides in lateral contact, except distally, where at least the outer side and sometimes the whole corallite is free, and is frequently curved outward. The septa represented by vertical stria, of which about twenty-five can be recognized at the aperture of the larger corallites. Tabulæe present, but not abundantly.

Remarks.-In some cases the surface of rather large slabs of limestone are entirely covered with fragments of the branching colonies of this coral. The colonies were apparently free throughout the greater part of their extent, being only attached basally. They have the general appearance of a large Aulopora, but apparently do not, as in that genus, grow parasitically upon other objects. The coral is entirely different from any of the heretofore-recognized speres from the Trenton, and is referred provisionally to the genus Romingeria. This genus has not previously been recognized in strata older than the Niagaran, and the best-known species, R. umbellifera (Bill.), is from the Devonian. R.? trentonensis differs from $R$. umbellifera in the form of the septa, they being represented by vertical striæ, and not hy row of spinules, and in the absence of the rerticillate manner of branching, which characterizes the Devonian species. 
The specimens of this species which have been available for study are all imperfectly preserved, being present upon weathered surfaces of Trenton limestone slabs.

\section{HYDROZOA.}

\section{ACTINOSTROAL 'TRENTONENSIS $\mathrm{n}$. sp.}

Plate VI., Fig. S, and Plate VII., Figs., 3-4.

Description.-Conosteum subglobose or pyriform, often exceedingly irregular in form. In cross-section, as exposed on weathered surfaces, it is seen to consist of a series of concentric layers or laminæ, varying from 1 to $3 \mathrm{~mm}$. in thickness, which, by the aid of a lens, are seen to be composed of minute, crowded, parallel fibres, whose direction is vertical to the surfaces of the laminæ. In the thin, vertical section, under the microscope, the fibrous structure is conspicuously exhibited, the vertical fibres being irregularly joined together by vertical, lateral, plate-like expansions. In the thin, transverse sections the vertical fibres, with their lateral expansions, are seen to coalesce in a most irregular manner, leaving numerous, vertical openings, which are exceedingly variable in form and size.

The usual diameter of masses of this organism is from 25 to $40 \mathrm{~mm}$.

Remarks.-In the lower portion of the Trenton limestone, in strata which are probably of Black River age, certain beds are frequently more or less completely composed of the colonies of this organism, though upon the unweathered rock surfaces they often can scarcely be detected. On the weathered surfaces, however, they may usually be easily recognized by their texture and slightly different color, which distinguishes them from the matrix in which they are buried. The organism is clearly one of the Stromatoporoids, and has been placed provisionally in the genus Actinostroma, because of its conspicous fibrous structure. It differs from the usual members of that genus, howerer, in the apparent absence, or at least small number, of horizontal rods connecting the vertical fibres, which usually gives to the thin, vertical section of Actinostroma a reticulate appearance. 


\title{
MOLLUSCOIDEA.
}

\author{
BRYOZOA. \\ PRASOPORA SIMULATRIX Ulrich.
}

Plate VIII., Figs. 1-3.

1856. Prasopora simulatrix Ulr., 14th Ann. Rep. Geol. Nat. Hist. Surv. Minn., p. 85.

1895. Prasopora simulatrix Ulr., Pal. Minn., pt. I., p. 245, pl. 16, figs. $1-10$.

"Zoarium discoid in the younger stages, hecoming hemispheric or subconical with age; occasionally the centre part of the upper surface is drawn out, and in a few instances has been observed even to divide into two branch-like lobes. The last conditions, as well as various other irregular developments, are to be considered as abnormal. Base more or less concave, usually with a central cicatrix of attachment, beyond which it is covered with a concentrically-striated and wrinkled epitheca. Upper surface celluliferous. Height of zoarium varying from $5 \mathrm{~mm}$. or less to $50 \mathrm{~mm}$. or more; diameter from 10 to over $100 \mathrm{~mm}$. Zocecia with direct, subcircular apertures, thin walls, those of neighboring cells generally in contact, except at the angles of junction, the latter being oceupied by angular mesopores of variable, though usually small, size. In the youngest specimens the zoecia are the roundest, and the interspaces, oceupied by the mesopores, the widest, while in the oldest the opposite conditions prevail. More or less conspicuous clusters of cells of larger size than the average occur at intervals of nearly $4 \mathrm{~mm}$, measuring from centre to centre. Between these cells the mesopores are commonly more numerous than elsewhere, and in nearly all cases constitute aggregations of variable extent and substellate form. In many casce, chiefly old examples, the mesopores between the zoocia occupying the intermacular spaces might be overlooked, although, as shown in thin sections, they are really numerous even there. Diameter of an ordinary zoceium about $0.25 \mathrm{~mm}$., with an arerage of eleven in 
$3 \mathrm{~mm}$. Those forming the clusters vary in size, generally, from 0.25 to $0.38 \mathrm{~mm}$. Acanthopores wanting.

"Internal Characters.-These, as shown in over one hundred thin sections, are very constant in all the essential parts. In tangential sections the form of the zocecial tubes varies from perfectly circular to polygonal, their walls in most cases being very thin, and the cavity of each intersected by the crescentic edges of one or more cystiphragms. The opening left by the cystiphragms is generally lateral and of bi-convex shape; occasionally it is subcentrally situated and oval, but more commonly two or more cystiphragms combine to give it a subtriangular form. An abnormality is sometimes met with in the confluence of two zoœcia. The zoœcia are in contact with each other only in part, perhaps only at limited points, the interspaces left between them being occupied by small mesopores. These vary somewhat in number, and more so in size, but are always decidedly angular. At intervals they are collected into substellate maculæ of greater or less extent, and in the immediate vicinity of these the zoccia are of appreciably larger size than elsewhere. No evidence whatever of acanthopores has been detected.

"In vertical sections the cystiphragms form continuous series on one or both sides of the tubes, according as they extend all around the circumference or embrace only a portion of the same, while an equal number of straight diaphragms crosses the remaining portion of the tube."-Ulrich. The tabulation of the tubes is quite uniform, the cystiphragms averaging sixteen or seventeen in $2 \mathrm{~mm}$. In the mesopores the diaphragms are simple, and average about eighteen in $1 \mathrm{~mm}$.

Remarks.-This species of bryozoan is the most common one in the Trenton limestone of New Jersey. As it usually occurs, it is firmly imbedded in the limestone, so that only the cross-sections of the specimens can be observed. Only rarely is a complete colony weathered free from the matrix. Thin sections of the New Jersey specimens show them to be identical with the typical form of the species as described from Kentucky, Tennessee and Minnesota. The variety orientalis, said to come from New York and Canada, has not been detected among the New Jersey specimens. 
MONO'TIPA GLOLOSA n. Sp.

Plate VIII., Figs, 4-6.

Description.-Zoarium subglobular, 12 to $20 \mathrm{~mm}$. in diameter, base or point of attachment small, the direction of the central zoceial tubes nearly straight, the lateral ones strongly curved outward and then downward, the intermediate ones becoming progressively more and more curved from the centre to the sides. Internally, as shown in tangential sections, the zoceia are rather thick walled, and their duplex character can be readily seen. They are polygonal in outline, and acanthopores are lacking. Mesopores of variable size are present, from none at all to three being in contact with each full-grown zonecium ; they are more abundant among groups of somewhat thickerwalled zoœcia. As shown in longitudinal section, the mesopores are but the initial portion of normal zocecia, which rapidly increase in size to their normal condition, because of the rapid spreading of the tubes, due to their strong curvature towards the sides of the zoarium. Diaphragms are scarce, there rarely being more than a single one in the entire length of a zonecial tube, while many tubes are apparently entirely free from diaphragms.

Remarks. - This species has not been found rery commonly in the Trenton limestone of New Jersey, but it is quite distinct in its characters. It may always be recognized by its strongly-curved zoocial tubes and the small number of diaphragms. The surface characters of the species have not been determined, because all the specimens observed are firmly imbedded in the matrix. The groups of thickerwalled zoceia with more numerous mesopores, seen in the trangential sections, were probably somewhat elevated above the surface as monticules.

CALLOPORA sp. undet.

Plate VII., Fig. 5.

Fractured specimens of Callopora are occasionally met with in the Trenton limestone of New Jersey, but they are always in a poor state of preservation, and their specific identity cammot be made out with any degree of certainty. The members of this genus of bryozoa have a more or less dendritic zoarium, with subcylindrical branches. 
'The zoœeia are at first nearly parallel with the axis of the branches, but finally curve outward somewhat abruptly, so that theif outer portion is at nearly right angles to the axis. Diaphragms are present abundantly in some species, but more rarely in others.

PIYLLOPORINA: FENESTRATA. (Hall).

Plate VII., Fig. 6.

1850. Retepora fenestrata Hall, 3d Rep. N. Y. State Cab. Nat. Hist., p. 170 , pl. 2, figs. $1 a-e$.

Description.-Zoarium a reticulate expansion, with the branches irregularly anastomosing or united by transverse bars. The branches cylindrical, celluliferous on but one side, the obverse side marked by fine, raised, angular striæ, whose general direction is longitudinal, but which, also, have transverse branches, which give to them an irregular, reticulate arrangement.

The diameter of the branches is 0.3 or $0.4 \mathrm{~mm}$., the transverse bars being somewhat smaller; the spaces between the branches are $1 \mathrm{~mm}$. or less.

Remarks.-This species has been recognized only in the lower portion of the Trenton limestone, in strata which are probably of Black River age. The celluliferous surface has in no case been observed on the New Jersey specimens. Hall's original illustration of the species shows the cells to be triangular or quadrangular in outline and arranged irregularly, from four to six occupying the entire width of each branch. The species can be distinguished from other members of the genus by its definite, transverse bars joining the branches of the zoaria, which, in Hall's figures, are shown to be non-cell-bearing.

RHINIDICTYA sp. undet.

Plate VIII., Figs. 7-9.

One or more species of Rhinidictya occur in the Trenton limestone of New Jersey, but the material is usually in too imperfect a condition to be satisfactory for study. Some of the specimens seem to 
agree more closely with $R$. trentonensis (Ulr.) than with any other described species, but the specific identification cannot be made with any certainty. In such specimens as exhibit the branching of the zoarium, the divisions are dichotomous and rather widely spreading. About eight rows of zoœcia are present on each side of the zoarium, the specimens showing but little variation from this number. In most cases the external surface of the specimens adheres closely to the matrix, and the bifoliate zoarium divides along the mesotheca. The material may represent one or more undescribed species.

\section{BRACHIOPODA.}

\section{LINGULA RICINIFORMIS Hall.}

Plate IX., Fig. 8.

184\% Lingula riciniformis Hall, Pal. N. Y., vol. I., p. 95, pl. 30, figs. $2 a-c$.

1893. Lingula riciniformis Winchell and Schuchert, Pal. Minn., pt. I., p. 343, pl. 29, fig. 9 .

Description.- Shell subelliptical in outline, the anterior margin regularly rounded, the lateral margins slightly convex, subparallel, the postero-lateral margins rounded, the apex rather blunt. The two valves equally convex. Surface marked by concentric lines of growth. The dimensions of a rather small specimen are: length, $6 \mathrm{~mm}$., and breadth, $3.5 \mathrm{~mm}$.

Remarks.-The little shell identified as this species is not uncommon in the Trenton limestone of New Jersey, but its condition of preservation is such that its distinctive characters camnot be determined. In general size and form it resembles $L$. riciniformis far more closely than any other species, so that the identification is made with but little hesitation. The individuals studied vary somewhat in size, but $10 \mathrm{~mm}$. is about the maximum length which has been observed. Upon many specimens, in their exfoliated condition, a slight, median furrow can be seen, extending backward from the beak to beyond the middle of the shell. In a few cases faint, radiating striæ have been detected in the median portion of the shell near the front. 
LINGULA PHILOMELA Bill.?

Plate IX., Fig. 7.

1862. Lingula philomela Billings, Pal. Foss., vol. I., p. 49 , fig. 53. 1893. Lingula philomela Winchell and Schuchert, Pal. Minn., pt. I., p. 342 , pl. 29, figs. $7-8$.

A few imperfect specimens of a much larger species of Lingula than the last have been noticed in the New Jersey collections. This species attains a length of nearly $25 \mathrm{~mm}$., with a breadth of $11 \mathrm{~mm}$. It has much the form of $L$. phitomela, and is therefore provisionally identified with that species.

\section{LFEGULASA GLLENEASTS W. \& $\mathrm{S}$.}

Plate IX., Figs. 10-11.

1892. Lingulasma gatenensis Winchell and Schuchert, Am. Geol., vol. IX., p. 285.

1893. Lingulasma galenensis. Winchell and Schuchert, Pal. Minm., pt. I.. 1. 35t, pl. :30, figs. 1-t.

Description.-Shell large, subquadrangular in outline, both valves convex. Anterior margin slightly convex, rounding narrowly at the sides into the straight, subparallel, lateral margins, the posterior margin convex, the postero-lateral angles rounded. Brachial valve more convex than the pedicle, the posterior third of its interior sreatly elevated, as a concave platform, which is excavated in front and supported medially by a septum, which terminates at about the centre of the valve.

'The dimensions of the only specimen observed are: length, $29 \mathrm{~mm}$.; breadth, $24 \mathrm{~mm}$.; convexity of brachial valve, $10 \mathrm{~mm}$.

Remarks.-A single, imperfectly-preserved internal cast of this species has been observed. The internal characters of the brachial valve are fairly well exhibited, showing the form of the platform and the mesial septum. The pedicle valve is so badly crusherd that 
its characters camnot be distinguished, but it is known that this valve also bears an internal, elevated platform somewhat similar to that of the brachial valve. The surface characters of the species cannot be recognized upon the New Jersey specimen.

\author{
SCHIZOCRANIA FILOSA (Hall).
}

Plate IX., Figs. 3-4.

1875. Schizocrania filosa Hall and Whitfield, Pal. Ohio, vol. II., p. 73, pl. 1, figs. 12-15.

Description.-Shell orbicular or subovate, the beak of the free or mathial valve projecting slightly beyond the limits of the eircle, giving a somewhat greater diameter along the median line than in a transreres direction. I'edicle or attached ralve discoid, very thin, deeply and broadly notched on the posterior side; the notch occupying nearly one-quarter of the circumference of the valve on the outer margin and extending nearly to the centre of the valve, its border thickened, wiscially at the hare. which is rounded, with the centre marked by a slightly-projecting point, marked by strong, irregular, coneentric molulations parallel to the margin, but interrupted by the border of the notch. Birachial or free valve moderately convex, most prominent near the centre, its surface marked by fine, even, thread-like, radiating strial, which increase both by bifurcation and interealation, and beeome stronger toward the border of the shell.

Remarks.- The specimens of this species found in the Trenton limestone of New Jereey compare farorably with specimens of similar age from New York, but they do not grow so large as is usually the case with specimens from the Cincinuatian beds of the Ohio valley. The perticle or attached valve has not been observed among the New Jersey specimens, the description of this portion of the shell being taken from Ohio specimens. 
ORBICULOTDEA LATELLOSA (Hall).

Plate Lx, Figs. 1-2.

1892. Orbiculoidea lamellosa Hall and Clarke, Pal. N. Y., vol. VIII., pt. I., pl. $4 \mathrm{E}$, fig. 12.

Description.-Shell depressed-conical, nearly circular in outline, the anex of the brachial valve situated about one-third of the breadth of the shell from the margin. Surface marked by rather irregular, elevated, more or less lamellose, concentric lines, the grooves between the lines being rather wider than the ridges themselves.

Pericle valve not observed in the New Jersey collections.

The dimensions of a nearly perfect brachial valve are: length, 9.5 $\mathrm{mm}$.; width, $8.75 \mathrm{~mm}$; convexity, $2.5 \mathrm{~mm}$.

Remarks. - With the possible exception of a single one, all the specimens of Orbiculoidea which have been observed in the Trenton limestone fauna of New Jersey belong to this species. It is characterized by rather conspicuous, sublamellose, concentric markings. and seems to agree with the descriptions and illustrations of $O$. lamellosa.

ORBICULOIDEA sp. undet.

Plate IX., Figs. 5-6.

A single specimen of a peculiar shell, which is apparently one of the inarticulate brachiopods, has been observed in a collection of Trenton limestone fossils from near Branchville, New Jersey. The form of the shell is obliquely subconical, the elevation of the bluntlyrounded apex being about three-fourths the width of the shell. The length is somewhat greater than the width, the outline of the margin being nearly elliptical.

The dimensions of the specimen are: length, $13 \mathrm{~mm}$.; width, 10 $\mathrm{mm}$.; convexity, $7.5 \mathrm{~mm}$.

In general form the shell resembles some of the simple, cap-shaped gastropod shells, but the shell substance is that of the inarticulate brachiopods, such as Orbiculoidea, in which genus the shell has been placed provisionally. The pedicle valve has not been observed. 
CIANIA sp. undet.

Plate IX., Fig. 9.

A few imperfect specimens of a species of Crania have been observed in the 'Trenton limestone of New Jersey. They resemble $C$. trentonensis Hall, but the apex of the brachial valve is usually close to the posterior margin.

RhFixesquixa ALTERATTA (Emm.).

Plate IX., Figs. 12-13.

18\%3. Strophomena alternata Meek, Pal. Ohio, vol. I., p. ss, pl. ¡, figs. 1-3.

Description.-Shell semi-elliptical or semi-circular in outline; greatest breadth of the shell along the hinge-line; cardinal extremities

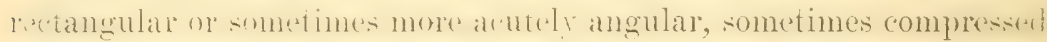
and moderately deflected; lateral margins a little convex or slightly sinuous posteriorly, rounding forward to the front, which is semicircular in outline. I'edicle valve depressed, convex at the umbo, but usually much compressed orer the whole visceral region in the adult (which includes the whole surface of the young and half-grown shells), becoming more conrex, frequently more or less geniculate, anteriorly and laterally, and thence more or less curved to the marrins of the shell. Cardinal area of moderate height, flat and directed obliquely backward, nearly at right angles to that of the other valve; heak small, scarcely distinct from the margin of the area, minutely perforated; delthyrium broadiy triangular and arched over by the reltidium; which is deeply sinuous on its inner edge, the sinus being nearly or quite closed by the cardinal process and chilidium of the other valve.

Brachial valve flattened on the umbonal and cardinal regions, rently or more or less strongly concave in the central and anterior portions, and curved upward around the anterior and lateral margins; Irak small. but projecting slightly heyond the edge of the area, whicl: is very narrow or sublinear, and directed nearly in the plane of the 
valve. Surface of both valves marked by numerous. moderately-fine. radiating costæ. Those of the pedicle valve usually increasing by intercalation, and usually arranged with one to six or eight smaller and shorter ones between each two larger and more prominent ones. the largest one of which often occupies the mesial line. On the brachial valve the radiating stria more frequently increase by division, and are usually more uniform in size. In addition to the radiating lines, the shell is marked by numerous, minute, regular, closelyatranged, concentric strix, which are visible only on well-preserved specimens by the aid of a magnifying glass. A few more or less distinct, subimbricating lines of growth are also seen near the free margins of adult shells.

The approximate dimensions of a nearly-complete pedicle valve are: length $26 \mathrm{~mm}$.; width, $31 \mathrm{~mm}$. The species at times attains a much larger size than this, but the New Jerser specimens are usually smaller.

Remarks. - This very characteristic Ordorician brachiopod occurs abundantly in some strata of the Trenton limestone of New Jersey. Usually, however, it is not an abundant form, and the specimens are imperfectly preserved. The shell is a variable one in most of its characters, but it may always be recognized by its convex pedicle valve, with conspicuously alternating, radiate markings.

PLECTAAronites SERICEUS (Sowerby).

Plate IX., Figs. 14-15.

1873. Leptrena sericea Meek, Pal. Ohio, vol. I., p. 70, pl. 5, figs. $3 a-h$.

Description.-Shell subsemi-elliptical or subsemi-circular in outline, concavo-convex, hinge-line equaling or usually a little longer than the breadth of the valves in front; cardinal extremities varying from nearly rectangular to acutely angular, anterior and lateral margins, forming together a nearly-regular. semi-circular curve. Pedicle ralve moderately convex, nearly evenly, but gently, arched along the median line from the beak to the front; beak yery small, scarcely, if at all, distinct from the cardinal margin; cardinal area two to three times as high as that of the opposite valve, inclined backward or more or less nearly parallel to the plane of the valve; delthyrium 
arched over near the beak by a small deltidium, and nearly closed hetween this and the hinge margin by the prominent cardinal process and chilidium of the other ralve. Brachial valve concave, its greatest roncavity near the middle, following noarly the curve of the perticle ralve, so as to leave but a narrow, visceral cavity within; beak not Aistinct from the ardinal margin; cardinal area narrow or nearly linear, lying at a right angle to the plane of the valve. Surface of both valves marked by numerous, fine, losely-arranger, equal, radiating costx, or with every fourth, fifth or sixth one larger and more prominent than those between.

The dimensions of a rery large specimen are: length, $15 \mathrm{~mm}$; width, $23 \mathrm{~mm}$.

Remarks.-This a variable species, especially in regard to its size. In the Trenton limestone of New . Tersey two forms are conspiculons, which are usually not associated in the same bed. A large form, having a witth of $20 \mathrm{~mm}$. or more, ocurs usually in the lower strata, while higher up a smaller form, from 12 to $15 \mathrm{~mm}$. in width, is abundant, often constituting almost "utirely some of the thinner strata. The large form in the lowrer beds is frequently marked by several folds or wrinkles, of greater or loss strength, on each sile of the beak, which axtend from the eardinal margin obliquely toward the median line of the shell. This spectus is probahly more abundanty represented in the Trenton fauna of New Jersey than any other.

Stropiomiena incurrata (Shep.).

Plate IX., Figs. 16-17.

1892. Strophomena filitexta Hall and Clarke, Pal. N. Y., vol. VIII., pt. I.. pl. ?. figm. 1-г, pl. ! .1, fig- 11-14.

Description.-Shell wider than long, the greatest width along the hinge-line, more or less strongly concavo-onver, subsemi-elliptical in mutline: carlinal extremities angular and deflected, lateral and antwior margins regularly rounded. Pediele valve slightly consex in the umbonal region, but otherwise more or less deeply concare, often with an ill-definer sinus foward the front; the beak extending but little berond the cardinal margin. minntely perforated; cardinil area variahle in width and eleration. slightly retrorse in rerr gibbou- speci- 
mens, or strongly elevated in flatter ones. Delthyrium as wide or wider than long, filled with a conspicuous, convex deltidium, which is broadly excavated anteriorly and occupied by the chilidium. Brachial valve flattened or slightly concave in the umbonal region, more or less strongly convex laterally and anteriorly, often with a shallow. narrow sinus extending from the beak to the middle of the shell, and with a broadly-rounded median fold near the front margin; cardinat area narrow, vertical, centrally occupied by a broad and short chilidium. Surface of both valves marked by numerous, fine, subequal, crowded, rounded or subangular costie, which increase by intercalation, every second, third or fourth one being more prominent. The whole surface is also crossed by numerous, crowded, delicate, raised, concentric lines and by a few stronger marks of growth. In some specimens oblique wrinkles are present along the cardinal margin on each side of the beaks.

The dimensions of a medium-sized brachial valve are: length, $1 \hat{\imath}$ $\mathrm{mm}$.; width, $23 \mathrm{~mm}$.; conrexity, $8 \mathrm{~mm}$.

Remarks.-This species occurs quite commonly in the Trenton fauna. In its more or less imperfect condition of preservation it may sometimes be confused with Rafinesquina alternata, although its brachial valve, and not its pedicle valve, is convex. On the convex valve of $S$. incurvata, however, there is always a slight flattening or shallow concavity near the beak, while in $R$. alternata the same portion of the shell is slightly convex. The delicate concentric surface markings of this species are characteristic, but these are usually destroyed upon the New Jersey specimens, because of their manner of preservation.

ORTHIS TRICENARIA Conrad.

Plate 1X., Figs. 18-21.

1892. Orthis tricenaria Hall and Clarke, Pal. N. I., rol. VIII., pt. I., pl. 5, figs. 9-14.

Description.--Shell plano-convex, longitudinally semi-elliptical in outline; hinge-line equal to the greatest width of the shell, rarely shorter. Cardinal area well dereloped on each valve. Surface marked by thirty to thirty-six usually nearly equal, simple, subangular, radiating costæ, which are crossed by exceedingly delicate, concentric lines 
of growth. Pedicle ralve strongly convex, subangular along the median line, with the greatest elevation on the umbo. Cardinal area very high, more or less concave, striated longitudinally and transversely, divided by a very narrow delthyrium, whose apical third is oreupied by a flat, concare or convex deltidium. Brachial valve nearly flat, slightly elevated at the beak, from which point the surface slopes gradually into a broat, sarcely-perceptible. rarely well-defined, median sinus. Cardinal area nearly one-third as wide as that of the pedicle valve, flat, divided by a triangular delthyrium, which is as broad as long and more or less covered by a convex chilidium, the anterior margin of which is concave.

The dimensions of a rather large specimen are: length, $19 \mathrm{~mm}$.; width, $20 \mathrm{~mm}$.; thickness, $10.5 \mathrm{~mm}$.

Remarks.-The presence of this species always indicates a low Trenton horizon, it being entirely absent from the higher beds. The New fersey suecimens are always porly preserved, being more or less exfoliated, the two valves being rarely found in articulation.

PLECTORTIIS PLICATELLA (Hall).

Plate IX., Figs. 22-24.

184\%. Orthis plicatella Hall, Pal. 1. I., rol. I., p. 122, pl. 32, fig. 9. 1892. Plectorthis plicatella Hall and Clarke, Pal. N. Y., vol. VIII., pt. 1., p. 194, pl. 5̆, figs. 18-20.

1895. Orthis (Plectorthis) plicatella Winchell and Schuchert, Pal. Minn., pt. I., p. 436, pl. 33, figs. $\tilde{\jmath}-\hat{\imath}$.

Description.-Shell lenticular, transversely subelliptical in outline, cach valve marked by from twenty-two to thirty-two strong, simple, radiating plications. In some specimens a few much-finer plications are intercalated between the primary ones near the front margin. Hinge-line shorter than the greatest width of the shell; cardinal extremities angular or somewhat rounded. Pedicle valve regularly convex, the greatest elevation being at or a little back of the middle. In front of the middle point the mesial portion is usually slightly flattened, but never enough to make a mesial sinus. The cardinal area is sharply defined, broadly triangular and moderately concave. The brachial ralve is usually a little less convex than the pedicle, its greatest elevation being near the middle. No mesial fold is developed. 
The dimensions of a rather large individual are: length, $18 \mathrm{~mm}$; Breadth, $21 \mathrm{~mm}$.; convexity of both valves, $9 \mathrm{~mm}$.

Remarks.-This species is not uncommon in many of the middle and upper beds of the Jacksonburg section, and also frequently occur: elscwhere. The New Jersey specimens differ from the Cincinnatian shells, which are referred to this species in being generally longer in proportion to the breadth, some of the New Jersey specimens being nearly subcircular in outline. When imperfectly preserved, it is frequently difficult to separate specimen of this specics from Dinorthis pectinella, but in complete specimens the pedicle valve of $P$. plicatella is much more convex and the cardinal area slopes backward much more than in $D$. pectinella. The brachial valves of the two species, as preserved in the New Jersey rocks, are frequently wholly indistinguishable.

PLATYSTROPHIA BIFORATA (Schl.).

Plate IX., Figs, 25-28.

1895. Platystrophia biforata W. \& S., Pal. Minn., pt. I., p. 45̆, pl. 33 , figs. 51-5 4 .

Description.- Shell subequally biconvex, with strong fold and sinus, wider than long, the breadth ranging from 10 to $20 \mathrm{~mm}$. Hinge-line equal to or a little shorter than the greatest width of the shell. Cardinal angles rectangular or a little obtuse. Lateral margins straight or slightly convex at first, then curving gently into the regularly-rounded front. Surface of each valve marked by from thirteen to eighteen strong, angular plications, of which three or four occupy the fold and sinus. Pedicle valve most prominent on the umbo, more or less flattened towards the cardinal extremities; beak incurved and pointed; cardinal area well defined; sinus reaching nearly to the point of the beak, where it is occupied by a single plication, sharply defined by an angular plication on each side, deep and rounded anteriorly, where one or two additional plications are added on either side of the initial central one. Brachial valve with its greatest elevation in the centre, more or less flattened toward the cardinal angles; cardinal area nearly equal to that of the pedicle valve; the fold prominent and sharply defined. 
The dimensions of a nearly-perfect specimen are: length, $9.5 \mathrm{~mm}$; width, $12 \mathrm{~mm}$.; thickness, $7 \mathrm{~mm}$.

Remarks.-As it occurs in the Trenton limestone of New Jersey, this species never grows to the large size which it frequently attains flsewhere. The largest specimens observed do not exceed $20 \mathrm{~mm}$. in hreadth and hut few specimens exceed $15 \mathrm{~mm}$. The range of variation among the New Jersey specimens is not great, and the above description has been drawn up to accord with these as nearly as possible.

DINORTHLS PECTINELLA (Emm.).

Plate IX., Figs. 29-30.

1892. Orthis (Dinorthis) pectinella Hall and Clarke, Pal. N. Y., rol. VIII., pt. I., pl. 5, figs. 27-33.

Description.- Shell resupinate, transversely subelliptical in outline, wider than long, in about the proportion of four to three; cardinal line usually less than the greatest width of the shell, the cardinal extremities rounded; surface of each valve marked by from twentytwo to thirty prominent, rounded, simple costr, which are equal in width to the spaces between, and are crossed by fine, closely-crowrled, elevated, concentric lines of growth. Pedicle valve slightly convex near the beak, flattened on the sides, with a broad, shallow, ill-defined depression along the centre, usually most distinct in front, but frequently nearly obsolete. Cardinal area moderately large and well defined, flat, lying nearly at right angles to the plane of the shell. Brachial valve regularly convex, most prominent in the centre, flattened and slightly deflected near the cardinal extremities. Cardinal area much narrower than that of the opposite ralve, lying nearly in the plane of the shell.

The dimensions of a nearly-perfect pedicle valve are: length, 21 mm. ; width, 2\%.5 $\mathrm{mm}$.

Remarls.-This species is almost always imperfectly preserved in the Trenton limestone of New Jersey, and it is often next to impossible to distinguish specimens of the brachial valve from Plectorth is plicatella. There is no difficulty, however, in recogaizing the nearly-. flat pedicle valre. The species is characteristically a low 'Trenton form. 
DALMANELLA TESTUDINARIA (Dal.).

Plate X., Figs, 1-2.

1895. Orthis (Dalmanella) testudinaria W. \& S., Pul. Minn., It. I., p. 441, pl. 33, figs. 17-22.

Description.-Adult shells subcircular and the younger ones transversely subelliptical in outline; hinge-line less than the grvatest width; cardinal angles rounded, lateral and anterior margins bradly rounded, though the extreme front of the shell is sometimes straight for a short distance. Surface of both valves marked by unequal, angular, radiating costax, about ten or twelve of the largest mes having their origin at the beak, the remainder being lateral branches from these. In some of the larger individuals as many as sixty $\mathrm{ol}^{\circ}$ more costæ are present along the margin of the shell. The branches from the main costæ are small at first, but increase in size towards the margin of the shell, and themselves give off additional branches. In many individuals this manner of branching gives to the costa a more or less fasciculate appearance, each fascicle having one large rib in the centre, with smaller ones on either side. In those specimens having the shell well preserved the bottoms of the grooves between the costæ exhibit a series of fine, transverse crenulations. Pedicle valve convex, subcarinate along the median line, the lateral slopes nearly straight, the greatest convexity of the valve about one-third the distance from the beak. Cardinal area moderately concave, forming an angle of about $45^{\circ}$ with the plane of the valve, about five or six times as wide as high. Delthyrium a little higher than wide. Brachial valve nearly flat, with a sinus beginning close to the leak and expanding in a broad, shallow depression towards the front.

The dimensions of an average-sized specimen are: length, $8 . \mathrm{mm}$; width, $8.25 \mathrm{~mm}$. ; convexity of pedicle valve, $2.5 \mathrm{~mm}$.

Remarks.-This species is nearly as abundant in the Trenton limestone as Plectambonites sericeus. The New Jersey specimens are all of one variety, which are particularly characterized by the subcarinate pedicle valve and the rather coarse, fasciculately-arranged radiating costx. 


\section{DATMANELLA SUBAEQUATA. (Con.).}

Plate X., Figs. 3-4.

14.13. Orthis suberquta Conrad, Proc. Acal. Nat. Sci. Phil., vol. I., p. 333.

184\%. Orthis subaquata Hall, Pal. N. Y., vol. I., p. 118, pl. 32, fig. 2. 14y:. Datmunelle subequata Hall and Clarke. Pal. N. Y., vol. VIII., pt. I., p. 20\%, pl. 5 c, figs. 6-11.

is!s. Orthis (Datmanella) subarquata Winchell and Schuchert, Pal. Minn., pt. I., p. 446, pl. 33, figs. 30-36.

Description.-Shell subequally biconvex, usually wider than long; thr hinge-line shorter than the greatest width of the shell, except -nmotimes in young individuals; cardinal extremities angular or romoled. Surface of rach valve marked by numerous, fine, tubulose strim. which bifurcate about twice in passing from the beak to the antrior margin. Pedicle valve strongly and evenly convex, the greatwht. "levation posterior to the middle of the shell; near the beak and upon the umbo no mesial depression exists, but near the middle of the valve a broad, shallow and indistinct sinus hegins and becomes dexper toward the anterior margin. The cardinal area is well defined, broadly triangular, elevated and only moderately concave; the tholthyrium, with slightly-curved sides, is atout twice as high as wide. Branhial valve more evenly, but a little less, convex than the pediele, the greatest elevation near the middle. Near the beak the mesial purtion of the shell is usually flattened or slightly depressed, but near the middle of the shell this flattening gradually changes into a low, frrabl, ill-rlefined elevation, corresponding with the sinus of the pedicle valv. 'The cardinal area is narrow and concave, with a delthyrium as broad or broader than high.

'The dimensions of an arerage specimen are: breadth, $16 \mathrm{~mm}$., and length, $14 \mathrm{~mm}$.

firmarts. This speries oceurs in great numbers in the lower beds of the Jacksonburesection. It exhibits some variation in its size and preprertions, one of the largest specimens observed being $25 \mathrm{~mm}$. in hwalth, 1: mm. in length, and with a thickness of both valves of 15 mm. In immature specimens the ill-defined sinus of the pedicle valve flowe not exist, and in many adult specimens the low, broad fold of the brachial valve is nearly or quite obsolete. 


\section{SCENIDIUM ANTHONENSIS Sard.}

Plate X., Figs. 5-7.

1892. Scenidium anthonensis Sardeson, Bull Minn. Acad. Nat. Sci., vol. III., p. 333, pl. 4, fig. \%.

1893. Scenidium anthonensis Winchell and Schuchert, Pal. Minn., pt. I., p. 381, pl. 30, figs. 20-23.

Description.-Shell small, subsemi-circular in outline, the greatest. width along the hinge-line. Each valve marked by from twenty to twenty-six simple, rounded plications. Pedicle valve subpyramilat. the beak erect; cardinal area large, flat, broadly triangular, with : large delthyrium. Along the median line a slight elevation or illdefined fold is developed. In the interior of the apical portion of the valve is a small spondylium. Brachial valve depressed, convex with a slight mesial sinus.

The dimensions of an average specimen are: length, $2.5 \mathrm{~mm}$., and breadth, $5 \mathrm{~mm}$.

Remarks.-This species has been only rarely observed, and is restricted to the lower portion of the Trenton formation, which is of Black River age or older.

CAMARELLA INORNATA n. Sp.

Plate X., Figs. 8-10.

Description.- Shell subovate in outline, lenticular or subglobose, with subequally convex valves, varying from longer than broad to broader than long. Surface nearly smooth, marked only by fine, inconspicuous, concentric lines of growth. Pedicle valve with a pointex? incurved boak; the sinus originating near the middle of the valve ant deepening towards the anterior margin. Brachial valve quite regularly convex, with little or no mesial elevation, even having a slight sinus towards the front in some individuals.

The dimensions of a rather large individual are: length, $15 \mathrm{~mm}$; breadth, $15 \mathrm{~mm}$; thickness, $9 \mathrm{~mm}$. Another individual: length, 10 mm.; breadth, $10.4 \mathrm{~mm}$. ; thickness, $7.2 \mathrm{~mm}$. Another pedicle valve: length, $14 \mathrm{~mm}$. ; breadth, $16 \mathrm{~mm}$. 
Remarks.-The internal characters of this shell have not been obs.rveri, so that its generic reference may be erroneous. Externally it rembles members of the genus Camarella more closely than any othre shells which occur at this horizon. It differs from $C$. ambigua H. in the absence of the strong fold of the brachial valve and in the smaller sinus of the pedicle valve. From C. panderi Bill. it may be distinguished by its larger size and by the absence of the median plication in the sinus of the pedicle valve.

PARAS'TROPHIA HEMIPLICATA (Hall).

Plate X., Figs. 11-14.

I'scription.-Shell subglobose, subpentagonal in outline, wider than long: the thickness frequently equal to the length. Cardinal line short, with sometimes the appearance of a small area on the pedicle valve. Earh valve marked ly from eight to twelve simple, subangular, radiating plications, which reach from one-third to one-half the distance from the margin to the beak, leaving the older portion of each valve smenth. Besides the radiating plications, the entire surface is marked by fine, concentric, subimbricating lines of growth, which are more compicuous near the margin of the shell. Pedicle valve depressedconvex, with an abrupt, broad, but not deep sinus, which originates nirout one-third of the distance from the beak to the anterior margin, and is produced as a lingual extension in front at nearly a right angle to the plane of the valve; it. is marked by from three to five radiating plications. The beak is small, closely incurved; delthyrium small and triangular. Brachial valve strongly convex or gibbous, with a broai mesial fold commencing one-third of the distance from the beak to the anterior margin, which is marked by from four to six radiating plications.

The dimensions of a perfect individual are: length, $13 \mathrm{~mm}$. ; width. $16.5 \mathrm{~mm}$; thickness, $12.5 \mathrm{~mm}$.

Remarls.-This species is characteristic of a zone near the base of the 'Trenton, which may be the same as the Parastrophia zone recognized by White* in the region about Lake Champlain.

\footnotetext{
"Bull. Geol. Soc. Am., vol. X., p. 459.
} 
RHYNCHOTREIIA INAEQUIVALTIS (Castel.).

Plate X., Figs. 15-1S.

1895. Rhynchotrema inaquivalvis W. \& S., Pal. Minn., pt. I., p. 459, pl. 34, figs. 9-25.

Description.- Shell varying from narrowly to broadly subtriangular in outline. Each valve marked by from sixteen to twenty-two simple, prominent, subangular plications, with from three to five on the fold and two to four in the sinus. Pedicle valve strongly convex in the umhonal region, sloping more or less abruptly laterally, often angular near the anterior margin: mesial sinus originating on the umbo, often profound anteriorly, with abrupt sides. Beak more or less incurved, and always elevated beyond the umbo of the dorsal valve, with a narrow dethyrium, partially closed by deltidial plates. Brachial valve more convex than the other, mesial fold beginning at the apex of the shell as a flattening or slight depression, more or less strongly elevated anteriorly. Beak projecting into the delthyrium of the pedicle valve.

The dimensions of an average specimen are: length, $10 \mathrm{~mm}$.; width, $11 \mathrm{~mm}$. ; thickness, $6.5 \mathrm{~mm}$.

Remarks.-This species is a common one in some localities of the Trenton limestone of New Jersey in the lower half of the formation, but it is never preserved so as to show the more delicate surface characters. On well-preserved specimens from some other regions the shell is marked by conspicuous, sublamellose, concentric growth lines, which are crowded near the anterior margin of the shell, but these are not exhibited on any New Jersey specimens which have come ander observation.

\section{RHYNCHOTREATA DENTATA (Hall).}

Plate X., Figs. 19-22.

184\% Atrypa dentata Hall, Pal. N. Y., vol. I., p. 148, pl. 33, figs. $14 a-c$.

Description.--Shell small, transversely subelliptical in outline, the proportions of length to breadth being about as five to six; obtusely angular at the beak. Each valve marked by seven or eight simple, 
ancular, matiating plications on each sich of the fold and sinus, with one plication in the bottom of the sinus of the pedicle valve and two upron the fold of the brachial valve. The interlocking. angular plications give to the anterior and lateral margins of the shell, in an anterior view, a sharply zig-zag ontline. Crosing the plications, and parallel with the margin, are fine, concentric lines of growth, which can only be detected by the aid of a magnifying glass. Pedicle valve strongly arehed from beak to front, the plications bounding the simus very prominent, the lateral slopes concave, so that the valve just at the beak and a little in front is subcarinate. Sinus not continuous. to the beak. At the beak the mediar plication is slightly elevated above the two adjacent ones, but in passing anteriorly it soon becomes. depressed below them, and at the anterior margin occupies the bottom of the rather profound sinus. Brachial valve less convex than the opposite one, flattened in the middle and passing in a convex curve to the margin all around, except directly in front in the area occupied by the median fold. The fold, starting at the beak as a narrow, shallow sinus, becomes elevated above the general surface of the shell at a point about one-third the distance from the beak to the anterior margin.

The dimensions of a perfect specimen are: length, $5 \mathrm{~mm}$; width, $6 \mathrm{~mm}$.; thickness, $3 \mathrm{~mm}$.

Remarks. - This species was originally described from the Trenton limestone of Lewis county, New York, but it seems to be a rare shell in this formation. The shell usually representing the species in collections is from the upper Cincinnatian beds of Southern Ohio and Indiana, and has been well illustrated in the Ohio Paleontology, Tolume I. In the New Tersey collections the species is represented by a single, perfect individual. It is much smaller than the specimens from Indiana and Ohio, being only $5 \mathrm{~mm}$. in length and $6 \mathrm{~mm}$. wide. In general form it agrees more closely with the figures of the typical form of the species as illustrated in the New York Paleontology, but is eren smaller than the specimens there figured. In the concave, lateral slopes of its pedicle valve and the subcarinate character of the posterior portion of the same valve it is quite different from the Ohio and Indiana shells. and it is quite possible that the Cincimmatian speres should be considered as distinct from the Trenton limestone. specimens. 


\section{ZYGOSPIRA RECURVIROSTRA (Hall).}

Plate X., Figs. 23-26.

1895. Zygospira recurvirostra W. \& S., Pal. Minn., pt. I., p. 466, pl. 34, figs. 38-41.

Description.- Shell small, subcircular or longitudinally suborate in outline, subglobular; surface of both valves marked by twenty-four to twenty-eight rounded or subangular, radiating plications, which are crossed by fine, concentrie lines of growth. Pedicle valve gibbous, with its greatest elevation near the centre; subcarinate near the beak, the keel becoining broader toward the front and forming a rather welldefined, more or less flat-topped median fold; beak small and pointed, incurved over the beak of the brachial valve. Brachial valve less convex than the other, marked by a rather broad, shallow, rounded median sinus, which corresponds with the fold of the pedicle valve and which reaches nearly to the beak.

The dimensions of an average specimen are: length, $6 \mathrm{~mm}$.; width, $6 \mathrm{~mm}$. ; thickness, $4 \mathrm{~mm}$.

\section{ZYGOSPIRA NICOLLETI (IT. \& S.).}

Plate X., Figs. 27-30.

1892. Hallina nicolleti W. \& S., Am. Geol., vol. IX., p. 293.

1893. Hallina nicolleti W. \& S., Pal. Minn., pt. I., p. 474, pl. 34, figs. $59-62$.

1893. Zygospira nicolleti B. \& S., Proc. Biol. Soc. Wash., vol. VIII., pp. 74, 81, pl. 10, fig. 23, pl. 11, figs. 11-12.

Description.-Shell small, rostrate, elongate-oval to subcircular in outline, smooth. Pedicle valve subcarinate, with a slight mesial depression in the carina near the front margin; beak acute, not incurved, the lateral slopes, from the carina to the sides, concave. Brachial valve less convex than the pedicle, with a rounded, mesial sinus extending from near the beak to the front margin. 
The dimensions of an average specimen are: length, $3.5 \mathrm{~mm}$.; breadth, $2.8 \mathrm{~mm}$; thickness $1.8 \mathrm{~mm}$.

Remarlis.-This interesting species has hitherto been recorded only from the Mississippi valley. The New Jersey specimens are indistinguishable from the western ones, but are somewhat smaller, the largest specimen observed being less than $5 \mathrm{~mm}$. in length. In the eastern specimens the faint marginal plications, which are present in the larger western individuals, have not been observed.

\title{
MOLLUSCA.
}

\section{PELECYPODA.}

\author{
CUNEATIA TREACATLLA CIT.
}

Plate XI., Fig. 6.

189\%. C'uneamya truncatula Ulr., Pal. Minn., pt. II., p. 622, pl. 36, fig. 39 .

Description.-"Shell of medium size, transversely somewhat elongate, the two ends of nearly equal height, with broad, compressed, nearly terminal, prominent and incurved beaks; postero-cardinal region subalate, escutcheon less than half the length of the hinge. Cardinal and basal margins diverging slightly posteriorly; anterior end truncate, almost vertical, the upper two-thirds sharply inflected, forming a rather narrow, deep and unusually long lunule, from whose lower end the outline slopes abruptly backwards into the basal line; the latter is gently convex in the posterior half, straight or very slightly sinuate in front of the middle, very obtusely angular in the anterior third, and straight again when it ascends from the anterior basal angle to the lower extremity of the lunule; posterior margin somewhat produced and strongly rounded in the lower half, and very obliquely subtruncate in the upper. Posterior umbonal ridge

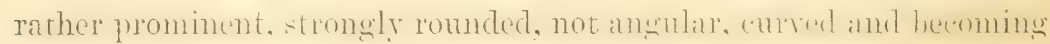
almost obsolete in the posterior third of the shell; cardinal slope concave, very abrupt near the beaks; a narrow, but distinct, anterior umbonal ridge descends at right angles to thr hing-line from the 
beak to the antero-basal angle; between it and the edge of the lunule a narrow sulcus; behind it a small, well-marked, mesial sulcus, out of which the surface rises more gradually to the summit of the posterior umbonal ridge. The most prominent point of the surface of the valves is situated on this ridge, somewhat above the middle of the height and about two-fifths of the length from the anterior extremity. Surface marked with nearly equal, concentric undulations or ridges. These are strongest in the mesial sulcus, somewhat flattened, yet distinct, in the anterior sulcus, and nearly obsolete on the cardinal slope. Hinge and muscular impressions undetermined."-Ulrich.

Remarks.-The most perfect individual of this species which has been observed from the T'renton limestone of New Jersey differs from the illustration of the type of the species in having the posterior cardinal portion of the shell less alate. In all other respects the agreement between the two shells is very close, and there seems to be no justification in considering them as specifically distinct.

CTENODONTA NASUTA (Hall).

Plate XI., Fig. 1.

189\%. Ctenodonta nasuta Ulr., Pal. Minn., pt. II., p. 584, pl. 42, fig. 30 .

Description.- "Shells transversely elongate, subovate, the length one-twenticth or more greater than twice the greatest height; beaks rather small, not very prominent, incurved, situated about one-twelfth of the entire length in front of the middle; anterior end large, broadly and regularly rounded; posterior end produced, tapering, rather narrowly rounded at the extremity; cardinal margin nearly straight, basal line broadly convex, except for some distance behind the middle, where it is straight or, more often, gently sinuate. Greatest thickness near the middle of the anterior half, equaling about one-third of the length of the shell. Umbones moderately inflated, the posterior cardinal slope defined by an obscure umbonal ridge, very abrupt for a short distance behind the beaks, more so than on the anterior side; a broad and very shallow sulcus crosses the valves obliquely from the umbones to the contraction in the base. Ligament attached to a sharply-defined groove on each side of the hinge-line, extending from the beaks 
about one-third of the distance to the posterior extremity. Surface marked by obscure, concentric lines."-Ulrich.

The dimensions of a large right valve are: length, $58 \mathrm{~mm}$.; height, $26 \mathrm{~mm}$. ; convexity, $8 \mathrm{~mm}$.

Remarks.-Two forms of shells in the T'renton limestone of New Jersey have been identified as $C$. nasuta. One of these is represented by the large specimen which has been illustrated, and occurs in the lower portion of the formation, asiociated with Leperditia fabulites, \&c., in strata which are doubtless of Black River age. All of the specimens. found at this horizon are more or less fragmentary, but all are of this large form of the species. Much higher up in the formation, associated with a typical 'Trenton fauna, a small form of the species is occasionally met with, which does not have a length to exceed 25 $\mathrm{mm}$. So far as the specimens of both forms are preserved, they seem to be identical in all respects, except in size.

CTENODONTA JERSEYENSIS n. sp.

Plate XI., Fig. 17.

Description.-Shell of medium size, moderately convex, longitudinally subovate in outline. Beak small, situated a little in front of the middle, closely incurved and pointing posteriorly. Umbo flattened, umbonal ridge rather prominent, the posterior slope being abrupt and slightly concave; in front of the umbonal ridge the surface is flattened and very gently sloping towards the anterior extremity of the shell to near the margin, where it drops off abruptly; the slope from the umbo to the basal margin is gently concave. Extending from the beak across the umbo, directly downward towards the basal margin, is a shallow, indistinct sinus, which becomes obsolete below the middle of the shell. Surface marked by inconspicuous, concentric lines of growth.

The dimensions of a well-prescrved right valve are: length, 12.5 $\mathrm{mm}$; height, $10 \mathrm{~mm}$; convexity, $3 \mathrm{~mm}$.

Remarks.-This species has been found only in the very base of the Trenton formation. In its flattened surface, extending from the umbo towards the basal margin, this species resembles $C$. carinata Ulr., but the two species are quite different in outline, and in $C$. jerseyensis the greatest convexity is on the posterior umbonal slope rather than in front. The New Jersey shell is also the larger. 
CTENOdONTA LEVATA (Hall).

Plate XI., Figs, 18-22.

184\%. Nucula levata Hall, Pal. N. Y., vol. I., p. 150, pl. 34, figs. $1 a-k$.

Ctenodonta levata, as described by Hall under the name Nucula levata, undoubtedly includes shells which belong to several distinct species. There are much greater differences exhibited among the several specimens illustrated by Hall which are referred to this species than among many of the species of the levata group of the genus Ctenodonta described by Ulrich. Apparently all of the small, pelecypod shells having this general form were referred by Hall to a single species, and the exact value of $C$. levata can only be determined when Hall's original specimens are more thoroughly investigated.

In the fauna of the Trenton limestone of New Jersey more or less imperfect specimens of what are clearly several small species of Ctenodonta are not infrequently met with, most of them agreeing more or less closely with one or another of Hall's illustrations of C. levata. They are usually not in a proper condition of preservation for accurate identification or description, and although some of them resemble more or less closely some of Ulrich's species of the genus, none of them can be specifically identified with any certainty. Under these circumstances, it is thought best to refer them all to C. levata, as Hall undoubtedly would have done at the time he established the species, at the same time keeping in mind that this name is a sort of catch-all for these small, pelecypod shells, awaiting a thorough revision of the genus.

CLIDOPHORus Neglectus Hall.

Plate XI., Fig. 16.

189\%. Clidophorus neglectus Ulrich, Pal. Minn., pt. II., p. 60\%, pl. 42 , figs. $20-25$.

Description.- "Shell transversely subelliptic, rather strongly convex; ends subequally rounded, the anterior generally a little narrower than the posterior; the outline of the latter, however, often exhibits 
a tendeney to become angular just beneath the middle and ohliquely subtruncate above; basal and dorsal margins broadly convex. Beaks small, somewhat tumid, placed about one-third of the length of the shell behind the anterior extremity. Surface marked by fine, concentric lines and several stronger varices of growth; the latter show through the shell, so as to be visible on casts of the interior. Hingeplate narrow, not over half the length of the shell, minutely toothed; denticles twenty or more in each valve, three-fourths of the number being posterior to the beaks, placed obliquely and so that they converge inwardly, the direction of the anterior series being nearly at right angles to that of the posterior series. Clavicle strong, nearly straight, almost vertical, sharply defining the somewhat semi-circular and large anterior, muscular scar, and leaving a strong furrow in casts of the interior just in advance of each beak. The furrow extends beyond the middle of the distance to the basal margin. Posterior scar faint, smaller than the anterior, occupying a central position on the post-cardinal slope. Sereral small umbonal scars may be observed on good casts, and obscure rays are occasionally visible on their sides."-Ulrich.

The dimensions of a left valve are: length, $9 \mathrm{~mm}$; height, $5 \mathrm{~mm}$.

Remarks.-Only a few specimens of this species have been found in the Trenton limestone of New Jersey. They are all more or less imperfect casts of the interior of the shell, and are somewhat more pointed posteriorly than the typical members of the species. If a sufficient number of properly-preserved specimens were available for study, it is possible that the New Jersey shells would be found to constitute a distinct species, but for the present it seems best not to attempt to separate them.

\section{CYITTODONTA BILLINGSI Ulr.}

Plate XI., Fig. T.

189\%. Cyrtodonta billingsi Ulr., Pal. Minn., pt. II., p. 538, pl. 40, figs. $2-6$.

Description.- "Shell of medium size or less, transverse, obliquely ovate, highest in the posterior half; valves strongly ventricose in the umbonal and central regions. Hinge-line at least two-thirds the length of the shell, slightly arculte, posteriorly declining and pasing grad- 
ually into the broadly and uniformly-curved posterior margin; basal line most prominent and strongly convex behind the centre, in front of which point it ascends rather rapidly, with a much more gentle curve, into the short, small and sharply-rounded anterior end. Umbones full, large and prominent, beaks small and strongly incurved; umbonal ridge subangular near the beaks only, inconspicuous in a lateral view. Surface marked with concentric lines of growth. These, with the exception of a few near the margin, are obseure in the material at hand. Ligamental area very narrow. Hinge-plate of moderate strength, with three slightly-curved and nearly-horizontal cardinal teeth and two or three slender, posterior, lateral teeth in each valve. Pallial line and anterior adductor muscle distinct, the latter rather small and of obovate or subcircular shape; posterior adductor faintly impressed, situated immediately beneath the lateral teeth. Internal umbonal sulcus and ridge slightly developed, but always distinguishable on good casts of the interior."-Ulrich.

The dimensions of a somewhat imperfect specimen are: length, 17 mm.; height, $18 \mathrm{~mm}$; thickness through both valves, $12 \mathrm{~mm}$.

Remarks. - This species has not been found abundantly in the Trenton limestone of New Jersey, but the specimens seem to be identical with the more typical representatives of the species from the Miscissippi valley, except in being somewhat smaller.

\section{CYRTODONTA CANADENSIS Bill.}

Plate XI., Fig. 3.

1858. Cyrtodonta canadensis Bill., Can. Nat. and Geol., vol. III., p. 434, figs. 8-10.

Description.- "Transversely broad-cval; anterior, posterior and ventral margins, and also the posterior half of the dorsal margin, regularly rounded; a portion of the ventral margin about the centre of the width is sometimes nearly straight; dorsal margin elevated, somewhat compressed; diagonally and rounded ventricose from the umbones towards the posterior ventral angle; beaks short, obtusely rounded, incurved; surface nearly smooth or obscurely marked with concentric ridges; a few strong, imbricating lamellæ of growth near the margin of some specimens."-Billings. 
The approximate dimensions of an imperfect right valve from New Jersey are: length, $40 \mathrm{~mm}$.; height, $35 \mathrm{~mm}$.; convexity, $11 \mathrm{~mm}$.

Remarks.-A large species of Cyrtodonta from the lower portion of the Trenton limestone in New Jersey seems to agree closely with Billings' description and illustrations of C. canadensis, the only difference noticeable being that the anterior margin is more broadly rounded. None of the species are perfectly preserved, and there may be some doubt as to the correctness of the identification, but more perfectly-preserved specinens are essential before a specific distinction can certainly be made.

WHITELLA SUBORBICULARIS n. sp.

Plate XI., Fig. 2.

Description.-Shell of medium size, erect, ventricose, suborbicular in outline, the hinge-line rather long, areuate. Beaks of moderate size prominent, strongly incurved; umbones prominent, umbonal ridge sharply angular near the beak, beenning more broadly rounded after passing the umbonal region. The post-umbonal slope alorupt, concave, with the suggestion of a faint recond ridge, diverging from near the beak, about one-third of the distance from the umbonal ridge to the posterior margin. The anterior slope, from the umbonal ridge, is slightly convex and less abrupt than the posterior slope.

The dimensions of a left valve are: length, $22 \mathrm{~mm}$.; height, 24 $\mathrm{mm}$.; convexity, $10 \mathrm{~mm}$.

Remarks.-This species is established upon a nearly-complete left valve. It may be distinguished from other members of the genus by its more erect attitude and its suborbicular outline. In the erect attitude of the shell it resembles Plethorardir umboneta Ulr., and it is possible that it should be referred to the genus Plethocardia rather than to Whitella. The distinguishing character between these two genera is a strong process, which projects downward from beneath the beak in each valve of Plethocardia, but the New Jersey specimen is not in a proper condition of preservation to determine the presence or absence of such a process. 
whitella subtruncata (Hall).

Plate XI., Fig. 4.

184\%. Edmondia subtruncata Hall, Pal. N. Y., vol. I., p. 156, pl. 35 , figs. $3 a-b$ (not fig. $3 c$, or pl. 34 , fig. 9 ).

Description.-Shell oblique, elongate, ventricose, subelliptical in outline. Beaks small, prominent, strongly incurved; umbones prominent, projecting beyond the hinge-line. Anterior extremity of the shell rather sharply rounded, the antero-basal margin gently convex or nearly straight, the posterior extremity broadly rounded, the postero-dorsal margin convex, rounding into the posterior extremity of the arcuate hinge-line. Umbonal ridge arcuate, sharply angular near the beak, becoming more and more broadly rounded as it approaches the postero-basal extremity of the shell. The post-umbonal slope abrupt, concave; the anterior slope convex.

The dimensions of a nearly-perfect right valve are: length from beak to postero-basal extremity, $37 \mathrm{~mm}$; width at right angles to last dimension, $25 \mathrm{~mm}$. ; convexity, $11 \mathrm{~mm}$.

Remarks.-The several specimens illustrated by Hall to represent Edmondia subtruncata undoubtedly belong to more than one species and probably to two or more genera. The New Jersey shell which is referred to this species is somewhat common in some of the higher Trenton beds in the Jacksonburg section, and is believed to be specifically identical with Hall's specimen illustrated by figure $3 a$. Figure $3 b$ may also be the same, but the other specimens illustrated are distinct. The New Jersey specimens are evidently members of the genus Whitella, and the species is here transferred to that genus.

\section{MODIOLOPSIS FABA (Con.).}

Plate XI., Figs. 13-15.

184\%. Modiolopsis faba Hall, Pal. N. Y., vol. I., p. 158, pl. 35, figs. $6 a-c$.

Description.-Shell small, ahout twice as long as high, the greatest height in the posterior half; the beak situated about one-fifth the length of the shell from the anterior extremity, somewhat compressed 
and slightly incurved; the postero-cardinal region subalate. Basal and cardinal margins diverging posteriorly; the anterior end rather sharply rounded; the basal margin more or less sinuate at or a little in front of the middle of the shell, curving upward, both in front and behind, to meet the anterior and posterior margins; posterior margin broadly rounded below and obliquely truncate above. Umbonal ridge extending from the beak obliquely backward to the postero-basal portion of the shell, sharply rounded or subangular near the beak, but becoming more broadly rounded posteriorly. In front of the umbonal ridge, extending from the beak obliquely backward to near the middle of the basal margin, is a rather broad and shallow sinus, which gives rise to the sinuosity of the basal margin. The most prominent point on the surface of the shell is upon the umbonal ridge at about the centre of the shell. Surface marked with somewhat irregular, concentric lines of growth, which are usually more or less inconspicuous.

The dimensions of average specimens are: length, 6 to $\% \mathrm{~mm}$; height, 3.5 to $4 \mathrm{~mm}$.

Remarks.-This is one of the commoner species of pelecypods in the fauna of the higher beds of the Trenton formation, and it is believed to be identical with the little shell described from the New York Trenton limestone as Modiolopsis faba. The greater number of specimens preserved are right valves. Only a few left valves have been seen; they are slightly less convex, with a less conspicuous umbonal ridge.

MIODIOLOPSIS JEISEYENSIS n. sp.

Plate XI, Fig. 9.

Description.- Shell rather short and broad, subovate or subtriangular in outline, anterior margin narrowly rounded, basal margin nearly straight through the greater part of its length, but curving upward in front and behind; posterior margin broadly rounded, curving regularly into the nearly-straight cardinal margin. Beak compressed, incurved, projecting a little above the hinge-line. Umbo flattened, umbonal rilge prominent, rounded, post-umbonal slope at first convex. becoming concave as it approaches the posterior cardinal extremity. The anterior slope from the umbonal ridge is occupied by a rather broad, shallow, ill-defined simus, which extends from the 
beak obliquely backward to the basal margin. Anterior extremity of the shell compressed. The most prominent point on the shell is near the centre, on the umbonal ridge. Surface marked by more or less obscure, concentric lines of growth.

The dimensions of a perfect cast of the right valve are: length, 15 mm.; width, $10 \mathrm{~mm}$.; convexity, $3 \mathrm{~mm}$.

Remarks.-This species may be recognized by its rather short and broad form, the flattened umbo and the oblique sinus.

MODIOLOPSIS DEPRESSA n. sp.

Plate XI., Fig. 8.

Description.-Shell subovate in outline, the valves depressed-convex. Anterior margin regularly rounded from beneath the beak into the nearly-straight or slightly-convex basal margin; the posterior margin broadly and regularly rounded. Beak small, a little elevated above the hinge-line; umbonal ridge broadly rounded and ill-defined; the post-umbonal slope convex above, becoming concave toward the hinge-line; antero-basal slope with a rather broad, shallow, ill-defined depression or sinus extending from the basal margin half way to the beak. Surface marked by obscure, concentric lines of growth.

The dimensions of a nearly-complete right valve are: length, 16 $\mathrm{mm}$; width, $10.5 \mathrm{~mm}$; convexity, $1.5 \mathrm{~mm}$.

Remarks.-This species may be recognized by its depressed-convex, nearly-smooth valves, with obscure umbonal ridge and small beak.

ORTHODESAIA CANALICULATUMI Ulrich.

Plate XI., Fig. 5.

189\%. Orthodesma canaliculatum Ulr., Pal. Minn., pt. II., p. 520, pl. $3 \%$, figs. $\%-11$.

Description.- "Shell elongate, the length three times the height; cardinal and basal margins straight, nearly parallel; posterior margin oblique, rounding into the hinge-line, below which it slopes back- 
ward with a gentle curve to the postero-basal extremity, where it turns abruptly into the basal line; anterior end contracted in front of the haks, of moderate length, rounded, most prominent a little above the middle. In a side view the beaks project very little, are compressed by a broad, shallow sulcus, which crosses the valves and occupies a large part of the anterior three-fifths of the shell; umbonal ridge rather distinct, extending from the beaks to the postero-basal extremity. In a cardinal riew of casts of the interior, the only condition in which the suecius has been noticed, the hinge-line is strongly depresed, lying at the hottom of a wide and deep channel, deepest hetween the rather wirlely-sejarater beaks and gratually shallowing posteriorly. Casts usually almost smooth, exhibiting only a small number of obscure, concentric furrows. One specimen preserves a small part of the shell, and this shows that near the dorsal edge the outer surface is marked with somewhat regular, raised lines, about six of them in $5 \mathrm{~mm}$. The best-preserved casts exhibit in the posterior half of the mesial sulcus a number of obscure radii. Anterior muscular scar shaply defined at the inner side, rather small, broad-oval or circular, occupying the middle two-fourths of the upper half of the anterior end. Posterior impression somewhat larger than the anterior, subcircular, with a narrow prolongation extending forward nearly parallel with the posterior cardinal margin. Pallial line distinct in the anterior half, consisting (on the casts) of a straight row of obscure pustules extending in a slightly-oblique direction from the base of the anterior adductor impression towards a point much nearer the ventral border."-Ulrich.

The dimensions of a nearly-complete intermal cast of both valves are: length, $34 \mathrm{~mm}$; height, $11.5 \mathrm{~mm}$; thickness, $12 \mathrm{~mm}$.

Remarks.-This species was originally described from the Cincinnatian beds of the west, but the New Jersey specimens from the Trenton limestone secm to represent the same species. Like the westem specimens, the New Jersey representatives are casts and the two valves oceur together, but they do not grow to so large a size. The only difference noticeable in the New Jersey specimens which seems worthy of mention is the direction of the row of pustules forming the pallial line, which are more nearly parallel with the ventral margin of the shell. 
GONIOPHORA CARINATUS (Hall).

Plate XI., Fig. 23.

184\%. Modiolopsis carinatus Hall, Pal. N. Y., vol. I., p. 160, pl. 35, figs. $11 a-c$.

Description.-Shell small, subovate in outline, angular posteriorly. Anterior margin sharply rounded; basal margin nearly straight or slightly convex; postero-basal extremity acutely angular; posterior margin obliquely truncate, meeting the hinge-line in an obtusely rounded angle; cardinal margin straight, subparallel with the basal margin. Beaks small, incurved, elevated above the hinge-line, situated at about the anterior fourth of the total length of the shell. Umbonal ridge usually describing a slight, sigmoidal curve, sharply angular or carinate; the post-umbonal slope concave, sometimes with a slight, nearly-obsolete ridge extending from the beak to the middle of the truncate posterior margin. Antero-basal slope convex, with a slight, ill-defined, shallow sinus extending from the beak obliquely backward to near the middle of the basal margin. Surface marked by rather strong, more or less irregular, concentric lines of growth.

The dimensions of the largest specimens observed, a left valre, are: length, $14 \mathrm{~mm}$.; height, $7 \mathrm{~mm}$. ; convexity, $3.5 \mathrm{~mm}$.

Remarks.-This little shell is rather uncommon in the Trenton fauna of New Jersey, but may be easily distinguished from any of its ascociates by its strongly-carinate umbonal ridge. It was originally described as a species of Modiolopsis, but it clearly does not belong in that genus, and there seems to be no reason for considering it to be generically distinct from Goniophore, which is more characteristically a Deronian genus.

\section{AMIPHINURA.}

$$
\text { CHITON? sp. }
$$

Plate XIII, Figs. 9-10.

A single plate, probably the posterior terminal one, has been observed in the New Jersey collections, which probably belongs to one of the Chitons. Its true generic reference is uncertain, but doubtless 
it is not a member of the recent genus Chiton. It is subpentagonal in outline, obtusely angular in front, its posterior margin slightly sinuate. Along the median line it is quite sharply rounded toward the apex, but becomes more broadly rounded posteriorly, with a slight, longitudinal, median garoove, hecoming stronger posteriorly. The sidey slope down to the lateral margins with a gentle convexity. The surface is smooth.

Its dimensions are: length, $7 \mathrm{~mm}$. ; brearth, $7 \mathrm{~mm}$.

\section{GASTROPODA.}

ARCHINACELLA PATELLIFORMis (Hall).

Plate XII., Figs. 1-2.

184\%. Carinaropsis patelliformis Hall, Pal N. Y., vol. I., p. 183, pl. 40 , figs. $2 a-b$.

Description.-Shell subovate in outline, slightly narrowed posteriorly, patelliform, obliquely depressed, conical, obtusely subcarinate along the median, dorsal line; the apex situated anteriorly, slightly incurred and extended in a line with or a little beyond the margin. Surface marked by fine, concentric lines of growth.

The dimensions of a nearly-perfect specimen are: length, $11 \mathrm{~mm}$.; breadth, $9 \mathrm{~mm}$.; convexity, $4 \mathrm{~mm}$.

Cyrtolites onNates var. aitnor U. \& S.

Plate XII., Figs. 6-7.

189\%. Cyrtolites omatus var. minor U. \& S., Pal. Minn., pt. II., p. 861, pl. 62, figs. 30-31.

Description.-Shell small, usually not excecding $10 \mathrm{~mm}$. in diameter. Volutions two or three, rapidly increasing in size, strongly and sharply carinate dorsally, rhombic-subquadrate in section; sides prominent and subangular or narrowly rounded along a line about three-fifths of the height of the rolution within the dorsal carina, 
the dorsal slopes gently convex and distinctly undulated by strong, slightly-curved, transverse furrows and subangular ridges; the ventral or umbilical slopes almost flat and usually without undulations; ventral side with a sharp, central furrow for the reception of the dorsal carina of the preceding rolution. Umbilicus well-defined, wide and deep, the edge wavy. Aperture a little wider than high, the height a little more than half the greatest diameter of the shell, more or less rhombic-subquadrate in outline.

The dimensions of the best-preserved specimen observed are: greatest diameter, $11.5 \mathrm{~mm}$.; width of aperture, $8.5 \mathrm{~mm}$.

Remarks.-This variety of Cyrtolites ornatus differs only from the typical form of the species in its smaller size. The variety is the older form, being known only from the Trenton, while the larger, more typical form occurs in younger beds. But few individuals have been observed in the New Jersey collections, and all of these are internal casts, so that the delicate surface markings of the species cannot be seen. These markings consist of delicate, raised lines, running almost straight across the volutions, with short, connecting lines arranged alternately.

protowarthia catoetlata (Hall).

Plate XII., Figs. $3-\mathbf{5}$.

189\%. Protowarthia cancellata U. \& S., Pal. Ninn., pt. II., p. 872, pl. 63, figs. 1-14.

Description.-Shell of medium size, subglobose, close coiled, with no umbilicus when the shell is preserved, but with a small one in the casts. In immature specimens the dorsum of the outer volution is rather sharply rounded, but with increasing age it becomes more broadly zounded, losing entirely the obscure carination of the younger shells. Sinus shallow, rounded; the lateral margins of the aperture on either side of the sinus regularly and rather gently convex. Aperture wider than high, subsemi-circular in outline. On the larger internal casts one or more rather broad and shallow, rounded, transverse, wrinkle-like depressions are frequently present near the aperture and parallel with the apertural margin. 
The dimensions of a large specimen are: maximum diameter, 21 mm.; width of aperture, $18 \mathrm{~mm}$.

Remarks.-In none of the New Jersey specimens have the delicate surface markings of this species been observed. These markings should consist of fine transerse and still-finer revolving lines, giving to the surface of the shell a cancellated appearance.

\section{TETRANOTA BIDOISATA (Hall).}

Plate XII., Figs. 18-19.

184\% Bucania bidorsata Hall, Pal. N. Y., vol. I., p. 186, pl. 40, figs. $8 a-g$.

189\%. Tetranota bidorsata U. \& S., Pal. Minn., pt. II., p. s7\%, pl. 65, figs. 10-1S:

Description.-_"Shell usually about $12 \mathrm{~mm}$. in height, but the height may exceed $20 \mathrm{~mm}$., and occasionally reaches $25 \mathrm{~mm}$.; volutions two and a half to three and a half, vertically compressed, sublunate in section; the width for the inner volutions or in young specimens a little greater than twice the height; in old examples the increasing altitude of the centro-dorsal ridges causes the width just behind the aperture to be proportionally somewhat less; umbilicus large, deep, rather sharply defined, the width generally about half the greatest diameter of the shell; the latter dimension is to the greatest width of the aperture about as three is to four. Aperture somewhat abruptly expanded laterally, the height and width about as three is to seven; slightly indented by the preceding whorl; lips thin, the outer one, with a moderately-deep emargination, taking up between one-fourth and one-third of the anterior outline; depth of same about one-fifth less than its width. Dorsum with four strong, revolving ridges, the two central ones nearer each other than to the lateral ones and higher, the altitude, also, increasing gratually to the aperture; between them lies the hroad slit-band. which is more distinctly concave on the shell than on internal casts, the double ridge in the latter, particularly near the aperture, often appearing as a broad and more or less flattopmerl single ridge: on each side of the central ridges there i.s. first, a hrabl serowe, then an obtusely angular ridge, and finally a narrower 
groove, which slopes down to the angular or sharply-rounded side of the rolution. While the central pair of ridges increases in prominence, the lateral pair becomes more and more indistinct on the last volution, till, at the apertural margin, they are scarcely distinguishable-at any rate, this is true of casts. The transverse surface markings are prominent, regular, visible to the unassisted eye, about three in $1 \mathrm{~mm}$.; the course of the striæ from the umbilicus is at first nearly straight across, and it is only in the centro-lateral grooves that they curve backward very strongly. When the characters of the external layer are preserved, these very fine, short lines are to be seen crossing the transverse lines rectangularly."-Ulrich and Scofield.

\section{BUCANIA PUNCTIFRONS (Emm.).}

Plate XII., Figs. 10-12.

1842. Bellerophon punctifrons Emm., Geol. Rep. 2d Dist. N. Y., p. 392, fig. 5.

181\%. Bucania punctifrons Hall, Pal. N. Y., vol. I., p. 18\%, pl. 40 A, figs. $1 a-e$.

189\%. Bucania punctifrons U. \& S., Pal. Minn., pt. II., p. 894, pl. 67 , figs. 41-44.

Description.- "Shell rather small, probably not exceeding $20 \mathrm{~mm}$. in height. Volutions three or four and a half, rounded on the back, subangular on the sides: umbilicus large, its width somewhat greater than half the height of the shell; aperture slightly wider than high, subpentagonal. In a transrerse section the volutions are semi-circular in the dorsal half, with the umbilical slopes almost straight and the ventral side broadly indented by the preceding whorl. The width of the last volution expands from $6 \mathrm{~mm}$. to $12 \mathrm{~mm}$. in a specimen 18 $\mathrm{mm}$. high. In the same specimen the slit has a length of $16.5 \mathrm{~mm}$. and a width of $0.7 \mathrm{~mm}$. The slit-band is concave, bordered on each side by a delicate line and crossed by numerous fine lunulæ. On each side of the slit and band the whole exposed surface is covered by a strong and very sharply-defined network, the deep meshes of which are so arranged that they form rows running in two directions, one 
almost directly across the volutions, the other obliquely fortrard and outward from the band. Finally, in certain lights, a third arrangement of the meshes will be observed, namely, in a series passing obliquely forward from the sides to the slit-band. The last direction is approxinnately at right angles to certain more or less distinct lines or varices of growth, which interrupt the regularity of the network on old examples."-Ulrich and Scofield.

mimitganoltas compresses Con.

Plate XII., Figs. 16-17.

1838. Phragmolites compressus Con., Ann. Rep. Geol. Surr. X. Y., 1. 119 .

18t\%. Cyrtolites compressus Hall, Pal. X. T., vol. I., p. 18s, pl. $\pm 0 \mathrm{~A}$, figs. $2 a-f$.

Shell discoid. Tolutions two or three, slightly embracing, strongly carinate upon the dorsm, sulbtriangular in cross-section, wider than ligh; the sides moderately convex from the base of the carina to the inargin of the umbilicus, where they are bent abruptly inward at nearly right angles to the plane of the shell; umbilicus from twofifths to one-half the total diameter of the shell. The lateral surfaces marked by slightly-oblique, transverse, imbricating, folded, lamellar expansions, whose position, when removed, is indicated by transverse, wary lines.

The dimensions of the only specimen observed are: maximum diameter, $9 \mathrm{~mm}$.; width of aperture, $-1.5 \mathrm{~mm}$.

Remarks. - This shell is not a common one in the Trenton limestone of New Jersey. On remoral from the limestone matrix in which it occurs the lamellar expansions of the shell, and frequently the shell substance itself, is entirely iremoved, so that the wary, transverse lines characteristic of the genus are almost or wholly obliterated. The proposal of a new generic name, Conradella, by Ulrich and Scofield for this group of shells seems to be entirely mwarranted, for althongh Conrad's name, Phragmotites, was but briefly defined and was proposed under the supposition that it belonged with the Cephalopods 
rather than with the Gasteropods, his type species cannot be mistaken. Under these conditions, the name Pluragmolites is used in this place rather than Conradella.

oxymiscus SUBACUTUS Ulrich.

Plate XII., Figs. 8-9.

189\%. Oxydiscus subacutus Ulrich, Pal. Minn., pt. II., p. 913, pl. 62, figs. 62-65, pl. 82, figs. 23-25.

Description._-"Shell lenticular; dorsum acutely carinated; greatest diameter from $15 \mathrm{~mm}$. to $28 \mathrm{~mm}$.; greatest thickness or width nearly one-half the diameter. Volutions three and one-half to four and onehalf, thickest near the umbilicus, from which the surface ascends, first, with a gently convex, then with a concave slope to the sharp periphery; each volution embracing between one-third and one-half of the preceding one; umbilicus exposing all the whorls; its width somewhat less than one-third of the diameter of the shell; edge of umbilicus abrupt, subangular; aperture obcordate, indented below by the sharp dorsum of the perceding whorl; margin of aperture thin, in a side view with a strong, backward sweep; slit long, very narrow. Surface marked by fine and rather indistinct lines of growth."-Ulrich.

\section{PTEROTHECA EXPANSA (Emm.)?}

Plate XII., Fig. 35.

1842. Delthyris expansus Emmons, Geol. Rep. 2d Dist. N. Y., p. 39\%, figs. 109-112.

1861. Clioderma expansa. Hall, 14th Ann. Rep. N. Y. State Cab. Nat. Hist., p. 98.

A single imperfect specimen, which may belong to this species, has been observed. It is a shell which, when complete, was subelliptical in outline and strongly carinate along its median line. Each lateral slope from the median line of the shell is at first abrupt to 
the base of the carina and is then gently convex to the lateral margins, with a single, shallow, rounded furrow extending from the apex obliquely to the postero-lateral margin.

The approximate dimensions of the shell must have been: length, $24 \mathrm{~mm}$. ; width, $30 \mathrm{~mm}$.

RAPHISTOALA PERÁCUTUM U. \& S.

Plate XII., Figs. 22-23.

189\% Raphistoma peracutum U. \& S., Pal. Minn., pt. II., p. 940, pl. 68 , figs. 1-6.

Description.- "Shell small, not known to exceed $12 \mathrm{~mm}$. in diameter, consisting of three or three and one-half whorls, flat above, rounded below; periphery very sharp and thin; umbilicus equaling a little more than a fourth of the greatest diameter, its edge narrowly rounded; height of shell very slightly exceeding a fourth of the width. Surface marked on the flat, upper side with very fine, subequal stria, swerping on the whole rather strongly backwarl from the suture. About at third of the width of a whorl from the suture the strix are interrupted by a delicate, revolving line. Between the latter and the extreme edge of the peripheral carina the strix make a distinct, sigmoid curve. Below the periphery the surface is marked with similar striæ, which, in descending, curve first forward and then almost directly toward the centre of the umbilicus."-Ulrich and Scoficld.

Remarks.-The specimens of this species in New Jersey are all poorly preserved, but seem to agree essentially with the Minnesota species, whose description has been copied above. They also essentially agree with the western specimens in their geological horizon, as they have only been observed in New Jersey in the lower or Black River horizon of the formation associated with Leperditia fabulites and Dalmanella subcrquate. In none of them are the delicate surface markings well presered. but upon one specimen the revolving line about one-third of the width of the whorl from the suture can be detected. The New Jersey specimens sometimes attain a diameter of $15 \mathrm{~mm}$., which is a little greater than the dimensions mentioned in the original description. 
LOPHOSPIRA MEDIALIS U. \& S.

Plate XII., Fig. 28.

189\%. Lophospira medialis U. \& S., Pal. Minn., pt. II., p. 973, pl. 73, figs. 23-29.

Description.- "Height 12 to $22 \mathrm{~mm}$.; apical angle $58^{\circ}$ to $70^{\circ}$, the average about $63^{\circ}$. Volutions six or seven, all contiguous, somewhat depressed, rounded below; upper slope nearly flat, generally a little concave in the outer half and gently convex toward the suture, occasionally convex enough to form an obscure, subsutural angulation; lower carina becoming less distinct with age, never strong, generally quite indistinct; between it and the prominent peripheral carina, which carries the rounded band, the outline is more or less concave; umbilicus small, but always present. Surface markings rather strong, lamellose, strongly curved backward, often gathered into undulating groups near the umbilicus."-Ulrich and Scofield.

\section{LOPHOSPIRA OWENT U. \& S.}

Plate XII., Fig. 34.

189\%. Lophospira oweni U. \& S., Pal. Minn., pt. II., p. 980, pl. 73, figs. $41-45$.

Description.- "Height 25 to $36 \mathrm{~mm}$; apical angle $59^{\circ}$ to $62^{\circ}$. Volutions six or seven, the first very minute, decidedly angular. Peripheral band prominent, thick and rounded, sometimes margined by a delicate line on each side. Upper slope concave, except near the suture, where there is usually a broad, rounded ridge or carina; this ridge, however, becomes quite obsolete on the sixth or seventh volution. Lower side sloping inward, scarcely ventricose, the outline being first concave, next convex, then straight or concave and finally convex again, there being a peculiar swelling just behind the minute umbilicus. The first convexity beneath the peripheral band represents the lower carina of $L$. perangulata and other species, and in young shells it is sharp enough to be called a carina, but as growth 
proceeds it becomes more and more obtuse. Aperture straight at the inner margin, somewhat narrowly produced at the lower angle. Surface markings rarely preserved; whenever preserved, they consist of rather distant, delicate, sublamellose strix, with very fine lines between them, all curving backward strongly to the peripheral band."Ulrich and Scofield.

Remarks.-This species is rare in the Black River horizon of the Trenton formation at Jacksonburg, and has not been observed in a satisfactory condition of preservation to exhibit all its characteristics. There seems to be no doubt, however, that the New Jersey shell is identical with the species which has been described as $L$. oweni from Minnesota.

L.IOSPIRA MITUULA (Hall).

Plate XII., Figs. 24-25.

1862. Pleurotomaria micula Hall, Geol. Rep. Wis., vol. I., p. 55, fig. 4 (no description).

189\%. Liospira micula U. \& S., Pal. Minn., pt. II., p. 994, pl. 68, figs. 24-29.

Description.--Shell small, discoidal-lenticular, consisting of about four volutions. The umbilicus filled by a perfectly-smooth, rather distinctly outlined, concave, reflexed callosity of the inner lip. The sutures very shallow; the spire forming an almost contimuous, even slope from the apex to the periphery, the apical angle being from $120^{\circ}$ to $127^{\circ}$. The periphery of the outer volution is sharply angular in the casts, but is more rounded when the shell is preserved. 'The volutions subrhomboidal in cross-section. The aperture irregulary triangular in outline, wider than high, the inner lip nearly vertical. Diameter of shell usually from 9 to $12 \mathrm{~mm}$.

Remarks.-In 1848 Hall* described Pleurotomaria subtilistriata from the Trenton limestone at Watertown, New York. The size of the species was described as follows: "Most of the specimens being scarcely visible to the naked eye." The specimens illustrated, however, said to be the largest seen, are $10^{\circ} \mathrm{mm}$. and $11.5 \mathrm{~mm}$. in diameter, respectively, and, so far as can be judged from the figures, are not

\footnotetext{
* Pal. N. Y., vol. 1, p. 172.
} 
different from the specimens here referred to L. micula. Pleurotomaria micula was illustrated, but not described, by Hall, the specimens coming from the Trenton formation in Wisconsin. The species was afterwards reidentificd and described by Ulrich and Scofield in their Minnesota report, and it has been recognized as a rather common Trenton form in the Mississippi valley. The real status of $L$. subtilistriata still remains in doubt. It is possible that it is really a minute species, and that the large specimens illustrated for the species are spceifically distinct from the minute specimens indicated in the description, and should be referred to $L$. micula. It is also possible that the small individuals mentioned by Hall are only the young of the larger one, and that the two supposed species, subtilistriata and micula, are one and the same, in which case the name subtilistriata, having priority, would be the proper designation of the species.

HORIOTOALA SAITERI Ulrich.

P'late XII., Fig. 29.

189\%. Hormotoma salteri Ulr., Pal. Minn., pt. II., p. 1016, pl. ^o, figs. $41-51$.

Description.-Height 12 to $\pm 0 \mathrm{~mm}$.; apical angle $24^{\circ}$ to $25^{\circ}$. Volutions nine or ten in large individuals, rounded, with a central, flattened or slightly concave, revolving band, which is bordered on each side by a delicate, raised line; not recognizable on the internal casts. Suture simple, deep. Lines of growth fine, bending strongly backward from the suture to the band, and beneath this curving very strongly forward again. Aperture nearly circular, the outer lip deeply notched at the revolving band.

Remarks.-This species has been separated from the common $H$. gracitis (Hall) by Ulrich because of its greater apical angle, the typical form of $H$. gracilis having an apical angle of but about $18^{\circ}$. In all other respects the two species are essentially alike, and the specimens now referred to $H$. salteri have always previously been referred to $H$. gracitis. The species is rather common in the Trenton limestone of New Jersey in some localities, and in none of those observed is the apical angle less than $24^{\circ}$, and in but few is it 
as much as $25^{\circ}$; the great majority of species measures exactly $24^{\circ}$. The New Jersey specimens usually lose their surface markings in being removed from their limestone matrix, and are usually broken up to such an extent that it is rare to secure fragments more than 12 or $15 \mathrm{~mm}$. in length.

\section{HELICOTOLA sp.}

In the faunas of the lower beds of the Jacksonburg section, and dwewhere, sereral specimen- helonging to one or more species of the genu: IIelicotoma have been noticed. All of them are badly crushed and are in such a condition that they camnot be specifically identifiect.

\section{ECCTIOATPHALUS TRENTONENSIS (Conrad).}

Plate XII., Figs. 20-21.

1842. Cyrtolites trentonensis Conrad, Jour. Acad. Nat. Sci. Phil., rol. VIII., p. 270 , pl. $1 \%$, fig. 4.

184\%. Cyrtolites trentonensis Hall, Pal. N. Y., vol. I., p. 189, pl. $40 \mathrm{~A}$, figs. $3 a-d$, pl. 41 , figs. $1 a-c$.

Dexriptim.- Shell consisting of less than one rolution, increasing gradually in size from the apex, coiled in one plane. Cross-section angularly suborate. Ventral side of the shell conver from the periphery to the inner margin; the periphery rather sharply rounded; about midway between it and the inner margin, on the dorsal side of the shell, is an angular, subcarinate ridge, the space betreen this ridge and the fripheral angulation heing nearly flat: from the doral ridge to the inner margin of the shell the surface is convex. The surface is marked by rather obseure and irregular lines of growth, which, on the dorsal side. slope backward to the dorwal ridge, thus indicating the presence of an angular sinus in the aperture at that point. The most complete specimen observed has a length of about $35 \mathrm{~mm}$. around the periphery of the shell from apex to aperture.

Remarks.-This shell is apparently closely allied to E. subrolundus U. \& S. from Minnesota, and it is not altogether clear that the two species are really distinct. Cyrtolites trentonensis was not recognized 
as a member of the genus Eccyliomphalus by Ulrich and Scofield, but the Ner Jersey specimens are certainly cogeneric with the species referred by them to this genus, and there also seems to be no question as to their identity with the shells described as Cyrtolites trentonensis from New York.

\section{ECCYLIOMPHALUS CONTIGUUS Ulrich.}

Plate XII., Figs. 13-15.

189\%. Eccyliomplatus contiguus Clrich, Pal. Minn., pt. II., p. 103\%, pl. 74 , figs. 48-52.

Description.- "Shell 12 to $30 \mathrm{~mm}$. in diameter, 7 to $16 \mathrm{~mm}$. in height, consisting of three or four rapidly-enlarging, contiguous whorls, coiled so as to leave a deep umbilicus, in which from a third to a half of each of the inner whorls is visible; whorls subovate in section, higher than wide, somewhat narrowly rounded in the outer half of the upper surface. On the upper side the inner whorls may be sunken slightly beneath or raised above the level of the last; innermost whorl with a free termination. Mouth obliquely subovate, the margin rather deeply notched above, broadly curved forward on the outer side and gently sinuate below. Surface markings somewhat irregular and coarse, parallel with the edge of the mouth."-Ulrich.

Remarks. - A single specimen from the Trenton limestone of New Jersey scems to be identical or at least closely allied to $E$. contiguus, described by Ulrich from the Stone's River group of Tennessee. It is smaller than the dimensions recorded for the Tennessee shell, having a maximum diameter of only about $6.5 \mathrm{~mm}$., but this may be due to the immaturity of the shell. The shell itself is apparently entirely removed from the specimen, so that the surface markings and the outline of the aperture cannot be certainly determined, but the general contour of the shell agrees closely with Ulrich's figure 52, except that the New Jersey shell is slightly lowar. If sufficient material could be examined, it is possible that the New Jersey specimens would constitute a species distinct from, but closely allied to, this species described from Tennessee. 
'CYCLONEMA MONTREALENSIS Bill.

Plate XII., Fig. 33.

1865. Cyclonema montreatensis Bill., Pal. Foss., vol. I., p. 30, fig. 28, p. 29.

Description.-Shell with the height and width about equal, the diameter of full-grown individuals being from 20 to $30 \mathrm{~mm}$. Apical angle about $90^{\circ}$. Volutions about four, rather rapidly enlarging and strongly convex. Suture distinct. Aperture subcireular. Surface marked by strong, revolving lines, .5 to $1 \mathrm{~mm}$. apart, and by much finer, oblique, transverse lines.

Remarks.-All the specimens of this speeies which have been studied are more or less crushed, so that the amount of variation of the apical angle cannot be determined, though it is probably never less than $90^{\circ}$. The apex of all the specimens seen is imperfect, so that there may have been one or two additional volutions in the perfect shells.

IIOLOPEA STMmetrica Hall.

Plate XII., Figs. 26-27.

184\%. Holopea symmetrica Hall, Pal. N. Y., rol. I., p. 170, pl. 3\%, fig. 1.

Description.-Shell attaining a height of $12 \mathrm{~mm}$. to $15 \mathrm{~mm}$., the width about equal to or less than the height. Volutions three or four, rounded, ventricose, increasing gradually from the apex; the aperture nearly circular, slightly oblique. Surface marked by fine, raised, more or less crowded lines of growth, which are sometimes slightly fasciculate in their arrangement. 
HOLOPEA PARVULA Ulrich.

Plate XII, Fig. 30.

189\%. Holopea parvula Ulrich, Pal. Minn., pt. II., p. 106\%, pl. \%9, frg. 19 (II. pyrene var. parvula in explanation of plate).

Description.- "Shell small, 6 to $10 \mathrm{~mm}$. in width, the height equaling about three-fourths of the width; spire depressed-conical; whorls four, including two very small ones at the apex, neatly rounded, subcircular in section; suture distinct, very slightly canaliculate; umbilicus large, equaling about one-fourth of the diameter of the shell; aperture moderately oblique, rounded, slightly modified above by the preceding whorl; surface with very fine, obscure lines of growth, and on the latter half of the body whorl a number of more or less obscure undulations running parallel with the apertural margin."Ulrich.

Remarks.-Among the New Jersey specimens a single one seems ? to be a member of this species. It is imperfectly preserved, but, in so far as its characters can be determined, it does not differ essentially from Ulrich's description, which has been copied above. The umbilicus is so filled with the matrix that its size cannot be determined, the surface marking cannot be seen, and none of the obscure undulations mentioned in the description can be detected.

HOLOPEA SUPRAPLANA U. \& S.?

Plate XII., Figs. 31-32.

189\% Holopea supraplana U. \& S., Pal. Minn., pt. II., p. 1068, pl. 79, figs. $27-28$.

A single imperfect specimen from New Jersey, from which all the inner whorls are missing, seems to be referable to this species. It is characterized by its rapidly-expanding, outer volution, the vertical expansion being much the most pronounced, so that the aperture is nearly twice as high as it is wide. 


\section{PTEROPODA.}

\section{CONULARIA TRENTONENSIS Hall.}

Plate XIII., Figs, 7-8.

184\%. Conularia trentonensis Hall, Pal. N. Y., vol. I., p. 222, pl. 58 , figs. $1 a-f$.

Description. - Shell of medium size, pramiclal in form, quadrangular in cross-section, the sides diverging from the apex at an angle of about $25^{\circ}$. The sides slightly convex, the angles furrowed. Each side marked by a series of angular, transwerse costa, which are directed obliquely forward toward the aperture from each lateral margin, forming a rounded angle of about $130^{\circ}$ at the median line; from two to four of these costæ occupy the space of $1 \mathrm{~mm}$, being closer together and finer near the ajex of the shell and becoming progresively coarser towards the aperture. The furrows between the costre are wider than the ridges, rounded in the bottom, and are crossed at right angles by fine, raised bars joining adjacent costa, which are somewhat closer together than the costre themselves and not quite as high.

The dimensions of a specimen which is somewhat incomplete at the apex are: length, $38 \mathrm{~mm}$; diameter at aperture, $18 \mathrm{~mm}$.

Remarks.-This is the only species of Comularia which has been recognized in the Trenton limestone of New . Tersey. It is the common Trenton species of the genus which occurs in New York and other localities.

CEPHAT_OPODA.

ORTHOCERAS TENUISTRIATUM (Hall).

Plate XIII., Figs. 1-2.

189\%. Orthoceras tenuistrialum Clarke, Pal. Minn., pt. II., p. \%88, pl. 55, figs. 4 and 6 .

Description.- "Shell long, straight, gradually expanding. Sutures direct; septum regularly concare and rery slightly oblique. Sipho 
subcentral, small. Surface of the shell without annulations or ridges; marked by fine, crowded, horizontal lines, somewhat undulating or irregular, often running into one another, rounded on the summit and subimbricating, separated by low furrows and divided at irregular intervals by a furrow of more than average width. The horizontal lines and furrows are crossed by extremely fine, vertical lines, seen only under magnification."--Clarke.

Remarks.-Fragments of this species of Orthoceras are sometimes met with in the Trenton fauna of New Jersey. One specimen, which is possibly a member of the species, has a length of $75 \mathrm{~mm}$., with a diameter of $21.5 \mathrm{~mm}$. at the larger and $14 \mathrm{~mm}$. at the smaller end. This specimen does not preserve the characteristic transverse markings of the shell, but they may have been eroded. It is marked, however, by a series of dull-colored, vertical bands about $1 \mathrm{~mm}$. in breadth, separated by darker bands of about twice the width. A similar banding of the shell is noted by Clarke, and is considered by him as being a trace of original color lines in the living shell.

\section{orthoceras tenNuitextum (Hall).}

Plate XIII., Figs. $3-4$.

184\%. Endoceras proteiforme var. tenuitextum Hall, Pal. N. Y., vol. I., p. 210, pl. 45, figs. 2-5.

Description.-Shell straight, gradually expanding. Sutures, septa and sipho not observed. The surface is marked by a series of fine, angular, longitudinal, raised lines, about three or four occupring the space of $1 \mathrm{~mm}$., and also by transverse, raised lines, more rounded and a little closer together than the longitudinal markings, giving to the entire surface a fine, regular, reticulate ornamentation.

The dimensions of the best specimen observed are: length, $54 \mathrm{~mm}$. diameter at larger end, $13 \mathrm{~mm}$; diameter at smaller end, $5.5 \mathrm{~mm}$. This specimen is somewhat compressed, so that the diameters given above are a little too great. 
Remarks.-Fragments of this shell occur with the last, but they can always be distinguished by their very different surface markings. In general size and proportions the two species are much alike.

\section{oRTHOCERAS sp. undet.}

\section{Plate XIII., Fig. 6.}

A single imperfect specimen of an Orthoceras in the collection is apparently different from either of the two preceding species. The shell expands more rapidly and seems to be marked by obscure annulations. The specimen is slightly curved, and if this feature is not accidental, it should, perhaps, be referred to the genus Cyrtoceras.

The dimensions of the specimen are: length, $25 \mathrm{~mm}$; diameter at larger end, $8 \mathrm{~mm}$; diameter at smaller end, $3 \mathrm{~mm}$.

\section{CAMIEIOCERAS PROTEIFORALE (Hall).}

Plate XIII., Fig. 5.

18t\%. Endoceras proteiforme Hall, Pal. N. Y., vol. I., p. 208, pl. 46, figs. $1 a-b, 2(?)$, pl. 48 , figs. $1,2($ (?), 3, 4, pl. 49, figs. 1. $a-e$, pl. 50, figs. $1-3$, pl. 52, figs. $1 a-b$, pl. 53, figs. $1 a-c$, pl. 55, fig. 1, pl. $5 \%$, figs. 1 a $-b$.

189\%. Cameroceras proteiforme Clarke, Pal. Minn., pt. II., p. ra\%, pl. 48, figs. 1-2, pl. 49, fig. 2, pl. 50, figs. 1-3, pl. 51, figs. 1-3, pl. 53, figs. 4-5.

A few imperfect specimens of the siphonal casts of this species have been recognized in the New Jersey collections. The larger ones have a diameter of $35 \mathrm{~mm}$., but all are too imperfect for description. An illustration of one of the best specimens is given. 


\title{
ARTHROPODA.
}

\author{
TRILOBITA.
}

H.IRPINA OTTATENSIS (Bill.).

Plate XIV., Figs. 1-2.

1865. Harpes ottawaensis Bill., Pal. Foss., vol. 1, p. 182, fig. 165. 189\%. Harpina, cf. H. ottawensis Clarke, Pal. Minn., pt. II., p. $75 \%$, fig. 79.

Description.- "Head strongly convex, with a wide, punctured border, which extends backward to about the thirteenth segment of the thorax. If a line be drawn across touching the posterior edge of the neck segment, the contour in front of that line is nearly a perfect semicircle. Glabella regularly conical, its length about five-ninths that of the head; posterior furrows distinct, entering at about one-half the distance from the ocular ridge to the posterior margin of the neck segment, thence running obliquely inward and backwards at an angle of about $45^{\circ}$, apparently not quite one-third the width; two anterior furrows on each side, represented by obseure pits; neck furrow narrow; neck segment convex, strongly elevated on the fixed cheeks. The eyes [ocelli], are small and situated on a line drawn across the glabella at the anterior fourth; ocular ridge well defined, smooth, prolonged, with a backward curve outside of the eye. Thorax a little more than half the width of the head; the axis strongly convex and gradually tapering backwards; side lobes flat; pluræ with a wide groove along the middle, a small portion of their outer extremities turned backward. Surface of thorax, glabella and a subreniform space on each side of the base of the glabella smooth; the border with circular punctures about $[0.2 \mathrm{~mm}$. $]$ in width, and separated by smooth, rounded interspaces half their own width; the punctures larger and more distant at the inner edge of the border; on the elevated part of the cheeks they have a subreticulated arrangement." - Billings.

Remarks. - Fragments of the head of this species are not uncommon at Jacksonburg, but no perfect individual or even a perfect head has been observed. The commonest occurrence of the species is as 
the impression of the wide, punctured, marginal border of the head, these specimens being similar to the one illustrated by Clarke from Minnesota.

\section{TRINUCLEUS CONCENTRICUS (Eaton).}

Plate XIV., Figs. 3-4.

184\%. Trinucleus concentricus Hall, Pal. N. Y., vol. I., p. 249, pl. 65 , figs. $4 a-c$.

Description.-Head semi-circular or subcrescent-form in outline, the genal angles either destitute of spines or produced into long, slender, straight spines. Glabella smooth, very prominent, ovoid in outline, the widest portion being in front, with a short, blunt spine posteriorly; chechis smooth, prominent, but depressed considerably below the glabella, from which they are separated by a well-defined dorsal furrow; eves wanting. The entire anterior and lateral marsins of the head are surrounded by a broad, somewhat flattened or comeave border, which is marked in front hy from three to fire concentriv rows of deep, rounded pits; one or two additional rows are introduced on the sides, and toward the genal angles the pits often become irregularly scattered.

The thorax and pygidium have not been observed in New Jersey.

The dimensions of one of the best specimens observed, a nearly-complete head, are: length, $10 \mathrm{~mm}$.; width, $15 \mathrm{~mm}$. ; convexity, $6 \mathrm{~mm}$.

ISOTELUS GIGAS De Kay.

Plate XIV., Figs. 5-7.

1824. Isotelus gigas De Kay, Ann. Lyc. Nat. Hist., N. Y., vol. I.,

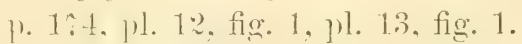

184\%. Isotetus gigas Hall, Pal. N. Y., vol. 1, p. 231, pl. 60, figs. $7 a-i$, pl. 61, figs. $3 a-m, 4 a-c$, pl. 62 , figs. $1 a-c, 2$, pl. 63. 189\%. Isotelus gigas Clarke, Pal. Minn., pt. II., p. \%01.

Description.-Outline of an entire individual subelliptical. with the anterior and posterior extremities somewhat pointed the triloba- 
tion nearly obsolete. Head subtriangular to semi-elliptical in outline, convex, slightly flattened in front; the anterior margin rather sharply rounded; facial sutures meeting at an angle, at or just behind the frontal margin, from this point they describe a broad, subarcuate curve, and, after passing around the eyes, they curve outward and then downward, intersecting the posterior margin at some distance outside of the eyes; glabella obscurely defined and more obscurely lobed; occipital furrow and segment obsolete; free cheeks marked by an intramarginal furrow, above which their general surface is elevated into a more or less conspicuous node, crowned by the eye. Thorax with a broad axial lobe, occupying more than one-third the width, consisting of eight segments. Pygidium subtriangular in outline, of nearly the same size and shape as the head, its lobation very obscure, especially in the larger individuals, the dorsal furrows being hardly distinguishable; axis much narrower at its anterior extremity than the axis of the thorax, tapering rapidly to the obtusely rounded posterior extremity, which lies at about one-fourth the length of the pygidium from the posterior margin; pluræ convex, smooth in the larger individuals, but in younger ones marked by about ten obscure segments, which also continue across the axis; the entire margin of the pygidium, except where it joins the thorax, bordered by a rather broad, slightly depressed, marginal border; the anterior, lateral angles bent abruptly downward.

Remarks.-No complete individuals have been observed, but fragments of heads, pygidia and thoracic segments of this species are not uncommon in the Trenton limestone of New Jersey, some of them indicating individuals which must have had a total length of over $150 \mathrm{~mm}$.

PTYCHOPYGE JERSEYENSIS $\mathrm{n}$. sp.

Plate XIV., Fig. 16.

A single imperfect pygidium from Jacksonburg is apparently referable to this genus, and as it can be referred to none of the described species, the above name is proposed for it. The general form of the pygidium is semi-elliptical. The pluræ are convex near the axis, becoming concave in the outer half; they are marked by four welldefined furrows, which extend almost to the margin. The segments 
between the furrows are broad and flat. The axis is apparently unsegmented, though this cammot he stated with certainty, because of the imperfect condition of the specimen.

\section{BUIASTUS TRENTONENSIS (Emm.).}

Plate XIV., Figs. 8-13.

1842. Illcenus trentonensis Emm., Geol. N. Y., Rep. on 2d Dist., ]. 39 , fig. 3 .

189\%. Bumastus trentonensis Clarke, Pal. Minn., pt. II., p. F18, figs. $30-35$.

Description.-Head strongly convex, subsemi-circular in outline, not trilobate, and with no prominenees save the eyes, which are located posteriorly, well toward the lateral margins. A pair of longitudinally elongate, sublunate depressions are -ituated on a transverse line joining the eyes, about half way between the eyes and the median line of the hear. 'These depressions are slight or almost obsolete unon the exterior of the test. being much more strongly marked upon the casts. Aside from these depressions and a few fine lines near the anterior marein and rumning parallel with it, the test of the head is perfectly smooth. The pygidium is smooth throughout, not trilobate, resemhling the head in size and general outline. Nine thoracic segments are fresent in the only specimen observed in which they are preserved.

The dimensions of a rather small specimen are: total length of body, $20 \mathrm{~mm}$; breadth, $10 \mathrm{~mm}$.; length of head, $8 \mathrm{~mm}$.; length of thorax, $6 \mathrm{~mm}$.; length of pygidium, $6 \mathrm{~mm}$.

Remarks.-This species is one of the commonest trilobites in the Trenton limestone of New Jersey, and occurs at nearly all horizons from which fossils have heen secured. It is associated with Leperditia fabulikes in the Black Rirer horizon of the formation at Jacksontures, and continues to occur in most of the beds nearly to the top of the same section. The species exhibits considerable variation in size, the largest heads attaining a length of $16 \mathrm{~mm}$., though the usual size is about 9 or $10 \mathrm{~mm}$. The large specimens have some resemblance to B. orbicaudatus Bill., but are more conver. 


\author{
BUMASTUS TRANSVERSALIS n. sp.
}

Plate XIV., Fig. 14.

Description.-Head convex, subelliptical in outline, not trilobate, much wider than long; the eyes situated posteriorly near the lateral margins. Test smooth, with a pair of longitudinally elongate, sublunate depressions on the transverse line between the eyes, about midway between the eyes and the median line of the head. Pygidium similar to the head in size and outline, perfectly smooth throughout. The complete thorax unknown.

The dimensions of one of the type specimens are: breadth of head between eyes, $13.5 \mathrm{~mm}$. ; length of head, $6 \mathrm{~mm}$.; breadth of pygidium, $13 \mathrm{~mm}$.; length of pygidium, $6 \mathrm{~mm}$.

Remarks.-This species resembles $B$. trentonensis, but is proportionately very much broader; in all other respects the two species are alike. It has only been observed in the lower or Black River horizon of the Trenton limestone.

BUMASTUS ELONGATUS n. sp.

Plate XIV., Fig. 15.

At a single locality south of Newton a species of Bumastus has been found in the Trenton limestone which resembles $B$. trentonensis in all respects except in the much greater proportional length of the parts. A nearly-perfect pygidium having a length of $13 \mathrm{~mm}$. and a width of $12 \mathrm{~mm}$. is illustrated. Associated with this elongate pygidium there are fragments of heads which also have similar elongate proportions.

PROETUS LATIMARGINATUS n. $\mathrm{sp}$.

Plate XIV., Figs. 17-24.

Description.-Head sublunate in outline, the genal angles produced into long, sharp spines. Glabella elevated, broadly subconical, rounded in front; lateral furrows nearly obsolete exteriorly, but sometimes their position is indicated by dark lines on the surface, which seem 
to indicate an internal thickening of the test; the two anterior pairs are short and lie in front of the eve-lobes; they are close together, and are directed obliquely backward from the margin of the glabella; the posterior pair are more conspicuous than the others, and are sometimes marked by slight depressions; they are situated a little in front of the middle of the eyc-lobes, and are directed obliquely backward from the margin of the glabella, becoming more curved posteriorly. joining the occipital furrow at nearly right angles. The dorsal furrow well defined throughout. Occipital furrow sharply impressed, deeper than the dorsal furrow. Oecipital segment with subparallel margins, scarcely as highly elevated as the glabella, marked by a small, rounded tubercle at its central point. Palpebral lobes of moderate width, subsemi-cireular in outline, depreswed below the level of the glabella. Facial sutures curving into the margin of the glabella, both in front and behind the palpebral lobes; posteriorly they intersect the margin of the head close to the axial lobe; in front of the palpebral lobes they curve outward nearly to the margin of the head, where they make a rather sharp bend and recurve inwardly, intersecting the anterior margin at some distance from its median point. Anterior limb of the cranidium broad, with a convex marginal border, between which and the glabella there is a rather broad, shallow, concave furrow. Free cheeks depressed-convex, with the eyes abruptly elevated, marked by a rather broad marginal border on both the lateral and posterior margins, on the inner side of which there is a rather sharply impressed furrow. Pygidium small, subsemi-circular in outline; the posterior margin regularly rounded; the anterior margin straight nearly to the lateral angles, where it is curved backward. Axis narrow, not reaching to the posterior margin, marked by six or seven annulations. Pluræ convex, much depressed below the axis, marked by five or six grooved segments, only the anterior two or three of which reach the margin of the yygidium. Thorax unknown.

The entire surface of well-preserved specimens is fincly granulose.

Remarks. - This species resembles P. partiusculus Hall. No measurements of that species are given with the description, but the figured type specimen, when reduced to natural size, has a total length of head of only $2.5 \mathrm{~mm}$. None of the New Jersey specimens are as small as this, and the larger ones have a length of head of $8 \mathrm{~mm}$. The lateral furrow of the glabella are also said to be not visible in that species, but at least the posterior pair can always be detected 
in the New Jersey specimens. The small tubercle upon the occipital segment is not mentioned in the description of $P$. parviusculus, nor is it shown in the illustration. Another species allied to this one is $P$. alaricus Bill., from the Upper Ordovician of Canada.

PRoETUS BREVIMARGINATUS $\mathrm{n}$. sp.

Plate XV., Figs. 1- $\mathbf{T}$.

This species resembles the last in general form and size, but the heads may always be distinguished by the greater convexity of the glabella, with a deeply-impressed posterior pair of lateral, glabellar furrows and two anterior pairs of slightly-impressed furrows, also by the much shorter frontal border of the cranidium. The proportions of the head are broader, with broader free cheeks, and the tubercle upon the occipital segment is usually less conspicuous than in P. latimarginatus. The pygidium which is believed to belong to this species has a broader axis, more broadly rounded posteriorly, than that of $P$. latimarginatus, and has a less number of segments on both axis and pluræ:

The two species occur associated together in the same strata, and are about equally abundant.

\section{CYPHASPIS TRENTONENSIS n. sp.}

Plate XV., Figs. 8-10.

Description.-Glabella bounded on all sides by a deep furrow; the median lobe orate or subpyriform, narrower behind, strongly arehed, both longitudinally and transversely; basal lobes prominent, less than one-half the length of the median lobe and separated from it by deep furrows. The anterior marginal border of the cranidium narrow, bounded internally by a sharply impressed marginal furrow. Between the marginal furrow and the dorsal furrow bounding the glabella is a convex band, broader than the marginal border, which extends backward to the occipital furrow and surrounds the glabella, except posteriorly. The palpebral lobes are rather prominent and elevated, but do not rise as high as the glabella. Occipital furrow rather deeply 
depressed. Occipital segment broader than the furrow, produced posteriorly at its median point into a short, blunt spine or tubercle. Surface of the median and basal lobes of the glabellat, the posterior portion of the band surrounding the glabella and the oceipital segment, covered with minute tubercles, which are most abundaut upon the glabella. The hand between the dorsal and marginal furrows, in front of the glabella, has a closely-pitted surface. The anterior marginal border, the palpebral lobes and the bottom of all the furrows are smooth.

The free cheeks, thorax and pygidium are unknown.

The dimensions of the largest specimen observed are: total length of head, $4.75 \mathrm{~mm}$. : width between palpebral lobes, $5 \mathrm{~mm}$.; length of glabella, $3 \mathrm{~mm}$. : width of glabella, $2.33 \mathrm{~mm}$.

Remarks. - This species is closely allied to $C$. planifrons Eich. of Russia, as described by Fr. Schmidt. ${ }^{*}$ It dilfers from that species in the absence of the abrupt descent of the glabella prosteriorly into the occipital furrow, and in its different surface markings, the head of C. planifrons being covered throughout with scattered tubercles.

\section{BRONTEUS LUNATUS Bill.}

Plate XV., Figs. 14-16.

185.5. Bronteus 7unatus Bill., Geol. Surv. Canada. Rep. Prog., p. 338. 186i3. Bronteus lunatus Bill., Geol. Canada (Logan), p. 188, fig. 18\%. 189\%. Bronteus lunatus Clarke, Pal. Minn., pt. II., p. 725 , fig. 43.

Description.-Pygidium subcircular in outline; axis semi-oval or subtriangular, partially terminated at a point a little more than onefourth the length of the prgidium from the anterior border and beyond that point continued as a flattened ridge, with slightly diverging sides. Pleura marked by six shallow, lateral furrows on each side; the first lies parallel with the anterior margin of the pygidium until it has proceeded half way to the lateral margin; it then curves backward and soon becomes obsolete; the second originates in nearly the same point with the first, but curves backward more directly; the other four are nearly straight and at equal distances from each other, but all disappear as they approach the margin.

\footnotetext{
* Rev. Ostbalt. Sil. Tril., pt. IV., p. ฮs.
} 
Remarls.-Only the prgidium of this species has been observed in New Jersey, but Billings illustration of a complete individual is introduced to show the characters of the remaining portions of the body. In Billings' figure the broad, flat, posterior, axial rib of the pygidium is deeply divided for about one-half its length, although this division is not mentioned in the description of the species. In the New Jersey specimens no such hifurcation of this rib is noticeable, although just at the posterior margin of the pygidium there is the faintest suggestion of a median furrow.

The surface of the test is marked by exceedingly fine, raised, concentric lines, which arch forward in crossing the ribs of the prgidium.

ARGES TUBERCULATUS n. sp.

Plate XV., Figs. 11-13.

Description.-Cephalon subtriangular to subpentagonal in outline, flattened above, the eye-lobes prominent. Glabella flattened above, its median and lateral lobes, as well as the eye-lobes, having the same elevation, strongly curved downward in front; median lobe broadest in front, its anterior portion strongly conver and extending beyond the lateral lobes; the second pair of glabellar furrows obsolete, the posterior and anterior ones continuous, separating off a pair of subovate, lateral lobes, which are strongly convex in front, each of which is as broad anteriorly as the median lobe; the posterior lobes illdefined. Dorsal furrows nearly as strong as the glabellar furrows anteriorly, but becoming fainter posteriorly and nearly obsolete before reaching the occipital furrow. Occipital furrow strongly impressed, curving forward medially. Occipital segment broad, its greatest breadth being back of the median lobe of the glabella. Fixed cheeks strongly convex. Eye-lobes prominent, placed about midway in the length of the head. Surface marked by scattered tubercles, which vary in size, being largest and most numerous upon the median lobe of the glabella. Free cheeks, thorax and pygidium unknown.

In the best-preserved specimen the length of the head is $6 \mathrm{~mm}$., the breadth between the eyes being $9 \mathrm{~mm}$.

Remarks.-But one other member of the genus Arges has been recognized in the Ordovician strata of America, Arges vestenbergensis var. paulianus* from Minnesota. The New Jersey specimens differ

\footnotetext{
* Pal. Minn., pt. II., p. 744.
} 
from this species in the more angular outline of the head, the more prominent eye-lobes, the flattened dorsal surface and the much broader occipital ring. Our species also occurs at a somewhat lower horizon than those from Minnesota, being in the Black River horizon of the Trenton limestone as it occurs in New Jersey.

\section{PLATYMETOPUS TRENTONENSIS (Con.).}

Plate XV., Figs. 17-19.

1842. Asaphus? trentonensis Con., Jour. Acad. Nat. Sci. Phil., vol. VIII., p. 2\%\%, pl. 16, fig. 10.

184\%. Platynotus trentonensis Hall, Pal. N. Y., vol. I., p. 235, pl. 64 , figs. $1 a-d(\operatorname{not} 1 e)$.

189\%. Platymetopus trentonensis Clarke, Pal. Minn., pt. II., p. 753.

Description.-Head ventricose, the curve along the median line from the posterior to the anterior margins being very nearly a semicircle, subsemi-circular in outline, attaining a breadth of 35 or 40 mm. The glabella very large, oceupving nearly the entire breadth of the cranidium, strongly protuherant in front; with a single pair of glabellar furrows, which originate at the anterior, lateral margins, and, after curring inward, then backward and then slightly outward again, forming something more than a semi-circle, they join the occipital furrow, dividing the glabella into three lobes; the frontal or median lobe is broad in front, becoming narrower posteriorly to a point back of the middle of the head, and then again broadens out, becoming nearly as wide on the occipital furrow as it was on the anterior margin; the two lateral lobes about as prominent as the median lobe, suberesentiform in outline. Dorsal furrows concave inward, about as deeply impressed as the glabellar furrows. Fixed cheeks rather broad along the posterior margin of the head, becoming rapidly narrower to a point just behind the palpetral lobe; the palpetral lobe rather prominent, the cheek becoming very narrow anteriorly. Occipital furrow and oceipital segment well defined, extending across the fixed cheeks. The entire surface ornamented with small, low, rounded tuhereles, somewhat variable in size.

Free cheeks, thorax and pygidium unknown. 


\section{ODONTOPLEURA PARVULA (Walc.).?}

Plate XV., Figs. 21-22.

1879. Acidaspis parvula Walcott, 31st Rep. N. Y. State Mus. Nat. Hist., p. 69.

189\%. Odontopleura parvula Clarke, Pal. Minn., pt. II., p. 744 , fig. 61 .

Description. - Width of the cranidium along its posterior border 8 $\mathrm{mm}$., width between the eyes $5.5 \mathrm{~mm}$., the outline anterior to the eyes forming nearly a semi-circle. Glabella proportionally large, its greatest width $3.25 \mathrm{~mm}$., subtriangular in outline; each member of the two pairs of glabellar lobes entirely isolated; frontal or median lobe reaching from the extreme anterior margin of the head to the occipital furrow, its sides parallel and straight, with a pair of minute lateral extensions just back of the anterior extremity, which may, perhaps, be considered as a rudimentary third pair of glabellar lobes; the posterior pair of glabellar lobes subelliptical in outline, with their long axes directed obliquely to the axis of the median lobe; the anterior pair about one-half the size of the posterior pair, nearly circular in outline and placed in the angles between the posterior pair and the median lobe. The glabellar furrows about as deeply impressed as the dorsal furrows. The occipital furrow broad and deep; the occipital segment narrower than the furrow, with a small tubercle in its centre. Fixed cheeks nearly as prominent in their median portion as the lateral lobes of the glabella; palpebral lobes minute, situated just in front of the occipital furrow; back of the palpebral lobes the cheek is abruptly depressed to its long, lateral extensions. From the occipital furrow forward to the antero-lateral margin of the median lobe of the glabella the fixed cheek is marked by a marginal furrow, which is nearly as deeply impressed as the dorsal and glabellar furrows. Whole surface marked by fine, circular tubercles of variable size. The free cheeks, thorax and pygidium unknown.

Remarks.-Odontopleura purvula was originally described by Walcott from the Trenton limestone of Trenton Falls, New York, but the description of the head is so meagre that, in the absence of illustrations, it cannot be certainly identified. The glabellar furows are said to be so slight that "the lateral lobes and cheeks are scarcely defined." This is certainly not the case in the specimen from New 
Jerser. At a later date Clarke published an illustration of a specimen of the species from the type locality, but this figure shows much larger eyes than could have been present in the New Jresy specimen and the lateral margins of the median lobe of the glabella are not straight and parallel as in the specimen under consideration. The marginal border continuing around the anterior margin of the head, which is shown in clarke sigure, is not precent in the specimen from New Jersey. By reason of these differences it sems possible that the New Jersey trilobite should be considered as a distinct and undescribed species.

ENCRINURUS TRENTONENSIS WalC.

Plate XV., Figs, 26-27.

189\%. Encrinurus trentonensis Walc., 31st Rep. N. Y. State Mus. Nat. Hist., p. 68 (p. 14 of reprints).

Description.-Pygidium subtriangular in outline, length and brealth nearly equal; the lateral marerins straight or slightly concalve: the posterior extremity sharply rounded or subangular. "Axis narrow, with tapering sides, terminating within the posterior margin of the proidium, with about twenty-fire narrow segments in the larger individuals. In the best-preserved specimen observed the first, fourth, serenth, eleventh. fiftenth and nimeteenth axial segments each bear a low, blunt tubercle at the median line of the axis, while some of the intertubercular segments become fainter and even almost obsolete in the middle. The pluræ curve abruptly to the lateral margins, especially posteriorly, and are marked with nine or ten ribs on each side, besides a median rib, which joins the posterior extremity of the axis with the posterior margin. The lateral segments curve backward distally. so that the outer portion of the anterior ones and nearly the whole length of the posterior ones is directed backward, the most posterior ones having a direction nearly parallel with the axis.

An average adult specimen of the prgidium has a length of $9 \mathrm{~mm}$, with the breadth the same.

Remarks.-Aside from the pygidia, which are fairly common in the upper portion of the section at Jacksonburg, only a few fragments of glabellæ and cheeks which probably belong to this species have been observed. These fragments are all strongly tuberculate through- 
out. Among the specimens of pygidia which have been observed there are some which are smaller and proportionately much broader, with a smaller number of segments both on the axis and on the pluræ. The axial segments of these smaller specimens are intermittently tubercular as in the larger ones, and it is believed that they are only immature individuals of the same species.

The original $E$. trentonensis, which was described from Wisconsin and Illinois, has never been illustrated, but the New Jersey specimens agree in general very closely with the description of the species. There is some difference in the arrangement of the tubercular segments of the axis, but the New Jerrey specimens exhibit some variation in this respect among themselves; the important character seems to be the intermittence of the tubercular segments, and not the exact position of these segments.

The species is a close analog of $E$. serbachi Schm. from Russia.

CALYMENE SENARIA Con.

Plate XV., Fig. 23.

184\%. Calymene senaria Hall, Pal. N. Y., vol. I., p. 238, pl. 64, figs. $3 a-n$.

Description.-Head sub-semi-circular or sublunate in outline, the anterior and lateral margins being more or less nearly regularly rounded, and the posterior broadly sinuous, with the posterior lateral extremities bluntly subangular or abruptly rounded. Free cheeks irregularly triangular in outline, with thick, rounded, lateral margins, defined by a distinct, rounded, marginal furrow, which is continuous with the furrow separating the anterior end of the glabella from the prominent, elevated, anterior margin of the head. Facial sutures originating just in front of the genal angles, passing obliquely forward and inward for a little more than half the distance to the eyes, then curving inward to the base of the eye-lobe, and, after passing around the eyes, extending forward and intersecting the anterior margin at points a little nearer together than the breadth between the eyes. Eyes small and rather prominent. Glabella more prominent than the cheeks and separated from them by deep, dorsal fur-

* Rev. Ostbalt. Sil. Tril., pt. I., p. 229. 
rows: about as wirle behind as its length, including the occipital segment. much narrower in front; the frontal and three pairs of lateral, glabellar lobes separated by three pairs of glabellar furrows, of which the anterior pair is much the faintest and shortest, each member of the second pair extends about one-fourth the distance across the glabella, slightly'curved posteriorly, the posterior pair deeper and wider than either of the others, each member extending about one-third of the distance across the glabella and directed obliquely hackward. Occipital furrow deep and prominent, connecting with the dorsal furrows and less conspicuously with the marginal furrows of the posterior margin of the fixed cheeks, arching slightly forward at the middle of the glabella. Occipital segment well definerl, arching a little forward, ahout as high as the most prominent portion of the glabella in front. Fixed cheeks convex, provided with a deep, broad furrow along their posterior margin.

Pygidium wider than long, more or less subtrigonal in outline, but with the anterior margin broadly rom ded. Axis well defined, convex, extending nearly to the posterior margin, with five or six transverse segments, which grow fainter posteriorly. The pluræ convex, each with about five segments, which are furrowed distally.

Whole surface of the test minutely granular.

Remarks.-Fragments of this species are common in the Trenton fauna of Xew Jersey, lut no complete individuals have been observed. This species is most closely allied to the common Cincinnatian species of Southern Ohio and Indiana, which Clarke has referred to $* C$. callicephala Green. 'The 'I'renton species, however, can always be distinguished from it hy the grooring of the segments of the plura of the pygidium.

CERAURUS PLECREXANTHEMets Green.

Plate Xr., Fig. 28.

184\%. Ceraums pleurexanthemus Hall, Pal. N. Y., vol. I., p. 242, pl. 65 , figs. $1 a-n$, pl. 66 , figs. $1 a-h$.

Description.-Head crescentiform in outline, with the posterior lateral angles extended into long, curved, genal spines, which are attached to the fixed checks. Free cheeks irregularly triangular in

* Pal. Minn., pt II., p. 699. 
outline, the eyes small. Facial suture starting at the lateral margin, and after extending inward toward the glabella, making a sharp turn forward just back of the eye, and after passing around the eye, curving gently forward, cutting the anterior margin of the head in front of the glabella. Glabella prominent, convex, broadest in front, extending nearly to the anterior margin of the head. Glabellar furrows well defined, but not extending across the glabella. The two anterior pairs straight, each portion extending over about one-fourth the width of the glabella. The third pair extending inward about as far as the other two, and then bending abruptly backward and joining the occipital furrow, leaving the posterior glabellar lobes more or less detached. Occipital furrow deep and well defined, arching a little forward upon the glabella, extended laterally upon the fixed cheeks nearly to the lateral margins, where it joins a marginal furrow just in front of the genal spine, which passes anteriorly. Occipital segment well defined. Dorsal furrow rather sharply impressed. Fixed cheeks convex, their posterior lateral angles extended into prominent, curved, genal spines. Whole surface of the head, except the dorsal, glabellar, occipital and marginal furrows, strongly granulose or papillose, with some scattered tubercles larger than the others.

Thorax and pygidium not recognized in the New Jersey collections.

Remarks.-This species is more or less abundant in the Trenton limestone throughout the United States wherever this formation occurs, but is rarely preserved, except in a fragmentary condition. The New Jersey material consists entirely of fragmentary portions of the head; in most cases the glabella alone being recognized. This need never be mistaken, however, even in its fragmentary condition, because of its peculiar granulose ornamentation.

PSEUdosPHAEREXOCHUS TRENTONENsis Clarke.

Plate XV., Figs. 24-25.

189\%. Pseudosphcrexochus trentonensis Clarke, Pal. Minn., pt. II., p. 734 , figs. $53-54$.

Description.-Glabella subhemispherical, a little wider than long, with three pairs of distinct glabellar furrows. The first pair is the shortest, originating close to the frontal margin, the length of each 
being about one-half the distance between their outer extremities measured in a straight line. The second pair are longer, parallel for about one-half their length with the first pair, then directed more strongly backward. The third pair are longer than the second, subparallel with them, but deflected abruptly backward at their extremities, where they are widened into a slight pit or excavation, not reaching the occipital furrow. The occipital segment is widest in the middle. The cheeks are but imperfectly preserved. The entire surface of the glabella is corred with low, distinct, scattered tubercles.

The dimensions are: length of glabella, $12.5 \mathrm{~mm}$.; length of glabella and occipital segment, $14.5 \mathrm{~mm}$.; width of glabella, $13.5 \mathrm{~mm}$.

Remarks. - This species was originally described from the Middle Trenton limestone at Trenton Falls, New York. In New Jersey the species has been observed only in the Black River horizon of the formation, where it is associated with Leperditia fabulites and Dalmanella subcequata. Cheirurus vulcanus Bill.," described from the

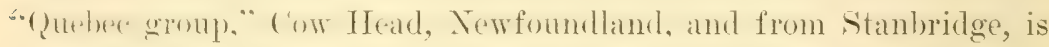
a very similar species. It is possible that the two are identical, in which case the specific name, vulcanus, has priority.

\section{PTERYGOAETOPUS CALLICEPHALUS (Hall).}

Plate XV., Figs. 29-32.

1841. Phacops calliceplaalus Hall, Pal. N. Y., vol. I., p. 247, pl. 65, figs. $3 a-i$.

189\%. Pterygometopus callicephalus Clarke, Pal. Minn., pt. II., p. 731, figs. 51-52.

Description.-Head sublunate in outline, obtusely subangular in front, genal angles broad and rounded, with no indication of spinules. Glabella large, depressed-convex, broad and rounded in front, becoming much narrower behind; frontal lobe large, subelliptical in outline; anterior pair of glabellar furrows starting from opposite the anterior axtremities of the eyes, directed obliquely backward and each one extending over a little more than one-third the width of the glabella; second pair of glabellar furrows shorter and a little shal-

* Pal. Foss., vol. I., p. 284, fig. 271; p. 324, fig. 310. 
lower than the first, directed obliquely forward; third pair of glabellar furrows directed toward the axis of the glabella for a short distance and then bending abruptly backward and joining the occipital furrow, leaving the small, basal glabellar lobes wholly detached. Occipital furrow rather deep and broad. Occipital segment rather broad, its elevation about eren with the glabella in front, its posterior margin conrex. Palpebral lobes prominent, their elevation being nearly that of the glabella, separated from the glabella by the deep dorsal furrow, and marked by a conspicuous furrow just within the border of the eye. Eyes large, lunate, their inner margins elevated nearly or quite to the height of the glabella, their anterior ends opposite the first glabellar furrows and their posterior ends reaching nearly to the occipital furrow. Checks, outside the eyes, sloping rather abruptly to the lateral margins of the head; marked along the posterior margin to a point about one-half the distance from the eye to the margin by the narrow, but rather sharply impressed, occipital furrow, whose distal extremity is rather abrupt; the lateral borders marked by an ill-defined marginal furrow, which originates at the outer extremity of occipital furrow, and, after passing forward nearly parallel with the margin, joins the dorsal furrow just in front of the eye.

Pygidium subtriangular in outline, rather abruptly rounded or subangular posteriorly. Axis prominent, but rather narrow, its margin slightly incurved and abruptly rounded behind, marked by from eight to ten-somewhat sinuous annulations; the pluræ slightly flattened adjacent to the axis, but soon curving rather abruptly to the lateral margins, marked by about six grooved segments, with slight traces of others posteriorly.

Surface of the glabella, palpebral lobes, occipital segment and cheeks inside the marginal furrow distinctly pustulose, the little tubercles being more or less irregular in size; upon the cheeks outside the border of the eyes the pupillæ are much less conspicuous than upon the glabella and the marginal border is perfectly smooth. Pygidium unornamented, except by the grooves marking the segments, which do not extend entirely to the border, thus learing a plain, perfectly smooth, narrow marginal border. 
PTERYGOMETOPUS INTERMEDIUS (Walcott).?

\author{
Plate XV., Fig. 33.
}

18:9. Dulmanites intermedius Walcott. 31st Rep. I. Y. State Mus. Nat. Hist., p. 69 (p. 16 of adv. sheets, $18 \% \%$ ).

189\%. Pterygometopus intermedius Clarke, Pal. Minn., pt. II., p. ґ27, figs. $45-47$.

In some of the lower beds of the Jacksonburg section, below those containing $P$. callicephalus, the pygidium of another species of Pterygometopus sometimes occurs. These pygidia are longer and much more triangular in outline than those of $P$. callicephalus and are msually smaller. 'The sides of the axis are slightly concave inward, giving it a slightly constricted appearance near the centre of its length. The axis extends nearly to the posterior extremity of the pygidium, is rounded at its end, and has about twelve annulations, with sometimes faint traces of several additional ones. The pluræ slope away abruptly from the axis, especially posteriorly, and are marked by eight ribs, the first two or three of which are usually slightly grooved.

The head of this species has not been observed, so that it cannot be identified with certainty as $P$. intermedius, but the characters of the pygridium approach more elosely to that suecies than to any other.

\title{
OSTRACODA.
}

\section{LEPERDITIA FABUlites (Con.).}

Plate XIII., Figs. 11-12.

1843. Cytherina fabutites Conrad, Proc. Acad. Nat. Sci. Phil., vol. I., 1. 3.32 .

189\%. Leperditia fabulites Clrich. Pal. Minn., pt. IT., p. 634, pl. 43, figs. 10-14.

"(tarapace of medium size, ohliquely subovate, comparatively long, widest posteriorly: rentral curves moderate. strongest just behind the midlength: cardinal line straight, comparing with the length 
of the valve as two is to three, the two extremities almost equally angular; height of ends about as three is to four. both obliquely truncate above, the anterior narrowly rounded in the middle; the posterior outline more broadly and evenly curved, though haring the usual backward swing. Tentral edge of carapace obtuse, scarcely flattened, with a slight furrow on each side near the edge of the right valve, in which a row of minute punctio is generally distinguishable; overlap extending all around the free edges, strongest ventrally; except in rare instances neither valve has a flange or flattened border, and when present, it is in all cases very narrow and undefined; lorsal edge somewhat thickened, especially upon the left side. Surface of valves smooth or very faintly pitted, rather evenly convex, with the greatest thickness somewhat beneath the centre; a low ridge-like thickening along the posterior half of the dorsal margin of the left valve is to be noticed. Eye tubercle just distinguishable in most cases, often not to be detected. On the inner surface, however, it is always marked by a distinct pit. Muscle spot not distinguishable externally, except when the specimens are weathered, but on the inner side it is often well marked and surrounded by fine, reticulating. radial lines, short dorsally, longest post-ventrally. On the inner side of the ventral edge of the right valve there are two rows of small papillæ, three to five each, the number seeming to increase with age. The purpose of the papilla, one series of which occurs in the anteriol. third, the other in the posterior, evidently was to prevent undue overlapping of the valves by presenting an obstacle to the entering ventral edge of the left valve." - Ulrich.

LEPERDITELLA ORNATA n. sp.

Plate XIII., Figs. 13-15.

Carapace subelliptical; length of a large specimen, $3 \mathrm{~mm}$.; height, $2 \mathrm{~mm}$.; thickness, $1.7 \mathrm{~mm}$; length of hinge line, $1.7 \mathrm{~mm}$. Valves equally convex, greatest thickness below the middle. Free margin of the right valve abruptly inflexed, with a row of minute tubercles upon the angular, marginal ridge thus formed. Free margin of the left valve incurved and covering the inflexed margin of the opposite valve, with an external, longitudinal groove ncar the rentral margin. 
Licmurh.-This species differs from any of the described species of the genus in its marginal row of tubereles upon the right valve. The yewimens studied range from $1 \mathrm{~mm}$. to $3 \mathrm{~mm}$. in length, but scarcely lary in their proportions. The right valve of the species closely resembles. in its form and ormamentation, the left valve of A parchites mmnilabiulus Ulr., * but the left valve of this New Jersey species is yuit. different from that of Ulrich's species. Furthermore, the free martin of the left valve of the speeies here described overlaps. the matrin of the right valve, this being a character which would exclude it from the genus A parchites.

\section{EURTCHILINA OCULIFERA n. sp.}

Plate XIII., Fig. 16.

Carapace subelliptical; valres moderately convex, with a nearly wntral. subcircular pit surrounded by a slightly-elevated rim, with a sight prominence olliciuly above and to the front of it. Marfinal area conves, separated from the hody of the valve by a sharplyimpresed groove, the free marwin extender into a narrow frill. Surfale nearly smooth, the marginal border and frill marked by obscure, radiating lines.

The dimensions of a rather large speemen are: length, $2.7 \mathrm{~mm}$; height, $1.8 \mathrm{~mm}$.; length of hinge-line, $2 \mathrm{~mm}$.

lemarlis.'This species may be distinguished from most other members of the genus by its sharply-defined, subcentral pit, which is not connected with the dorwal margin ly a sulcus. In this character, howaver. it resembles E. solida Reudemamn, but may be distinguished from that species by it: sreater obliquity and its smooth surface. The next species resembles $E$. solida more closely than this one.

EURYCHILINA JERSEYENSIS n. sp.

Plate XIII., Fig. 17.

Carapace subelliptical, moderately convex, with a subcentral, nearly - ircular pit, surromeded by a slightly-elevated rim, not connected with the dor:al margin by a sulcus. $\Lambda$ slight prominence lies obliquely

\footnotetext{
* Pal. Minn., pt. II., p. 644, pl. 45, figs. 21-23.
} 
above and in front of the central pit. A slight, moderately-sharp, oblique ridge extends from the dorsal margin, near the anterior extremity of the hinge-line, forward and downward to above the middle of the anterior extremity of the body of the shell. Free margin bordered throughout by a rather broad, concave frill. Surface very finely punctate, the marginal frill marked by more or less obscure, radiating lines.

The dimensions of an average specimen are: length, $2.3 \mathrm{~mm}$; height, $1.5 \mathrm{~mm}$; length of hinge-line, $1.7 \mathrm{~mm}$.

Remarks. -This species closely resembles the last one in many of its characteristics, but may always be distinguished from it by reason of the absence of the convex marginal area within the marginal frill and by its much wider frill.

Description of Species from the Hudson River Formation.

The slates and arenaceous beds of the Hudson River formation are almost barren of organic remains, and at only three localities have fossils been found. At Sussex there is a thin stratum containing many individuals of but very few species of brachiopods. The other two localities, one near Branchville and the other in the railroad cut at Jutland, have afforded only graptolites.

\section{COELENTERATA.}

HYDROŻOA.

DIPLOGRAPTUS FOLIACEUS (Murch.).

Plate XVI., Fig. 7 .

184\% Graptolithus pristis Hall, Pal. N. Y., vol. I., p. 265, pl. 72, figs. $1 a-s$.

Description.-Polypary flat, straight, colluliferous on two sides, besoming gradually broader from the distal extremity for one-half to two-thirds of their length, and then again becoming a little narrower. The maximum width attained is from $2 \mathrm{~mm}$. to $2.5 \mathrm{~mm}$. About four- 
teen thera usually occupy the space of $10 \mathrm{~mm}$; their free extremities are angular; their inclination to the axis is about $45^{\circ}$.

Remarks. - This is by far the most abundant graptolite at the Branchville locality, being the only one which is at all common.

\section{DIPLOGRAPTUS ANGUSTIFOLIUS (Hall).}

Plate XVI., Figs. 8-9.

1859 Graptotithus angustifolius Hall, Pal. N. Y., vol. III., p. 515, figs. 1-2.

This species resembies the last, but the polypary is narrower, the there are a little further apart, there being about eleven in the spate of $10 \mathrm{~mm}$, and their onter extremities are rounded.

LASIOGRAPTUS MUCRONATUS (Hall).

Plate XVI., Figs. 16-17.

184\%. Graptolithus mucronatus Hall, Pal. N. Y., vol. I., p. 268, pI. 73, figs. $1 a-d$.

This species resembles Diplograptus foliaceus, but the outer extremities of the thece are produced in mucronate appendages.

CLIMACOGRaptus PIIrlophorus Gurley.

Plate XVI., Figs. 14-15.

1896. Climacograptus phyllophorus R. R. Gurley, Jour. Geol., vol. IV., p. 7\%, pl. 4, figs. 4-6.

Description.- - ['o] ypary gradually widening from distal t'xtrimity. ataining its full wilth in the length of six to eight thecus: rentral margins above this point parallel. Ix ngth, exclusive of proximally prolonged viroula, $10 \mathrm{~mm}$. to $30 \mathrm{~mm}$. (usually about $20 \mathrm{~mm}$.) ; maxi- 
mum width, $1.5 \mathrm{~mm}$. to $2 \mathrm{~mm}$.; distal extremity narrow and abrupt, with two short, lateral spines; and an extension of virgula for $2 \mathrm{~mm}$. to $6 \mathrm{~mm}$. Proximal extremity abrupt, showing a prolongation of the virgula, which terminates in a "disk," varying in shape (apparently with age) from narrowly lanceolate to broadly elliptic, $6 \mathrm{~mm}$. to 10 $\mathrm{mm}$. long and $1 \mathrm{~mm}$. to $3 \mathrm{~mm}$. broad. Theca thirty to thirty-six in $2: 5$ Inm.; short, perpendicular, apertural margins concave, the excavation nearly horizontal (slightly inclined distalward), occupying nearly one-third of width of the polypary."-Gurley.

Remarks.-This species is very distinct from $C$. bicornis and $C$. typicalis, differing from the former in the absence of the three prominent spines and the disk developed around them, and from the latter by the constantly prolonged virgula. It is also much smaller than either bicornis or typicalis.

\section{DICRANOGRAPTUS RAMIOSUS (Hall).}

Plate XVI., Figs. 10-11.

184\%. Graptolithus ramosus Hall, Pal. N. Y., vol. I., p. 270, pl. 73, figs. $3 a-h$.

Description.-Polypary flat, linear below, with thecæ on two sides, diriding above into two divergent branches, which bear thecre on the outer margins only. Thecæ obtusely rounded at their outer extremities, rather distant, slightly narrowed toward the base, about twelve occupying the space of $10 \mathrm{~mm}$.

Remarks.-This species may be easily recognized by its bifurcating prolypary, being different in this respect from any of its associates in the New Jersey fauna. 
COENOGRAPTUS GRACILIS (Hall).

Plate XVI., Fig. 19.

1859. Graptolithus gracilis Hall, Pal. N. Y., vol. III., p. כ̃10, figs. 1-7.

Description.-Polypary convisting of two principal stipes, which diverge from a point of attachment, and in the adult forms a sigmoidal curve. The branches arise from the outer sides of the two principal stipes; they are slender, gradually enlarging and bear there only on one side, the thece being rather distant, their length greater than the width of the branch upon which they are borme.

Remarks.-This species is represented in the New Jersey cullections only by exceedingly imperfect specimens, which but partially exhibit the detaits of strueture. The acempanying illustration is copied from Hall's.

CORYXotdes CALICULARIS Nich.

Plate XVI., Figs, 12-13.

186\%. Corynoides calicularis Nich., Geol. Mag., rol. IV., p. 108, pl. 7 , figs. $9-11$.

Description.- "The stipe varies in length from one-third to half an inch, and has an average breadth of one-twentieth of an inch: the hase or proximal extremity is provider with two small, slightly-rlirerging spines or mucros, which are wanting in other less perfect specimens, when the stipe terminates below by tapering to a point. There are no cellules, the lateral margins of the stipe being perfectly plain; but the polpary expands at its distal extremity into a sort of cup or calyx, the free edge of which is divided into four or five equal or unequal teeth. There are no certain traces of any central, solid axis, but the surface of the stipe is sometimes striated."Nicholson.

Remarks.-Certain specimens from the graptolite locality near Branchrill. have been inentified by Dr. Reulemam as Corynnides 
calicularis Nich. These New Jersey specimens, however, are poorly preserved, and in none of them is the toothed, distal margin well shown. The figures of the species giren on plate XVI. are all copied from Nicholson, none of the New Jersey specimens being well enough preserved for illustration.

\section{RETEOGRAPTUS GEINITZIANUS Hall.}

Plate XVI., Fig. 18.

1859. Reteograptus geinitzianus Hall, Pal. N. Y., rol. III., p. 518, fig.

This imperfectly-understood graptolite possesses a peculiar reticulate skeleton, consisting of three or more rows or series of subquarlrangular or hexagonal reticulations, without central axis. No definite thecæ have been observed. In the New . Jersey collections it is represented by a single incomplete specimen from Jutland.

\section{VERIMES.}

ANNELIDA.

CORNULITES sp. undet.

Plate XVI., Fig. 1.

Scattered among the brachiopod thells in the fosiliferous layer of the Hudson River slate at Sussex there are ocedsional specimens of a small, tubicolor annelid, which is doubtless a member of the genus Cornulites. The material is altogether too imperfect, however, for' specifie identification. 


\title{
MOLLUSCOIDEA.
}

\author{
BRACHIOPODA. \\ PLECTAMBONITES SERICEUS (SOW.).
}

Plate XYI., Figs. 2-3.

See, also, p. 149 , pl. IX.

In the flagstone quarry at suswex a thin, arenareous layer, charged with calcareous material, is filled with a fer species of fossils, by far the most abundant of which is $P$. sericeus. The specimens are all much smaller that the Trenton representatives of the species and many of them are proportionately broader.

\section{PLECTORTHS PLICATELLA (Hall).}

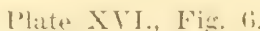

See, also, p. 15\%, pl. IX.

A single incomplete impremsion of the perlicle valve of this species has been recognized from Sussex. Scarcely enough of it is preserved to exhibit its characters properly, but it is apparently less nearly circular than the Trenton representatives of the species, being propertionally broader, in this respect resembling more downly the Cincinnatian representatives of the species.

DALMANELTA TESTUDINARIA (Dal).

Plate XY1., Figs. 4-5.

See, also, p. 155, pl. X.

The representatives of this species which are present in the Hudson Tiver formation al susex are usually smaller than those of the Trenton limestone, but in other respects are not essentially different. 


\section{CHAPTER VIII.}

\section{FAUNAS OF SILURTAN AGE.}

The geologic formations in New Jersey which are here referred to the Silurian are the Shawangunk-Green Pond conglomerate, the Iledina-Longwood sandstone, the Poxino Island shale, the Bossardville limestone, the Decker Ferry formation, the Rondout formation ind the Manlius limestone. Of all these the Shawangunk-Green Poud *nglomerate, the Medina-Longwood sandstone, the Poxino Island and the Bossardville formations have not been found to be fossilferous, their strata being absolutely destitute of organic remains so far as investigations have been carried. The Decker Ferry formation, on the other hand, is highly fossilferous and contains a most interesting fauna of Silurian age. The fauna is not entirely homogeneous throughout, as several distinct life zones have been recognized, as already described in an earlier portion of this report. The fauna, however, has much in common throughout, and all the species, in whichever zone they may occur, are here described in one faunal group.

The fauna of the Rondout formation is very different from the Decker Ferry fauna, being constituted almost exclusively of Ostracorle crustaceans belonging to the genus Leperditia, while in the Manlius limestone there is a recurrence of the brachiopods and other forms of life which were present before the Rondont time, associated with numerous ostracode crustaceans. 
Descriptions of Species in the Decker Ferry Fauna.

\section{COELENTERATA.}

ANTHOZOA.

Diphyphyludir integumentum Barrett.

Plate XVII., Fig. 11.

1878. Diphyphyllum integumentum Barrett, Ann. N. Y. Acad. Sci., rol. I., p. 123.

I) xeription.-Corallum simple, sulurlintrical, grartually enlarging in size, the external surface marked by vertical, rounded costæ and by more or less irregular transverse wrinkles. In transverse section the outer wall is seen to be thick; the septa are from forty-four to fifty-two in number. about every fourth one of which reaches the centre; within the outer wall is a zone about equal to the thickness of the wall itself, which is apparently free from dissepiments; within this zone, to the centre of the corallite, constituting about two-thirds of the entire diameter, dissepiments are always present in greater or less abundance. In vertical section the open zone, which appears to be free from dissepiments in cross-section, is seen to be occupied by large, nearly horizontal dissepiments, the esutral area being oceupied hy smallew and more nearly vertical dissepiments.

The usual diameter of the species is from 12 to $15 \mathrm{~mm}$., the outer wall being about $1 \mathrm{~mm}$. in thickness. The longest individual observed, an incomplete specimen, is $45 \mathrm{~mm}$.

Remarks.-This sperese has only been observed in the condition of excedingly irrecular lragments, to which the matrix clings tightle, and whose character can be recognized only in thin sections. 


\section{PRISMATOPHYLLUM INEQUALIS (Hall).}

Plate XVII., Figs. 12-13.

1852. Columnaria inequalis Hall. Pal. N. Y., vol. II., p. 323, pl. 72, figs. $3 a-b, 4 a-c$.

Description.-Corallum growing in irregularly subhemispleric masses, composed of prismatic corallites, in contact on all sides, having five to eight sides when mature, but often with only three or four curved sides when immature. Each corallite has a calyz of moderate depth, and when full grown has thirty-six septa. In cross-section the septa are seen to be arranged more or less irregularly in four subequal groups, and between the septa are curved dissepiments, which, near the surface of the corallum, are restricted to a peripheral zone, surrounding a central, circular portion of about one-third the diameter of the corallite. Deeper in the corallum the dissepiments also occupy the central portion of the cross-section, but are thinner and less abundant than in the outer zone. In vertical section, when cut directly through the middle of the corallite, the outer zone is seen to be filled with short, curved, vesicular dissepiments; in the central portion the dissepiments are much more elongate vertically. In a vertical section, cut a little to one side of the centre, the cross-sections of the septa, seen in the central vertical area, bear lateral spinules, which reach about one-half the distance across the interseptal loculæ. These lateral processes seem to be continuous horizontally across the inner portion of the septa.

The masses of this coral frequently attain a diameter of 15 or 20 cm., and range in size from these dimensions to small colonies. The largest corallites have a diameter of $10 \mathrm{~mm}$., but this size is exceptional, and they range from this to the younger corallites only 1 or 2 mm. in diameter near the initial points.

Remarks.-This species is evidently a nember of the genus: Prismatophyllum as established by Simpson.* It is one of the commonest forms in the coralline bed of the Decker Ferry formation.

* Bull. N. Y. St. Mus.; No. 39, vol. VIII., p. 218. 
FAVOSITES CORRUGATUS $n$. sp.

Plate XVII., Figs. 1-2.

llescription.-Corallum explanate, forming masses 15 to $20 \mathrm{~cm}$. in willth by 2 to $2.5 \mathrm{~cm}$. in thickness. Corallites polygonal, usually hxaronal in cross-section, 1 to $1.5 \mathrm{~mm}$. in diameter. Tabulæ numurous, situated at distances of about one-half tube diameter apart. 'The sides of the corallites are transversely corrugated, the corrugations being strongest near the augles, so that in longitudinal section the sides of the corallites are way lines. Walls of the corallites perforated by a single vertical row of mural pores.

Re'marks. - This species may be easily recognized by the conspicuous transverse corrugations of the corallite walls, in which respect it thifers from any similar form.

FAVOSITES PYRIFORME (Hall).

Plate XVII., Figs. :3-5.

1852. Astrocerinum pyriforme Hall, Pal. 1. Y., vol. II., p. 123, pl. 34 , figs. $1 a-e$.

Breription.-Corallum nyciform or obconical in the smaller colonirs, the point of attachment small, becoming subhemispherical in the larger coloniex. 'The corallites are exceedingly irregular in size, the larger ones from $1.5 \mathrm{~mm}$. to $2 \mathrm{~mm}$. in diameter, being surrounded by smaller ones, which vary in size down to mere points, their size ileruding upon the proximity to their points of origin. The tabula ar" "Insely arranged, from three to five occupying a space equal to the mib. diameter. The sentia are represented by twelve vertical rows of suiniform processes, one or two in each row being situated in each intertabular space. The walls of the corallites are perforated by lathre large, circular, mural pores, arranged in one or two vertical series.

himurks.-This species grows in colonies which vary in size up to $10(1 \mathrm{~mm}$. or more, and which become more and more hemispherical with and It is the only species of the genus which has been recog- 
nized in the coralline layer at the summit of the Decker Ferry formation. It may be easily distinguished from the last species by its habit of growth and by the absence of the transverse corrugations of the walls. The two species have not been seen together in the same stratum, one being characteristic of the lowest and the other of next. to the highest bed in the Decker Ferry formation.

\section{CLADOPORA RECTILINFATA Simpson.}

Plate XVII., Figs. 14-17.

1889. Cladopora rectilineata Simpson, Trans. Am. Phil. Soc., n. ser., vol. XVI., p. 459, fig. 30.

Description.-Corallum consisting of nearly cylindrical, occisionally branching stems from 2.5 to $3 \mathrm{~mm}$. in diameter. The corallites are arranged in nine vertical series in the cylindrical branches; they are simple tubes radiating obliquely from the axis and gradually nlarging towards the aperture, with neither septa nor tabula. 'The: apertures are wider than high, the lower side being margined by a slightly-projecting lip. The apertures in adjacent vertical series are irregularly alternating in position.

Remarks.-In none of the New Jersey material is the form of the complete corallum of this species shown, all the specimens observed being but broken branches, which are rarely observed to be more than $25 \mathrm{~mm}$. in length. There may be some rariation in the number of vertical series in which the corallites are arranged, but in all the specimens in which their number could be definitely counted it was found to be nine. The species most closely resembles $C$. seriata Hall, but in that species the apertures of the corallites are more closely crowded together laterally, and are more regularly alternating in position, so that their arrangement is apparently in spiral lines rather than in the straight, vertical lines of $C$. rectilineata. 


\section{malysites Catenularia (Linn.).}

Plate XVII., Figs. 6-8.

17ti. Tubipora catenularia Linn., syst. Nat., 12th edit., p. 1:270.

1.51. Halysites catemularia E. \& H., Nonog. dos. Polyp. Fose, P. 281.

1852. Catenipora escharoides Hall, Pal. N. Y., vol. II., p. 12\%, pl. 35 , figs. $1 a-c$.

1876. Halysites catemulata Rominger, Geol. Surv. Mich., vol. III., pt. II., p. 7S, pl. 29, figs. 1, 2, 4.

1499. II alysites catenularia Iambe, Cont. Canadian Pal., rol. IV.. pt. I., p. 68, pl. 3, figs. 1-1 b, 2-2 b.

Description.-Corallum forming large masses, 10 to $40 \mathrm{~cm}$. in fiannets, made up of elongate, upright, subelliptical corallites, joined together hy their edges in chain-like series, so as to form vertical, mastonosing lamina, inclosing interspaces of variable form and size. Between each jair of corallites is a small, vertical tubule, which is forallel with and of the same length as the corallites. In transverse section the corallites are about $2 \mathrm{~mm}$. Wide and $2.5 \mathrm{~mm}$. long, subcircular or subelliptical in outline, with twelve septal spines. The tubules are quadrangular in outline, with their longer diameter transverese to the vertical lamina of corallites, and crossing the interspace may usually he detected one or more sections of the highly-convex tabule. In vertical section the corallites are crossed by numerous more or less concare tabula at varying distances apart. The tubules are crossed by highly-couvex tabula. which are placed much closer together than those in the corallites.

Remurks.-The form of chain coral which occurs in the coralline bed of the Decker Ferry formation is near the form considered ats most typical of the species by Lambe, and is the fom which most commonly occurs in the Niagaran faunas of America. 
ZAPHRENTIS sp. undet.

Plate XVII., Figs. 9-10.

Numerous specimens of horn coral, usually imperfectly preserved, are present in the fauna of the coralline bed at the summit of the Decker Ferry formation. Several species are probably present, but all are too imperfectly represented for satisfactory study. Other specimens representing the same genus are more rarely present in the lower strata of the formation.

\title{
HYDROZOA.
}

stromatopora concentrica Goldf.

Masses of a stromatoporoid hydrozoon are not uncommon in the coralline layer at the summit of the Decker Ferry formation, which may be provisionally referred to Stromatopora concentrica. In none of the specimens examined in thin section were the characters suffiهiently well preserved for accurate identification.

\section{MOLLUSCOIDEA.}

\author{
BRYOZOA.
}

MONOTRYPA COIRUGATA n. sp.

Plate XVIII., Figs. 1-5.

Description.-Zoarium forming lenticular or hemispheric masses. A large hemispheric specimen has a diameter of $40 \mathrm{~mm}$., with a height of $22 \mathrm{~mm}$., the base being concavely excavated to a depth of $7 \mathrm{~mm}$. Other specimens are frequently much flatter, sometimes with a height of not more than $5 \mathrm{~mm}$. The celluliferous surface of the zoarium is usually so closely covered with matrix that the zœcial apertures are not exhibited. In longitudinal fractures the zoccial walls separate readily along their median lines, and the walls themselves are seen 
to be transversely corrugated. In cross-section the zoœcia are frolygonal in outline, about ten of average size occupying the space "f $3.5 \mathrm{~mm}$. Interspersed with the averige-sized zocecia are smaller onte which are younger, but no true mesopores are present. In longitudinal section the walls of the zoceia are wavy. Diaphrams are absent from the lower portion of the tubes, but are present distally, lecoming more and more frequent toward the exterior, the outermost ones being about one tube diameter apart.

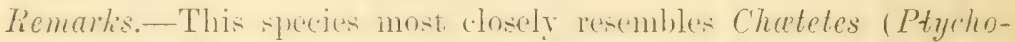
nema) tabutatus IT. \& S., since referred to the genus Monotrypa by Nichles and Bassler, which is said to he derived "probably from the

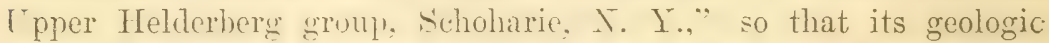
horizon is somewhat uncertain. The transerse zocecial corrugations cif M. tabutatus are more conspicuous than in the New Jersey speres. and the diaphrams are apparently entirely absent.

PTHLODICTYA FRONDOSA 11. sp.

Plate XIX., kigs. 1-4.

Dexcriftion. - Zoarim hifoliate. frondesernt in form, often more on luss undulate: begimning with a narrowly-rounded or obtusely-pointed hase of attachment or articulation, from which point it broadens rapidly, the distal end more or less bluntly rounded; the axial line is curved gently near the base, becoming nearly straight beyond the first third of its length. The mesotheca, along which specimens almost unformily separate, is marked by concentric lines subparallel with the margins. The zocecia are arranged in parallel, longitudinal rows. In tangential section they are seen to be subelliptical in outline; the forr or five axial rows are slightly smaller than the others, but are not sharply differentiated from them, with their longer axes directed !)arallel with the axis of the zoarium. On either side of these medial rows the longer axes of the zocecial openings are slightly oblique. liverging outward at an angle of about $15^{\circ}$, while the zocecial openings themselves are arranged in diagonal rows, diverging at an angle of about $55^{\circ}$ from the axis. In vertical section the zoocia are slightly rurved and are crossed by numerous diaphragms, many of which are incomplete, situated at distances of from one-half to one tube diameter apart.

Some of the larger zoaria attain a length of from $70 \mathrm{~mm}$. to 80 
mm., with a width of $30 \mathrm{~mm}$., but usually they are relatively somewhat narrower. About four zocecia occupy the space of $1 \mathrm{~mm}$. longitudinally and about four and one-half transversely.

Remarks. - This species resembles $P$. cxpansa Hall, but is currerl and does not have the perfectly parallel margins of that species; it also lacks the axial rows of zoceia, which are conspicuously narrower than those on the sides. In form the zoarium is almost identical with Phœnopora platyphylla Jas., but thin sections show the two forms to be generically distinct. The species is apparently most closely allied to that called Ptilodictya lanceolata var. americana by Fœrste, but it does not have the sharply differentiated medial rows of smaller zoœcia which seem to be indicated in the illustrations of that species, and the basal portion of the zoarium is more curved. In none of the New Jersey specimens has the cell-bearing surface been seen clear of the matrix, so that it is not possible to state with certainty whether. or not monticules are present, but they seem to be absent.

ESCHAROPORA SILURIANA n. sp.

Plate XVIII., Figs. 6-7. Plate XIX., Figs. 8-9.

Description.-Zoarium thin, bifoliate, complete outline unkwown. The mesothecal surface, along which the specimens uniformly separate, is uneven, with numerous, more or less imegular, curved, transverse wrinkles. In tangential section the zoceia are more or less irregularly hesagonal in outline, the opeinings being subelliptical. The prostrate portions of the zoccia are elongate and are initially arranged in longitudinal series, but when they become erect adjacent series are crowded together, giving to the apertures an irregularly decussate arrangement. In vertical section the zoccia are thick walled alove and in their erect portions usually about four slightly-conrex diaphragms are present. The two hemisepta have been clearly scen in but one zoccium, though it is possible that they may usually $x^{2}$ present.

Remarks.-This genus has not before been recorded from stratid younger than the Ordovician. 'These specimens, however, agree essentially in all generic characters with the Ordovician forms, but the zoaria are apparently larger and more irregular in form than is usually the case in the older species. 


\title{
BRACHIOPODA.
}

\author{
PHOLIDOPS OVATA Hall.
}

Plate XX., Figs. 27-29.

1454. Photidops oialus Mall, Pal. N. Y., vol. III., 1. 490, nl. 103 B. figs. $\% a-b$.

Description.-Shell mall, ovate to subelliptical in outline, slightly narrower in front, aped excentric posteriorly. Surface marked by fin, sublamellose, concentric lines. Internally the anterior adductor inuscle impressions are situated at about the midlength of the shell; rach impression is elongate-subelliptical in outline, their anterior ex1\%mities not in contact and their long axes at nearly right angles. 11. "ar h other. The posterior adductor muscle impressions much maller, circular in ciulliue, and situated just beyond the posterior extremities of the anterior impressions.

The dimensions of one of the largest specimens observed are: length: $2.7 \mathrm{~mm}$; width, $2.25 \mathrm{~mm}$.

\section{STROPHEODONTA BIPARTITA (Hall).}

Plate XX., Figs. 1-5.

1852. Leptona — sp. Hall, Pal. N. Y., vol. II., p. 326, pl. 74, figs. $3 a-b$.

1852. Leptana bipartita Hall, Pal. N. Y.. vol. II., p. 326, pl. 74, figs. $4 a-b, 5 a$.

185\%. Strophodonta tertitis Hall, Pal. N. Y., vol. II., p. 32\%, pl. 74 , figs. $6 a-d$.

1859. Strophomena bipartita Hall, 12th Rep. N. Y. State Cab. Nat. Hist., p. 82.

1878. Strophoulontu nearpassi Barrett, Am. Jour. Sci., 3d ser., vol. XV., p. 372 .

1892. Stropheodonta (Leptostrophia) textilis H. \& C., Pal. N. Y., vol. VIII., pt. I., p. 288. 
189\%. Stropheodonta nearpassi S.huchert, Bull. L. S. Geol. Surt. No. $8 \%$, p. 425 .

189\%. Stropheodonta textilis Schuchert, Bull. U. S. Geol. Surv., No. $8 \%$, p. $42 \%$.

189\%. Strophomena (?) bipartita Schuchert, Bull. L. S. Geol. Surv.. No. 87, p. 429.

Description.-Shell with thin, nearly-flat brachial valve and slightlyconvex pedicle valve, longitudinally subsemi-elliptical in outline, the hinge-line produced beyond the body of the shell into mucronate extensions, hinge-line crenulate. Surface of both valves marked by fine, irregularly alternating, angular, raised strixe, which are not continuous over the umbo to the beak, and which curve outward on the sides of the shell in passing to the margin, the curvature becoming stronger on approaching the hinge-line. The surface is also marked by much finer, crowded, concentric lines, which continue to the beak. Oblique wrinkles along the cardinal margin are present in many specimens. The interior of the valves, more especially the pedicle, is corered with fine, closely-crowded papillæ, which gives to the surface of internal casts a finely-pitted or punctate appearance. These internal papilli may frequently be detected through the thin shell substance as dark spots, giving it a punctate appearance, but there are apparently no perforations. The muscular impressions of the pedicle valve are rather large and divergent and are free from impressions of papilla. In the interior of the brachial valve a low median ridge reaches more than half way to the front of the shell.

The dimensions of a medium-sized specimen are: length, $28 \mathrm{~mm}$, and breadth, $30 \mathrm{~mm}$.

Remarks.-This species is a variable form, and undoubtedly includes the three shells described by Hall under the names Leptcona sp., Leptona bipartita and Strophodonta textilis, all from the Coralline limestone at Schoharie, New York. The name Strophodonta nearpassi was applied by Barrett to specimens from New Jersey from the locality where most of our material was.secured. If the generic or subgeneric name Leptostrophia, given by Hall and Clarke to the very flat forms of Stropheodontas, is to be retained, the present species will be there included. 
The finer surface characters of the shell are rarely preserved upon the specimens studied, but different individuals, or even different mortions of the same individual, under various conditions of exfolintion, exhibit all the types of fine surface markings figured by Hall for his three species. These markings, as seen upon a well-preserved thell surface, are most nearly correctly illustrated under his S. textitis. 'Toward the beak the radiating markings are absent, and young shells freserving only this portion of the shell present the aspects of species. of Pholidostrophin. The mucronate extensions of the hinge-line are bint rarely preserved, but the direction of the fine, concentric markings near the hinge-line indicate their presence on most individuals. Perhaps the most characteristic feature of the species is the strongly papillose interior of the ralves, which is lrest shorm only on exfoliated specimens.

\section{LEI'TAENA RHOMBOIDALIS (Wilck.).}

Plate XX., Fig. 10.

For eomplete biography ser Schuchert, Bull. U. S., Geol. Surv, No. 87, p. 240 .

Description.- Shell roncave-convex, flattened posteriorly, geniculite towards the latral and front margins, hinge-line straight, usually aqualing the greatest width of the shetl. Pedicle valve convex, beals small and inconspicuous. Brachial valve concave, following elosely the curvature of the opposite one and leaving but a narrow visceral cavity betreen the two valves. Surface of both valves marked by conspicuous, more or less irregular concentric wrinkles upon the Hatrened portion of the shell, and by numerons fine, radiating stria. which continue to the shell margin.

The dimensions of a specimen from the coralline layer of the Decker Ferry formation are: length, $11 \mathrm{~mm}$; width, $16 \mathrm{~mm}$.

licmarks. - All the specimens of this cosmopolitan species which we:ur in the Decker lierry formation are smaller than usual, witl proportionately coarser concentric wrinkles. The specimen whose dimensions have bern given above is one of the largest that has frem olserved. 
ORTHOTHETES INTERSTRIATUS (Hall).

Plate XX., Figs. 8-9.

1852. Orthis interstriata Hall, Pal. N. Y., vol. II., p. 326, pl. it, figs. $1 a-b, 2 a-b$.

189\%. Orthothetes interstriatus Schuchert, Bull. U. S. Geol. Surr., No. $8 \%$, p. $29 \%$.

Description.-Shell small, subplano-convex, wider than long, the hinge-line straight, about equal to the greatest width of the shell. The lateral margins meet the cardinal line at nearly right angles and are then regularly rounded to the front of the shell. Pedicle valve abscurely subcarinate, its greatest depth near the prominent, suberect beak: cardinal area rather high, nearly flat. Brachial valre depressed convex or nearly flat, with a broad, shallow, ill-defined mesial sinus. Surface of both valves covered with rather coarse, angular, radiating costr, which increase by implanation toward the margin, and by rather coarse, concentric lines of growth.

The dimensions of a pedicle valve are: length, $5.5 \mathrm{~mm}$.; width, $7 \mathrm{~mm}$.; convexity, $1.5 \mathrm{~mm}$. A brachial valve measures: length, 4.5 $\mathrm{mm}$.; width, $6 \mathrm{~mm}$.

Remarks.-All of the specimens of this species which have come under observation are more or less exfoilated, so that the concentric markings are usually wholly obliterated. On a few specimens, however, they may be detected.

\section{OR'CHOTHETES DECKERENSIS n. Sp).}

Plate XX., Figs. 6-7.

Description.--Shell subplano-convex, transversely subelliptical in wutline, the hinge-line shorter than the greatest width of the shell, which is near the middle. Pedicle valve depressed, the umbonal resion usually irregularly concave; the concave area, having been a facet of attachment to some external object, retains the reverse of the contour of the object to which the shell was attached. Between the ambonal concavity and the margin this valve is marked by one or more conspicuous, more or less irregular, concentric wrinkles, with 
less conspicuous intermediate ones. The cardinal area is unsym-

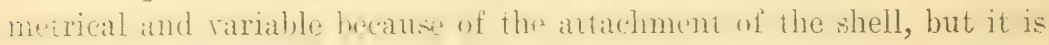
always rather low; its margin is sometimes sharply defined, but is often very poorly defined. The brachial valve is more or less regularly convex, the greatest convexity usually being posterior to the midale; it is never so strongly marked by concentric wrimkles as the opposite valve. Both valves are marked by fine, more or less unequal, radiating ribs, of which three or four occupy is space of one millimeter at the margin of tie shell. The larger ribs extend the entire length of the shell, while the smaller ones are intercalated at various distances from the beak.

The dimensions of a rather large pedicle valve are: length, 20.5 mm.; width, $25.5 \mathrm{~mm}$.; height of area at centre, 3 mm.; maximum 3epth of valve, 4.) mm. I brachial valve having the sime length and breadth has a convexity of $9 \mathrm{~mm}$.

Remarks.-This species differs greatly from any other Silurian species of the genus, having a much closer resemblance to younger forms steh as (). rhemunensis of the Devolian and some Carbmiterous species. It differs from any of these younger forms, however, in

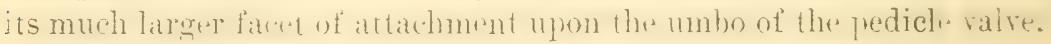

CHONETES JERSEYENSIS Weller.

Plate XX., Figs. 11-16.

1900. Chonetes jerseyensis Weller, Ann. Rep. Geol. I. J. for 1899, p. $s$.

Descriplion.- Shell concavo-convex or nearly plano-convex, leugtl

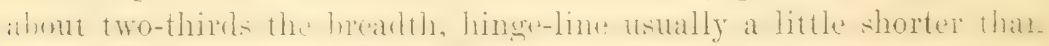

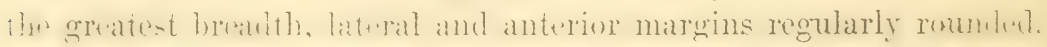

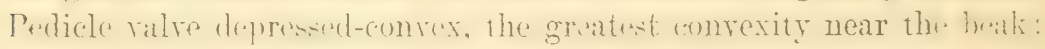
beak small, not prominent; cardinal area low, with as many as seren slightly-oblique marginal spines on each side of the beak upon the

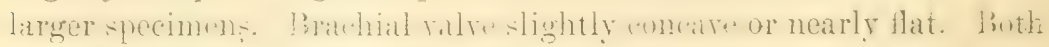
valves marked by rather coarse, radiating ribs, which increase by implantation and bifurcation, three or four of them occupying a space of $2 \mathrm{~mm}$. at the front margin. On the younger shells the ribs are usually finer and more angular and the lateral ones often have a 
slight anterior curvature as they approach the margin. As the shells increase in size this peculiar curvature of the ribs beromes more and more conspicuous, and can always be detected to a greater. or less degree in the adult individuals, and it is always more conspicuous in the brachial than in the pedicle valve. Just anterior to the beak in both valves there is a small area where the radiating ribs are obsolete. In addition to the radiating ribs, both ralves are marked by exceedingly fine, concentric lines.

The dimensions of a large individual are: length, $14 \mathrm{~mm}$., and width, $22 \mathrm{~mm}$.

Remarks. - This species is exceedingly abundant in the lower beds of the Decker Ferry formation. It may be always recognized, in the larger specimens at least, by the peculiar curvature of the radiatiny ribs. Among the smaller, and therefore younger, specimens, however, this character is a variable one, the curvature of the ribs seeming to start earlier in the life history of some individuals than in others. On comparing young individuals of approximately the same size one will frequently be seen to possess perfectly-straight ribs, while in the other the ribs will be slightly curved. In the large specimens, however, the curvature may always be detected. On comparing smaller. specimens with straight ribs and larger ones with "urver ribs the differences seem to be sufficient to indicate distinct species, but as all intermediate characters seem to exist, they are all placed together in the same species.

ORTHIS FLABEILITES Foerste.

Plate XX., Fig. 20.

189\%. Orthis flabellites Schuchert, Bull. U. S. Geol. Surv., No. 8\%, p. 286. (A full bibliography of this species will be found here.)

Description.-Brachial valve subelliptical in outline, depressed con$\mathrm{V} \cdot \mathrm{x}$, hinge-line equal to or a little shorter than the greatest breadth of the shell; median portion flattened or slightly concare, forming a broad, shallow, median sinus, whose centre is scarcely depressed below its sides. Surface marked by from thirty to thirty-six strong; radiating ribs, between which, near the margin in internal caste, therw: are intercalated some finer ribs. Pedicle ralve not recognized in the New Jersey collections. 
'The dimensions of the bet fpeciman observed are: length, $17 \mathrm{~mm}$; width, $22 \mathrm{~mm}$.

Remark. - The only specimens of this shell which have come under - Heriation are more or less imperfere casts of the interior, and only hrachial valses have leen seen. These camnot be ecrtainly identified with o. flebellites Fourste, but they are closely allied to that specien, and it is probable that they should be included in it.

DALMANLLLA POSTELEGANTULA 11. SP.

I'late XX., Figs. 21-24.

Description.--Silkell subcircular in outline, usually wider than long, the hinge-line shorter than the greatest breadth. Pedicle valve stroninly convex. subcarinate, the beak incurved over the cardinal area. Brachial valve depreswed romrex with a shallow, rounded mesial sinus which does not reach to the heak. Surface of both valves marked with fine radiating strix, from seren to nine of which occupy the space of $2 \mathrm{~mm}$, at the shell inargin.

The dimensions of an average specimen are: length, $10.5 \mathrm{~mm}$; width, $12 \mathrm{~mm}$.

Remarks. - This species is intermediate in its characters between

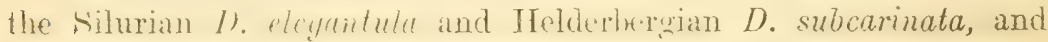
in a previous report was identified with $D$. elegantula. It differs from D. eleyemtula. howerer, in being usually wider than long insteut of longer than wide, and in having a more convex brachial valve, with a much more omsuleuous mesial simus. In these same characters it approaches the Helderberian species $D$. subcarinata, but it does not attain so large a size, and the sinus in the brachial valve does not extend to the beak, as in that species.

RHIPIDOMELLA PREOBLATA n. SP.

Plate XX., Figs. 25-2t.

Description. - Shell lenticular in form, subcircular to subelliptical

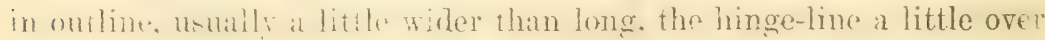
on -half the greatest width of the shell. Pedicle valve with a large, 
Habellate, muscular impression, divided along its median line by a prominent median ridge, which reaches more than half way to the front of the shell. Surface marked ly fine, radiating striæ, of which shoul five occupy the space of two millemeters at the shell margin.

The dimensions of an arerage specimen are: length, $11.5 \mathrm{~mm}$.; width, $13 \mathrm{~mm}$.

Remarks.-This little shell is in all respects a diminutive form of the Helderbegian $R$. oblata $\mathrm{H}$. In size it is similar to the Niagaran 1. hybrida Sow., but differs from that species in usnally being wider than long, instead of longer than wide. It also has a much larger muscular impression in the pedicle valve than $R$. hybrida, in this respect resembling $R$. oblata. The prominent median ridge in the pedicle valve is also a character of $R$. oblata. The shell is in some iespects intermediate between these two species, but approaches closest to the Helderbergian $R$. oblata.

PENTAMERUS CIRCULARIS $\mathrm{n}$. sp.

Plate XX., Figs. 17-19.

Description.-Pedicle valve subcircular in outline, gibbous, the beak blunt, slightly incursed, cardinal area absent, delthyrium broadly triangular. Surface smooth, without mesial sinus, marked only by inconspicuous lines of growth. Internally the valve has a strong median septum. The brachial valve is known only from fragments; it resembles the pedicle valve, but is less convex and lacks the prominent beak.

The dimensions of the best-preserved specimen, a pedicle valve, are: length, $16 \mathrm{~mm}$.; width, $16.5 \mathrm{~mm}$; convexity, $7.5 \mathrm{~mm}$.

Remarks.-The material representing this species is not as perfectly preserved as might be desired, but it seems to constitute an undescribed species. It most closely resembles $P$. ovalis, as identified by Foerste, * from Tennessee and Alabama, but is unlike the original $P$. ovalis of Hall, which is, perhaps, only a diminutive $P$. oblongus.

* Proc. Bost. Soc. Nat. Hist., vol. XXIY., p. 324, pl. 5, figs. 17-18, and Geol. Surv. Ohio, vol. VII., pl, 30, figs. 17-1S. 
RHYNCHONELLA DECKEREXISIS n. Sp.

Plate XXI., Figs. 1-t.

Description.- Shell subtriangular, wider than long, the posterolateral margins sloping from the beak, where they form an angle of from $95^{\circ}$ to $115^{\circ}$, in nearly straight lines to a point a little posterior to the middle of the shell; the lateral and front margins regularly rounded. The pedicle valve is usually a little less conver than the opposite one; its beak is prominent, arched, but not strongly incurved; the sinus is rather abrupt, not reaching quite to the beak. The suface of the brachial valve curres gently to the margins, except toward the front, where the mu-ial fold is rather abruptly elevated. The surface of each valve is marked by from twenty to twenty-four simple, angular plications, of which two or three, somewhat coarser than the remainder, are depressed in the median sinus, with a corresponding number elevated in the fold of the brachial valve.

The dimensions of a rather large specimen are: length, $15 \mathrm{~mm}$; width, $19.5 \mathrm{~mm}$; thickness, $10 \mathrm{~mm}$.

Remarks.-This shell is a rather common one in the lower beds of the Decher Ferry formation. It resembles Rhynchotrema formasum Hall, from the hisher portion of the Helderbergian stries, but maty les distinguished from that speres by its coarser plications, its gratel proportional width and by its less-strongly conver valves, which gires to members of this species a less thickness of the shell. The generic

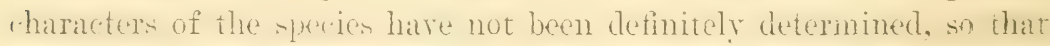
it is for the present referred to the genus Rhynchonella.

RIIYTIIONELLA AGGLOMERATA 11. sp.

Plate XXI., Figs. 5-11.

Description.- Shell subtriangular, usually a little wider than long, the ralves subequally convex, the postero-lateral margins tapering to the beak, where they form an angle of about $90^{\circ}$; the lateral and anterior margins rounded. Pedicle valve most prominent near the nmbo, the beak sharply pointed, arched over that of the opposite valve; mesial sinus rather shallow, rounded in the bottom, not extending 
back of the centre of the valve. Brachial ralve most prominent at and in front of the middle; mesial fold not conspicuous, except near the front margin. Each valve marked by from eighteen to twenty-two simple, angular plications, three of which are usually included in the sinus of the pedicle valve. The finer markings of the shell, if they were present, have been obliterated by exfoliation.

The dimensions of an arerage adult specimen are: length, 9 mm.; width, $9.5 \mathrm{~mm}$., and thickness, $5.5 \mathrm{~mm}$.

Remarks. - This little shell is one of the most abundant specien in the Decker Ferry formation, being present in each of the faunal zonts. It is especially abundant in the lower beds. The species resemhles. $R$. transversa of the Helderbergian fauna, and may be ancestral to it, liut the mesial fold of the brachial ralve is never so much elevatud in front as in the adult individuals of that species. The species also resembles Camarotochia neglecta Hall, as illustrated in volume II. of the New York Palcontology, from the Clinton and Niagaran faunis, but it does not at all resemble the shell from the Niagaran faunia at Waldron, Indiana, to which that name is applied.

WILSONIA GLOBOSA n. sp.

Plate XXI., Figs. 12-22.

Description.- Shell subglobose, a little longer than wide. Pedicle valve less convex than the brachial, its beak suberect or stightly arched, acutely pointed, umbo smooth and convex, mesial sinus shallow, beginning near the middle of the valve and produced as a lingual extension in front, at nearly a right angle to the plane of the valve. Brachial valve strongly convex or gibbous, smooth posteriorly, anterior margin deeply sinuate, mesial fold slightly elevated, originating near the middle of the valve. The surface of each valve is marked by sixteen or eighteen simple, low, rounded plications, sometimes slightly grooved anteriorly and becoming nearly or quite obsolete posteriorly, leaving that portion of both valves smooth. From two to five plications are included within the sinus, the more common number being four, with a corresponding number in the fold of the opposite valve.

The dimensions of a rather large globose individual are: length, $12 \mathrm{~mm}$; ; width, $11 \mathrm{~mm}$; thickness, $10 \mathrm{~mm}$. Those of another less globose specimen are: length, $11.25 \mathrm{~mm}$; width, 10.5; thickness, $7.5 \mathrm{~mm}$. 
Hemarks.-In some of its characters this species resembles the HAderbergian forms L ncinulus mutabilis $\mathrm{H}$. and $U$. nucleolata $\mathrm{H}$. Il dilfers from both of them, however, in its smaller size, and in the vlsisescence of its plications on the posterior portions of the shell. Internally there are comspicuous differences which are of even generic value. In Wilsonia globosa the cardinal process is absent, the hingeHite is divided and is supported by a strong median septum. These Haracters, when associated with its external form, place it in the wnus Wilsonia, while the two Helderbergian species mentioned possess woll-developed cardinal processes and the other characters which distingnish the genus Uncinulus.

ATRYPA RETICULARIS (Linn.).

Plate XXI., Figs. 35-37.

14.7. Arypu recticularis sichuchert, Bull. U. S. Geol. Surv., No. 87, p. 154. A complete bibliography of this species may be found in this place.

Hescription.-Shell subcircular or subelliptical in outline and submmispherical in general form, hinge-line shorter than the greatest irmalth. Pedicle valve nearly flat, slightly convex on the umbo but (.) ncave toward the margins, beak suall. Brachial valve strongly «mvex or gibbous, the greatest eleration near the centre, from which puint it curves down regularly to the margins on all sides, the beak sirnngly incurved mier the beak of the opposite valve. Surface of wh valves marked by coarse, rounded plications about $1 \mathrm{~mm}$. apart at the marcin of the shell. which increase by intercalation and by dirision; al:o marked hy strong, concentric, lamellose extensions of the :hril, which are usually obliterated by exfoliation, their position being indicated by concentric ridges.

The dimensions of an average specimen are: length, $22 \mathrm{~mm}$; wirlth, $22 \mathrm{~mm}$; convexity of brachial valve, $10 \mathrm{~mm}$.

Bemurk. - This cosmopolitan species is often exceedingly abundam in the lower berts of the Decker Ferry formation, some strata being mite up almost exchusely of the crushed and broken shells. The farticular variety of the species present is a rather coarsely-marked form: with exeretionally tat perlicle valve and correspondingly gibbous 
brachial valve. Most of the Helderbergian representatives of the species are the more finely-marked forms, but in the Silurian faunis both coarsely and finely-marked varieties occur.

ATRYYA? LAMELLATA Hall.

Plate XXI., Figs. 23-29.

1852. Atrypa lamellata Hall, Pal. N. Y., vol. II., p. 329, pl. 74, fig. 11.

189\%. Rhynchonella? lamellata Schuchert, Bull. U. S. Geol. Surv., No. 87, p. 359.

Description.-Shell small, subrhomboidal in outline, the valves suhequally convex. Pedicle valve with an acutely-pointed, incurved beak; the sharply-defined mesial sinus deep in front and flattened in the hottom, not continuous to the beak. Brachial valve with an elevaterl fold in front, the lateral slopes regularly convex. Surface of each valve marked by from ten to fourteen simple, rounded or subangular, radiating plications, one, two or three, but usually two, of which are within the mesial sinus of the pedicle valve, with a corresponding number on the fold of the opposite valve. The radiating plications are crossed by strong, imbricating, concentric lamellæ, which give to the whole surface of the shell a rugose appearance.

The dimensions of a large specimen are: length, $7 \mathrm{~mm}$.; widti, $7.25 \mathrm{~mm}$.; thickness, $5 \mathrm{~mm}$. Another specimen measures: length, $5.66 \mathrm{~mm}$.; width, $7 \mathrm{~mm}$. ; thickness, $4 \mathrm{~mm}$.

Remarks.-Most specimens of this species are smaller than thos whose dimensions have been given. The shell has a strong resemblance to those members of the genus Atrypa which are allicd to $A$ marginalis Dal.--in fact, this species resembles in many respects a diminutive A. marginalis. In order to determine whether or not a brachidium of the type of that in the genus Atrypa is present in this species, numerous specimens have been ground down, but in no case have the spires been observed, but a pair of long, slender crura have been detected. The generic rcference of the species, therefore, remains in doubt, and it is quite possible that it should be placed with the Rhynchonelloids, as has been done by Schuchert. 
SPIRTEER VANUXEMI Hall, var. MINOR n. var.

Plate XXI., Figs. 41-42.

1859. Spirifer vanuxemi Hall, Pal. N. Y., vol. III., p. 198, pl. 8, figs. 17-23.

Description.- Shell small, subelliptical in outline, the hinge-line a iittle shorter than the greatest width of the shell. Umbo of pedicle alve prominent, heak incurved over the moderately high, concave, illupfined cardinal area; mesial sinus rather broad, rounded in the botfom, the lateral slopes marked by three broadly-rounded plications on wither side. Brachial valve depressed-convex, with a rounded median fold, which is but slightly elevated above the plications on either side. Surface of both valves marked by concentric lines of growth.

"he limensions of the largest specimen of the pedicle valve are: width, $7 \mathrm{~mm}$.; length, $5.5 \mathrm{~mm}$, and convexity, $3 \mathrm{~mm}$.

Remurlis.-This little shell is not abundant in the Decker Ferry famn. It seems to agree closely with Spirifer vanuxemi Hall, of the Manlius limestone famn, except in being smaller and in having the concentric markings less conspicuous.

CYRTINA MAgNAPLiCATA n. sp.

Plate XXI., Figs. $46-49$.

Description.-Pedicle valve subpyramidal with a strong median septum, the beak more or less incurved orer the elevated, concave, ardinal area, which is not sharply defined on the margin. Mesial sinus sharply defined, subangular in the bottom; lateral slopes marked by four strong, angular plications on each side of the sinus, with sometimes an additional fainter one near the cardinal margin, only the first two of which reach the point of the beak. Brachial valve depressedconvex, subelliptical in outline, with a mesial fold and three or four subangular plications on either side, all rising to about the same elewation.

The dimensions of the best preserved pedicle valve are: width along the hinge-line, $16 \mathrm{~mm}$. ; length from beak to front margin, $14 \mathrm{~mm}$. 
The best-preserved brachial ralve is somewhat smaller: breadth, 11 mm., and length, $8 \mathrm{~mm}$.

Remarks.-Although the punctate shell structure has not been derected in any of the specimens of this species which have come under observation, it has all the outward characters as well as the strong median septum in the pedicle valve, of the genus Cyrtina, and there seems to be no doubt as to its correct generic reference here. This species differs from the only other American Silurian species of the genus, C. pyramidata H., in its larger size and in its concave and less sharply-defined cardinal area. From any of the Devonian members of the genus it may be distinguished by its coarser plications and by its less sharply-defined cardinal area.

\section{RETICUlaRia BICOSTATA (Vanuxem).}

Plate XXI., Figs. 41-45.

1812. Orthis bicostatus Van., Geol. N. Y., Rep. 3d Dist., pp. 91, 94. 1852. Spirifer bicostatus Hall, Pal. N. Y., vol. II., p. 263, pl. 54, fig. 4.

1893. Spirifer bicostatus H. \& C., Pal. N. Y., vol. VIII., pt. II., pl. 36, fig. $\%$.

189\%. Reticularia bicostata Schuchert, Bull. U. S. Geol. Surt., Nio. 87, p. 341.

Description.-Shell transversely subelliptical, the hinge-line less than the greatest breadth. Pedicle valve strongly convex, beak prominent and incurved, cardinal area arched, not sharply defined, mesial sinus shallow, without plications. On each lateral slope of the valve are three or sometimes four, low, rounded, inconspicuous plications, which do not reach to the beak; the largest one of these bounds the mesial sinus, while the others successively grow smaller. Brachial valve less convex than the opposite one, with a low, rather sharplydefined mesial fold, and with indistinct plications on the sides of the valve corresponding with those of the pedicle valve. The surface of woth valves marked by moderately fine, concentric, lamellose lines.

The dimensions of a large pedicle valve are: length, $13 \mathrm{~mm}$; width, $16 \mathrm{~mm}$.; convexity, $6 \mathrm{~mm}$. 
Remarks. The pedicle valve of this abundant species of the lower Iecker Ferry beds is most commonly preserved, brachial valves being (4)mparatively uncommon. The species may usually be recognized by its inconspicuous plications, though in some individuals, particularly the younger ones, they are wholly obsolete. Nost of the specimens are expoliated so that the fine, concentric markings of the surface are usually obliterated. but they may be detected upon occasional specimens.

RHYNCHOSPIRA FORMIOSA Hall.

Plate XXI., Figs. 30-3t.

1859. Trematospira formosa Hall, Pal. N. Y., vol. II., p. 215, pl. 36, figs. $2 a-t$.

1859. Rhynchospira formosa Hall, Pal. N. Y., vol. II., p. 485, pl. $95 \mathrm{~A}$, figs. $\mathrm{y}-11$.

1893. Rhynchospira formosa H. \& C., Pal. N. Y., vol. VIII., pt. II., p. 109 , pl. 50 . figs. $21-25$.

Description.-Shell ovoid in outline, usually a little longer than wide, valves subequally convex, rostrate posteriorly, rounded in front, usually with a slight emargination in the middle. Pedicle valve with a prominent, incurved beak and with a narrow, flattened or depressed area along the mesial line. Brachial valve usually most frominent posteriorly, the beak incurved under that of the opposite valve, the mesial line usually flattened in a manner similar to the pericle vilve hut les conspicuously. Surface of each valve marked by sixteen or cighteen rounded or subangular radiating plications. those on the lateral sopes heing simple and contimuing to the beak. while those in the mesial depressions are usually a little finer and often do not continue to the beak.

The dimensions of a somewhat erushed specimen are: length, 10 mm.; width, $9.5 \mathrm{~mm}$; thickness, $5 \mathrm{~mm}$. A more gibbous specimen with a similar length and width has a thickness of $7 \mathrm{~mm}$.

Remarks.-The specimens of this little shell from the coralline layer of the Decker Ferry formation do not differ essentially from those in the Helderbergian faunas, except that the shell is more uniformly strongly plicated, not showing so great a variation in this respect as 
the Helderbergian specimens, the more coarsely plicated individuals from the higher beds being similar to the Decker Ferry specimens. These specimens seem also not to grow as large as those in the Helderbergian fauna.

WHITFIELDELla NUCLEolata (Hall).

Plate XXI., Figs. 33 10.

1852. Atrypa nucleolata Hall, Pal. N. Y., vol. II., p. 328, pl. r.t, figs. $10 a-m$.

1897. Whitfieldella (?) nucleolata Schuchert, Bull. U. S. Geol. Surv., No. 8\%, p. 461.

Description.-Shell subglobose, small, subovate in outline, a little longer than wide, rostrate posteriorly, slightly flattened or emarginate in front. Pedicle valve with a prominent, incurved beak, slightly flattened or sinuate along the median line. Brachial ralre slightly less convex than the pedicle, most prominent posterior to the middle, usually flattened or slightly sinuate along the median line torards the margin. Surface of both valves smooth or marked only by inconspicuous, concentric lines of growth.

The dimensions of an arerage specimen are: length, i mmn.: width, $6.5 \mathrm{~mm}$.; thickness, $5 \mathrm{~mm}$.

\title{
MOLLUSCA.
}

PELECYPODA.

\author{
EDMIONDIA? DECKERENSIS n. sp.
}

Plate XXII., Figs. 6-7.

Description.--Shell suborate in outline, height about three-fourths the length; the beak rather small, situated about one-fifth the length of the shell from the anterior end; hinge-line arcuate. Anterior margin rather sharply rounded, the rentral and posterior margins broadly rounded; the curve from the centre of the ventral margin to the posterior extremity of the hinge-line being nearly a semi-circle. The 
value are rather strongly convex, the greatest depth being near the centre.

The dimensions of the type specimen, a right valve, are: length, 24 $\mathrm{mm}$. ; height, $18 \mathrm{~mm}$.; convexity, $5 \mathrm{~mm}$.

Remurlis. - The hinge characters of this shell are not preserved, so that its generie reference is somewhat uncertain. The surface chararters are also ohliterated, but the shell is believed to be nearly smooth or to be marked only by lines of growth.

\section{NUCULA? sp. undet.}

Plate XXII., Fig. 5.

Description.-Shell small, subovate in outline, obliquely truncater posteriorly, regularly convex. The beak is prominent, situated a little in front of the middle of the shell. Surface marked by fine, concentris: lines of growth.

The dimensions of the most perfect valve are: length, $14.5 \mathrm{~mm}$; height, $10 \mathrm{~mm}$., and convexity, $3.5 \mathrm{~mm}$.

Remarks. - The hinge characters of this species have not been observed, but the shell itself has the general form and appearance of many Nuculoid hells, so that it is referred provisionally to the genus Nucula.

\section{pterinea emacerata (Con.).}

Plate XxiI., Fig. 4.

1842. Avicula emacerata Conrad, Jour. Acad. Nat. Sci. Phil., vol. VIII., p. 241, pl. 12, fig. 15.

1852. Avicula emacerata Hall, Pal. N. Y., vol. II., p. 83, pl. 27, fig. $1 a-b$, p. 282, pl. 59, fig. $1 a-e$.

Description.- Shell oblique and, apart from the posterior wing, subovate in outline. Left valve convex, with straight hinge-line. The posterior wing extended a little further than the posterior margin and separated from the body of the slell by a concave sinus; terminating in an acute point, below which the margin of the shell is sinuate. Beak nearly terminal, slightly elevated above the hinge- 
Iine. Whole surface of the valve covered with narrow, angular, raised strix, with interspaces two or three times the width of the ridges, and by similar concentric striæ. Right valve not seen.

The dimensions of a nearly-perfect left valve are: length, $10.5 \mathrm{~mm}$. and height, $9.5 \mathrm{~mm}$.

Remarks. - This little shell is rare in the Decker Ferry fauna, but it seems to agree in all essential characters with $P$. emacerata Con. of the Niagaran fauna. The typical representatives of the species occur in the Rochester shale of Western New York and are larger than the New Jersey shell. Because of their mode of preservation, they are also usually crushed so as to appear less convex. In form, proportions and markings, however, the shells from the two localities are essentially identical.

\section{PTERINEA? sp. undet.}

Description.-A single imperfect specimen of an oblique, winged shell, marked by alternately larger and smaller, radiating ribs, is, perhaps, a member of the genus Pterinea. So far as can be judged, its dimensions are: length, about $20 \mathrm{~mm}$, and height, about $18 \mathrm{~mm}$.

PTERONITES? SUBPLANA (Hall).

Plate XXII., Fig. 1.

1852. Avicula subplana Hall, Pal. N. Y., vol. II., p. 283, pl. 59, fig. $3 a-c$.

Description. - Left valve depressed-convex, winged posteriorly, subovate in outline, apart from the posterior extension of the hingeline: beak nearly terminal, hinge-line equaling the greatest length of the shell. From the anterior extremity of the hinge-line the margin curves regularly to the postero-ventral angle, the curvature becoming more gentle posteriorly; it then curves rather abruptly into the posterior margin, which is sinuate and meets the posterior extremity of the hinge-line at an acute angle. The entire surface of the shell is marked by rather fine, somewhat irregular, concentric lines of growth, with no indications of radiate markings. 
The dimensions of the largest and best specimen observed are: length, $45 \mathrm{~mm}$, and height, $28 \mathrm{~mm}$.

Remurs.-Hall's original figures of frirulu subplana allow a great deal of variation in the outline of the species. 'The several Decker Ferry specimens refered here also exhibit considerable variation, but mone of them errespond exactly with either of Hall's figures, the posterior marsin being more simuate, with the posterior extremity of the hinge-line more acute. The species is here referred to the genus Pteronites, as it seems to be more nearly in accord with members of that genus than with any other Paleozoic genus, although in no specimens have the hinge characters been preserved, nor has the right valve been seen. Heretofore the members of this genus have not been recorded farlier than the Chemung fauna of the Devonian, and all of the describerl suectes are from the Chemung and the lower Carboniferous faunas.

I'TYCHOPTERIA? SUBQUADRATA n. sp.

Plate XxiI., Fig. 2.

Description.-Right valye unknown. Left valve subquadrangular in outline, depressed-convex, with anterior and posterior wings; hingeline a little shorter than the total length of the shell, the beak projecting slightly leyond the hingt-line and situated about one-thirel the length of the shell from the anterior margin. The anterior marwin forms nerly a right angle with the hinge-line; below it roumb regularly into the arcuate rentral margin; posteriorly the rentral margin joins the posterior margin with a rather abrupt turn; the mstrior marein is gently anvex and joins the hinge-line in an obtuse? angle. The surface of the shell is marked by fine, concentric lines of growtl..

The dimensions of the type specimen are: length, $30 \mathrm{~mm}$.; length of hinge-line, $25 \mathrm{~mm}$; height at beak, $23 \mathrm{~mm}$.

Remarks.-The hinge characters of this shell are unknown, but in seneral form and markings the specimens resemble members of the gemus Plychopterin more closely than any other Paleozoic genus, and it is therefore plared here provisionally, although that genus has not hitherto been recognized rarlier than the chemung fauna of the Deronian. This speeies differs from any of the other members of the genus in its less obliquity and in its more nearly vertical anterior margin. 
ACTINOPTERIA RETICULATA n. sp.

Plate XXII., Fig. 3.

Description.-Left valve large, subrhomboidal in outline; the body stibovate, with an obliquity of $27^{\circ}$ between the hinge-line and the numbonal ridge; beak but slightly elevated abore the hinge-line. Anterior margin nearly straight or slightly simuate, forming a rounded angle of about $80^{\circ}$ with the hinge-line; basal margin regularly curved; josteriorly it rounds more abruptly into the nearly straight or slightly sinuate posterior margin, which is nearly parallel with the anterior margin. Posterior wing large, slightly convex, limited below by a Inoderately distinct, rounded sinus; the posterior cardinal extremity obtuse. The body of the shell is marked by conspicuous, concentric lines of growth and by more or less discontinuous, radiating costæ. Near the margin of the shell the concentric lines are more crowded and the radiating costre are less conspicuous, but on the upper portion of the shell the two sets of markings give to the surface a nodose appearance. The posterior wing is marked like the body of the shell, lut the radiating markings are much less conspicuous. Right valve unknown.

The dimensions of the type specimen are: height. $35 \mathrm{~mm}$; oblique lingth from beak to postero-basal extremity, $48 \mathrm{~mm}$. : length of hingeline, $29 \mathrm{~mm}$.

Remarks.-Nothing but the general outline and surface markings of this shell are preserved, but in these characters it seems to resemble more closely the species of Actinopteria than any other generic group, and it is consequently placed in this genus, although no members of it have before been recognized earlier than the middle Deronian faunas. Additional material, more perfectly preserved, may serve to change its generic reference.

MYTILARCA OBIIQUA 11 . SP.

Plate XXII., Fig. S.

Description.-This species has been observed only in the form of somewhat indefinite casts, in which the hinge characters are not preserved. The general form of the shell resembles $M$ : arctirostra $\mathrm{H}$. and 
1I. mytiliformis Foerste, and it is therefore "onsidered as cogen rite with them. The frominent beak is terminal, and from it an angular umbonal ridge, becoming rounded posteriorly, extends obliquely to the postero-rentral angle of the shell. From the umbonal ridge to the rorsal and posterior margins the surface of the shell is convex; anternrentrally the slope is abrupt and nearly vertical to the margin.

The dimensions of the type specimen are: extreme length from the beak to the postero-ventral angle, $34 \mathrm{~mm}$.; greatest width at right angles to the above line, $20 \mathrm{~mm}$.; greatest convexity, $10 \mathrm{~mm}$.

Remarks.-This species resembles M. mytiliformis Foerste more closely than any other member of the gemus, but the shell is more oblique. with a more obtuse beak and with a much more abrupt slope from the umbonal ridge to the antero-ventral margin.

GONIOPHORA sp. undet.

Description.-All the specimens of this species which have been observed are imperfect, so that its characters cannot be detemined with certainty. It is a sharply-carinate, oblique shell, with an incurved beak. Dorsally from the carina the shell surface is convex and ventrally it is concave. In no specimen is the outline of the shell complete, but the depth of rach valve is apparently greater thats the height of the shell. The length of the best-preserved valve, although imperfect, is $16 \mathrm{~mm}$., with a height of $5 \mathrm{~mm}$. and a depth of $\gamma \mathrm{mm}$. These dimensions, howeter, probably do not correctly represent the dimensions of a perfect shell.

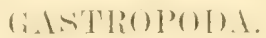

STRAPAROLLUS sp. undet.

Ilate Nxu., Fig. 14.

A single imperfect specimen has been observed in the lower beds of the Decker Ferry formation, which is referred to the genus Straparollus. It has a diameter of $25 \mathrm{~mm}$., with four or five volutions, 
which are plane above, with a broad umbilicus below, in which all of the volutions are probably visible. In cross-section the rolutions are subcircular.

LOXONEMA? sp. undet.

Plate XXII., Figs. 9-11.

One or more species of coiled shells, with elevated spres. are present in the lower beds of the Decker Ferry formation. These are all in perfect casts, and preserve no characters by which they may be referreil to their proper genera. They may be placed prorisionally in Loronema.

PLATYCERAS sp. undet.

Plate XXII., Figs. 12-13.

Description.-Several specimens of what appears to be a small species of Platyceras or Platyostoma have heen observed in the lower beds of the Decker Fery formation. As nearly as can be determined they have about two contiguous rolutions, the inner one being very small and the outer one expanding rapidly to the aperture, which is relatively large. In cross-section the rolutions are suboral or sul)elliptical in outline. The upper surface of the rolutions lies in a plane.

The dimensions of the most perfect specimen are: diameter, 11 $\mathrm{mm}$.; height of aperture, $8.5 \mathrm{~mm}$.

Remarks.-All the specimens of this little shell which have been observed are imperfectly preserved. One which resembles the remainder in other respects has a sharply carinate periphery, and consequently the cross-section of the volutions is subtriangular. It is not possible to determine from the specimen whether this variation is normal or whether it is produced by a distortion. of the shell. 


\title{
ARTHROPODA.
}

\author{
TRTLOBTTA.
}

Proetus PACHyderimatus Barrett.

Plate XXII.. Figs. $16-21$.

18\%8. Proetus pachydermatus Barrett, Am. Jour. Sci., 3d ser, vol. XI.. 1. $3 \approx 1$.

Description.- Head semi-circular in outline, with a broad, flattened marginal horder, the genal angles produced into sharp spines. Glabellas subtriangular, with a pair of small, liscommetad, ownid basal lobes: shtusty pointed in front. hordered by a sharply-defined rorsal furrow; the first and second parrs of lateral furrows are rather faint, slightly rourverl and directed oblinterly backward from the margin of the glabellat the third pair mor prominent. (-urverl. directed backward and commerting with the oceipital furrow ly a les sharply-defined depression. ('heek envex to the marginal border, the eyes opposite the thire juir of lateral glatellar furrows. Facial sutures making a sigmoidal curve from the anterior margin of the head to the front of the eye-lobe, and alter passing around the rye, lembling outward and cutting the postroior marerin near the bas of the genal spines. Occipital segment broadened in the middle with a small median tubercle. Thorax unknown. Pygidum semi-rbliptical in sutline. l,roader than long, with a hroul, Hattened marginal horeler: the axis much elevated, oceupying about one-third the entire width in front, tapering gradually to the oldus ly-romeled extremity wheh lies just within the flattened border. rivised into thirten or fourtern sexnents: the plura strongly convex to the flattened border, divided into eight or nine sharply-grooved segments, which become obsolete at the marginal border.

The entire surface of the glabella, except the lateral furrows, also the axial protion of the oceipital segment, coreded with fine, irregular fapillat: the anterior portion of the checks is covered with elongate,

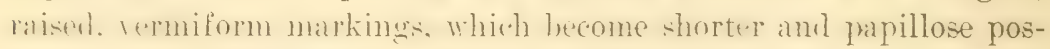
teriorly: The marginal border and genal spines are smooth, except on the edge, where they are covered with fine, elongate, raised lines. The axial and pleural segments of the pygidium are papillose, the 
Hattenes border being smooth within, but toward the margin corered with fine, raised tubercles and elongate flexuose markings.

The dimensions of an average-sized pygidium are: length, $10 \mathrm{~mm}$.; width, $13 \mathrm{~mm}$; and convexity, $4.5 \mathrm{~mm}$. A rather small head is 7 mm. long on the median line and probably $11 \mathrm{~mm}$. wide, but some framentary specimens must have been more than twice this size when complete.

Remark.-Fragments of the head and prgidium of this species are not uncommon in the coralline layer at the Nearpass cliff. The - jecies was first recognized and named by Dr. Barrett, but no proper elescription of it was ever given.

\section{PROETUS? DEPIRESUS $n$. Sp.}

Plate XXII.. Fig. 27.

Description.-Known only from the pygidium, which is semi-circular in outline. The axis is depressed, about five-sixths the total length of the pygidium. with about tem segments; occupying one-third the width of the prgidium anteriorly. tapering rather abruptly posteriorly, where it is bluntly rounded, the lateral, bounding furrows mntinning indefinitely to the posterior margin of the pygidium. Pluræ flattened adjacent to the axis, convex toward the border, with a slight, concave furrow within the convex marginal border; marked by six grooved segments on each side, the grooves being located centrally and being fully as deep as the furrows between the segments, but not extending across the marginal border. The bounding furrows of the segments are continued as faint, ill-defined grooves across the marginal border.

The dimensions of the largest and best specimen observed are: length, $5.5 \mathrm{~mm}$., and width, $9 \mathrm{~mm}$.

Remarks.-This species, so far as it has been observed, resembles Proetus protuberans Hall, from the Coerman's limestone of the Helderbergian period. The Decker Ferry specimens differ from $P$. protuberans in haring a less conspicuous marginal border and in haviug a larger number of segments on both axis and pluræ of the pygidium. 
PROETUS? SPIAOSA n. sp.

Plate XXII., Fig. 26.

Description.-Pygidium semi-circular in outline, rather strongly convex, with a very slight, blunt point posteriorly. Axis with eight

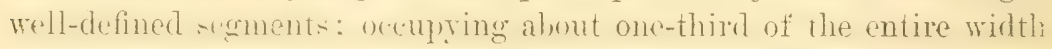
of the pygidium anteriorly, tapering regularly to the posterior extremity, which is hluntly rounderl and hes within the marginal horder. Pluræ convex, marked by six well-defined, grooved segments, curving rather abruptly to the margin, with a concave furrow within the narrow marginal border.

The dimensions of the best-preserved specimen are: length, 10 mam.; width, $13 \mathrm{~mm}$.

Remarks.-This trilobite is represented only by several pygidia, most of which are but fragmentary. It apparently belongs to some species of Proetus or, perhaps, Phacops, but the material is not sufficient for certain generic identification.

\section{CALYMIENE CAMERATA Con.}

Plate XXII., Figs. 22-25.

1842. Calymene camerata Con., Jour. Acad. Nat. Sci. Phil., vol. IIII.. I. ?...

1852. Calymene camerata Hall, Pal. N. Y., rol. II., p. 33\%, pl. YS, figs. $10 a-f$.

Description.-Head semi-circular in outline, the marginal border elevated in front. Glabella prominent, truncate in front, broadest through the posterior pair of lateral lobes; the dorsal furrow narrow and deeply impressed. The first pair of lateral furrows and lobes very faint, scarcely recognizable in some specimens; the second pair of lateral furrows repoly impreside directed olliquely hackward, their length a little less than one-fourth the width of the glabella, connected posteriorly by a slight depression with the third furrows; second lateral lobes convex, subelliptical in outline, connected across the dorsal furrow with the fixed cheeks; third pair of lateral fur- 
rows longer than the second, indefinitely divided within and surrounding a small tubercle on the side of the glabella; the posterior division directed more obliquely backward than the outer portion and continued as a slight, indefinite depression to the occipital furrow. Posterior lateral lobes large. subglobose. Occipital furrow rather narrow and deep across the axial portion of the head, becoming broader on the cheeks; occipital segment conver, broadest in the middle. Cheeks convex, the eyes opposite the second lateral lobes of the glabella. Pygidium subtriangular in outline, much elerated anteriorly, sloping abruptly to the sides and back; axis occupying about one-third of the width in front, bounded by the depressed, dorsal furrow, tapering gradually to the obtusely-rounded extremity which is close to the posterior margin of the pygidium; divided into about eight segment. Pluræ sloping abruptly from the axis to the sides, divided into five grooved segments. A small hypostome, which accompanies the speximens of this species and which probably belongs to it, is longer than wide, with the sides sinuate, making the middle portion much nirrrower than either of the extremities; the posterior margin is notched and the centre of the axial portion is elevated into a conspicuous, spiniform process. The entire surface of both head and pygidium, so far as preserved, except in the furrows, is covered with numerous, small, irregularly-arranged, rounded papillæ.

The dimensions of the best-preserved head are: length, $14 \mathrm{~mm}$; width, $26 \mathrm{~mm}$. Another much larger individual has a length of $: 3$ mm., but the width cannot be determined. The dimensions of a small pygidium are: width, $10.5 \mathrm{~mm}$; length, $6 \mathrm{~mm}$; ; convexity, 7 $\mathrm{mm}$. Some of the larger, fragmentary specimens of pygidia are fully twice this size.

Remarks.-In his illustrations of this species Hall shows three sharply-defined pairs of lateral glabellar lobes. In the New Jersey specimens these three pairs of lobes may all be detected, but the anterior pair is so inconspicuous as to be easily overlooked, and in no case has it been seen at all approaching the prominence given it by Hall's illustrations. In his description of the species the anterior lobes are said to be minute, and it is probable that they were made too prominent in the illustrations. All the material representing the species from New Jersey is fragmentary and unsatisfactory for stidi, but there can be no doubt as to its correct identification. 
DALALANITES ASPINOSA 11. sp.

Plate XXII., Fig. 15.

Description.-Known only from the prgidium, which is longitudinally smi-elliptical in outline. obtusely pointed posteriorly. Axis rusularly tapering and rounded posterinrly; in the type specimen reaching to within $4.5 \mathrm{~mm}$. of the posterior margin, which makes it alunt sixth-serenths of the entire length of the pygidium; marked by alwut sixten annulations, which gradually decrease in size posteriorly, mitil they lecome entirely obsolete. The pluræ are rather strongly Anuvex to the marcin. With no flattened or concave border; marked ly ten prominent, narrow, grooved ribs, which extend to the margin of the pygidium and are separated by broad, concave furrows.

The dimentions of the trpe specimen are: length, $32 \mathrm{~mm}$; width, $40 \mathrm{~mm}$.; convexity, $9 \mathrm{~mm}$.

Remarks.-The only specimen of this suecies in the collection which is in any degres complete is an internal cast of the pygidium. This symimen, howerer, preserves essentially all the characters of the prgidium, thrugh another specimen, not a cast. would show the phoral ribs to he somewhat brouler. The speres differs somewhat ronspicuonsly from any of the other silurian members of the genus in the American faunas, and may be recognized by the absence of any sinous extension from the posterior extrenity. by the absence of any flattened or concave marginal borker and by the shary pleural ribs, which extend to the border of the pygidium.

OSTRACODA.

LEPERDITIA ALTOIDES n. Sp.

Plate XxuII, Figs. 1-2.

Desciption.-Carapace of medium size. obliquely subreniform, narww+r in front. somewhat variable in proportions: valves strongly (n)w $x$, gibbous in the middle. Dorsal margin straight, from threefillis to two-thirds the trial length: dorsal extremities obtusely angular, posterior margin broadly rounded, ventral margin convex, 
anterior margin narrower and often more sharply rounded than the posterior. Eye tubercle small, but rather prominent, situated at a point about one-third the length of the straight dorsal margin from its anterior end and about three-fourths of the height of the valve at that point from the basal margin. Surface of the valves flattened at the antero-dorsal angle, the flattening extending as a narrow, indistinct, marginal border nearly to the centre of the anterior margin. Along the posterior margin there is a similar, narrow, indistinet, flattened border, which extends from the postero-dorsal angle to a point in the ventral margin directly below. Surface of valves perfectly smooth.

The dimensions of an average specimen are: length, $7 \mathrm{~mm}$. ; height, $4.5 \mathrm{~mm}$.; convexity of one valve, $1.5 \mathrm{~mm}$.

Remarks.-This species most closely resembles L. alta of the Manlius limestone, but may be always distinguished from that species ly the indistinct, posterior marginal border. It also resembles $L$. jonesi, but does not have the pitted surface of that species.

BEYRICHIA SUSSEXENSIS n. sp.

Plate XXIII., Figs. 3-4.

Description.-Carapace subelliptical in outline; the dorsal margin straight, its length about nine-tenths of the total length of the valres, its extremities angular. Ventral margin gently convex; the anterior and posterior margins both broadly rounded, the posterior extremity being a little higher than the anterior and its margin being nearly straight for a short distance below the postero-dorsal angle. The entire free margin of the valves with a distinct, flattened, marginal border, which is abruptly separated from the body of the valve. The dorsal half of the surface of each valve is divided into three lobes by two deep furrows, which reach to about the middle of the valve. 'i'he posterior furrow divides the valve at about the middle of its length and is nearly straight; the anterior furrow lies about half way hetween the posterior one and the anterior extremity; it is a little shorter than the other and its lower extremity is slightly bent backward. The two furrows are connected below by an indistinct depression in the valve, partially isolating the middle lobe. The anterior and posterior lobes are connected ventrally. The middle lobe is sub- 
folotrine and is the most prominent of the three: the posterior love is a little more prominent than the anterior. The entire surface, except in the furrows and on the marginal border, is finely papillose.

'The dimensions of the type specimen are: length, $3 \mathrm{~mm}$; height, $1.8 \mathrm{~mm}$.

BEYRICHIA BAFRETTI 11. SP.

I'late XXIII, Fig. ?.

Description.-'This species resembles the last, but is smaller, with the anterior furrow narrower and with the posterior one produced further toward the ventral margin, giving to the median lobe a more mliptical outliue. The surface is also very differently marked, it being (*)vered with rather large, irregular pits. The ventral margin is nearly straight in the central portion, the anterior and posterion extremities of the valve being of nearly equal height.

The dimensions of the type specimen are: length, $2.3 \mathrm{~mm}$; height. $1.5 \mathrm{~mm}$.

BEYIICHIA PERINFLATA 11 . sp.

Plate XXIII., Fig. 6.

Deseriptron.-Carapace subelliptical in outline, highest in front, sreatly inflated antero-ventrally. Hinge-line straight, about fourlifths the total length. The free margin, from the postero-dorsal angle to the middle of the ventral margin, with a depressed marginal border, which is concave within, with a rounded ridge externally. sutside of which the surface drops vertically to the edge of the valve. In the anterior half of the valve the marginal border is covered by the strong inflation of the hody of the ralve. Valres divided by two vertical furrows from the dorsal margin; posterior furrow beginning at about the middle of the hinge-line and extending nearly vertically downward to beyond the middle of the valve: anterior furrow a little narrower, about midway between the posterior one and the anterior margin of the valve, nearly vertical in its upper half, bent obliquely backward below and joining the posterior furrow. Posterior lobe occupying nearly one-half of the valve; median lobe subglobose, entirely isolated; anterior lobe small and low. The antero-ventral pro- 
imberance is partially separated from the anterior lobe in front and the posterior lobe behind by a slight depression in the surface of the valve, which is continuous with the oblique portion of the anterior furrow. Surface of valves, except in the furrows and on the marginal border, minutely pustulose.

The dimensions of the type specimen are: length, $3.1 \mathrm{~mm}$; height, $\therefore .2 \mathrm{~mm}$.

BEYRICHIA JERSEYENSIS 7 . sp.

Plate XXIII., Fig. 5 .

Description.-Carapace subelliptical in outline, height in front and Behind nearly equal. Hinge-line straight, about two-thirds the length of the valve. Free margin with a narrow, marginal border, which is flattened above and drops vertically to the edge of the valve externally. Valve divided near the middle by a narrow furrow, starting from the hinge-line and extending to below the middle of the valve, with a slight, forward curve. A second furrow originates from the median furrow a little below the hinge-line and, after describing nearly a semicircle towards the front of the valve, again joins the median furrow a little above the middle of the valve. The lower half of this semicircular furrow is less deeply impressed than the upper, and a faint depression joins its upper portion with the dorsal margin of the valve. Surface of the valve smooth, regularly convex throughout, with the median, semi-circular lobe slightly more prominent.

The dimensions of the type specimen are: length, $2.5 \mathrm{~mm}$.; height, $1.5 \mathrm{~mm}$.

BEIRICHIA NEARPASSI n. SP.

Plate XXIII., Figs. T-8.

Description.-Carapace subelliptical in outline, the posterior extremity equaling or a little narrower than the anterior; the hingeline straight, about four-fifths of the total length of the valves. Free margin, with a flattened, marginal border. Valves divided into three lobes by two rather-broad and deeply-impressed, nearly-equal furrows, which start from the dorsal margin and extend vertically downward to about the middle of the valve. A shallower and less sharply- 
defined furrow extends vertically upward from the ventral margin, directly beneath the anterior furrow from the dorsal margin, the two leing indefinitely comnected across the middle of the valve by a slight depression. The posterior lobe is strongly convex and is the largest of the three, occupying about one-half of the total length of the valw; inedial lobe subglobular, about as high as the posterior one; anterior lobe about the same width as the median one, but less strongly convex. Entire surface of the valves smooth.

The dimensions of an average specimen are : length, $1.75 \mathrm{~mm}$; height, $1 \mathrm{~mm}$.

\section{BEYRICHIA DECKERENSIS n. $\mathrm{sp}$}

Plate XxmI., Fig. 11.

Description.-Carapace subelliptical, a little narrower in front, hinge-line straight, a little more than four-fifths the total length of the valve. Free margin depressed in a narrow border from the postero-dorsal angle around the posterior margin, ventrally and anteriorly the body of the valve is slightly inflated so as to project beyond the marginal borter, entirely hiding it in a direct view. Valves divided into three lobes, by two vertical furrows, extending downward from the dorsal margin: the posterior furrow is the strongest, and extends beyond the middle of the valve, being but slightly curved lorward below; the ancerior furrow is shorter, and its lower extremity "urves lackwart. The posterior lobe is strongly convex, and occupies about one-half of the entire ralve; the median lobe is subglobular, having about the sinne elevation as the posterior one; the anterior lobe is lower than either of the others, and slopes gently to the anterior margin: in width, it about equals the median lobe. Surface of the valve, except in the furrows and on the marginal border, very finely pitted.

The dimensions of the type specimen are: length, $2.75 \mathrm{~mm}$; height, $1.5 \mathrm{~mm}$. 


\section{BYTHOCYPRIS NEARPASSI n. sp.}

Plate XXIII., Fig. 12.

Description.-Carapace suboval in outline, twice as long as high, much narrower in front. Ventral margin nearly straight, dorsal margin gently convex, posterior margin broadly rounded, anterior margin narrowly rounded. Valves strongly convex, their surface smooth. The left valve overlapping the right along both the dorsal and the ventral margins.

The dimensions of one of the type specimens are: length, $1.33 \mathrm{mn}$.; height, $0.66 \mathrm{~mm}$.

\section{Uncertain Species.}

In addition to the species enumerated, there are several forms too imperfectly preserved for identification or description. Several specimens are fragments of a horn coral, but the preservation is not such as to allow even the genus to be determined with certainty, although it is probably a Zaphrentis. Several additional pelecypoda, most of them in a very imperfect state of preservation, have been observed. One of these is the anterior extremity of a small shell, with conspicuous, concentric markings, like those on Grammysid or Allorisma. Another specimen is apparently an imperfect Orthoceras, although no sutures can be detected.

Descriptions of Species in the Rondout Fadna.

\section{PROTOZOA.}

\section{FORAMINIFERA.}

In the "pethstone" bed (2 $\mathrm{A}^{19}$ of the Nearpass section) of the Rondout formation small, subglobular or more or less irregular bodies may sometimes be detected, which are not certainly organic, but which suggest some forms of foraminifera. It is possible that they are the fossil remains of some of these lowly organisms. 


\title{
MOLIUSCOIDEA.
}

\author{
BRACHIOPODA.
}

\author{
HYATTELLA? LAMELLOSA n. sp.
}

Plate XxIII., Figs. 15-18.

Description.-Shell small, transversely subelliptical in outline. Pedicle valve prominent on the umbo; the beak blunt, not strongly incurved; the surface curving rather abruptly from the umbo to the cardinal margin, and sloping gently, with a slight convexity, to the lateral margins; toward the front it is deeply depressed in a broad, somewhat flat-bottomed sinus, which reaches to the umbo. Brachial valve strongly convex, most prominent near the middle; the mesial fold not strongly elevated above the general surface, with a slight, depressed, mesial line. Surface of both valves marked by strong and broad, concentric, lamellose lines of growth.

The dimensions of the type specimen are: length, $6 \mathrm{~mm}$; width, 7 mm.; thickness, $4 \mathrm{~mm}$.

Remarls.-This species is established on a single, nearly-perfect indiridual, which is of interest, because it is the only specimen of brachiopod which has been observed in the strata of the Rondout formation in New Jersey. All other recognizable species which have been found in the formation are ostracodes helonging to the genus Leperditia. The generic position of this little brachiopod is uncertain, as its internal characters cannot be determined from the single specimen. Its general form is strongly suggestive of a diminutive individual of the Carboniferous species, Athyris lamellosa. It seems to have a general outward similarity with the species of the genus IIyattella, and it is therefore placed in that genus provisionally. 


\title{
ARTHROPODA.
}

\section{OSTRACODA.}

\author{
LEPERDITIA ALTA (Con).
}

See, also, p. 265, pl. XXIV.

In some beds of the Rondout formation there are numerous crushed specimens of a species of Leperditia, which, so far as can be determined, possess the characters of $L$. alta, the species which is so abundant in the Manlius limestone, or of L. altoides, from the base of the Decker Ferry formation.

\section{LEPERDITIA ELONGATA n. $\mathrm{sp.}$}

Plate XXIII., Fig. 13.

Description.-Carapace large, obliquely subreniform, posterior extremity the highest. Dorsal margin straight, two-thirds of the total length of the valves, its extremities obtusely angular. Anterior margin obliquely truncate from the hinge-line, sharply rounded in front into the broadly-convex ventral margin, which, in turn, curves regularly into the nearly semi-circular posterior margin. Eye tubercle distinct, situated a little above the middle of the anterodorsal quarter of the valves. Both anteriorly and posteriorly the margin is slightly flattened in a rather indistinct marginal border, extending from the extremities of the hinge-line to the middle of the valve. Surface smooth.

The dimensions of an average specimen are: length, $12 \mathrm{~mm}$; height, $6.5 \mathrm{~mm}$.; convexity of one valve, $2.5 \mathrm{~mm}$.

Remarks.-This species resembles $L$. alta, but is larger and more elongate. 
LEPERDITA GIGANTEA n. sp.

Plate XXIII., Fig. 14.

Description.-Carapace very large, subreniform in outline. Dorsal margin straight, about three-fifths of the total length of the valves, its anterior extremity oldusely angular, its posterior extremity rounding into the nearly semi-circular posterior margin. Ventral margin gently convex, anterior margin broadly rounded, nearly as high as the posterior margin. Eve tubercle distinct, situated at about the middle of the antero-dorsal quarter of the valves; behind the eye tubercle there is a broad, shallow, indistinct, flattened sulcus, which extends downward from the hinge-line nearly to the centre of the valve. The antero-dorsal angle is distinctly compressed, and the flattened area extends around the anterior margin an a marginal border. The posterior margin is also bordered by a more or less distinct, flattened border. Surface smooth.

The dimensions of a large specimen are: length, $22.5 \mathrm{~mm}$.; height, $14 \mathrm{~mm}$.; convexity of one valve, $6 \mathrm{~mm}$.

Descriptions of Species in the. Mindius Iitiestone Fauna.

\section{COELENTERATA.}

HYDROZOA.

stromatopora sp. undet.

In the lower beds of the Manlins limestone some layers are almost completely composed of mall, more or lesis subglobular or lenticular masses of a Stromatoporoil, which at metrally not over $20 \mathrm{~mm}$. or 30 $\mathrm{mm}$. in diameter. They are not preserved in such a way as to exhibit the minute structure, even in thin sections, so that any definite identification of the material, either gencric or specific, is impracticable. 


\title{
MOLLUSCOIDEA.
}

\author{
BRACHIOPODA.
}

STROPHEODONTA VARISTRIATA (Con.).

Plate XXIV., Figs. 13-14.

See, also, p. 274.

1859. Strophodonta varistriata Hall, Pal. N. Y., vol. III., p. 180, pl. 8, figs. $1-16$, pl. 16 , figs. $1-8$.

Description.- Shell concavo-convex, subcircular, subelliptical or subquadrangular in outline, length equal to, less or greater than the width, hinge-line equaling, less or greater than the width, cardinal extremities rounded or angular. Pedicle valve depressed-convex, umbonal region rather prominent, beak extended a little beyond the hinge-line, arched over the narrow, cardinal area. Brachial valve concave or nearly flat. Surface of both valves marked by fine, sharp, radiating striæ, which vary in size, the stronger ones usually being equidistant, with several finer ones between. Crossing the radiate markings are much finer, somewhat undulating, concentric lines.

The dimensions of an average specimen from the Manlius limestone are: length, $1 \% \mathrm{~mm}$. ; width, $19 \mathrm{~mm}$.

Remarks.-Every specimen of the genus Stropheodonta which has been observed in the Manlius limestone seems to be referable to this variable species. Its most constant characteristic is to be found in the surface markings, the proportionate dimensions of the shell being different in almost every individual.

CENTRONELLA? BIPLICATA n. sp.

Plate XXIV., Figs. 1-8.

Description.-Shell small, longitudinally subovate in outline, the valves subequally convex. Pedicle valve with a sharply-pointed, arched beak, the mesial sinus narrow, shallow and extending nearly to the beak, but becoming very indistinct or almost obsolete back of the 
middle of the shell; it is limited on each side by a single, low, rounded plication, which is not conspicuous, except near the anterior margin. The brachial valve with a low, rounded, median fold near the anterior margin, bounded by a shallow, rounded furrow on each side and not rising above the general surface of the valve. Internally it bears a short, Centronella-like brachidium. Besides the two plications which bound the fold and sinus, each valve, in the larger individuals, is marked by one or two additional, extremely-faint plications near the margin on each side and by more or less indistinct lines of growth.

The dimensions of a rather large specimen are: length, $4.75 \mathrm{~mm}$; width, $3.5 \mathrm{~mm}$.; thickness, $2 \mathrm{~mm}$.

Remarks.-This little shell is probalbly not a member of the genus Centronella, but its brachidium, as seen in transparent or translucent specimens, is similar to the loop of this genus, and therefore it is placed here provisionally. In external form the shell differs materially from the typical members of the genus, and, in fact, it differs in external form from all the genera of the family Centronellide. With a more perfect understanding of the loop of this shell, it is entirely probable that it would constitute the type of a new genus.

In certain layers of the Manlius limestone in the Nearpass quarry this little shell occurs in great numbers, many of which can be removed from the rock in perfect condition. In the smaller or younger specimens of the species the two plications near the front margin are very faint or entirely obsolete, but in full-grown individuals they can always be detected.

SPIKIFER VANUXEMII Hall.

Plate XXIV., Figs. 9-12.

1859. Spirifer vanuxemi Hall, Pal. N. Y., vol. III., p. 198, pl. 8, figs. $17-23$.

Description.-Shell small, wider than long, hinge-line a little shorter than the greatest width of the shell, cardinal extremities rounded. Pedicle valve strongly convex, beak elerated and arched over the concave, ill-defined cardinal area, mesial sinus rounded, not much stronger than the rounded furrows on the sides. Brachial valve less convex than the pedicle, with a rounded, mevial fold, slightly flattened on the top. Surface of each valve marked by from two to four broadly- 
rounded or slightly-flattened plications on each side of the fold and sinus and by conspicuous, more or less crowded, concentric lines, which are arched over the plications. Besides these markings, very fine, radiating strix may be detected on well-preserved specimens by the aid of a magnifying glass.

The dimensions of a rather large pedicle valve are: length, $10 \mathrm{~mm}$; width, $11.5 \mathrm{~mm}$.; convexity, $4.5 \mathrm{~mm}$. Those of a brachial valve are: length: $7.5 \mathrm{~mm}$.; width, $11 \mathrm{~mm}$.; convexity, $2.5 \mathrm{~mm}$.

Remarks. - This is one of the most characteristic species of the Manlius limestone fauna, and occurs throughout the formation, being especially abundant in some of the beds.

\title{
MOLLUSCA.
}

\author{
PELECYPODA.
}

MIEGAMBONIA AVICULOIdEA Hall.

Plate XxIV., Figs. 17-18.

1859. Megambonia avicutoidea Hall, Pal. N. Y., vol. III., p. 274, pl. 49 , figs. 7 a-b, pl. $49 \mathrm{~A}$, fig. 8 .

Description.--Shell oblique, winged posteriorly. Beaks nearly terminal, prominent, obtuse, incurved, elevated above the hinge-line. Hinge-line straight; anterior margin curving forward from beneath the beaks for a short distance, then curving backward, with a long, gentle sweep, to the postero-basal extremity, which is more or less broadly rounded; posterior margin sinuate below the hinge extremity, convex towards the base. Surface of valves strongly convex on the umbonal ridge; the anterior slope rather abrupt, slightly convex; posterior slope concave, the posterior wing not sharply separated from the body of the shell. Surface marked by fine, more or less unequal, concentric lines of growth, which are uniform in character upon the body of the shell and the posterior wing.

The approximate dimensions of an imperfect specimen are: height, $16 \mathrm{~mm}$. : length, $16 \mathrm{~mm}$. 


\title{
GASTROPODA.
}

\author{
HOLOPEA ANTIQUA (Van.).
}

Plate IXIV., Figs. 15-16.

1859. Holopea antique Hall, Pal. X. Y., rol. III., p. 294, pl. 5.t, figs. $2 a-b, 3 a-b$.

Description.- Shell subconical, spire elerated, with four or more rolutions. Suture moderately impressed, the volutions regularly conгех. Aperture ovate or subcircular. Surface marked by fine, transverse lines of growth.

Remarlis.-The specimens which have been referred to this species are all imperfect, and are usually only the internal casts. The apical angle of the New Terser specimens apparently raries between $55^{\circ}$ and $60^{\circ}$. which is somewhat les than that of Hall's illustrations of the species, in which it measures nearly $r 0^{\circ}$. This measurement of the Tew Jerser specimens, howerer, camnot he made with certainty, because in no case is the complete spire retained.

\section{PTEROPODA}

TENTACULITES GrRACANTHUS (Eaton).

Plate XXIV., Figs. 19-20.

1859. Tentaculites irregularis Hall, Pal. N. Y., rol. III., p. 137, pl. 6, figs. 22-23.

18s8. Tentaculites gyracanthus Hall, Pal. N. Y., vol. V., pt. II., Supp. (Supp. to vol. VII.), p. 5, pl. 114, figs. 7-13.

Description.--Shell elongate, circular in cross-section, annulate, gratually tapering to the apex. Annulations smooth, rounded, situated at irregular intervals, from one to three in the space of $1 \mathrm{~mm}$. ; the interspaces between the annulations are marked by fine, annular striæ. In internal cast: the ammulations are smaller and the fine, amnular striæ are lacking from the interspaces. 
The maximum diameter of internal casts of this species is about 1 mm., though specimens with the shell preserved sometimes attain a diameter of $1.5 \mathrm{~mm}$.

Remarks.-As it occurs in New Jersey, this species has been observed only in the form of internal casts, but the irregular length of the interspaces between the annulations is sufficient to distinguish the species. It has never been observed to occur in such abundance in New Jersey as it sometimes does in the Manlius limestone of New York.

\section{CEPHALOPODA.}

ORTHOCERAS sp. undet.

Plate XXV., Fig. 1.

A single weathered specimen of a large Orthoceras has been observed in the Manlius limestone fauna of New Jersey. It has a maximum diameter of about $53 \mathrm{~mm}$. and a total length of $270 \mathrm{~mm}$. The septa are rather deeply concare, and in the larger portion of the shell they vary from $6 \mathrm{~mm}$. to $9 \mathrm{~mm}$. apart; at the smaller extremity of the shell they are sometimes as close together as $2.5 \mathrm{~mm}$. The siphuncle is apparently central, and has a diameter of about $2.5 \mathrm{~mm}$. The external surface characters cannot be determined.

\section{ARTHROPODA.}

OSTRACODA.

leperditia ALta (Con.).

Plate XXIV., Figs, 25-28.

1859. Leperditia alta Hall, Pal. N. Y., vol. III., p. 373.

Description.-Carapace obliquely subreniform, valves strongly conres, gibbous in the middle. somewhat rariable in their proportions. Dorsal margin straight, from three-fifths to two-thirds the total length of the valves; its extremities obtusely angular. Posterior margin 
broadly rounded, ventral margin convex, anterior margin more sharply rounded than the posterior. Eye tubercle distinct, situated at about the centre of the antero-dorsal quarter of the valve. Anterior margin slightly flattened at the dorsal angle, the flattened area sometimes extended for a short distance as a marginal border. Surface of the valves smooth.

The dimensions of an arerage specimen are: length, : mm.; height, $4.5 \mathrm{~mm}$.; convexity of one valve, $2 \mathrm{~mm}$.

Remarks.-This species oceurs abundantly in the Manlius limestone, where it is one of the most characteristic species.

\section{BEYRICHIA KÜMMELI n. sp.}

Plate XXIV., Fig. 21.

Description.-Carapace subelliptical in outline, a little narrower in front, hinge-line straight, about three-fifths of the total length. Free margin with a depressed, concave border, whose outer edge is slightly elevated in a rounded, marginal ridge, outside of which the surface drops abruptly to the edge of the valve. Talve divided into three lobes by two furrows, which extend ventrally downward from the hinge-line to about the middle of the valve; the anterior furrow a little shorter than the other, with its lower extremity slightly curved backward. Posterior lobe the largest, including nearly one-half of the valve, with a small, but distinct, tubercle a little in front of its middle point. Middle lobe subglobular in form, more highly conver than either of the others, with a slight, concave excavation at its base. Anterior lobe more depressed-convex than either of the others. Surface finely pitted, except on the marginal border and in the furrows; the pits appearing to be angular depressions, with narrow, dividing ridges.

The dimensions of the type specimen are: length, $4 \mathrm{~mm}$; height. $2.5 \mathrm{~mm}$.

\section{BEYRICHIA WALLPACKENSIS n. sp.}

Plate XXIV., Fig. 22.

Description.-Carapace oblique, narrower behind, with a straight hinge-line, nearly equaling the total length of the valve. Posterior margin straight above, meeting the hinge-line in a little less than a 
right angle, curving below into the convex, ventral margin; anterior margin broadly rounded, meeting the hinge-line in an obtuse angle. Free margin with a narrow, flattened border. Valve divided into three lobes by two vertical furrows from the dorsal margin; the posterior furrow extending nearly to the middle of the valve, its lower extremity slightly curved forward; anterior furrow less deeply impressed, only about one-half as long as the posterior one. Posterior lobe occupying nearly one-half the total length of the valve; middle lobe subglobular, about as high as the posterior one; anterior lobe sloping away to the front. Surface marked by fine, closely-arranged, circular pits, except in the furrows and on the marginal border.

The dimensions of the type specimen are: length, $1: 9 \mathrm{~mm}$; height, $1 \mathrm{~mm}$.

\section{BEYRICHIA MONTAGUENSIS n. sp.}

Plate XXIV., IFig. 23.

Description.-Carapace suboval in outline, narrower in front, the hinge-line straight, about five-sixths of the entire length of the valve. Postero-dorsal angle a little produced, so that the posterior margin is slightly concave above. Free margin with a rather broad, flat border. Valves divided into three lobes by two furrows, which extend vertically downward from the dorsal margin; the posterior furrow the longer, reaching a little below the middle of the valve, its lower portion slightly curved toward the front; anterior furrow scarcely reaching the middle of the valve, slightly curved, with its concave side posterior, a little narrower and less deeply impressed than the posterior one. Posterior lobe convex, occupying about one-half of the length of the valve; middle lobe the most prominent, subglobose; anterior lobe the lowest of the three, its surface sloping to the anterior border. Surface of the valve minutely pitted or punctate, except in the furrows and on the marginal border.

The dimensions of the type specimen are: length, $2.4 \mathrm{~mm}$.; height, $1.6 \mathrm{~mm}$. 


\author{
BEYRICHIA SMLOCKI n. sp.
}

Plate XXIV., Fig. 24.

Description.-C'arapace subelliptical in outline, a little narrower in front, hinge-line straight, albout nine-elevenths of the total length of the valve. Free margin depressed, with a narrow, concave furrow within, which is bordered externally by a narrow, rounded elevation, outside of which the surface lrops abruptly to the edge of the valve. Along the postern-rentral margin the horder is hidden for a short distance by the protrusion of the body of the valve. Valves divided into three lobes by two rertical furrows; the posterior furrow longest, reaching helow the middle of the valve, its lower portion slightly curved toward the front; anterior furrow narrower, shorter and deeply impressed, curving backwards. Posterior lobe strongly convex, its greatest elevation nearest its anterior margin; median lobe subglobular, alhout as highly elevaterl as the posterior one; anterior lobe much lower, shping sently to the anterior margin. Surface of valves smooth.

The dimensions of the type specimen are: length, $2.6 \mathrm{~mm}$; height, $1.5 \mathrm{~mm}$.

BEYRICIIA MANLIENSIS n. sp.

Plate XxIII., Fig. 10.

Description.-Caralace subelliptical, slightly narrower in front, the hinge-line straight, a little more than five-sixths of the entire length of the valve. Free margin of the valve with a flattened border. Valve divided into thres lolus ly awo furrows extenting from the hinge-line rertically downward; posterior furrow reaching to about the middle of the valve; the anterior furrow shorter, its lower extremity curving slightly backward below. Posterior lobe depressed-convex, occupying nearly one-half of the entire valve; median lobe most prominent, subglobose; anterior lobe nearly equaling the posterior in convexity and about equaling the median one in width. Entire surface, except in the furrows and on the marginal border, marked by small, closely-arranged, subcireular pits.

The dimensions of the type specimen are: length, $3 \mathrm{~mm}$.; height, $1.9 \mathrm{~mm}$. 


\section{CHAPTER IX.}

\section{FAUNAS OF DEVONIAN AGE.}

All the Paleozoic formations in New Jersey lying above the Manlius limestone are referable to the Devonian period. The formations recognized are the Coeymans limestone, the New Scotland beds, the Becraft limestone and the Kingston beds belonging to the Helderbergian serics. Following these is the Oriskany formation, with its beds of siliceous limestones and sandstone; then comes the Esopus slate, followed by the Onondaga limestone. All these formations occur in the Delaware Valley region. In the Green Pond region there are some still younger Deronian formations. The Newfoundland grit is usually a quartzite with fossils of Onondaga age; following this are the J[onroe shales and Bellrale flags of Hamilton age, and the Slimmemunk conglomerate, which is undoubtedly Deronian in age, althongh it has not been found to be fossiliferous.

In the Helderbergian series only two faunas have been differentiated and described separately, they being the Coeymans limestone fauna and the New Scotland-Becraft fauna, the faunas of the two latter formations having so much in common, although each has some peculiar species, that it has been thought best to include them together in one faunal group. The Kingston beds have not been found to be fossiliferous in New Jersey, unless the "trilobite hed" characterized by Dalmanites dentatus should be considered as the summit of the formation. This bed, however, contains so many species allying it with the superjacent Oriskany that it has been considered as being of lower Oriskany age, and its fauna is treated separately. The higher Oriskany faunas, although two distinct faunal zones may be easily recognized, are all described together. The Esopus slate is unfossiliferous, and the fauna of the Onondaga limestone is a small one. From the Green Pond region the fauna of the Newfoundland grit is treated by itself, while those of the MIonroe shales and Bellvale flags are described together. 
Descriptions of Species in the Cominans Limestone Fauna.

\section{COELENTERATA.}

ANTHOZOA.

ZAPHRENTIS ROEMERT E. \& H.?

Plate XXVI., Fig. 1.

Specimens of horn corals, which may be provisionally referred to the genus Zaphrentis, are oceasionally met with in the Coeymans limestone. They are all poorly preserved, and are not in a condition of preservation for aceurate identification, but some specimens seem to resemble $Z$. roemeri.

FAYosites HeLderbergiaE Hall.

188\%. Favosites helderbergice Hall, Pal. N. Y., vol. VI., p. 8, pl. 4, figs. 1-2, pl. 5, figs. 1-3, pl. 6, figs. 1-8.

Description.-Corallum consisting of large, lenticular, depressedconvex or hemispherical masses; base covered by a strongly-wrinkled epitheca. ('orallites polygonal, their inner surface showing evidence of a few strong, longitudinal strix. 'Tabulx frequent, from ten to fifteen in the space of $10 \mathrm{~mm}$; thickness equal to that of the walls. Mural pores in one or two ranges, comparatively large, circular, with margins distinctly clevated. Walls of corallites thin, but frequently much thickemed near the surface by silicification, and sometimes granulose or spinulose on the inner face. On some specimens the corallites, at the surface, are nearly equal, having a diameter of about $1.5 \mathrm{~mm}$.; on other specimens the diameter varies from $.66 \mathrm{~mm}$. to $1.5 \mathrm{~mm}$. On many suecimens some of the corallites are larger and less angular than those surrounding them, being a little more than $2 \mathrm{~mm}$. in diameter.

Remarlis.-This species occurs abundantly at the base of the Coeymans limestone, where, associated with masses of Stromatopora, it 
characterizes a conspicuous coral bed. The New Jersey specimens are always more or less completely silicified, and have been altered so that the mural pores can rarely be detected, even in thin sections.

\section{CLADOPORA MULTISERITA $\mathrm{n}$. sp.}

Plate XXVI., Figs. 2-3.

Description.-Corallum consisting of cylindrical branches, which occasionally divide. Corallites cylindrical, directed obliquely to the axis of the branches, apparently free from septa or tabulæ, arranged in twelve or thirteen vertical series; the apertures in adjacent series being more or less irregularly alternate. Because of the obliquity of the corallites, their apertures are elliptical, the peripheral borders regular, subangular.

The diameter of the branches is from $2 \mathrm{~mm}$. to $3.5 \mathrm{~mm}$., with six or seven corallites occupying a space of $5 \mathrm{~mm}$. longitudinally.

Remarks.-This species has only been recognized in the upper beds of the formation near Hainesville.

\section{HYDROZOA.}

STROMATOPORA CONCENTRICA Goldf.

Masses of a Stromatoporoid, which may provisionally be referred to Stromatopora concentrica, occur more or less abundantly in the coral bed at the base of the Coeymans limestone. They are always more or less silicified, so that they are not in a proper condition for study, and no correct identification of either the genus or the species can be made. The form may always be recognized by the more or less subglobular form of the masses, with their concentric, laminar structure. 


\section{VERMES.}

ANNELIDA.

CORNULITES CINGULATUS Hall.

Plate XXXII., Fig. 3.

1888. Cornulites cingutites Hall, Pal. N. I., vol. V., pt. II. (vol. VII., suppl.), p. 20, pl. 116, fig. 29.

1900. Cornulites cingulites Clarke, Men. N. I. St. MIns., No. 3, vol. III., p. 27, pl. 2, figs. 35-38.

Description.-Shell having the form of a gradually-tapering, more or less curved or flexuose, ammulated cone. On the internal casts the annulations have the aspect of insheathed concs, the slope being abrupt below and gradual above. The width of the annulations is rariable, but is usuilly a little less than one millemeter; they are somewhat irregular, there occasionally being one which does not entirely smrround the tube.

The dimensions of the best specimen observed, which is nearly straight and incomplete at its maller extremity, are: length, 14.j mm.; diameter at larger end, 4.5; diameter at smaller end, $3 \mathrm{~mm}$.

Remarks.-The New Jersey specimens of this species are from the higher beds of the coermans limestone near Hainesville. 'They agree more closely with Clarke's figures of the species from the Oriskany beds than with Hall's original figures.

\section{MOLLUSCOIDEA.}

BRYOZOA.

$$
\text { PTILODICTYA LOBATA n. sp. }
$$

Plate XXVI., Figs. 4-6.

Description.-Zoarium bifoliate, frondescent in form, slightly undulate, with no monticules. Base of attachment not observed, distal end broad, lobate. 'The mesotheca, along which all the speci- 
mens observed have separated, is marked by more or less irregular concentric lines, which follow the direction of the lobate distal margin. The zoøcia are arranged in longitudinal rows, additional rows being rarely interealated, except along the lines dividing the lobes of the frond; in tangential section they are seen to be elliptical in outline, with their longer axis parallel with the zoœcial rows; those in adjacent rows are alternate in position, so that they appear, also, to be arranged in diagonal lines. The lobation of the zoarium introduces some irregularity in the arrangement of the zoceia along the lines separating the lobes, the parallel lines of openings in each lobe having a different direction, and the openings themselves often being more or less oblique. In vertical section the outer portions of the zoccia are seen to be at nearly right angles to the mesotheca, the basal portion being slightly procumbent; diaphrams are entirely absent, but the superior hemisepta are uniformly present.

Remarks.-As it occurs in the Coeymans limestone in New Jersey, split along the mesothecal wall, this species resembles $P$. frondosi of the Decker Ferry formation, but it may always be distinguished from that species by its lobed distal margin, and in thin sections by the absence of diaphrams. It also resembles $P$. nebulosa Hall, from the Helderbergian of New York, but the internal characters of that species have never been described; that species, however, is not described as being lobate, and in $P$. lobata there are no monticules with larger zoceia shown in the tangential sections.

LICHENALIA TORTA Hall.

Plate XXVI, Figs. 7-8.

188\%. Lichenatia torta Hall, Pal. N. Y., vol. VI., p. 31, pl. 15, figs. $1-5, \%$.

Description.- "Zoarium consisting of lamellate expansions, sometimes flat, at other times more or less involuted or contorted. Under surface a thin epitheca, marked by concentric wrinkles and striæ, with fine, radiating striæ. When the celluliferous tissue of the bryozoum has been removed, the radiating striæ on the upper surface of the epitheca are very sharp and prominent, and at their junction with the concentric striæ form minute nodes. Cell apertures broadly oval 
or circular', sometimes subtriangular or trilobate; diameter $0.30 \mathrm{~mm}$; space between adjacent apertures equal to or less than the diameter of. an aperture. Anterior maruin -lighty aleated, posterior side strongly elevated, with two slight denticulations. Surface with slightlyelevated monticules."-Hall.

MIONOTRYPA SPHAERICA (Hall).

Plate Xxv1., Figs. 9-11.

188\% Favosites sphoricus Hall, Pal. N. Y., vol. VI., p. 9, pl. 7, figs. 1-12, pl. 8, fig. 8 .

Description.-Zoarium massive, subhemispheric or explanate in form, with monticules situated at distances of about $5 \mathrm{~mm}$. Zoœcia polygonal, thin walled, the larger ones $0.5 \mathrm{~mm}$. in diameter and the smaller ones less than $0.25 \mathrm{~mm}$. In the thin, tangential sections the monticules are represented by groups of larger zoccia, with a few much smaller ones interspersed, which appear as scattered mesopores. From the centres of these groups the size of the zoceia gradually diminish to the middle of the interspaces, where the smallest ones occur. The diaphragms are flat and horizontal, averaging about two tube diameters apart, though frequently they are much closer together.

Remarks.-More than one distinct form has probably been confused in Hall's species, Favosites spharicus. Mlost of the specimens illus-

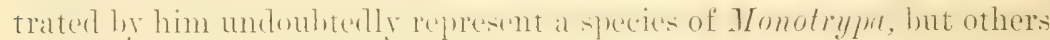
seem to be a true Favosites. In New Jersey the species occurs in the coral bed at the base of the Coeymans limestone.

\section{BRACHIOPODA.}

STROPHEODONTA VARISTRIATA (CON.).

Plate XxVII., Fig. 4.

See, also, p. 261.

Description. - The shell usually identified as this species from the Coeymans limestone is somewhat different from most of its Manlius limestone representatatives. They are usually larger and more 
convex, in the rariety arala much more so, and they are apt to have a proportionately greater width. The surface markings are also different, although in both forms they consist of alternating larger and smaller ridges or striæ. In the Coeymans limestone specimens there is a greater difference between the coarse and fine markings, the coarser ridges being less sharply angular, with about five or six exceedingly fiue filiform stria in the interrening spaces. In the Manlius limestone specimens the median portion of the pedicle valve is usually rather broadly flattened toward the front, while in the Coeyman's limestone individuals no such flattening is observable. The average forms in the trro faumas certainly exhibit sufficient differences to be ranked as distinct species, although they are doubtless genetically related, and are probably comected by intermediate forms. The material in the New Jersey collections is not sufficiently well preserved nor sufficiently abundant to permit the proper limitations and relationships of these forms to be shown, but with the proper material for study it is quite probable that it would be found necessary to recognize two distinct species now included in Strophedonta varistriata.

STROPHEODONTA VARISTRIATA Var. ARATA H.

Plate XXVII., Fig. 3.

1859. Strophodonta varistriata var. arata Hall, Pal. N. Y., vol. III., p. 183, pl. 18, figs. $1 a-i$.

Description.-The shell referable to this variety is closely related to, and grades into, the typical Coeymans limestone form of S. varistriata. It is a more convex and porportionately wider shell, with the coarser, radiating ridges more angular and stronger, with a smaller number of intervening, finer strix, which are really placed upon the sloping sides of the larger ridges, instead of upon a flattened area between adjacent ones. 
STROPHEODONTA PLANULATA Hall.

Plate XxVII., Figs. 1-2.

1859. Stropheodonta planulate Hall, Pal. N. Y., vol. III., p. 184, pl. 16, figs. 9-12.

Description.-Shell plano-convex, subsemi-elliptical in outline, wider than long, the hinge-line equal to, a little greater or a little less than the width of the shell below. Pedicle valve depressed-convex, slightly flattened toward the cardinal extremities, the beak not prominent, cardinal area narrow, linear. Brachial valve flat. Surface marked by fine, rounded, hifumating strie, which become strongly curved as they approach the cardinal margin, about fire or six of them occupying the space of $2 \mathrm{~mm}$. on the margin. 'These radiating markings are crossed by much finer, concentric strix, which are only visible through a magnifying glass, and by a few inconspicuous lines of growth.

The dimensions of a rather small specimen are: length, $28 \mathrm{~mm}$; width, $32 \mathrm{~mm}$; convexity, $2.5 \mathrm{~mm}$.

STROPHEODONTA INDENTA (Con.).

Plate XXVI., Fig. 12.

1838. Leptcona indenta Con., 2d Ann. Rep. N. Y. Geol. Surv., p. $11 \%$.

Description.-Shell small, wider than long, semi-circular or semielliptical in outline, the hinge-line equaling the greatest width. Pedicle ralve convex, umbn prominent, flattened towarl the cardinal angles, most elevated near the middle. Surface marked by strong, subangular, radiating ribs and by finer, (oncentric markings, which are strong in the furrows between the ribs, but scarcely recognizable upon the ribs themsches. giving to the furrows a conspicuous. indented appearance. Brachial valve not seen.

'The dimensions of the hest-preserved specimen observed are: length, $6 \mathrm{~mm}$.; width, $\% .5 \mathrm{~mm}$. 
Remarks.-Conrad's original description of Leptcena indenta was rery meagre, and Hall included the species in Stropheodonta varistriate. In his hibliographic list, however, Schuchert has recognized it as a distinct species, and doubtless he is correct in so doing. None of the New Jersey specimens identified with this species are as large as the one described by Conrad, which is said to be three-fourths of an inch in length, but they are all very characteristically marked by the strong, transverse indentations in the radiating furrows, and may always be recognized by this character.

STROPHONELla PUNCTULIFERA (Con.).

Plate XXVII., Figs. 6-8.

1859. Strophodonta punctulifera Hall, Pal. N. Y., vol. III., p. 188, pl. 21, figs. $4 a-b$, pl. 23, figs. $4 a-c, 5 c, 7 e$.

Description.-Shell subsemi-circular in outline, strongly concavoconver, the hinge-line about equaling the greatest width. Pedicle valve slightly convex on the umbo, then becoming strongly concave to the lateral and front margins; the cardinal area narrow; the beak inconspicuous, scarcely projecting beyond the hinge-line. Brachial ralve slightly concave on the umbo, then becoming strongly convex or geniculate towards the lateral and front margins, following somewhat closely the curvature of the opposite valve. Surface of both valves marked by strong, angular, raised, radiating striæ, which increase by bifurcation and implantation; becoming finer toward the margins. On well-preserved specimens these striæ are seen to be punctate. The interior surface of the valves is pustulose, giving to the surface of internal casts a pitted appearance.

The dimensions of an average-sized individual are: length, $33 \mathrm{~mm}$; width, $50 \mathrm{~mm}$.

Remarks.-This shell is always poorly preserved, the best specimens observed being but fragmentary. It can be easily recognized, howerer, in most cases, by its strong, angular, radiating markings and by the strongly-pitted surface of internal casts. 
ORTHOTHETES WOOLWORTHANA (Hall).

Plate XXVII., Fig. 5.

1859. Strophomena wootworthana Hall, Pal. N.Y., vol. III., p. 192, pl. $1 \%$, figs. $1 a-t, 2 a-c$.

Description.- Shell longitulinally seni-elliptical, hinge-line equaling the greatest width. Pedicle valve slightly convex or flattened on the umbo, concave toward the front, marked interiorly by a broad, flabellate, muscular impression; the beak elevated, but scarcely projecting beyond the cardinal line; cardinal area flat, rather high; delthyrium broadly triangular, closed by a deltidium. Brachial valte conves, flattened on the umbo, most elevated toward the front. Surface of both valves marked by angular, raised, radiating striæ, which are crossed by fine, concentric strix and by a few more conspicuous lines of growth.

The dimensions of an average specimen are: length, $32 \mathrm{~mm}$; width, $34 \mathrm{~mm}$.

\section{LEPTAENA RHOMBOIDALIS Wilck.}

Plate Xxvil., Fig. 9.

See, also, pp. 228, 302, 325, 366.

This species is not a common one in the Cocymans limestone fauma. The specimens observed are of mislium size, one of the most perfect ones being $17 \mathrm{~mm}$. long by $24 \mathrm{~mm}$. wide. As compared with the Decker Ferry representatives of the species, they are larger, with proportionally-finer concentric wrinkles and less sharply-defined radiating strix.

SCHIZOPHORIA BISINUATA $\mathrm{n}$. sp.

Plate XXXI., ligs. 12-14.

Description.- Shell subcircular or transversely subelliptical in outline, the hinge-line about one-half the width of the shell. Pedicle value convex, it greatest depth usually posterior to the middle, from which point it curves abruptly to the cardinal margins, but more gently to the sides and to the front, where there is a broad, shallow, ill- 
defined sinus, which is usually deeper on the two sides, with a rounded elevation in the middle, giving to the shell the appearance of having a double sinus. The beak is of moderate prominence, somewhat incurved over the narrow, concave, cardinal area. Brachial valve more convex than the pedicle, with a broad, low, ill-defined mesial fold toward the front. Surface of both valves marked by fine, radiating stria.

The dimensions of a rather small pedicle valve are: length, $18 \mathrm{~mm}$; width, $21 \mathrm{~mm}$; convexity, $5.5 \mathrm{~mm}$. Those of an average-sized brachial valve are: length, $22 \mathrm{~mm}$; width, $25 \mathrm{~mm}$.; convexity, $7 \mathrm{~mm}$.

Remarks.-This species is closely allied to Schizophoria multistriata H. of the higher Helderbergian beds, but may be distinguished from that species by its more or less conspicuous double sinus in the pedicle valve.

GYPIDULA GALEATA (Dal.).

Plate XxVIII., Figs: 1-8.

1859. Pentamerus galeatus Hall, Pal. N. Y., vol. III., p. 25\%, pl. 46, figs. $1 a-z$, pl. $4 \%$, figs. $1 a-m$.

Description.-Shell subglobose, becoming more and more elongate with age. Pedicle valve gibbous, becoming exceedingly ventricose in the umbonal region in old shells; longitudinally subovate in outline when mature, the younger shells often being transversely subelliptical in outline; the surface smooth in young indivduals, becoming plicated and developing a mesial fold with age; the beak prominent and strongly incurved. Internally the dental plates extend forward from the margins of the delthyrium, and are united to form a prominent spondylium, which is supported by a strong median septum. Brachial valve depressed-convex, usually transversely subelliptical in outline, but sometimes becoming longer than wide in old age. Surface smooth in young shells, and on the umbonal portion of adults, becoming plicated with age and developing a shallow, indefinite median sinus. Surface of both valves marked with low, rounded plications, which are more or less variable in number and in prominence, and which do not reach to the beak, leaving the umbonal region smooth. Toward the beak and upon the umbonal region the concentric lines of growth 
are mistally inconspicuous or obsolete, but towards the anterior margin, in old shells, they become coarse and crowded.

The dimensions of an arerage-sized pedicle valve are: length, 27 mm.; width, $24 \mathrm{~mm}$.; convexity, $14 \mathrm{~mm}$. The dimensions of the largest pedicle valve observed are: length, $44 \mathrm{~mm}$.; width, $31 \mathrm{~mm}$.; convexity, $23 \mathrm{~mm}$.

Remarls.- This shell, in its typical American form, is exceedingly abumdant in the lower beds of the Coeymans limestone, and, except in characters due to different. stages of growth, does not exhibit any great variation. Formerly the species was placed in the genus Pentumerus, and, because of its great abundance, the formation was designater the "Pentamerus limestone" in the older geological and paleontological reports of New York State. The species may always be recognized ly its subglobular form and its smooth umbonal region. Frequently, in breaking the rock containing specimens of this whell, individuals are split longitudinally along the line of the median septum, and in such specimens the characteristic median septum can be clearly seen.

GYPIDULA GALEATA (Dal.) var.

Plate XXYIII, Figs. 9-12.

In the upper portion of the Coeymans limestone near Hainesville there occurs a form of crypidula which may, perhaps, be considered as a variety of $G$. galeata. It differs from the typical American form of the suecies in haring somewhat finer and more conspicuous radiating plications and in having the fold and sinus entirely obsolete.

GIIIDULA ANGULATA n. sp.

Plate XXVIII.; Figs. 13-21.

lhiseriptiun.-Shell subglobular in form, usually wirler than long. Pedicle valve suborate or subquadrate in outline, gibbous; the beak prominent and strongly incurved, the median portion of the shell elerated in a sharply-defined fold, which reaches to the umbonal portion of the valre. The fold is sometimes plane on top, but usually bears thrce prominent, subangular plications which reach to the umbo. The 
lateral slopes convex, rounding into the posterior region of the valve, sometimes bearing a single, subangular plication on each side adjacent to the mesial fold. Brachial valve transversely subelliptical in outline, much less convex than the opposite one, with a more or less aloruptly-depressed median sinus near the anterior margin, which usually contains two well-defined, rounded or subangular plications. The surface of both valves, aside from the plications already described, is smooth, or marked only by inconspicuous lines of growth.

The dimensions of a large pedicle valve are: length, $21 \mathrm{~mm}$.; width, $23.5 \mathrm{~mm}$.; convexity, $11.5 \mathrm{~mm}$. Those of a smaller brachial valve are: length, $13.5 \mathrm{~mm}$.; width, $16.5 \mathrm{~mm}$.; convexity, $4 \mathrm{~mm}$.

Remarks.-This species has only been observed in the upper portion of the Coeymans limestone, associated with the variety of $G$. galeata last described. It differs from G. galeata in its much more prominent fold of the pedicle valve, which is extended further toward the beak, and in its much coarser and more conspicuous subangular plications, which are either restricted to the mesial fold and sinus, or to these portions of the shell and the immediately adjacent parts of the lateral slopes. These characters are constant in all the specimens observed, and they show no intermediate forms connecting them with $G$. galeata, and, as they also occur at a somewhat higher geologic horizon than the typical galeata, is believed that they are worthy of being distinguished as a separate species.

RHTNCHONELLA SEMIPLICATA (Con.).

Plate XXIX., Figs. 12-19.

1859. Rhynchonella semiplicata Hall, Pal. N. Y., vol. III., p. 224, pl. 29, figs. $1 a-0$.

Description.-Shell small, subtriangular or suboval in outline. Perlicle valve with a closely-incurved beak, smooth on the umbo and to about the middle of the shell; plicated toward the margin, the mesial portion depressed toward the front in a rather deep sinus, usually with a. single, short, median plication. Brachial valve a little more convex than the pedicle, smooth posteriorly, with an elevated mesial fold toward the front, and plications toward the margin. Both valves marked by two or three angular plications on each side of the fold 
and simus, which do not extend beyond the middle of the shell, and usually by a single median plication in the fold and sinus. In the younger individuals, before the plications legin to be developerd, the surface is entirely smooth.

The dimensions of a full-grown individual are: length, $5.5 \mathrm{~mm}$.; width, $5.5 \mathrm{~mm}$.; thickness, 3..5 $\mathrm{mm}$.

Remarks.-This little species resembles younger individuals of $R$. altiplicata, but may always be distinguished by the smooth posterior portion of the shell, the plications ending at about the middle, while in $R$. altiplicata they reach nearly to the beak.

RIINCHONELLA ALTIPLICATA Hall.

Plate XxIX., Figs. 2t-27.

1859. Phtynchonella altiplicata Hall, Pal. N. Y., vol. III., p. 231, pl. 33 , figs. $2 a-k$.

Description.-Shell broader than long, subtriangular or broadly subovate in outline. Pedicle valve with a pointed, incurved beak, depressed anteriorly in a deep, angular sinus, which extends to the umbo and hears a single, strong, angular, median plication. Brachial valve more convex than the pedicle, elevated in front in an angular mesial fold. Both valves marked by three or four simple, angular plications on each side of the fold and sinus, which continue nearly to the beak, and with a single median plication on the fold and sinus.

The dimensions of a large specimen are: length, $8.5 \mathrm{~mm}$.; width, $10.5 \mathrm{~mm}$.; thickness, $6.5 \mathrm{~mm}$.

Remarks.-This species, as described in the New York Paleontology, is typically a member of the fauna of the New Scotland beds, but in New Jersey the shell so identified occurs in the Coeymans limestone, where it rarely grows as large as in New York. Usually the shell does not attain a greater length than $6 \mathrm{~mm}$., but oceasionally an individual is observed fully as large as the New York representatives. It resembles the associated li. semiplicute, and sometimes seems to grade into that species, but typically it is proportionally broader and is marked by plications which reach much nearer to the beak. 
REIYYCIONELLA TRANSVERSA Hall.

Plate XXIX., Figs. 2S-31.

1859. Rhynchonella transversa Hall, Pal. N. Y., vol. III., p. 234, pl. 3t, figs. 9-16.

Description.- Shell subtriangular in outline, wider than long, the postero-lateral margins meeting at the beak in an angle of $90^{\circ}$ or a little more. Pedicle valve depressed-convex, most prominent on the umbo; depressed anteriorly in a rather broad, rounded sinus; the beak pointed, incurved over that of the opposite valve. Brachial valve more convex than the pedicle, flattened on the umbo, elevated anteriorly in a prominent mesial fold. Surface of each valve marked by about fifteen simple, angular plications, which extend to the beak, about three of them being included in the fold and sinus.

The dimensions of an average-sized individual are: length, $8 \mathrm{~mm}$; width, $10 \mathrm{~mm}$; thickness, $5.5 \mathrm{~mm}$.

\section{UNCINULUS MUTABILIS (Hall).}

Plate XXIX., Figs. 1-5.

1859. Rhynchone7la mutabilis Hall, Pal. N. Y., vol. III., p. 225, pl. 29 , figs. $4 a-0$, pl. 30, figs. $1 a-e, 2 a-r$.

Description.--Shell subglobose, usually longer than wide. Pedicle valve strongly convex, most prominent on the umbo; beak small, pointed, closely incurved over that of the opposite valve, the anterior margin produced into a linguiform extension nearly at right angles to the plane of the valve and fitting into a corresponding sinus in the margin of the brachial valve. The mesial portion of the valve, opposite the lingual extension, slightly depressed anteriorly into a shallow, more or less inconspicuous mesial sinus. Brachial valve usually a little more convex than the opposite one, its beak closely incurved under that of the pedicle valve. Toward the front its mesial portion is slightly elevated in an indistinct, depressed fold. Surface of each valve marked by twenty-two to twenty-eight depressed, 
romnded, simple plications, which reach to the beak, about six or eight of them being included in the sinus and lingual extension of the perticle valve, with a corresponding number on the fold of the brachial valve. Toward the front each plication is marked by a slight median groove.

The dimensions of a nearly perfect specimen are: length, $19 \mathrm{~mm}$; width, $1 \% \mathrm{~mm}$.; thickness, $18 \mathrm{~mm}$.

UNCINULUS NUCLEOLATUS (Hall).

Plate XXIX., Figs. 6-9.

1859. Rhynchonella nucleolata Hall, Pal. N. Y., vol. III., p. 22\%, pl. 31, figs. $1 a-f, 2 a-y$.

Description. - Shell subglobular or subcubical in form, longer than wide, the anterior view subquadrangular. Pedicle valve suboval or subpentagonal in outline, flattener on the umbo, the lateral and front margins bending moro or less abruptly to the line of junction of the two valves. The median portion of the valve depressed toward the front in a shallow sinus. which is produced anteriorly into a linguiform extension at nearly a right angle to the plane of the valve. Brachial valve more convex than the pedicle, its lateral margins bending abruptly to meet the margin of the opposite valve. The mesial fold ill-elefincel, sarcery distinguishable axcept close to the front margin. Surface of each valve marked by from eighteen to twenty-two depressed, rounded, simple plications, grooved near the margins of the valves and extending to the beak. From three to five plications are included in the mesial sinus of the pedicle valve, with a corresponding number on the fold of the brachial valve.

The dimensions of a perfect specimen are: length, $17 \mathrm{~mm}$. ; width, $13 \mathrm{~mm}$ : thickness, $13 \mathrm{~mm}$.

Remarks. - This shell resembles $U$. mutabilis, but is less nearly globular and has coarser and fewer plications. 
UNCINULUS PYRAMID.ITUS (Hall).

Plate XXIx., Figs. 10-11.

See, also, p. 309.

1859. Rhynchonella pyramidata Hall, Pal. N. Y., vol. III., p. 229, pl. 32, figs. $1 a-z, 2 a-d$.

Description.- Shell subglobular or subpyramidal in form, suboval or subpentagonal in outline, length and breadth equal or broader than long. Pedicle valve depressed-convex, more or less sharply deflected along the postero-lateral margins, the beak rather blunt, closely incurved over that of the opposite valve; the anterior margin produced in a lingual extension, which is bent at nearly right angles to the plane of the valve, the mesial sinus but slightly depressed. Brachial valve very gibbous toward the front, sloping with a gentle, convex curve from near the front margin to the beak; umbo flattened, incurved under that of the opposite valve. Surface of each valve marked by thirteen to eighteen simple, rounded plications, which are flattened or slightly grooved toward the front margin. Three or four plications are included in the sinus and lingual extension of the pedicle valve, with a corresponding number on the fold of the brachial valve. The plications of the pedicle valve become obsolescent upon the umbo and do not reach the beak; those of the brachial valve become much fainter, but do not wholly disappear on the umbo.

The dimensions of a nearly-perfect individual are: length, $16 \mathrm{~mm}$; width, $16 \mathrm{~mm}$.; thickness, $16 \mathrm{~mm}$.

Remarks.-This species is most closely related to Unicinulus nucleolatus, and it is quite possible that the two grade into one another. Typically $U$. pyramidutus has somewhat coarser plications, which are not so conspicuously grooved toward the front margin, and the brachial valve is much more elevated in front, giving it a subpyramidal form. In the Coeymans limestone the species does not grow so large as in the New Scotland beds. It has been found in this formation only in the higher beds near Hainesville. 


\section{RIINCIIOTRETA TRANSVERSA n. sp.}

Plate XxIx., Figs. 32-39.

Description.-Shell small, broadly subtriangular, valies subequally (onvex, aratest width antrior to the midille, the mostero-lateral slopes flattened, meeting at the beak in an angle of less than $90^{\circ}$. Pedicle valve depressed-convex, the beak slightly attenuate, sharply pointed, erect, the delthyrium broadly triangular, the median portion of the valve depressed anteriorly in a shallow simus. Brachial valve depressedconvex, the median portion slightly elevated in front in an indefinite fold, the beak sharply incurved. 'The surface of each valve marked by from seven to nine simple, angular plications, which continue to the beak, one being included in the sinus of the pedicle valve and two elevated in the fold of the brachial valve.

The dimensions of a very perfect individual are: length, $5.5 \mathrm{~mm}$. width, $6.5 \mathrm{~mm}$; thickness, $2 \mathrm{~mm}$. Those of another more mature specimen are: length, $6 \mathrm{~mm}$.; width, $7.5 \mathrm{~mm}$.; thickness, $3 \mathrm{~mm}$.

Remarks.-In its sharply-pointed, erect beak, in the form of the delthyrium and in the flattened postero-lateral slopes, this little shell resembles Phynchotreta cuneata of the Niagaran faunas, and the two shells are believed to be cogeneric. It differs from the Niagaran shell, however, in its smaller size and its greater proportionate breadth. 'The species is not uncommon in the higher beds of the Coeymans limestone near Hainesville, but has not been observed elsewhere.

ATRYPA RETICULARIS (Linn).

Plate XXX., Figs. 11-1s.

See, also, pp. 236 and 369.

Description.-Shell subelliptical in outline, longer than wide. Pedicle valve depressed-conver, with a shallow, rounded mesial sinus extending from near the middle to the front margin; beak small, pointed, closely incurved over that of the opposite valve. Brachial valve gibbous or ventricose, its greatest convexity a little back of the 
middle, from which point it curves regularly to the margin on all sides. Surface of each ralve marked by about forty bifurcating plications, which are crossed by concentric lamellæ of growth.

The dimensions of a nearly perfect individual are: length, $25 \mathrm{~mm}$; width, $23 \mathrm{~mm}$; thickness, $18 \mathrm{~mm}$.

Remarks.-This is a variable form, the description given being made to fit the more usual form of the species as it occurs at this horizon. The most conspicuous variations of the species are the relative convexity of the two valves, which are sometimes almost equally convex, and the number and size of the plications. The representatives of the species in the Coeymans limestone, as well as in the Helderbergian fauns generally, are usually more finely plicated than those of the Decker Ferry fauna.

SPIRIFER CYCLOPTERUS Hall.

Plate XXX., Fig. 2.

See, also, p. 314, pl. XXXVIII.

The genus Spirifer is usually not abundantly represented in the fauna of the Coeymans limestone, except at the very top of the formation, where several species occur. The commonest, and almost the only member of the genus in the midst of the formation, is a shell which has been identified as S. cyclopterus, a species which, as originally described, is typically a member of the fauna of the New Scotland beds. The Coeymans limestone specimens in New Jersey are all more or less fragmentary, and in none of the full-grown ones is the surface perfectly enough preserved to retain the characteristic, concentric and fimbriate markings of the species. A few small specimens, which are apparently the young of this species, agree closely with specimens of $S$. vanuxemi from the Manlius limestone, and at first were so identified, and some of these retain the fine surface markings of the species. It is possible that $S$. vanuxemi is ancestral to this Helderbergian species. 


\section{SPIRIFER MIAROPLEURUS (Con.).}

Plate XXX., Fig. 1.

See, also, p. 313, pl. XXXVII.

A single specimen referable to this species, belonging typically in the fauma of the New Scotland beds, has been observed in the Coeymans limestone associated with Gypidula galeatus and other typical members of the fauna. It is a pedicle valve, and is smaller than the usual size of the species in the higher fauna, it having a length of 19 $\mathrm{mm}$. and a width of $28 \mathrm{~mm}$.

\section{SPIRIFER OCTOCOSTATUS Hall.}

Plate XXX., Figs. 5-8.

1859. Spirifer octocostatus Hall, Pal. N. Y., vol. III., p. 205, pl. 28, figs. $4 a-e$.

Description.- Shell wider than long, the hinge-line shorter than the greatest width, cardinal extremities rounded, anterior margin broadly rounded. Pedicle valve rather strongly convex, most elevated on the umbo, beak prominent, incurved over the short, ill-defined concave cardinal area, delthyium broarlly triangular, the median sinus smooth, continuing to the beak, subangular in the bottom. Brachial valve a little less convex than the pedicle, most prominent in the middle, the mesial fold slightly or not at all elevated above the lateral slopes. Surface of each valve marked by about four prominent, subangular plications on each side of the fold and sinus.

The dimensions of a nearly-perfect brachial valve are: length, 10 mm.; width, $19 \mathrm{~mm}$.

Remarks. - This species has only been observed in the higher beds of the Coeymans limestone near Hainesville. All the specimens observed are fragmentary, and the finer surface characters have been destroyer hy exfoliation, hut near the front margin of one of the bestpresired specimens sereral conspicuous, concentric lines of growth may be detected. 


\section{SPIRTFER CONCINNUS Hall.}

Plate Xxx., Fig. 3.

1859. Spirifer concinnus Hall, Pal. N. Y., vol. III., p. 200, pl. 25, figs. $2 a-i$, pl. 28 , figs. $7 a b$.

A single imperfect brachial valve from the upper beds of the Coeymans limestone near Hainesville is referable to this species. The hinge-line is about equal to the greatest width of the shell, the lateral margins meeting the cardinal margin at about right angles. The mesial fold is prominent and rounded, continuing to the beak, without plications. Each lateral slope is marked by eight simple, rounded plications, which become fainter toward the cardinal margins, the last two or three being almost obliterated by reason of the exfoliated condition of the specimen.

The dimensions of the specimen are: length, $13 \mathrm{~mm}$; width, 18 $\mathrm{mm}$.

CIRTINA sp. undet.

Plate XXX., Figs. 9-10.

In the upper beds of the Coeymans limestone near Hainesville there occurs a species of Cyrtina which seems to be different from the only described Helderbergian species, C. dalmani Hall. The material is too imperfect for certain identification or for description. The larger specimens of the pedicle valve have a very high, slightlyconcave, cardinal area, with a broad delthyrium. The median sinus is rather broad and shallow, and each lateral slope of the shell is marked by about three, broadly-rounded plications.

RHYNCHOSPIRA FORMIOSA (Hall).

Plate XXXI., Figs. 9-11.

See, also, p. 240.

This species has already been described from the Decker Ferry formation, although it is typically a member of the Helderbergian faunas. The Coeymans limestone specimens are usually somewhat more finely plicated than those in the Decker Ferry fauna, but they 
vary considerably in this character, a specimen occasionally being observed which has fully as coarse plications as the earlier ones. The species varies considerably in size, one of the larger specimens observed being $18 \mathrm{~mm}$. long by $1 \% \mathrm{~mm}$. wide, which is considerably larger than any which have been seen in the Decker Ferry fauna.

\section{MERISTELLA LAEVIS (Van.).}

Plate XXXI., Figs. 1-8.

See, also, p. $\$ 17$.

The representatives of this species in the Coeymans limestone fauna of New Jersey are all small, it rarely attaining a length of more than $10 \mathrm{~mm}$. At the very summit of the formation near Hainesville, however, some larger individuals have been observed, one being 16.5 $\mathrm{mm}$. in length and another $18 \mathrm{~mm}$. They agree in all respects with the younger individuals of the species as it occurs in some of the higher beds, being smooth, longitudinally subovate shells, with no sinus in the pedicle valve except in the case of the somewhat larger individuals already mentioned from the top of the formation.

NUCLEOSPIRA VENTRICOSA Hall.

Plate XXX., Figs. 19-2:2.

1859. Nucleospira ventricosa Hall, Pal. N. Y., vol. III., p. 220, pl. 14, figs. $1 a-n$, pl. $28 B$, figs. 2-9.

Description.- Shell small, subglobose, usually a little wider than long, the valves subequally convex. Pedicle valve with a narrow and shallow mesial depression, which becomes faint or almost obsolete on the umbo; the beak closely incurved over that of the brachial valve. Brachial. valve with a merlian depressed line which is less conspicuous than that of the pedicle valve. Surface marked by indistinct, concentric lines of growth; when perfect, covered with minute hair-like spines.

The dimensions of a small, but nearly perfect individual, are: length, $6 \mathrm{~mm}$; width, $6.25 \mathrm{~mm}$.; thickness, $4.25 \mathrm{~mm}$.

Remarks.-This little species has been observed in the Coeymans limestone, only in the upper beds, near Hainesville. 


\section{IMOLLUSCA.}

\section{PELECYPODA.}

\section{RHOMBOPTERIA CLATHRATUS n. SP.}

Plate XXxi., Figs. 16-18.

Description.-Shell inequivalvate, oblique, subrhomboidal in outline, the anterior and posterior margins subparallel, the hasal margin rounded. Hinge-line straight, produced anteriorly, as well as posteriorly from the beak, which is located anterior to the middle. Left valve strongly convex transversely across the umbonal ridge, scarcely auriculate in front, a shallow, indefinite sinus extending from the beak nearly vertically to the anterior margin. Surface marked by broad, concentric bands, which, on their lower margins and reaching for more than half their width, are crossed by two sets of fine strix, making an angle with each other. The right valve associated with this shell, and doubtless belonging to it, is nearly flat, with rounded, concentric wrinkles, not marked by the cross-lines of the left valve.

A left valve somewhat larger than the average has a height, obliquely from the beak to the basal margin, of $22 \mathrm{~mm}$.; its width, at right angles to this line, is $15 \mathrm{~mm}$., and its convexity, $5 \mathrm{~mm}$.

Remarks.-This species is rather common in the uppermost beds of the Coeymans limestone near Hainesville. The left valves are by far the most common, but very few specimens of the right valve, and all of these small, having been observed. Many of the specimens are entirely exfoliated, so that only the concentric bands can be recognized, the finer cross-lined surface markings being wholly obliterated. On the casts the anterior sulcus, extending vertically downward from the beak, is far more conspicuous than when the shell is preserved, and consequently, also, the anterior auriculation of the shell.

In general form and in surface markings this species resembles Rhombopteria mira Barr., from Bohemia, which has been made the type of the genus by Jackson,* but the anterior cardinal angle is more broadly rounded in the American shell and it is less auriculate anteriorly.

\footnotetext{
* Mem. Bost. Soc. Nat. Hist., vol. IV., No. 8, p. 380.
} 
RHOMBOPTERIA CLATHRATUS var.

Plate XxxI., Fig. 15.

In the Coermans limestone near Peter's Valley a single specimen of Rhombopteria has been observed, which may represent a species distinct from the shell just described. The single imperfect specimen is not sufficient, however, to determine this with certainty, and it may for the present be considered as a variation of $R$. clathratus. Its contour is more irregular than that of the trpical form of the species, the beak is more anterior and the anterior auriculation is more pronounced. The surface is, for the most part, exfoliated, but enough is retained to determine that its markings are essentially identical with $R$. clathratus.

\section{ACTINOPTERTA COMMUNIS (Hall).}

\section{Plate XXXI., Fig. 21.}

1859. Avicula communis Hall, Pal. N. Y., vol. III., p. 286, pl. 52, figs. $1-\%, \mathrm{pl} .53$, figs, $1,4,6$.

Description.-"Shell obliquely ovate; the left valve gently convex in the middle, and becoming gibhous towarls the beak, which, in the young shell, is narrow and projecting above the hinge-line; right valve flat or gently concave in the middle and below, and becoming slightly convex on the umbo; anterior side gently curving to the base, which is broadly rounded, the curvature of the posterior side being more abrupt; anterior wing small, trigonal, obtuse at its extremity, strongly defined from the body of the shell; posterior wing three times as long as the anterior wing, obtusely or subacutely pointed, extending more or less beyond the margin of the shell, concave on the outer or lateral margin, its junction with the body of the shell not strongly defined.

"Surface of left valve marked by slender, sharply-defined, rounded radii, the principal of which are distant from two to four or fire times their width, and the spaces occupied by one, two or three finer interstitial, radiating striae (these radii are but faintly, and some- 
times not at all, perceptible on the posterior wing, except along its upper margin, while they are not seen on the anterior wing), concentrically marked by fine, lamellose striæ, which, in the more perfectly-preserved surfaces, are elevated and subimbricating; these strix are usually conspicuous on both the anterior and posterior wings. Surface of the right valve marked by broader and scarcely elevated radii and less-defined concentric striæ."-Hall.

Remarks.-Fragments of a winged pelecypod shell are occasionally found in the Coeymans limestone, which are apparently to be identified with this species. No specimens perfect enough for description have been observed, so that the above description has been copied from the New York Paleontology.

CONOCARDIUN sp. undet.

Plate XXXI., Figs. 19-20.

Representatives of the genus Conocardium are rare in the Helderbergian faunas. A single specimen from the Coeymans limestone near Peter's Valley is too fragmentary for identification or description, but when complete it must have been a shell $15 \mathrm{~mm}$. in height by 18 $\mathrm{mm}$. in length. It is marked by flat ribs about equal in width to the flat-bottomed grooves which separate them.

\section{GASTROPODA.}

BULIMORPHA? HELDERBERGIAE n. sp.

Plate XXXII., Fig. 8.

Description.-Shell small, with five or six volutions, apical angle about $45^{\circ}$, the apex obtuse. Surface of the volutions depressed-convex, the suture shallow. Aperture subovate in outline, outer lip entire, columella lip smooth. Surface nearly smooth, with very fine lines of growth, which can only be detected with the aid of a lens.

The dimensions of a nearly-perfect specimen are: length, $\% .5 \mathrm{~mm}$.; diameter of last volution, $4.5 \mathrm{~mm}$. ; height of aperture, $4.5 \mathrm{~mm}$. 
Remarks.-This species from the upper beds of the Coeymans limestone near Hainesville resembles the little shells from the Carboniferous faunas, to which the name Bulimorpha has been applied by Whitfield.* So far as the specimens are preserved, they seem not to be generically distinct from Carboniferous specimens, and may be referred provisionally to that genus.

LOXONEMA? sp. undet.

Plate XXXII., Figs. 9-10.

Description.- Shell with a highly-elevated spire, apical angle about $21^{\circ}$, volutions eight or more in number, regularly convex, gradually apanding, the suture moderately deep. Aperture not well preserved, but apparently subcircular in outline. Surface nearly smooth, but with a magnifying glass exceedingly-fine lines of growth may be detected.

With the apex completed, the dimensions of a full-grown specimen are, approximately: length, $20 \mathrm{~mm}$.; diameter of last whorl, $6.5 \mathrm{~mm}$.

Remarks.-More or less fragmentary specimens of this little shell are rather common in the higher beds of the Coeymans limestone near Hainesville. In none of them is the apex of the spire preserved, so that the total length of the shell and the total number of rolutions have never been observed. It is quite possibly an unnamed species, but better material should be available for comparison with other forms.

PLATyCeras gibBosum Hall.

Plate XXXII., Figs. 5-7.

1859. Platyceras gibbosum Hall, Pal. N. Y., vol. III., p. 323, pl. 59, figs. $6 d-g, \% a$.

Description. "Shell obliquely subovoid, with one or two closelycontiguous volutions at the apex, from which the last one expands more or less rapidly, becoming ventricose in the middle and below;

\footnotetext{
* Bull. Am. Mus Nat. Hist., vol. I., No. 3, p. 74.
} 
upper part of the last volution rounded, becoming angular and plicate below: aperture somewhat rounded; peristome sinuous. Surface marked by fine, undulating, transverse strix. which are crossed by much finer, obscure or obsolete, longitudinal striæ."-Hall.

Remarks.-This type of gasteropod shell is not common in the Coeymans limestone fauna, most of the specimens observed being from the upper beds near Hainesville. Those which are well enough preserved for identification seem to agree most closely with Hall's figures and description of $P$. gibbosum, and are consequently so named.

TENTACULites ELONGATUS Hall.

Plate XXxII., Fig. 4 .

See, also, pp. 319 and 363.

Fragments of this species are occasionally present in the Coeymans limestone fauna. They are usually in the form of internal casts, but the surface of the shells may occasionally be observed. The casts have the appearance of being a series of truncated cones placed end to end, each one being slightly smaller than the preceeding one, and forming a series of anmulations, of which the lower slope is perpendicular and the upper one very gradual. Externally the annulations are rounded, the entire outer surface of the shell being marked by fine, annular striæ.

\section{ARTHROPODA.}

\section{TRILOBITA.}

DALALANITES PLEUROPTYX (Green).

Plate XXXII., Fig. 1.

1859. Dalmania pleuroptyx Hall, Pal. N. Y., vol. III., p. 356, pl. \%, figs. 1-12, pl. $\% 5$, fig. 1.

Description.- "Pygidium triangular, transversely convex; the posterior extremity acute, attenuate; the axis a little depressed toward the lower extremity, which rises in strong relief above the border 
below. The axis is gradually attenuate, the width at the posterior extremity being about onc-third as great as at the anterior extremity, which is about five-eighths as wide as the greatest width of the lateral lobe at its upper margin; its outline is curved and sometimes scarcely carinate, the latter feature more often seen in the casts. The number of articulations in the axis is serenteen; and on each of the latera! lobes are eleven to thirteen ribs, which are little wider than the furrows which separate them, the whole bending downards toward the outer extremities and uniting in a thickened border. Each rib of the lateral lobe is marked by a longitudinal groore, parallel with the margin and a little nearer to the upper than the lower margin."Hall.

The dimensions of a full-grown pygidium are, approximately: length, $53 \mathrm{~mm}$; breadth, $68 \mathrm{~mm}$.

Remarks.-Only the pygidium of this species has been detected in the New Jersey collections, and the specimens observed are, in almost every case, mere fragments. There is no doubt, however, of the identity of these imperfect specimens with this rather common species of the New York Helderbergian fauna.

proetus protuberans Hall.

Plate XXXII., Fig. 2.

1859. Proetus protuberans Hall, Pal. N. Y., vol. III., p. 351, pl. 73, figs. 5-8.

Only the pygidium of this species has been observed in the fauna of the Coeymans limestone in New Jersey. The only specimens observed are fragmentary, but they can be distinguished from the pygidium of Phacops logani by the flattened marginal border. 
Descriptions of Species in the New Scotland-Becraft Fauna.

\title{
COELENTERATA.
}

\author{
SPONGIAE. \\ HINDIA FIBROSA (Roemer). \\ Plate XXXIII., Figs. 1-2.
}

1883. Hindia fibrosa Hinde, Cat. Foss. Sponges Brit. Mius., p. 5\%, pl. 13, figs. 1-1 $b$.

1895. Hindia fibrosa Girty, 14th Ann. Rep. N. Y. State Geol. for 1894, p. 263.

Description.- "Sponges globular in form, with an even, rounded surface and without peduncle or any point of attachment. The specimens vary between $13 \mathrm{~mm}$. and $38 \mathrm{~mm}$. in diameter. As seen in section through the centre, the growth of the sponge commences with a small, foreign body or even loose tissue in the centre, from which extend minute, straight canals, about $0.3 \mathrm{~mm}$. wide, in close proximity to each other, to the outer surface. The canals are circular or polygonal in section; their walls are formed by the spicular skeleton. The individual element of the skeleton appears to have a thickened, spherical centre, from which four to six short arms radiate in different directions, and by their attachment to the ends of adjoining spicular arms form a continuous, open, very regular mesh. The spicular arms or rays appear to be either smooth or tuberculated. No special surface-spicules have been preserved."-Hinde.

Remarks.-This sponge has been observed in New Jersey only in the lower, cherty limestone member of the New Scotland beds. In most cases the spicular mesh surrounding the radiating canals has been dissolved, leaving only the empty mould. Such specimens are always siliceous, and may be easily recognized by their globular form and their radiate, spicular structure, which may be seen when the specimens are broken. Occasionally, however, specimens are preserved in the peculiar condition described by Girty, in which the radiating canals appear to be entirely surrounded by double walls, between which 
is preserver an imperfect cast of the spicular framework. Such specimens show a strong resemblance to a small, globular, Favosite coral. According to Girty, the size of the species has a considerably-greater variation than that indicated by Hinde, the specimens he studied ranging from $6 \mathrm{~mm}$. to $64 \mathrm{~mm}$. in diameter. The New Jersey specimens are usually from $15 \mathrm{~mm}$. to $20 \mathrm{~mm}$. in diameter.

\section{ANTHOZOA.}

STREPTELASMA STRICTUAI Hall.

Plate XxxIII., Figs. 3-4.

188\%. Streptetasma strictum Hall, Pal. N. Y., vol. VI., p. 1, pl. 1, figs. $1-10$.

Description.- "Corallum simple, conical, very gradually and regularly enlarging; straight or very slightly curred, except at the apex, which is sometimes more ahruptly bent. Exterior marked with strong undulations of growth and numerous, fine, concentric strix; external rays very prominent, from forty-five to fifty at a point where the diameter of the corallum is $15 \mathrm{~mm}$., the increase in numbers taking place usually at three distinct points, but sometimes at only two. Calyx deep, sides thin and nearly erect; a flat space at the bottom. In one calyx, having a diameter of $20 \mathrm{~mm}$., there are fifty-four lamellax; alternate lamellax extending only al short distance from the walls at the base of the calyx and frequently coalescing with the primary lamellæ. For some distance below the calyx-margin the lamellæ are of the same size, their edges smooth and rounded, becoming sharp below, and their sides often distinctly granulose or spinulose. The primary lamellæ unite and coalesce at the centre of the calyx, forming an indistinct plate or vesiculose core from 3 to 5 mm. in diameter. Fossette obscure or obsolete. This species is distinguished by the usually rigid straightness of its form and the strongly-ribbed exterior."-IIall. 


\title{
ECHINODERIMATA.
}

\author{
CRINOIDEA. \\ ICTHYOCRINUS MAGNARADIALIS n. sp.
}

Plate XXXIII., Fig. 5.

Description.-Caylx cup-shaped, truncated at the base, the sides flaring at an angle of about $58^{\circ}$. Underbasal plates not exposed. Basal plates large, sharply pointed above, the distal angles reaching nearly one-half the distance from the base to the tops of the radials. Radial plates large, pentagonal, about as broad as high, pointed below. A single costal, very much wider than high, follows the radial in each ray and supports two series of distichals above. Brachial plates not known above the second distichals. Anal and radianal plates absent.

The dimensions of the type specimen are: height of calyx to top of radials, $6 \mathrm{~mm}$.; diameter of calyx at top of radials, $11 \mathrm{~mm}$.; height of costals at their lateral extremities, $1 \mathrm{~mm}$.; width of costals, $6 \mathrm{~mm}$.

Remarks. - This species may be easily distinguished from all other heretofore-described species of the genus Icthyocrinus by its large basal and radial plates and the rery short costals, it haring more the aspect of members of the genus Lecanocrinus, but lacking the anal and radianal plates of that genus. This is the first recognition of a Helderbergian or Devonian species of the genus, it having previously been recognized only in the Niagaran faumas and in the much younger lower Mississippian faunas.

\section{MOLLUSCOIDEA.}

BRYOZOA.

In some localities the lower, cherty beds of the New Scotland formation contain an abundance of bryozoans, belonging to several genera and species, but their condition of preservation is not satisfactory for proper study. 


\title{
BRACHIOPODA.
}

\author{
GLOSSINA SPATIOSA (Hall).?
}

Plate XXXIII., Fig. 6.

1859. Lingula spatiosa Hall, Pal. X. T., vol. IIT., p. 158, pl. 9, figs. $10-10 a$.

In the lower cherty limestone member of the New Scotland beds near Hainesville a single specimen of a rather large, linguloid shell has been observed, which may belong to this species. It is broadly triangular in form, resembling G. spatiosa more closely than any other described Helderbergian species, but beyond this it has no characters preserved which can be used for identification.

Pholidops ovata Hall.

See, also, p. 226, pl. XX.

Occasional specimens of a small species of Pholidops may be detected in the strata of the New Scotland formation, especially upon the weathered surfaces of the cherty limestone beds. The specimens are usually poorly preserved, but, so far as can be determined, they seem to be members of the species $P$. ovata.

\section{STROPHEODONTA BECKEI Hall.}

Plate XxxiII., Figs. T-8.

1859. Strophodonta beckii Hall, Pal. N. I., vol. III., p. 191, pl. 22, figs. $1 a-t$.

Description.- Shell subsemi-elliptical to subquadrate in outline, length and breadth sometimes equal, but usually the length is from two-thirds to three-fouths the width; hinge-line crenulate, nsually equaling the greatest width. Pedicle valve depressed convex, beak small and inconspicuous, cardinal area linear. Brachial valve nearly flat or a little concave near the hinge-line. Surface of both valves 
marked by fine, irregularly bifureating, raised, radiating striæ, and by strong, more or less irregular, concentric wrinkles, which curve outward on approaching the cardinal margin.

The dimensions of a large specimen are: length, $37 \mathrm{~mm}$.; width, $46 \mathrm{~mm}$.

Remarks.-This species occurs occasionally in the lower cherty limestone of the New Scotland beds, is of more common occurrence in the shaley members of the formation, but is most conspicuous in the Becraft limestone, where it occurs in great abundance. The species may always be recognized by its strong, concentric wrinkles, resembling, in this character, Leptona rhomboidalis, with which species it may sometimes be confused when imperfectly preserved. L. rhomboidalis, however, is always strongly geniculate towards the front, the concentric wrinkles being confined to the posterior, flattened portion of the shell, while in $S$. beckei the depressed-convex form of the shell continues to the margin, as do the concentric markings. The crenulated hinge-line of $S$. beckei would also always distinguish the two species, but this is a character which is rarely preserved.

\section{STROPHEODONTA sp. undet.}

There are in the New Scotland beds and the Becraft limestone, and especially in the latter formation, more or less numerous specimens of Stropheodonta, which doubtless represent several species. They are all so poorly preserved, however, that their surface characters have been practically destroyed, and it is not possible to identify them. One or two forms are possibly undescribed species, but much better material must be had before their characters can be made out satisfactorily.

STROPHONELLA PUNCTULIfERA (Con.).

Plate XXXIII., Fig. 9.

See, also, p. 277.

This species has already been described from the Coeymans limestone. The New Scotland and Becraft limestone specimens are similar in all respects to those of the preceding fauna, and their state of preservation is much the same, all the specimens observed being fragmentary. 
STROPHONELLA LEVENWORTHANA (Hall).

Plate XXXIV., Figs. 1-3.

1859. Stropheodonta levenworthana Hall, Pal. X. Y., vol. III., p. 189, pl. 21, figs. 5-7, pl. 23, figs. 1-2.

Description.- Shell longitudinally semi-elliptical, length greater than the breadth. hinge-line cremulated. afualing the greatest width of the shell. Pedicle valve depressed-convex on the umbo, flattened toward the cardinal margin, abruptly inflected toward the lateral and front margins, giving to the entire valve a deep concavity; beak inconspicuous, cardinal area linear. Brachial valve slightly concave in the umbonal region, strongly convex or geniculate toward the front and lateral margins, following somewhat closely the curvature of the opposite valve. Surface of both valves marked by fine, irregularlybifurcating, raised, radiating strix, which are crossed on the flattened portion of the valves by more or less irregular, concentric wrinkles.

The dimensions of a large specimen are: length, $36 \mathrm{~mm}$; width, $4.3 \mathrm{~mm}$. ; convexity of brachial valve, $15 \mathrm{~mm}$.

Remarks. - This is one of the rarer species of the New Scotland fauna in New Jersey, and has been observed only in the lower cherty limestone member of the formation, where it is always in a poor condition of preservation. In some respects the species resembles Leptana rhomboidatis, but, when compared with that species, it is resupinate, the pedicle, and not the brachial, valve being the strongly-concave one. This character, with the crenulated hinge-line, which can only rarely be detected in the New Jersey specimens, will always distinguish the two species. The species also somewhat resembles Stropheodon ta beckei in its markings, but in that species the pedicle valve is depressed-convex and not deeply concare, as in the shell under discussion.

LEPTAENA IIHOMBOIDALIS (Wilck.).

Plate Xxxil., Fig. 10.

See, also, pp. 228, 27s, 328, 366.

The New Scotland and Becraft representatives of this species do not materially differ from those in the Coeymans limestone fauna, although they frequently attain a somewhat greater size. 


\section{ORTHOTHETES WOOLWORTHANUS (Hall).}

Plate XXXIV., Figs. 4-5.

See, also, p. 278, pl. XXYiI.

This species, as it occurs in the New Scotland beds, differs in no respect from the Coeymans limestone specimens.

$$
\text { ORTHOSTROPHIA STROPHOAENOIDES (Hall). }
$$

Plate Xxxiv., Figs. 6-8.

1859. Orthis strophomenoides Hall, PaI. N. Y., vol. III., p. 17\%, pl. 14, figs. $2 a-l$, pl. 23, figs. $\% a-g$.

Description.-Shell subquadrate in outline, regularly rounded in front; hinge-line straight, a little shorter than the greatest width of the whell; cardinal angles obtusely angular. Pedicle valve depressedconvex on the umbo, flattened or slightly concave toward the lateral margins, with a narrow mesial elevation extending from the beak to the anterior margin, but becoming less sharply-defined anteriorly; heak small, but slightly elevated above the hinge-line; cardinal area narrow. Brachial valve much more convex than the pedicle, most prominent a little posterior to the middle, with a narrow and shallow mesial depression extending forward from the umbo, becoming broader and less sharply-defined anteriorly. Surface of both valves marked by fine, radiating plications, which increase by irregular bifurcation and intercalation. When the surface is not exfoliated, rather strong, concentric, lamellose lines of growth are present.

The dimensions of a nearly-perfect specimen are: length, $27 \mathrm{~mm}$; width, $31.5 \mathrm{~mm}$.; thickness, $15 \mathrm{~mm}$.

Remarks.-This species has been observed only in the shaley member of the New Scotland formation, and even there it is usually not a common species. The shell itself is frequently wholly destroyed, learing the specimens in the form of casts of the interior, upon which the strong muscular impressions are a conspicuous character. 
RHIPIDOMELLA OBLATA (Hall).

Plate XXXV., Figs. 9-13.

See, also, p. 350.

1859. Orthis oblata Hall, Pal N. Y., vol. III., p. 162, pl. 10, figs. $1-22$.

Description.- Shell sublenticular in form, transversely subelliptical in outline when adult, the hinge-line a little less than one-half the total width. Pedicle valve convex at the beak and on the umbo, flattened in the middle and slightly concave toward the lateral and front margins; the beak pointed, produced but slightly beyond that of the brachial ralve; cardinal area small, concave. Brachial valve convex, deeper than the pedicle valve, with a slight mesial flattening, extending from the beak to the front margin; the beak nearly even with that of the opposite ralve. Surface marked by fine, raised, rounded strix, which increase by frequent bifurcation, and are curved toward the lateral and cardinal margins. The strix are crossed ly finer concentric strix and by stronger lines of growth, which become more numerous and crowded towards the margin of the older shells.

The dimensions of a nearly-perfect specimen of arerage adult size are: length, $28 \mathrm{~mm}$; width, $31 \mathrm{~mm}$.; thickness, $12 \mathrm{~mm}$.

RHIPIDOMELLA EMINENS (Hall).

Plate XXXIV., Fig. 9.

1859. Orthis eminens Hall, Pal. N. Y., vol. III., p. 16\%, pl. 11, figs. $7-14$.

Description.-Shell subcircular in outline, usually a little wider than long; hinge-line about two-thirds the greatest width, cardinal angles obtusely angular. Pedicle valve strongly convex posteriorly, the umbo prominent, the surface sloping rather steeply to the cardinal border, flattened or depressed anteriorly; beak prominent, slightly incurved, projecting beyond that of the opposite ralve; cardinal area rather large, moderately concave; the delthyrium broadly triangular. 
Brachial valve convex in the middle, depressed toward the margins, the beak produced but slightly beyond the hinge-line. Surface of both valves marked by fine, raised, radiating, irregularly-bifurcating strix, which are curved toward the cardinal margin; also by more or less conspicuous, concentric lines of growth.

The dimensions of an average specimen are: length, $2 \% \mathrm{~mm}$.; width, $28 \mathrm{~mm}$.

Remarks.-This species is associated with $R$. oblata and resembles it in some respects, but is much less frequent. It has a relatively longer hinge-line, with a much larger cardinal area, and consequently a more prominent beak on the pedicle valve. The length of the shell is also usually greater, as compared with its width.

DALMANELLA PERELEGaNs (Hall).

Plate XXxV., Figs. 5-8.

See, also, p. 327.

1859. Orthis perelegans Hall, Pal. N. Y., vol. III., p. 1\%1, pl. 13, figs. 4-12.

Description.-Shell transversely subelliptical in outline, the hingeline about equal to one-half the greatest width. Pedicle valve strongly elevated along the median line from the beak towards the front, sloping laterally; the beak small, pointed, incurved over the narrow, concave, cardinal area, extending a little beyond that of the brachial valve. Brachial valve nearly or quite as convex as the pedicle valve, more or less flattened or depressed along the median line; beak small and but little produced beyond the hinge-line. Surface marked by fine, irregularly-bifurcating, radiating, raised striæ, which are often irregularly alternating, several smaller ones occupying the spaces between larger ones. These radiating markings are crossed by concentric lines of growth, of greater or less prominence.

The dimensions of a full-grown specimen of average size are: length, $24 \mathrm{~mm}$.; width, $27 \mathrm{~mm}$.; thickness, about $12 \mathrm{~mm}$. 


\section{DALMANElla SUBCARINATA (Hall).}

\section{Plate XXXIV., Figs. 10-13.}

See, also, p. 326.

1859. Orthis subcarinata Hall, Pal. N. Y., rol. III., p. 169, pl. 12, figs. $7-21$.

Description.- Shell subplano-convex in form, subcircular, subquadrangular or transversely subelliptical in outline, the hinge-line onehalf to two-thirds the greatest wilth. Pedicle valve strongly convex, subcarinate along the median line, sloping to the lateral margins: beak small, incurved over the narrow area. Brachial valve more or less flattened, with a distinct depression along the median line, which becomes wider anteriorly, producing a sinus in the front margin of the shell. Surface marked by fine, raised, equal or alternating striax. which increase by irregular bifurcation and are curved towards the cardinal margin; marked, also, by finer, concentric striæ over the entire surface and by strong lines of growth toward the margin of adult shells.

The dimensions of an adult specimen of arerage size are: length, 17 $\mathrm{mm}$; width, $18 \mathrm{~mm}$. ; convexity of pedicle valve, $6 \mathrm{~mm}$.

Remarks.-This shell resembles $D$. perelegans, and it is probable that the two species run together. In its typical form it differs from the last in being more nearly plano-convex and usullly in being somewhat smaller.

BILOBITES FARICA (Con.).

Plate XXXY., Figs. 14-18.

1859. Orthis varica Hall, Pal. X. Y., vol. III., p. 179, pl. 24, figs. $1 a-k$.

Description.- Shell small, subcordate in outline, deeply bilobed in front, with a deep sinus in each valve; hinge-line from one-third to one-half the greatest width. Pedicle valve the most convex, with a somewhat deeper and sharper sinus; the beak pointed. slightly incurved over the rather high, concave, cardinal area; delthyrium 
broadly triangular. Brachial valve depressed-convex, flattened toward the cardinal extremities, the beak projecting nearly as far as that of the pedicle valve. Surface marked by more or less unequal, raised, radiating strix, which increase by irregular bifurcation; marked, also, by much finer concentric striæ and by lines of growth which are most conspicuous near the front margin of adult shells.

The dimensions of a rather large adult shell are: length, $6 \mathrm{~mm}$.; width, $7.5 \mathrm{~mm}$.; thickness, $3.33 \mathrm{~mm}$.

SCHIZOPHORIA MULTISTRIATA (Hall).

Plate XXXV., Figs. 1-4.

1859. Orthis multistriata Hall, Pal. N. Y., vol. III., p. 1\%6, pl. 15, figs. $2 a-t$.

Description.-Shell subcircular or transversely subelliptical in outline, hinge-line equaling about one-half the width of the shell. Pedicle valve convex, the greatest elevation posterior to the middle, a broad, shallow, ill-defined mesial sinus extending from the umbo to the front margin; beak projecting a little beyond that of the opposite valve, slightly incurved. Brachial valve more convex than the pedicle, gibbous posteriorly. Surface of both valves marked by fine, crowded, subequal, raised, radiating striæ, which increase by intercalation and by bifurcation, and are crossed by a few inconspicuous lines of growth.

The dimensions of an arerage specimen are: length, $20 \mathrm{~mm}$.; width, $25 \mathrm{~mm}$.

Remarks.-This species has been observed only in the Becraft limestone. It differs from $S$. bisinuata, from the Coeymans limestone, in the simple sinus of the pedicle valve, not having a double depression, as in that species. In other characters the two species are much alike. 


\section{SCENIDIUMI INSIGNE (Hall).}

Plate XXXVI., Figs: 1-4.

1859. Orthis insignis Hall, Pal. N. Y., vol. III., p. 173, pl. 13, figs. $13-16$.

Description. - Shell minute, subpyramidal in form, greatest width along the hinge-line. Pedicle valve with an extremely-elevated, pointed, straight or slightly-incurved beak, cardinal area large, flat or slightly concave, delthyrium broadly triangular, mesial line slightly elevated in a low, narrow, rounded fold, from which the sides slope away to the cardinal and lateral margins. Brachial ralre semi-circular, nearly flat. with a well-marked sinus along the mesial line. Surface of each valve marked by from five to seven flat, rounded plications on each side of the fold and sinus.

The dimensions of a full-grown specimen are, approximately: length, $2 \mathrm{~mm}$.; width, $4 \mathrm{~mm}$.; height of area on pedicle valve, $2 \mathrm{~mm}$.

Remarks. - This minute species is occasionally detected upon the weathered surfaces of the rherty limestone at the base of the New Scotland beds.

\section{UNCINULUS VELLICATUS (Hall).}

Plate XXXVI, Figs. 5-7.

1859. Rhynchonella vellicata. Hall, Pal. N. Y., vol. III., p. 230, pl. 33, figs. $1 a-p$.

Description. - Shell suborate to subrhomboidal in outline, wider than long. Pedicle valve convex on the umbo, the cardinal and lateral margins inflected, depressed toward the front along the median portion of the shell in a rather broad and shallow sinus, which is produced anteriorly; beak rather inconspicuous, closely incurved over that of the opposite valve. Brachial valve much more convex than the pedicle, most prominent in front, with a rather ill-defined mesial fold, reaching from the middle of the shell to the anterior margin. Surface of each valve marked by from twenty-four to thirty-four low, rounded plications, which continue to the beak. On the pedicle ralve 
from five to eight plications are included in mesial sinus and a corresponding number on the fold of the brachial valve.

The dimensions of an average specimen are, approximately: length, $17 \mathrm{~mm}$.; width, $19.5 \mathrm{~mm}$.

Remarks.-This species may be distinguished from most of the other Rhynchonelloid shells in the Helderbergian faunas of New Jersey by its much finer plications. The only other species with as fine plications is $U$. mutabilis, from the Coeyman's limestone, but the subglobose form of that species will easily distinguish it from $U$. vellicatus. The species is usually poorly preserved in New Jersey, and occurs, for the most part, in the upper portion of the New Scotland beds or the Becraft limestone.

\section{UNCINULUS PYRAMTDATUS (Hall).}

Plate XXXVI., Figs. 8-11.

See, also, p. 285, pl. XXIX.

This shell attains a much larger size in the fauna of the New Scotland beds than in the Coeyman's limestone, and is also a much commoner species.

RHYNCHOTREMA FORMOSA (Hall).?

Plate XXXVI., Figs. 12-15.

See, also, p. 328.

1859. Rhynchonella formosa Hall, Pal. N. Y., vol. III., p. 236, pl. 35 , figs. $6 a-y$.

Description.-Shell subrhomboidal in outline, wider than long. Pedicle valve convex on the umbo, from which point the surface curves abruptly to the cardinal and gently to the lateral margins, depressed toward the front in a deep and sharply-defined mesial sinus, which is produced in front. Brachial valve more convex than the pedicle, greatest elevation at the anterior margin, with a prominent median fold beginning at the middle of the valve and continuing to the front. Surface of each valve marked by from sixteen to eighteen simple, angular, radiating plications, of which three occupy the mesial sinus of the pedicle valve and four the fold of the brachial valve. 
The dimensions of a nearly-perfect specimen are: length, $9 \mathrm{~mm}$.; width, $11.5 \mathrm{~mm}$. ; thickness, $7.5 \mathrm{~mm}$.

Remurks-Geveral specimens of this little shell have been observed in the upper portion of the Now Scotland beds and in the Becraft limestone. They resemlle the illustrations of R. formosa in the New York laleontology. lut are much smaller than the mature forms of that species, although they are evidently adult shells.

\section{EATONIA MEDIALIS (Van.).}

Plate XXXVI., Figs. 16-23.

1859. Eatonia medialis Hall, Pal. N. Y., vol. III., p. 241, pl. 3\%, figs. $1 a-y$.

Description.- Shell transersely subelliptical, subcircular or subquadrate in outlinc. Pedicle valve depressed-convex on the umbo, flattened or concave toward the lateral margins, depressed in front in a deep mesial sinus, which i= more or less produced into a lingual extension at nearly a right angle to the plane of the valve; the beak not prominent, incurved over that of the opposite valve. Internally the muscular impression of the pedicle valve is rather large, ovate, distinctly defined by a prominent border and marked by longitudinal, slightly-radiating plications: near its centre is the small, cordiform, longitudinally striated impression of the adductor muscle. Brachial valve strongly convex, with a more or less elevated mesial fold toward the front; greatest elevation of the valve on the mesial fold at or near the front margin. Surface of each valve marked by from twelve to nineteen broad. low, rounded plications. which frequently continue to the heak, hut which are sometimes ohsolete hevond the middle of the valves. About three of the plications usually occupy the sinus of the pedicle valve, with four upon the fold of the brachial valve. In well-preserved specimens the surface is also marked by fine, radiating striæ and sometimes by a few concentric lines of growth.

The dimensions of a nearly-perfect specimen are: length, $20 \mathrm{~mm}$; width, $22.5 \mathrm{~mm}$; thickness, $15 \mathrm{~mm}$. Those of another specimen are: length, $18 \mathrm{~mm}$.; width, $22.5 \mathrm{~mm}$. ; thickness, $12 \mathrm{~mm}$. 


\section{EATONIA SINGULARIS (Van.).}

Plate XXXVI., Figs. 24-27.

1859. Eatonia singularis Hall, Pal. N. Y., vol. III., p. 243, pl. 38, figs. 14-20.

Description.-Shell broader than long, varying from broadly subovate to subrhomboidal in outline, the postero-lateral margins meeting at the beak in an angle greater than $90^{\circ}$. Pedicle valve depressedconvex on the umbo, flattened or concave toward the lateral margins, depressed toward the front in a deep mesial sinus, which is produced in front in a lingual extension at nearly right angles to the plane of the valve; beak small, closely incurved over that of the opposite valve. Brachial valve strongly convex, with a conspicuous mesial fold toward the front; greatest elevation at the middle of the anterior margin. Surface marked by fine, radiating striæ, which, on well-preserved specimens, are crossed by much finer, concentric striæ. Usually a rather broad, flat, rounded ridge occupies the median line of the pedicle valve. Toward the front margin of full-grown shells there are several strong, closely-crowded, concentric lines of growth.

The dimensions of a nearly-perfect, full-grown individual are: length, $16 \mathrm{~mm}$.; breadth, $17.5 \mathrm{~mm}$.; thickness, $12.5 \mathrm{~mm}$.

\section{CENTRONELIA ? SUBRHOMBOIDEA n. sp.}

Plate XXXiI., Figs. 7-10.

Description.-Shell subrhomboidal in outline, longer than wide. Pedicle valve prominent along the median line, sloping away to the cardinal and lateral margins; the cardinal margins infolded and forming a sort of false cardinal area; beak sharply pointed and slightly incurved. Brachial valve depressed-convex, most prominent near the middle. Surface of both valves marked by fine, concentric lines of growth, which are slightly fasiculate at intervals. Shell substance apparently punctate.

The dimensions of the nearly-perfect type specimen are: length, 11 mm.; width, $9.5 \mathrm{~mm}$.; thickness, $6 \mathrm{~mm}$. 
Remarhs.-The internal characters of this species have not been observed, but it is apparently a member of the family Centronellidie. although it may not belong to the genus Centronella. In some respects it resembles members of the genus Oristania, especially in the general outline of the shell, the infolded cardinal margin of th. pedicle valve and the pointed beak, and this species may be an early representative of that genus.

ATRFPINA IMBRICATA (Hall).

Plate XxxyII., Figs. 17-22.

1859. Leptornelia imbricata Hall, Pal. X. I., rol. III., 1. 2 46, pl. 38. figs. 8-13.

T)escription.- Shell small, varying from subcircular to subrhomboidal and to longitudinally subsemi-elliptical in outline: hinge-line shorter thin the greatest width, cardinal angles rounded. Pedicle valve convex, most prominent at about the middle, sloping to the lateral and cardinal margins; beak small, pointed, slightly incurved, perforated at its apex by the foramen. Brachial valve depressed-convex or nearly tlat, its beak sarcely produeed beyond the hinge-line. Surface of each valve marked by from six to twelve strong. rounded, radiating plications, of which some of the central ones sometimes divide in the larger specimens. On the pedicle valve the two central plications are larger and more elevated than the others, the depresion between them forming a narrow mesial sinus, while in the brachial valve there is one larger median plication opposite the median depression of the pedicle valve. The radiating plications are crossed by strong, imbricating, lamellose, concentric lines of growth.

The dimensions of a large specimen are: length, $9 \mathrm{~mm}$; width, $9.5 \mathrm{~mm}$.; thickness, $4.5 \mathrm{~mm}$.

Pemakix.-This species has been olserved only in the shaley member of the New Scotland beds, where it is not usually abundant. It occurs almost universally in the fom of moulds of the exterior and casts of the interior, the brachial valve frequently being so crushed as to appear to be strongly concave. 


\section{SPIRIFER MACROPleURUS (Con.).}

Plate XXXVII., Figs. 1-3.

1859. Spirifer macropleurus Hall, Pal. N. Y., vol. III., p. 202, pl. 27 , figs. $1 a-p$, pl. 28 , figs. $8 a-d$.

Description.-Shell large, varying from semi-circular to transrersely subelliptical in outline; hinge-line varying from a little less than the greatest width to somewhat extended beyond the shell in front; cardinal extremities usually angular, varying from somewhat obtusely so, to acutely angular in specimens with an extended hingeline. Pedicle valve strongly convex, the beak extended beyond that of the opposite valve, abruptly incurved over the rather large, concave area; the mesial sinus non-plicate, broad and deep; three broadlyrounded plications on each lateral slope. Brachial valve equally or a little less convex than the pedicle valve, with broad, prominent, rounded, non-plicate mesial fold; two broadly-rounded plications and sometimes a third smaller one on each side of the fold. The entire surface is marked by fine, crowded, radiating striæ, and by finer concentric striæ, which have usually been destroyed. The shells are also usually marked by several more or less prominent, concentric lines of growth.

The dimensions of a rather small pedicle valve are: length. $2 \% \mathrm{~mm}$; width, $36 \mathrm{~mm}$.; convexity, $10 \mathrm{~mm}$.

Remarks.-This is the largest species of Spirifer in the Helderbergian faunas, and has rarely been observed in New Jersey save in the shaley member of the New Scotland beds, where it usually occurs in the form of internal casts.

SPIRIFER PERLAMELLOSUS Hall.

Plate XXXVII., Figs. 4-6. Plate XXXVIII., Fig. 7.

1859. Spirifer perlamellosus Hall, Pal. N. Y., vol. III., p. 201, pl. 26, figs. $1 a-t, 2 a-g$.

Description.- Shell subtrigonal to subsemi-circular in outline, greatest breadth usually along the hinge-line; cardinal extremities varying from rounded to mucronate. Pedicle valve strongly convex, 
umbo prominent, beak incurved over the rather wide and sharplydefined, concave, cardinal area, much extended beyond that of the opposite valve; mesial sinus deep, rounded in the bottom, reaching to the beak, extended in front. Brachial valve nearly or quite as convex as the pedicle valve, most prominent on the rounded mesial fold near the anterior margin. Surface of both valves marked by six to eight abruptly and strongly-devated, subangular plications on each side of the fold and sinus; corered, also, by strong, imbricating, concentric lamella, which are abruptly arched in palsing over the plicattions, giving to the entire surface an extremely rough appearance.

The dimensions of an average-sized specimen are: length, $22 \mathrm{~mm}$. : width, $34 \mathrm{~mm}$. ; thickness, $15 \mathrm{~mm}$.

Remarks.-This species is common in the lower portion of the New scotlond beds. The New Jersey specimens differ in no particular from those which oceur so abundantly in the same formation in New York State.

SPIRIFER CYClopterus Hall.

Plate XXxviII., Figs. 1-6.

1859. Spirifer cyclopterus Hall, Pal. N. Y., vol. III., p. 199, pl. 25, figs. $1 a-z$.

Description.-Shell usually wider than long, varying from semicircular to transtersely subelliptical in outline: the hinge-line usually shorter than the greatest width, with the ardinal angles rounderl. but sometimes the hinge-line is extenderl, with the cardinal angles angular. Pedicle valve-strongly convex, the umbo prominent, the beak elevated and more or less incurved over the small, ill-defined, concave, cardinal area; mesial sinus of moderate depth, non-plicate. rounded in the bottom. Brachial valve with about the same convexity as the pedicle, mesial fold ahruptly elevated, prominent. Surface of each valve marked by from five to seven rounded plications on each side of the fold and sinus, which are crossed by fine, more or less prominent, imbricating lamellie, which are ormamented with fine, vertical striæ near their outer edges. 
The dimensions of a specimen from the shaley member of the New Scotland beds are: length, $12 \mathrm{~mm}$; width, $19 \mathrm{~mm}$.

Remarks.-This species is present in the Coeymans limestone fauna, but becomes much more abundant in the New Scotland fauna, attaining its greatest numerical proninence in the Becraft limestone. No specimens have been observed in New Jersey attaining the size of the larger examples illustrated in the New Iork Palcontology, but they possess all the characteristics of the species. In the hard, cherty limestones the delicate surface markings, both the concentric lamellæ and their fine, marginal fimbriations have been destroyed, but upon some of the shale specimens these markings have been very perfectly preserved.

\section{TREMATOSPIRA MULtistriata Hall.}

Plate xxxviII., Figs. 8-10.

1859. Trematospira multistriata Hall, Pal. N. Y., rol. III., p. 209, pl. 24 , figs. $3 a-t, p l .28 \mathrm{~A}$, figs. $5 a-f$.

Description.--Shell transversely subelliptical in outline, hinge-line about two-thirds the greatest width, cardinal angles rounded. Pedicle valve rather strongly convex, beak incurved over that of the opposite valve, cardinal area narrow; mesial sinus broad, rounded in the bottom, ill-defined, sometimes, but not always, becoming obsolete before reaching the beak. Brachial valve usually a little more convex than the pedicle, the mesial portion elevated in front in an ill-defined, rounded fold. Surface of both ralves marked by strong, subangular, raised, radiating striæ, which bifurcate one or more times in passing from the beak to the front of the shell. These radiating markings are crossed by concentric lines of growth.

The dimensions of an average-sized specimen are: length, $15 \mathrm{~mm}$.; width, $24 \mathrm{~mm}$.

Remarks.-This species has been observed only in the shaley member of the New Scotland beds, where it often occurs in considerable abundance, but is usually very poorly preserved. 
NUCLEOSPIRA VENTRICOSA Hall.

Plate XXxviI., Fig. 16.

See, also, p. 290, pl. XXX.

In the shaley Tew Scotland beds a few specimens of this species, all of them internal casts, have been found.

\section{ANOPLOTHECA CONCAVA (Hall).}

Plate XxxvII., Figs. 11-15.

See, also, p. 371.

1859. Leptocalia concara Hall, Pal. 1. Y., vol. III., p. 245, pl. 38, figs. $1-\%$.

Description.- Shell small, subcircular or subelliptical in outline, varying from wider than long to longer than wide; cardinal angles rounded. Pedicle valfe convex, subcarinate along the median line, sloping to the lateral and cardinal margins; beak small, slightly incurred. Brachial ralre flattened towards the lateral margins, with a broad, undefined, concare, mesial sinus, which is deeper in the middle of the valve than at the front margin. Surface of each valve marked by from fourteen to serenteen rather small, rounded plications, of which some of the central ones sometimes bifurcate; the median plication of the predicle ralve is somewhat smaller than those on either side of it.

The dimensions of an arerage specimen are: length, $5 \mathrm{~mm}$.; width, $5.5 \mathrm{~mm}$.

Remarks.-This little shell is one of the commonest species in the shaley member of the New Scotland beds, but it usually occurs in the form of moulds of the exterior and casts of the interior. 
MERISTELLA LAEVIS (Van.).

Plate XXXVIII, Figs. 11-18.

1859. Merista lavis Hall, Pal. N. Y., vol. III., p. 24\%, pl. 39, figs. 1-4.

Description.-Shell subovate in outline, a little longer than wide. Pedicle valve strongly convex, greatest prominence at about the middle, with a shallow mesial sinus toward the front; the beak prominent, incurved. Brachial valve less convex than the pedicle, strongly convex on the umbo, with an ill-defined mesial fold towards the front. Surface of both valves smooth or marked only by obscure, concentric lines and by a few stronger, concentric lines of growth.

The dimensions of a large specimen are: length, $28 \mathrm{~mm}$; width, $27 \mathrm{~mm}$. ; thickness, $18 \mathrm{~mm}$.

Remarks. - This species attains its largest size in the Becraft limestone; its average size becoming less and less in the lower and lower beds, down to the Coeymans limestone. In the shaley member of the New Scotland beds the epecies is common, but the shells are almost universally crushed and distorted, so that they are usually proportionally broader, and resemble $M$. arcuata.

\section{MOLLUSCA.}

PELECYPODA.

CYPRICARDINIA SUBLAMELLOSA Hall.

1859. Cypricardinia sublamellosa Hall, Pal. N. Y., vol. III., p. 26\%, pl. 50, fig. 1 .

A fragment of an elongate, pelecypod shell, marked by concentric wrinkles, may represent this species. It occurs in the lower cherty limestone member of the New Scotland beds near Hainesville. 
ACTINOPTERIA sp. undet.

Fragments of winged pelecypod shells are frequently met with in hoth members of the New Scotland beds and in the Becraft limestone, hut none of the specimens observed are sufficiently well preserved for -recific identification, although all are doubtlesir members of the genus Actinopteria.

MYTILARCA? sp. undet.

Plate Xxxix., kig. 4.

An imperfect specimen of a pelecypod shell resembling members of the Silurian genus Mytilarca occurs in the lower cherty limestone member of the New Scotland beds near Hainesville. It is altogether too imperfect for identification or description, but may be referred provisionally to this genus.

\title{
GASTROPODA.
}

\author{
STROPHOSTYLUS GEBHARDI (Con.).
}

Plate Xxxix., Figs, 1-3.

1859. Platyceras gebhurdi Hall, Pal. X. I., rol. III., p. 312, pl. 56. figs. 5 $a, b, 6, \%, 9$, pl. 55 , figs. $6 a-b$.

Description.-. Shell deeply umbilicate below, consisting of three or four rather papidly-xpanding rolutions, which are contiguous throughout or to near the aperture and are subcircular or subovate in crosssection. Apex of the spire lying nearly in the plane of the outer volution, the suture deeply impressed. Surface marked by fine, transverse lines of growth.

The dimensions of a nearly-perfect specimen are: maximum diameter, $31 \mathrm{~mm}$; height of aperture, $22 \mathrm{~mm}$.; width of aperture, $21 \mathrm{~mm}$. 


\section{Loxonema attendata Hall.}

Plate XXxIx., Figs. 5-6.

1859. Loxonema attenuata Hall, Pal. N. Y., vol. III., p. 296, pl. 54, fig. 8 , pl. $6 \%$, fig. 3 .

Description.—"Shell fusiform, somewhat rapidly attenuating above the last rolution, which is rentricose; aperture undetermined. Surface unknown."-Hall.

Remarks.- Some fragmentary specimens which agree in every respect with this description and the accompanying illustration have been observed in the lower cherty limestone member of the New Scotland beds, and may be so identified.

\section{PTEROPODA.}

\section{téntaCUlites elóNgatus Hall.}

See, also, pp. 295 and 363.

This species of Tentaculites is occasionally present in the fauna of the New Scotland beds, although it is rare and has as yet been observed only in the shaley member of the formation. Here it occurs only as more or less crushed, internal casts, and does not differ essentially from similar specimens in other formations.

\section{CEPHALOPODA.}

ORTHOCERAS sp. undet.

Several indeterminable fragments of Orthoceras have been observed in the lower cherty limestone member of the New Scotland beds. 


\title{
ARTHROPODA.
}

\author{
TRILOBITA.
}

Lichas pustulosus Hall.

Plate XL., Figs. 1-2.

1859. Lichas pustulosus Hall, Pal. N. Y., vol. III., p. 366, pl. figs. $9-12$, pl. $\% 8$, figs. $1-\%$.

Dscription.- Prgidium somewhat triangular, excluding the marginal extensions of the ribs. The axis is extremely prominent, occupsing about one-third the entire length, rising at its posterior extremit! into a rounded boss, from the centre of which proceed two strong spines, with a smaller one on each side, and two in front and behind in the line of the two central ones. Median lobe below the axis prominent and rising in the middle into a strong node, bearing a double spine, and thence sloping abruptly backwards, and deeply bifurcate at the extremity. Ribs broad, extending in broad, mucronate processes beyond the sinuosities, which diride them for about one-thirr of their entire length; the submedian groove extends to the extremities, which are always gently bent upwards. The inner fold of the marginal limb isextremely thickened and deeply striated."Hall.

Remarks.--Two imperfect specimens of the pygidium of this species have been observed from the Becraft limestone. One of these has the test partly preserved and shows, in an exceedingly indefinite manner, the prominent axis and the broadly-ribbed pluræ, with some scattered spine bases upon the surface. It is broken along the entire margin, so that the spine-like extensions of the ribs are not preserved. The second specimen is an impression of the doublure of the posterior portion of the prgidium, and shows the two terminal, marginal spines and a single lateral one on one side, all the remaining portion of the individual having been destroyed. These terminal and lateral spines are somewhat more obtusely pointed than in any of the original illustrations of the species, but there can be no doubt as to the specific identity of the New Jersey specimens. 
HoMralonotus VANUXEMI Hall.

Plate Xxxix., Figs. 7-8.

See, also, p. 338, pl. XLIV.

A single specimen of the prgidium of this trilobite has been recognized in the Becraft limestone. It is of about average size. having a length of $38 \mathrm{~mm}$., and differs in no respect from the later representatives of the species. So far as has been observed in New Jersey, this is the earliest occurrence of the species, it being most abundantly represented in the limestone at the base of the Oriskany series.

PHACOPS LOGANI Hall.

Plate XL., Figs. $3-4$.

1859. Phacops logani Hall, Pal. N. Y., vol. III., p. 353, pl. 73, figs. $15-25$.

Description-General form of the entire trilobite longtitudinally elliptical. Head subcrescentiform, somewhat pointed in front, the genal angles rounded. Glabella large, subpentagonal in outline, broader than long, prominent and protuberant in front, bounded laterally by deep and narrow dorsal furrows, which converge posteriorly; upper surface convex. The two anterior pairs of lateral furrows very faint, extending obliquely forward from the margins of the glabella; the third pair strongly defined and continuing across the posterior portion of the glabella, cutting off a well-defined posterior segment, at each extremity of which is a prominent, subovate tubercle. Cheeks comparatively small, not extending forward beyond about the mdidle of the glabella, but more conspicuous posteriorly, where they are bordered by a smooth, convex margin. Eyes rather large, their summits less elevated than the glabella, containing seventeen vertical rows of lenses, full-grown individuals having about one hundred lenses altogether in each eye. Occipital furrow strongly defined on the axis, produced upon the checks, terminating within the marginal border. Occipital segment convex, rather broad and prominent. Surface of the glabella pustulose, and on perfectly-preserved specimens the occipital segment bears one median tubercle, with several smaller ones on each side. 
Pygidium semi-circular in outline, with a prominent axis, bearing about nine annulations; the plure each have about five or six segments grooved along their median line.

The dimensions of an arerage adult head are: length, $13 \mathrm{~mm}$; width, $22 \mathrm{~mm}$.

Remarks.-Fragments of this species are not uncommon, especially in the more calcareous beds of the New Scotland formation and in the Becraft limestone.

DALMANITES PLEUROPTYX (Green).

Plate Xxxix, Figs. 9-10. See, also, p. 295, pl. XXXII.

The fragmentary remains of this species are somewhat more common in the New Scotland beds, especially in the lower cherty limestone member, than in the Coeymans limestone. Fragments of both the head and the pygidia have been observed, but their condition of preservation is always very poor.

Description of Species ta the Lower Oriskiny or Dalarantates Dentatus Fauna.

\section{MOLLUSCOIDEA.}

BRTOZOA.

VERTTPORA SERPULOTDES Hall.

Plate XLI., Fig. 1.

188\%. Termipora serpuloides H. \& S., Pal. N. Y., rol. VI., p. 5, pl. 2, figs. 24-31.

Description._"Corallum ramose, composed of contiguous, subcylindrical tubes, increasing by lateral gemmation. Branches infrequent, generally diverging at an angle of about $90^{\circ}$ : diameter from 3 to $:$ mm. Cell tubes flexuose, sometimes flattened or subtriangular from mutual pressure. Some of the tubes attain a length of $14 \mathrm{~mm}$.; diameter from 0.05 to $1 \mathrm{~mm}$. Exterior marked by transrerse wrinkles 
of growth, and sometimes by numerous fine, concentric striæ and obscure, longitudinal striations. Interior smooth."-Hall and Simpson.

Remark's. - This species has been olserred in New Jersey only in the Dalmanites dentatus fauna, where fragmentary specimens are not uncommon. The genus Vermipora was originally described by Hall * as a bryozoan, T. serpuloides being the type species, but in Volume VI. of the New York Paleontology it is apparently considered as a coral, more or less closely allied to Aulopora. Girty, $\dagger$ howerer, has pointed out that the manner of budding in Vermipora is fundamentally different from Aulopora, and he places the genus with the Bryozoa, in close proximity to Hederella.

\section{BRACHIOPODA.}

\section{SCHIZOCRANIA SUPERINCRETA BarTett.}

Plate XLI., Fig. 4.

18\%8. Trematis (Schizocrania) superincreta Barrett, Ann. N. Y. Acad. Sci., vol. I., p. 122.

Description.-Shell subcircular in outline, attached by the pedicle valve to some external object. Brachial valve depressed-convex, greatest convexity posterior to the middle; beak obtuse, marginal. Surface corered by fine, radiating lines, which, in the specimen examined, reach only about half way to the beak, those near the posterior margin being curved. The radiating markings are crossed by fine, concentric lines of growth.

The dimensions of the only specimen observed are: length, 17 mm.; width, $17 \mathrm{~mm}$; convexity, $2 \mathrm{~mm}$.

Remarks.-A single specimen of this species, from the "trilobite bed" at Peter's Talley, has been observed, it being attached to the brachial valve of a species of Stropheodonta. The species was originally described from the same bed near the New York State line. In the original description the radiating lines are said to continue to the beak, which is not the case in the specimen studied, although this absence of markings toward the beak may be due to the eroded

* Twenty-sixth Rep. N. Y. St. Mus. Nat. Hist., p. 109.

$\div$ Fourteenth Am. Rep. N. I. St. Geol. for 1894, p. 307. 
condition of the shell. Although the pedicle valve of the species has never leen observed, there is little doubt of its being cogeneric with S. filosa, the type of the genus Schizocrania, which it resembles more or less closely.

\section{ORBICULOIDEA AMPLA (Hall).}

Plate XLI., Figs. 2-3.

1859. Discina grandis IIall, Pal. N. Y., vol. III., 1). 406, pl. 92, figs. $1 a-d$.

Description.- Shell broadly suboval in outline. Brachial valve depressed-subconical, apex subcentral, slightly inclined posteriorly, the surface slightly concave from the apex to the posterior margin, becoming slightly convex laterally and anteriorly. Surface marked by strong, sublamellose, concentric lines of growth, about $0.5 \mathrm{~mm}$. apart. Pedicle valve not seen.

The dimensions of a nearly-perfect brachial valve are: length, 29 mm.; width, $27 \mathrm{~mm}$. ; convexity, $9 \mathrm{~mm}$.

Remarks.-This species may be easily recognized by its large size and its conspicuous concentric markings. It was originally described from the Oriskany sandstone of New York.

LINGULA? sp. undet.

Some mere fragments of a linguloid shell, too imperfect for identification, have been detected in the "trilobite bed" in the Nearpass section.

STROPHEODONTA MLAGNIFICA (Hall).

Plate XLI., Figs. 5-6. See, also, p. 345, pl. XLV.

Among the representatives of the genus stropheodunta in the fauna of the "trilobite bed" one of the commoner forms seems not to be distinguishable from s. magnifica of the Oriskany fama. The specimens at this horizon do not attain so great a size as most of those illustrated by Hall in the Paleontology of New York, but they are as large as the majority of the New Jersey Oriskany specimens. 
STROPHEODONTA sp. undet.

Plate XLI., Figs. 7-S.

Associated with the specimens identified as $S$. magnifica there are others representing another species, which are apparently members of the genus Stropheodonta, although the crenulated hinge has not been observed. They are all imperfectly preserved, and cannot be identified with any degree of certainty with any of the described species of the genus. The shell is much more strongly concavo-convex than S. magrifica, the convexity of one pedicle valve, $30 \mathrm{~mm}$. in length, amounting to $8 \mathrm{~mm}$. The radiating markings are also different, the costæ being sharper and more or less alternating in size. The specimens, especially the larger ones, are usually considerably wider than long, one external impression of the concare brachial ralve being $34 \mathrm{~mm}$. long by $48 \mathrm{~mm}$. wide. It is possible that these specimens represent an undescribed species, but the material available for study is too unsatisfactory to warrant the establishment of a new species.

\section{LEPTAENA RHOMBOIDALIS (Wilck.).}

Plate XLI., Fig. 10.

See, also, pp. 228, 278, 302, 366.

This is not a common species in the fauna, but the specimens observed do not essentially differ from those in the earlicr Helderbergian faunas.

ANOPLIA NUCLEATA Hall.

Plate XLI., Fig. 9.

See, also, p. 349, pl. XLVI.

Specimens of this species from the "trilobite bed" are not different from those in the overlying beds, except in usually being of somewhat smaller size. 
CHOxostrophia JERVExsis Schuchert.

Plate XLII., Figs. 1-2.

1901. Chmostrophie jerensis schuchert. Am. Geol., rol. XXVII., p. 250 , figs. $c-d$.

Description.- Thell subsemi-circular or subsemi-elliptical in outline, hinge-line straight, usually equaling the greatest width of the shell. Cardinal extremities usually nearly rectangular, the lateral margins subparallel for a short distance, then curring into the broadly-rounded anterior margin. Pedicle valve slightly concare, cardinal margin straight, bearing on each side of the beak three or four spines directed obliquely outward, of which the outer ones are the larger, the others becoming regularly reduced in size; cardinal area flat, narrow. Brachial valve depressed-convex, flattened toward the cardinal extremities. Surface of both valres marked by fine, subequal, subangular, often somewhat wary, radiating costie, which increase by intercalation. about four occupring the space of $1 \mathrm{~mm}$. at the margin. These radiating markings are crossed by much finer concentric markings.

The dimensions of an arerage specimen are: length. $9.5 \mathrm{~mm}$; width, $15 \mathrm{~mm}$.

Remarks.-This species is excecdingly abundant in the Dalmanites dentatus fauna. some layers or lenticular masses being constituted very largely of these shells. It is easily distinguishable from the common Oriskany representative of the genus by its smaller size, its flatness and its fine and often somewhat wary, radiating markings.

DALIIAXELLA SUBCARIXATA (Hall).

Plate XLII., Figs. 3-4.

See, also, p. 306 .

1859. Orthis subcarinata Hall, Pal. N. Y., vol. III., p. 169, pl. 12, figs $7-21$.

Description.-Shell subcircular or transversely subelliptical in wuthes hingt-line shorter than the greatest width; cardinal extremities rounded. Pedicle valve convex, subcarinate along the 
median line, lateral slopes nearly straight; beak rather small, incurved over the narrow cardinal area. Brachial valve depressedconvex on the umbo, flattened laterally, depressed medially in a shallow, ill-defined sinus, which broadens rapidly toward the front. Surface of both valves marked by numerous, fine, angular, radiating costæ, which increase by bifurcation and which become more and more strongly curved as they approach the cardinal margins. The radiating markings are crossed by much finer concentric striæ, which have usually been entirely obliterated on the New Jersey specimens.

The dimensions of a pedicle valve are: length, $15 \mathrm{~mm}$; width, $17 \mathrm{~mm}$. ; convexity, $5 \mathrm{~mm}$.

Remarks.-This species is closely allied to $R$. perelegans, but is a smaller shell, with the brachial valve much-more flattened and the pedicle valve more sharply carinate.

DAlufaxella PERELEgaNs (Hall).

See, also, p. 305, pl. XXXV.

A few specimens in the "trilobite bed" seem to represent this species, which is more abundant in some of the older beds. They are associated with $D$. subcarinata, which is much the commoner form, but differ, from members of that species in their larger size and less sharply-carinate pedicle valve. The only specimens observed are fragmentary, and do not at all perfectly represent the species.

\section{RHYNCHONELLA BIALEATA Hall.}

Plate XLII., Figs. 9-10.

1859. Rhynchonella? bialveata Hall, Pal. X. I., vol. III., p. 233, pl. 34, figs. 1-4.

Description.-Shell small. elongate, subtrigonal or suborate in outline; postero-lateral margins converging toward the beak at an angle of $55^{\circ}$ to $65^{\circ}$. Pedicle valve moderately convex; surface rather abruptly curred to the postero-lateral margins, the median portion depressed anteriorly in an ill-defined, shallow sinus, which reaches 
only to about the middle of the valve; beak acute, erect. Brachial valve about equally convex with the pedicle, flattened in the centre, the lateral slopes curving rather abruptly to the postero-lateral margins; slightly depressed along the median line near the beak, lut elevated toward the front in an ill-defined mesial fold scarcely higher than the general surfice. Surface of each valve marked by twelve or thirteen angular, radiating plications. On the pedicle valve the median plication bifurcates near the beak, and near the centre of the valve an additional plication is intercalated between these two divisions. On the brachial valve the median plication bifureates near the centre of the valve. 'The remaining plications on both valves are simple and continue to the beak.

The dimensions of an average specimen are: length, $6 \mathrm{~mm}$.; width, $5 \mathrm{~mm}$. ; thickness, $3 \mathrm{~mm}$.

Remarks. The specimens which have been identified as $R$. bialventa agree closely with Hall's original deseription and illustrations of the species in general form. size and proportions, but the peculiar hifurcations of the central plications of each valve of the New Jersey shell is not as described by Hall. The number of New Jersey specimens available for study is small, and it is quite probable that with a larger number of sperimens this character would be found to be more or less variable.

Ritichotrema Forifosa (Hall).

Plate XiLI., Figs. 5-8.

See, also, p. 309, pl. XXXVI.

1859. Rhynchonella formosa Hall, Pal. N. Y., vol. III., p. 2̇36, pl. 35, figs. $6 a-y$.

Description.- Shell broadly suboval, subtrigonal or subrhomboidal in outline, usually broader than long: the cardinal margins meeting at the beak in an angle varying from $78^{\circ}$ to $110^{\circ}$. Pedicle valve convex; the surface curving rather abruptly from the umbo to the cardinal margins and more gently laterally; the median portion depressed in a more or less abrupt sinus, which does not reach quite to the beak; the beak prominent, moderately incurved. Brachial valve more strongly convex than the pedicle, its surface curving gently to the lateral margins; the mesial fold more or less abruptly elevated 
in front. Each valve marked by twenty to twenty-four simple, angular, radiating plications, three or four of which usually occupy the fold and sinus.

The dimensions of a nearly-perfect individual are: length, $16 \mathrm{~mm}$; width, $14 \mathrm{~mm}$. ; thickness, $9 \mathrm{~mm}$.

RENSSELAERIA SUBGLOBOSUS $\mathrm{n}$. sp.

Plate XLII., Figs. 11-18.

Description.-Shell subglobular in form, longer than wide. Pedicle valve strongly-convex, its greatest elevation near the middle, sometimes slightly subcarinate along the median line near the beak. Beak sharply-pointed, closely incurved over that of the opposite valve. Brachial valve a little less convex than the pedicle, its greatest eleration near the middle. Surface of each valve marked by from fifty to sixty simple, rounded plications, which become obsolete before reaching the beak.

The dimensions of an average specimen are: length, $18 \mathrm{~mm}$.; width, $16 \mathrm{~mm}$. ; thickness, $11.5 \mathrm{~mm}$.

Remarks.-This species is one of the very abundant ones in the "trilobite bed." It resembles $R$. aquiradiatus, but never attains the size of that species, the largest specimen observed out of several hundred examined, being $21 \mathrm{~mm}$. in length, while adult individuals of $R$. cequiradiatus are 30 to $35 \mathrm{~mm}$. in length. $R$. subglobose is also proportionally wider than $R$. aquiradiatus. The species also resembles $R$. mutabilis, but grows larger than that shell, is smoother, not being so conspicuously marked by concentric wrinkles of growth, and bears a greater number of plications.

SPIRIFER MURCHISONi Castel.

Plate XLII., Fig. 26.

See, also, p. 354, pl. XLVIII.

A few specimens of this Oriskany species have been observed. They do not differ essentially from those in the higher beds except in not reaching the maximum size of the later shells. 


\author{
SPIRIFER NEARPASSI n. sp.
}

Plate XLII., Figs. 19-22.

Description.-Shell very small, wider than long; the hinge-line shorter than the greatest width, cardinal extremities rounded. Pedicl. valve subpyramidal, the beak elevated, incurved, the surface slopin: abruptly from the umbo to the lateral and anterior margins, lateral slopes curving rather abruptly into the cardinal area along the carlinal margin; mesial sinus shallow, but well-defined, extending to the beak; cardinal area high, concare, not sharply-defined. Brachial valve depressed-convex, the mesial fold not elerated above the plications on either side. Surface of each valve marked by about two strong, rounded plications on each side of the fold and sinus, the fold and simus being scarcely more prominent than the plications on either side.

The dimensions of a perfect specimen are: length, $3 \mathrm{~mm}$.; width. 41-3 mm.; thickness, $3 \mathrm{~mm}$.

Remark:-Unless this be an immature form it is quite distinct from any of the Helderbergian or Oriskany species of the genus. It is believed to be an adult shell, however, because all the specimen:observed are of about the same size, and no larger shells have been seen associated with them, of which they could be the young. The species may be recognized by its small size, its subpyramidal pedicle valve and its few plications.

CIRTINA Rostrata Hall.

Plate XLII., Figs. 23-25.

1859. Cyrtia rostrata Hall, Pal. N. Y., vol. III., p. 429, pl. 96, figs. $1-6$, pl. 98 , figs. $8 a-b$.

Description.- Shell subsemi-circular or subsemi-elliptical in outline; hinge-line straight, equaling the greatest width of the shell: cardinal extremities angular, sometimes more or less extenclert. Pexticle valye sulppyramidal. with a well-defined mesial sinus extending to the beak; beak greatly elevated, angular, often more or less distorted or 
twisted; cardinal area high, flat, slightly concave or convex; delthyrium narrowly triangular, closed below by deltidial plates. Brachial valve depressed-convex. flattened toward the cardinal angles; mesial fold sharply defined, low, flattened on top with a slight, longitudinal mesial depression. Surface of each valve marked by from five to nine simple, subangular, radiating plications on each side of the fold and sinus, by finer concentric striæ and a few stronger lines of growth.

The dimensions of a nearly-perfect, but rather small, specimen are: length, $9 \mathrm{~mm}$.; width, $15 \mathrm{~mm}$; thickness, $11 \mathrm{~mm}$. The approximate dimensions of a larger brachial valve are: length, $13 \mathrm{~mm}$.; width, $30 \mathrm{~mm}$.

Remarks.-Fragmentary specimens of this species are common in the fauna of the "trilobite bed," but complete shells are rare. The species differs from C. varia Clarke of the higher beds in being larger and coarser in its general characters, in the more twisted or distorted beak of the pedicle valve and in the more nearly-flat cardinal area.

MERISTELLA PRINCEPS Hall.

Plate XLII., Figs. 27-28.

1858. Merista princeps Hall, Pal. N. Y., vol. III., p. 251, pl. 44, figs. 1-5.

Description.-Shell large, subovate in outline; the postero-lateral margins converging toward the beak in an angle of about $60^{\circ}$. Pedicle valve convex, the greatest convexity posterior to the middle; the lateral slopes curving rather sharply to the cardinal margins, depressed medially in the anterior half of the valve in a deep and more or less subangular sinus; beak prominent, incurved. Brachial valve strongly convex, much elevated along the median line towards the front; the lateral slopes curving rather strongly to the margins: Surface nearly smooth or marked by obscure, radiating and concentric striæ, with a few more conspicuous lines of growth most prominent towards the margin.

The dimensions of a large brachial valve are: length, $36 \mathrm{~mm}$.; width, $35 \mathrm{~mm}$.; convexity, $14 \mathrm{~mm}$.

Remarks.-This species is rarely represented in the "trilobite bed" in the Nearpass section, but is a little more common farther south. 
The specimens observed are all more or less fragmentary and imperfect, and the description given above has been drawn up largely from Vew York specimens. The species is especially characterized by the large size which it attains.

\title{
MOLLUSCA.
}

\author{
PELECYPODA.
}

\author{
ACTINOPTERIA TEXTILIS (Hall).
}

Plate XIJII., Figs. 13-14.

1859. Aricula tertilis Hall, Pal. X. Y., rol. III., p. 288, pl. 52, figs. $9-10$, pl. 53, figs. $2,3,5, \%, 10$.

Description.-Body of shell obliquely subovate, anterior wing small, convex: posterior wing large, produced along the hinge-line, flat posteriorly, becoming convex towark the beak. Hinge-line longer than the vertical height of the shell, the beak situated near its anterior extremity. Surface of left ralve marked by strong, sharplyelevated, more or less alternating radiating ribs, much narrower than the intervening depressions, and by fainter concentric lines, which usually form slight nodes where they cross the radiating ribs, the motose appearance being more conspicuous towards the beak. Upon the wings the radiating ribs become much reduced, being about equal in size with the concentric markings. The right valve is more nearly flat than the left, and is nearly smooth, or with a few faint, radiating ribs upon the central portion of the shell.

The dimensions of a rather large individual are: vertical height, $2 \%$ mm.; oblique height from beak to the postero-basal extremity, $32 \mathrm{~mm}$.; length of hinge-line, $29 \mathrm{~mm}$.

Remarks.-This species identified as A. textilis is a common one in the fauna of the "trilobite bed." 'The specimens observed rary" in size from no more than $6 \mathrm{~mm}$. or $8 \mathrm{~mm}$., to the maximum height of over $30 \mathrm{~mm}$. The angle of obliquity also varies from $60^{\circ}$ or less to nearly $80 .^{\circ}$ The shell has the general aspect of both $A$. tertilis and A. communis of the Helderbergian faunas, but does not agree exactly with the descriptions of either of these species. It seems to be closest to $A$. textilis, and is therefore so identified. 
MEGAMIBONIA PARVA 11 . sp.

Plate XLIII., Fig. 12.

Description.-Shell small, oblique; hinge-line straight, about three-fourths the total length of the shell; both cardinal extremities rounded. Posterior, basal and lower portion of the anterior margin regularly rounded; a little below the middle the anterior margin is sinuate and above the sinus it is convexly-curved to the anterior extremity of the hinge-line. Left valve strongly convex, the beak prominent and projecting beyond the hinge-line, situated at about the anterior third of the shell. Posterior umbonal slope concave, the posterior wing not sharply separated from the body of the shell. Anterior wing convex, separated from the body of the shell by a rounded sinus, which extends towards the beak from the sinuosity in the anterior margin; in front of this sinus is a rounded fold, the anterior slope of which is slightly concave. Surface marked by fine, radiating costæ, about four or five in the space of $1 \mathrm{~mm}$., which on the body of the shell are flat-topped and broader than the intervening furrows, and bear two or three very fine longitudinal strix. On the wings the radiating costie are narrower and sharper, being much narrower than the intervening furrows. The radiating markings are crossed by finer concentric lines, which are inconspicuous upon the body of the shell, but which become sublamellose between the costæ upon the wings, more especially upon the posterior wing. Toward the beak the surface markings resemble those of the posterior wing rather than those of the body of the shell below.

The dimensions of a. nearly-perfect left valve are: length, 10.5 mm.; height, $10 \mathrm{~mm}$; conviexity, $5 \mathrm{~mm}$.

Remarks.-This shell resembles $M$. crenistriata Clarke, from the Oriskany beds of Becraft mountain, but is smaller, with a straighter hinge-line and with quite different surface markings.

MEGAMBONIA? sp. undet.

A single fragmentary specimen of a pelecypod shell resembles somewhat the illustrations of $M$. lamellosa Hall, except in being a diminutive shell, the total length of the specimen not having been more than 14 
mm. The specimen may represent a new species, but is altogether too imperfect for description. The only surfare markings to be detected are concentric lines of growth.

GONIOPHORA? sp. undet.

I single fragment which seems to be a portion of a small pelecypod shell of the genus Goniophora has been observed in the fauna of the "trilobite bed." Eren the generic ilentification, however, is subject. to much uncertainty.

\section{GASTROPODA.}

PLATYOSTOAIA NEARPASSI 11. sp.

Plate XLIII., Figs, 1-4.

Description. - Shell more or less subglobular in form, consisting of three or four volutions. Spire low, but little elevated abore the outer volution; suture becoming deeply and abruptly jupressed as it approaches the aperture. Aperture slightly oblique, subcircular in outline, its margin entire, immer lip free below, leaving a narrow, deep umbilicus. Surface marked by fine, regular, crowded lines of growth, which are sharply raised from the general surface of the shell:

The dimensions of an arerage specimen are: maximum diameter, $10 \mathrm{~mm}$.; height, $\% \mathrm{~mm}$. The largest specimen observed has a maximum diameter of $14 \mathrm{~mm}$.

Remarks.-In its general form and proportions this little species resembles $P$. rentrirosa and $P$. desmulum of the higher beds, but may be distinguished from either one or both of them by its smaller size, its rewular. sharply-elevated lines of growth. the absence of revolving lines and the abruptly-impressed suture in the younger portion of the shell. The species was fomerly provisionally identified as a small form of strophostylus transversu. Hall, but the immer lip of the aperture prores to be entirely different from that species. 
PLATYCERAS sp. undet.

Plate XLIII., Figs. 5- 7 .

At least two different species of Capulid shells which may be referred to the genus Platyceras occur in the fauna of the "trilobite bed," but they are represented by such a limited number of specimens, all of which are imperfect, that it is not possible to identify them with certainty. The larger species consists of about one rolution, which expands with great rapidity, so that the maximum diameter of the aperture of the largest and most perfect specimen examined is about $26 \mathrm{~mm}$., while the depth of the shell, measured from the plane of the aperture, is only about $10 \mathrm{~mm}$.

The second species is a shell consisting of about two and a half closely-coiled, gradually-expanding volutions, the outer one of which is subangular along the periphery. The spire is not elerated above the outer volution, and the shell has the aspect of members of the genus Platyostoma, and it is possible that it should be referred to that genus rather than to Platyceras. The maximum diameter of the only specimen of this shell which has come under observation is $9.5 \mathrm{~mm}$., the height of its aperture being $5 \mathrm{~mm}$.

LOXONEMA JERSEYENSIS $\dot{n}$. sp.

Plate XLIII., Figs. 8-10.

Description.-Shell with an elevated spire, consisting of as many as fourteen volutions in the larger specimens. Apical angle, $23^{\circ}$ to $26^{\circ}$. Volutions regularly convex, the sutures moderately impressed. Aperture subovate, higher than wide, the outer lip broadly sinuate, the greatest depth of the sinus being above the middle of the whorl. Surface marked by fine, transverse lines of growth, which follow the outline of the margin of the aperture.

The dimensions of a large individual with the apical portion destroyed are: maximum diameter, 11.5; total length with apex restored, $34 \mathrm{~mm}$. 
Remarks.-This is a common species of the "trilobite bed" in the Nearpass section and is apparently distinct from any of the described species of the genus.

\section{P'TEROPODA.}

HYolithes CENTENNIALIS Barrett.

Plate XLIII., Fig. 15.

18\%. Ilyolithes centennialis Barrett, Ann. Lyc. Nat. Hist. X. I., vol. XI., p. 299.

188s. Hyolithes centennialis Hall, Pal. X. Y., vol. T., pt. II., Supp., p. 6, pl. 114, figs. 21-23 (Supp. to Pal. N. Y., vol. VII.)

Description.-Shell subtrigonal or nearly semi-circular in crosssection, tapering gradually backward from the aperture to the obtusely-rounded posterior extremity, the sides converging a little more rapidly towards the posterior end. Ventral side slightly convex, lateral edges narrowly rounded, dorsal side strongly convex, more or less angular along the median line. Surface covered with fine, somewhat irregular, crowded, transverse lines of growth.

The dimensions of a specimen incomplete posteriorly are: length, $20 \mathrm{~mm}$. ; diameter at aperture, $10 \mathrm{~mm}$.; diameter at broken posterior extremity, $3 \mathrm{~mm}$.; thickness at aperture, $4.5 \mathrm{~mm}$.

TENTACULites ACULA Hall.?

Plate XLIII., Fig. 11.

1888. Tentaculites acula Hall, Pal. N. Y., vol. V., pt. II., Supp., p. 6, pl. 114, figs. 15-1\%. (Pal. N. Y., vol. VII., Supp.)

Description.-A species of Tentaculites occurs rather commonly in the "trilobite bed," but the surface of the shell adheres so firmly to the matrix in which it is imbedded that in no case have the finer surface characters been observed. The internal casts resemble a 
series of trmeated cones arranged one above the other, and are not unlike the casts of T'. elongatus which occur in both earlier Helderbergian faunis and in the Oriskany, but the specimens are smaller than the typical $T$. elongatus, the largest specimen observed having a maximum diameter of $2 \mathrm{~mm}$.

Tentaculites acula was originally described from the "Lower Helderberg Group, Port Jervis, Orange county," but the particular stratum from which the specimens were secured is not mentioned. The species probably came from the "trilobite bed," however, as all the new species which have been described as coming from the Helderbergian series of Port Jervis are, so far as can be determined, from this bed. The larger specimens which have come under observation are much larger than those which Hall described, although many individuals may be found of the size of that figured by Hall. The smaller specimens agree with Hall's brief description in having regular, equidistant annuli, but the few annular striæ on the intervals cannot be detected on the casts. In the larger individuals the annulations become somewhat more irregular.

\section{CEPHALOPODA.}

ORTHOCERAS sp. undetermined.

Plate XLIII., Figs. 16-17.

The only Cephalopods detected in the "trilobite fauna" are fragments of one or two species of Orthoceras too imperfect for identification. The largest specimen observed (fig. 16) is a shell $22 \mathrm{~mm}$. in diameter, with sutures about $4 \mathrm{~mm}$. apart. The septa are rather deeply-concave and the sipuncle is situated centrally. The shell itself is wholly destroyed, so that the nature of the surface-markings cannot be determined. Another smaller specimen is apparently a fragment of the chamber of habitation of an Orthoceras, as no sutures are present. It has a diameter of about $8 \mathrm{~mm}$. and seems to be marked by fine, transverse lines of growth. 


\section{ARTHROPODA.}

TRILOBITA.

HOMALONOTUS PANUXEMI Hall.

Plate XLIV., Figs. 4-7.

1859. Homalonotus vanuxemi Hall, Pal. N. Y., vol. III., p. 352, pl. 73, figs. 9-14.

1888. Homalonotus vanuxemi Hall and Clarke, Pal. N. Y., vol. VII., p. 11, pl. s $B$, fig.s. 1-?.

Description.-Cranidium subtrigonal in outline, truncated anteriorly. Glabella depressed-convex, hounded by an ill-defined dorsal furrow, subquadrangular in outline, narrower in front; lateral lobes and furrows obsolete; occipital furrow well-defined, produced laterally upon the fixed cheeks: necipital segment rather nurrow, flat. Anterior margin of the cranidium froduced into a rather hroad and flat border in front of the ghalnella. Fixed cheeks molerately convex, eye-lobes not conspicuous. Free cheoks subtriangular, longer than broad, with an ill-defined marginal border. Entire surface of the cephalic test, so far as observed, minutely pitted or punctate.

Pygidium subtriangular in outline, the lateral margins meeting at the posterior extremity in an obtusely-rounded angle of less than $90^{\circ}$. strongly-convex transerely along its anterior margin, sloping steeply along its median line from the anterior margin to the posterior extremity, the slope beyond the extremity of the axis being steeper than in front of that point. Axis scarcely defined, occupying more than one-third of the width of the pygidium anteriorly, and about five-sixths its total length, marked by about twelve segments, which become fainter upon the pleural slopes.

The dimensions of a large pygidium are: length, $70 \mathrm{~mm}$; width, $60 \mathrm{~mm}$.; and convexity, $50 \mathrm{~mm}$. This would indicate an individual of from $250 \mathrm{~mm}$. to $2 \% 5 \mathrm{~mm}$. in total length. The dimensions of the head of a smaller individual are: length, $20 \mathrm{~mm}$.; width, $40 \mathrm{~mm}$.

Remarks. - This is one of the common species in the trilobite bed at the base of the Oriskany series, but it always occurs in a frag- 
mentary condition. Fragments of the pygidia and thoracic segments occur abundantly, but the heads are less common. The species has also heen observed in the Becraft limestone fauna, and specimens from this lower horizon are indistinguishable from those in the trilobite bed. The moşt perfect specimen of the head of this species which has been observed is not so greatly produced anteriorly as is indicated in the restoration of the head of the species given by Hall and Clarke.

\section{Dalmanites Dentatus Barrett.}

Plate XLIV., Figs. 1-3.

18\%6. Dalmanites dentata Barrett, Am. Jour. Sci. (3), vol. II., p. 200 , plate.

1888. Dalmanites (Corycephalus) dentatus Hall and Clarke, Pal. N. Y., vol. TII., p. 58, pl. $11 A$, figs. 4-6.

Description.-Head subcrescentiform, the lateral and anterior margins forming a parabolic curve, the genal angles extended into rather blunt spines. Glabella depressed-convex, broadest in front, surrounded by a well-defined dorsal furrow, frontal lobe broader than long, subelliptical to subrhomboidal in outline. First pair of lateral furrows broad and deep, extending obliquely backward from the dorsal furrow and connected across the median portion of the glabella by a shallow depression. First and second lateral lobes partially coalescent externally by the shallowing of the second lateral furrows, the third pair of lateral lobes entirely separate from the second. Second and third pairs of lateral furrows indistinetly continuous across the median portion of the glabella by slight depressions. Occipital furrow sharply defined, continuous across the glabella and extending out upon the cheeks. Occipital segment of about the same width, but a little higher than the posterior lateral lobes. Cheeks conrex in general contour, with a slightly-thickened marginal border. Eyes large, subcrescentiform, their summits as high or higher than the glabella, their anterior extremities opposite the first and their posterior extremities opposite the third lateral furrows of the glabella, bounded externally around the base of the faceted surface by a sharp depression, beyond which is a subangular ridge. Between this ridge and the slightly-thickened check margin the surface is 
concare. 'The entire lateral and anterior margin of the head is ornamented with a continuous series of from twenty-five to thirty-five triansular, tonth-like froceses, larowet in front and decreasing regularly in size to the genal angles. The surface of the glabella and those portions of the cheres lring between the eves aud the glabella, except in the furrows, is covered with rather coarse, irregularlyarranged, circular tubercles, the outer portions of the cheeks, including the marginal denticles, being finely papillose. Thorax consisting of eleven segments, the axis a little less than one-third the entire wisth, plure extended into sharp, posteriorly-pointing spines. Pygidium sultriangular in outline, the posterior extremity proluced into a dorsally-curving, attenuate spine, a little less than onefourth the total pygidial length. Axis depressed-convex, indistinctly subangular alomg its median line, about one-fourth the entire width of the proidium at its anterior margin, its sides nearly straight, gradually converwing to the obtusely-rounded posterior extremity, which lies a little anterior to the base of the posterior pygidial spine. Plure with 10 conspicuous marginal border, flattened above, becoming rather strongly convex in the middle, and then sloping away to the lateral margins with a slightly convex surface. Axial segments fifteen in number: pleural segments grooved, eleven in number, curving rather abruptly backward as they approach the margin, the two or three posterior ones nearly straight. Each segment of the pygidium marked by a more or less irregular line of tubercles.

The dimensions of a rather large but imperfect head of this species are: extreme width between genal angles. $60 \mathrm{~mm}$. length from the front to the posteror margin of the occipital segment, $31 \mathrm{~mm}$. The dimensions of a pygidium are: length, $30 \mathrm{~mm}$.; width, $24 \mathrm{~mm}$.

Remarks.-Broken fragments of the heads, pygidia and thoracic segments of this speedes are excedingly abundant in the strata at the base of the Oriskany formation. By reason of the great abundance of fragments of this species and of Homnlonotus ranuxemi, this bed has frequently been designated as "the trilobite bed." In the more or less complete coalescence of the outer extremities of the first and second pairs of lateral glabella lobes, this species is allied to those Oriskany species which Clarke has described under the subgeneric name Synphoria.*

\footnotetext{
* Men. N. Y. State Mus., No. 3, vol. III., pp. 15-19.
} 


\title{
Descriptions of Species in the Middle and Upper ORISKANY FAUNAS.
}

\section{COELENTERATA.}

\author{
AN'THOZOA. \\ TRACHYPORA ORISKANIA n. sp.
}

Plate XLY., Figs. 1-2.

Description.-Corallum dendroid, with cylindrical branches 6 to $8 \mathrm{~mm}$. in diameter; corallites essentially polygonal in outline, more or less irregularly arranged, from 1 to $2 \mathrm{~mm}$. in diameter, with walls thickened toward their mouths, so that the actual aperture is much smaller and subcircular in outline, being somewhat depressed below the polygonal margin. The outer surface of the thickened walls of the corallites is marked by twelve to fourteen broad, rounded, radiating ridges, separated by sharp, narrow grooves.

Remarks.-This is the oldest recognized member of the genus Trachypora, other species being of middle Devonian age. The species may be distinguished by its more conspicuously polygonal corallites, the central circular aperture being much depressed below the polygonal margin.

\section{FAvosites sp. undet.}

Near Flatbrookville a specimen of Favosites has been collected from the calcareous Oriskany beds. It is too poorly preserved to exhibit specific characters, but it somewhat resembles masses of the Helderbergian species $F$. helderbergice, but seems to have somewhat smaller corallites. 


\title{
ECHINODERIATA.
}

\author{
CRINOIDEA.
}

EDRTOCRtNus sacculus Hall.

Plate XLV., Figs. 3-5.

1859. Edriocrinus sacculus Hall, Pal. N. Y., vol. III., p. 143, pl. 8\%, figs. 1-22.

Description.-Body free, not having a columnar attachment. Bare solid, no sutures, recognizable, varying from turhinate to subglobular in form, its upper margin indented by six more or less distinct, shallow, rounded sinuses, which are oceupied lye the five radial plates and the anal. Radial plates subquadrangular in outline. usually a little wider than long; the proximal margin convex, in contact laterally, except on the posterior side: distally the articulating facets for the arms ocenpy the entire width of the plates. Anal plate resting upon the base and separating the two posterior radials. quadrangular in outline, higher than wide. Arms free above the radials, broad and flat at the base. consisting of rery broar am short brachial plates, which bifurcate somewhere from the ninth to the fifterenth plate, and later hifurcate several more times.

The dimensions of a large calyx, not preserving the arms, are: height, $49 \mathrm{~mm}$.; maximum diameter, $38 \mathrm{~mm}$.

Remarks.-In New Jersey only the imperfect bases of this species have been observed, and even such specimens are not common. No specimen preserving the radial plates or the arms has been observed. and the deseription given above has been drawn up from Cumberland. Maryland, specimens. 


\section{MOLLUSCOIDEA.}

BRYOZOA.

FENESTELLA? sp. undet.

Fragments of a fenestelloid bryozoan, too poorly preserved for identification, are not infrequently observed in the basal portion of the Oriskany, associated with the Orbiculoidea jervensis fauna.

\section{BRACHIOPODA.}

ORBICULOIDEA JERVENSIS Barrett.

Plate XLV., Figs. 7-8.

1878. Discina jervensis Barrett, Ann. N. Y. Acad. Sci., vol. I., p. 121.

Description.--Shell broadly suboval or nearly elliptical in outline. Pedicle valve depressed-convex posteriorly and nearly flat anteriorly and laterally, or nearly flat throughout; the apex a little more than one-third the distance from the posterior margin. Internally a prominent, rounded elevation extends from the apex more than half way to the posterior margin, growing narrower posteriorly, with the internal pedicle opening at its posterior extremity. This interior elevation represents the external pedicle groove. Brachial valve depressedconvex, its apex opposite that of the pedicle valve; the surface usually slightly concave from the apex to the posterior margin and convex to the anterior margin. Surface of both valves marked externally by fine, concentric lines of growth, and internally by indefinite, radiating lines, as well as by concentric markings.

The dimensions of an average specimen are: length, $19 \mathrm{~mm}$.; width, $17 \mathrm{~mm}$.

Remarks.-This species occurs abundantly in the basal portion of the Oriskany, in the zone immediately following the trilobite berl. The zone characterized by this species is a well-marked one, and has 
been definitely recognized from the New York state line to below Hainesrille. The external surface of the shells usually artheres to thr. matrix, so that they are badly exfoliated, the interior surface being more commonly preserved than the exterior. The apical portion of the pedicle valve, including the pedicle opening, is usally destroverl. leaving an irregular, subcentral opening through that valve.

PHOLIDOPS ARENARIA Hall.?

Plate XLY., Fig. 6.

186\%. Pholidops arenaria Hall, Pal. N. Y., vol. IV., p. 413, pl. 3, fig. 3 .

Description.-Shell rather large, subcircular or slightly longitudinally subelliptical in outline. On the casts of the hrachial valre the muscular impresions are situated on an abrupt, subcircular alevation a little excentrically located toward the posterior margin, the elevation being somewhat more abrupt posteriorly. The entire marginal border is flattened. The casts of the anterior adductor muscular impresions are excavated from the central elevation; they are subovate or subelliptical in outline, their axes diverging posteriorly, and are separated by a median ridge or elevation which is narrow in front but grows rapidly liroader posteriorly. The external surface characters have not been observed.

The dimensions of a nearly-complete cast of one valve are: length, $7 \mathrm{~mm}$.; width, $7 \mathrm{~mm}$.

Remarks.-Only the casts of what is usually supposed to be the brachial valve of this species have been observed. The size of the species is above the arerage of members of the genus, and it may be distinguished by this character and hy its more or less subcircular outline. The New Jersey specimens do not agree exactly with Hall's original illustraton of the species, and there may be some question as to their correct identification. 


\title{
PHOLIDOPS OVATA Hall.
}

See, also, p. 226, pl. XX.

The internal casts of a small species of Pholidops are accasionally observed in the Oriskany formation of New Jersey, which apparently do not differ in any essential particular from those in the earlier faunas which have been identified as $P$. ovata.

\section{STROPHEODONTA MLAGNIFICA Hall.}

\author{
Plate XLV., Figs. 10-11.
}

See, also, p. 324.

1859. Strophodonta magnifica Hall, Pal. N. Y., vol. III., p. 414, pl. 93, fig. 4, pl. 94, figs. $2 a-d$, pl. 95, fig. 8, pl $95 A$, $15-19$.

Description.-Shell subsemi-elliptical in outline, hinge-line equaling or a little shorter than the greatest width; cardinal extremities angular or somewhat rounded. Proportions of length to breadth rarying from longer than broad to broader than long. Pedicle valve lepressed-convex near the beak; flattened laterally and anteriorly, cardinal margins sloping gently from the beak, cardinal area narrow, marked by rertical lines which indicate the position of the marginal crenulations. Internally the valve is marked by a large and broadlyflabellate muscular impression, beyond which the internal surface is papillose, giving to the surface of internal casts a punctate appearance. Brachial valve slightly concave or nearly flat. Surface of both valves marked by fine, radiating striæ, which increase by bifurcation.

The dimensions of a somewhat distorted specimen are: length, 30 $\mathrm{mm}$.; width, $34 \mathrm{~mm}$.

Remarks.-The shell which is identified as Stropheodonta magnifica is one of the common members of the Oriskany fauna in New Jersey, but it has never been observed to attain the large size ascribed to it by Hall. It agrees closely, however, so far as it is preserred, with Hall's illustrations of the smaller specimens of his species, and there can scarcely be any doubt as to the specific identity of the Nerr York and the New Jersey specimens. The most common occurrence of the species 
is in the comdition of internal casts of the pedicle valve, upon which the cast of the flabellate muscular impression and the punctate surface are always conspicuous characters.

LEPTAENA RHOAboidatis (Wilck.) var. ventricosa (Hall).

Plate XLVI., Fig. 1.

1859. Strophomena rugosa var. ventricosa Hall, Pal. N. Y., vol. III., p. $41 \%$, pl. 94 , figs. $2 e-f, 3$.

The variety of this cosmopolitan species, which occurs in the Oriskany beds, differs markedly from its earlier representatives in the Tew Jersey famas. The pedicle valve is more or less strongly convex toward the beak, not conspicuously flattened, as is the condition of the more usual member's of the species, and because of this convexity posteriorly, the valve does not have the usual geniculation toward the front, but is strongly convex or gibbous. The concentric wrinkles are also much stronger, broader and further apart on these Oriskany specimens, giving to the shell altogether a different appearance than the typical form of the species. The brachial valve is strongly concave and is much more coarsely marked than is usually the case in the typical form of the species.

This shell is quite generally distributed in the Oriskany beds of New Jersey, but has never been observed in great abundance and is always imperfectly preserved. It sometimes attains a great size, one individual having a length of $55 \mathrm{~mm}$; this size, however, is exceptional.

hipfarionty proxinus (Van.).

Plate XLV., Fig. 12.

1859. Orthis hipparionyx Hall, Pal. N. Y., vol. III., p. 40\%, pl. 89, figs. 1-4, pl. 90, figs. 1-7, pl. 91, figs. 4-5, pl. 94, fig. 4.

Description.-Shell subcircular to subsemi-elliptical in outline; hinge-line shorter than the greatest width. Perdicle valve depressedconvex near the beak, flattened or slightly concave toward the lateral 
and front margins; beak obtuse, not incurved; cardinal area of moderate height, flat; delthyrium broadly triangular, closed by a deltidium. Brachial valve regularly convex, the greatest elevation near the middle. Surface of both valves marked by rather coarse, radiating strix, which increase by bifurcation and which become stronger toward the margin of the shell. Toward the cardinal margin the radiating striæ curve posteriorly as they approach the margin.

The approximate dimensions of an imperfect cast of the brachial valve are: length, $32 \mathrm{~mm}$; width, $32 \mathrm{~mm}$.

Remarks.-This is a rare species in the Oriskany fauna of New Jersey, and no specimens attaining the great size of some of those from New York have been observed. The New Jersey specimens studied are all imperfect casts of the brachial valve, and do not at all fairly represent the species.

oRTHOTHETES sp. undet.

Plate XLV., Fig. 9.

Several imperfect specimens of a species of Orthothetes have been observed associated with the Orbiculoidea jervensis fauna of the Oriskany formation, but they are too imperfect for identification.

The dimensions of one of the best ones are: length, $12 \mathrm{~mm}$. ; width, $16.5 \mathrm{~mm}$.

CHONETES HUDSonicA Clarke.

Plate XLVI., Fig. 11.

1900. Chonetes hudsonica Clarke, Mem. N. Y. St. Mus., No. 3, vol. III., p. 49 , pl. \%, figs. $1-6$.

Description.-Shell of medium or small size, hinge-line equaling the greatest width; cardinal extremities angular, lateral margins subparallel for a short distance, then curving rather abruptly into the broadly-rounded anterior margin. Greatest convexity of the pedicle valve posterior to the middle, slightly flattened toward the cardinal extremities. Surface marked by fine, rounded costæ, with rounded interspaces, increasing by bifurcation and implantation, a shell 11 
mm. wide hearing from eighty to ninety costut at the margin. Cardinal margin marked by two or three spines on each side of the beak, of which the outermost ones are directed more obliquely outward than the second ones. Brachial valve not observed.

The dimensions of a nearly-perfect pedicle valve are: length, 7.5 $\mathrm{mm}$; width, $11 \mathrm{~mm}$.

Remarks.-This species is one of the rarest in the New Jersey Oriskany fauna, and has been observed only as a member of the Orbiculoidea jercensis fauma. It seems to be identical with the little shell from New York described by Clarke as C. Tudsonicus.

CHONOSTROPHIA COIPLANATA (Hall).

Plate XLVI., Fig. 12.

1859. Chonetes complanata Hall, Pal. N. Y., vol. III., p. 418, pl. 93, figs. $1 a-d$.

Description.-Shell semi-circular to semi-elliptical in outline, broader than long, greatest width along the hinge-line; cardinal extremities usually nearly rectangular. Pedicle valve depressed-convex on the umbo, nearly flat or concare toward the lateral and front margins: the cardinal margin with three or four tubular spines, directed obliquely ontward, on each side of the beak: cardinal area narrowly linear. Brachial valve depreswed-convex, flattened toward the cardinal extremities, most prominent near the middle. Surface of both ralves marked by fine, radiating. irregularly-bifurcating striæ, of which about four occupy the space of $1 \mathrm{~mm}$. near the margin. Internally the valves are finely papillose, the papilla being arranged radially along the lines of the external radiate markings.

The dimensions of a rather large pedicle valve are: length, 16.5 mm.; width, $28 \mathrm{~mm}$. 
ANOPLAA NUCLEATA (Tall).

Plate XLVI., Figs. 8-10.

See, also, p. 325.

1859. Leptcena? nucleata Hall, Pal. N. Y., vol. III., p. 419, pl. 94, figs. $1 a-d$.

Description.-Shell small, subsemi-circular or subsemi-elliptical in outline, a little wider than long; hinge-line equaling or a little less than the greatest width; cardinal extremities angular or obtusely rounded. Pedicle valve strongly convex or gibbous, slightly flattened toward the cardinal angles; beak strongly incurved; cardinal area narrow, sloping dorsally from the plane of the valve. Intemally a strong median septum extends anteriorly from the beak for about onethird the length of the valve. Surface smooth.

The dimensions of an average-sized specimen are: length, $5 \mathrm{~mm}$.; width, $6.5 \mathrm{~mm}$.

Remarks.-This little shell has not been observed to occur abundantly in the Oriskany fauna of New Jersey. Its usual condition of preservation is in the form of internal casts, in which the slit, extending anteriorly from the beak and representing the medium septum of the pedicle valve, is a conspicuous character.

RHIPIDOMELLA sp. cf. R. MUSCULOSA (Hall).

1859. Orthis musculosa Hall, Pal. N. Y., vol. III., p. 409, pl. 91, figs. 1-3, pl. 95, figs. 1-7.

In an Oriskany fauna from near Layton there have been observed a few imperfect specimens of a species of Rhipidomella which may be $R$. musculosa. The specimens are all smaller than the normal, fullgrown individuals of that species, usually not exceeding $18 \mathrm{~mm}$. in length. The characteristic muscular impression has not been observed, and, although the specimens have a close general resemblance to the smaller individuals of $R$. musculosa, it is difficult to determine in what respect they differ from some Helderbergian species. 


\section{RHIPIDOMELLA OBLATA (Hall).}

Plate XLVI., Figs. 5-7.

See, also, p. 304, pl. XxxV.

In the middle zone of the New Jersey Oriskany, associated with Orbiculoidea jervensis, Metaplasia plicata, de., there occurs somewhat commonly a large species of Rhipidomella which seems to be identical in all respects with the Helderbergian $R$. oblata.

\section{RHYNCHONELLA BREVIPLICATA n. sp.}

Plate XLVI., Figs. 2-4.

Description.- Shell subcircular, slightly wider than long. Perlicle valve convex, depressed towards the front in a shallow, mesial sinus, which is produced anteriorly into a lingual extension at nearly right angles to the plane of the valve; cardinal margins abruptly inflected. slightly concave, forming an angle of about $90^{\circ}$ at the beak; beak acute, not strongly incurved. Brachial valve much more strongly convex than the pedicle; elevated toward the front in a low, mesial fold. Surface of both valves smooth posteriorly or marked only by very fine, indistinct, radiating lines; towards the margin there are about three rounded plications on cach side of the fold and simus, and three or four in the sinus, which become obsolete rery quickly as they extend back from the margin.

The dimensions of a pedicle valve are: length, $13 \mathrm{~mm}$; width, 14 $\mathrm{mm}$.; those of a somewhat larger brachial valve are: length, $15 \mathrm{~mm}$. : width, $1 \% .5 \mathrm{~mm}$; convexity, $6 \mathrm{~mm}$.

Remarks. - This species is strikingly different from any of the contemporaneous Rhnychonelloid shells, and resembles, in its lack of plications except near the margin, some of the much younger Paleozoic species referred to the genus Pugnax. In some respects it rexubles some speres of Eatonia, especially E. peculiaris and $E$. sinfuluris, but the fine radiating lines are much less conspicuous than on those species, as they can scarcely be detected save with a lens. The inflected cardinal margin of the pedicle valve is like Eatonia, but the valve has not the flatness of that of the described species of that 
genus. The internal characters of the shell have not been observed, so that no proper generic reference of the species can be made at the present time, it being, therefore, referred provisionally to Rhynchonella.

\section{CAMAROTOECHIA BARRANDEI (Hall).}

A fragment of a large Rhynchonelloid shell found in the calcareous Oriskany beds near the New York State line seems to represent the species Camarotochia barrandei.

\section{EATONAa PECUlaris (Con.).}

Plate XLVII., Figs. 1-4.

1859. Eatonia peculiaris Hall, Pal. N. Y., vol. III., p. 244, pl. 38, figs. 21-26, pl. 101, fig. 2; also, p. 436, pl. 101, figs. $2 a-g$, pl. $101 \mathrm{~A}$, figs. $1 a-h$.

Description.--Shell usually longer than broad, sometimes the length and breadth nearly equal, subovate in outline; the cardinal margins meeting at the beak in an angle usually a little less than $90^{\circ}$. Pedicle ralve depressed-convex on the umbo, inflected along the cardinal border, flattened laterally, depressed toward the front in a deep mesial sinus, which is more or less produced in a lingual extension anteriorly; beak rather small, closely incurved over that of the opposite valve. Brachial valve strongly convex, with a mesial fold conspicuous toward the front, but obsolete posterior to the middle. Surface of both valves marked by fine, radiating strix, which increase by bifurcation, and usually by a few inconspicuous, concentric lines of growth. On the lateral margins adjacent to the fold and sinus there are usually two or three slight denticulations, which may be produced backward upon the surface of the valves for a short distance as indistinct plications.

The dimensions of a large individual are: length, $27 \mathrm{~mm}$; width, $23 \mathrm{~mm}$. ; thickness, $15.5 \mathrm{~mm}$.

Remarks.-There is some doubt as to whether the specimens in the Oriskany fauna of New Jersey which have been identified as Eatonia peculiaris should not be considered as a variation of Eatunia singularis. These two species are closely allied, and seem to grade from one into 
the other by almost imperceptible variations. In New Jersey the Oriskany specimens are more elongate than the Helderbergian $E$. singularis, the inflection of the cardinal border of the pedicle valve is more conspicuous and the strong median stria is much less conspicuous, and sometimes may not be recognized at all. The denticulation of the lateral margins of the two valves is absent from the Helderbergian specimens, but this is not a conspicuous feature of the Oriskany specimens, and may apparently be absent altogether in some cases.

BEACIIIA SUESSANA (Hall).

Plate XLVII., Figs. 5-14.

1859. Rensseleria suessana Hall, Pal. N. Y., vol. III., p. 459, pl. 10\%. figs. 1-15.

Description.- Shell longitudinally subovate or sub-elliptical in outline, usually longer than wide; hinge-line shorter than the greatut width. Pedicle valve moderately convex, most elevated along the median line posterior to the middle, sometimes more or less flattener laterally; the lateral margins in adult shells sometimes abruptly inflected; beak sharply pointed, incurved, but not touching the oppositi valve, perforated at the apex by a small, circular foramen; delthyrium closed by deltidial plates abore and by the cardinal process of the brachial valve below: cardinal margin abruptly inflected. forming a false cardinal area. Brachial valve a little lesis convex than the pedicle. point of greatest elevation posterior to the middle; cardinal margin nearly straight or sloping gently from the slightly-produced beak; the cardinal angles obtusely rounded, lateral margins sometimes abruptly inflected in adult shells. Surface marked by indistinct, radiating plications and by concentric lines of growth.

The dimensions of a complete specimen are: length, $30 \mathrm{~mm}$. : wirth, $26 \mathrm{~mm}$. : thickness, $14 \mathrm{~mm}$. Another large individual has a width of $42 \mathrm{~mm}$.

Remarks.-This species, originally described from the Oriskany of Cumberland, Maryland, is not an uncommon form in the New Jersey fauna. Terr few of the New Jersey specimens retain the radiating markings, but the concentric markings are often stronger and more numerous than is usally the case in the Maryland specimens. These 
specimens, having the strong, concentric lines of growth and the obsolete, radiating plications, seem to be essentially like the shell from New York which is known as Megalenteris ovalis (Hall). This shell from New York, however, has never exhibited the brachidium, so that it is not really known to be a member of the genus to which it has been referred. A specimen from New Jersey retains the brachidium, however, and it is essentially the same as that of Beachia suessana as known from Cumberland. Maryland. This would indicate either that M. ovatis and $B$. suessana are synonrmous, representing extreme variations in the surface markings, or that they are two distinct species, both belonging to the genus Beachia.

SPIRIFER ARENOSUS (Con.).

Plate XLVIII., Fig. 5.

1859. Spirifer arenosus Hall, Pal. N. Y., vol. III., p. 425, pl. 98, figs. $1-8$, pl. 99 , figs. $1-10$, pl. 100, figs. $1-8$.

Description.-Shell large, subsemi-circular, subsemi-elliptical or subelliptical in outline; hinge-line equaling the greatest width of the shell or a little shorter; cardinal extremities angular or rounded. Pedicle valve strongly convex or gibbous on the umbo; the surface somewhat flattened toward the cardinal angles and curving regularly toward the front, depressed along the median line in a shallow, rounded, more or less ill-defined mesial sinus; beak prominent, somewhat incurred; cardinal area becoming rather wide in old shells, concave, sharply defined, reaching to the extremities of the hinge-line; delthyrium broadly triangular. Internally the muscular impressions are large and deep. Brachial valve with its greatest convexity near the middle; mesial fold low, rounded, more or less ill-defined. Surface of both valves marked by from fifteen to twenty depressed, rounded plications on each lateral slope. The fold and sinus are also similarly plicated, but on these portions of the shell the plications increase in number by bifurcation, those on the sides being simple. The surface is also marked by fine, concentric striæ and by stronger, imbricating lines of growth. 
The dimensions of an imperfect brachial valve are, approximately: length, $44 \mathrm{~mm}$.; width, $56 \mathrm{~mm}$; convexity, $20 \mathrm{~mm}$.

Remarks.-This rery characteristic Oriskany species is one of the rery rarest members of the fauna in New Jersey. It may always be easily recognized by its large size when adult and by its completelyplicated valves, it having no associates in the same genus which do not have a smooth fold and sinus.

SPIRIFER MIURCHISONI Castelnau.

Plate XlviII., Figs. 1-4.

1859. Spirifer arrectus Hall, Pal. X. Y., rol. III., p. 422, pl. 9\%, figs. $1 a-h, 2 a-i$.

Description.- Thell semi-circular to semi-elliptical in outline, greatest width nsually along the hinge-line: ardinal angles usually angular, rarely a little rounded, often somethat mucronate. Pedich valve gibbous on the umbo: the surface slightly flattened toward the carlinal angles, regularly curved to the front: mesial sinus sharply defined, subangular or rounded in the bottom; beak incurved; cardinal area high, sharply defined, concave toward the beak. Brachial valve strongly convex, more or less flattened toward the cardinal extremities; the subangular fold usually greatly elevated towards the front. Surface of both valves marked by from five to eight simple, rounded or subangular plications on wach lateral slope, the fold and sinus non-plicate. The surface also marked by fine, concentric, fimbriate lines and by stronger lines of growth.

The dimensions of a rather latce pedicle valve are, approximately: length, $34 \mathrm{~mm}$; wjdth, $5 \% \mathrm{~mm}$; convexity, $16 \mathrm{~mm}$.

Remmrs. - This is, perhaps. the commonest and most characterist ic species in the Oriskany fauna of New Jersey. It is almost universal in its oceurrence, hut the specimesns are nerer perfectly preserved and are frequently in the form of imperfect casts of the interior. In such spermens the brachial valve is msually not greatly different from the exterior of the shell, except in having somewhat stronger plications, but the pedicle valve is conspicuously marked by the cast of the large and deep muscular impression. 


\section{CYRTINA VARIA Clarke.}

Plate XLVIII., Figs. 13-16.

1900. Cyrtina varia Clarke, Mem. N. Y. State M[us. Nat. Hist., rol. III., No. 3, p. 49, pl. 6, figs. 15-22.

Description.-Shell obliquely subprramidal, its greatest width along the hinge-line; cardinal extremities angular, at times somewhat mucronate. Pedicle ralve greatly elevated at the beak, sloping away to the lateral and front margins, with a well-defined, narrow mesial sinus extending from the beak to the front margin; beak pointed, a little incurred; cardinal area about twice as wide as high, flat or a little concare toward the beak; delthyrium narrowly triangular, closed below by the deltidial plates, the elongated foramen occupying the upper portion just beneath the beak. Interiorly the dental lamellæ unite at their bases and are continued as a mesial septum, which extends nearly to the anterior margin of the shell. Brachial valve depressed-convex, flattened towards the cardinal extremities; mesial fold low, rounded or slightly flattened, with a faint, median, depressed line. Surface of each valve marked by from six to nine simple, rounded or subangular plications on each side of the fold and sinus and by fine, imbricating, concentric, lamellose lines of growth.

The dimensions of a nearly-perfect specimen are: length of brachial valve, $10 \mathrm{~mm}$.; width of same, $1 \% \mathrm{~mm}$.; height of cardinal area of pedicle valve, $7 \mathrm{~mm}$.

METAYLASIA PYXIDATA (Hall).

Plate XLVIII., Fig. 6.

1859. Spirifer pyxidatus Hall, Pal. N. Y., vol. III., p. 428, pl. 100, figs. 9-12.

Description.-Shell semi-elliptical to subtriangular in outline; hinge-line about equal to the greatest width; cardinal extremities angular or a little rounded. Pedicle valve gibbous on the umbo and strongly elevated medially to the anterior margin, flattened toward 
the cardinal extremities, with a narrow mesial groove or sinus on the summit of the mesial elevation ; cardinal area narrow and linear; the beak rather blunt, incurved. Brachial valve flattened on the umbo and toward the lateral margins, depressed medially in a broad sinus, along the median line of which is a small, elevated ridge. The surface of perfectly-preserved specimens is marked by fine, concentric and radiating stria.

The dimensions of an imperfect pedicle valve are, approximately: length, $8 \mathrm{~mm}$.; width, $10 \mathrm{~mm}$.; convexity, $3.5 \mathrm{~mm}$.

IETAPLASIA PLICATA n. sp.

Plate XLVIII., Figs. 7-12.

Description.- Shell subcircular or subelliptical in outline, wider than long, greatest width along the hinge-line, cardinal extremities angular. Pedicle valve strongly convex, having a prominent mesial elevation extending from the beak to the front margin, with a rounded longitudinal depression. From this mesial elevation the surface slopes away somewhat gradually to the lateral margins and (urves rather abruptly to the cardinal margin: the beak is prominent and strongly incurved; the cardinal area is of moderate width, sharply defined and extending to the cardinal extremities. Brachial valve depressed-convex on the umbo, flattened toward the cardinal. margins, flat or concave laterally, depressed medially toward the front in a broad sinus, with a rather broad, rounded plication along the median line. Surface of each valve marked by from eight to twelve rounded plications, of which the two median ones of the pedicle valve are much the largest and form the two sides of the mesial elevation of that valve. 'The three median depressions of the pedicle valvethat is, the one lying between the two larger median plications and the two adjacent lateral ones-are conspicuously broader than those beyond; the plications on the lateral slopes gradually decrease in size to the cardinal margin. On the brachial valve there are three broad median plications corresponding to the three broad furrows of the opposite valve, the one on the median line, and the adjacent ones forming the sides of the mesial sinus; beyond these the plications decrease gradually in size to the cardinal margin. Besides the plications the surface is marked by indistinct concentric striæ, by ex- 
tremely fine radiating striæ and usually by a few lamellose lines of growth.

The dimensions of the most-nearly perfect specimen observed are: length, $12 \mathrm{~mm}$; width, $19 \mathrm{~mm}$; thickness, $8.5 \mathrm{~mm}$.

Remarks.-This species is rery abundant at Locality 6 A, near MIontague post-office. The pedicle valves are by far the most abundant, only a few brachial valves having been observed. One of these, an interior, preserves the primary lamellie of the brachidium, each with a short jugal process near the centre of the valve, pointing towards the pedicle valve, but not joined together to form a jugum, the brachidium being similar to that of the genus Spirifer. In some cases the brachial valve appears to be nearly flat throughout, or has a slight, general convexity. The species differs from either of the other members of the genus in its greater size and in its strongly-plicated shell.

\section{ANOPLOTHECA FLABELlites (Con.).}

Plate XLIX., Figs. 1-2.

1859. Leptoccelia flabellites Hall, Pal. N. Y., vol. III., p. 449, pl. $103 B$, figs. $1 a-f$, pl. 106, figs. $1 a-f$.

Description.-Shell semi-elliptical, subcircular or subovate in outline, usually broader than long; the cardinal extremities rounded. Pedicle valve convex, most prominent towards the beak, sloping rather abruptly to the cardinal margin and more gently to the lateral margins, more or less depressed medially toward the front in a narrow sinus, with a single plication in the bottom; beak pointed, rather strongly incurved, with a circular foramen in the apex; delthyrium closed in its lower part by a pair of deltidial plates. Brachial valve flat, with a low, narrow mesial fold in the anterior half, marked by two plications; the cardinal margins diverging from the beak at a variable angle of from $110^{\circ}$ to $150^{\circ}$. Surface of each valve marked by from twelve to sixteen simple, rounded or subangular, radiating plications, of which two somewhat larger ones, with a smaller one between, occupy the median portion of the pedicle valve, the smaller median one being depressed between the larger ones toward the front into a narrow and more or less prominent sinus. On the brachial valve the two median plications are somewhat elevated above the 
others anteriorly in a narrow mesial fold. The surface is also marked in wnentric lines of growth. which w-ually hecome more crowded toward the margin.

The dimensions of a rather small specimen are: length, $13 \mathrm{~mm}$ : width, $15 \mathrm{~mm}$.; thickness, $4 \mathrm{~mm}$.

AxoplothecA DICHOTOMA (Hall).

Plate XLIX., Figs, 3-6.

1859. Leptocretia dichotoma Hall, Pal. N. I., rol. III., p. 452, pl. $103 B$, figs. $3 a-c$.

Description.- Shell broadly suborate in outline, concaro-conrex. Prticle valve strongly comvex. its greatest deration near the mildle. with a flat-tomerl mesial elevation. frome which the surface slnpes a may to the lateral marcins: leak sharply pointed. incurved. Brachial valve flattened laterally. with a rather broarl. ill-rlefined mesial sinus: axtending from the heak to the front marein. surface of each ralve market hy from funrten to sixteren rombled or subangular. rarliating plications. which increas hy hituration, although in some ases the hifurations are on dose th the brak that the plications almost seem to be simple. The plications are crossed by a few sublamellose, concentric lines of growth.

The dimensions of a nearly-perfect specimen are: length, $9 \mathrm{~mm}$; width, $10 \mathrm{~mm}$.; thickness, $4 \mathrm{~mm}$.

Remarts. - This shell resembles A. concava of the Helderbergian fauna. but is a much larger species. Shunchert* has suggesterl that it is possibly the young of $L$. flabellites, but specimens haring the characteristics of the species seem to be adult shells.

* Bull. C. S. G. S., No. ST, p. 144. 


\title{
MERISTELIA LATA (Hall).
}

Plate XLVII., Figs. 15-20.

1859. ILerista lata Hall, Pal. I. I., rol. III., p. 431, pl. 101, figs. $3 a-m$.

Description.-Shell transrersely subelliptical. subrhomboidal. or longitudinally suboral in outline, vsually wider than long. Pedicle ralre strongly conrex, its greatest eleration near the middle. with a rounded mesial sinus of moderate depth toward the front, the beat incursed orer that of the opposite ralre. Internally the muscular impressions are large and strongly-lefined. Brachial ralre nearly as conrex as the pedicle, often somerhat flattened laterally, with an ill-defined mesial fold torrard the front. Surface of both ralres marked by fine, concentric strix and by a fer stronger. sublamellose lines of growth.

The dimensions of an arerage specimen are: length, $30 \mathrm{~mm}$.; width, $3 \pm \mathrm{mm}$.

Pemarks.-This species is nerer trell preserved in the Oriskany formation of Tell Jerser, and usually occurs in the form of internal casts of the pedicle ralre. Such specimens may almars be easily recognized by the broad and strongly-elerated cast of the muscular impression. The species is a common one and may usually be detected whererer fossils are present in this formation.

\section{MOLLUSCA.}

\section{PELECYPODA.}

ACTINOpteria IXsigais Clarke (?).

\author{
Plate L., Fig. 2.
}

1900. Actinopteria insignis Clarke, Mem. N. Y. St. Mus., To. 3, rol. III., p. 35, pl. 4, figs. 10-13.

Sereral imperfect examples of a winged pelecrlod shell haring the size and characteristics, so far as ther can be determined, of 
Actinopteria insiginis have been observed in the Orbiculoidea jervensis fauna of the Oriskany. Associated with them are fragments of other winged shells, which may belong to some other species of the same genus or to Pterinea.

ACtiNopteria textilis (Hall) var. ARexaria (Hall).

Plate L., Fig. 1.

1859. Avicula textitis var. arenaria Hall, Pal. N. Y., vol. III., p. 465, pl. 109, figs. 1-2, pl. 110, fig. 2.

Description.-Shell large, obliquely suborate, the proportions of length and height variable. Left valve becoming moderately and regularly convex from the base, the greatest convexity being about the first third below the hinge-line. Posterior wing large, extending along the margin of the body of the shell half way from beak to base. Anterior wing small, triangular, wrinkled. Surface marked by strong, radiating ribs. sonetimes regularly dichotomosing and subequal, and in other specimens quite unequal, showing a few stronger ribs, with several finer ones between, and these are crossed by strongly-elevated, imbricating lamellie. The right valve is slightly concave, smaller than the other, faintly marked by the radiating ribs, which sometimes are scarcely seen.

Remarks.-More or less fragmentary specimens of a species of Artinopteriu, which are quite certainly representatives of this common Oriskany species of the genus, are of not uncommon occurrence in the Oriskany formation in New Jersey. Some specimens, when complete, must have had a height of $75 \mathrm{~mm}$. or more.

MEGAMBONIA BELLISTRIATA Hall.

Plate L., Fig. :3.

1859. Megambonia bet7istriata Hall, Pal. N. Y., vol. IIT., p. 46\%, pl. 109, fig. 4.

Description.- Teft valve subsemi-clliptical in outline, height and width subequal; hinge-line less than the greatest width; the beak a 
little in front of the middle; margin convexly rounded from the anterior extremity of the linge-line to about the middle of the anterior side of the shell, where it is conspicuously sinuate; from this sinus it is again convexly rounded ventrally and posteriorly to the angular posterior extremity of the hinge-line. The body of the valve is moderately convex, the greatest elevation being above the middle. Anteriorly a convex wing is separated from the body of the shell by a rather narrow and abruptly-depressed, rounded sinus, which extends from a point just in front of the beak to the sinuosity of the anterior margin, the greatest elevation of this wing being about one-half that of the body of the shell. Surface of the entire valve marked by fine, flattened, radiating costæ and by conspicuous, concentric lines of growth. Right valve unknown.

The dimensions of an imperfect specimen are: height, $39 \mathrm{~mm}$.; width, about $39 \mathrm{~mm}$.; convexity, $10 \mathrm{~mm}$.

Remarks. - But a single imperfect specimen of the left valve of this species has been observed. It is in the condition of an internal cast, upon which the radiating surface markings are less sharply defined than upon the actual surface of the shell. It agrees essentially, so far as it is preserved, with Hall's original illustration of the species, and there can be no doubt as to its correct identification.

\section{GASTROPODA.}

\section{PLATYOSTONA VENTRicosa Con.}

Plate XLIX., Figs. 7-11.

1859. Platyostoma ventricosa Hall, Pal. N. Y., vol. III., p. 469, pl. 112, figs. 1-10, pl. 113, figs. \%-8, pl. 115, fig. 8; also, p. $4 \%$, pl. 118, figs. $3-9$.

Description.-Shell variable, more or less subglobular in form, consisting of three or four rather rapidly-expanding rolutions, which may be contiguous throughout or the outer one may be more or less free. Spire not at all or but moderately elevated above the outer volution. Aperture slightly oblique, subcircular, suboval or subelliptical in outline. Surface marked by fine, more or less irregular, transverse lines of growth, which are sometimes more or less fasciculate at intervals. 
The dimensions of a very large individual are: maximum diameter, $85 \mathrm{~mm}$.; maximum height, $55 \mathrm{~mm}$. Those of a smaller specimen are: maximum diameter, $28 \mathrm{~mm}$. ; maximum height, $25 \mathrm{~mm}$.

Remarks.-As it usually occurs in the Oriskany fauma of New Jersey, this species does not attain the great size of the specimen whose dimensions are given above, the average size being from 30 $\mathrm{mm}$. to $40 \mathrm{~mm}$. in diameter. The species is exceedingly variable, and all of the specimens of this general trpe so far recognized in the Oriskany of New Jersey seem to be included within the limits of this species as recognized by Hall.

Platiostoma desaratum (Clarke).

Plate XLIX., Fig. 12.

1900. Diaphorostoma desmatum Clarke, Mem. N. Y. St. Mus., No. 3, vol. III., p. 29, pl. 3, figs. 13-19.

This species agrees in all respects, except size and surface markings. with $P$. ventricosa. It does not grow so large as that species, the largest individual observed being $25 \mathrm{~mm}$. in diameter and $18 \mathrm{~mm}$. high. The surface markings differ from $P$. rentricose in having, in addition to the transverse lines of growth, which are finer and more regular, other fine revolving lines most prominent in the interspaces between the transterse lines, which give to the surface of the shell a cancellated appearance.

platyceras torteosuar Hall.

Plate XLIX., Figs. 13-14.

1859. Platyceras tortuosum Hall, Pal. N. Y., vol. III., p. 472, pl. 113, figs. 1-5.

Description. - Shell erect, spirally subconical in form, making alout one volution, which increases gradually in size towards the scarcelyexpanded aperture. One side marked by a spiral sinus, which extends from the apex to the margin of the aperture. 
The dimensions of the only specimen observed are: height, $1 \% \mathrm{~mm}$.; maximum diameter of aperture, $14 \mathrm{~mm}$.

Remarks.-A single specimen from the New Jersey Oriskany collection probably represents this species. It differs chiefly from the typical form of the species, as illustrated by Hall, in its less elevation.

\section{PTEROPODA.}

\section{TFxTACULITES ELONGATCS Hall.}

Plate L., Figs. 4-5.

See, also, pp. 295 and 319.

1859. Tentaculites clongatus Hall, Pal. N. Y., vol. III., p. 136, pl. 6, figs. 16-21.

1900. Tentaculites elongatus Clarke, Mem. X. I. State Mus., No. 3, vol. III., p. 2\%, pl. 3, figs. $8-12$.

Description.-Shell elongate, circular in cross-section, annulate, gradually tapering to the apex. Annulations strong, subangular or rounded, two of them occupying the space of $3 \mathrm{~mm}$. near the larger end of adult shells, while at the smaller end they are less than $1 \mathrm{~mm}$. apart. Entire surface covered by fine, annular striæ, which are most conspicuous in the depressions between the annulations, and are often nearly obsolete upon the outermost portion of the annulations. Internal casts lack the fine, annular strix, and the annulations have the appearance of a series of insheathed cones, with their apices toward the larger end of the shell.

Some of the larger individuals attain the following dimensions: length, 60 to $70 \mathrm{~mm}$.; larger diameter, $6 \mathrm{~mm}$.

Remarks.-This species makes its first appearance in the Coeymans limestone, where it is one of the rare species, and continues through the Helderbergian formations, but never in great abundance. It is most conspicuous in the Oriskany formation, where it sometimes occurs crowded together in great numbers. Its most usual occurrence is in the form of internal casts, the fine surface striæ being only detected in the moulds of the exterior of the shell. 
CEPHALOPODA.

ofthLoceras sp. undet.

A single fragmentary specimen, which is probably the cast of a portion of the chamber of habitation of a species of Orthoceras, has heen observed in the Orbiculoidea jervensis fauna.

\section{ARTHROPODA.}

\section{TRILOBITA.}

DALMANITES sp. undet.

Plate L., Fig. 6.

$A$ few more or less fragmentary specimens of the pygidia of Dalmanites have been observed in the Oriskany fauna of New Jersey. These specimens may represent more than one species, but they are ton imperfect for identification, expecially in the absence of any of the cephalic characters. The most norly-perfect specimen is a large pygidium from near the New York State line, north of the Nearpass section, and, when complete, the specimen must have had a length of nearly $60 \mathrm{~mm}$. and a width of over $80 \mathrm{~mm}$. 'The axis is rather narrow, subangular along it: median line. lemding upward posteriorly, and is composed of more than twenty segments. The posterior extremity is broken, so it is not certain whether it was produced as a spine or not. The pleural slopes are rather regularly convex and are marked by about sixteen segments.

PHACOPS? sp. undet.

Plate L., Fig. 7.

A single imperfect pygidium may represent a species of this genus, but it is too imperfect for certain identification. 
Descriptions of Species in the Onondaga Limestone Fauna.

\title{
COELENTERATA.
}

ANTHOZOA.

ZAPHRENTIS sp. undet.

Specimens of one or more species of horn corals are occasionally met with in the Onondaga limestone, but none of those observed are perfect enough for specific identification. They may be referred provisionally to the genus Zaphrentis.

\section{MOLLUSCOIDEA.}

\author{
BRYOZOA.
}

FENESTELLA ? sp. undet.

Bryozoans of the fenestelloid type are sometimes present in the Onondaga limestone, but in no case hare they been found to be preserved in such a condition as to allow of their identification.

\section{BRACHIOPODA.}

IINGULA sp. undet.

A single fragment of a rather large linguloid shell has been noticed in the Onondaga limestone. When complete the specimen must have had a length of 16 or $18 \mathrm{~mm}$., but the fragment preserved is not sufficient for identification. 
STROPHEODONTA PERPLANA (Con.).

Plate LI., Figs. 12-13.

186\%. Strophodonta perplana Hall, Pal. X. Y., rol. IV., p. 98, pl. 11, fig. 22, pl., 12, figs. 13-15, pl. 1\%, figs. $1 a-0$.

Description.-Shell subsemi-elliptical in outline, the hinge-line uinally equaling, but sometimes a little less tham, the greatest width of the shell; cardinal extremities angular, proportional length and breadth variable; lateral margins often more or less sinuate immertiately in front of the cardinal angles. Pedicle ralve depressedconvex on the umbo, nearly flat towards the lateral and anterior margins; beak scarcely projecting beyond the hinge-line; cardinal area narrow, linear. Brachial valve nearly flat, leaving but a very narrow interspace between the two valves. Surface of both valves marked by fine, subequal, radiating costix, which increase by bifur(ation and by intercalation, those of the pedicle ralve being somewhat finer than those of the brachial valve.

The approximate dimensions of a rery imperfect specimen are: length, $12 \mathrm{~mm}$; width, $20 \mathrm{~mm}$.

Remarks.-The only specimens of this species which have been observed in the Onondaga limestone of New Jersey are considerably smaller than the average size of the species as it usually occurs in the Middle Deronian fambs of New Tork and the west. The specimens are very imperfect and scarcely serve to illustrate the characters of the species.

LEPTAEXA RHOIBOIDALIS (Wilck).

Plate LI., Fig. 19.

See, also, pp. 228, 275, 302, 325.

Specimens of this widely-distributed species, not unlike those in the older formations. are not infrequently met with in the Onondaga limestone. 
ORTHOTHETES PANDORA (Bill.).

See, also, pp. 373 and 380.

186\%. Streptorhynchus pandora Hall, Pal. N. Y., vol. IV., p. 68, pl. 4, figs. 11-19, pl. 9, figs. 18-25, $2 \%$.

Description.-Shell semi-circular or semi-elliptical in outline, hinge-line equaling the greatest width of the shell, cardinal angles nearly rectangular. Pedicle valve convex, greatest elevation at the beak, from which point the surface slopes away regularly with a slight convex curve to the lateral and anterior margins; beak obtuse, not incurved; cardinal area rather high, sloping a little posteriorly, flat or slightly concave. Brachial valve depressed-convex, flattened toward the cardinal angles. Surface of both valves marked by numerous, fine, strongly-elevated, radiating costæ, which increase hy bifurcation and by intercalation.

The dimensions of a nearly-perfect pedicle valve are: length, 10 mm.; width, $14 \mathrm{~mm}$; convexity, $3 \mathrm{~mm}$.

Remarks.-More or less fragmentary specimens of this species have been found in the Onondaga limestone at several localities in New Jersey.

CHONETES ARCUATUS Hall.

Plate LI., Fig. 18.

186\%. Chonetes arcuata Hall, Pal. N. Y., vol. IV., p. 119, pl. 20, figs. $7 a-f$.

Description.-Shell semi-circular or semi-elliptical in outline; hinge-line equaling the greatest width; cardinal cxtremities angular. Pedicle valve gibbous, somewhat depressed toward the cardinal angles, a little flattened along the median line from the beak to the anterior margin; the beak strongly incurved, the cardinal margins sloping gently from the beak to the cardinal extremities, bearing about seven or eight spines, pointing in a slightly oblique direction outward, on each side of the beak. Surface marked by fine, radiating costæ, which increase by intercalation and rarely by bifurcation, about one hundred being present on the margin of a shell $1 \% \mathrm{~mm}$. wide, and 
crossed also by much finer, crowded, concentric striæ. Brachial valve not seen, but it is apparently deeply concave.

The dimensions of the best specimen observed are: length, $12 \mathrm{~mm}$; width, $17 \mathrm{~mm}$.; convexity, $6 \mathrm{~mm}$.

Remarks.-In common with most of the Onondaga limestone fossils, this species is represented only by fragmentary specimens. The New Jersey specimens are smaller than the typical New York representatives of the species as illustrated in the New York Paleontology, but they seem to agree with the characters of $C$. arcuatus more closely than with any other species. The species may be recognizer by its fine. radiating markings and its slight mesial flattening or depression of the pedicle valve.

RHIPIDOMELLA VANUXEMI (Hall).

Plate LI., Figs. 5-7.

186\%. Orthis vanuxemi Hall, Pal. N. Y., vol. IV., p. 4\%, pl. 6, figs. $3 a-r$.

Description.-Shell subcircular or suboval in outline; hinge-line much shorter than the greatest width of the shell: ardinal extremities rounded. Pedicle valve depresed-convex on the umbo, flattened or a little concave towarl the lateral and front margins; heak small, extended hut little beyond that of the opposite valve, hut little incurved: cardinal a rea small, concave. Brachial valve convex; the beak scarcely extended berond the cardinal horder. Firface of both ralves marked hy fine, crowded. rounded costar, which increase hy bifurcation and by inter(alation: and hy fine. concentric stria, with a few stronger, sub)lamellose lines of growth.

The dimensions of an arerage middle Deronian specimen are: length, $19 \mathrm{~mm}$.; width, $20 \mathrm{~mm}$.; thickness, $8 \mathrm{~mm}$.

Remarks.-Numerous fragmentary specimens of Rhipidomella, which may be referred to the species $R$. vanuxemi, are sometimes met with in the Onondaga limestone of New Jersey, but no specimens approaching completenes have heen observed. The description of the species here given has been drawn up from more perfect New York specimens. 
ATRYPA RETICULARIS (Limn.).

Plate LI., Figs. 1-4.

See, also, pp. 236 and 286.

The specimens of this species which occur in the Onondaga limestone are not essentially different from its earlier representatives.

SPIRIFER sp. undet.

A few fragments of a small, rather coarsely-ribbed species of Spivifer, with strong, lamellose lines of growth, have been detected in the Onondaga limestone. The specimens have somewhat the aspect of Spirifer varicosus Hall, but in no case are they sufficiently well preserved to be identified with certainty.

\section{RETICULARIA FIMibriata (Con.).}

Plate LI., Figs. 8-11.

186\%. Spirifera fimbriata Hall, Pal. N. Y., vol. IV., p. 214, pl. 33, figs. 1-21.

Description.-Shell transversely subelliptical in outline; hingeline shorter than the greatest width; cardinal extremities rounded. Pedicle valve strongly convex on the umbo, the surface sloping in a regular curve to the lateral and front margins, but curving much more abruptly to the cardinal margins; depressed along the median line in a more or less sharply-defined, shallow, rounded sinus; beak small, incurved over the area; cardinal area rather high, concave, not sharply defined. Brachial valve a little less convex than the pedicle, often somewhat flattened toward the cardinal extrenities; mesial fold rather abruptly elevated in front, but scarcely defined at the beak. Surface of each valve marked by from five to eight low, rounded, obscure plications on each side of the fold and sinus, and by more or less imbricating, concentric lamellæ of variable width, each one of which is marked by a row of small, radially elongate nodes having: 
somewhat the appearance of interrupted radiating costie, and which are really the bases of parallel, concentric rows of spines.

The dimensions of a nearly-perfect specimen from the Hamilton shale of New York are: length, $22 \mathrm{~mm}$; width, $25 \mathrm{~mm}$; thickness, $15 \mathrm{~mm}$.

Remarks.-This species is rarely represented in the Onondaga limestone of New Jersey, the only specimens observed being imperfect impressions of the exterior. These impressions, howerer, retain the characteristic surface markings of the species, and indicate a shell which was in no essential particulars different from the Onoudaga and Hamilton representatives of the species in New York. The above description has been drawn up from New York specimens in the absence of satisfactory material in the New Jersey collections.

ANoplotileca aCUTiplicata (Con.).

Plate LI., Figs. 14-17.

See, also, pp. 377 and 383.

186\%. Leptocoelia acutiplicata Hall, Pal. N. Y., vol. VI., p. 365, pl. $5 \%$, figs. $30-39$.

Description. - Shell plano-convex, subcircular or subovate in outline. Pedicle valve moderately convex, its greatest elevation near the centre; beak acute, incurved so that it points at about right angles to the plane of the valve and projects slightly bevond the brachial valve: marked by about nine strong, angular, simple, radiating plications, the central one being somewhat depressed toward the front and bordered on each side by a larger one. Brachial valve flat or slightly convex, a little depresised medially, its plications similar to those of the opposite valve. Surface of both valves marked by a few rather strong, subimbricating lines of growth toward the margin.

The dimensions of a nearly-perfect specimen are: length, $12 \mathrm{~mm}$; widtl, $13 \mathrm{~mm}$; thickness, $4 \mathrm{~mm}$.

limark. - This species is hardly distinguishable from A. flabelliles of the Oriskany famma. It does not grow as large as the usual representatives of the Oriskany shell, but it is doubtful whether the two species should be considered as distinct. 
ANOPLOTHECA CONCAVA (Hall).

See, also, p. 316, pl. XXXVII.

Specimens of a small species of Anoplotheca, indistinguishable from specimens in the New Scotland beds of the Helderbergian series, have been obserred in the Onondaga limestone at several localities. Hall, after first referring this Onondaga limestone shell to the Helderhergian species," afterwards established a new species for it, with the name camilla, + but the New Jersey specimens at least cannot be distinguished from A. concava.

\section{MOLLUSCA.}

\section{GASTROPODA.}

PLATYCERAS sp. undet.

Fragments of capulid shells, which may be referred to the genus Platyceras, are occasionally met with in the Onondaga limestone, but no specimens perfect enough for specific identification have been seen.

LOXONEMA sp. undet.

Plate LI., Fig. 20.

A few specimens of an elongate, coiled shell have been observed in the Onondaga limestone. All are too imperfect for identification, but may be referred provisionally to the genus Loxonema.

* Pal. N. Y., vol. IV., p. 329.

† Pal. N. Y., vol. IV., pl. 52, figs. 13-19. 
Description of Species in time Newfoundland Grit Fauna.

\title{
COELENTERATA.
}

ANTHOZOA.

ZAPHRENTIS sp. undet.

In the Newfoundland locality of this formation specimens of horr: coral are not of infrequent occurrence. All the specimens observed are imperfect casts of the cup, which retain neither specific nor generic characters sufficient for identification. All may be provisionally referred to the genus Zaphrentis. The largest specimen observed has a maximum diameter of $45 \mathrm{~mm}$.

\section{MOLLUSCOIDEA.}

\section{BRACHIOPODA.}

\author{
STROPHEODONTA INEQUIIADIATA Hall.
}

Plate LI., Fig. 22.

186\%. Stropheodonta inequiradiata Hall, Pal. N. Y., vol. IV., p. 8\%, pl. 11, figs. 24-31, pl. 13, figs. 6-11.

Several specimens of a species of stropheodonta from Newfoundland are eridently memhers of the species S. inequiradiata. All are poorly preserved, retaining the surface markings in a rery imperfect mamner. but the shells have the general form of this species, and it is believed that the identification is correct. The shells are subellipti(al in outline. with the hinge-line equaling the greatest width, and with the pedicle valve strongly (onvex, almost subhemisplereice in form. The specimens differ from $S$. concava in their smaller size and in the absence of the constrictions in front of the cardinal extremitics. 


\section{orthothetes PANDORA (Bill.).}

Plate LII., Fig. 8.

See, also, pp. 367 and 380 .

186\%. Streptorhynchus chemungensis var. pandora Hall, Pal. N. Y., vol. IV., p. 68 , pl. 4, figs. 11-19, pl. 9, figs. 18-25, $2 \%$.

Some imperfect specimens of Orthothetes from the Greenwood lake locality may quite certainly be referred to the species $O$. chemungensis or some variety of it. Members of this, species are characterized by the nearly-flat pedicle valve, with straight hinge-line usually equaling the greatest width of the shell, with the cardinal extremities varying either way from rectangular, and often with a more or less distorted beak. The brachial valve is more convex than the other. Both valves are marked by fine, radiating costæ, which increase by intercalation and by bifurcation. The New Jersey specimens agree most closely with the illustrations of the variety pandora and may be referred to that form without much doubt.

\section{CHONETES ARCUATUS Hall.}

Plate LI., Fig. 21.

186\%. Chonetes arcuata Hall, Pal. N. Y., vol. IV., p. 119, pl. 20, figs. $7 a-f$.

Description.- Shell semi-elliptical or semi-circular in outline, the hinge-line straight, about equaling the greatest width; cardinal extremities rectangular. Pedicle valve strongly convex, with a slight mesial flattening or depression, depressed toward the cardinal extremities. In the internal casts the hinge-line is apparently crenulate, the crenulations doubtless representing the bases of cardinal spines. A constricted line runs parallel to the front and lateral margins of the valve at a little distance from the margin, converging posteriorly to the beak; within this line the surface of the valve is somewhat elevated above the outer portion, the elevation being more conspicuous near the cardinal margin. Extending forward from the beak for about one-third of the length of the valve there is a low 
median septum represented by a shallow groove in the casts. The muscular scars are not well shown in any of the New Jersey specimens, lut seem to resemble quite closely Hall's figures of this species. Brachial valve not observed.

The dimensions of an average specimen are: length, $15 \mathrm{~mm}$; width, $23 \mathrm{~mm}$.; convexity, $5 \mathrm{~mm}$.

Remarls.-Because of the apparent crenulations of the hinge-line in the internal casts of this species, the specimens resemble members of the genus stropheodonta, but these crenulations doubtless represent the bases of cardinal spines. Internal casts of $c$. arcuatus from New York, illustrated by Hall, show similar cremulations. The constricted line in the internal casts is exactly as in the illustrations of typical specimens of C. arcuatus, and the muscular impressions are unlike any suecies of Stropheodonta, being closely similar, so far as they can be distinguished at all, to Hall's illustration of $(\therefore$ arcuatus.

\section{schizophoria sp. cf. s. striatula (Schl.).}

Plate LII., Figs. 9-10.

Several imperfect internal casts of a species of schizophoria have been collected at Newfoundland. They are all too poorly preserved for certain identification, but have the general form of st. striatula or S. propinqua. The pedicle valve, however, seems to be too depresied for the latter species, and they may be doubtfully referred to $S$. striatula.

\section{AMPHIGENIA ELONGATA (Van.).}

Plate LII., Figs. 6-7.

186\%. Amphigenia elongata Hall, Pal. N. Y., vol. IV., p. 383, pl. 58 A, figs. 21-24, pl. 59, figs. 1-11.

Description. - Shell subelliptical or sulovate in outline, the length greater than the wilth, but the proportions variable. Pedicle valve the most convex, but in some individuals the two valves are nearly equally convex. The surface of the internal casts is smooth or is marked by rather coarse, more or less distinct, concentric lines of 
growth. In the pedicle valve the dental lamelli are united to form a spondylium, which is supported by a median septum, and in the internal casts these dental lamellæ and the median septum are represented by slits.

The dimensions of the best specimen observed, apparently a brachial valve, are: length, $40 \mathrm{~mm}$; width, $25 \mathrm{~mm}$. ; convexity, $7 \mathrm{~mm}$.

Remarks. - This species has been recognized at both the Newfoundland and the Greenwood lake localities, always in the condition of imperfect internal casts, upon which the characters are always more or less obscure. There seems to be no other species, however, than A mphigenia elongata with which the specimens can be identified.

SPIRIFER MACROTHYRIS Hall.

Plate LII., Figs. 1-3.

186\% Spirifer macrothyris Hall, Pal. N. Y., vol. IV., p. 202, pl. 30, figs. 16-20.

Description.-Shell large, subelliptical in outline, much wider than long; hinge-line nearly equaling the greatest width; cardinal extremities angular or a little rounded. Pedicle valve moderately convex, with a well-defined, rather shallow, rounded, smooth mesial sinus; cardinal area of moderate width, a little concave, sharply defined and extending to the cardinal extremities; delthyrium large, broadly triangular. In the internal casts the muscular impression is large and prominent. Brachial valve more convex than the pedicle; mesial fold prominent, subangular posteriorly and rounded toward the front. Surface of each valve marked by from six to ten rather broad, depressed, rounded, simple plications on each side of the fold and sinus.

The dimensions of the largest specimen observed from New Jersey are: width, $98 \mathrm{~mm}$.; estimated length of shell, $40 \mathrm{~mm}$.

Remarks.-The only specimens of this species which have been observed are very imperfect, but they seem to possess characters which belong to no other Spirifer than S. macrothyris. Some of the smalier individuals from Newfoundland were at first thought to represent the Oriskany species, S. murchisoni, but the pedicle valves are less strongly 
convex and have less angular plications than that species, and they seen to agree essentially with the larger specimens, which exhibit more typically the characters of $S$. macrothyris.

\section{SPIRIFER sp. undt.}

\section{Plate LII., Fig. 4.}

Description.-A single, fairly well-preserved specimen of the brachial valve of a Spirifer has been observed from the Newfoundland locality which camnot be definitely identified with any of the described species. It is nearly semi-circular in outline, with the linge-line equaling the greatest width and with angular cardinal extremities. The mesial fold is not greatly elevated above the general surfice, and is marked along its median line by an angular furrow much deeper and wider than the furrows which separate the plications upon the lateral slopes of the valve. Each lateral slope is marked by eleven or twelve angular plications which become smaller and smaller toward the cardinal extremities.

The dimensions of the only specimen observed are: length, $16 \mathrm{~mm}$; width, $30 \mathrm{~mm}$.

Remarks.-The peculiar feature of this species is the dęep furrow along the mesial line of the fold. Spirifer pennatus Atw. frequently has a similar mesial furrow, but it is never so conspicuous as the furrows on the lateral slopes of the shell, and, moreover, the New Jersey specimen does not posiss the extended hinge-line of that species. Spirifer consobrinus D'Orb. is another species which frequently has a furrow upon the mesial fold of the brachial valve, but the furrow is never so prominent as in the New Jersey specimen, and the fold itself is much more elevated in front. The finer surface markings are not preserved on the New Jersey -pecimen, so it cannot be determined whether or not it resembles $S$. consobrinus in this character. 
CFRTINA HAMILTONENSIS Hall.

Plate LII., Fig. 5.

186\% Cyrtina hamiltonensis Hall, Pal. X. Y., rol. IT., p. 268, pl. 2\%, figs. 1-4, pl. 44, figs. 26-33, 38-52.

Description.-Imperfect specimens of a species of Cyrtina occur at both the Newfounland and the Greenwood lake localities of this formation, which seem to be identical with $C$. hamiltonensis. The pedicle valve is subpyramidal in form, with a high, nearly-flat cardinal area, and in the internal casts a slit representing the median scptum reaches from the beak more than half way to the front of the valve. The mesial sinus is well defined, smooth, rather shallow and rounded in the bottom, and on each lateral slope there are fire or six simple, rounded plications. The brachial valve is depressed-convex, with the mesial fold flattened and but little elevated abore the general surface of the valve; the plications upon the lateral slopes resemble those of the opposite valve.

The dimensions of the best pedicle valve observed are: length from beak to front margin, $9 \mathrm{~mm}$. ; width, $11 \mathrm{~mm}$.; height of area, $5 \mathrm{~mm}$.

Remarks.-The only specimens of this species which have been observed are imperfect internal casts, but they exhibit the characteristics of this common Devonian species.

ANOPLOTHECA ACUTIPLICATA (Con.).

See, also, pp. 370 and 383.

The specimens of this species in the Newfoundland grit do not differ materially from those found in the Onondaga limestone of the Delaware valley, except in being preserved in sandstone in the condition of internal casts. They somewhat resemble the Oriskany species, $A$. flabellites, but are constantly smaller. 


\title{
MOLLUSCA.
}

\author{
PELECY PODA.
}

\author{
PTERINEA FLABELLA (Con.).
}

Plate LII., Fig. 12.

1884. Pterinea fabeilla Hall, Pal. N. Y., vol. V., pt. I., p. 93, pl. 14, figs. 1-21, pl. 15, figs. 1, 1-6, 8-10, pl. 83, figs. 11-12.

In the Newfoundland locality sereral imperfect specimens of a large species of Pterinea have been observed, which seem to represent the common Hanilton speeies, $P$. Aabella, of New Iork. In none of the specimens can the complete form of the shell be observed, but the shell is oblique, with a broad and nearly-flat posterior wing, the anterior auriculation being destroved in all of the specimens observed. The body portion of the left valve is subovate in outline and is markenl with very coarse, rounded costax, with alternate finer ones, besides indistinct, concentric lines of growth. these markings being identical with those of authentic specimens of $P$. fabella from the New York Hamilton shales. The height of the hest-preserved specimen in the collection is about $40 \mathrm{~mm}$.

ACTINOPTERIA DECUSSATA Hall.

Plate LII., Fig. 11.

1884. Actinopteria decussata Hall, Pal. N. Y., vol. V., pt. I., p. 111, pl. $1 \%$, figs. 24 , 28 , pl. 18 , figs. $1-15$, pl. 20 , fig. 19 , pl. 84 , fig. 4 .

Description.- Shell rery oblique. with anterior and posterior wings; the hinge-line straight, extending from beneath the beak to the extremity of the posterior wing. The horly of the left ralve suborate in outline, anterior and basal margins regularly curved, the posterior margin from a little above the base, nearly straight to the beak; an- 
terior auriculation convex, limited posteriorly by a distinct, broadlyrounded sinus, its anterior margin rounded; posterior wing large, nearly flat, rather sharply-defined by the posterior umbonal slope, its posterior margin concave and its posterior extremity angular. Surface of the left valve marked by moderately coarse, radiating costre which alternate more or less irregularly with finer ones, the alternation being more conspicuous unon the posterior portion of the shell: also marked by concentric lines of growth, which give to the surface a reticulate appearance. Upon the wings the markings are less conspicuous than upon the body of the shell. Right valve not seen.

The dimensions of an average specimen are: height, $19 \mathrm{~mm}$.; extreme length, $34 \mathrm{~mm}$.

Remarks.-This species has been observed only in the Greenwood lake locality, where it occurs quite commonly. The specimens are all internal casts, so the surface markings are not so conspicuous as upon the external surface of the shell. The proportions and general form of the specimens seem to be most like authentic specimens of the New York Hamilton species, A. decussatu, but none of the New Jersey specimens have been observed to attain as large a size as the larger individuals of that species, and the anterior auriculation is more conspicuous than is usually, but not always, the case in the New York specimens.

Descriptions of Species in the Falxas of the Monroe Shale and Belltale Flags.

\section{MOLLUSCOIDEA.}

\section{BRYOZOA.}

FENESTELLA? sp. undet.

A few specimens of fenestelloid bryozoans have been collected from rarious localities in the Monroe shales of New Jersey, but none of them are in a proper state of preservation, even for accurate generic determination. 


\section{BRACHIOPODA.}

ORTHOTHETES PANDORA (Bill.).

Plate LIII., Fig. 6.

See, also, pp. 367 and 373.

1 few species of Orthothetes from Greenwood lake may be referred provisionally to the species $O$. pandora. The specimens are all imperfect and much distorted, so that in all of them the characters are more or less obscure.

\section{CHONETES CORONATUS (Con.).?}

Plate LIII., Fig. 5.

186\%. Chonetes coronata Hall, Pal. N. Y., vol. IV., p. 133, pl. 21, figs. 9-12.

A few distorted specimens of a flat, subelliptical brachiopod shell, some of which seem to retain the bases of cardinal spines, may be referred with doubt to the species Chonetes coronatus. If the shell really possesses cardinal spines and is a true Chonetes, then its size and rather coarse, radiating markings correspond more closely with the characters of $C$. curonatus than with any other species of the genus. This identification must remain doultful, however. because of the imperfection of the material for study.

\section{CHONETES sp. undet.}

Plate LIII., Fig. 4.

A single distorted specimen of a rather large species of Chonetes han been collected at the Greenwood lake locality. Its width along the hinge-line is $14 \mathrm{~mm}$. and the length of the shell is $9 \mathrm{~mm}$. The surface is marked by very fine, radiating strix, and from one end of the cardinal margin a spine, $6 \mathrm{~mm}$. in length. extends at nearly right 
angles to the hinge-line. Between this spine and the beak the bases of one or two additional spines may be detected. The characters of the shell are not well enough preserved to admit of its certain identification, and in the great length of the outer cardinal spines it seems to differ from any of the described species of the genus from the horizon to which it belongs.

CHONETES sp. undet.

An occasional small, imperfect and more or less distorted specimen of Chonetes is met with in the Monroe shales of New Jersey, which resembles more or less closely some of the smaller Hamilton species of the genus in New York, but none of them are perfect enough for certain identification.

CAMAROTOECHIA sp. undet.

Occasional specimens of Rhynchonelloid shells occur in the Monroe shales of New Jersey, which doubtless represent some of the New York Hamilton species of Camarotochia, but none of the specimens can be identified with certainty. From the locality north of the Clinton reservor a single specimen seems to possess the general form and proportions of $C$. sappho Hall, but the identification cannot be made with certainty because of the imperfection of the specimen.

TROPIDOLEPTUS CARINATUS (Con.).

Plate LIII., Fig. 2.

186\%. Tropidoleptus carinatus Hall, Pal. N. Y., vol. IV., p. 40\%, pl. 62, figs. $2-3$.

Description.-The New Jersey specimens of this species are all distorted and imperfect, but some of them retain characteristic features of the species. The shell is normally concavo-convex, but in nearly all cases the New Jersey specimens are crushed perfectly flat; the outline is subsemi-elliptical, with the straight hinge-line equaling, greater or less than, the width of the shell; the cardinal extremities are rounded or subangular; the lateral margins are straight or convex, 
rarely a little concare just in front of the hinge-line; the anterior margin regularly rounded. Pedicle valve convex, broadly subcarinate along the mesial line, from which the surface slopes to the lateral margins with a flattened conrex curve; beak small; cardinal area rather narrow, its margins subparallel. Brachial valve nearly flat, or slightly concave, often with a narrow mesial sinus which becomes more conspicuous anteriorly. Surface of each valve marked by from cighteen to twenty, hroad. simple, rounded plications, the median one on the pedicle valve being broader and more elevated than the others. with a corresponding broader furrow along the median line of the brachial valve. 'The plications are crossed by fine, concentric stria, and by a few stronger, imbricating, lamellose lines of growth.

'The dimensions of the best of the New Jersey specimens are: length, $14 \mathrm{~mm}$. ; width, $11 \mathrm{~mm}$.

Remarks.-The New Jersey specimens are all badly crushed and distorted, but some are sutficiently well-preserved to make the certain identification of the species possible.

\section{SPIRIFER ACDACULUS (Con.).?}

Plate LIII., Fig. 1.

186\% Spirifer medialis Hall, Pal. N. Y., vol. IV., p. 22\%, pl. 38, figs. 1-25, pl. 38\%, figs. 1-11.

Description.-A few small, distorted, more or less imperfect specimens of a species of spririfer from the outlet of the Oak Ridge reservoir stem to be referable to this common species of the New York Hamilton formation. The pedicle valve has a rather high, more or less concave cardinal area, with a moderately-incurved beak; the mesial sinus is sharply defined, angular toward the beak, becoming rounded anteriorly and is without plications; each lateral slope is marked by fifteen or sixteen simple plications. The brachial valve is less convex than the perlicle, with a well-defuned mesial fold and with plications similar to those upon the opposite valve. The width of the largest and hestpreserved specimen which has been observed in the collections is 19 $\mathrm{mm}$. along the hinge-line, which is the widest portion of the shell.

Liemarks-Although the New Jersey specimens of this shell are all smaller than full-grown specinens from the Hamilton formation of

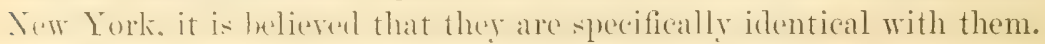


ambocoelia umbonata (Con.).

186\%. Ambocalia umbonata Hall, Pal. N. Y., vol. IV., p. 259, pl. 44, figs. $7-18$.

Description.-Shell small, plano-convex, length and width nearly equal or a little wider than long; hinge-line a little shorter than the width of the shell; cardinal extremities rounded. Pedicle valve gilybous; the umbo elevated; the beak rather large and incurved; mesial sinus narrow, distinct from the beak to the front of the shell; cardinal area high, concave. Brachial valve depressed-convex or nearly flat, sometimes concave towards the front and lateral margins. Surface of both valves smooth or with a few concentric lines of growth near the margin.

The dimensions of the best specimen observed from New Jersey are: length, $3.5 \mathrm{~mm}$.; width, $4.5 \mathrm{~mm}$.

Remarks.-The only specimens of this species which have been oiserved in the New Jersey collections are from the fossil locality in the Monroe shales near the shore of Greenwood lake. They are not at all common, and are found only in the condition of internal casts, which are usually distorted and poorly preserved.

\section{ANOPLOTHECA ACUTIPlicata (Con.).?}

Plate LIII., Fig. 3.

See, also, pp. 370 and 377 .

The internal casts of what seems to be a species of Anoplotheca are among the commonest fossils found in the Monroe shales at the Greenwood lake locality. The specimens in this condition do not seem to ilffer materially from those found in the Newfoundland grit which have been identified as $A$. acutiplicata. All of the specimens are in an unsatisfactory condition for study, but this identification seems to be the correct one. 


\section{MOLLUSCA.}

PELECYPODA.

ACTINOPTERIA sp. undet.

A few fragmentary specimens of Pelecypod shells which eridently belong to the gemu - Actinopleria have been observed in the Monroe shales. None of them are complete enough for specific identification, but they resemble, in general, the New York Hamilton members of the genus.

PALAEONEILO EMARgINATA (Con.).

Plate LIII., Figs. 10-11.

1885. Palconeilo emarginata Hall, Pal. N. Y., vol. V., pt. I., p. 338, pl. 50 , figs. 1-11.

Description.- "Shell of medium size or larger, subelliptical; length usually more than twice the height; basal margin gently curving or nearly straight from the post-inferior angle to the anterior end, where it is more abruptly rounded; posterior margin deeply sinuate. Cardinal line gently arcuate. Anterior end regularly and somewhat abruptly rounded. Talves regularly conver in the lower anterior half, becoming gibbous above. Beaks a little less than the anterior third from the end, and, except in the shorter forms, moderately prominent. T'mbonal slope marked by a strong elevation or ridge, with a depression above it, which produces a marked emargination. The post-carlinal extremity, above this, is produced into a linguiform extension, which is sometimes angular, but usually abruptly rounded at the termination. Surface marked by strong, elevated, distant, lamellose. concentric ridges, extending the entire length of the shell, between which are very fine concentric strix. The intermediate striæ become obscure or obsolete, according to the degree of weathering and nature of the matrix.

"Five specimens measune respectively $22,24,26,2 \%, 28$ and $40 \mathrm{~mm}$. in length, and 12, 13.5, 16, 12 and $16 \mathrm{~mm}$. in height."-Hall. 
Remark. - The New Jersey specimens of this species have been observed only from the outlet of the Oak Ridge reservoir near Newfoundland. They possess the characteristic, regular, strong, lamelliform, concentric ridges and the deeply-emarginate, post-inferior extremity of the species, and the identification is more satisfactory than that of almost any other species collected from this horizon.

\section{PARACYCLUS ELLIPTICA Hall.?}

1885. Paracyclus elliptica Hall, Pal. N. Y., vol. V., pt. I., p. 440, pl. 72, figs. 23-33, pl. 95, fig. 18.

A single distorted and imperfect specimen of a pelecypod shell from the outlet of the Oak Ridge reservoir suggests Paracyclus elliptica, but the identification is necessarily uncertain.

GRAMIIYSIA sp. undet.

Plate LIII., Figs. 8-9.

At the outlet to the Oak Ridge reservoir near Newfoundland several specimens of Grammysia have been collected. All of them are distorted, and are too imperfectly preserved for certain specific identification, but they possibly represent more than one species. Some of them resemble the illustrations of G. alveata (Con.), ${ }^{*}$ but the identification cannot be made with certainty.

The members of this genus may be easily recognized by their robust form and by the coarse, concentric wrinkles of the shell. These New Jersey specimens are probably identical with some of the numerous forms which have been described from the Hamilton formation of New York.

* Pal. N. Y., vol. V., pt. I., p. 370, pl. 60, figs. 1-11. 


\title{
GASTROPODA.
}

\author{
CrRTONELLA MITELLA Hall.
}

Plate LIII., Fig. 12.

18\%9. Cyrtolites (Cyrtonella) mitella Hall. Pal. T. I., vol. V., pt. II., p. 123, pl. 25, figs. 23-28.

Description.—"Shell arcuate, subovoid, making altogether less than two rolutions in the same plane: first rolution rery minute; the bodywhorl rapidly expanding to the aperture. which is nearly circular; the peristome sarcely spreading: the shell carinate. and the casts obtusely, but distinctly, angular on the dorsum : applarently not sinuate or but slightly undulated on the anterior margin. surface marked hy regular, sharply-elevated, subparallel, tramsverse stria. which are comparatively distant (at least twice or thrice their width) near the apex and on the upper part of the outer volution, but become more crowded towards the front of the shell. On the upper part and sides of the shell the intermediate spaces are regularly cancellated by short, revolving stria, which hardly rise so high as the transerse ones, giving the entire surface a pitted or finely-reticulate charactar. Approaching the margin the spaces between these striæ diminish, as the result of the rate of growth in the shell, and they often become so crowded as to present the character of simple, undulating, granulose lines of growth. These striæ are not sensibly curved in passing over the rounded carina. When the shell is partially exfoliated they give a lamellose-striate character to the surface."-Ha7l.

The dimensions of the best specimen observed in the New Jersey collection are: maximum diameter, $12 \mathrm{~mm}$.; width of aperture, 11 mm1.

Remarks.-This species occurs more or less commonly at the outlet of the Oak Ridge reservoir. 'The specimens are all internal casts, and the best-presured ones closely resmble Hall": illustrations of $C$. mitella, and it is believed that this identification is correct. . The surface markings described by Hall are, of course, absent from these internal casts, but upon some of them the transrerse lines of growth may be detected, although they are nerer conspicuous. 
STROPHOSTYLUS? sp. undet.

Plate LIII., Figs. 13-16.

Among the specimens collected from the Monroe shales of New Jersey there are several imperfect and distorted coiled shells, which are probably referable to the genus Strophostylus. In none of them are the characters sufficiently well-preserved for specific identification, and even the generic reference must be considered doubtful.

\title{
ARTHROPODA.
}

\author{
TRILOBITA.
}

\section{HOMALONOTUS DEKAYI (Green).}

1888. Homalonotus Dekayi Hall and Clarke, Pal. N. Y., vol. VII., p. 7, pl. 2 , figs. 1-11, pl. 3, figs. 1-5, pl. 4, figs. 1-6, pl. 5, figs. $1-10$.

At Sylvester's Corners a single thoracic segment of a trilobite has been found in the Honroe shales, which is evidently a portion of a species of Homalonotus, and is probably the common New York Hamilton species of the genus, $H$. dekayi.

$$
\text { PHACOPS RANA (Green). }
$$

Plate LIII., Fig. 18.

1888. Phacops rana Hall and Clarke, Pal. N. Y., vol. VII., p. 19, pl. \%, figs. 1-11, pl. 8, figs. 1-18, pl. 8 A, 21-33.

Imperfect and distorted specimens of the head of this species have been found in some of the localities of the Monroe shale in New Jersey. The species may be recognized by its large and broad glabella without lateral furows. The specimen here illustrated is the best 
one which has been observed, and it exhibits the characters of the species as well as they can be seen in any New Jersey specimen so far collected. The thorax and pygiduim have not been observed.

DALALANITES sp. ef. D. ANCHIOPS (Green).

Plate LIII., Fig. 17.

1888. Datmanites (Chasmops) anchiops Hall and Clarke, Pal. N. Y., vol. VII., p. 59, pl. 9, figs. 1-6, 10, 12-13, pl. 10, figs. 1-14.

A single specimen of the pygidium of a large species of Dalmanites has been collected at the Greenwood lake locality in the MLonroe shale. It is imperfect and distorted, but seens to risemble $D$. anchiops more closely than any other species. The axis tapers rather gradually and is divided into fifteen or sixteen segments. The plure are flattened and are marked by about twelve segments. The terminal spine of the pygidium is not preserved in the New Jersey specimen, but its posterior extremity is imperfect and the spine may have been destroyed. The specimen is in such a condition of preservation that this identification can in all erents be considered only as provisional. 


\section{Plates and Explanations.}

(All Figures Are Natural Size, Unless Otherwise Indicated). 


PLATE I.

PAGE.

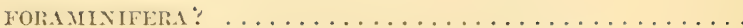

Figs. 1-2. Two specimens. Newton, Locality $136 \mathrm{~A}$.

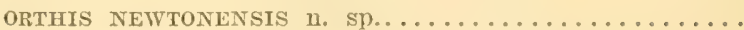

Fig. 3. The internal cast of a pedicle valve, showing the muscular scar. Locality 136 A. ( 2 2).

4. A similar, but larger pedicle valve. Same locality. ( $\left.x^{2}\right)$.

5. The internal cast of a brachial valve. Same locality. $(x \div)$.

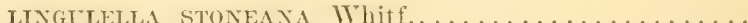

Irig. 6. A nearly perfect single valve, showing the peculiar surface markings. Nevoton, Locality 136 A. ( 2 2).

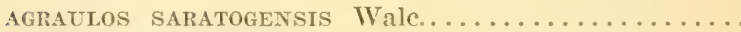

Fig. $\quad$ T. A large, nearly complete cranidium, with profile in outline. Blairstown, Locality $175 \mathrm{~A}$.

S. A large free cheek. Same locality.

9. A medium-sized pygidium. Same locality.

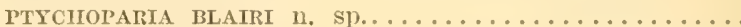

Figs. 10-11. Two cranidia of average size. Blairstown, Locality $17 \tilde{\mathrm{A}}$. (x 5).

12. Profile view of cranidium, in outline. (x 5).

13. Pygidium of average size. Same locality. (x 5).

PTYCHOPARIA CALCIFERA Wale..............

Fig. 14. The occipital segment and spine of a specimen which may belong to this species. Blairstown, Locality $175 \mathrm{~A}$. ( $\mathrm{x} 2)$. 
Geol. Survey of N. J.-1902. Paleontologr.

Plate I.
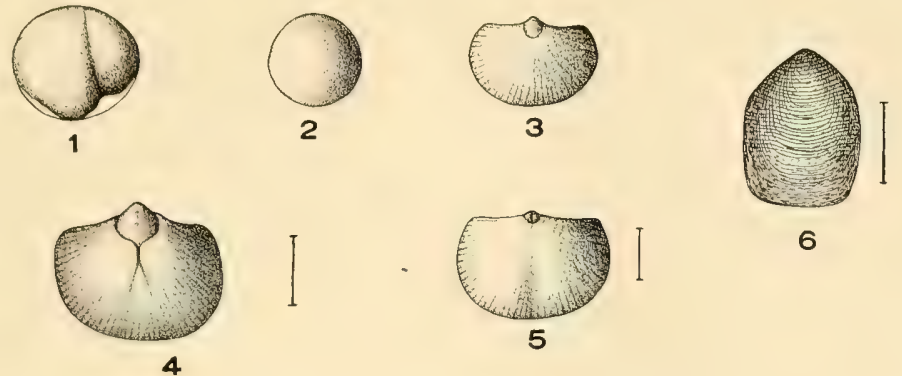

6
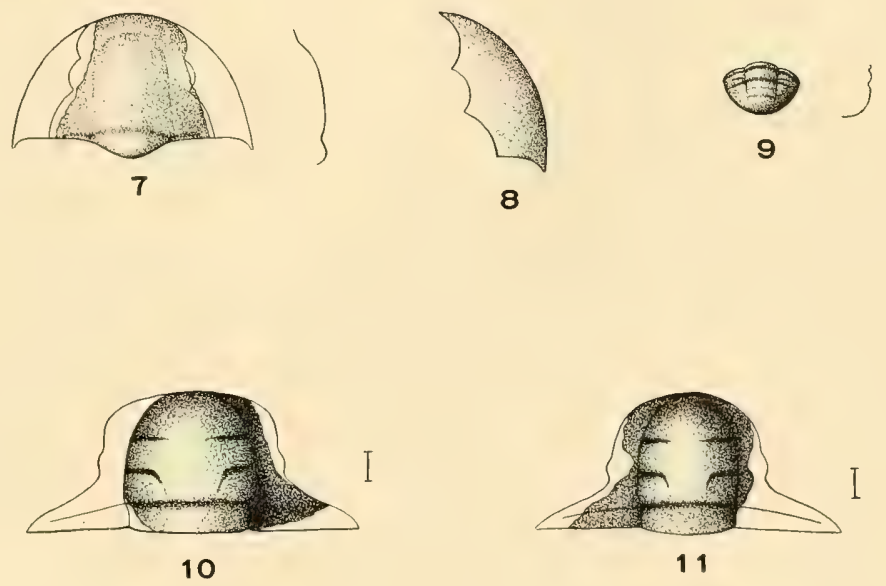

11

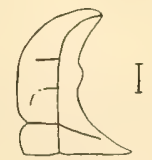

12
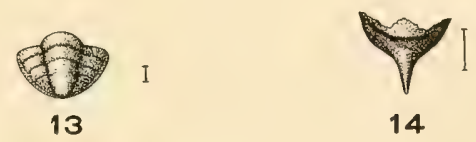

14

CAMBRIAN. 


PLATE II.

PAGE.

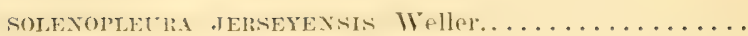

Figs. 1-6. Dorsal and lateral views of three cranidia. Carpentersville, Locality 3414. ( $\mathrm{x} 5)$.

7. Dorsal view of an incomplete pygidium. Same locality. $(x+1)$.

8. Transverse outline of the same.

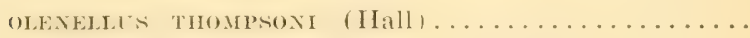

Figs. 9-10. Dorsal views of two eranidia. Franklin Furnace. (392) 
Geol. Survey of N. J.-1902. Paleontology.

Plate II.
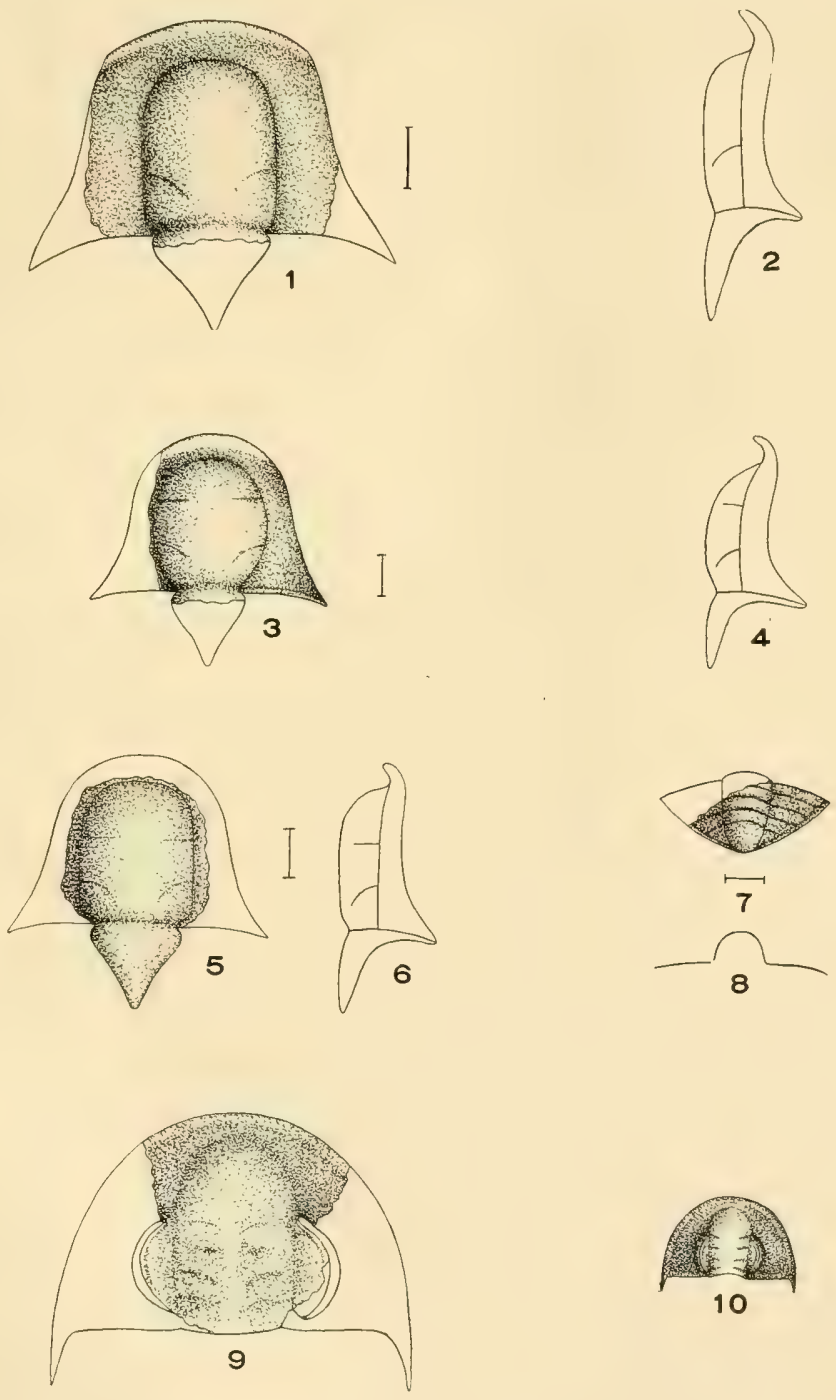

CAMBRIAN. 




\section{PLATE III.}

PAGE.

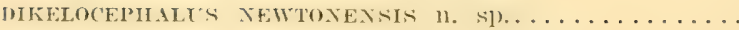

Fig. 1. Dorsal view of a nearly complete cranidium, with the profile in outline. Neuton, Locatity 136.1.

"3. Dorsal view of a cranidium, with flee cheek attached. Same locality.

$\therefore$ Dorsal view of a small pygidium, with profile in outline. Same locality.

4. Dorsal view of a large, imperfect pygidium. Same locality.

5-7. Dorsal views of three more or less incomplete free cheeks, probably belonging to this species. Same locality.

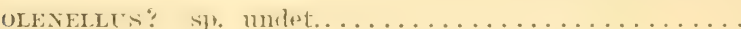

Iris. S. An imperfect free cheek. Nerton, Locality $136 \mathrm{~A}$.

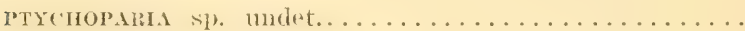

I'ig. !) Dorsal view of an imperfect craniclium. Nevoton, Locality 136 A. $(\times 2)$.

PTYCHOP.MRIA NEWTONEXSIS 11. S1)...........

Fis: 10. Dorsal view of a cranidium. Newton, locality $136 \mathrm{~A}$. $(\mathrm{x} t)$

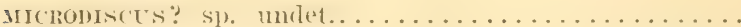

I'ig. 11. Dorsal view of an imperfect cephalon. Newton, Locality 136 A. $(x \dot{3})$.

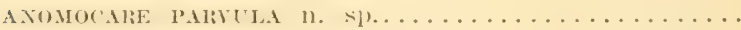

firg. 12. Dorsal riew of a cranidium, with profile in outline. Newton, Locality $136 \mathrm{~A}$. $(\mathrm{x}+)$.

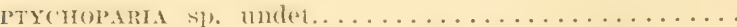

Wis 1:3. Dorsal view of a cranidium. Newton, Locality $136 \mathrm{~A}$. $(\mathrm{x}+)$. 

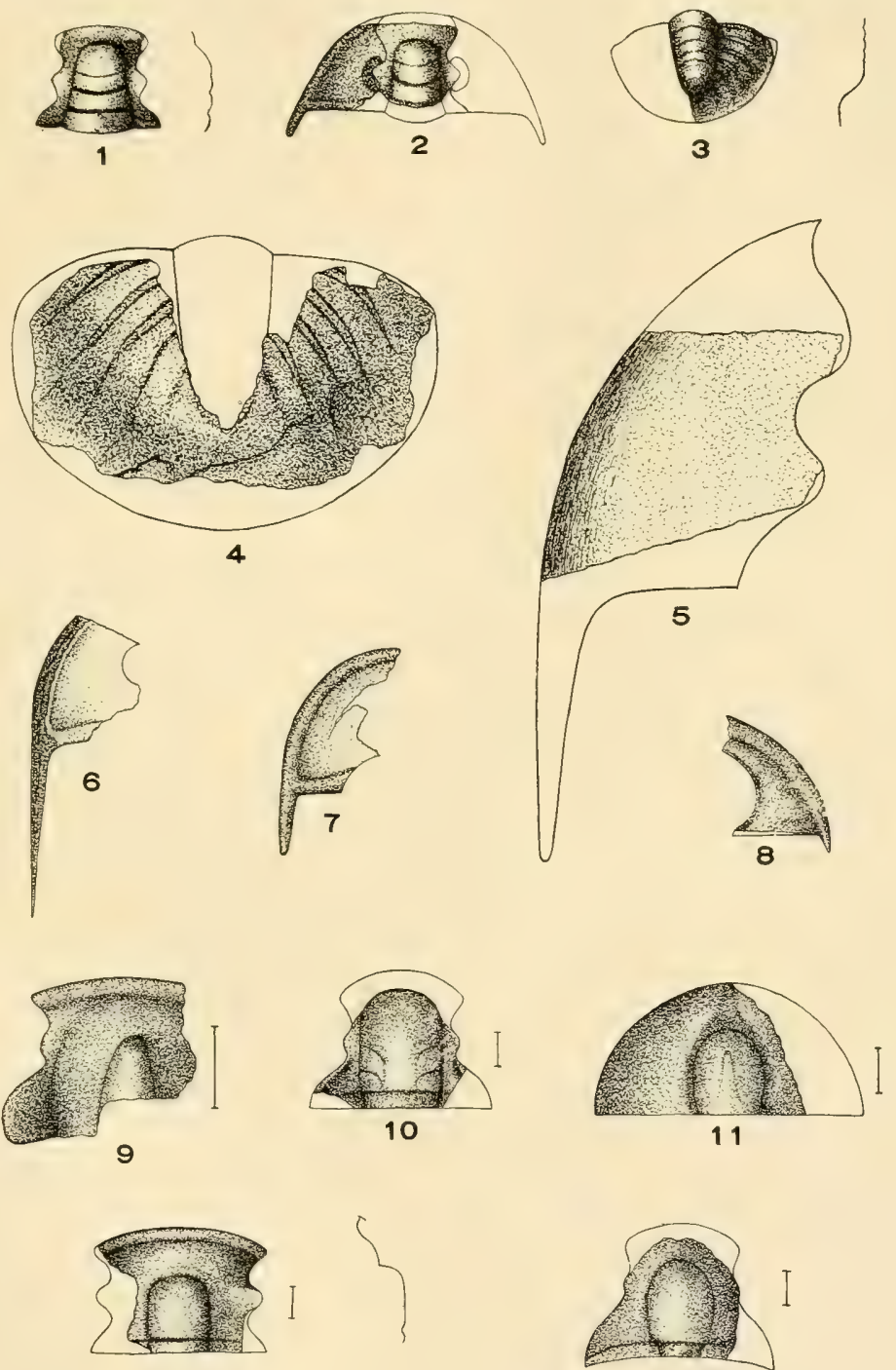

12

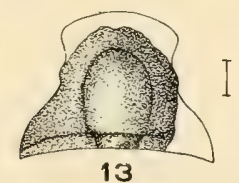

CAMBRIAN. 


PLATE $1 Y$.

Pilie.

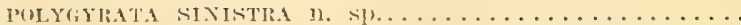

$1: 3$

Figs. $1: 2$. Vertical and profile views in outline. Columbia, Locality 210.4 .

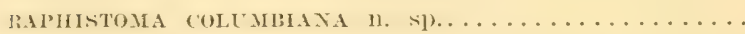

Figs. 3-4. Vertical and profile views of the type specimen. Columbia, Locality $210 \mathrm{~A}$

5. Cross-section of the periplseral angle, showing the thickening of the shell. (Enlarger.)

ECCYLIOMPIIALUS SUBELLIPTICA 11. sp............

Fig. 6. Tiew of the type specimen. Columbia, Locality $210 \mathrm{~A}$.

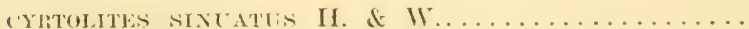

Fig. 9. Lateral riew of outer volution, with cross-section in outline. Columbia, Locality 210 1 .

DALMANELLA WeMPLET Clelant.............

Fig. 10. A large brachial valve. Columbia, Locality $210 \mathrm{~A} .\left(\mathrm{x}^{\prime 2}\right)$. 11-12. Two pedicle valres. Same locality. ( $\left.x_{2}^{2}\right)$.

DALMANEILA GLECTR (Bill. .............

Fig. 13. A pedicle valve. Columbia, Loeality $210 \mathrm{~A} . \quad(\mathrm{x} 2)$.

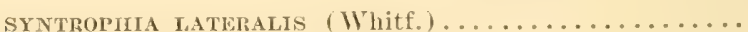

Figs. 14-15. Two views of a pedicle ralve. Columbia, Locality $210 \mathrm{~A}$. (394) 

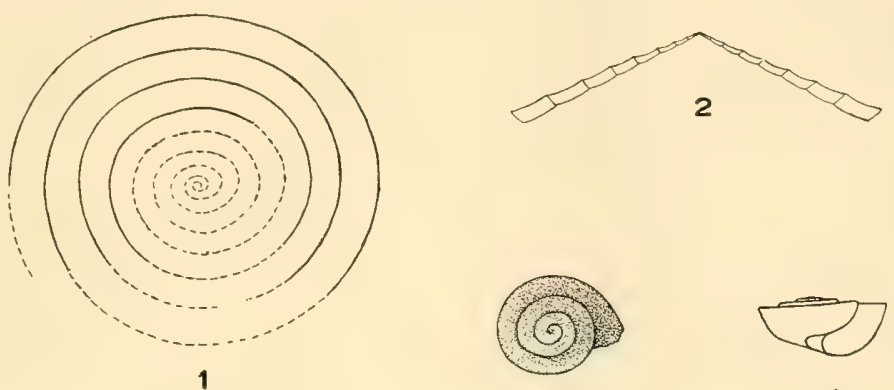

3

4
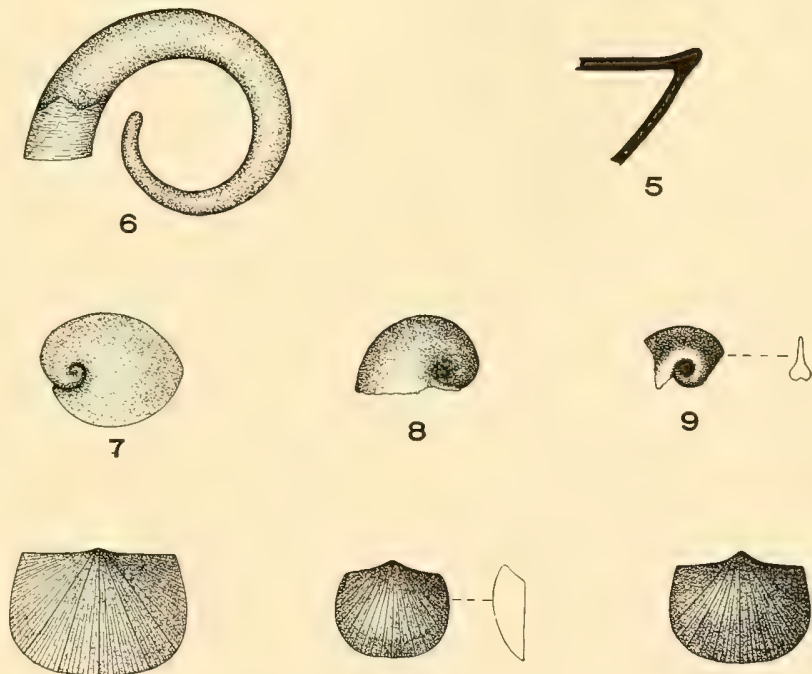

10

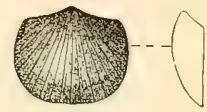

11

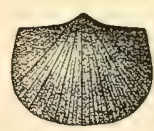

12

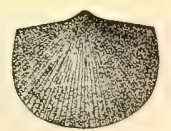

13
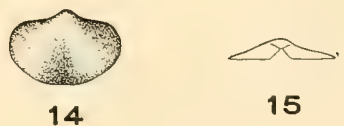

BEEKMANTOWN. 


PLA'TE $Y$.

PAGE.

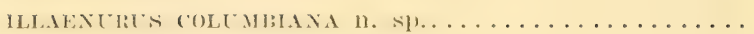

$13: 3$

Fix. 1. A free cheek. Columbia, Locality 210 $\mathrm{A}$.

$\because: \therefore$. Dorsal view and profile in outline of a large cranidium. same locality,

1. A perfect pygidium. Sume locality.

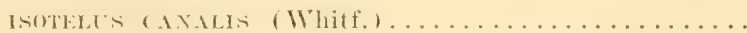

Wig. $\quad \therefore$ Cephalon restored in outline from an incomplete free cheek. Columbia, Locality $210 \mathrm{~A}$.

(i. Pygidium restored in outline. sume locality.

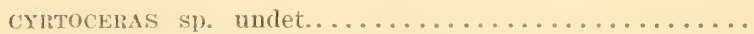

Kig. 7 . Lateral view of a weathered specimen, showing the septa and the slightly-curved shell. Columbia, Locality 210.1 .

S. Cross-section of another specimen partially restored. This is probably a distinct species from the last. Same loculity. 
Geol. Survey of N. J.-1902. Paleontology.

Plate V.
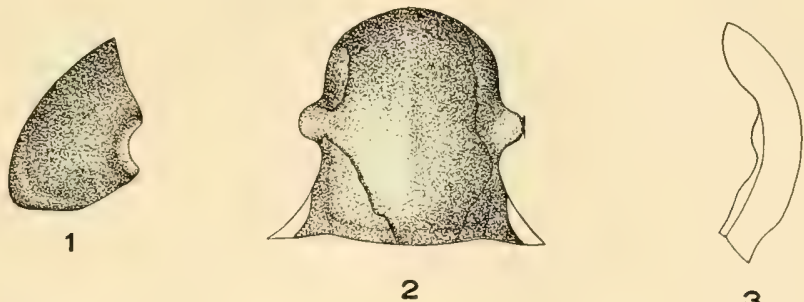

3
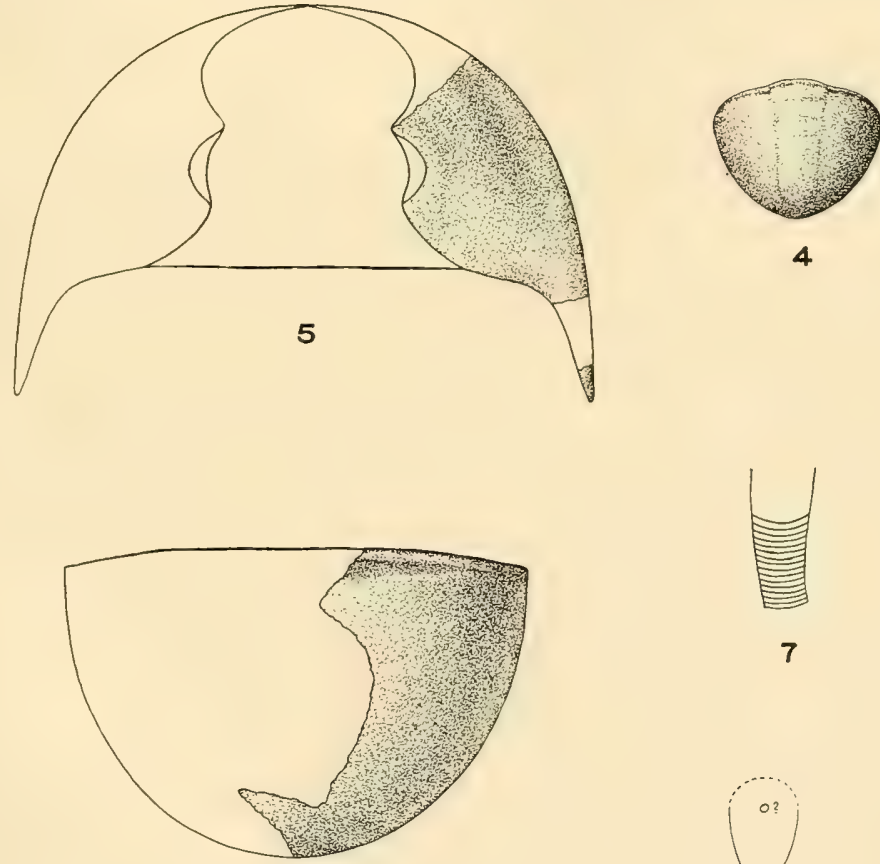

6

8

BEEKMANTOWN. 




\section{PLATE VI}

PAGE.

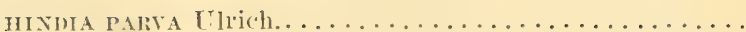

Fig. 1. A specimen of rather large size. Jacksonburg, Locality $17.1^{13}$

RECEPTACULt'ES OCCIDENTALIS Salt............

Fin. 2. Weathered section of a nearly complete, subcircular specimen. Near Stillwater, Locality 1534.

$\therefore$ Weathered surface, showing the arrangement of the terminations of the spicules. Near Springdale, Locality $156 \mathrm{~A}$.

4. Weathered surface with projecting spicules, the condition in which the species usually occurs. Same specimen as last.

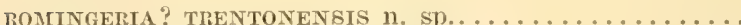

Fic. ․ A weathered specimen partially restored. Near Stillwater, Locality $153 \mathrm{~B}$.

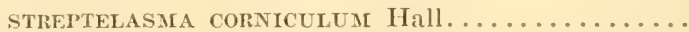

Fig. 6. A large specimen. Jacksonburg, Locality 17 4 $\mathrm{A}^{62}$

7. An average-sized specimen. Jacksonburg, Locality $174 \mathrm{~A}^{17}$

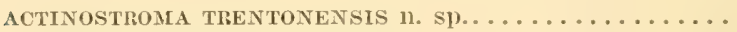

Fig. 8. A weathered section, showing the usual appearance of the species. Jacksonburg, Loculity 17/ $\mathrm{A}$. 
Geol. Survey of N. J.-1902. Paleontology.

Pinte VI.

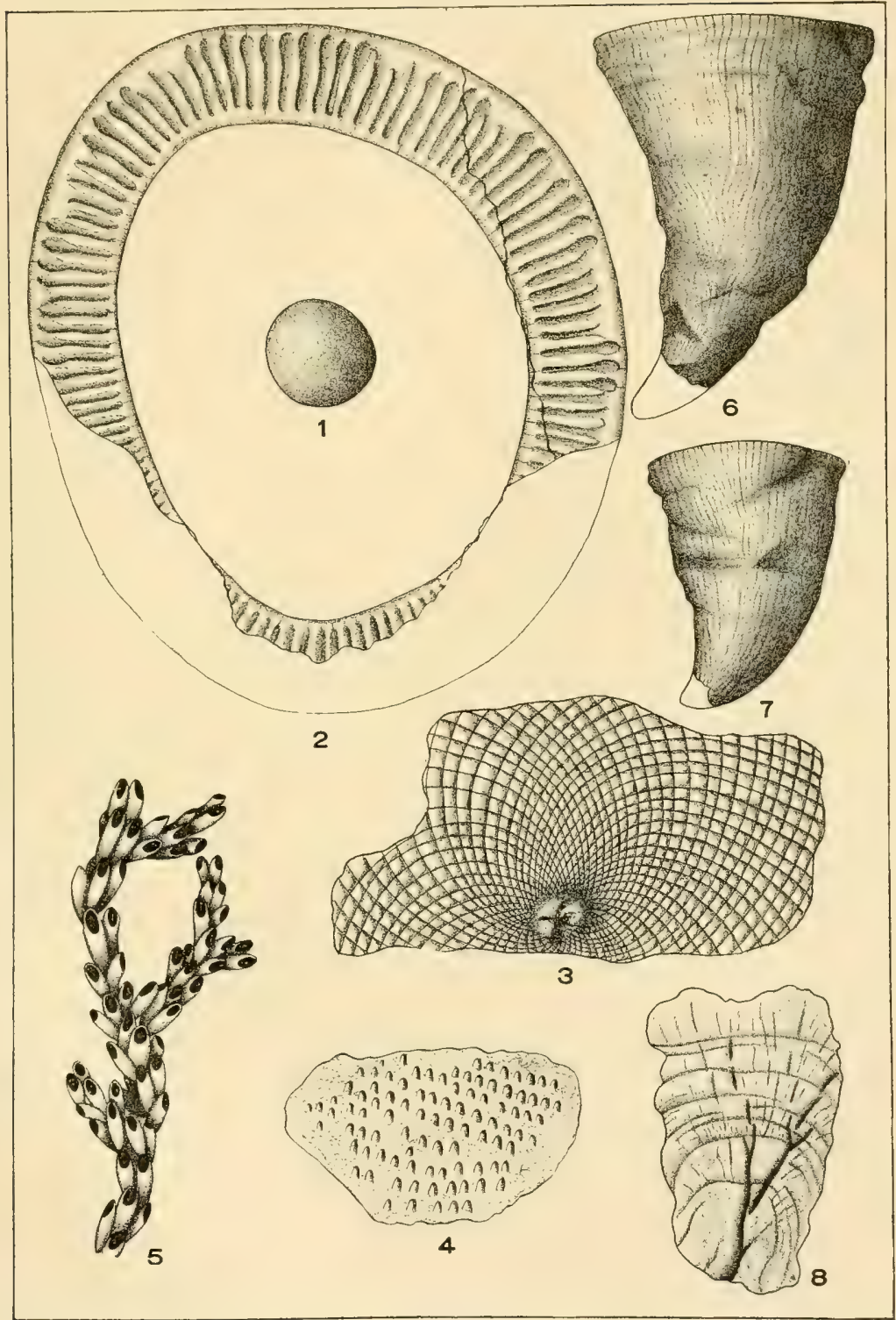

TRENTON. 


PLATE VII.

P.IGE.

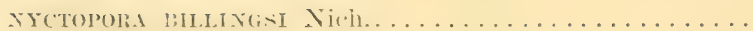

Fins. 1-2. Transverse and rertical sections of the species. Iacksonburg, Locality $1 \gamma^{\prime}+A$. ( 5 5).

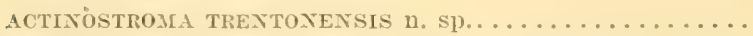

Fics. 3-4. Transwerse and rertical sections of the species, showing the minute structure. $(x+5)$.

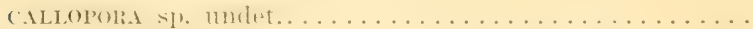

5. 5. Longitudinal section of a specimen. Tear Bearer Run. Locality $\approx 9$ 1. $(x \div 2 t)$.

PITLLOPORINA FENESTRATA (Hall)..............

1.iu. 6. Obverse side of a specimen. Near Bcarr Run. Locality i.) 1. $1 \mathrm{x}+1$. 

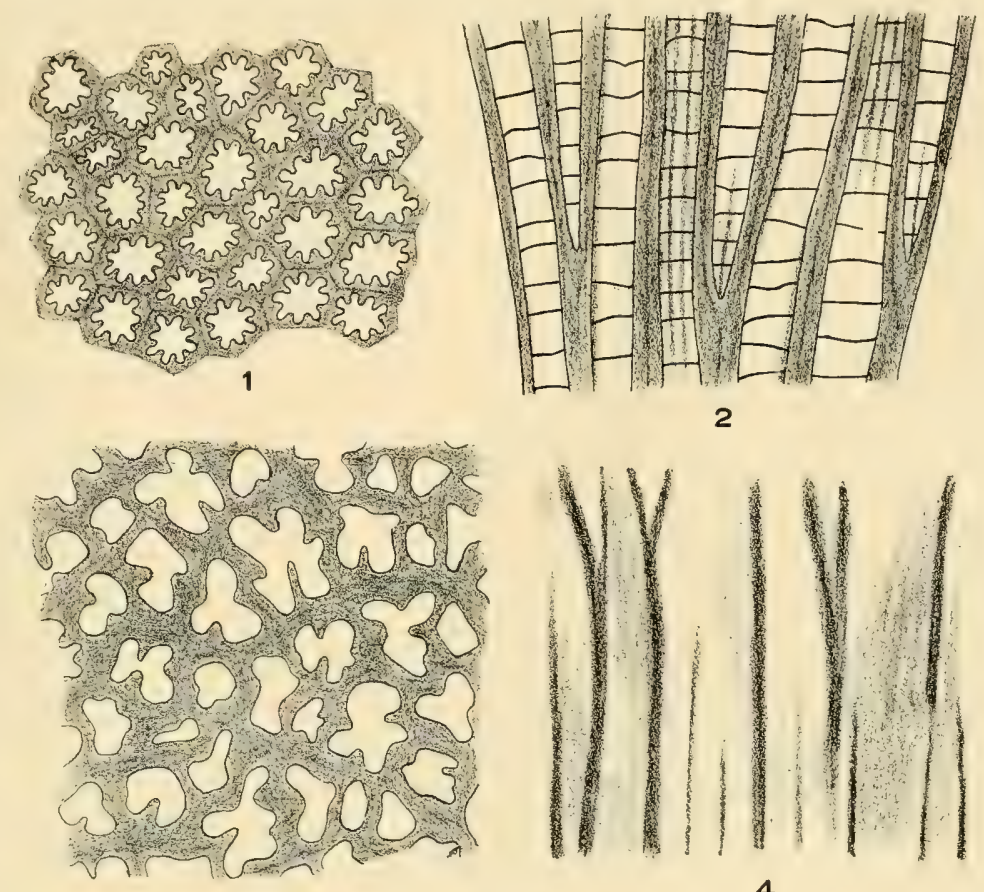

3
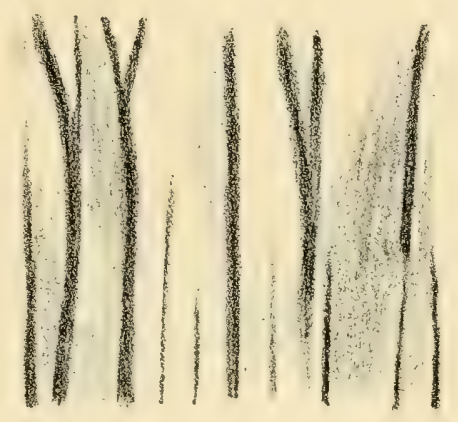

4
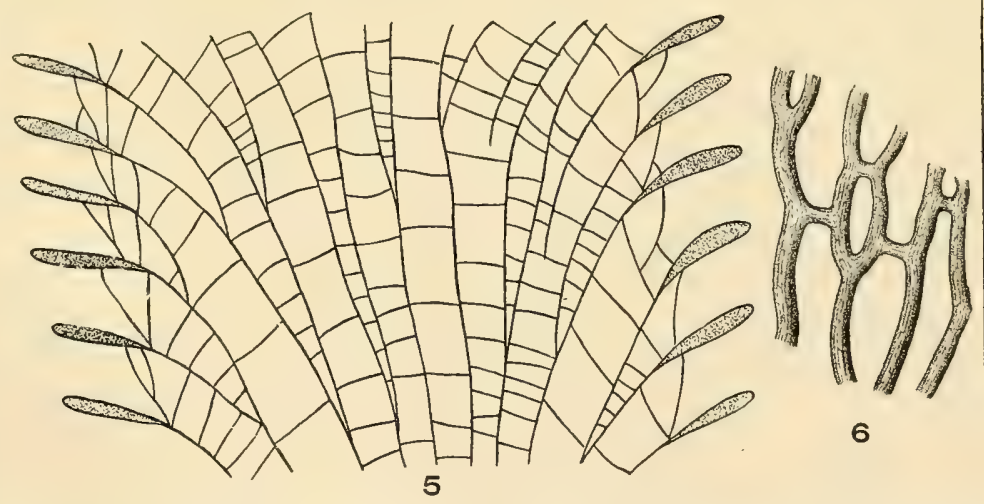

6

T'RENTON. 




\section{PIATE VIII.}

I'AGE.

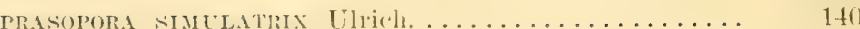

Figs. 1-2. Tangential and longitudinal sections. (x 24).

3. Section through a depressed-hemispherical zoarium. Jacksonburg, Locality 17's.

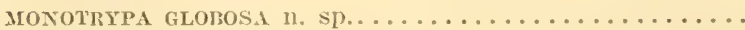

Figs. 4-5. Tangential and longitudinal sections. Near Beaver Run, Locality $79 \mathrm{~A} . \quad(\mathrm{x} 24)$.

6. Section through a subglobular zoarium. Same locality.

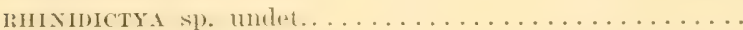

Fig. $\quad$ 7. An incomplete zoarium, showing method of branching. Drake's Pond. near Newton, Locality $186 \mathrm{~B}$.

8. Tangential section. Same specimen. (x 24).

9. Vertical section. Same specimen. (x 24). (398) 


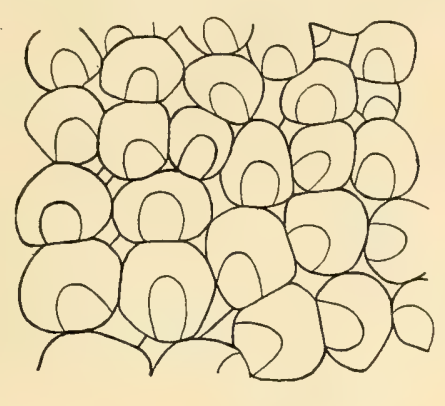

1
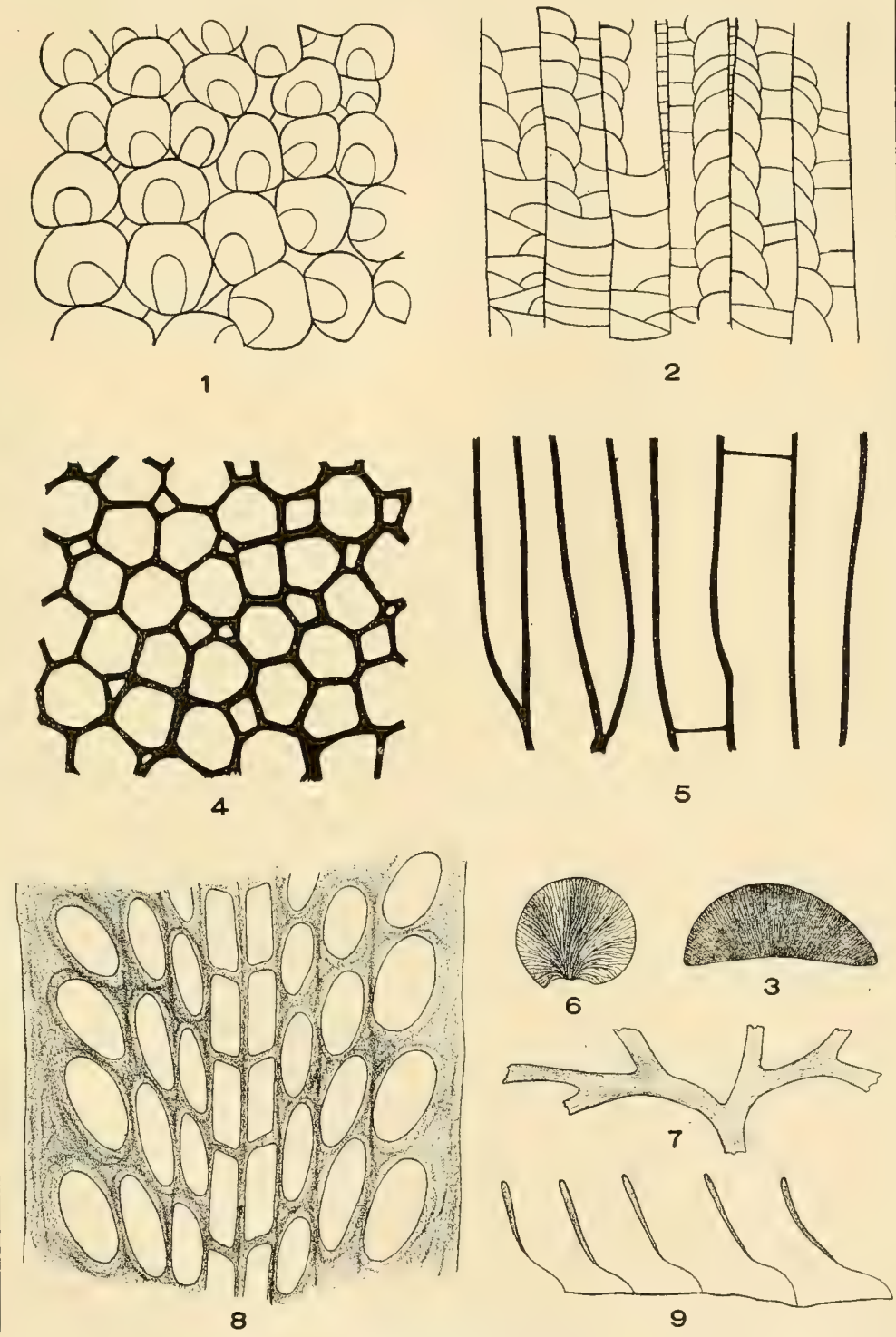

3
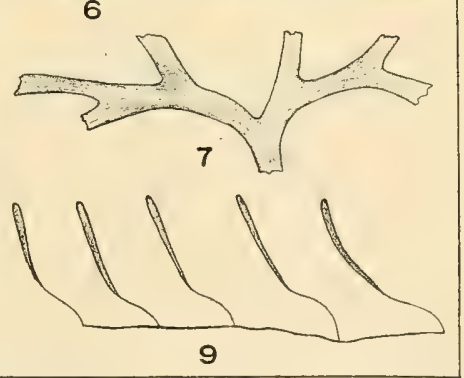

'TRENTON. 

ORBICTLOIDEA LAMELIOSA (IIall) ..............

Figs. 1-2. Vertical and lateral views of a nearly perfect brachial valve. Jacksonburg, Locality $1 \% / 4{ }^{49} \quad$ (x 2$)$.

SCHIZOCRANIA FILOSA (Hall) ...............

Figs. 3-4. Vertical views of two brachial valves. Jacksonburg, Locality 17\% A.

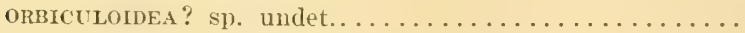

Figs. 5-6. Vertical and lateral views of an imperfect brachial valve. Near Branchville, Locality 75 A.

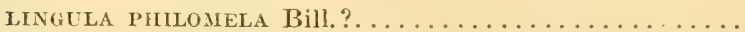

Fig. 7 An incomplete valve. Near Beaver Run, Loca7ity $79 \mathrm{~A}$.

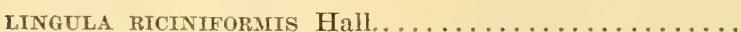

Fig. 8. A nearly perfect valve, partially exfoliated. Jacksonburg, Locality 17/4..$^{2 e}\left(\mathrm{x}_{2}\right)$.

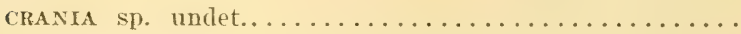

Fig. 9. A complete brachial valve. Near Beaver Run, Locality $79 \mathrm{~A}$.

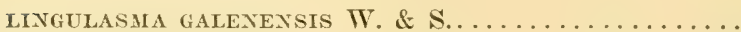

Figs. 10-11. Vertical and lateral views of the internal cast of a brachial valve. Drake's Pond, near Newton, Locality 136 B.

RAFLNESQUINA ALTERNATA $($ Emm. $) \ldots \ldots \ldots \ldots \ldots$

Fig. 12. View of a nearly complete pedicle valve. Jacksonburg, Locality 174 A.

13. Profile of the same specimen in outline.

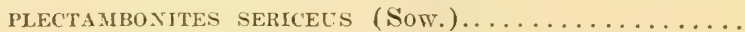

Fig. 14. A nearly perfect, large pedicle valve. Near Beaver Run, Locality 79 A.

15. A brachial valve. Jacksonburg, Locality 17/ A.

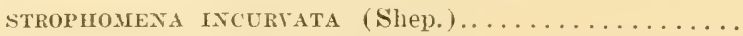

Fig. 16. An imperfect brachial valve. Jacksonburg, Locality $1 \% 4 \mathrm{~A}$.

17. A small pedicle valve. Same locality.

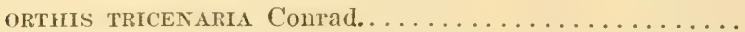

Figs. 18-21. Brachial, lateral, pedicle and posterior views of a nearly perfect specimen. Jacksonburg, Locality $17 / 4{ }^{17}$

PLECTORTHIS PLICATELLA (IIall) ...............

Figs. 22-24. Pedicle, lateral and anterior views of a nearly complete specimen. Near Beaver Run, Locality $\% 9$ A. 
PLATE IX.-- (Continued.)

Platystropira miforata (Schl.).............. PaGE.

Figs. 25-28. Brachial, pedicle, lateral and anterior views of a complete specimen. Near Beaver Run, Locality 79 A.

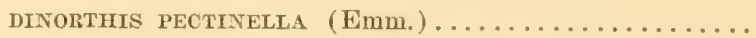

Fig. 29. A pedicle valve. Drake's Pond, near Newton, Locality $196 \mathrm{~B}$.

30. A brachial valve. Same locality.

(400) 


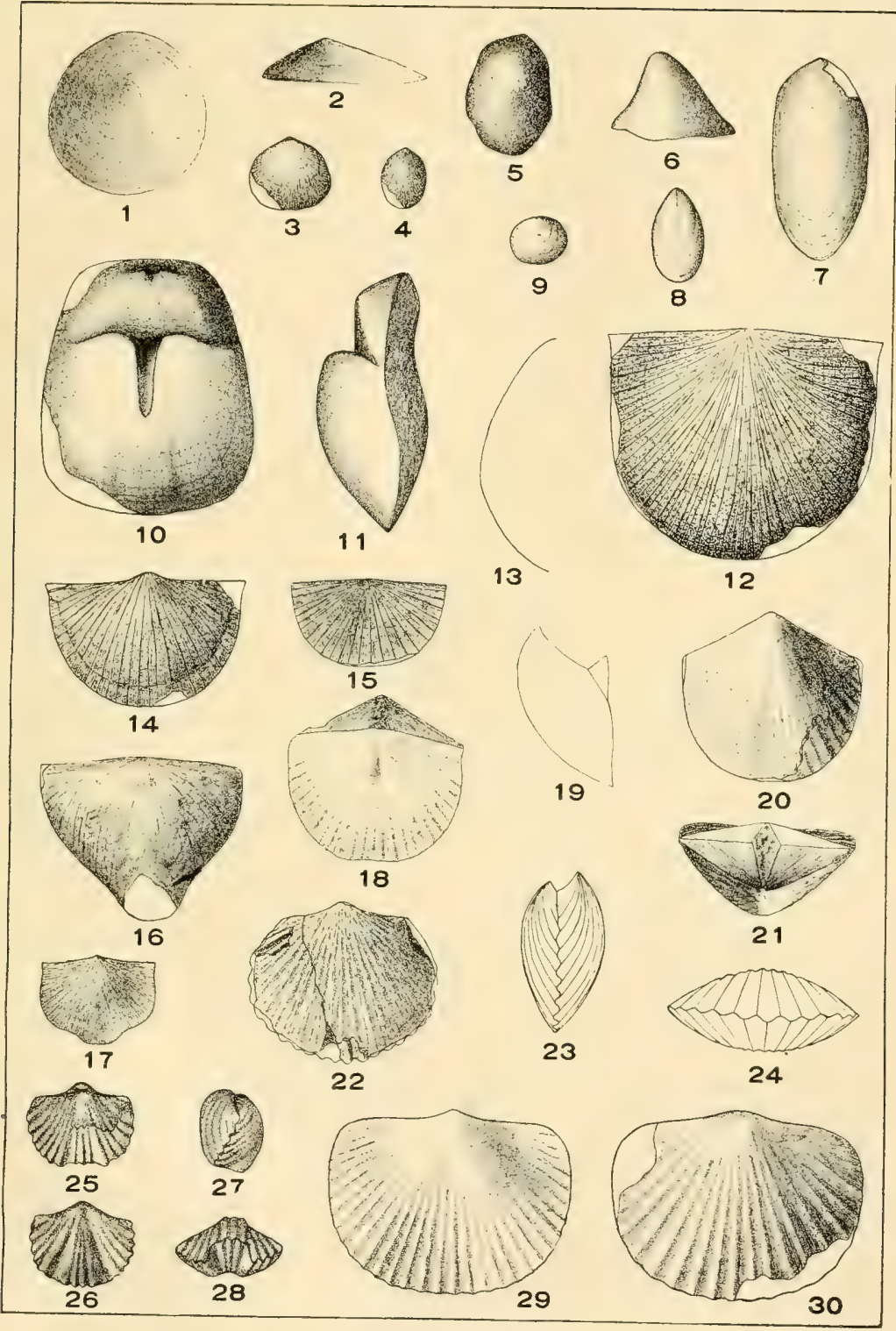

TREN'TON. 




\section{PIATE $\mathrm{X}$.}

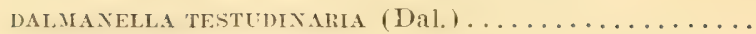

PAGE.

155

Fig. 1. A pedicle valve. Jacksonburg, Locality 17 / A. ( $\quad 2$ ).

2. A brachial valve. Jacksonburg, Locality 17 / $\mathrm{A}^{27}$ ( $\left.{ }^{2} 2\right)$.

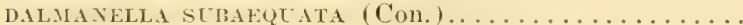

Fig. 3. A brachial valve. Jacksonburg, Locality $17 / \mathrm{A}^{6}$

4. Posterior view of a complete specimen. Same locality.

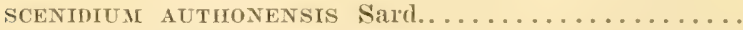

Fig. $\quad$ ). A brachial valve. Jacksonburg, Locality $1 \%$ A. ${ }^{4}(\mathrm{x} 2)$.

(i. A nearly complete pedicle valve. Same locality. (x2).

7. Profile of the same in outline. $(x: 2)$.

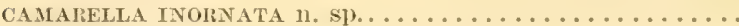

Fins. $\quad \$-10$. Pedicle, brachial and lateral views of a complete, large specimen. Hainesburg, Locality $192 \mathrm{~A}$.

PARASTROPHIA HEMIPLICATA (Hall) ..............

Figs, 11-14. Brachial, pedicle, anterior and lateral views of a complete specimen. Drake's Pond, near Newton, Locality $136 \mathrm{~B}$.

RHYNCHOTREMA INAEQUIVALVIS (Castel.)...........

Figs. 15-18. Brachial, pedicle, anterior and lateral views of a complete specimen. Jacksonburg, Locality 17 午 A.

IIYXCHOTIEMA DENTATA (Hall)............

Figs. 19-22. Pedicle, brachial, anterior and lateral views of a complete specimen. Jacksonburg, Locality 174 A. (x 2).

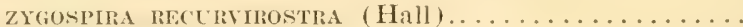

Figs. 23-26. Brachial, pedicle, anterior and lateral views of a complete

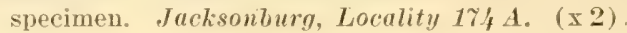

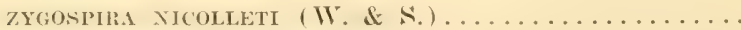

Figs. 27-:0). Brachial, pedicle, anterior and lateral views of a complete specimen. Near Beaver Run, Locality 79 A. (x4). 

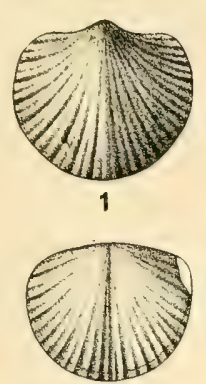

2

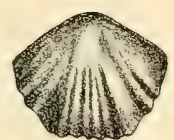

11

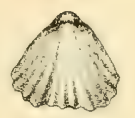

15

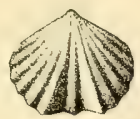

19
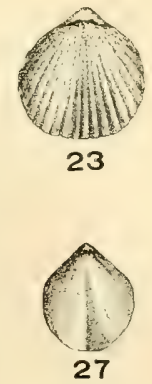

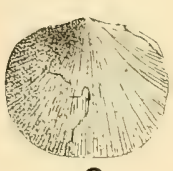

3
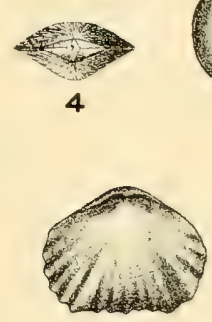

12

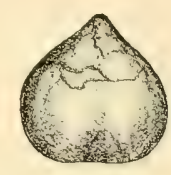

8

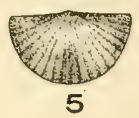

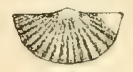

6

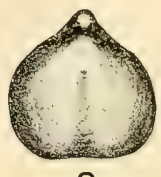

9
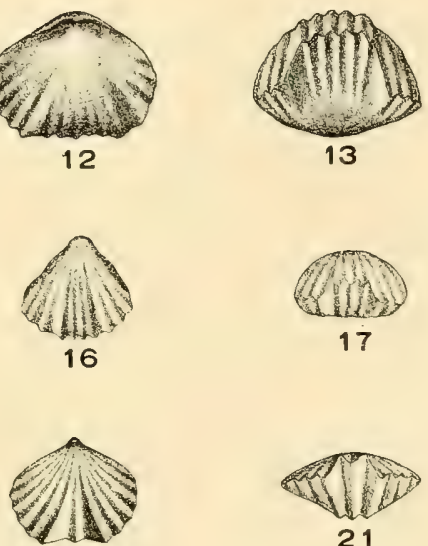

20
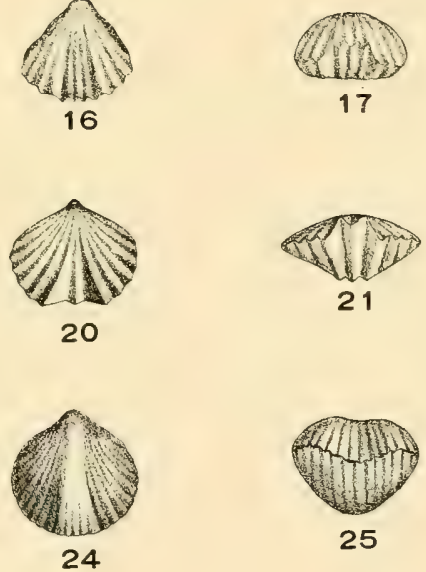

17
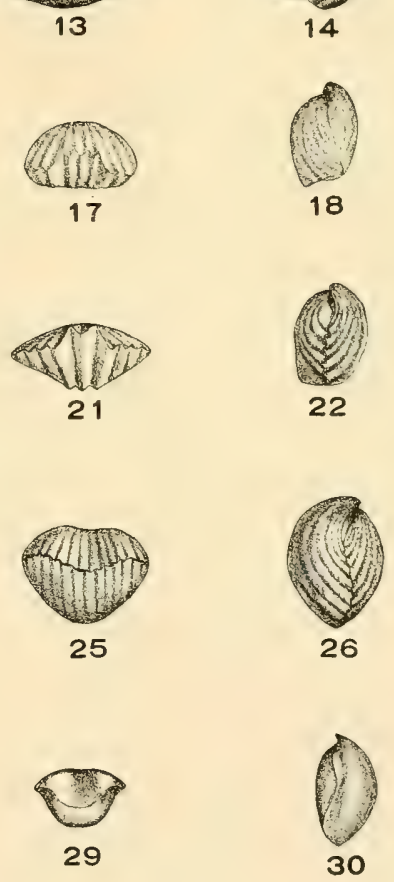

Fig. 1. The internal cast of a large right valve. Near Iliff's Pond, Locality 197 A.'

WIITELLA STBORBICULARIS n. Sp............

Fig. 2. A nearly complete left valve. Jacksonburg, Locality $174 \mathrm{~A}$.

CYRTOdonta CANAdExsis Bill................

Fig. 3. An incomplete right valve. Jaclisonburg, Locality $174 \mathrm{~A}^{1{ }^{17}}$ WHITELLA SUETRLYNCATA (ITall) .............

Fig. 4. A nearly complete right valve. Jacksonburg, Locality 174 A. $^{49}$

ORTHODESALA CANALICULATUM Ulrich............

Fig. 5. View of the right side of a nearly complete internal cast. Jacksonburg, Locality $17 \% \mathrm{A.}^{49}$

CUNEAMYA TRUNCATULA Ulrich..............

Fig. 6. A nearly complete right valve. Jacksonburg, Locality $174 \mathrm{~A}$.

CYRTODONTA BILLINGSI Ulrich $\ldots \ldots \ldots \ldots \ldots \ldots \ldots$

Fig. 7. View of the right valve of a nearly complete specimen. Drake's Pond, Near Newton, Locality $136 \mathrm{~B}$.

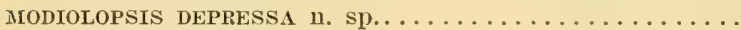

Fig. $\quad$ 8. A complete right valve. Jacksonburg, Locality 1 IIt A. $^{41}$

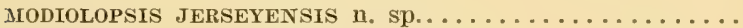

Fig. 9. A complete right valve. Jacksonburg, Locality 174 A.

MLODIOLOPsis sp. undet...................

Figs. 10-11. Two right valves. Jacksonburg, Locality $1 \%$ A.

Mrodolopsis sp. undet..................

Fig. 12. A small left valve, possibly M. jerseyensis. Jacksonburg, Locality 174 A. $^{9}$

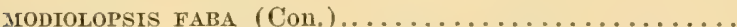

Fig. 13. A right valve. Jacksonburg, Locality $1 \%$ \&.

14. A left valve. Same locality.

15. Another right valve. Same locality.

CLIDOPHORUS NEGLECTUS Hall................

Fig. 16. A left valve. Jacksonburg, Locality 1\% A..$^{50}$ 
PLATE XI.-(continucrl.)

PAGE.

CTENODONTA JERSEYENSIS $n$. S1).............. 16 .

Fig. 17. A complete right valve. Jachsonburg, Locality 17 / A. ${ }^{1}$

CTENodonta LEYATA (Hall) .................. 165

Figs. 18-22. Views of several specimens referred to this species provisionally. Jacksonburg, Loculity $17 \% \mathrm{~A}$.

GONIOPHORA CARINATUS (Hall)...............

Fig. 23. A nearly complete left ralve. Jacksonbury, Locality 174.40 
Geol. Sulive of N. J.-1902. Paleontology.

Plate XI.

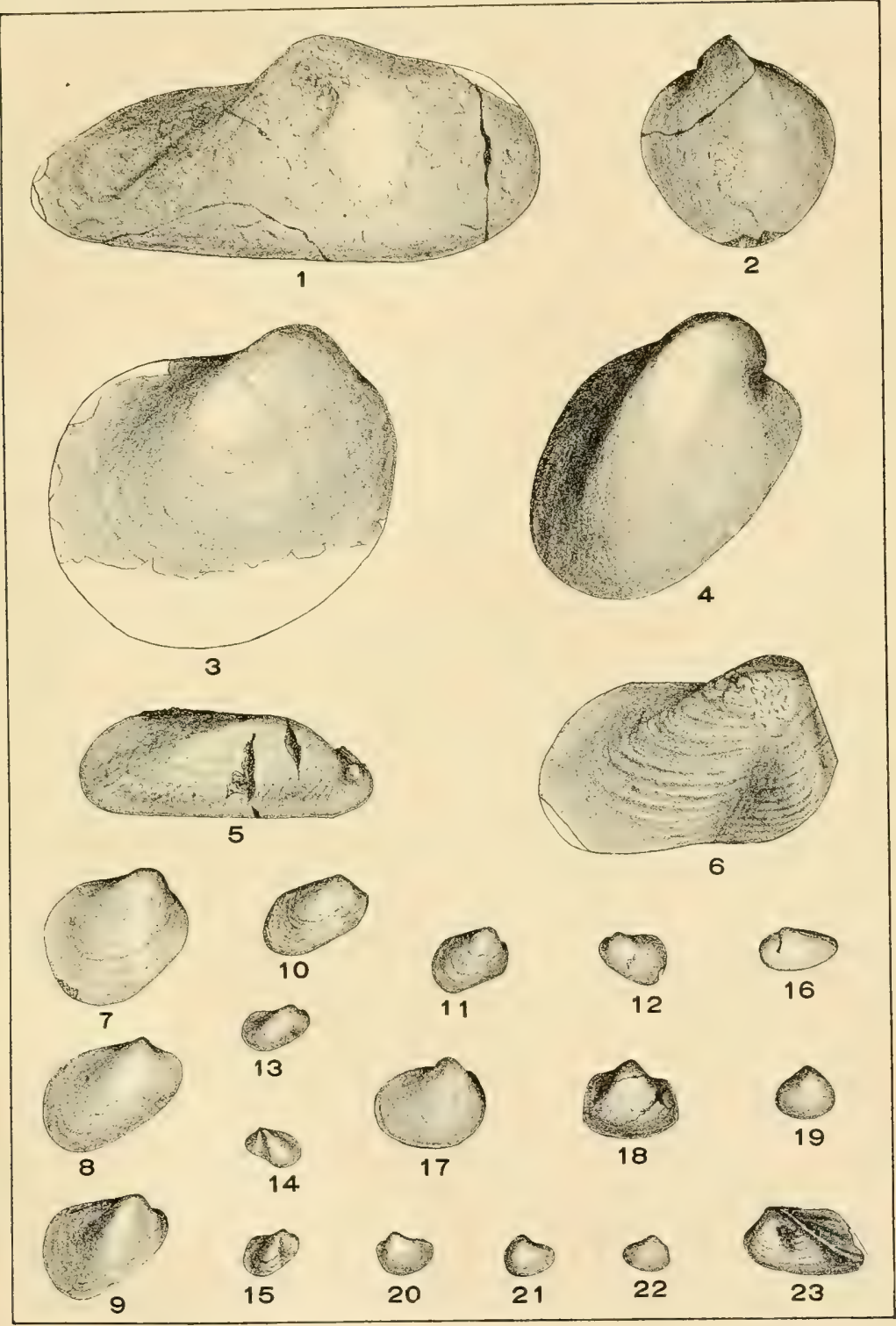

TRENTON. 



\section{PLATE XII.}

ARCIINACELLA PATELLTORMIS $($ Hall) .............

PAGE.

174

Eigs. 1-2. A dorsal and a lateral view of a nearly complete specimen. Jacksonburg, Locality $1 \% 4$ A.

PROTOWARTHA CANCELLATA (Hall) ..............

Fig. 3. Dorsal view of a large specimen, showing the transverse wrinkles near the aperture. Jacksonburg, Locality $17 / 4$.

Figs. 4-5. Dorsal and lateral views of a smaller, nearly complete specimen. Same locality.

CYRTOLITES ORNATUS Var. MINOR U. \& S...........

Figs. $\quad 6-7$. Dorsal and lateral views of an incomplete specimen. Jacksonburg, Locality $174 \mathrm{A.}^{52}$

oxydiscus subacutus Ulich...............

Figs. S-9. Two views of an incomplete specimen. Near Springdale, Locality 156 A.

BUCANIA PUNCTIFRONS (Emm.) ...............

Fig. 10. Lateral view of an average-sized specimen. Jacksonburg, Locality 174 A. $^{62}$

11. Dorsal view of a smaller specimen. Same locality.

12. The surface ornamentation much enlarged.

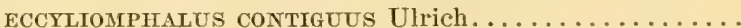

Figs. 13-15. Three views of a complete specimen. Jacksonburg, Locality $174 \mathrm{~A}$.

PHRAgMolites compressus Con................

Figs. 16. 17. Two views of an incomplete, somewhat distorted specimen. Jacksonburg, Locality 174 A.

TETRANOTA BIDORSATA (Hall) ..............

Figs. 18, 19. Two views of an incomplete specimen. Jacksonburg, Locality $1 \%$ \&.

ECCYLIOMPHARUS TRENTONENSIS (Con.)...........

Figs. 20, 21. Two views of an incomplete specimen. Jacksonburg, Locality $174 \mathrm{~A}$.

RAPHISTOMA PERACUtuar U. \& S............

Figs. 22, 23. Two views of an incomplete specimen. Jacksonburg, Locality 174 A. $^{10}$

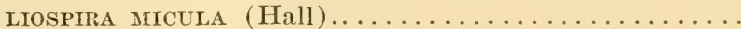

Figs. 24, 25. Two views of a nearly complete specimen. Jacksonburg, Locality 174 A 


\section{PLATE XII.-(Continued.)}

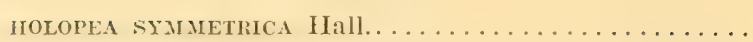

Figs. 26, 27. Lateral views of two incomplete specimens. Jacksonburg, Locality 174 A.

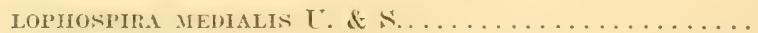

Fig. ' 2S. Lateral view of a nearly complete specimen. Jacksonburg, Locality $174 \mathrm{~d}$.

HORMOTOMA SALTERT Elrich...............

Fig. 29. Lateral view of an incomplete internal cast. Jacksonburg, Locality 17 \% 1 .

MOLOPEA PARVUIA Ulrich...................

Fig. 30. Lateral view of a nearly complete specimen, a partial internal cast. Jacksonburg, Locality $174 \mathrm{~A}$.

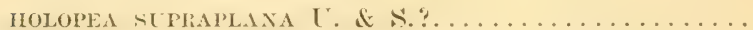

Figs. 31, 32. Two views of an incomplete specimen. Jacksonturg, Locality 17 . A.

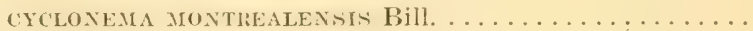

Fig. 33. Lateral view of an incomplete specimen. Near Branchville, Locality $75 \mathrm{~A}$.

LOPHOSPIRA OWENI U.\& S.................

Fig. :it. Lateral view of an incomplete specimen. Jacksonburg, Locality $1 \%$ A. ${ }^{10}$

PTEROTHECA EXPA.AA (Limm.) $: \ldots \ldots \ldots \ldots \ldots \ldots \ldots \ldots$

Fig. :35. Dorsal view of a fragmentary specimen, Jacksonburg, Locality 17 \&. 
Geol. Survey or N, J.-1902. Palfontology.

P'LATE XII.

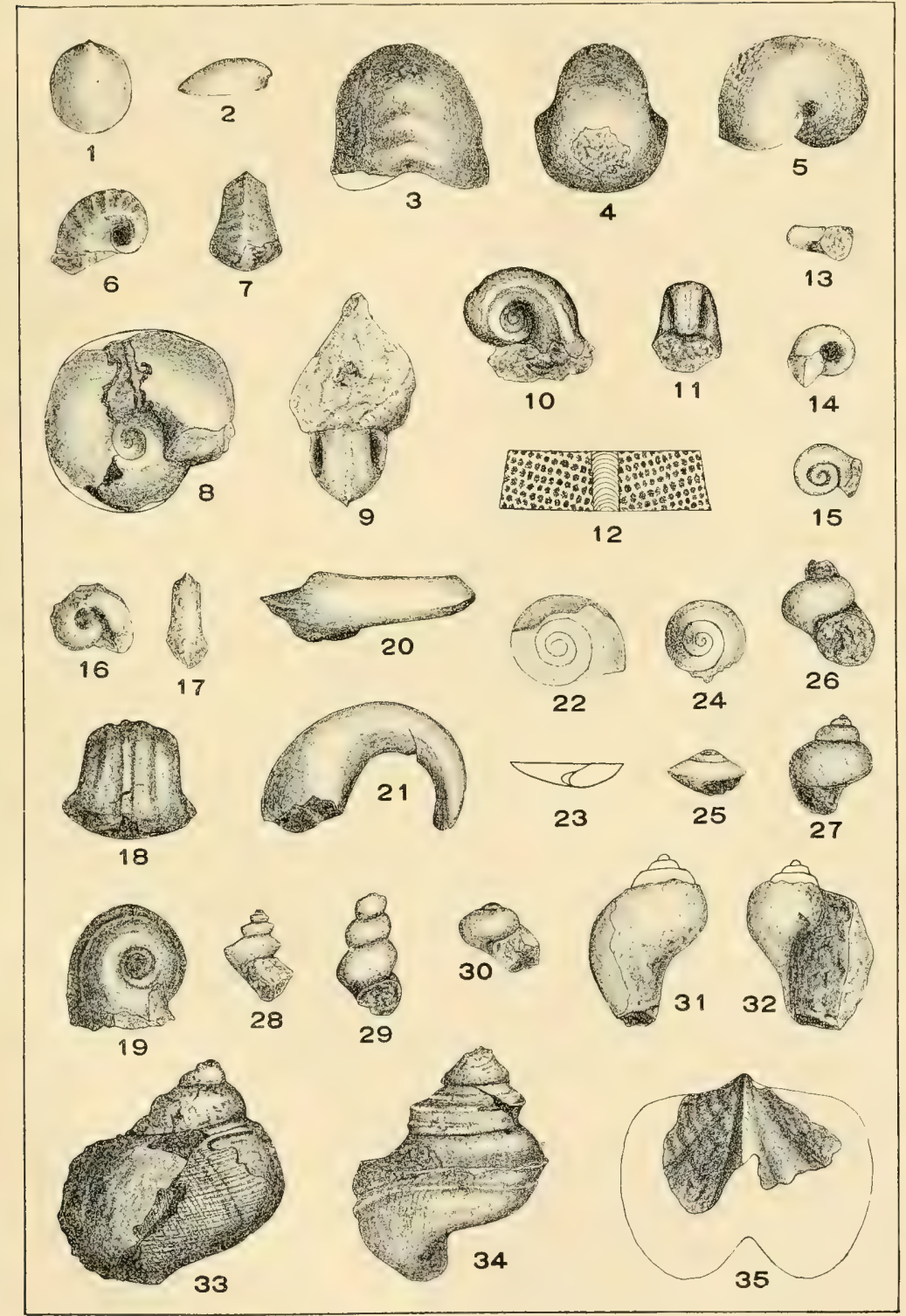

TRENTON. 




\section{PIATE XIII.}

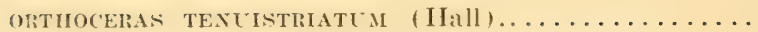

Fig. 1. A large specimen, showing the longitudinal banding of the shell. Jacksonburg, Locality 17.4 ..$^{29}$

2. A small fragment, showing the transverse markings of the shell.

ORTHOCERAS TEXTITEXTLM (IIall)............

Fig. $\quad 3$ Lateral view of an incomplete specimen retaining the delicate surface markings. Jacksonburq, Locality $1 \%$ ' A.

4. Surface markings of the same, much enlarged.

Cameroceras proteIfolrme (Hall)..............

Fig. 5. A fragment of a small siphonal cast. Near springdale, Locality $156 \mathrm{~A}$.

oituockias sp. undet..................

Fig. (i. Jacksonburg, Locality 17' A.

CONULATIA TRENTONENSIS Hall...............

Fig. 7. A nearly complete specimen. Jacksonburg, Locality $1 \%$, 1 ; :

S. Surface markings of the same, much enlarged.

(IIIT)X: : 51 .

Figs. 9.10. Two views of the only specimen observed. Jacksonburg, Locality $1 \%$ '. . $^{*}$

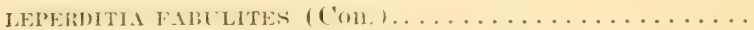

Irigs. 11. 12. Views of a left and a right valve. Near lliff's Pond, Locality $13 \%$ A.

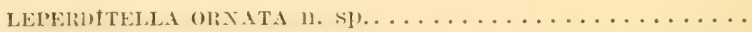

Figs. 13-15. Left, right and ventral views of a complete specimen. Near Iliff's Pond, Locality 13\% . $^{1} \quad$ (x 8).

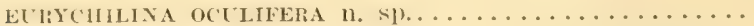

Fig. 16. View of a left valve. Near Iliff's Pond, Locality $13 \%$ A. $(\mathrm{x} S)$.

EUTRCHILINA JERSEYENSIS 1 . SP..............

Fig. 17. Niew of a right valve. Near Iliff's P'ond, Locality 137 A. ( $\mathrm{x} 8)$. 


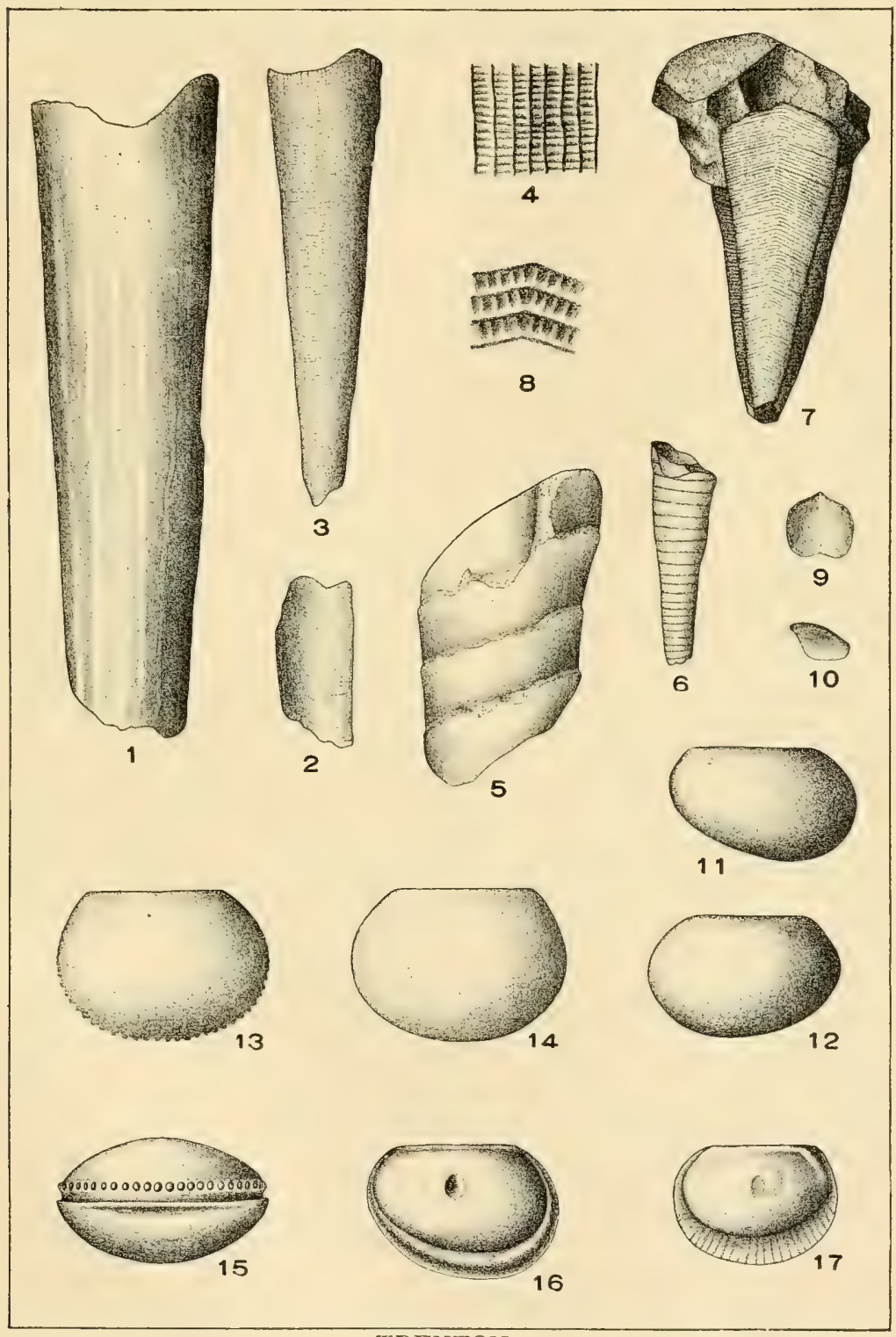

TRENTON. 

PLAT'P XIV.

PAGE.

IIARPINA OTTAWEXSIS (Bill, ..............

Fig. 1. Dorsal view of an incomplete head. Jacksonbury, Locality 1\%.4.

2 . Impression of the marginal border of the head. Same locality.

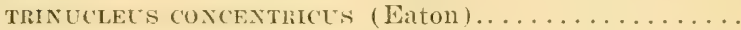

Figs. 3, 4. Dorsal and anterior views of a nearly complete head. Jacksonburg, Locality 174 A.32

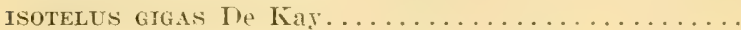

Fig. 5. A small, complete individual (after Clarke).

6. A small, incomplete pygidium. Jacksonburg, Locality $174 A$.

7. A large, nearly complete free cheek. Near Beaver Run, Locality 79 A.

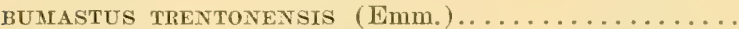

Fig. 8. A nearly complete individual with the head crowded out of place. Jacksonburg, Locality $174 A^{.77}$

9. A complete cranidium, partially exfoliated. Same locality.

10. A larger, incomplete cranidium. Jacksonburg, Locality $1 \%$. $A$.

11. A nearly complete pygidium. Jacksonburg, Locality $174 . .^{57}$

12. A small, complete pygidium. Near Iliff's Pond, Locality 137. . $^{1}$

13. A complete free cheek. Jacksonburg, Locality $174 A^{57}$

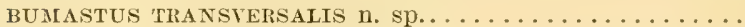

F'ig. 14. The cranidium and prgidium of an individual, with fragments of the thoracic segments. Hainesburg, Locality $192 \mathrm{~A}$.

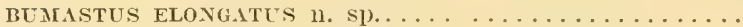

Fig. 15. A complete pygidium, slightly distorted. Near springdale, Locality $156 \mathrm{~A}$.

PTYCHOPYGE JERSEYEXSIS $\mathrm{n} . \mathrm{Sp} \ldots \ldots \ldots \ldots \ldots \ldots \ldots$

Fig. 16. An incomplete pygidium. Jacksonburg, Locality $1 \gamma_{4} A .^{6}$ 


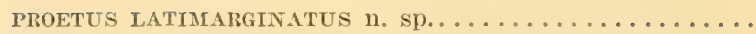

Figs. 17, 18. Dorsal and lateral views of a nearly complete cranidium. Jacksonburg, Locality 174A. (x 2).

19. Dorsal view of the same, natural size.

20. A complete flee cheek. Same locality. (x2).

21. 'The same. Natural size.

22. A complete pygidium. Jacksonburg, Locality 17 / $\mathbf{A .}^{26}$ $\left(x_{2}\right)$.

23. The same. Natural size.

24. Restoration in outline of the complete head. (x2).

25. A large pygidium which doubtfully belongs to this species.

PTERYgometopus? sp. undet..................

Fig. 26. An incomplete free cheek, differing from other representatives of this genus in its elongate genal spine. Jacksonburg, Locality $1 \%$ \& $1 .{ }^{13}$ (x2).

27. The same. Natural size.

(408) 


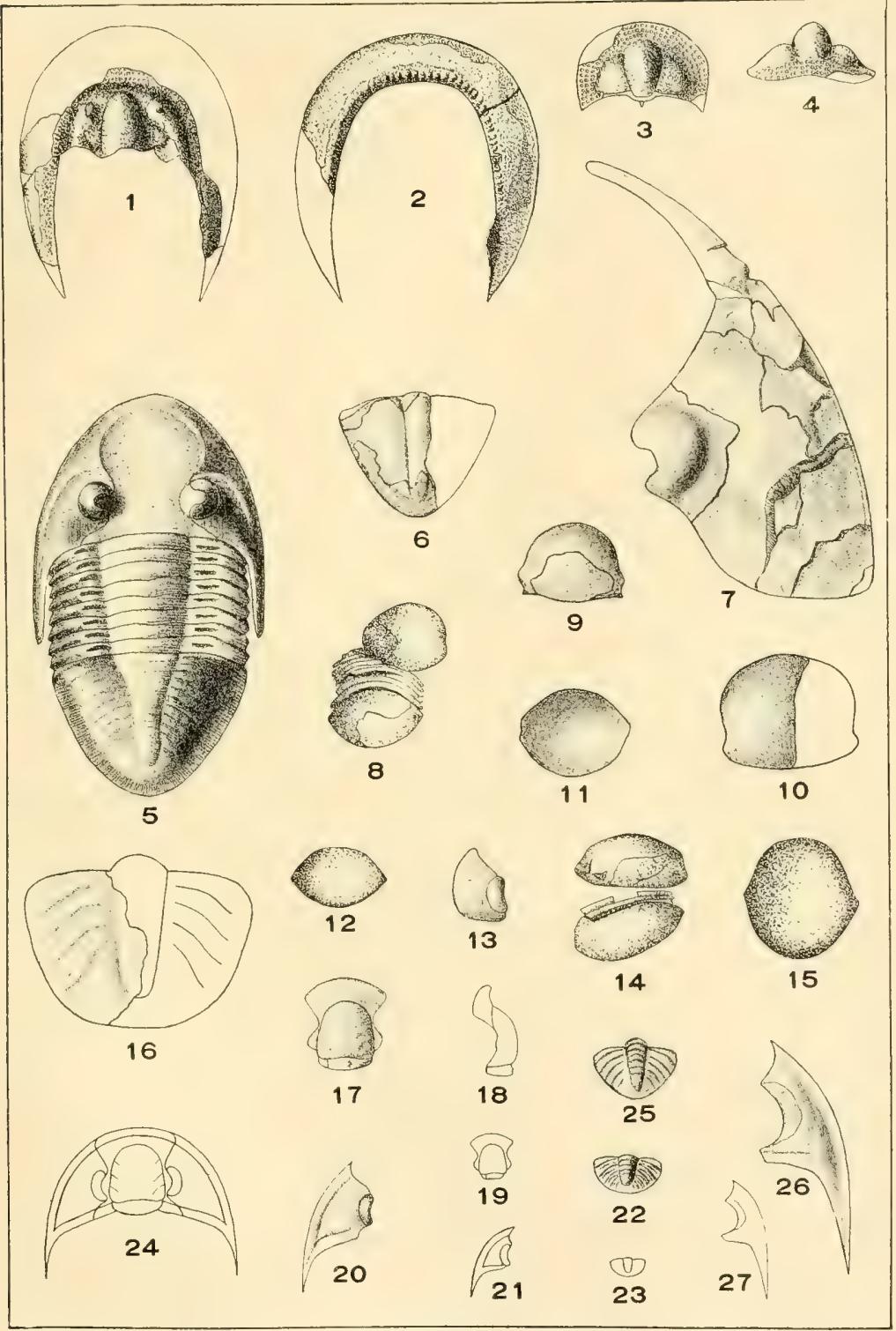

TREN'TON. 



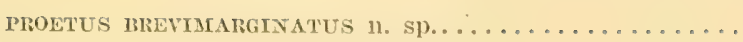

Fis. 1. Dorsal view of a nearly complete cranidium. Jacksonburg, Locality 174 1. (x2).

2. Dorsal view of the same. Natural size.

3. Lateral view of the same in outline. $\left(x_{2}\right)$.

4. A nearly complete free cheek. Jacksonburg, Locality $17 / 4 .^{20} \quad(\times 2)$.

5. A complete pygidium. Same locality. (x2).

6. The same in outline. Natural size.

7. Restoration in outline of the complete head. ( $\left.x_{2}\right)$.

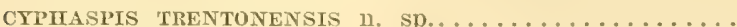

Fig. S. Dorsal view of a nearly complete cranidium. Jacksonburg, Locality $174 .{ }^{50}$

9. The same in outline. Natural size.

10. Lateral view of the same in outline. $\left(x_{2}\right)$.

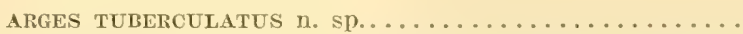

Fig. 11. Dorsal view in outline of a nearly complete cranidium. Near Iliff's Pond, Locality 137. A. ${ }^{1}$

12. Dorsal view of the same. $\left(x_{2}\right)$.

13. Anterior riew of the same. ( $\times 2)$.

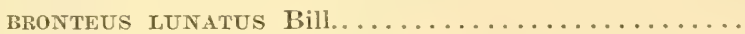

Fig. 14. A large, incomplete pygidium. Sulphur Springs, Mo. Pal. Coll. Walker Museum, University of Chicago, No. 5,879 .

15. A small, but complete pygidium. Jacksonburg, Locality $1 \% / 4$.

16. A complete individual (after Billings).

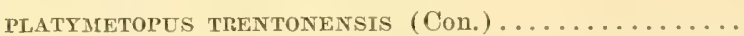

Figs. 17-19. Dorsal, anterior and lateral views of a nearly complete cranidium. Drake's Pond, near Newton, Locality $136 \mathrm{~B}$.

20. An hypostome which possibly belongs to this species. Jacksonburg, Locality 17 \& A.

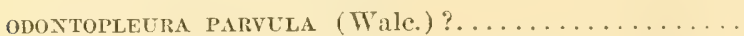

Fig. 21. Dorsal view of a nearly complete cranidium. Jacksonburg, Locality 17\%. (x2).

22. Lateral view of the same in outline. $\left(\mathrm{x}_{2}\right)$.

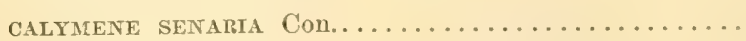

Fig. 23. Posterior view of a complete pygidium. Jacksonburg. Locality $174 \mathrm{~A}$. 


\section{PLATE XT.-(Continucd.)}

PSEUDOSPHAFRETOCHUS TRENTONEXSIS Clarke........

Fiss. 24.25. Dorsal and lateral viems of an incomplete cranidium. Jacksonburg. Locality 1if t. ${ }^{10}$

EXcRLNCRCS TRENTOXEXSIS Walc..............

Fig. 26. Dorsal riem of a nearly complete pygidium. Jacksonburg. Locality 1 if $A$. $(x: 2)$.

27. The same in outline. Natural size.

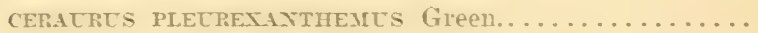

Fig. 2S. An incomplete cranidium. Jacksonburg, Locality 17 't $\mathbf{A .}^{10}$ PTERTGOMETOPCS CALLICEPHALCS (Hall) ..........

Fig. 23. An incomplete head. Jacksonbur\%. Locality $176 \mathrm{~A} .{ }^{62}$

30. A complete prgidium. Same localiti.

31. A nearly complete prgidium of larger size. Jacksonburg, Locality 1 íf 1.15

32. A complete individual (after Billings).

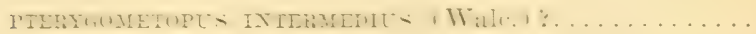

Fig. $\quad 33$. An incomplete prgidium. Jacksonburg, Locality $17^{\prime} A^{4}$ (410) 


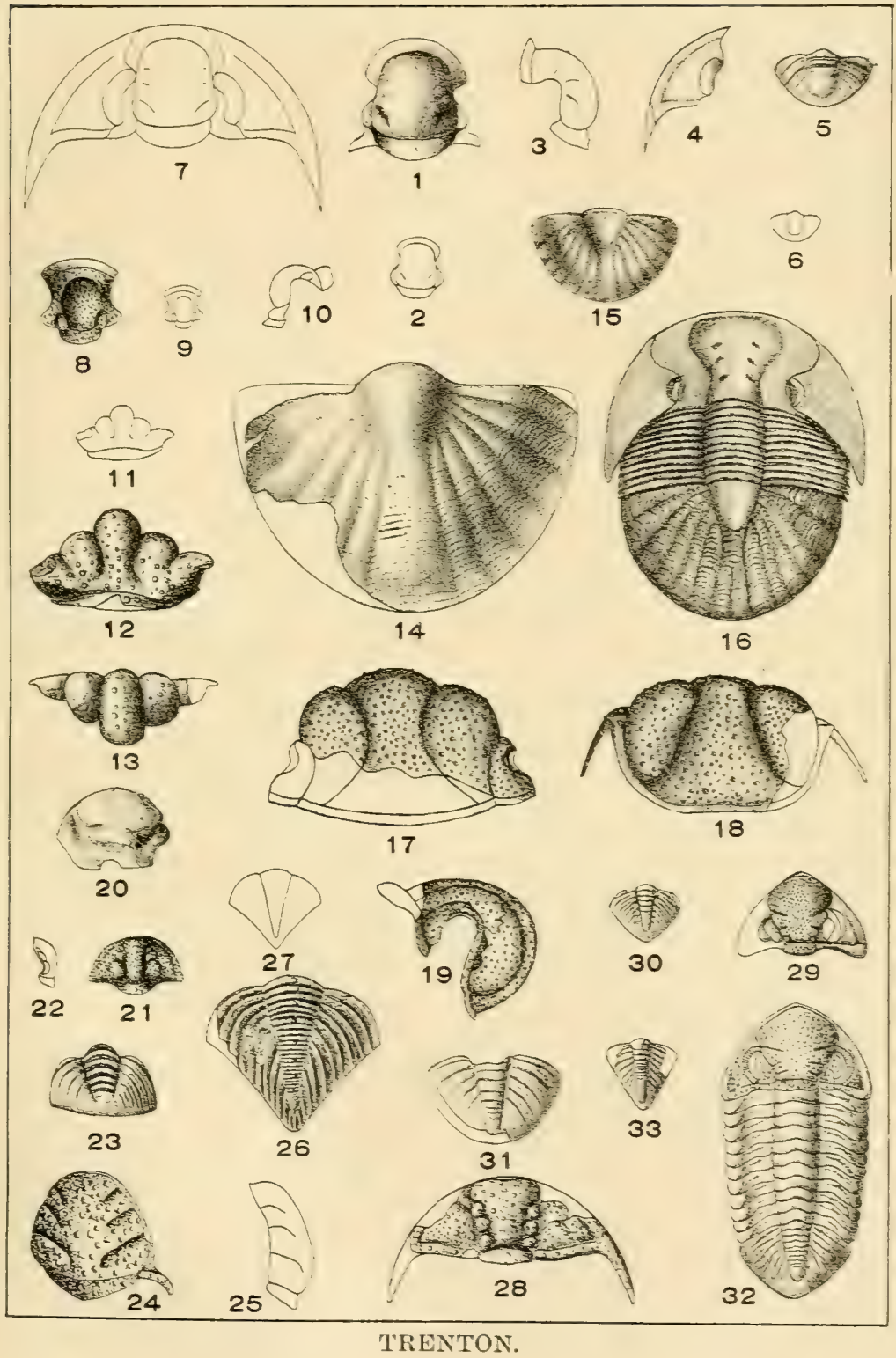






\section{PLATE XYI.}

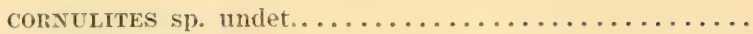

Fig. 1. Sussex, Locality 伎A.

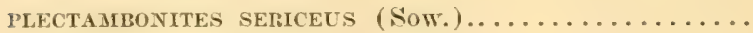

Figs. 2, 3. Two incomplete and somewhat distorted specimens. Sussex, Locality if $\mathrm{A}$.

DALMANELLA TESTLDINARIA (Dal.)............

Fig. 4. An incomplete pedicle valve. Sussex, Locality イ4:

₹. Internal cast of a brachial valve. Same locality.

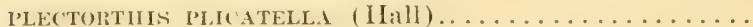

Fig. (i. An incomplete pedicle valve. Sussex, Locality f'A.

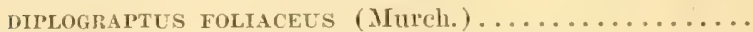

Fig. 7. A single stipe. Natural size (after Hall).

MPLOGRAPTLS ANGESTIFOLIES (Hall)...........

Fig. S. A single stipe (after Hall). ( 52$)$.

). A portion of the same still further enlarged (after Hall).

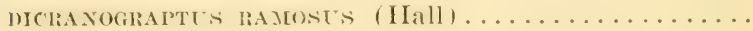

I.is. 11. A small specimen, showing the bifucation of the stipe (after Hall).

10. The same enlarged (after Hall).

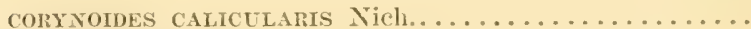

Fig. 12. A complete stipe (after Nicholson).

1:. The same enlarged (after Nicholson).

CLIMACOGRAPTUS PHYLLOPOHUS GUIPley...........

Iigs. 14. 15. Views of two stipes (after Gurley). (x2).

LASIOGRAPTUS MUCRONATUS (Hall) .............

Iig. 16. A single stipe (after Hall).

17. A portion of the same enlarged (after Hall).

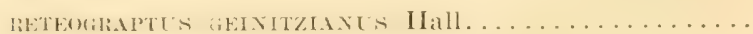

Fig. 1․ The type specimen (after Hall). ( $\left.x^{\prime 2}\right)$.

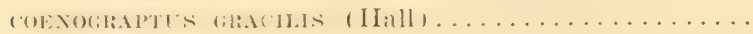

Fir. 1!). A very large colony (after Hall). 


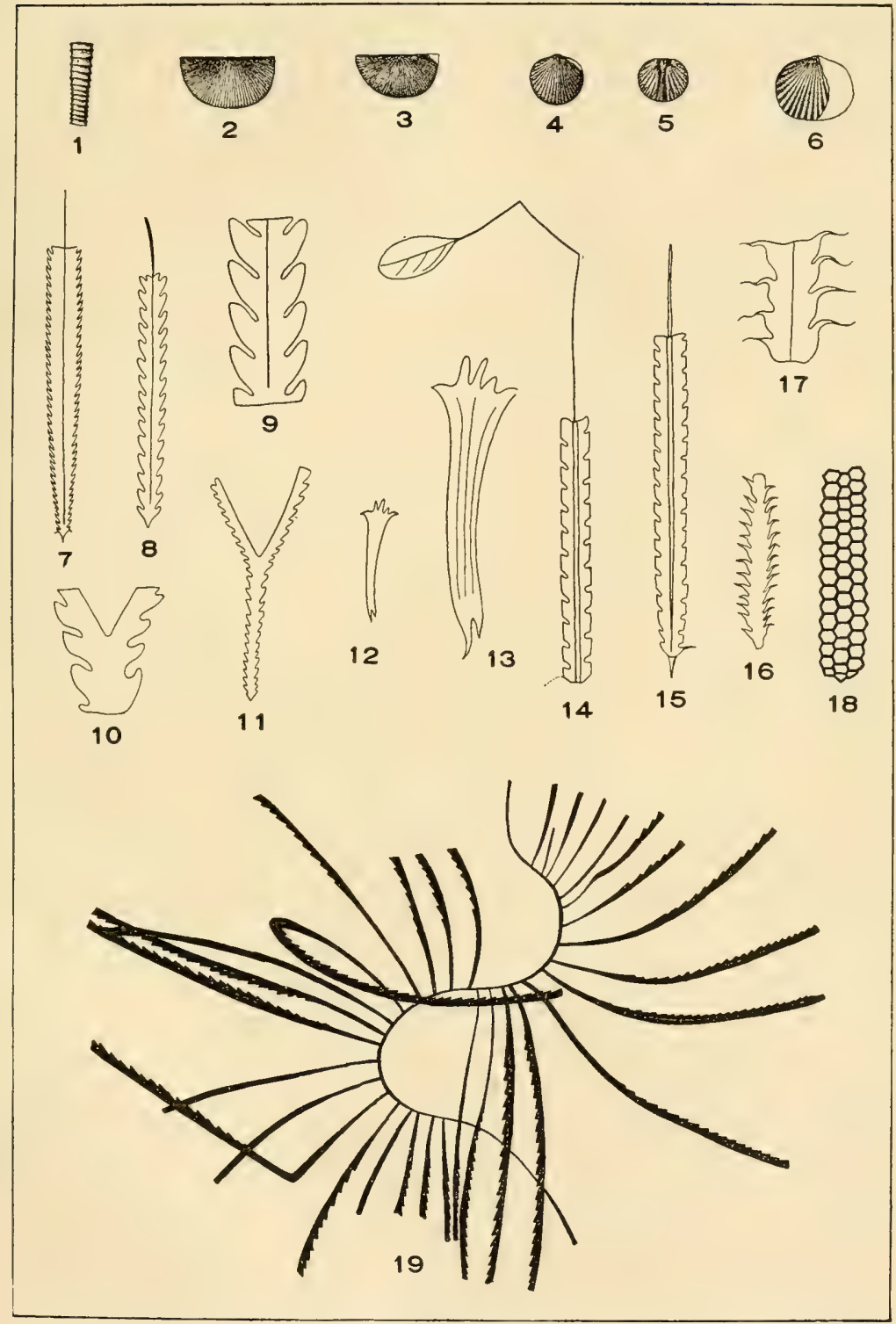

HUDSON RIVER. 




\section{PLATE XVII.}

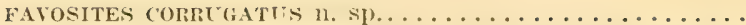

Fig. 1. A portion of a corallum. Flatbrookville, Locality $109 \mathrm{~B}$.

2. A portion of the same enlarged.

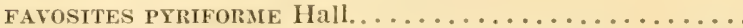

Wig. ¿. Vertical section through a small corallum. Vearpass section, Locality $2 \mathrm{~A}^{13}$

4. 5. Longitudinal and transverse sections of the same $\left(x_{2}\right)$.

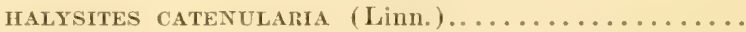

Fig. (i. Cross-section of a portion of a corallum. Nearpass section, Locality 24.12

7. 8. Longitudinal and transverse sections of two corallites of the same. ( $\mathrm{x} 5)$.

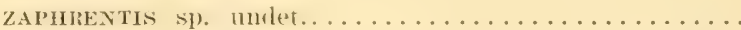

Figs. 9.10. Lateral views of two specimens, probably representing different species. Nearpass scetion, Locality $2 \mathrm{A.12}$

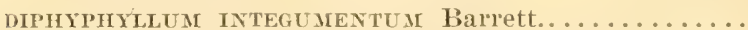

Fig. 11. Cross-section of a corallite. Nearpass section, Locality $2 A^{12}\left(x_{2}\right)$.

PRISMATOPIYLLL IXEQTALIS (Hall) ...........

Figs. 12, 13. Transverse and longitudinal sections of a portion of a corallum. Nearpass section, Locality $2 \mathrm{~A}^{12}$

Cradopoli reCtILINEATA Simpson.............

F'igs. $1+16$. Three fragmentary branches. Tcarpass section, Locality $\therefore$ 1."

17. A portion of a branch enlarged. same locality.

(412) 
Geol. Survey of N. J.-190:2. Paleontology.

PLATE XVII.

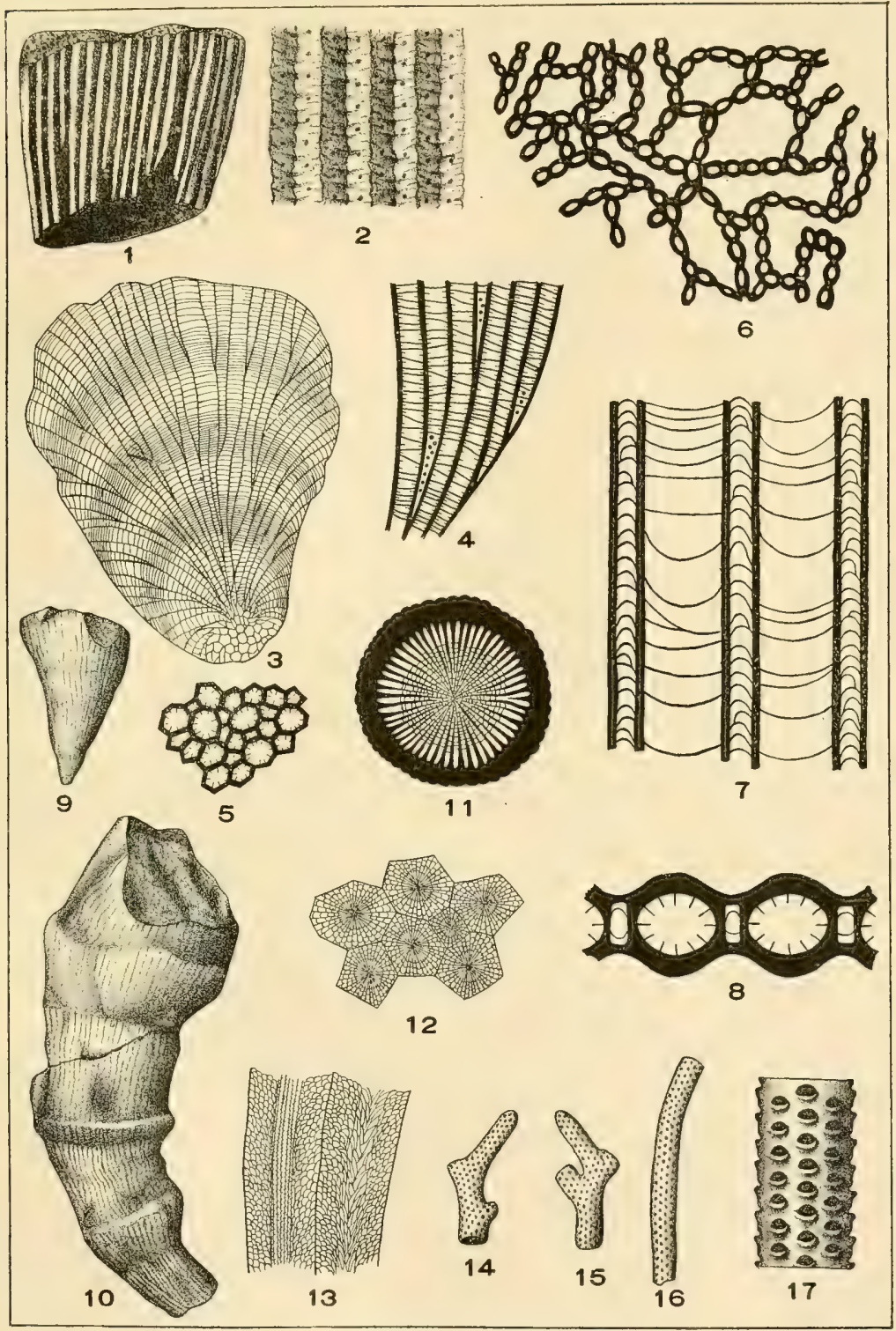

DECKER FERRY. 




\section{PLATE XVIII.}

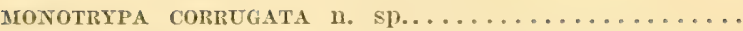

Fig. 1. A large, subhemispheric zoarium. Nearpass scetion, Locality $2 A .^{3}$

2.:. Two tangential sections, showing variation in the size of zoocia. Same locality. (x 24).

4. A vertical section from the inner portion of a zoarium. Same locality. (x 24).

5. A vertical section from near the surface of a zoarium. showing the more abundant diaphragms. Same locality. (x 24).

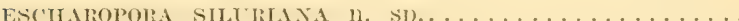

Fig. (i. A tangential section, showing the form of the zoocia in both their procumbent and erect portions. Nearpass section, Locality $2 \mathcal{A}^{10}$ (x 24).

7. A vertical section of the same. $\left(x^{2}-4\right)$. 
Geol. Survey of N. J.-1902. Paleontology.

PLATE XVIII.

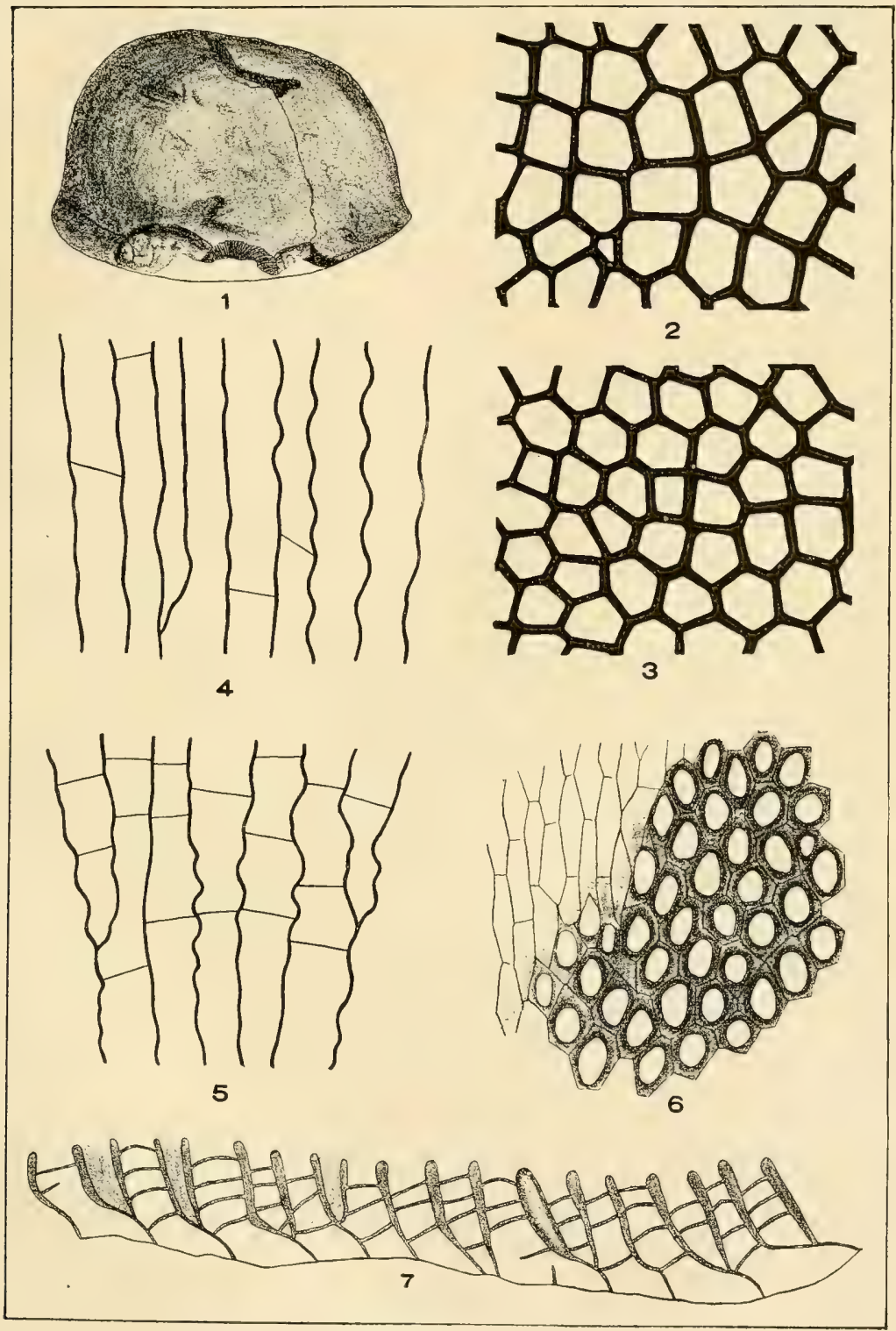

DECKER FERRY. 


PLATE XIX.

PAGE.

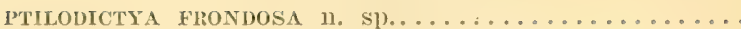

Wigs. 1,2. Vertical and tangential sections. Nearpass section, Locality $24.0^{5} \quad\left(x^{2} 4\right)$.

$\therefore 4$. Views of two zoaria, separated along the mesothecal layer. Same locality.

PHAENOPORA PLATYPHYLLA Tames..............

Fig. 5 . One of the type specimens, separated along the mesothecal layer. Pal. Coll. Walker Museum, University of Chicago, No. 641.

Figs. 6, 7. Tangential and vertical sections of the same. $(x 24)$.

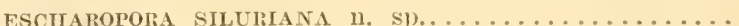

Figs. S,9. Two incomplete zoaria, separated along the mesothecal layer. Nearpass scetion, Locality $2 \mathcal{A}{ }^{10}$ 
Geol. Survey of N. J.-1902. Paleontology.

Plate XIX.

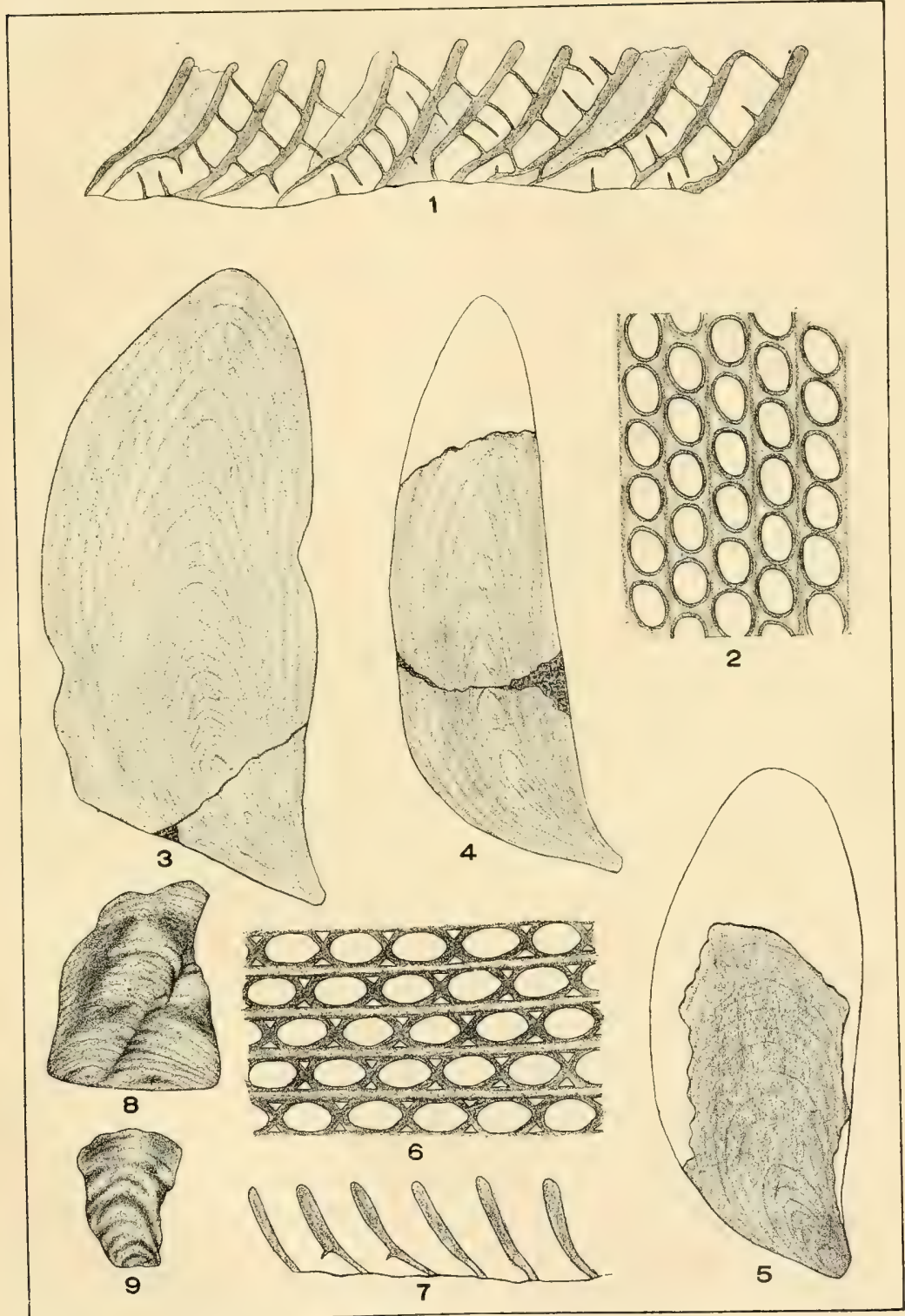

DECKER FERRY. 

Fig. 1. A nearly complete pedicle valve. Nearpass section, Locality $2 A . .^{10}$

2. The interior of an incomplete brachial valve partially exfoliated. Same locality.

3. A nearly complete pedicle valve, showing mucronate extension of the hinge-line. Same locality.

4. Internal cast of a pedicle valve. Same locality.

5. Surface markings enlarged. Same locality.

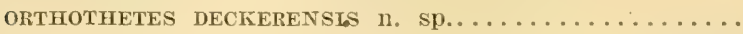

Fig. 6. A nearly complete brachial valve, with profile in outline. Nearpass section, Locality $24 .{ }^{3}$

7. A nearly complete pedicle valve. Nearpass secúion, Locality 8 A.

ORTHOTHETES INTERSTRIATUS (Hall).................

Figs. 8-9. A pedicle and a brachial valve. Nearpass section, Locality $24 .^{12}$

LEPTAENA RHOMBOIDALIS (Wilck.)..............

Fig. 10. An incomplete pedicle valve. Nearpass section, Locality $24 . .^{12}$

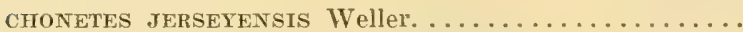

Fig. 11. A small pedicle valve. Nearpass section, Locality $8 \mathrm{~A}$.

12. A large, incomplete pedicle valve, showing spine bases and curved ribs. Nearpass section, Locality $2 A .^{3}$

13. A small pedicle valve, showing spine bases. Nearpass section, Locality 8 A.

14. A similar pedicle valve. Nearpass section, Locality $2 \mathrm{~A}^{3}$

15. A large brachial valve. Same locality.

16. A large pedicle valve. Same locality.

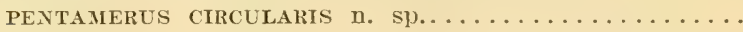

Figs. 17-19. Three views of a nearly complete pedicle valve. Nearpass section, Locality $2 A .^{8}$

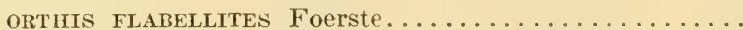

Fig. 20. A nearly complete brachial valve. Nearpass section, Locality $2 A .^{8}$

DALMTANELLA POSTELEgANTULA $n$. sp..................

Figs. 21, 22. Two pedicle valves. Nearpass section, Locality $2 A .^{3}$ and $8 \mathrm{~A}$.

23, 24. Two brachial valves. Nearpass section, Locality 8.4 . 
PLATE XX.-(Continued.)

PAGE.

MHIPIDOMELLA PREORLATA $11 . \$ 1 \% \ldots \ldots \ldots \ldots \ldots \ldots \ldots \ldots$

Fig. 25. A pedicle valve. Nearpass section, Locality 2 A. ${ }^{8}$

26. The internal cast of a pedicle valve. Same locality.

PHOLIDOPS OVATA Hall...................

226

Fig. 27. A complete shell, showing external markings. Nearpass scotion, Locality $2 \mathrm{~A}^{12} \quad(\mathrm{x} 3)$.

28. Internal cast of a similar shell. Same locality. (x3).

2!). Internal cast of a smaller individual. Nearpass section, Locality $2 A .^{3} \quad(\mathrm{x} 3)$.

(416) 
Geot. Survet of N. J.-1902. Paleontology.

Plate XX.

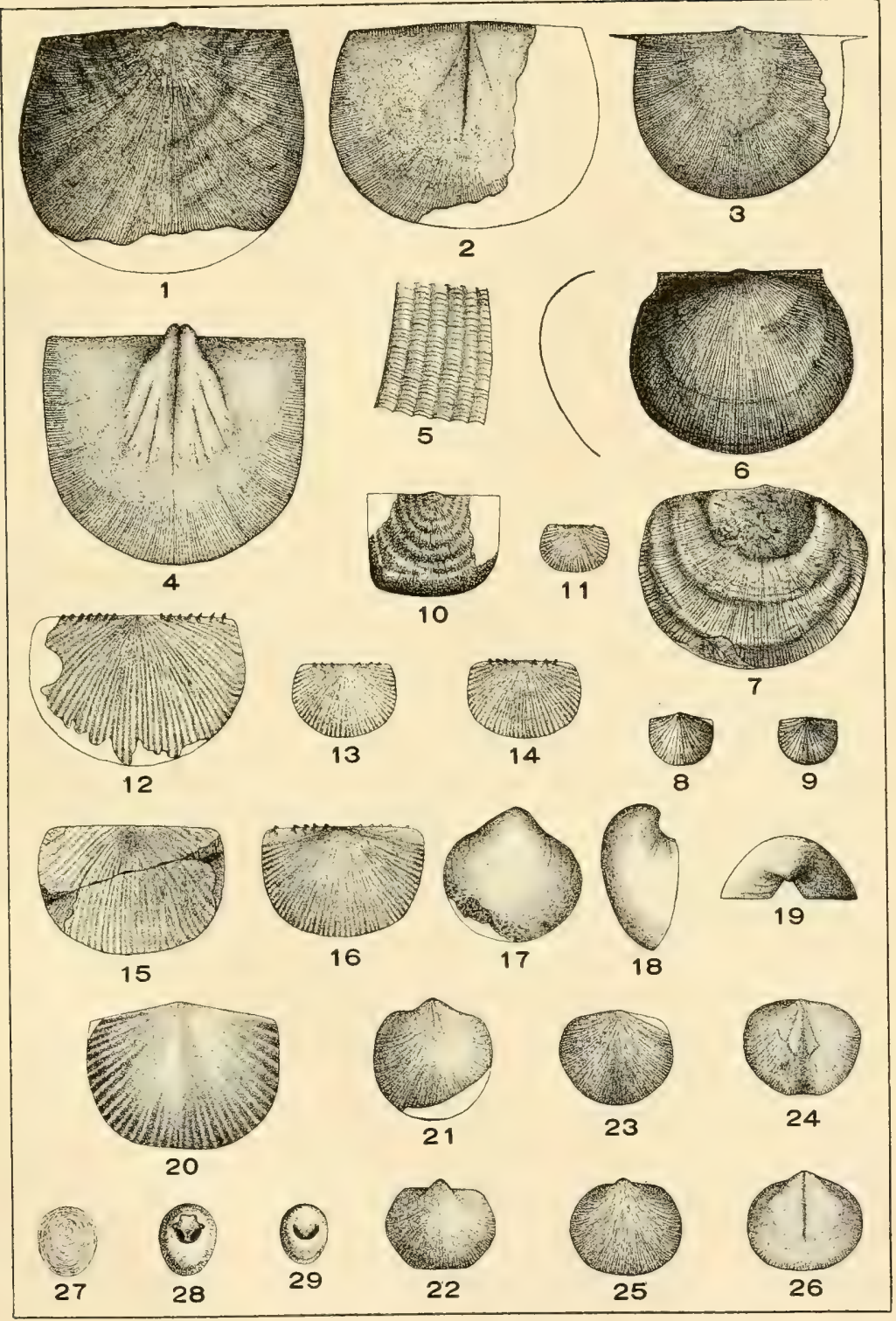

DECKER FERTY. 



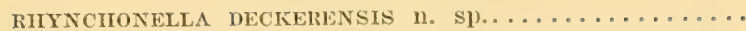

Figs. 1-4. Pedicle, brachial, anterior and lateral views of a nearly complete individual. Nearpass section, Locality $\& \mathcal{A}$.

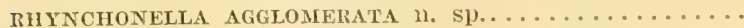

Figs. 5-8. Brachial, pedicle, lateral and anterior views of a complete individual. Ncarpass section, Locality $24 .^{3}$

9-11. Brachial, lateral and anterior views of a smaller individual. Nearpass section, Locality $2 \mathrm{~A} .{ }^{12}$

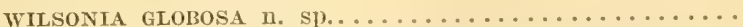

Figs. 12-15. Serial sections through the posterior portion of the shell, showing internal structure. Nearpass section, Locality $24 . .^{12}$

16-19. Lateral, brachial, pedicle and anterior views of a very globose individual. Same locality.

20-22. Lateral, brachial and anterior views of a less globose individual. Same locality.

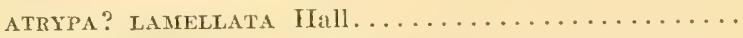

Figs. 23-25. Brachial, lateral and anterior views of a large individual. Nearpass section, Locality $2 \mathrm{~A} .^{12}$

26-29. Brachial, pedicle, lateral and anterior views of another individual. Same locality.

RHYNCHOSPIRA FORJIOSA Hall................

Figs. 30-31. Brachial and lateral views of an incomplete, subglobose individual. Nearpass section, Locality $2 A .^{12}$

32-34. Anterior, brachial aud lateral views of another less globose individual. Same locality.

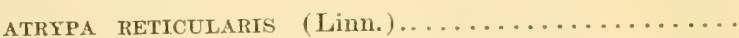

Fig. 35. A rather large brachial ralve, with lamellate extensions of the shell. Nearpass section, Locality $2 \mathrm{~A}^{3}$

36. Profile of the same in outline.

37. A smaller pedicle valve. Same locality.

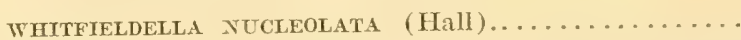

Figs. 38 40. Brachial, pedicle and lateral views of a complete inclividual. Nearpass section, Locality $2 \mathrm{~A}^{32}$

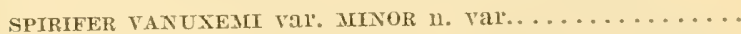

Figs. 41,42 . Two riews of a complete pedicle valre. Nearpass section, Locality $2 \mathrm{d.}^{10}$

SPIRILEK sl. undet.

Fig. 43. An incomplete pedicle valre. Nearpass section, Locality $24 .^{10}$ 
PLATL XXI.-(1"ontinaed.)

PAGE.

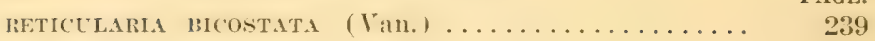

Fig. 44. A pedicle valve with the profile in outline. Nearpass section, Locality $2 \mathrm{~A}$. $^{3}$

45. A brachial valve. Same locality.

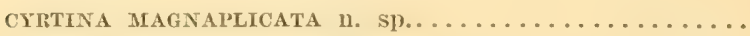

Hig. 4i. A brachial valve. Tearpass scction, Locality $2 \mathrm{~A} .4$ 47 49. Three riews of a pedicle valve. Same locality. (418) 


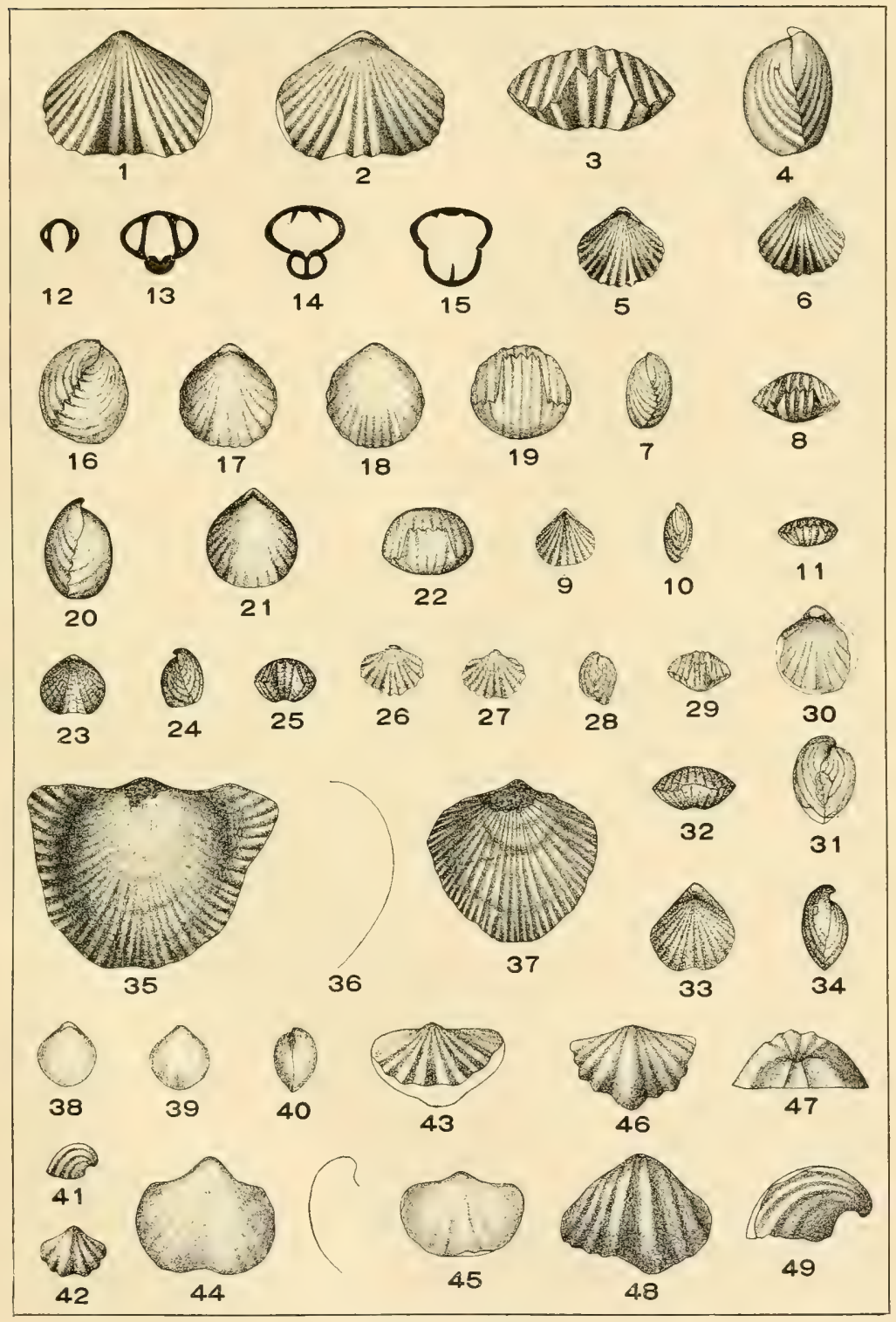

DECKER FERRY. 



\section{[PLATE XXII.}

PTERONITES? SCBILAXA ( Iall) ..............

Fig. 1. An incomplete left valve. Nearpass section, Locality $8 \mathrm{~A}$ PTYCHOPTERIA? StEQTADLATA 11. S1.............

Fig. 2. An incomplete left valve. Nearpass section, Locality 2 A."

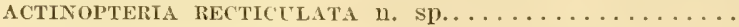

Fig. 3. An incomplete left valve. Nearpass section, Locality $2 \mathrm{~A} .{ }^{12}$ pterinea emacerata (Con.).................

Fig. 4. A nearly complete left valve. Nearpass section, Locality 2 A. $^{10}$

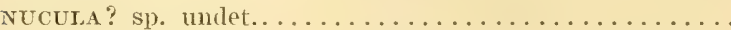

Fig. 5. A complete right valve. Nearpass section, Locality 8 A.

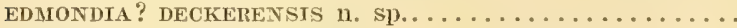

Fig. 6. A nearly complete right valve. Nearpass section, Locality $2 \mathrm{~A}^{3}{ }^{3}$

7. A more elongate right valve which may belong to this species. Same locality.

MYTTLARCA OBLTQUA $n, \$ p \ldots \ldots \ldots \ldots \ldots \ldots \ldots \ldots$

Fig. $\quad$ S. A complete left valve. Nearpass section, Locality $2 A^{3}$

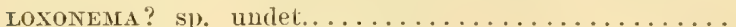

Figs. 9-11. Three imperfect specimens. Nearpass section, Locality $24 .^{3}$

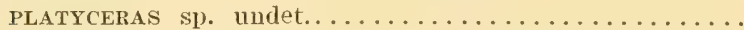

Figs. 12, 13. Two views of an incomplete shell. Nearpass section, Locality $2 \mathrm{~A}^{4}$

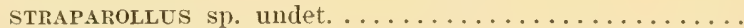

Fig. 14. Vertical view of an incomplete shell. Nearpass section, Locality $2 A .^{3}$

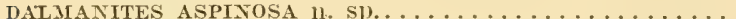

Fig. 15. Dorsal view of an incomplete pygidium, Nearpass section, Locality $2 \mathrm{~A}^{3}{ }^{3}$

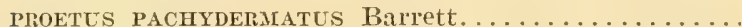

Fig. 16. Restoration of the complete head in outline.

17. An incomplete cranidium. Nearpass section, Locality $24 . .^{12}$

18. An incomplete cranidium. Same locality.

19. A complete free cheek. Same locality.

20. A very perfect pygidium. Same locality.

21. An hypostome, probably belonging to this species. Same locality. 
Calymene camerata Con....................... 20

Fig. 22. An incomplete cranidium. Nearpass section, Locality $2 A \cdot{ }^{12}$

23. 24. Posterior and lateral views of a perfect pygidium. Same locality.

25. Two views of an hypostome, probably belonging to this species. Same locality.

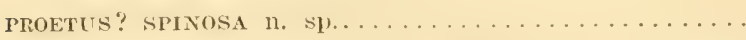

Fig. 26. A nearly complete pygidium. Vearpass section, Locality $8 \mathrm{~A}$.

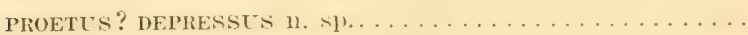

Fig. 27. A nearly complete pygidium. Jearpass section, Locality 2 A. $^{3}$

(420) 
Geol. Surver of N. J.-1902. Paleontologr.

P'LATE XXII.

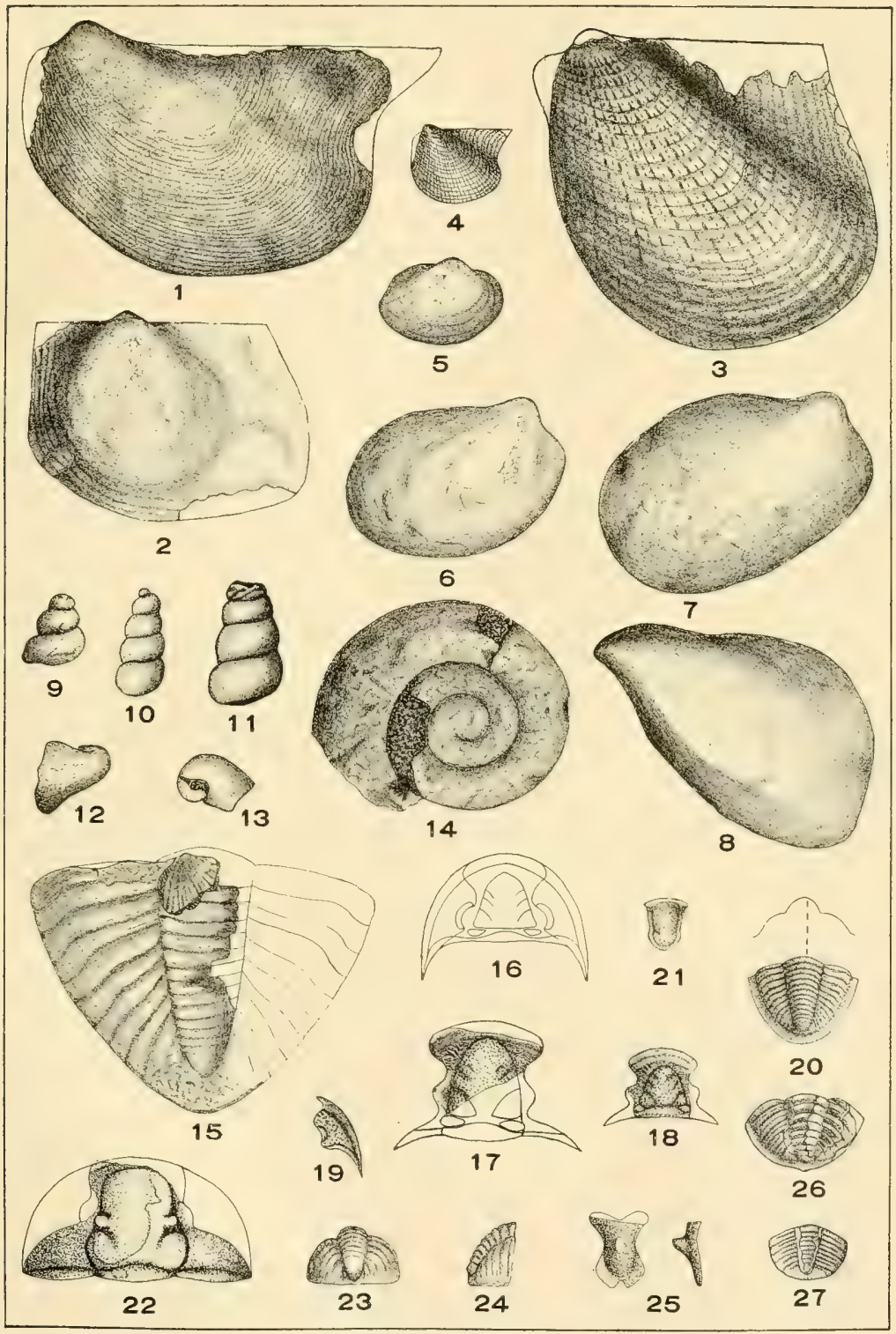

DECKER FERRY, 




\section{PLATE XXIII.}

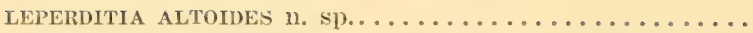

Fis. 1. A left valve. Flatbrookville, Locality $109 \mathrm{~B} . \quad(\mathrm{x} 21 / 2)$.

2. A right valve. Same locality. (x 21/2).

BETRICHIA STSEEXENSIS 11. Sp............

Fig. $\quad 3$. A left valve. Tearpass scction, Locality $2 \mathrm{~A}^{12}(\mathbf{x} 4)$.

4. A left ralve. Tearpass scetion, Locality $2 \mathrm{~A}^{13}$ (x $\left.\mathbf{6}\right)$.

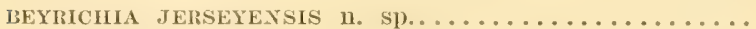

Fig. 5. A left valve. Tearpass section, Locality $2 \mathrm{~A}^{13}$ ( 5 ).

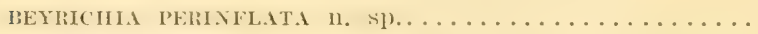

Fig. 6. A right valve. Tcarpass scction, Locality $24{ }^{13}(\times 4)$.

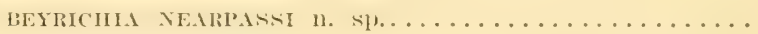

Figs. T.8. A left and a right valve. Nearpass scction, Locality : I. $^{13}(\mathrm{x}+\mathrm{i})$.

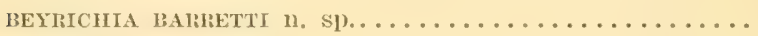

Hig. 9. A right valve. Tearpass scction, Locality $2 \mathrm{~A}^{12}(\times 5)$.

BEYRICHIA MANLIENAIS $\mathrm{H}$. SH.............

Fig. 10. A left valve. Tearpass scetion, Locality $2 \mathrm{~A}_{0}^{22}$ ( 44$)$.

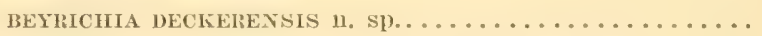

Fig. 11. A right valve. Tearpass section, Locality $2 \mathrm{~A}^{13}(\mathrm{x} t)$.

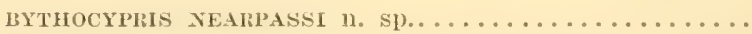

Fig. 12. A lateral and an end view of a complete individual. Nearpass scetion, Locality $2 A^{7} \quad(\times 71 / 2)$.

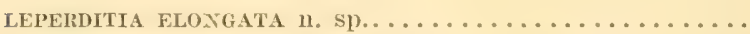

Fig. 13. A right valve. Nearpass section, Locality $2 A^{15}(\times 2)$.

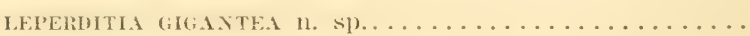

Fig. 14. A left valve. Nearpass section, Locality $2 \mathrm{~A}^{\mathbf{1}}$ (Nat. size).

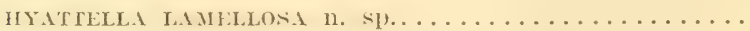

Figs. 1.,-1․ Pelicle, brachial, lateral and anterior views of a complete individual. Nearpass section, Locality $2 \mathrm{~A}^{1 \bar{i}}$ ( $\mathrm{x} 2$ ). 

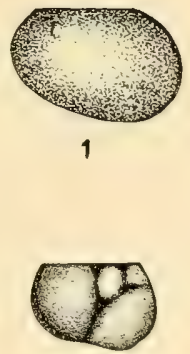

6

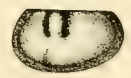

7

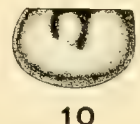

10

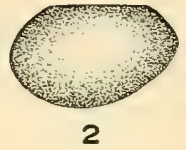

2

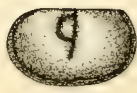

5

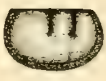

8
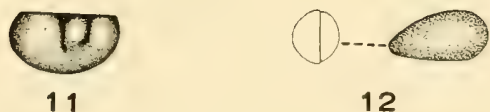

12
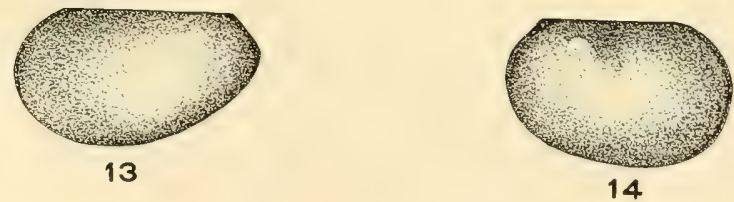

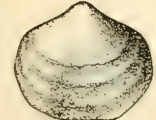

15
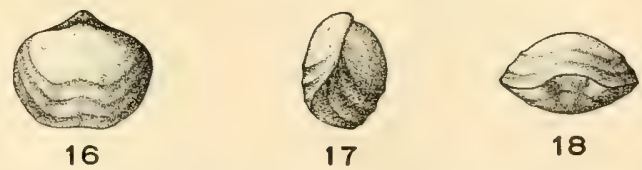

RONDOUT. 




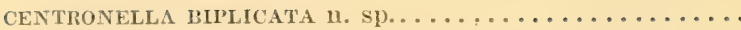

Figs. 1-4. Pedicle, brachial, lateral and anterior views of a large individual. Nearpass section, Locality $240_{0}^{25}(x \neq)$.

5-S. Pedicle, brachial, lateral and anterior views of a smaller individual. same locality. (x4).

SPIRIFER VANTAEMI Hall.....................

Fig. 9. A large pedicle valve. Nearpass scetion, Locality $2 \mathrm{A.} .^{: 4}$

10. A large brachial valve. Same locality.

11. A smaller pedicle valre. Same locality.

12. A smaller brachial valve. Same loculity.

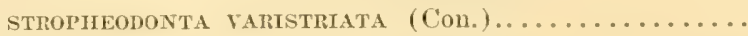

Figs. 13, 14. Views of two pedicle valves. Nearpass section, Locality $\therefore .10^{2+}$

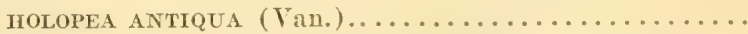

Figs. 15, 16. Lateral views of two incomplete individuals. Nearpass section, Locality $24 .^{* t}$

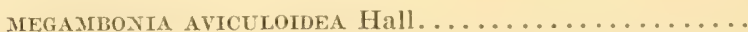

Fig. 17. An incomplete right ralre. Vearpass section, Locality $\therefore 1 .{ }^{2 *}$

18. An incomplete left valre. Same locality.

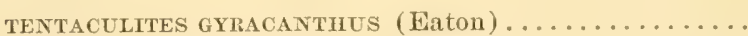

Fig. 19). An incomplete individual (after Hall). ( $\mathrm{x} 6)$.

20. An incomplete, exfoliated individual. Nearpass section, Locality $2 \mathrm{~A}^{2 \notin}(\mathrm{x} 4)$.

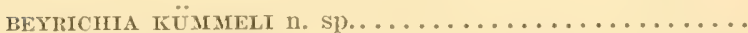

Fig. 21. A left valve. Nearpass section, Locality $2 A^{24}(\mathrm{x} 3)$.

BEYRICHIA WALLPACKENSIS $11 . \mathrm{sp} \ldots \ldots \ldots \ldots \ldots \ldots \ldots \ldots$

Fig. 22. A left valve. Ncarpass scction. ( $\mathrm{x} 6)$.

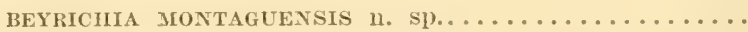

Fig. 23. A left valve. Nearpass scction, Locality $2 A^{26}$ ( $\left.\mathrm{x} 6\right)$.

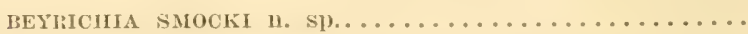

Fig. 24. A right valve. Nearpass section, Locality. $2 \mathrm{~A}^{25}(\mathrm{x} 4)$.

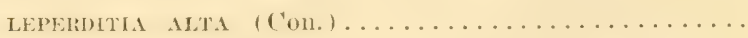

Fig. $\quad$ :- A right valve. Nearpass section, Locality $24.24 \quad\left(x 2 \frac{1}{2}\right)$.

24, 27. Two left valves. Same locality. ( $21 / 2)$.

28. A left valve. Nearpass section, Locality $2 A^{23}$ (.$_{2}$ ). (422) 
Geol. Surver of N. T.-1902. Paleontology.

Plate NXIV.

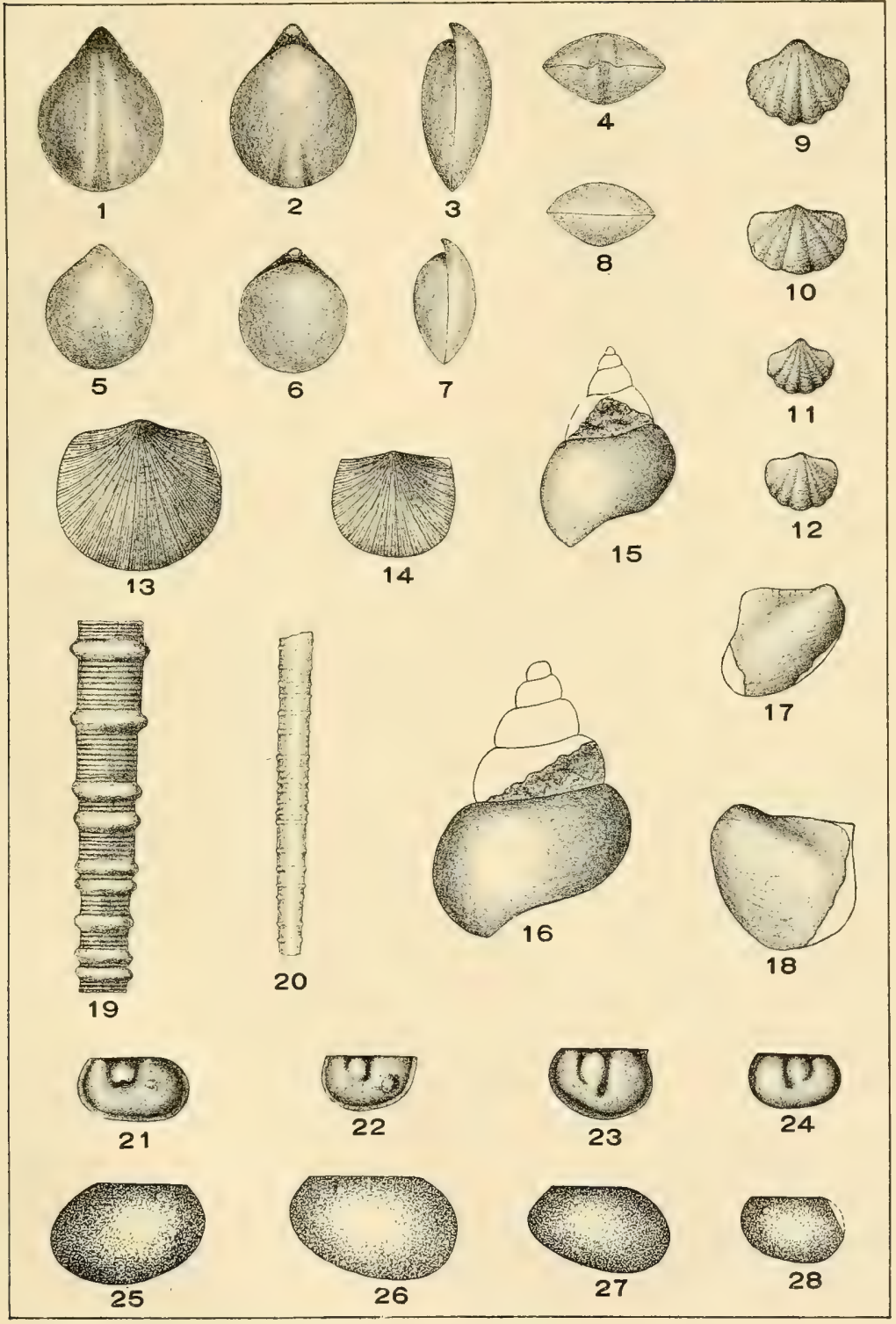

MANLIUS. 


PLATE NXY.

PAGE. ORTHoceras sp. undet................... 26.

Fig. 1. A large, weathered specimen. Nearpass section, Locality $2 A^{26}$ 
Geol. Survey of N. J.-1902. Paleontology.

Plate XXV.
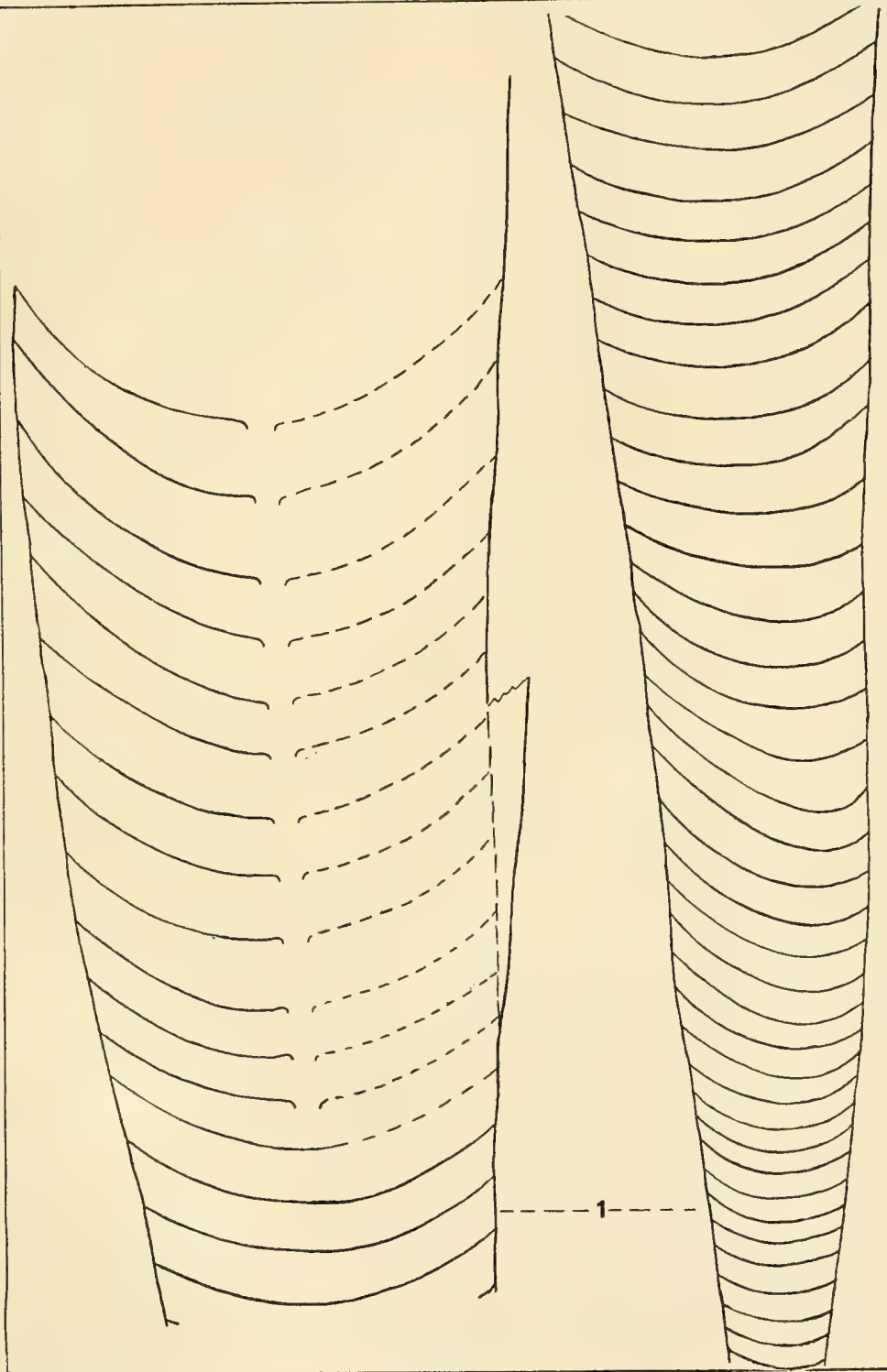

MANLIUS 




\section{PLATE XXYI}

ZAPHRENTIS ROEMERI E. \& H.?...............

Fig. 1. Lateral view of an incomplete individual. Near Haincsville, Locality $15 \mathrm{C}$.

(LADOPORA MLLTISERTATA n. Sp.............

Fig. 2. A fragment of a corallum showing a dividing branch. Near Hainesville, Locality 15 C.

3. The same enlarged. (x5).

I'TILODICTYA IOBATA 11. SH. . . . . . . . . . .

Fig. 4. An incomplete zoarium parted along the mesotheca. Nearpass section, Locality $24 .{ }^{27}$

5. Vertical section of the same. $(x 24)$.

6. 'Tangential section of the same. (x 24).

LiCHExali TOHTA Hall...................

Fig. 7. The epithecal surface of an incomplete zoarium. Nearpass scction, Locality $24 .{ }^{27}$

8. Tangential section of the same. (x 24).

MOAOTIYPA SPHAERICA $(\mathrm{II}$ all $) \ldots \ldots \ldots \ldots \ldots \ldots \ldots \ldots$

Figs. 9, 10. Two transverse sections from the same zoarium, showing rariation in size of zoccia. Nearpass section, Locality $24.27 \quad(x 24)$.

Fig. 11. Vertical section of the same. (x 24).

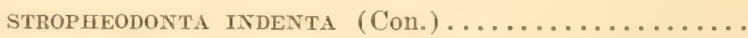

Fig. 12. A complete pedicle valve. Flatbrookville, Locality $109 \mathrm{~A}$. (424) 
Geol. Survey of N. J.-1902. Paleontology.

Plate XXVI.

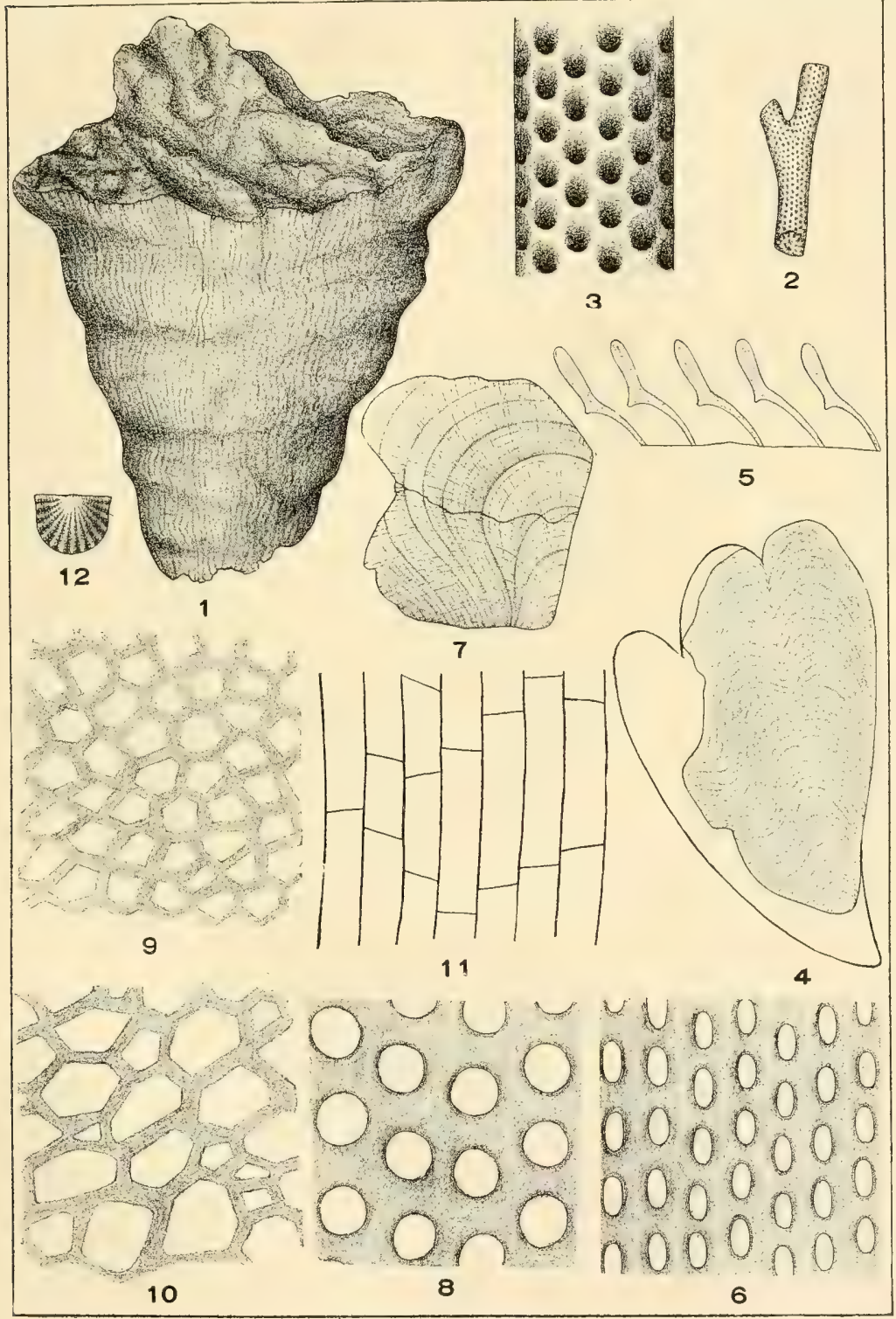

COEYMANS. 




\section{PLATE XYVII.}

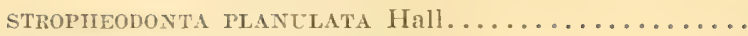

Fig. 1. A large, incomplete pedicle valve. Flatbrookville, Loculity $109 \mathrm{~A}$.

2. A smaller incomplete pedicle valve. Nearpass scction, Locality $2 \perp^{27}$

STROPIEODONTA VARISTRIATA Val. ARATA IIall.........

Fig. 3. A nearly complete pedicle valve with the profile in outline. Flatbrookville, Locality 109 A.

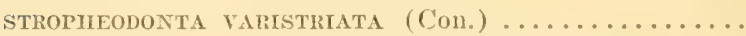

Fig. 4. A nearly complete pedicle valve with the profile in outline. Flatbrookville, Locality $109 \mathrm{~A}$.

ORTHOTIETES WOOLWORTIIANA (Hall).............

Fig. 5. An incomplete pedicle valve with the profile in outline. Flatbrookville, Locality 109 A.

STROPHONELLA PUNCTULIFERA (Con.)............

Fig. (i. An incomplete brachial valve with the profile in outline. Flatbrookville, Locality $109 \mathrm{~A}$.

7. A nearly complete pedicle valve with the profile in outline. Same locality.

8. A longitudinal section of the shell in outline.

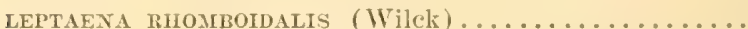

Fig. 9. An incomplete nedicle valve. Near Wallpack Center, Locality $71 \mathrm{~d}$. 
Geol. Survey of N. J.-1902. Paleontology.

Plate XXVII.

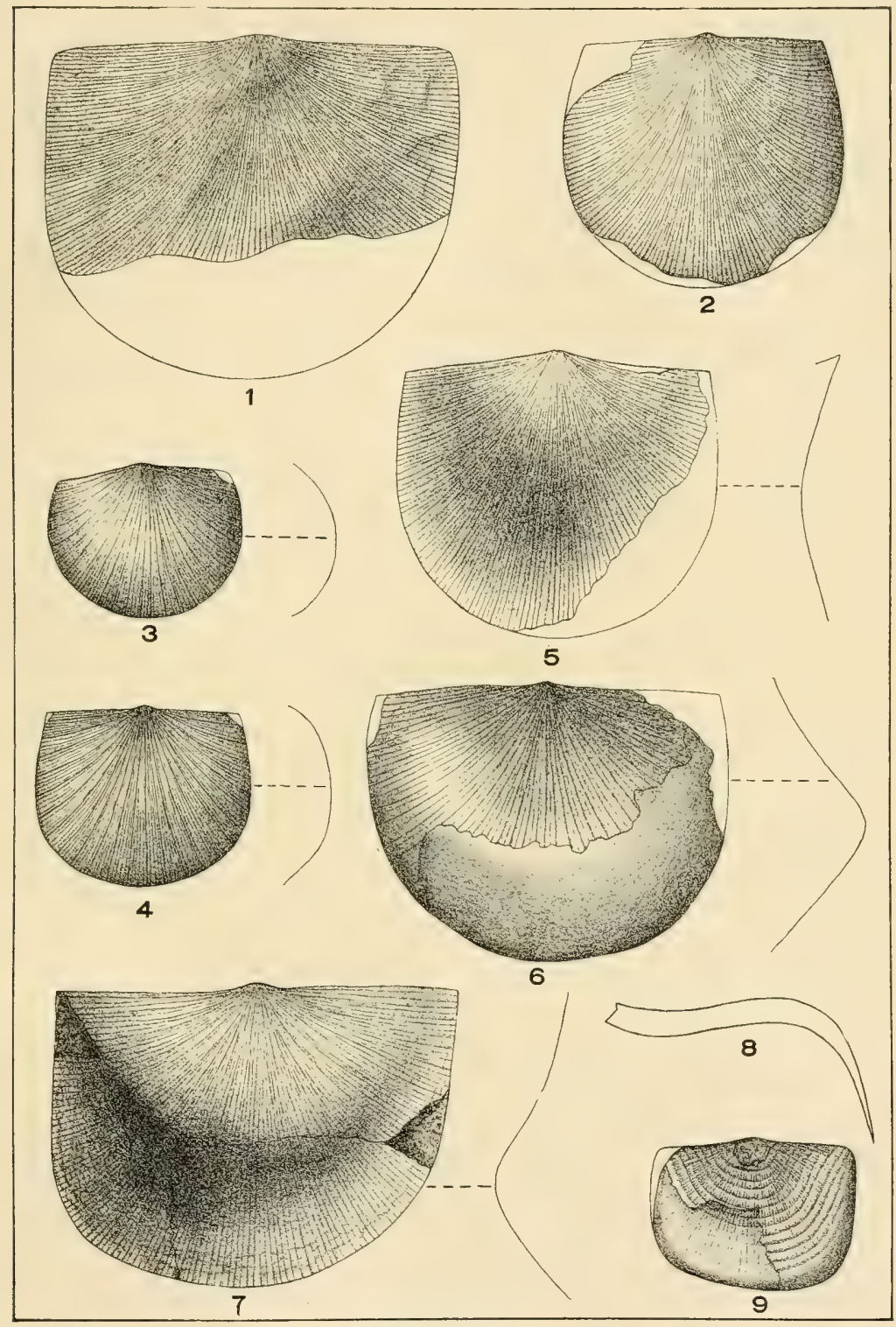

COEYMANS. 




\section{PLA'TE XXVIII.}

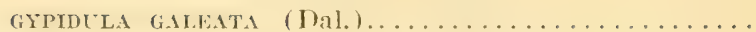

PAGE.

Figs. 1,2. Two views of a very elongate pedicle valve. Peters Vallcy, Locality $37 \mathrm{~A}$.

3, 4. Two views of an average-sized pedicle valve. Same locality.

5, (i. Two smaller pedicle valyes. Same locality.

7. A small brachial valve. Same locality.

S. A large brachial valve. Flatbrookville, Locality $109 \mathrm{~d}$.

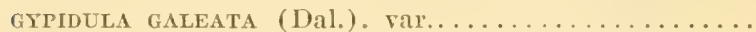

Figs. 9-12. Brachial, pedicle, lateral and anterior views of a nearly complete individual. Near Hainesville, Locality $15 \mathrm{C}$.

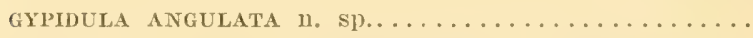

Figs. 13, 14. Two pedicle valves. Near Hainesville, Locality $15 \mathrm{C}$.

15, 16. Brachial and lateral views of a nearly complete individual. Same locality.

17. A brachial valve. Same locality.

18-21. Pedicle, brachial, lateral and anterior views of a young individual. Same locality. (x 2).

(426) 
Geol. Survey of N. T.-1902. Paleontology.

Plate XXViII.

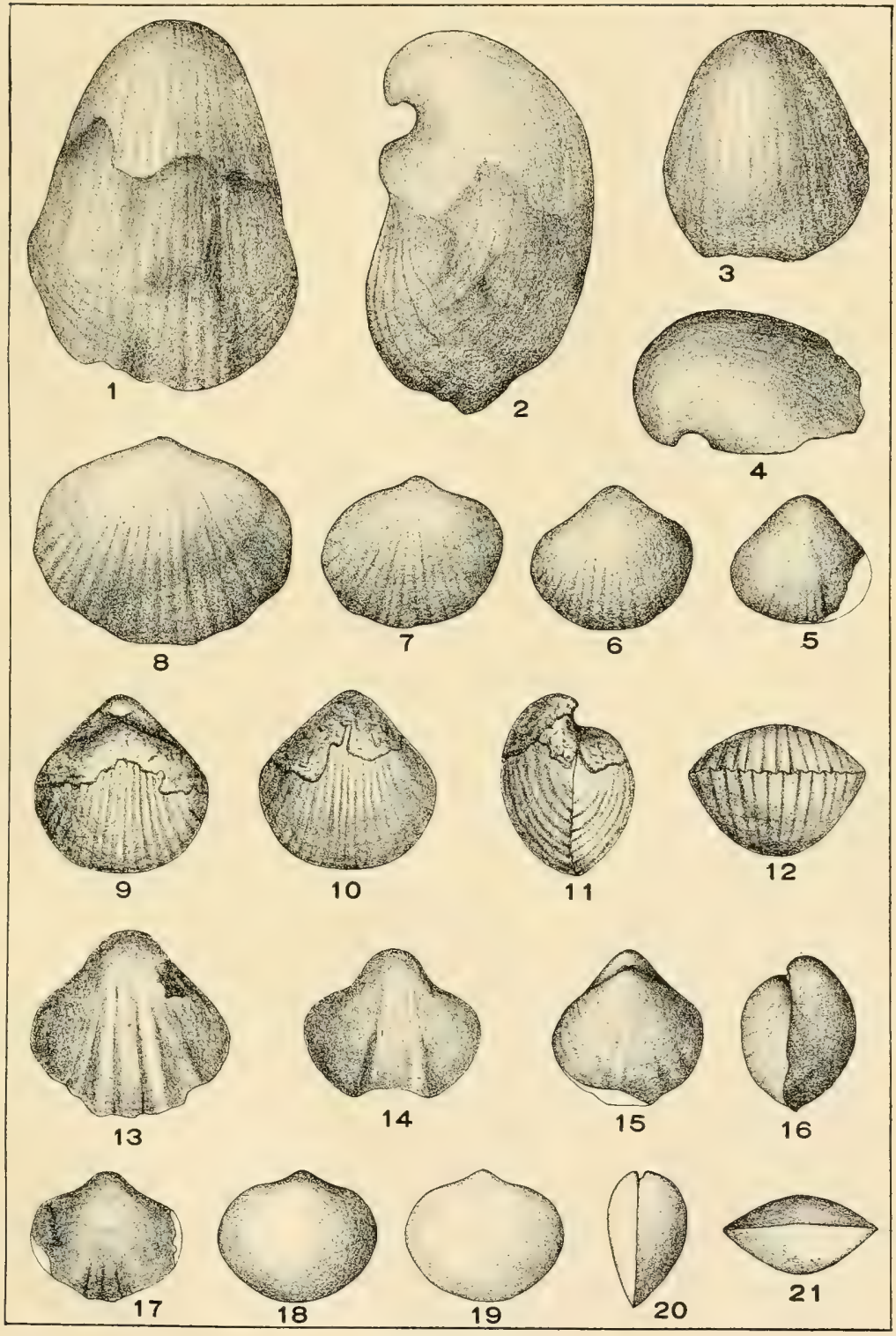

COEYMANS. 




\section{PLATE XXIX.}

UNCTNULUS MUTABILIS (Hall) ..............

PAGE.

283

Figs. 1-4. Pedicle, brachial, lateral and anterior views of a slightly distorted, complete individual. Nearpass section, Locality $2 \Lambda^{2 \pi}$

5. Another pedicle valve. Same locality.

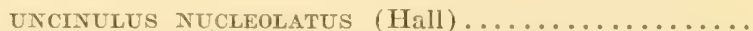

Figs. (j-9. Pedicle, brachial, lateral and anterior views of a complete individual. Flatbroolville, Locality $109 \mathrm{~A}$.

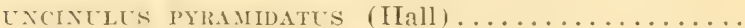

Figs. 10, 11. Brachial and lateral views of a nearly complete individual. Near II ainesville, Locality $15 \mathrm{C}$.

RHXNCHONELLA SEMIPLICATA (Con.) ...........

Figs. 12-15. Pedicle, brachial, lateral and anterior views of a small individual. Flatbrookville, Locality $109 \mathrm{~A}$. (x 2).

16-1!). Pedicle, brachial, lateral and anterior views of a larger individual. Same locality. (x 2).

RIITXCIIONELLA ALTIPLICATA HaIl. ............

Figs. 20-23. Brachial, pedicle, lateral and anterior views of a specimen. From Oriskany Falls, New York. Pal. Coll. Walker Museum, University of Chicago, No. S,496.

$21-27$. Brachial, pedicle, anterior and lateral views of a complete specimen. Peters-Talley, Locality $3 \%$ A. (х2).

JIIYXCHONELLA TRAXSTERSA Hall.............

Figs. 2-31. Brachial, pedicle, lateral and anterior views of a complete specimen. Flatbrookville, Locality $109 \mathrm{~A}$.

IRIYXCHOTRETA TIANSYERSA $\mathrm{n}$. Sp............

Higs. :2-:35. Brachial, pedicle, lateral and anterior views of a complete individual. Near Hainesville, Locality $15 \mathrm{C}$. (x 2). ;:-39. Brachial, pedicle, lateral and anterior views of another nearly complete individual. Same locality. (x2). 


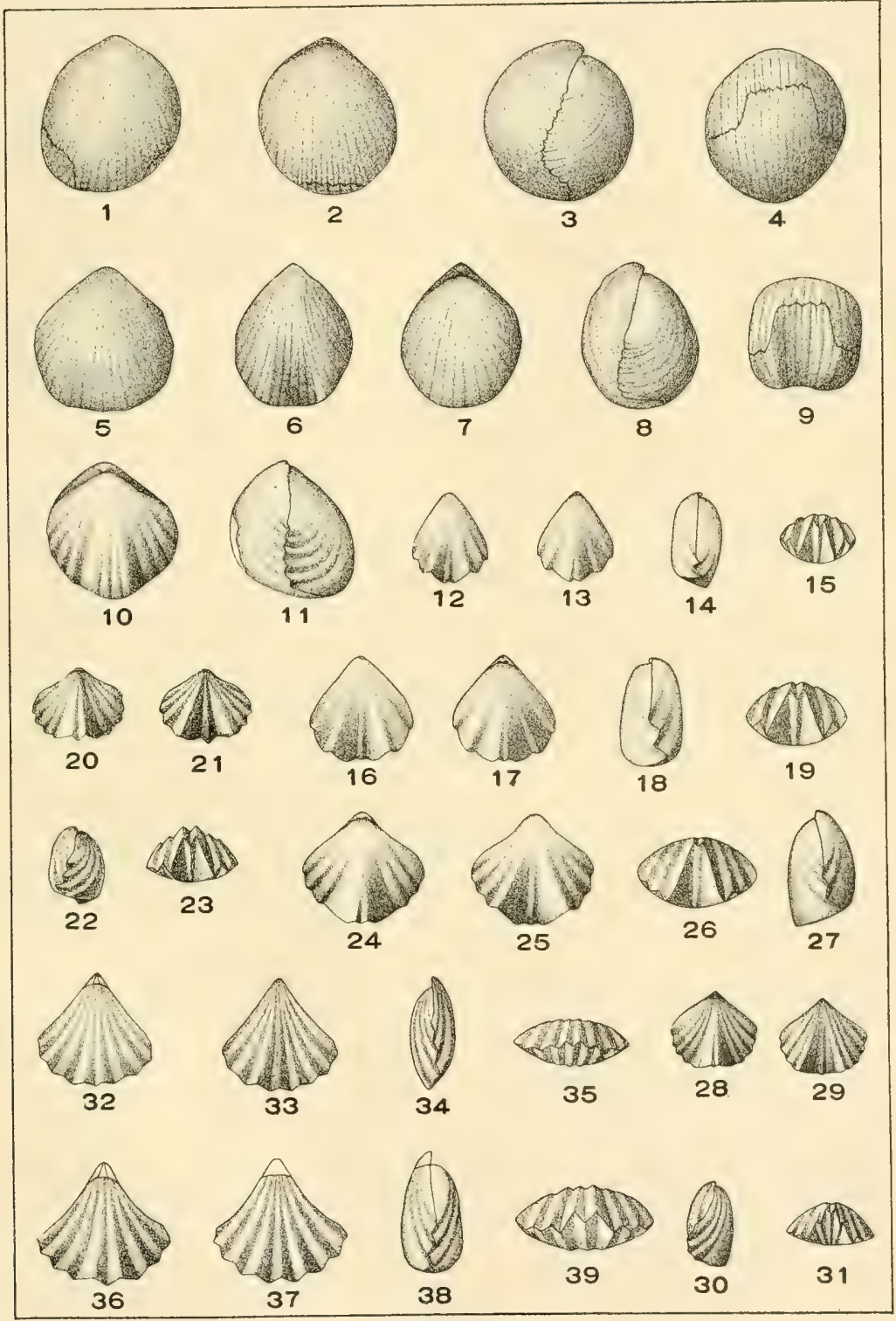

COEYMANS. 




\section{PLATE XXX.}

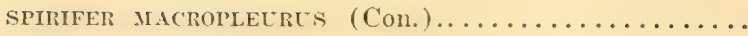

Fig. 1. An incomplete pedicle valve. Flatbrookville, Locality $109 \mathrm{~A}$.

SPIRIFER CTCLOPTLRT'S Hall...............

Fig. 2. An incomplete pedicle valve. Peters Valley, Locality 37 A.

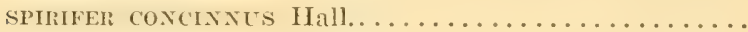

Fig. 3. An incomplete brachial valre. Near Hainesville, Locality $15 \mathrm{C}$.

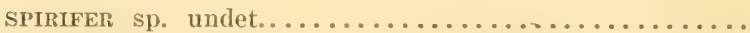

Fig. 4. A complete brachial valve. Near Hainesville, Locality $15 C$.

SPIRIFER OCTOCOSTATL'S IIAll...............

Fig. 5. An incomplete brachial valve. Near Hainesville, Locality 150 .

6, 7. Pedicle and anterior views of a nearly complete indiridual. Same locality.

8. A narrow pedicle valve. Same locality.

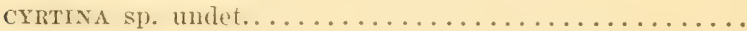

Figs. 9, 10. Anterior and lateral views of an incomplete pedicle valve. Near Hainesville, Locality $15 \mathrm{C}$.

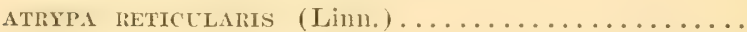

Figs. 11-14. Anterior, pedicle, brachial and lateral views of a nearly complete individual. Wallpack Center, Locality $71 \mathrm{~A}$.

15-18. Brachial, pedicle, lateral and anterior views of a complete individual. Near Hainesville, Locality $15 \mathrm{C}$.

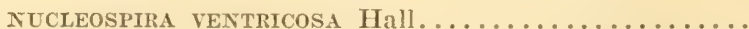

Figs. 19-22. Brachial, pedicle, anterior and lateral views of a complete individual. Near Hainesville, Locality $15 \mathrm{C}$. (x2). 


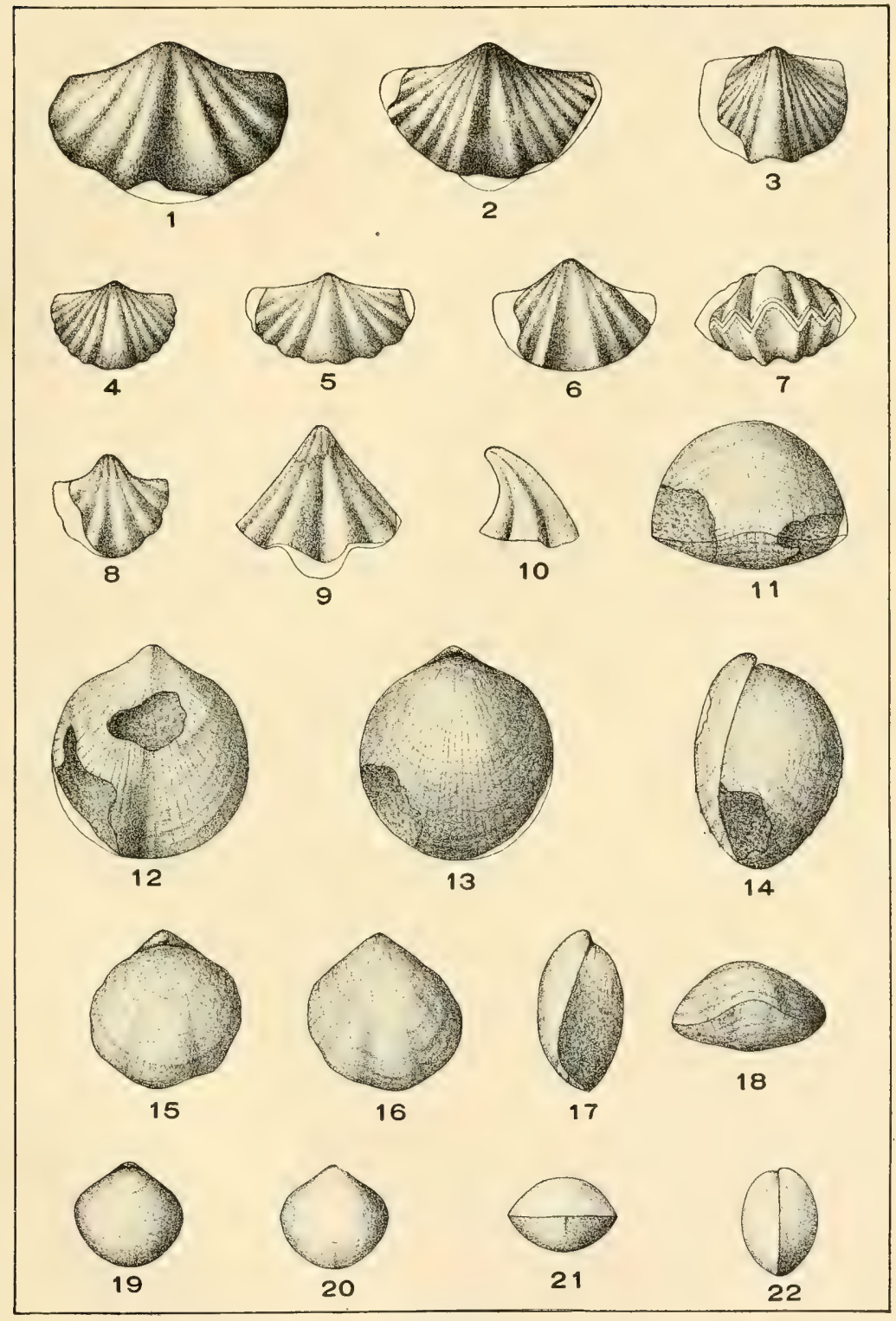

COEYMANS. 




\section{PLATE TXXI.}

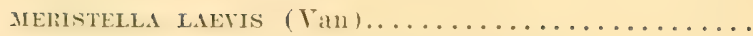

PAGE.

290

Figs. 1-1. Pedicle, brachial, lateral and anterior views of a complete individual. Near Hainesville, Locality $15 \mathrm{C}$.

5-8. Pedicle, brachial, lateral and anterior views of a small, complete individual. I'etcrs Valloy, Locality $37 \mathrm{~A}$.

RHYNCHOSPIRA FOIMOSA (Hall)...............

Figs. 9-11. Brachial, pedicle and lateral views of a complete indiviclual. Near Hainesville, Locality $1.5 \mathrm{C}$.

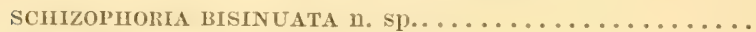

Fig. 12. A strongly bisinuate pedicle valve. Flatbrookville, Locality $109 \mathrm{\perp}$.

13. A less strongly bisinuate perlicle valve. Same locality.

14. A brachial valve. Same locality.

RHOMHOHTEHA ('LATHIATL'S Val ...........

Fig. 15. An incomplete left valve. Petcrs Valley, Locality 37 A.

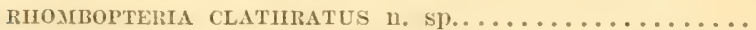

Fig. 16. A complete left valve. Near Hainesville, Locality 15c.

17. A small right valve. Same locality.

18. An incomplete left valve, probably belonging to this species. Sume locality.

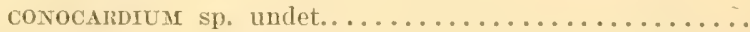

Fig. 19. A fragmentary specimen. Peters Vallcy, Locality 37 A.

20. Profile of the same.

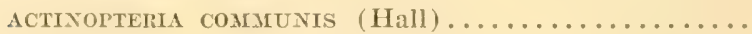

Fig. 21. An incomplete left valve. Flatbrookville, Locality $109 \mathrm{~A}$. 

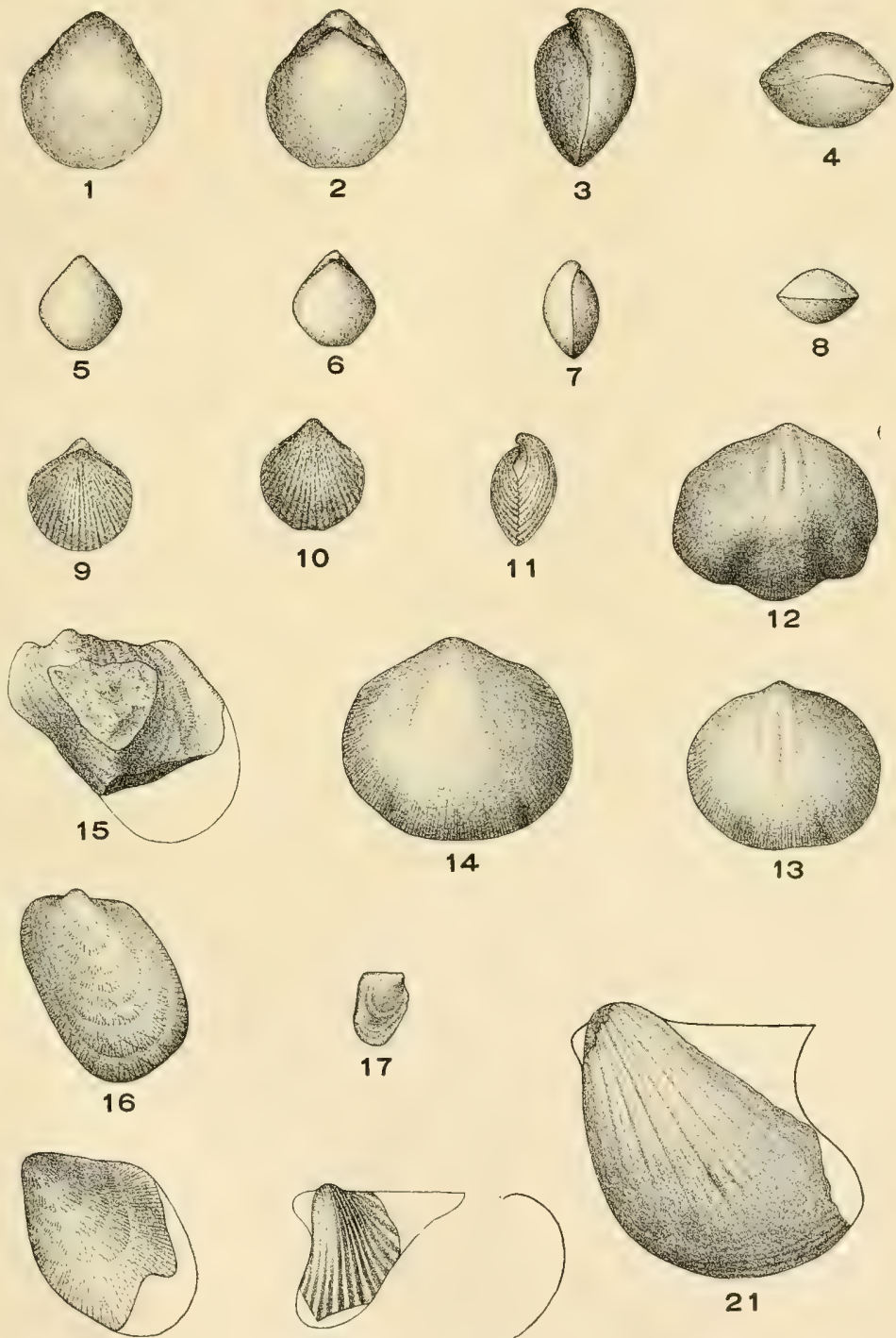

18
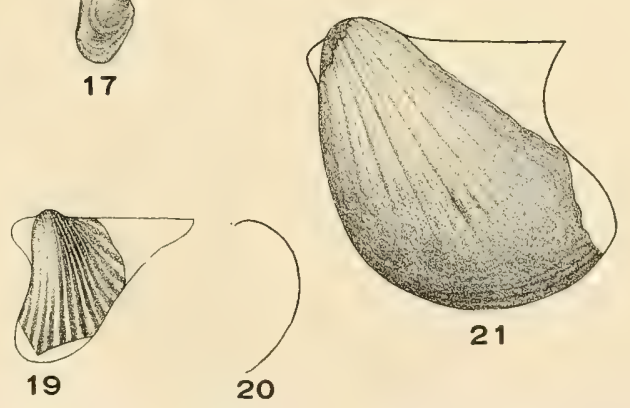

COEYMANS. 




\section{PLATE XXYII}

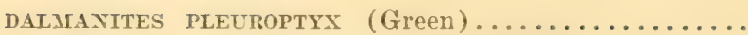

Fig. 1. An incomplete pygidium. Near Wallpack Center, Locality $71 \mathrm{~A}$.

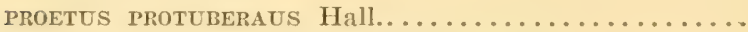

Fig. 2. An incomplete pygidium. Nearpass section, Locality 2 A. $^{27}$

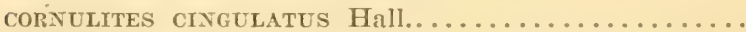

Fig. 3. An incomplete individual. Near Hainesville, Locality $15 \mathrm{C}$.

TENTACLLITES ELONGATtes IIall...............

Fig. 4. An incomplete individual. Flatbrookville, Locality 109 A.

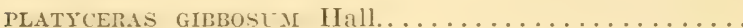

Figs, $\overline{\mathbf{j}-7}$. Three viers of a nearly complete shell, partially exfoliated. Near Hainesville, Locality $15 \mathrm{C}$.

BULIMORPHA? HELDERBERGIAE n. Sp.............

Fig. S. Lateral vien of a complete individual. Near Hainesville, Locality 15 C. ( 2 2).

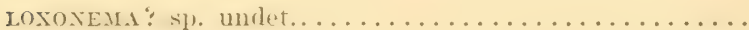

Figs. 9, 10. Lateral views of two incomplete individuals. Near Haineszille, Locality $15 \mathrm{C}$. 
Geol. Surver of N. J.-1902. Paleontology.

Plate XXXII.

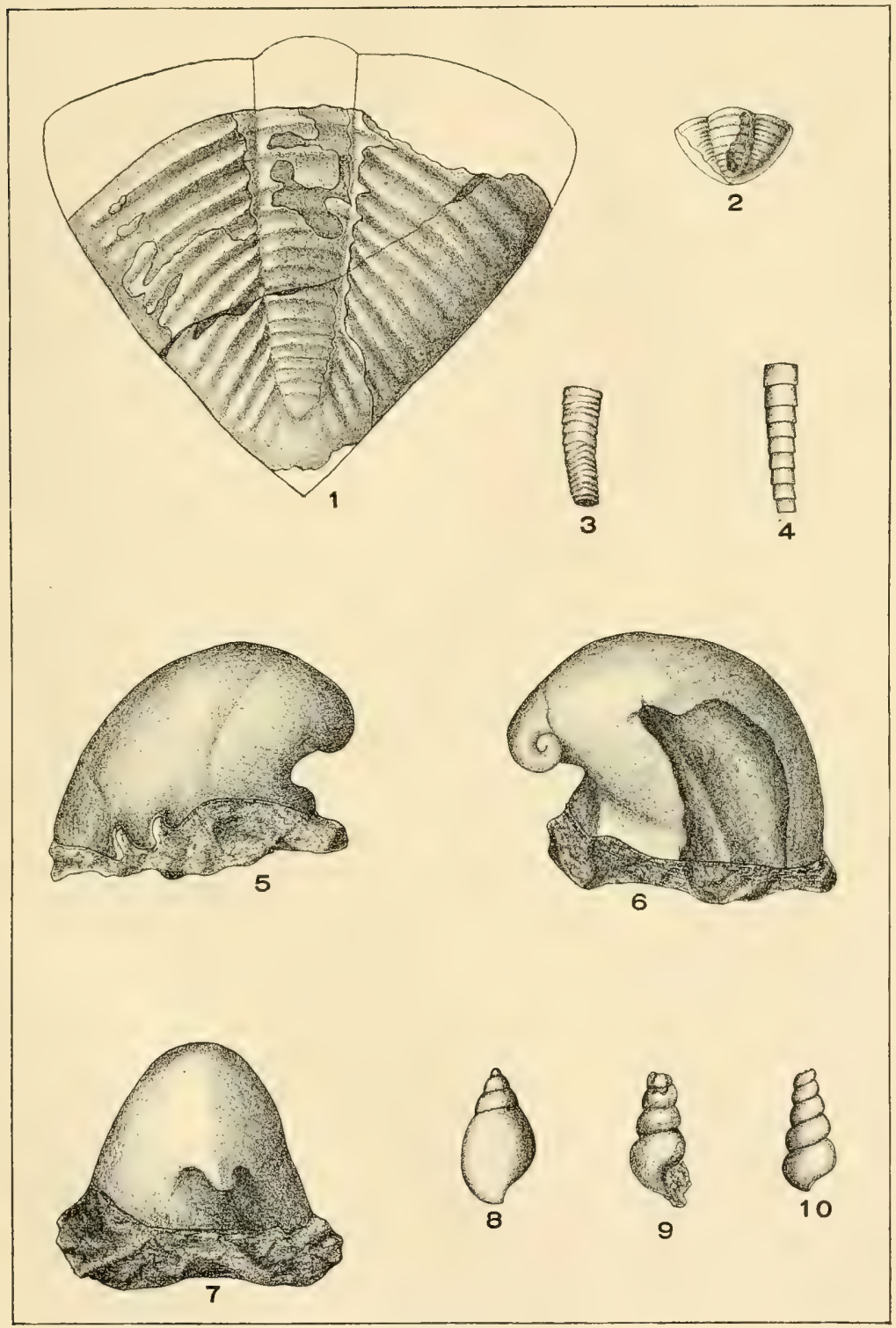

COEYMANS. 




\section{PLATE XXXIII.}

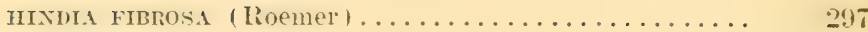

Fig. 1. Cross-section of a globular specimen (after Hinde).

2. Minute structure of the same (after Hinde). ( $x 8)$.

STREPTELASMA STRICTLYI Hall.................

Fig. 3. Lateral view of a nearly complete specimen (after Hall).

4. Lateral view of an incomplete specimen. Nearpass section, Locality $2 A .^{31}$

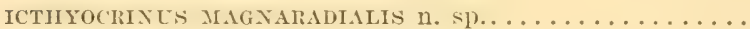

Fig. 5. Lateral view of the type specimen. Nearpass section, Locality $2 \mathrm{~A}^{29}$

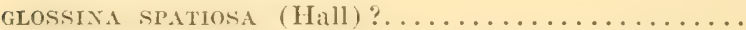

Fig. (i. A very incomplete specimen. Hainesville, Locality $25 \mathrm{C}$.

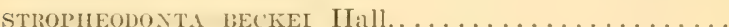

Fig. $\quad$ 7. An incomplete specimen. Locality $8 \mathrm{~A}$.

S. A larger, incomplete pedicle valve. Nearpass section, Locality $24.3^{31}$

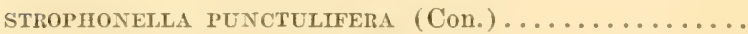

Fig. 9. A nearly complete brachial valve. Nearpass scction, Locality $2 A .^{31}$

LEPTAENA RHOMHOIDALIS (Wilck.). .............

Fig. 10. A complete pedicle valve. Nearpass section, Locality $2{\mathrm{~A} .{ }^{31}}^{3}$ 


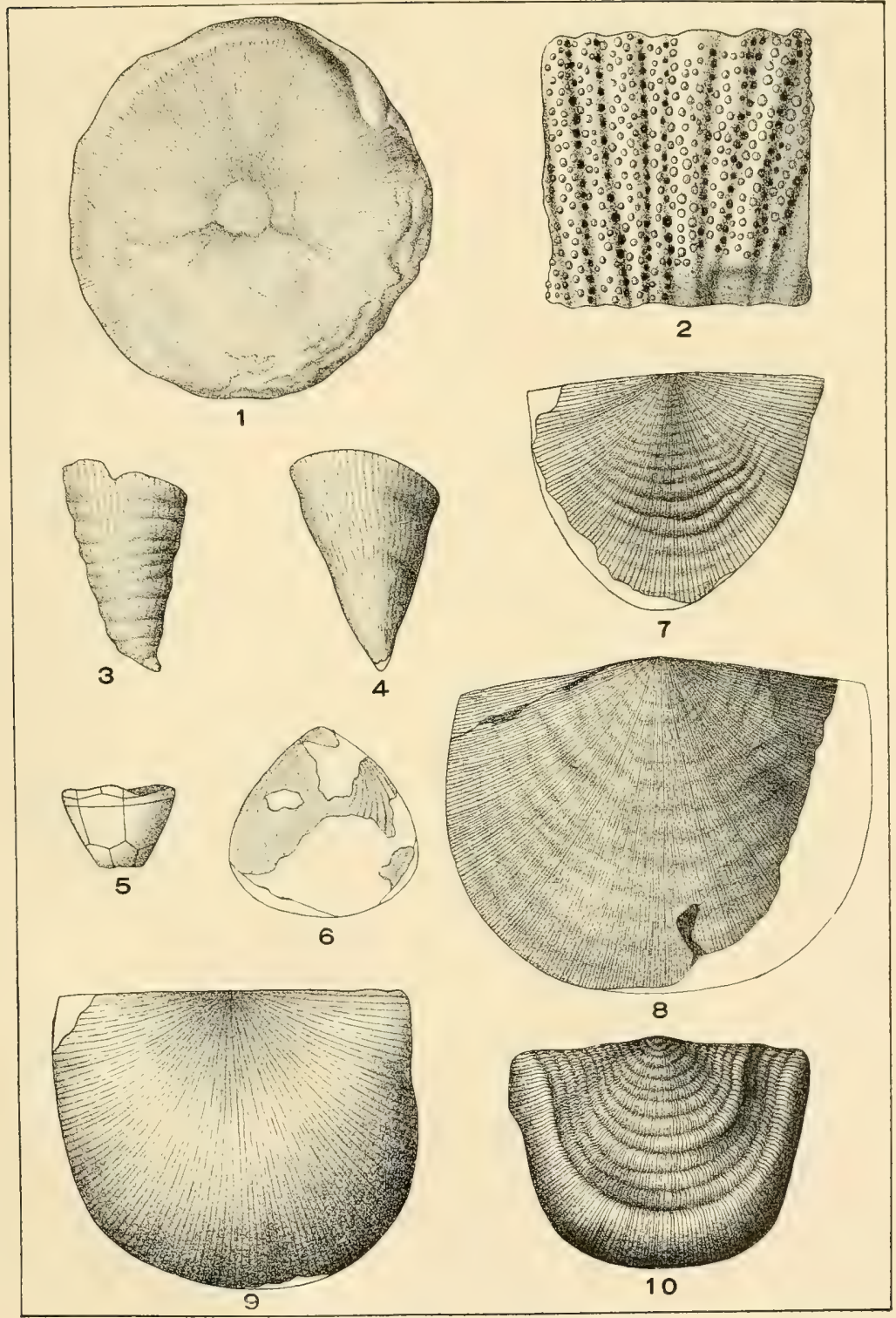

NEW SCOTLAND-BECRAF'T. 




\section{PLATE XXXIV}

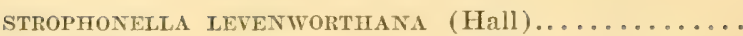

PAGE.

302

Figs. 1,2. Brachial and lateral views of a full-grown individual (after Hall).

3. View of an incomplete pedicle valve. Hainesville, Locality $25 \mathrm{C}$.

ORTHOTHETES WOOLWORTHANUS (Hall).............

303

Fig. 4. An incomplete pedicle valve. Hainesville, Locality $25 \mathrm{C}$.

5. A nearly complete brachial valve. Same locality.

ORTHOSTROPHIA STROPHOMENOIDES (Hall) ............

303

Figs. 6-8. Pedicle, brachial and lateral views of a complete individual. Flatbrookville, Locality $109 \mathrm{~A}$.

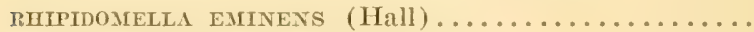

Fig. 9. A nearly complete pedicle valve. Nearpass section, Locality $24 . .^{2}$

DALMAYELLA SEBCARIXATA (IIall) ............

306

Figs. 10,11. A brachial and a pedicle ralve. Hainesville, Locality $25 \mathrm{C}$.

12, 13. Brachial and anterior views of a complete individual (after Hall). 
Geol. Survey of N. J.-1902. Paleontology.

Plate XXXIV.

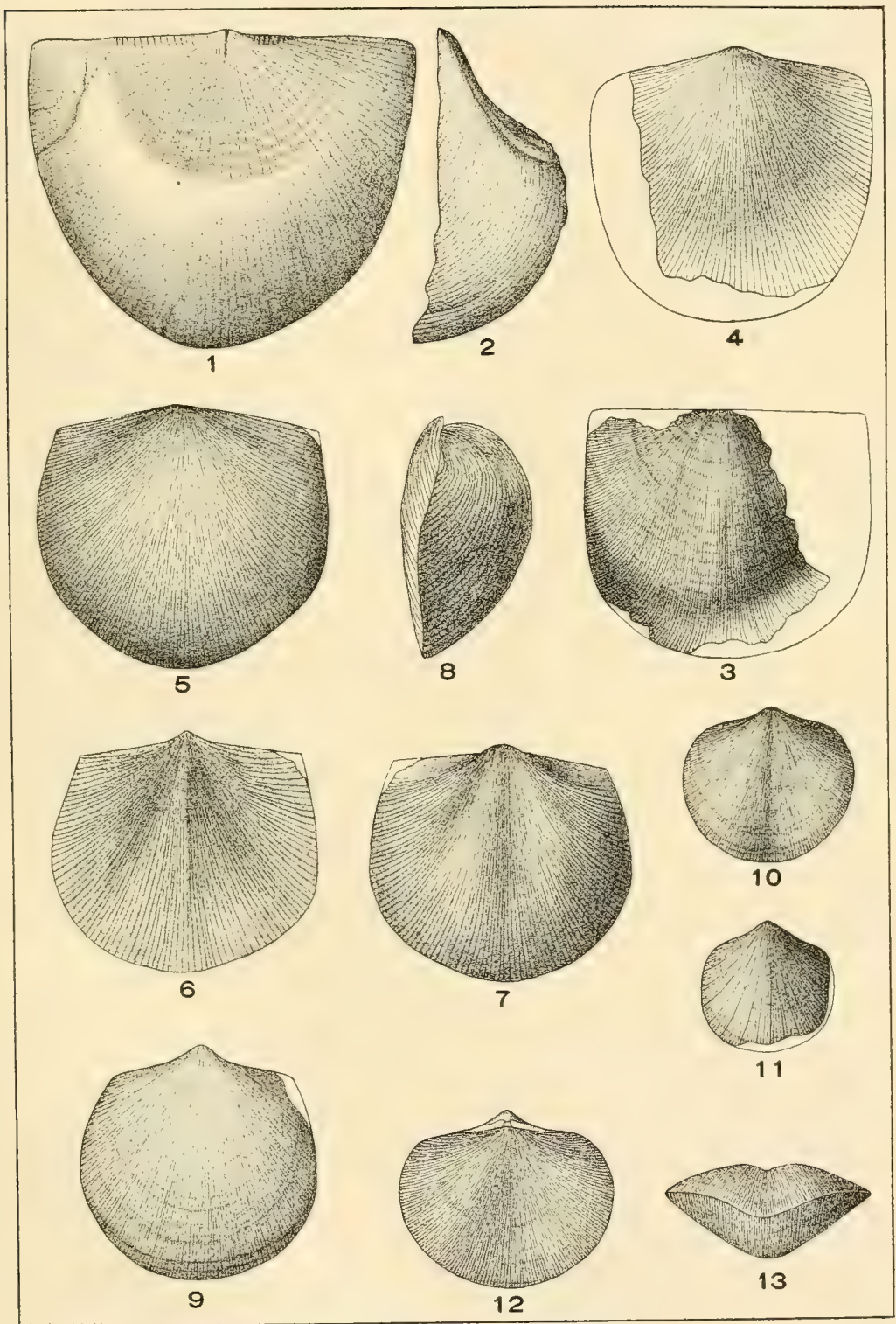

NEW SCOTLAND-BECRAFT. 




\section{PLATE XXYY.}

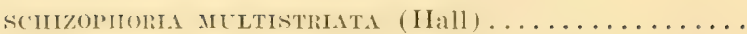

Figs. 1-3. Lateral, anterior and brachial views of a nearly complete individual (after Hall).

4. An incomplete brachial valve. Nearpass scction, Locality $24 .^{31}$

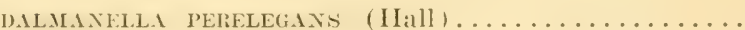

Figs. 5,6. A pedicle and a brachial valve. Nearpass scetion, Locality $24 .{ }^{29}$

7, S. Brachial and anterior views of a complete individual (after Hall).

RHPUOMELLA OHLATA (IIall) ...................

Figs. 9-12. Brachial, pedicle, lateral and anterior views of a complete individual. Hainesville, Locatity $25 C^{\prime}$.

13. Interior view of a pedicle valve (after Hall).

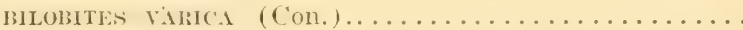

Figs. 14-17. Brachial, pedicle, lateral and anterior views of a complete specimen. From the Helderberg Mountains, New York. Pal. Coll. Walkel Museum, University of Chicago, No. So6. $\left(x_{2}\right)$.

18. An incomplete pedicle valve. Nearpass scetion, Locality $\therefore 1.2(x \div)$. 
Geol. Surtey of N. J.-1902. Paleontology.

PLATE SXXV.
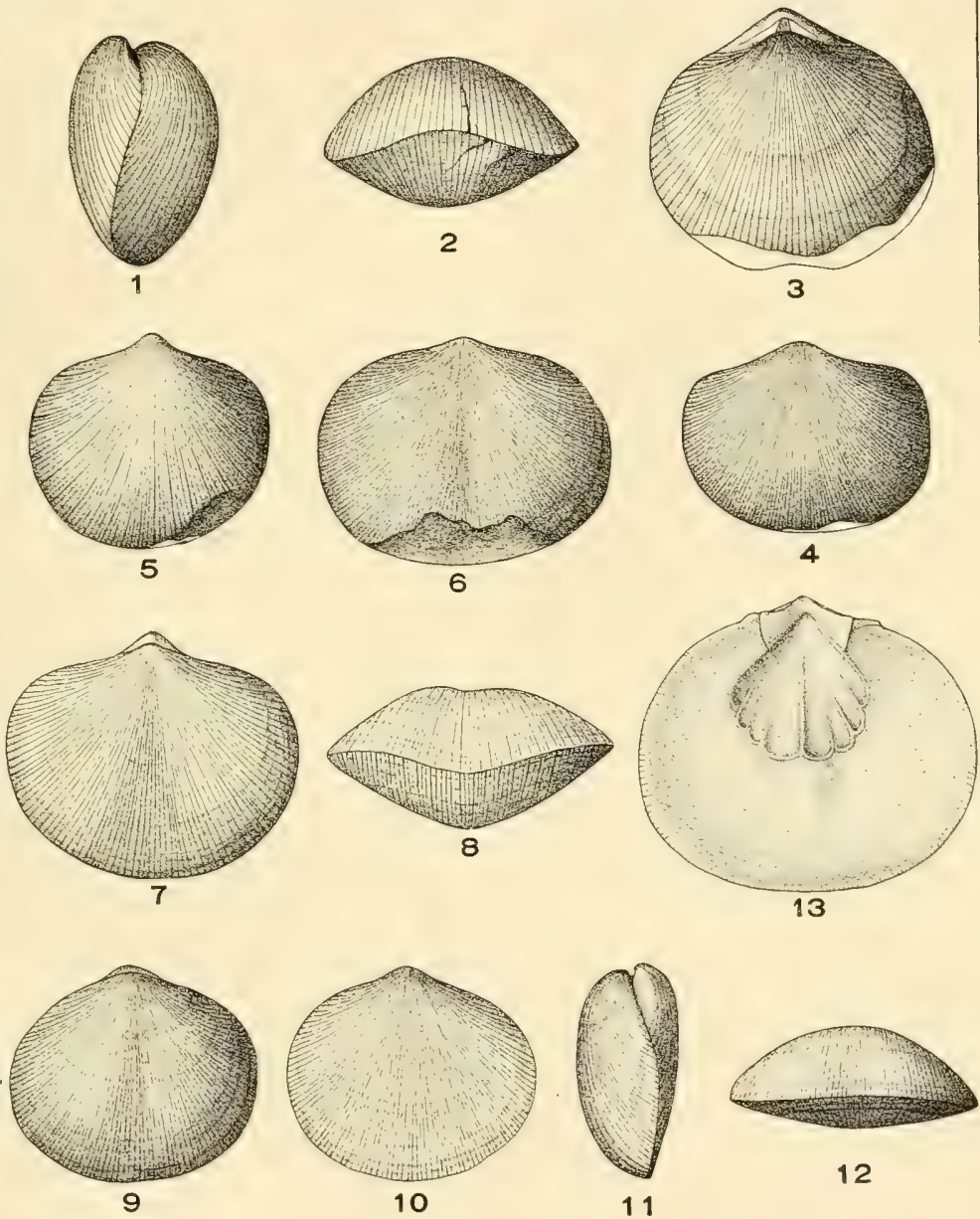

12

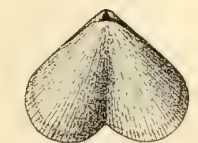

14
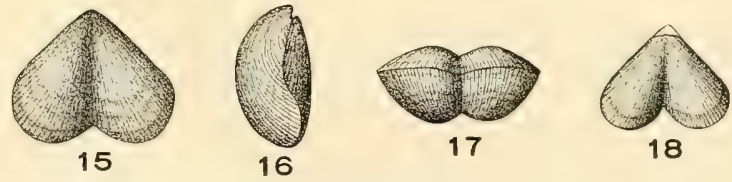

17

NEW SCOTLAND-BECRAF'T. 




\section{PLATE XXXVI.}

PAGE.

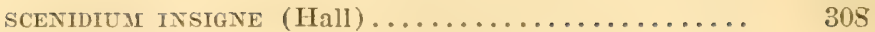

Irig. 1. The brachial valve. Natural size (after Hall).

2-4. Anterior, posterior and brachial views of a complete individual, enlarged (after Hall).

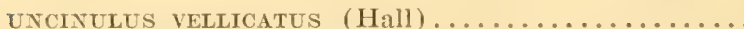

$30 \mathrm{~S}$

Fig. 5. An incomplete pedicle valve. Nearpass scction, Locality $2 \mathrm{~A}^{31}$

6. An incomplete pedicle valre. Nearpass section, Locality $2 \mathrm{~A}^{30}$

7. A more coarsely-ribbed pedicle valve. Hainesville, Locality $25 \mathrm{C}$.

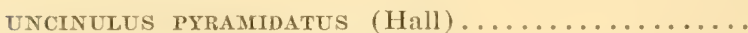

Figs. 8-11. Brachial, pedicle, lateral and anterior views of a nearly complete individual. Nearpass section, Locality $2 \mathrm{~A} . .^{29}$

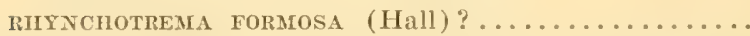

Figs. 12-15. Brachial, pedicle, lateral and anterior views of a complete specimen. Nearpass section, Locality $2 A^{31}$

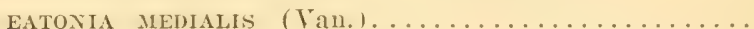

Figs. 16-19. Brachial, pedicle, lateral and anterior views of a complete individual. Hainesville, Locality $25 \mathrm{D}$.

20-23. Brachial, pedicle, lateral and anterior views of a complete individual. Hainesville Locality $25 \mathrm{C}$.

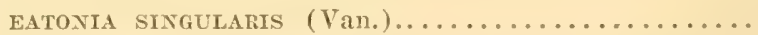

Figs, 24-27. Brachial, pedicle, lateral and anterior views of a complete individual. Hainesville, Locality $25 \mathrm{C}$.

(434) 
Ġeot. Survey of N. I.-1902. Paleontology.

Plate XXXVI.

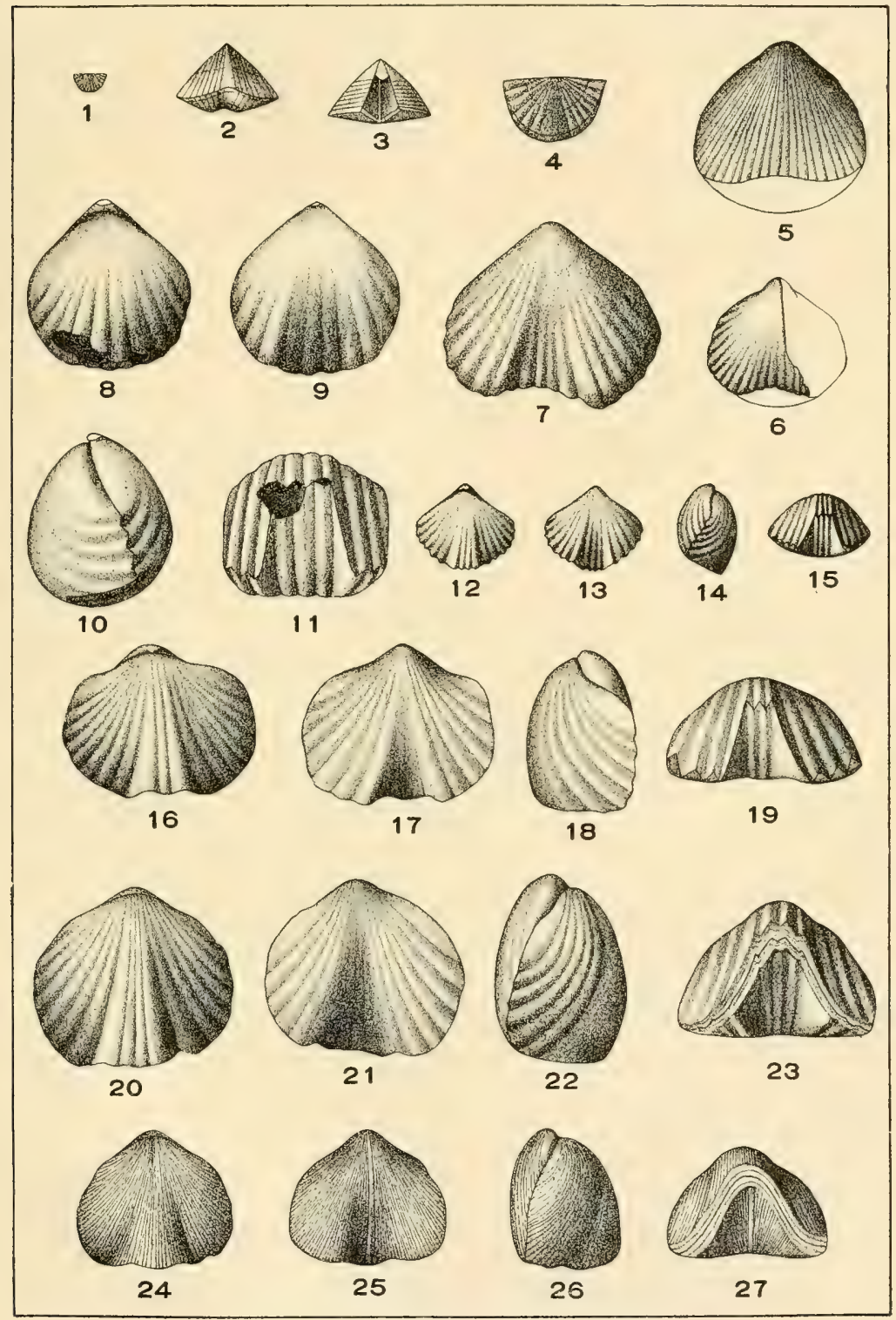

NEW SCOTIAND-BECRAF'T. 




\section{PLATE XXXYII.}

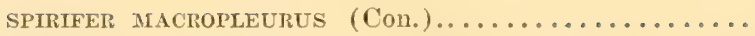

PAGE.

313

Figs. 1,2, Pedicle and anterior views of a complete individual (after Hall).

3. The internal cast of a pedicle valve. Locality $8 \mathrm{~A}$.

SPIRIFER PERLAMELLost's Hall...............

Fig. 4. An incomplete brachial valve. Nearpass section, Locality $2 \mathrm{~A}^{29}$

5, 6. Pedicle and anterior views of a complete individual (after Hall).

CENTRONELLA? SUBRHOMBOIDEA n. sp.............

Figs. 7-10. Brachial, pedicle, lateral and anterior views of a complete individual. Nearpass section, Locality $2 A .^{20}$

ANOPLOTHECA CONCAVA (Hall) ..............

Figs. 11-14. Pedicle, brachial, lateral and anterior views ofa complete individual. From Schoharie, New York. Pal. Coll Walker Museum, University of Chicago, No. 8,522. ( $\mathrm{x} 2$ ).

15. A pedicle valve. Hainesville, Locality $25 \mathrm{D} .\left(\mathrm{x}_{2}\right)$.

Nicleospirit ventricosa Hall...............

Fig. 16. An incomplete pedicle valve. Locality $8 \mathrm{~A}$.

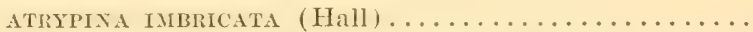

Figs. 17-20. Brachial, pedicle, anterior and lateral views of a complete individual. From the Helderberg Hountains, New York. Pal. Coll. Walker Museum, University of Chicago, No. 902. (x 2 ).

21. An elongate pedicle valre. Hainesville, Locality $25 \mathrm{D}$. ( $x 2)$.

22. A large brachial valve. From Schoharie, New York. Pal. Coll. Walker Museum, University of Chicago, No. 8,520 . ( $(x 2)$. 
Geol. Survey of N. J.-1902. Paleontology.

Plate XXXVII.

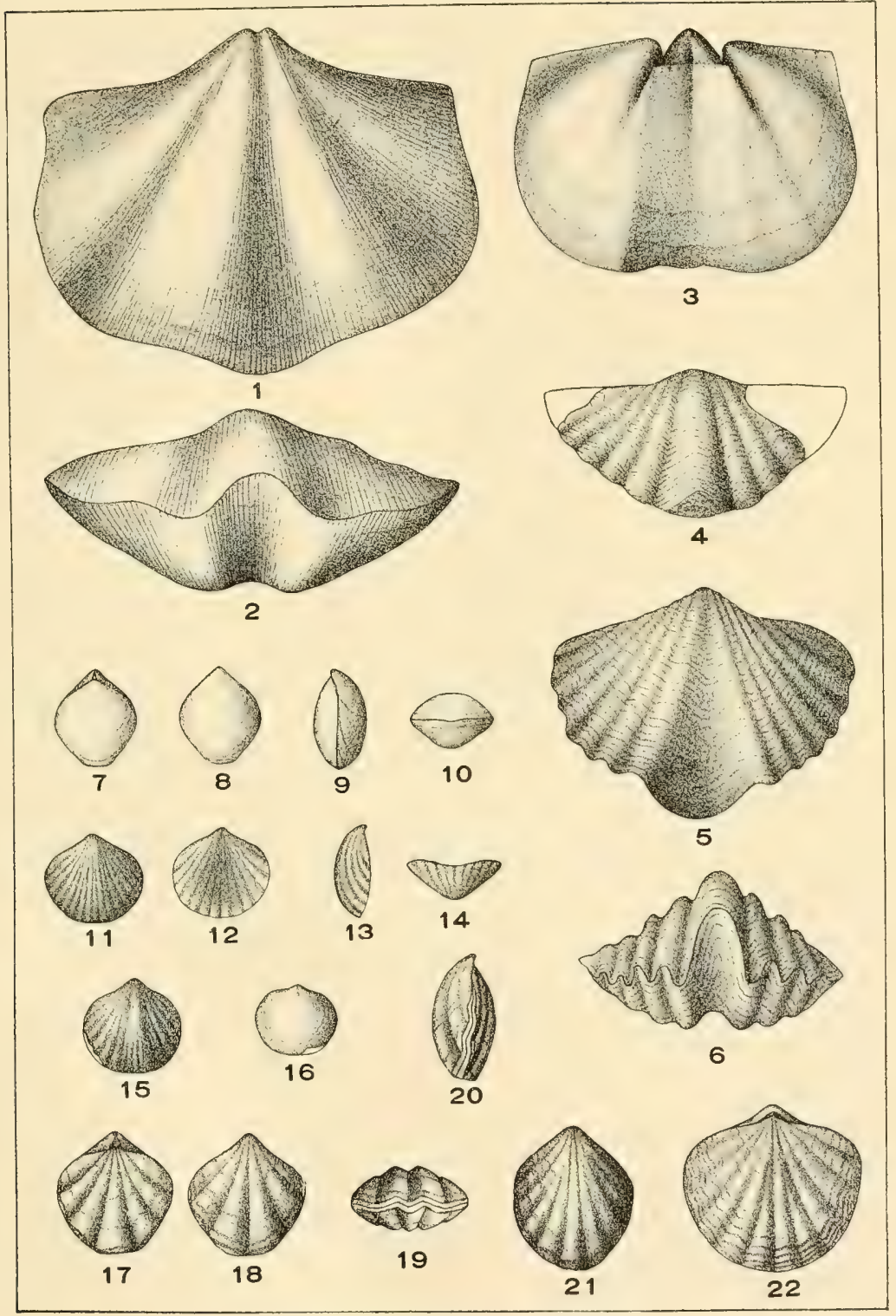

NEIV SCOTLAND-BECRAF'T. 




\section{PIATE XXXVIII.}

SPIRTFER (YCLOTERT's Hall..............

Figs. 1-4. Brachial, perlicle, anterior and lateral views of a complete individual. From Schoharie, New York. Pal. Coll. Walker Museum, University of Chicago, No. 8,455.

5. An incomplete pedicle valve. Hainesville, Locality $25 \mathrm{D}$.

6. A nearly complete pedicle valve. Nearpass scction, Locality $2 A .^{30}$

SPIRIFER PERLAMELLost's Hall. .................

Fig. $\quad 7$. An incomplete perlicle valve. Locality $S A$.

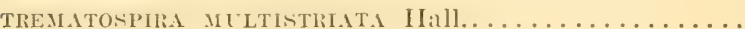

Fig. $\quad 8$ A distorted pedicle valve. Locality $8 \mathrm{~A}$.

9,10 . Anterior and brachial views of a complete individual (after Hall).

MERISTELLA LAETIS (Viu.) ...................

Figs. 11-14. Lateral, brachial, pedicle and anterior views of a large individual. Nearpass scction, Locality $2 \mathrm{~d}^{3 \mathrm{3}}$

15-18. Lateral, anterior, pedicle and brachial views of a smaller individual. Haincsville, Locality $25 \mathrm{C}$.

(436) 


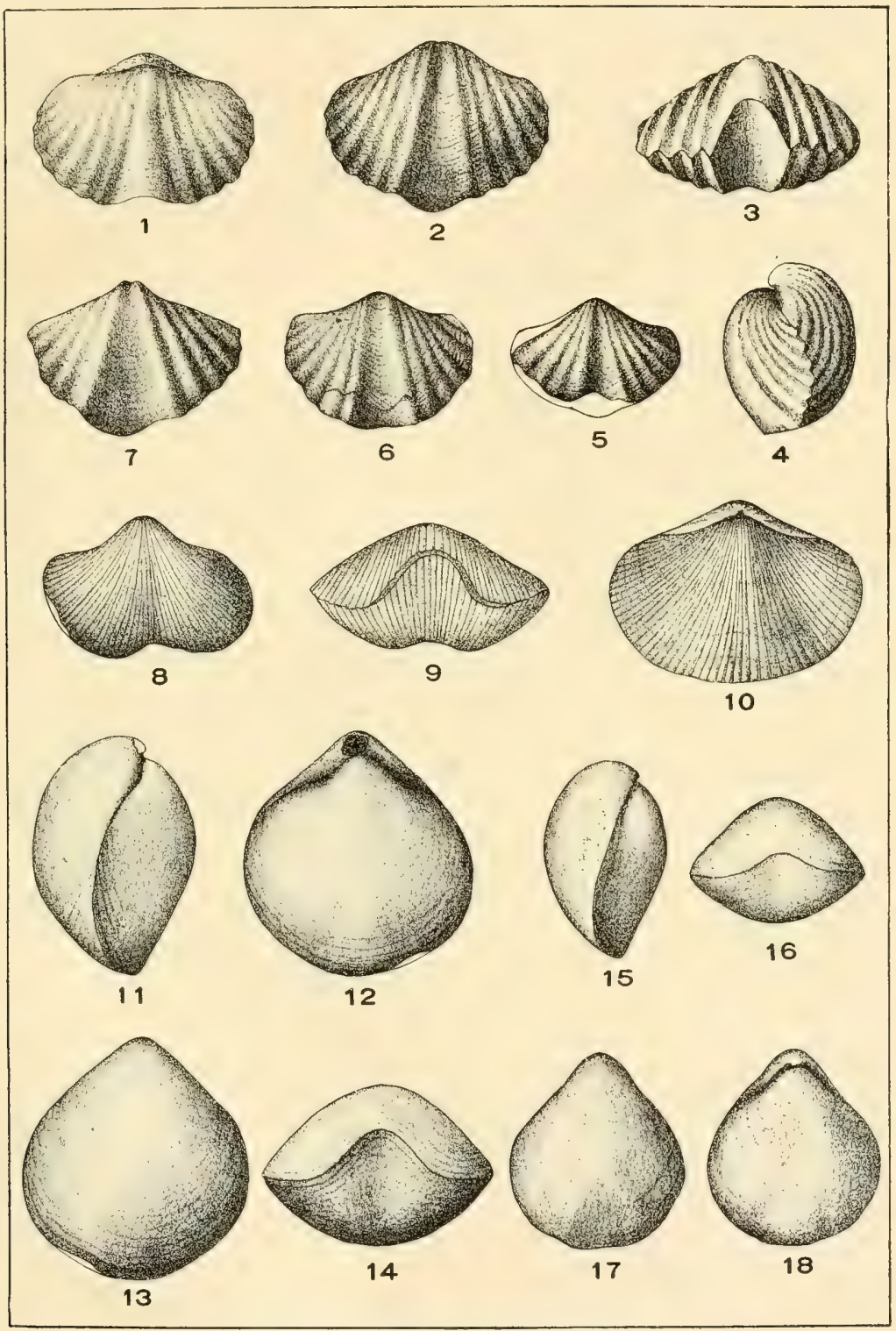

NEW SCOTLAND-BECRAFT. 




\section{PIATE XXXIX.}

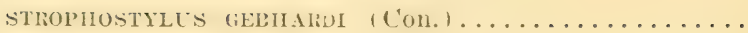

Figs. 1-3. Three riews of a nearly complete individual. Hainesville, Locality $25 \mathrm{C}$.

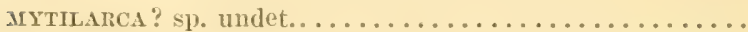

Fig. $\quad$ 4. A right valve. Haincsville, Locality $25 \mathrm{C}$.

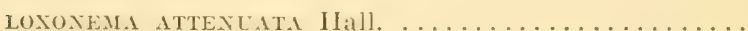

Fig. 5. Lateral view of a nearly complete individual (after Hall).

6. An incomplete shell. Haincsville, Lacality $25 \mathrm{C}$.

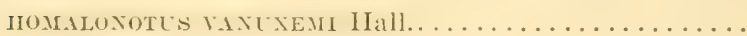

Figs. 7, S. Dorsal and lateral views of a nearly complete pjgidium. Nearpass section, Locality $2 \Lambda^{31}$

1).LLMNITES I'LET ROPTYX (GICen) ............

Fig. 9. An incomplete pygidium. Nearpass section, Locality $2 \mathrm{~A}^{23}$ 10. A complete head (after Hall). 
Geol. SURVEY of Y. J.-1902. PALEONTOLOGY.

Plate XXXIX.

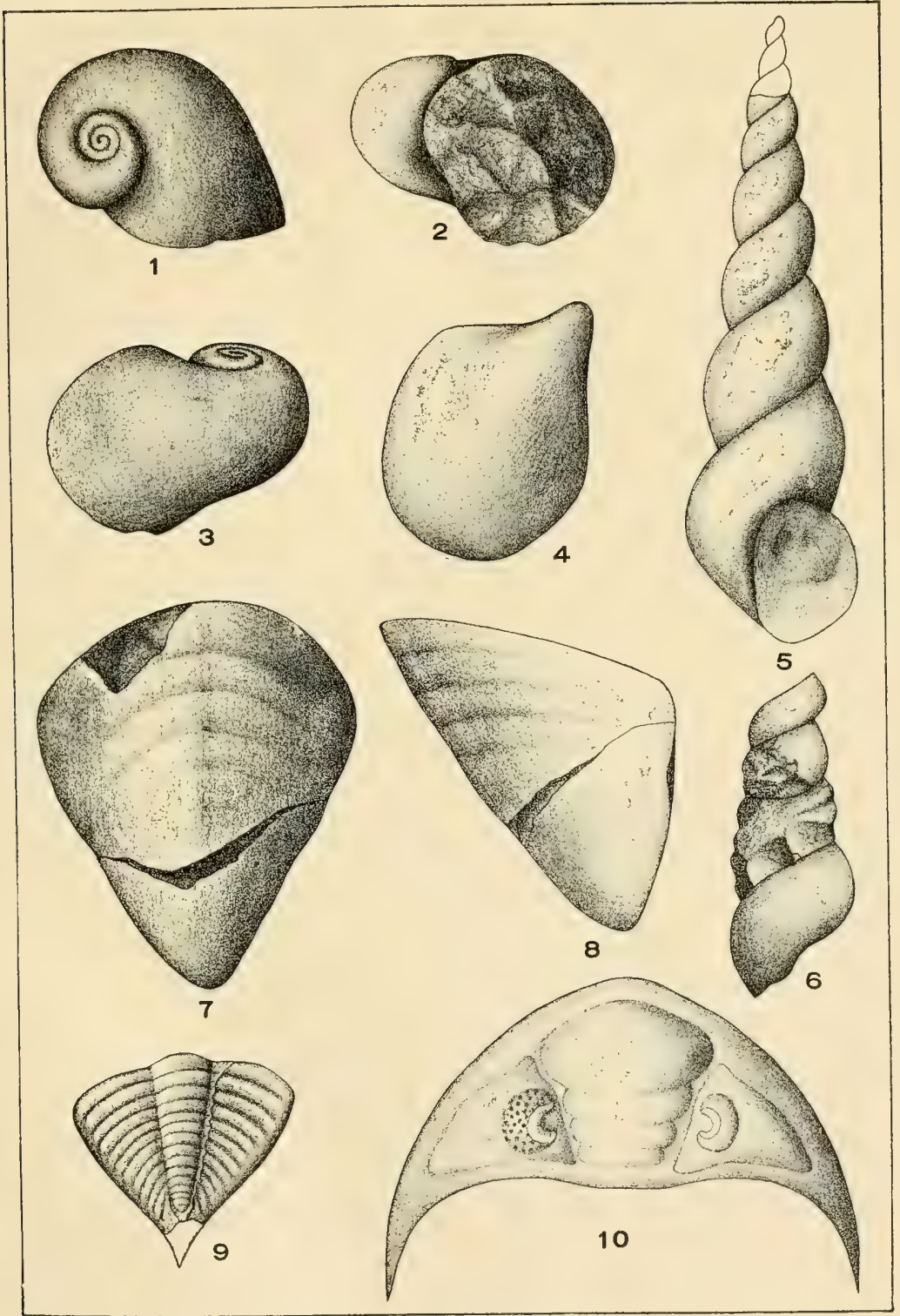

NEIV SCOTLAND-BECRAFT. 




\section{PLATE XL}

I'AGE.

IICHAS PITSTLIOSLS Hall............................. 320

Fig. 1. Impression of the doublure of the posterior portion of a fragmentary pygidium. Nearpass section, Locality $2 A .^{31}$

2. A nearly complete pygidium (after Hall).

PIIACOPS LOGANI IIall...................

Fig. 3. A complete head. Ncarpass section, Locality $2 \mathrm{~A}^{31}$

4. A nearly complete pygidium. Hainesville, Locality 25.C. (438) 
Geol. Survey of N. J.-1902. Paleontology.

Plate XI.

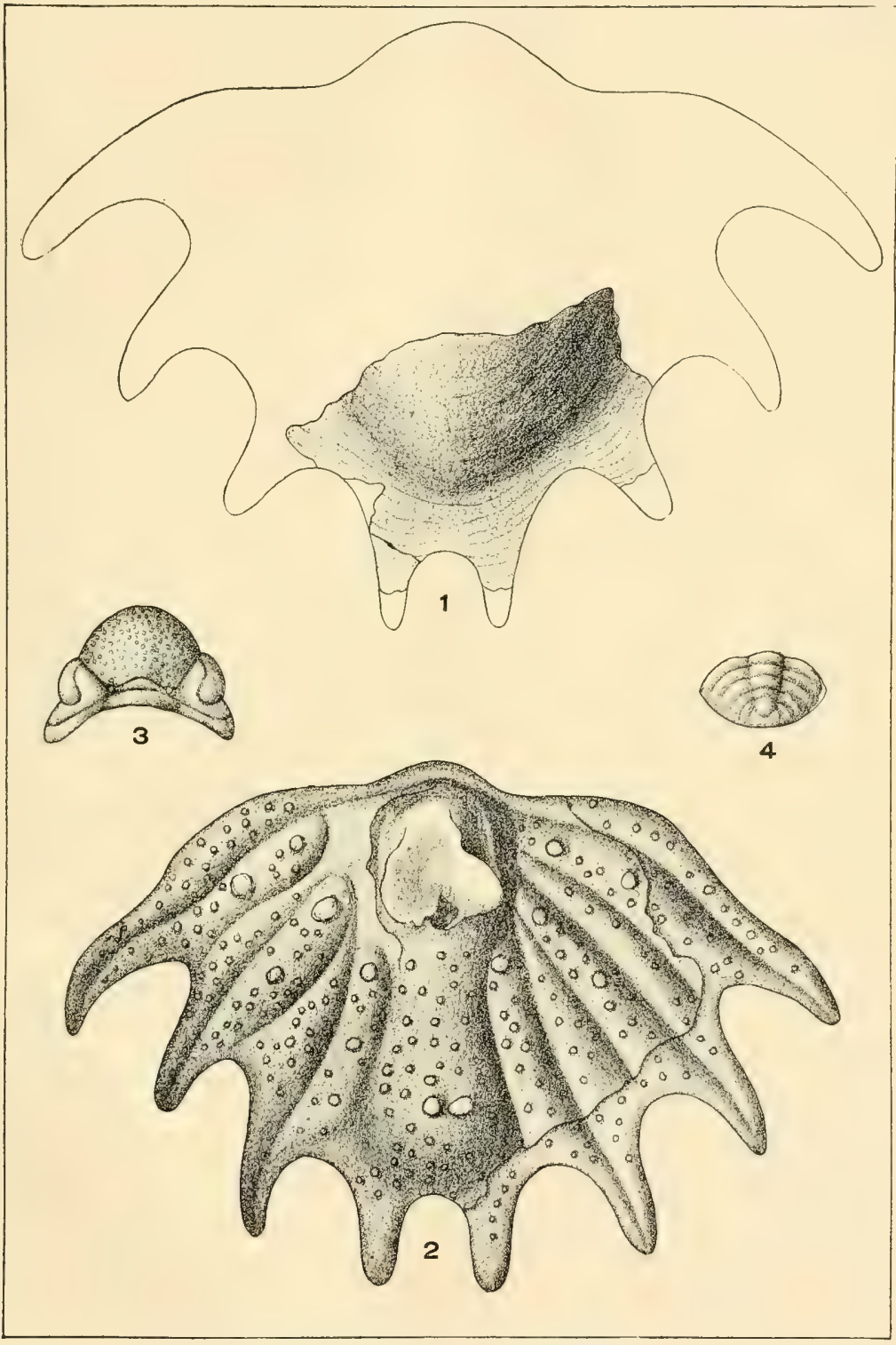

NEW SCOTLAND-BECRAFT. 




\section{PLATE XLI.}

VERMIPORA SERPLLOIDES Hall...............

Fig. 1. A large colony (after Hall).

ORBICLLOIDEA AMPLA $\left(\mathrm{H}_{\mathrm{a}} \mathrm{ll}\right) \ldots \ldots \ldots \ldots \ldots \ldots \ldots \ldots \ldots$

Figs. 2, 3. Two views of a large brachial valve. Nearpass section, Locality $2 A_{0}^{33}$

SCHIZOCRANIA sUPERINCRETA Barrett............

Fig. 4. A large brachial valve, partially restored. Peters Valley, Locality $53 \mathrm{~A}$.

Stropheodonta MAgNifica (Hall) ..............

Fig. 5. A nearly complete brachial valve. Nearpass section, Locality 24.3

6. An exfoliated pedicle valve. Same locality.

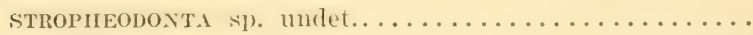

Fig. 7. External impression of a brachial valve. Nearpass section, Locality $2 \mathrm{~A}^{33}$

S. An incomplete pedicle valve. Same locality.

A NOPLIA NUCLEATA Hall...................

Fig. 9. The internal cast of a pedicle valve. Peters Valley, Locality 53 A. ( 2 2).

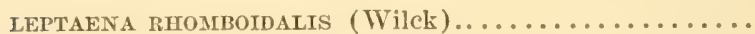

Fig. 10. Internal cast of an incomplete pedicle valve. Nearpass section, Locality $2 \mathrm{~A}^{33}$ 
Geol. Survey of N. J-1902. Paleontology.

PLate XLI.

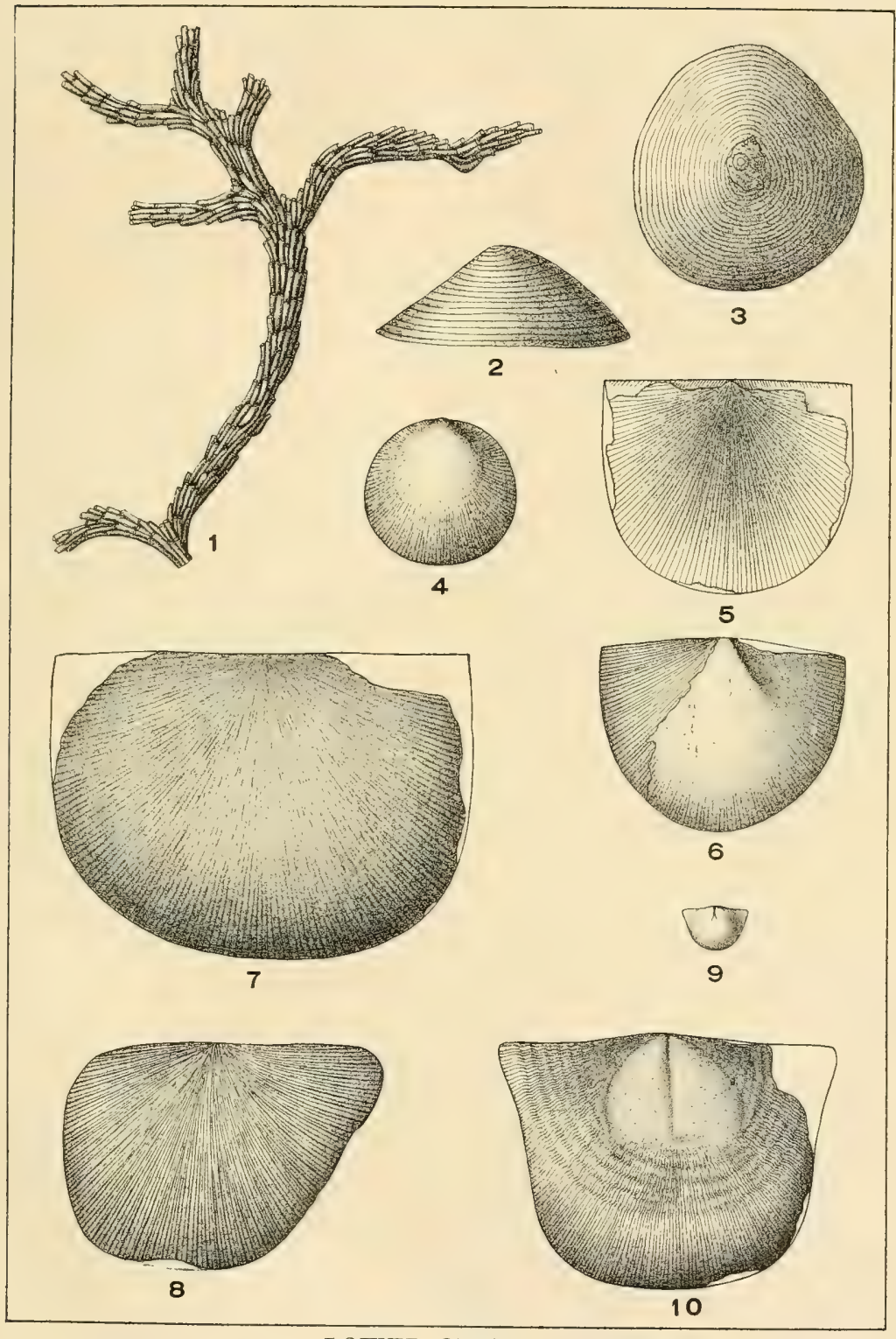

LOWER ORISKANY. 




\section{PLATE XLII.}

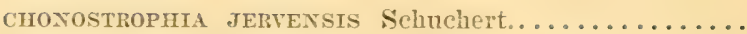

PAGE.

Fig. 1. A complete pedicle ralre. Nearpass scotion, Locality $2.1 .^{33}$

2. A complete brachial valve. Same locality.

DALMIANELLA SUBCARINATA (Hall) ..............

Fig. 3. A distorted pedicle ralre. Tearpass scction, Locality $2.4 .^{33}$

4. Posterior view of an incomplete individual. Same locality.

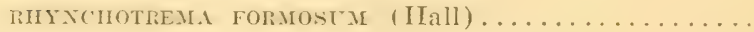

Figs. 5-8. Brachial, pedicle, lateral and anterior views of a complete individual. Nearpass section, locality $24 .^{33}$

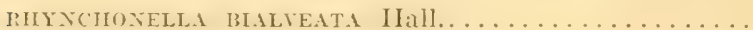

Fig. 9. An incomplete brachial valve. Nearpass scction, Locality $2 \mathrm{~A}^{33}$

10. A pedicle ralve. Same locality.

REXSTELAERIA STEGLOBOSA n. \$J............

Figs. 11-14. Pedicle, brachial, lateral and anterior views of a complete indiridual. Nearpass section, Locality 24.33

15-18. Pedicle, brachial, lateral and anterior views of another complete individual. Same locality.

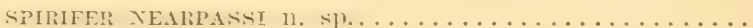

Figs. 19-22. Brachial, anterior, pedicle and lateral views of a complete individual. Nearpass scetion, Locality $24 .^{33}(\mathrm{x} 4)$.

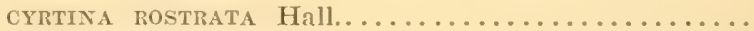

Figs. 23, 24. Anterior and lateral viems of an incomplete pedicle valve. Nearpass section, Locality $2 \mathrm{~A}^{33}$

25. An incomplete brachial valve. Same locality.

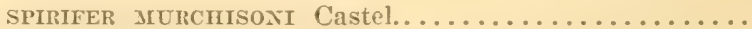

Fig. 26. A nearly complete brachial valve. Nearpass section, Locality $2 \mathrm{~A}^{33}$

MERISTELLA PRINCEPS Hall. .................

Figs. 27, 28. Two views of a brachial valre. Nearpass section, Locality $2 A^{33}$ 
Geol. Survey of N. J.-1902. Paleontology.

Plate XLII.

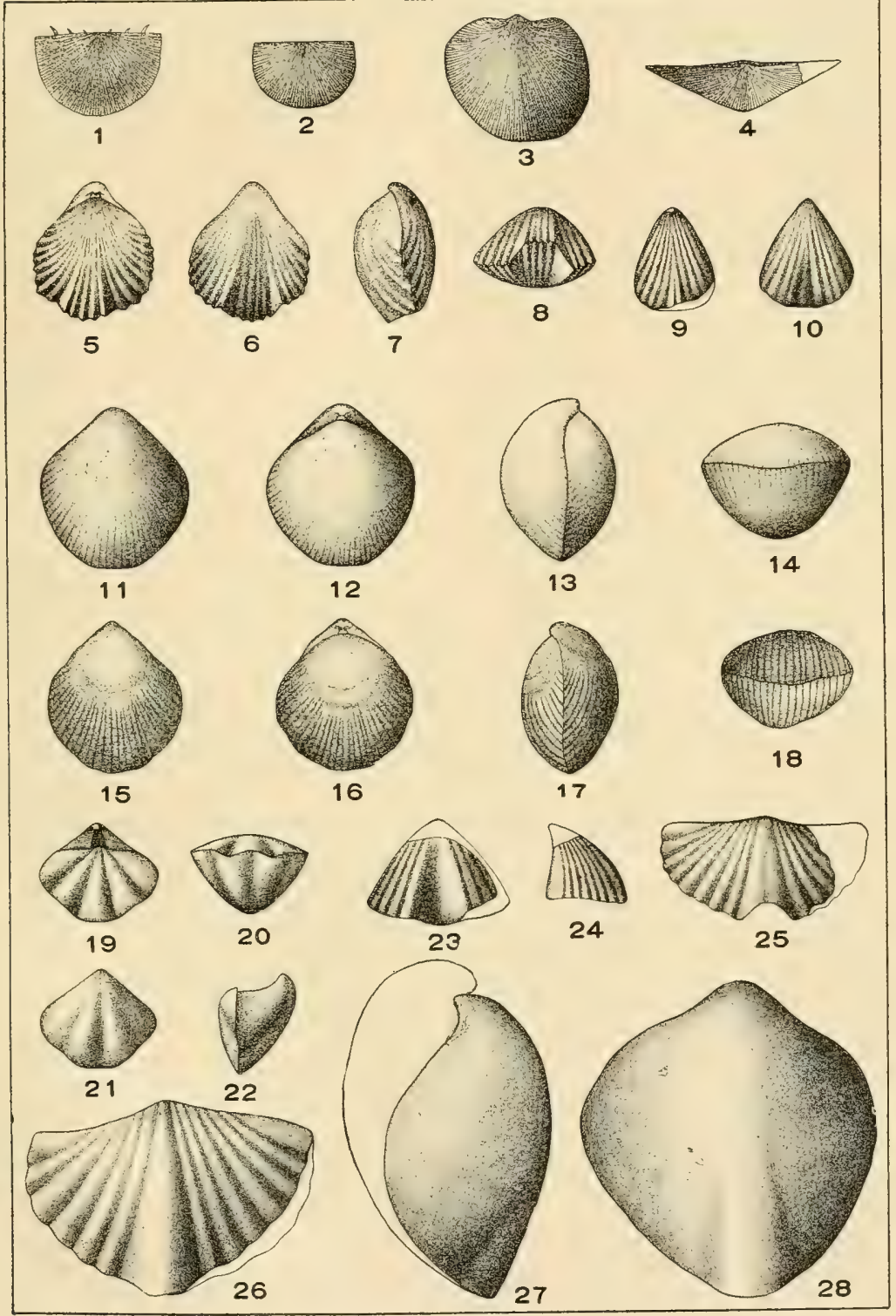

LOWER ORISKANY. 




\section{I'IATE XLIII.}

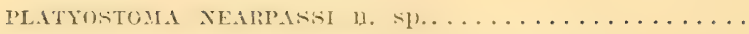

PAGE.

334

Figs. 1,2. 'Two views of a nearly perfect individual. Nearpass section, Locality 24 . $^{33}(\mathrm{x} 2)$.

3, 4. Two views of little larger nearly complete individual. Same locality (nat. size).

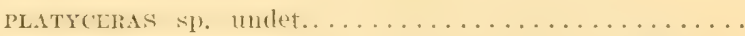

Firss. $\quad$ i, (5. Tro views of a nearly perfect individual. Nearpass scction, Locality $24^{33}\left(\mathrm{x}_{2}\right)$.

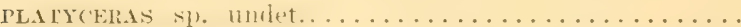

Fig. 7. A nearly complete individual. Nearpass section, Locality 2 A. $^{33}$

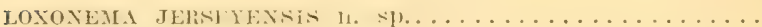

Iigs: S,9. Two lateral views of a nearly complete individual. Nearpass scction, Locality $21 .^{33}\left(x_{2}\right)$.

10. Another larger individual. same locality.

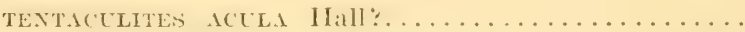

Fig. 11. The internal cast of an incomplete individual. Nearpass section, Locality $24 .^{33} \quad\left(x_{2}\right)$.

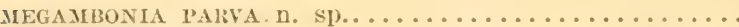

Fig. 12. A nearly complete left valve. Nearpass section, Locality $21.3(x \geq)$.

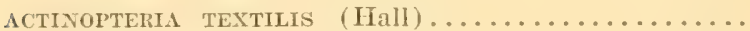

Fig. 13. A nearly complete right valve. Vearpass section, Locality $21 .^{33}$

14. A small, nearly complete, left valve. Same locality.

Irolitues centennialis Barrett..............

Fis. 15. Lateral view of an incomplete indiviclual. Vearpass section, Locality $24 .{ }^{\text {i3 }}$

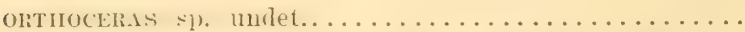

Fig. 16. An incomplete individual. Near Wallpack Center, Locality $\sim 1 \mathrm{C}$.

17. An incomplete individual. Nearpass section, Locality $24^{33}$ 
Geol. Survey of N. J.-1902. I'Aleontology.

Plate Xliil.

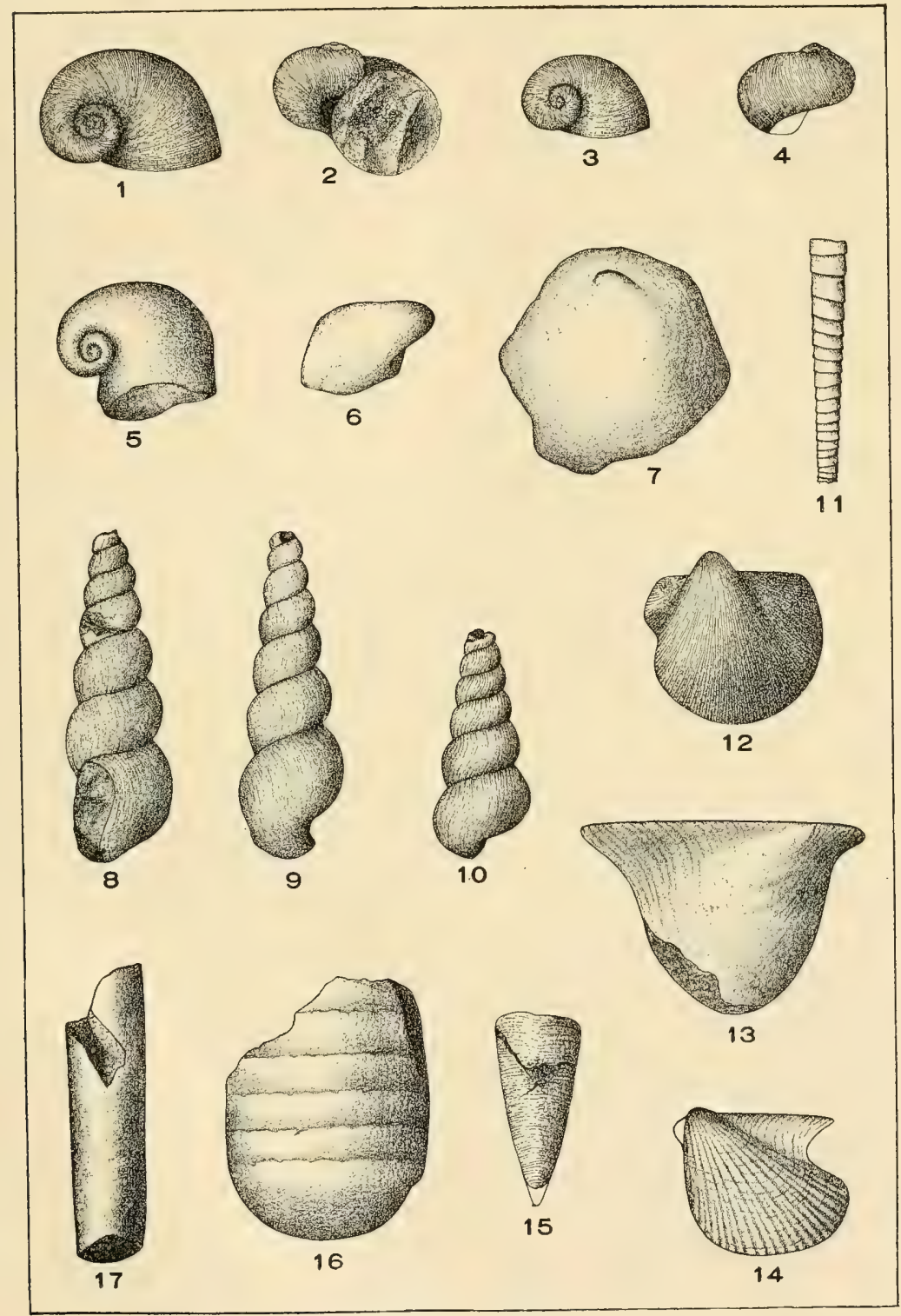

LOWER ORISKANY. 




\section{PLATE XLIV.}

PAGE.

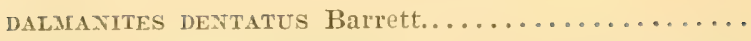

(3i:)

Fig. 1. A nearly complete individual (after Hall and Clarke).

2. A complete head (after Hall and Clarke).

3. A complete pygidium (after Hall and Clarke).

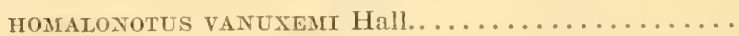

$3: 3$

Figs. 4, 5. Dorsal and lateral views of a very large pygidinm.

6. An incomplete cranidium. Tearpass section, Locality 2.1 .35

7. A free cheek. Same locality.

(442) 
Geol. Survey of N. J-1902. Paleontologr.

Plate Xliv.

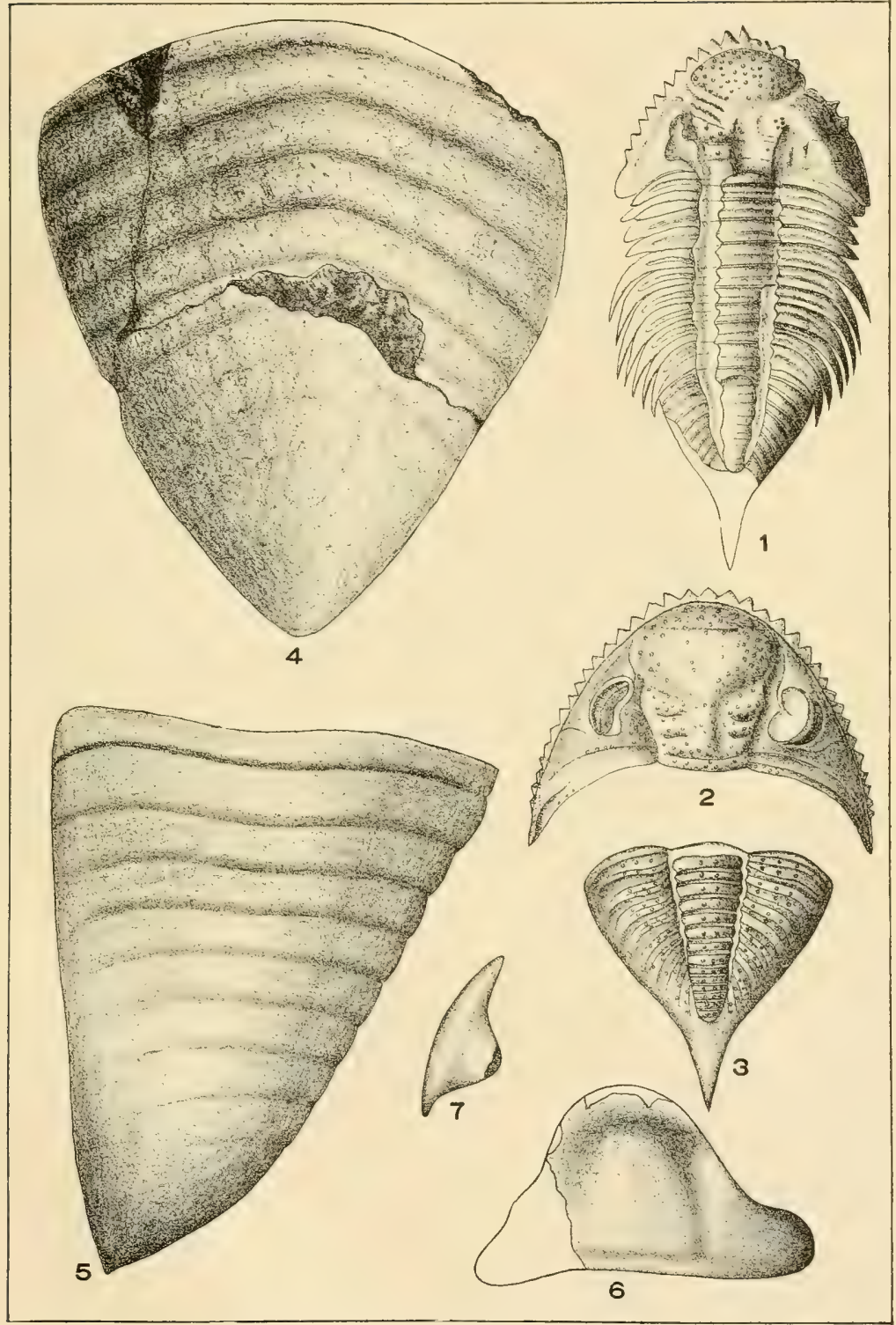

LOWER ORISKANY. 




\section{PLATE XLV.}

PAGE.

TRACHYPOI:A ORISTANIA $n$. Sp..............

Fig. 1. Portion of a corallum. Locality $6 \mathrm{~A}$.

‥ A group of corallites from the same, enlarged.

EDIOCRINUS SACCULUS Hall................

Fig. $\quad \therefore$ A very large dorsal cup. From Cumberland, $\mathbf{A} d$.

4. A complete base. Same locality.

5. An incomplete dorsal cup with portions of two arms preserved. Same locality. Pal. Coll. Walker Museum, University of Chicago, No. 9,519.

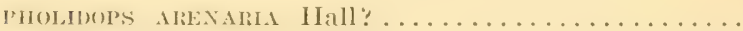

Fig. 6. The internal cast of a nearly complete valve. Near Layton, Locality 37 A. (× 2).

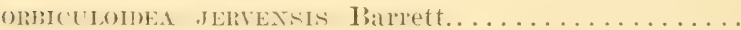

Nig. 7. The interior of a nearly complete pedicle valve. Locality $6 \mathrm{~A}$.

$\therefore$. A brachial valve. Same locality.

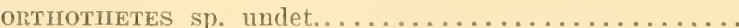

Fig. !. A nearly complete internal cast. Locality 6 A.

STROPHEODONTA MLANIFICA Hall.............

Fig. 10. The internal cast of an incomplete pedicle valve. Peters Valloy, Locality $53 \mathrm{~B}$.

11. A nearly complete pedicle valve. Locality 6 A.

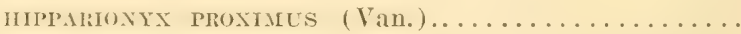

Fig. 12. An incomplete internal cast of a small pedicle valve. Peters Valley, Locality $53 \mathrm{~B}$. 
Geol. Suryey of N. J.-1902. PaIeontology.

Plate SIV.

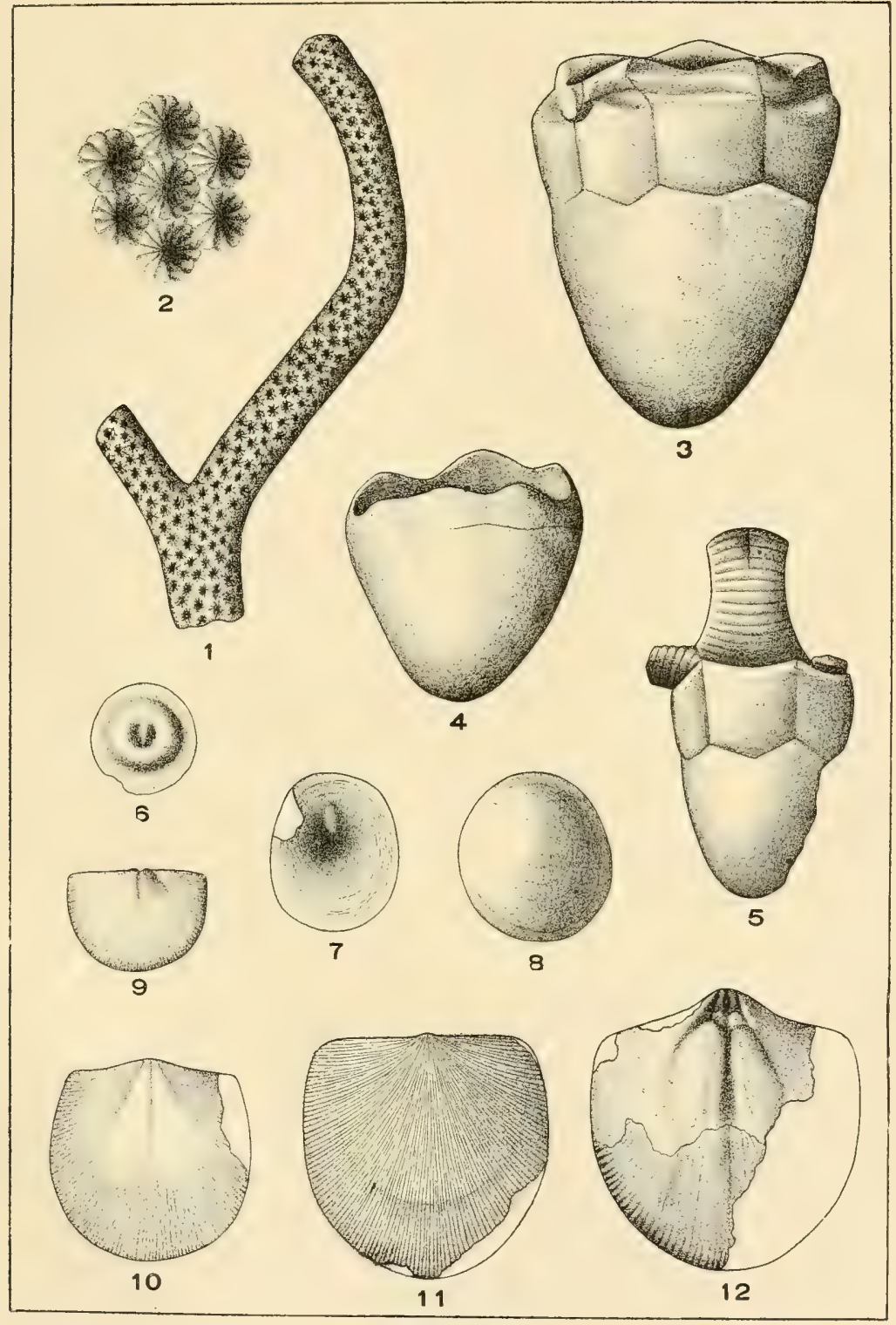

ORISKANY. 


PLATE XLVI.

PAGE.

LEPTAENA RHOMBOIDALIS val. veNTRICOSA (Hall) . . . . .

Fig. 1. A very large, incomplete brachial valve. Peters Valley, Locality $58 \mathrm{~B}$.

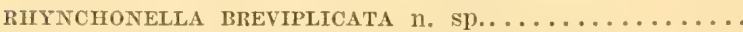

350

Fig. 2. A nearly complete brachial valre. Locality $6 \mathrm{~A}$.

3. A nearly complete pedicle valve. Same locality.

4. Anterior view of the same.

RHIPHDOMELLA OBLATA (Hall) ..............

Fig. 5. A large, incomplete brachial valve. Locality $6 \mathrm{~A}$.

6. An incomplete pedicle valie. Same locality.

7. Internal cast of an incomplete pedicle valve. Same locality.

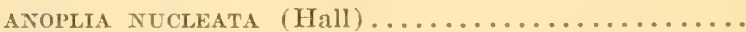

Fig. 8. The internal cast of a pedicle valve. Near Layton, Locality $3 \gamma$ A. $\left(x_{2}\right)$.

9, 10. Two views of a complete pedicle valve. Locality $6 \mathrm{~A}$. $(\mathrm{x}-1)$.

CHONETES IIUdSONiCA Clarke................

Fig. 11. A complete pedicle valve. Locality 6 A.

cironostropina complanata (Hall)...............

Fig. 12. An incomplete, partial, internal cast of a pedicle valve. Near Layton, Locality $37 \mathrm{~A}$. 
Geol. Survey of N. J.-1902. Paleontology.

Plate Xlvi.

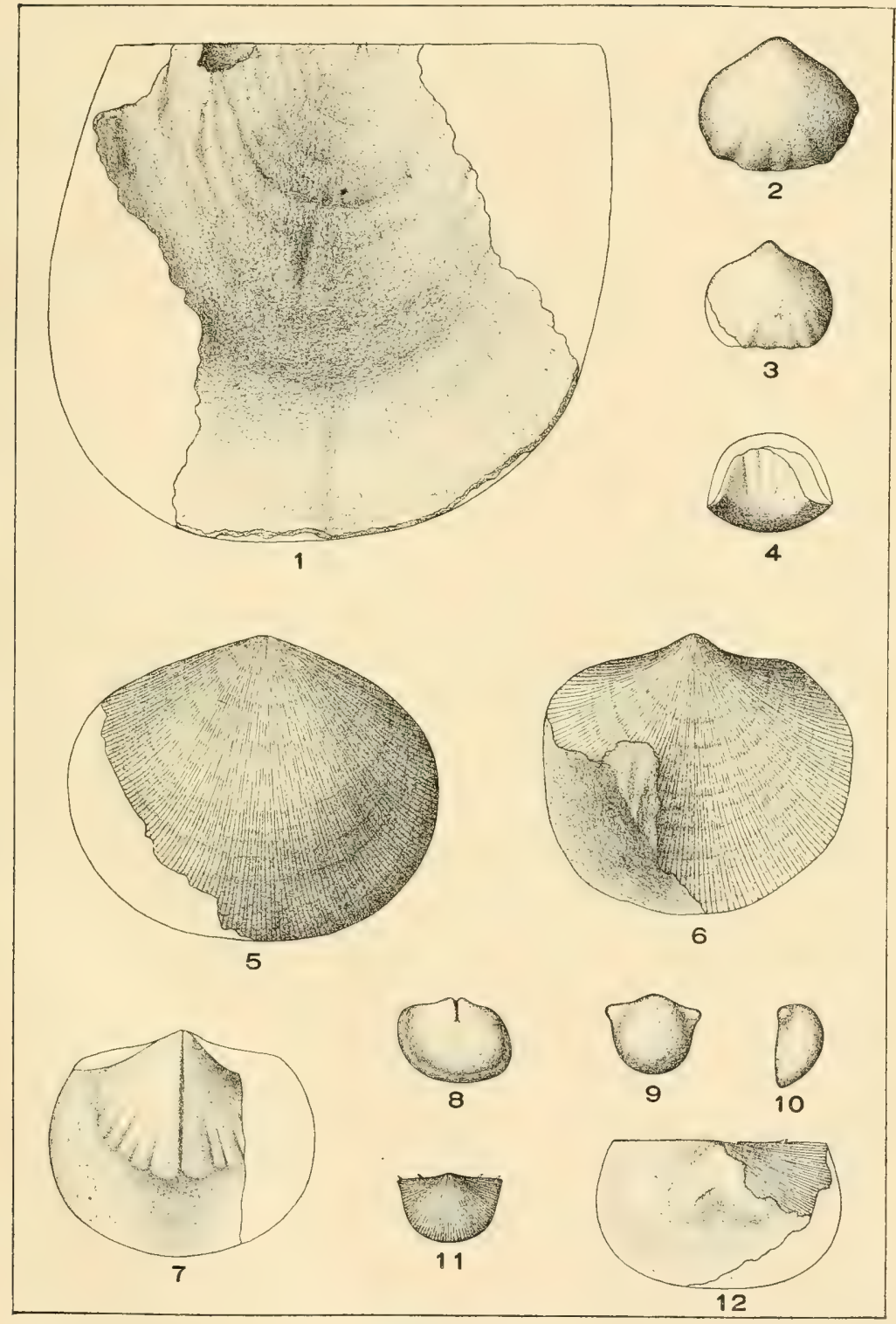

ORISKANY. 




\section{PLATE XLVII.}

PAGE. 3.51

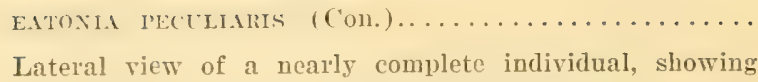

Fig. Lateral riew of a nearly complete individual, showing
denticulate margin of valses. Peters Valley, Locality $53 \mathrm{~B}$. hial, pedicle and anterior views of a nearly complete indiridual. Same locality.

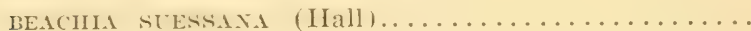

Figs. 5-8. Brachial, pedicle, lateral and anterior views of a nearly complete, small individual. Locality $6 \mathrm{~A}$.

9-12. Pedicle, brachial, lateral and anterior views of a nearly complete individual, with more conspicuous radiate plications. Same locality.

13, 14. Two views of a brachidium. Same locality.

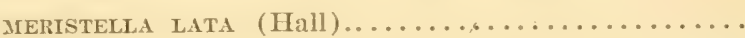

Figs. 15-18. Brachial, pedicle, lateral and anterior views of a small, complete individual. Locality $6 \mathrm{~A}$.

19. A large, nearly complete internal cast of a pedicle valve. Near Layton, Locality $37 \mathrm{~A}$.

20. An internal cast of the pedicle valve. Near Wallpack Center, Drift. 
Geol. Survey of N. J.-1902. Paleontology.

Plate XlviI.

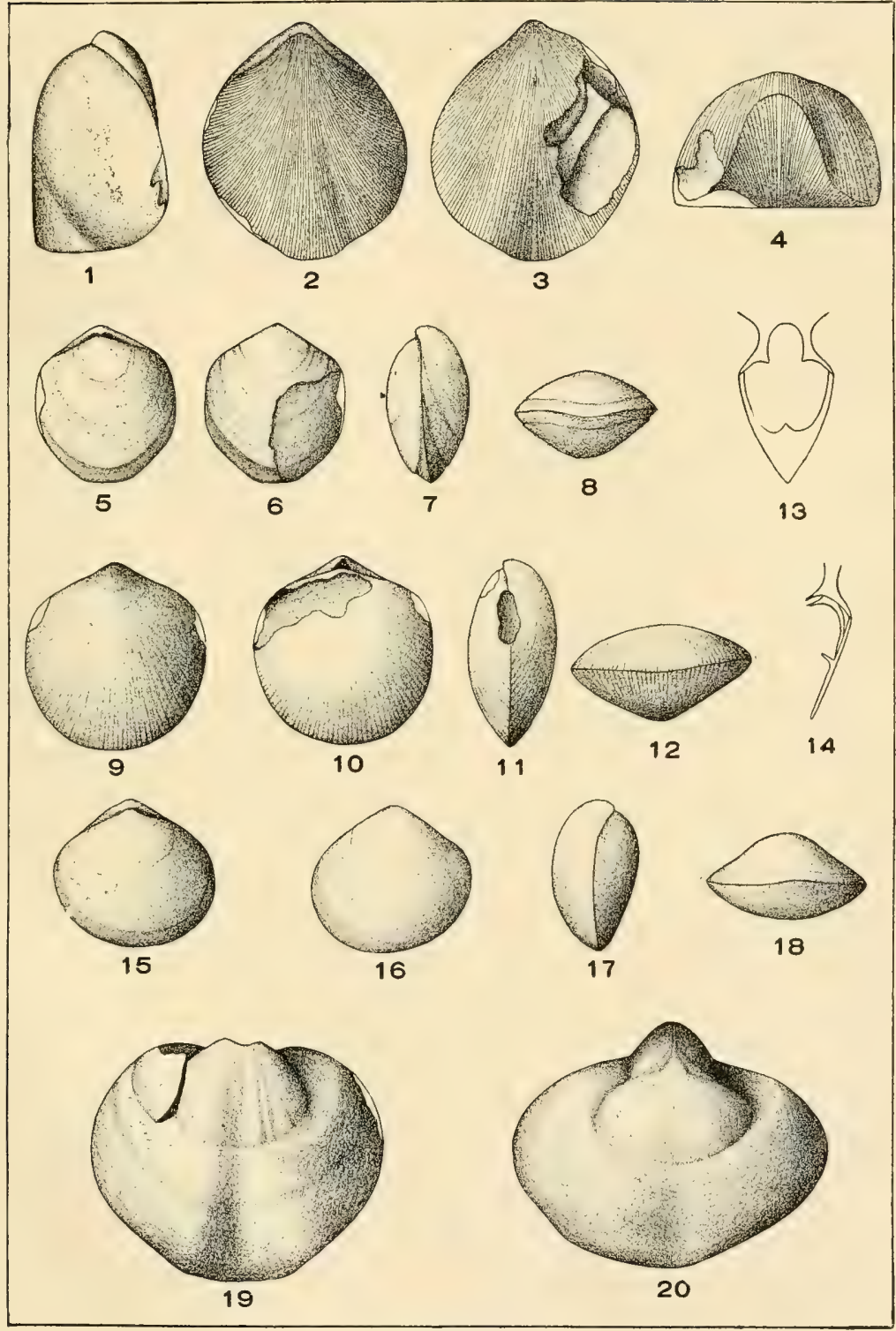

ORISKANY. 



\section{,}




\section{PLATE XLVIII.}

PAGE.

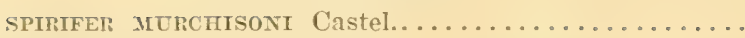

Figs. 1-4. Pedicle, brachial, anterior and lateral views of a nearly complete individual. Locality $6 \mathrm{~A}$.

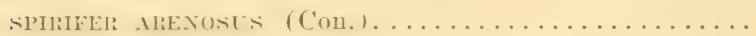

Fig. 5. An incomplete brachial valre. Near Layton, Locality 87 A. MLTALLALI PYXIDATA (Hall) ...............

Fig. 6. An incomplete pedicle valve. Tear Layton, Locality 37 A.

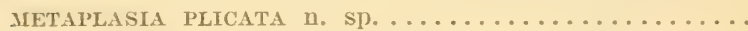

Figs. 7-11. Pedicle, brachial, posterior, anterior and lateral views of a nearly complete individual. Locality $6 \mathrm{~A}$.

12. The internal cast of a brachial valve. Peters Valley, Locality $53 \mathrm{~B}$.

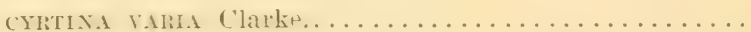

Figs, 13-16. Brachial, anterior, posterior and lateral views of a nearly complete individual. Near Layton, Locality $8 \% \mathrm{~d}$. (446) 


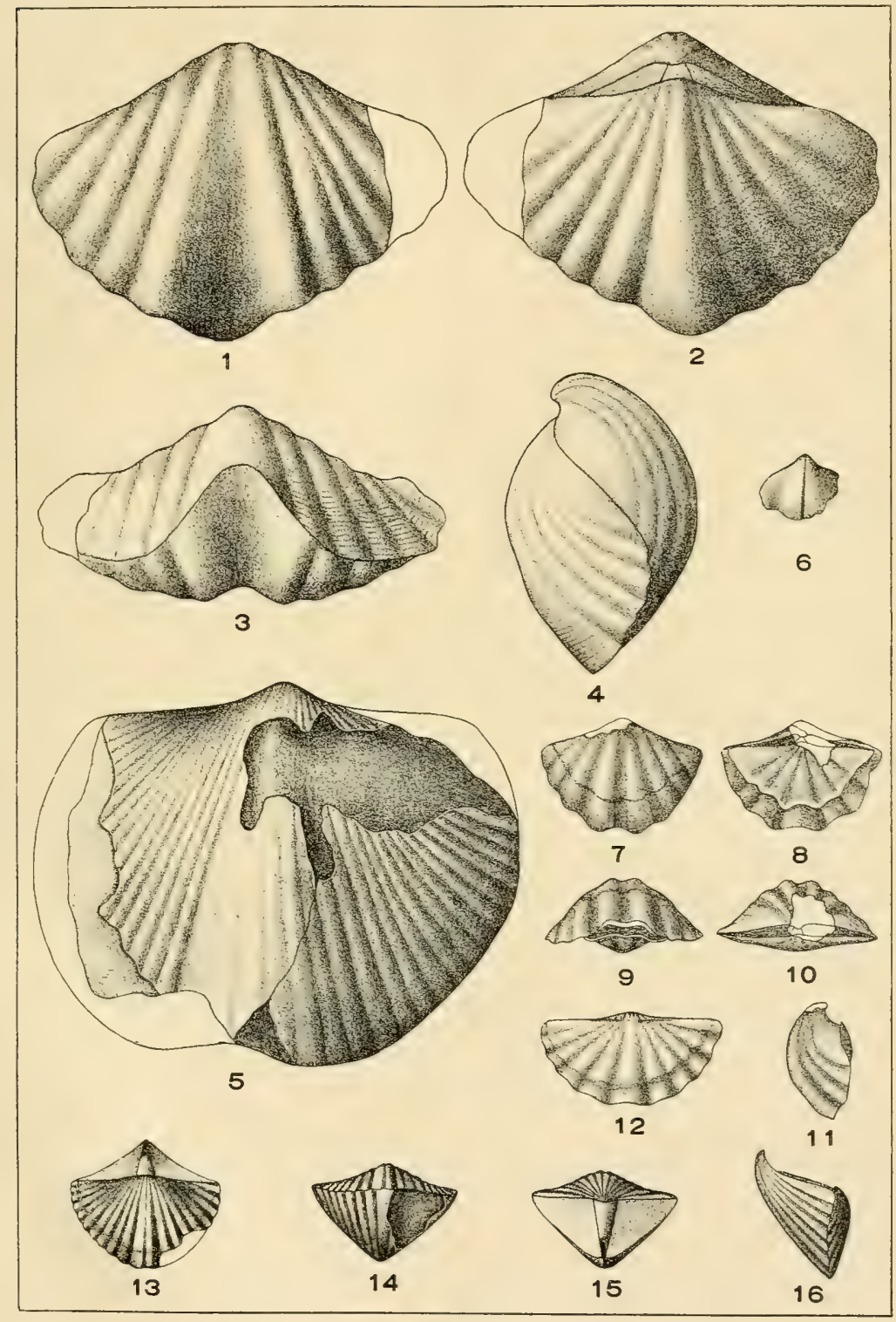

ORISKANY. 




\section{PLATE ILIX.}

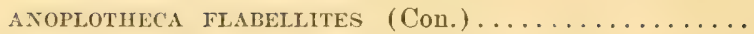

Fig. 1. A complete pedicle valve. Near Layton, Locality $37 \mathbf{A}$. 2. A complete brachial valve. Same locality.

AxolLotheca DICHOTOMA (Hall) ..............

Yigs. : 3 - Brachial, pedicle, lateral and anterior views of a complete individual. Locality $6 \mathrm{~A}$.

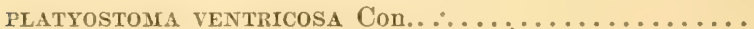

Fig. 7. Lateral view of a large individual. Near Layton, Drift. 8, 9. Two views of a smaller individual. Peters Valley, Locality $59 \mathrm{~B}$.

10, 11. Two views of another individual. Samc locality.

PLAtyostoma desmatum Clarke..............

Fig. 12. Lateral view of a nearly complete individual. Locality 6 A.

PLATyceras tortutosut Hall...............

Figs. 13, 14. Two views of a small individual. Peters Valley, Locality $53 \mathrm{~B}$. 


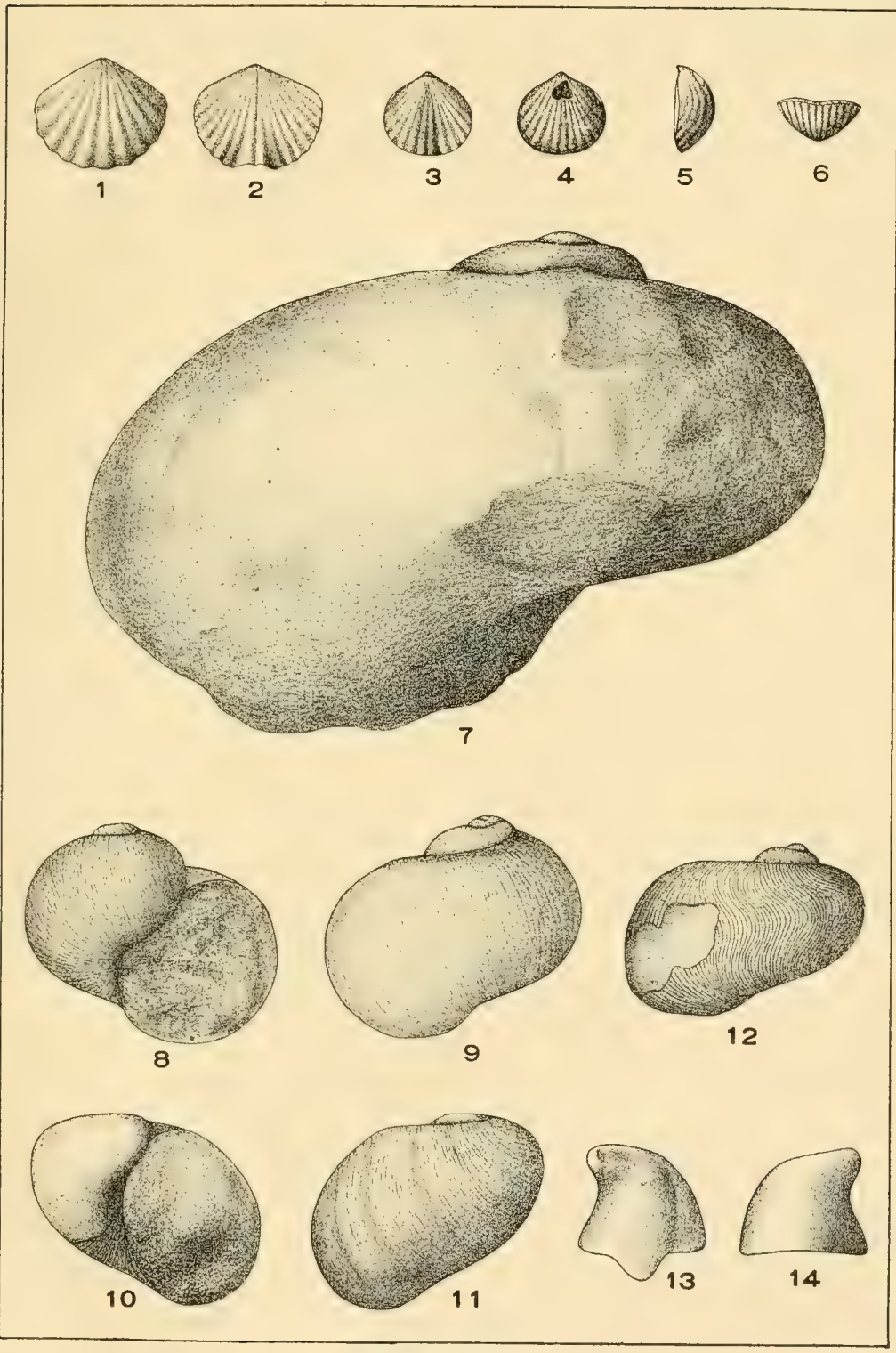

ORISKANY. 




\section{PIATE I.}

PAGE.

ACTINOPTERIA TEXTILIS val. ARENARIA (Hall) .........

Fig. 1. An incomplete left valve. Nearpass scetion, Locality $3 \mathrm{~A}$

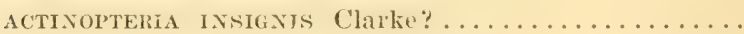

Fig. 2. A complete left valve. Locality $6 \mathrm{~A}$.

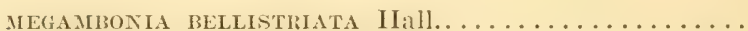

Fig. $\quad 3$. An incomplete left valve. Peters Valloy, Locality $53 \mathrm{~B}$. TENTACYLITES ELONGATL's Hall..................

Figs. 4,5. The internal casts of two incomplete individuals. Peters Valley, Locality $53 \mathrm{~B}$.

DALMANITES s]). Undet................

Fig. 6. A large, incomplete pygidium. Nearpass section, Locality $3 \mathrm{~A}$.

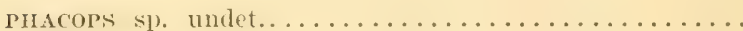

Fig. 7. An incomplete pygidium. Near Layton, Locality 37 A. (448) 
Geol: Sutiey of N. J.-1902. Paleontology.

I'LATE L.

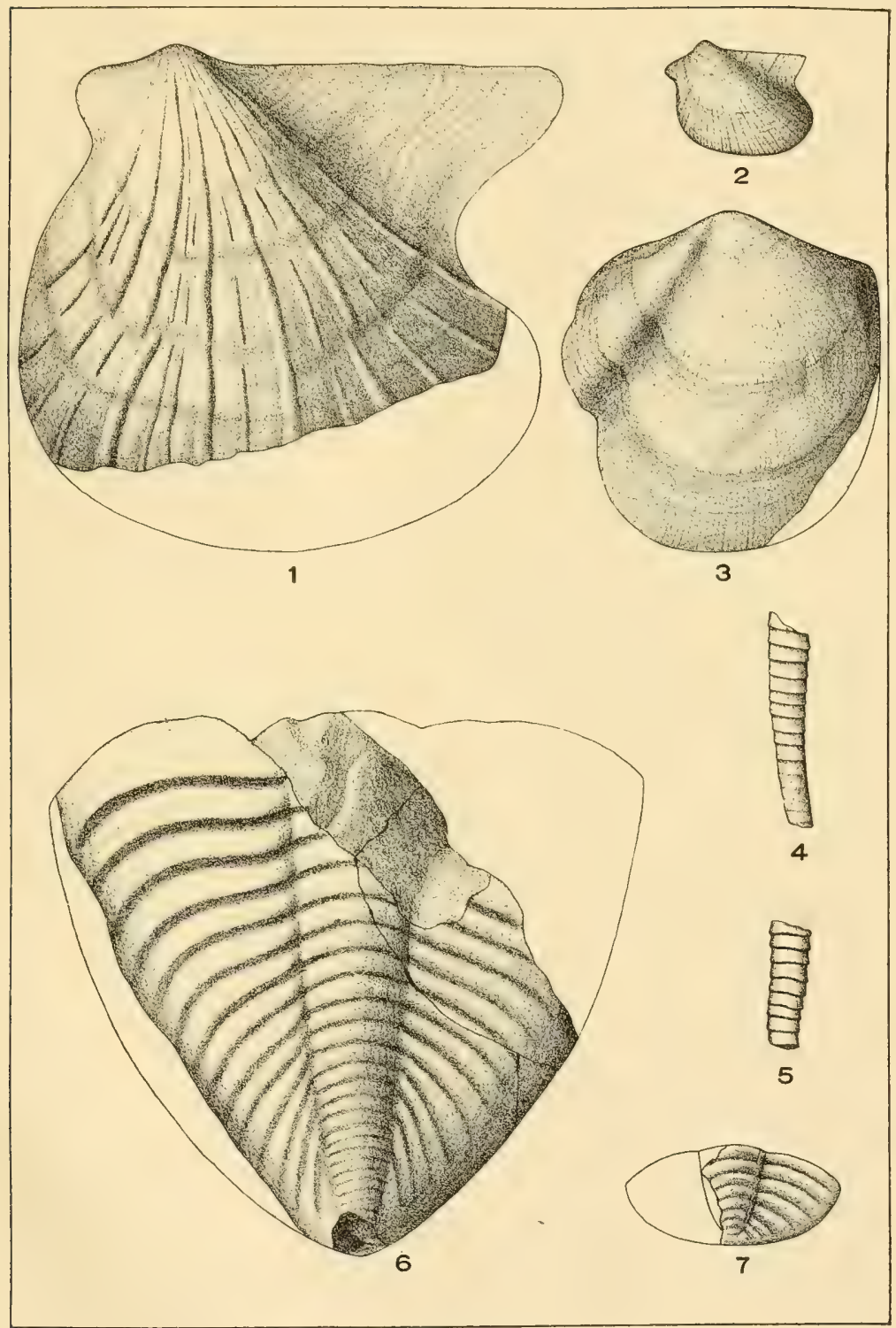

ORISKANY. 




\section{ILATE LI.}

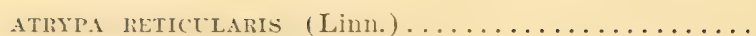

PAGE.

Figs. 1-1. Brachial, pedicle, lateral and anterior views of a nearly complete individual. Near Tri-States, Locality $2 B$.

RHIPHOMELLA VAXTEEM (IIall $\ldots \ldots \ldots \ldots \ldots \ldots \ldots$

Figs. 5-7. Pedicle, brachial and lateral views of a complete individual (after Hall).

RECTICULARIA FIMBRIATA (Con.)..............

Figs. S-11. Brachial, pedicle, anterior and lateral views of a complete individual (after Hall).

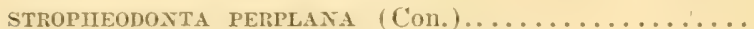

Fig. 12. A complete pedicle ralve (after Hall).

13. A complete brachial ralve (after Hall).

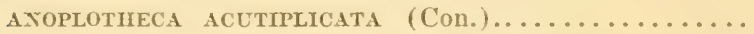

Figs. 14-17. Pedicle, brachial, lateral and anterior views of a complete individual. Near Flatbrookvillc, Locality $\$ 9$ B.

CHONFTES AR LATA Hall.................

Fig. 18. An incomplete pedicle valve. Peters Valley. Locality $52 \mathrm{~A}$. LEPTAENA RHOMBOIDALIS (Wilck.)

Fig. 19. A nearly complete pedicle valre. Locality io B. LOAOXEMA si), undet.

Fig. 20. Lateral view of an incomplete shell. Near Tri-States, Locality 2 B.

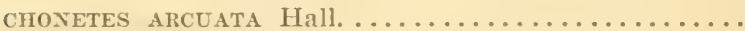

Fig. 21. The internal cast of a pedicle valve. Greenuood Lake, Locality 87 . .

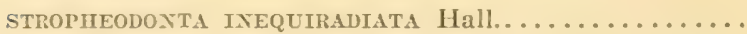

Fig. 22. An imperfect pedicle valve. Newfoundland, Locality 1.451. 
Geot. Strifex of X. T.-1902. Paleontology

Plate LI.

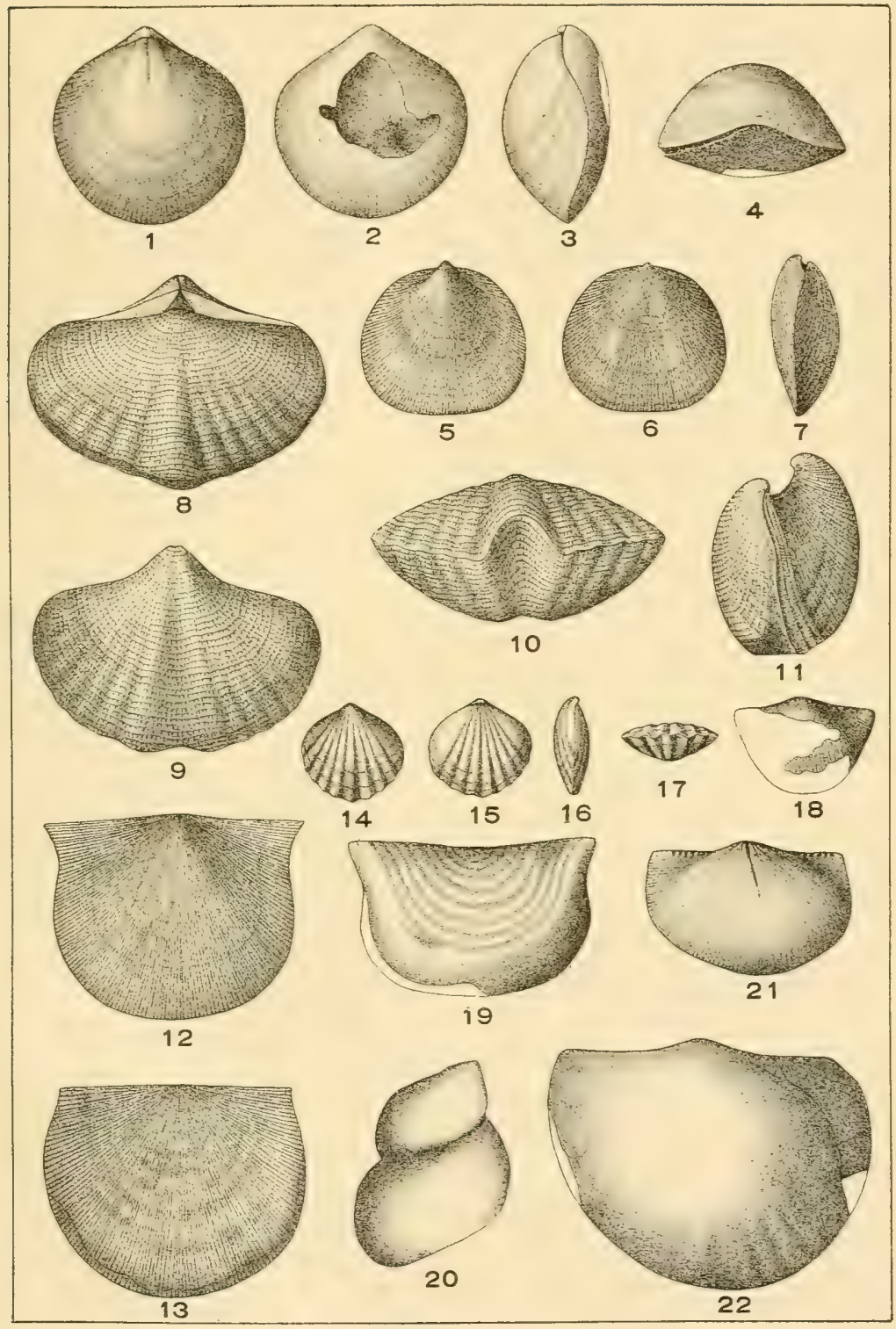

ONONDAGA. 


PLATE LII.

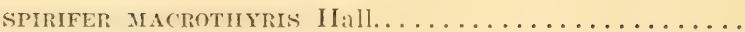

PAGE.

Fig. 1. Fragment of a large pedicle valve. Greenwood Lake, Locality $8 \gamma B$.

2. Internal cast of the same.

3. A smaller, incomplete pedicle valve. Newfoundland, Locality $1.45 \mathrm{~A}$.

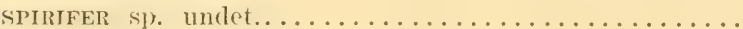

Fig. 4. An incomplete brachial valve. Newfoundland, Locality $1,5 \mathrm{~A}$.

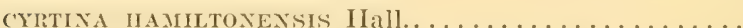

5. Anterior view of an incomplete pedicle valve. Grecnwood Lake, Locality 87 B.

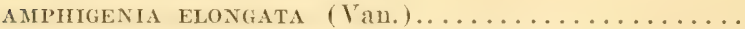

Fig. 6. A portion of the internal cast of a pedicle valve. Newfoundland, Locality $1.45 \mathrm{~A}$.

7. A larger, nearly complete valve. Grecnwood Lake, Locality 8 r $B$.

OIRTIOTIETES P.ANDORA (Bill.)..............

Fig. S. An incomplete pedicle valve. Greenwood Lake, Locality $87 \mathrm{~B}$.

SCHIZOPIORTA sp. ef. S. STRIATULA (Schl.).........

Fig. 9. An incomplete pedicle valve. Ncwfoundland, Locality $1.5 \mathrm{~A}$.

10. An incomplete brachial valve. Same locality.

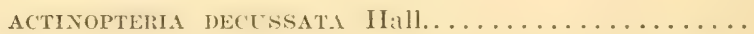

376

Fig. 11. A nearly complete left valve. Greenwood Lake, Locality $87 B$.

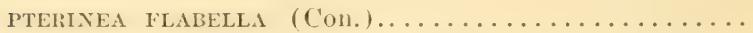

Fig. 12. An incomplete left valve. Newfoundland, Locality 1.45 A. $(450)$ 
Geol. Survey of N. I.-1902. Paleontology.

Plate Lil.

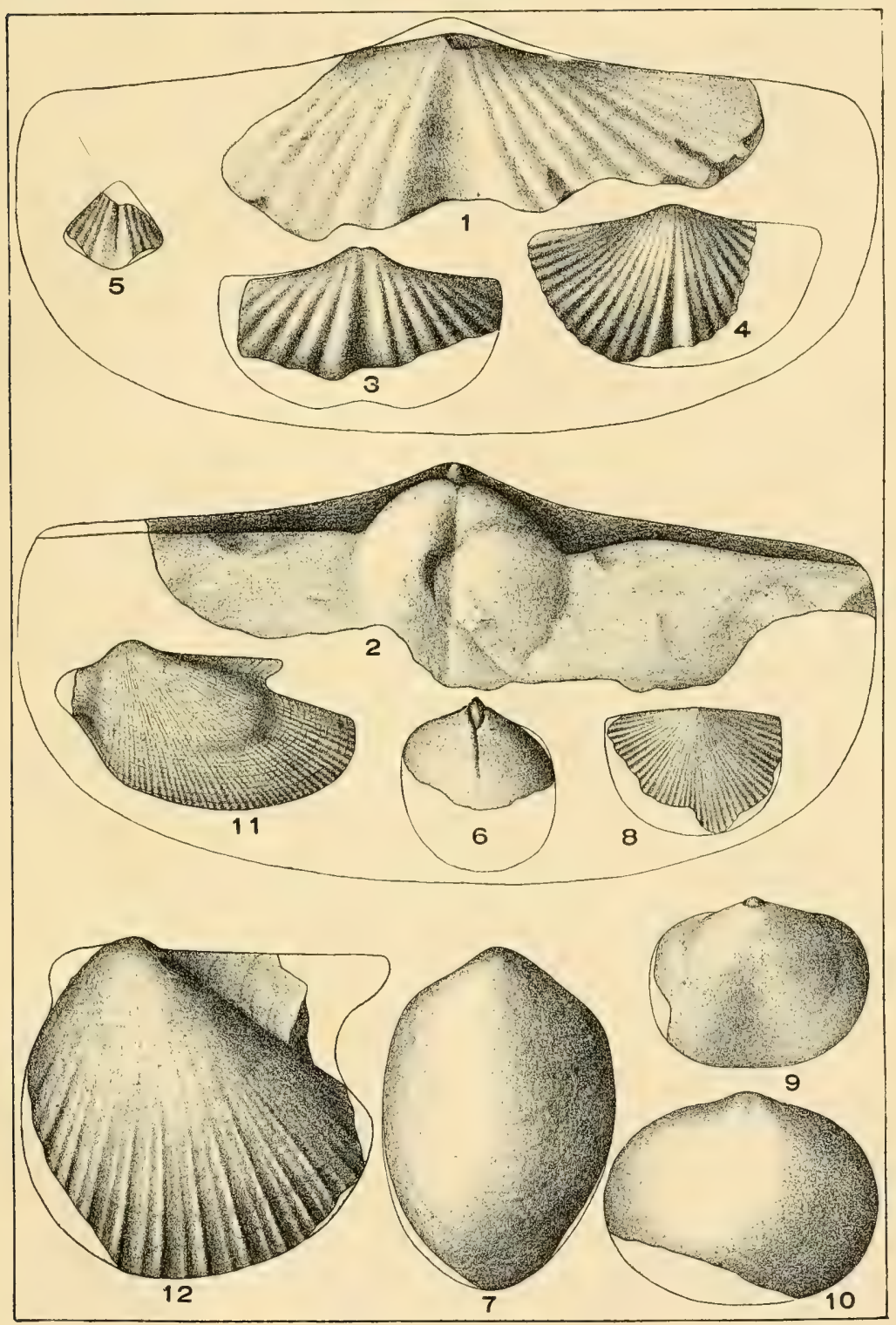

NEWFOUNDLAND GRIT. 

PLATE LIII.

SPIRIJER A UDACULUS (Com.). . . . . . . . . . . .

PAGE.

382

Fig. 1. A small, distorted pedicle valve. Oak Ridge, Locality $14, A$.

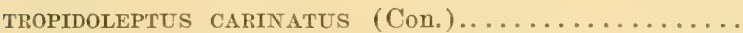

Fig. 2. A distorted brachial valve. Near IVest Milford, Locality $106 \mathrm{~A}$.

A NOPLOTHECA ACETIPLICATA (Con.) ?............

Fig. 3. A distorted, internal cast of the pedicle valve. Greenwood Lake, Locality 87 A.

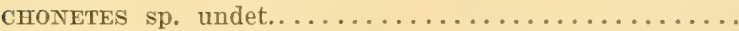

Fig. 4. A nearly complete, distorted pedicle valve. Greenuood Lake, Locality $8 \gamma$ A.

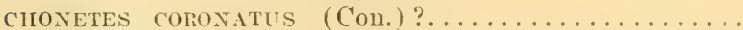

Fig. 5. A distorted pedicle ralve. Near Clinton Rescrvoir, Locality $104 \mathrm{~A}$.

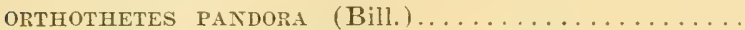

Fig. 6. An incomplete, distorted pedicle ralve. Greenwoood Lake, Locality $8 \%$ A.

UNDETERMINED BRACHIOPOD $\ldots \ldots \ldots \ldots \ldots \ldots$

Fig. T. A distorted pedicle valve. Oak Ridge, Locality $144 \mathrm{~A}$.

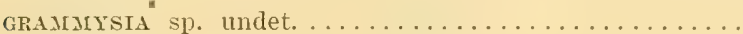

Fig. S. An incomplete, distorted right valve. Oak Ridge, Locality $144 \mathrm{~A}$.

9. A distorted left valre of another species. Same locality.

P.ILAEONEILO EMARGIXATA (Con.)..............

Fig. 10. A nearly complete right valve. Oak Ridge, Locality 144 A.

11. A smaller, incomplete left valve. Same locality.

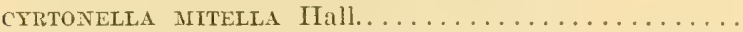

Fig. 12. Dorsal view of a nearly complete shell. Oat Ridge, Locality 14 f $A$.

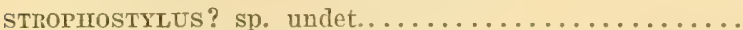

Fig. 13. Lateral view of a distorted, incomplete individual. Grcenwood Lake Locality $8 \gamma \mathrm{A}$.

Figs. 14, 15. 'Two views of a distorted specimeu, Oak Ridge, Locality 14 ' 1 .

16. Lateral view of another individual. Same locality. 
PLATE LIII.--(Continued.)

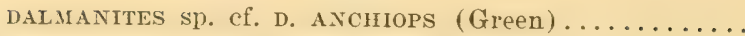

PAGE. 388

Fig. 17. Au incomplete, distorted pygidium. Greenuood Lake, Locality 87 A.

PIIACOPS RUNA (Green)..................

Fig. 18. An incomplete head. Greenuood Lake. Locality $8 \% \mathrm{~A}$. (452) 
Geol. Suriey of N. J.-1902. Paleontologx.

Plate LIII.

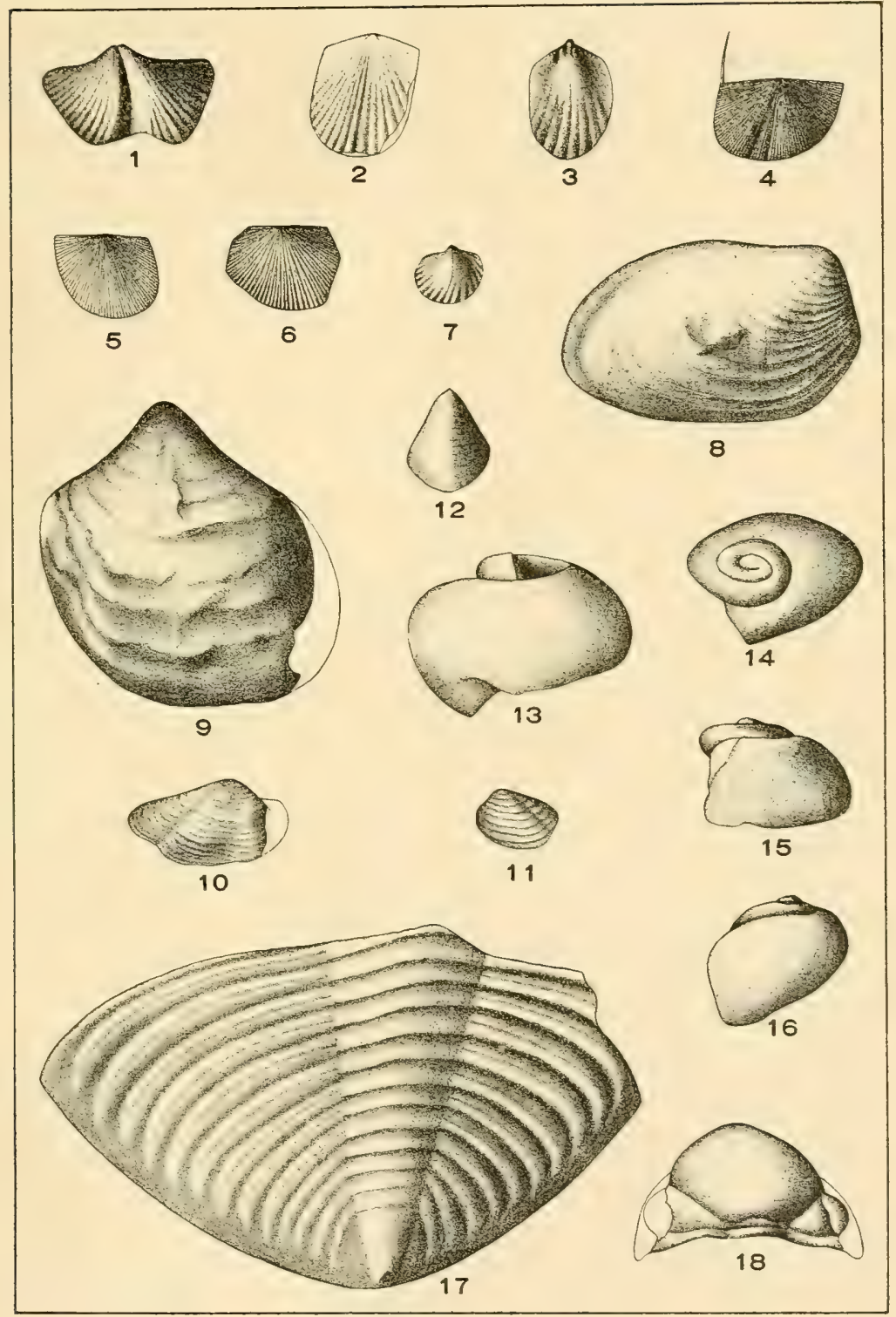

HAMILTON. 

I N D E X. 



\section{INDEX.}

Synonyms are in italics. Heavy-faced figures refer to pages on which species are described. Roman numericals refer to plate numbers.

A.

Acidaspis parvula Walcott. Actinopteria sp. undet. $97,100,10 €, 318$ communis (Hall) ..................82, 83, $85,292, \mathrm{XXXI}$. decussata Hall.........105, 378, LII. insignis Clarke.......... 98, 359, L. reticulata n. sp.....66, $\mathbf{2 4 5}$, XXII. textilis (Hall)......95, 332, XLIII. textilis var, arenaria (Hall)....100, $101,360, \mathrm{~L}$. Actinostroma trentonensis $\mathrm{n} . \mathrm{sp} . . .22,23,42,46$, $47,48,139$, VI. Agraulos saratogensis Walc. $13,118, \mathrm{I}$ Ambocœlia umbonata (Con.) 106,383

Amphigenia elongata (Van.).....105, 374, LII. Andover, fossils near. Anoplotheca acutiplicata (Con.)...104, 105, 106 370, 37 ' 383, LI., LIII. concava (Hall) ...87, 88, 89, 103, 104, 316, 371, XXXVII. dichotoma (Hall)..98, 358, XLIX. flabellites (Con.) ........ 98, 100, 101, 102, 357, XLIX

Anoplia nucleata Hall.................. 95, 98, 100, 325, 349, XLI, XLVI.

Anomocare parvula n. sp.............12, 120, III. Archinacella patelliformis (Hall)..28, 174, XII. Arges tuberculatus n, sp..............43, 199, XV. Asaphus canalis Whitf ............................. 132 Asaphus? trentonensis Con........................ 200 Astrocerinum pyriforme Hall...................... 220 Atrypina imbricata Hall. $88,89,90$, 312, XXXVII.

Strypa dentata Hall 159 lamellata Hall 237 nucleolata Hall 241

Atrypa reticularis (Linn.)...63, 64, 65, 68, 69, 70, $71,72,82,83,84,85,103,104$, 236, 286, 369, XXI., XXX., LI. Atrypa ? lamellata Hall..65, 66, 68, 70, 237 , XXI. avicula communis Hall.. 292 emacerata Conrad 242
Avicula subplana Hall........................... 243 textilis Hall............................... 332 textilis var, arenaria...................... $\mathbf{3 6 0}$

\section{B.}

Bathyurus ? sp undet....................... 16, 134 Bathyurus extans (Hall)......................... 24 Beachia suessana (Hall)....................97, 98, 100, 101, 35\%, XLVII. Beaver Run, fossils near.........................38, 39 Becraft limestone.................................59, 91 Beekmantown fauna, described............... 124 Bellerophon? sp. undet.......................15, 12y Bellerophon punctifrons Emm.................. 17' Bellvale flags-description of fossils in.... 107, 379

Belvidere, fossils near.......................... $\quad 48$ Beyrichia sp. undet................43, 78, 84, 92, 95 barretti n. sp..........66, 254, XXIII. deckerensis n. sp....66, 256, XXIII. jerseyensis, n. sp.....66, 255, XXIII kümmeli n. sp ........79, 266, XXIV. manliensis n. sp....78, 268, XXIII. montaguensis n. sp..79, $\mathbf{2 6}$, XXIV. nearpassi n. sp..........66, 255, XXIII. perinflata n. sp.......66, $\mathbf{2 5 4}$, XXIII. smocki n. sp...........79, $\mathbf{2 6 8}$, XXIV. sussexensis n. sp.....66, 253, XXIII wallpackensis n. sp....266, XXIV. Bilobites varica (Con)...........87, 306, XXXV. Blairstown, fossils near.......................13, 18 Bossardville limestone.........................57, 61 Branchville, fossils near.........................39, 52 Brick House, fossils near.................... 68, 100 Bronteus lunatus Bill........... 24, 45, 198, XV Bryozoa several undet. sp....................... 102 Bucania sp. undet.................................. 21 punctifrons Emm......23, 24, 26, 27, 28, $30,31,32,33,34,35,36,17 \%$, XII. Bucania bidorsata Hall.......................... 1 76 Bulimorpha? helderbergiae n. sp.............. 83, 293, XXXII. Bumastus elongatus n. sp..........46, 195, XIV. transversalis $\mathrm{n}$. sp...........195, XIV. 
Bumastas trentonensis (Emm.)....20, 21, 22, 25, $26,27,30,31,32,34,38,39,41,42$, $43,44,45,46,47,48,194$, XIV. Bythocypris nearpassi n sp....61, 257, XXIII.

\section{C.}

Callopora sp. undet.......38, 39, 43, 44, 142, VII. Calymene camerata Con......65, 66, 250, XXII. senaria Con.......23, 24, 25, 27, 29, 30, $31,32,33,35,36,39,40,41$, $42,43,44,46,203, \mathrm{XV}$. Camarella inornata..............20, 43, 47, 15 7, X. Camaroceras proteiforme (Hall)............. 46 , 190, XIII.

Camarotoechia sp. undet....................107, 381 barrandii (Hall).......... 99, 351 sappho Hall ?.................. 106

Cambrian faunas.. ................................... 111

formations............................10-14

Carinaropsis patelliformis Hall................ 174

Carpentersville, fossils near ................... 13

Catenipora escharoides Hall...................... 222

Centronella? biplicata n, sp...79, 261, XXIV, subrhomboidea n. sp.

311, XXXVII.

Ceraurus pleurexanthemus Green......21, 36, 38, 42, 44, 204, XV. 173, XIIr.

Chiton? sp

Chonetes sp. undet......106, 107, 380, 381, LIII.
arcuata Hall................. 105, 367, $373,36 \%, \mathrm{LI}$. arcuatus Hall..............143, 373, LI. complanata Hall........................ 348 coronata $\mathrm{Hall}$............................. $\mathbf{3 8 0}$ coronatus (Con.) ?......106, 380, LIII. hudsonica Clarke..97, 98, 347, XLVI. jerseyensis Weller....63, 64, 65, 68, 69, $70,71,72,230, \mathrm{XX}$.

Chonostrophia complanata (Hall) .......100, 101, 348, XLVI. jervensis schuchert.......94, 95, 326, XLII. Cladopora multiseriata...........82, 271, XXVI. rectilineata Simpson...............64, 65, 221, XVII. Cleidophorus sp. undet......................... 36 Climacograptus phyllophorus Gurley..........53, $\approx 12$, XVI.

Clinton reservoir, fossils near................. 166 Clioderma expansa Hall........................... 179 Conograptus graeilis (Hall).......53, 214, XVI. Coeymans limestone..............................59, 81 Coeymans limestone fauna, descriptions of. 270

Coiumbia, fossils at................................. $\quad 15$ Columnaria inequalis Hall ....................... 219 Conocardium sp, undet..........84, 293, XXXI. Conocephalites calciferus Walc.................. 117 Connlaria trentonensis $\mathrm{H} \ldots \ldots . .24,25,26,32,38$, 188, XIII.
Cornulites sp. undet................51, 215, XVY cingulatus Hall.... 82, 272, XXXII. cingulites Hall...................... 272

Coralline limestone.............................. 75

Corynoides calicularis Nich......52, 214, XVI. Crania sp. undet...............38, 39, 43, 148, IX. Ctenodonta sp. undet.........18, 19, 24, 25, 26, 27, $30,31,32,33,35$ jerseyensis n. sp........18, 164, XI. levata (Hall)................ 165, XI. nasuta (Hall)...... 20, 30, 33, 34, 43, $46,163, \mathrm{XI}$.

Ctenophora sp. undet. 26

Cuneamya truncatula Ulr..............162, XI: Cyclonema montrealensis Bill....40, 186, XII. Cyphaspis trentonensis n. sp.......31, 10\%, XV. Cypricardinia sublamellosa Hall...... 89, 317 Cytherina fabulites Conrad........................ 208 Cyrtia rostrata Hall.................................... 330 Cyrtina sp. undet..................88, 289, XXX. hamiltonensis Hall.......105, 377, LII. magnaplicata n. sp......64, 238, XXI. rostrata. Hall........... 94, 95, 330, XIJI. varia Clarke..98, 99, 100, 355, XLVIII. Cyrtoceras sp. undet...............16, 38, 131, III. Cyrtodonta sp. undet............................19, 31 Cyrtodonta? sp. undet.............................. 48 Cyrtodonta billingsi Ulr..............42, 166, XI. canadensis Bill.......22, $17,16 \%, \mathrm{XI}$.

Cyrtolites compressus Ball........................ 178 (Cyrtonella) mitella....................... 386 ornatus v\&r. minor U. \& 8............32,

$174, \mathrm{XII}$ sinuatus H. \& W............15, 127, IV. trentonensis Conrad.................... 184

Cyrtonella mitella Hall............................. 107

D.

Dalmanella electra (BIll)..............15, 125, IV. perelegans (Hall)....87, 88, 94, 305 . $327, \mathrm{XXXV}$. postelegantula n. 8p..63, $64,65,68$, $71,232, \mathrm{XX}$. subrequata (Con.)..18, 19, 20, 21, 22, $40,46,47,156, X$. subcarinata (Hall)......87, 88, 94, 95, 306,326, XXXIV., XLII. testudinaria (Dal.)....222, 23, 24, 25, $26,27,28,29,30,31,32,33,34,35$, $36,38,40,11,42,43,44,45,46,47$, $48,51,52,155,216, X, X V I$. wemplei Cleland.........15, 124, IV.

Dalmania pleuroptyx Hall...................... 295 Dalmanites sp. undet ....69, 98, 1C0, 102, 364, L. aspinosa n. :p..............64, 68, 72, 252, XXII.

sp. cf. D. anchiops (Green)..... 106 dentata Barrett..................... 339 dentatus Barrett.....................95, 96, 339, XLIV. 
Dalmanites dentatus fauna, description

dentatus zone....................... $\quad 91$

intermedius Walcott............... 208

pleuroptyx (Green)................. 82,

$84,85,87,89,90,92,295$,

$322, \mathrm{XXXII}$, XXXIX.

Decker Ferry faunas, correlation of........ $\quad 72$ description of...... 218

Decker Ferry formation. 57,62

Delaware valley, formations of.

9

Delthyris expansus Emmons..................... 1 79

Devonian formations............................ 81

faunas...................................... 269

Diaphorostoma desmatum Clarke................. 362

Dicranograptus ramosus (Hall).............. 53

Dikelocephalus newtonensis n, sp......... 12

121 , III.

Dinorthis pectinella (Emm.).........22, 39, 40, 42, $\$ 6,47,154, I X$.

Diphyphyllum integumentum Barrett...65. 70, 218, XVII.

Diplograptus angust folius (Hall).... ....... 52 , 212, XVI. foliaceus (Murch.)............. 52, 211, XVI.

Discina grandis Hall. 324

jervensis Barrett... 343

Drake's pond, fossils near. 42

E.

Eatonia medialis (Van.)................87, 88, 89, 90, 310, XXXVI. peculiaris (Con.),...............99, 101, 1(2, 351, XLVII.

singularis (Van.)......89. 311, XXXVI.

Eccyliomphalus contiguus Ulrich.....185, XII. subelliptica $\mathrm{n}$. sp.......... 16 , I29, IV. trentonensis (Hall)..... 31, 32,

184, XII.

Edmondia? deckerensis n. $\mathrm{sp}$.................63, 68,

Edmondia subtruncata Hall.

241, XXII.

Edriocrinus sacculus Hall.......101, 342, XLV.

Encrinurus trentonensis Walc..........22, 32, 35,

44, 202, XV.

Endoceras proteiforme Hall..................... 190 var. tenuitextum Hall .................. 189

Escharopora siluriana n, sp ...........65, 68, 70, 225, XVIII, XIX.

Esopus grit 60,102

Eurychilina jerseyensis n. sp.....43, 210 , XIII. oculifera n. sp......43, 210 , XIII.

E.

Favosites sp. undet.. $61,67,102,341$ corrugatus n. sp....71, 72, 220, XVII. helderbergiae Hall
Favosites pyriformis (Hall)......65, 220, XVII. spcericus Hall.

274

Fenestella sp. undet.............................. 83, 85

Fenestella ? sp. undet....................97, 103, 107,

$343,365,379$

Flatbrookville, fossils near...........63, $69,70,71$, $84,85,90,101,104$

Stormville sandstone at... 91

Foraminifera ? genus and sp. undet........ 12 Foraminifera....................................111, I.

Franklin Furnace, fossils near................ 11

\section{G.}

c. f. Glossina spatiosa (Hall)...88, 300, XXXIII. Goniophora sp. undet.................. 63, 95, $\mathbf{2 4 6}$ carinatus. (Hall) A.27, 28, 173, XI.

Goniophora ? sp. undet........................ 334

Grammssia sp. undet............................ 107

Graptolithus angustifolius $\mathrm{Hall} \ldots . . . . . . . . . . . . . . . .212$

gracilis Hall....................... 214 mucronatus Hall................... 212 pristis Hall.......................... 211 ramosus Hall....................... $\mathbf{2 1 3}$

Green Pond conglomerate..................... 5

Green Pond mountain region, forma-

tions of..

Green Pond mountain region, fossils in... 7

Greeuwood Lake, fossils near............. 105, 106 Gypidula angulatr n sp.......83, 280, XXVIII. galeata (Dal.)......................82, 84 85,279, XXVIII. galeata (Dal.) var...83, 280, XXVIII.

\section{H.}

Hainesburg, fossils at and near.............15, 47 Hainesville, fossils near......68. 69, 82, 88, 89, 98 Stormville sandstone near. $\quad 91$

Hallina nicolleti W. \& S.......................... 161

Halysites catenularia (Linn.)...65, 222, XVII. catenulata Rominger............... 222

Hamburg, fossils near........................... 38

Hardyston quartzite ............................ 10

Harđ̋ ystonville, fossils near.................... 11

Harpes ottawaensis Bill.. ........................ 191

Harpina ottawensis (Bill.)..25, 29, 31, 191, XIV. Helicotoma sp. undet............18, 19, 40, 46, 184. Hindia fibrosa (Roem).............86, 88, 89, $29 \%$,

XXXIII.

Hindia parva Ulr. $21,24,29$ $30,31,36,33,135, \mathrm{VI}$

Hipparionyx proximus (Van.)..101, 346, XLV. Holopea sp. undet.............................. 35 antiqua (Van.)...........79, 264, XXIV. parvuln Ulrich................. 187, XII supraplana U. \& S. ?......... 187, XII symmetrica Hall..............186, XII

Homalonotus dekayi (Green) ?............... 107 vanuxemi Hall....92, 95, 96, 321, 338 , XXXIX., XLIV. 
Hormotoma salteri Ulr......23, 24, 25, 26, 27, 28, $30,38,43,45,46,47,183$, XII.

Hudson River fauna, description of........ $\mathbf{2 1 1}$ slates...

49

Hyattella lamellosa n. sp........76, 258, XXIII. Hyolithes centennialis Barrett.............. 95, 336, XLIII.

\section{I.}

Icthyocrinus magnaradialis n. sp........86, $\mathbf{2 9 9}$, XXXIII,

Illaenurus columbiana n. sp.........16, 133, V. Illaenus trentonensis Emm. 194

Iliff's pond, fossils near.. Isotelus canalis (Whitf gigas DeKay. $25,26,27,28,29,30,31,32,35,38$, $40,41,42,43,45,46,192$, XIV.

J.

Jacksonburg, fossils at. section at......................... 18 18 Jutland, fossils near.

K.

Kingston beds.. 59,93

Kittatinny limestone.........................11, 15, 16 Kittatinny valley, formations of .

I.

Lasiograptus mucronatus (Hall)..52, $212, \mathrm{XVI}$. Layton, fossils near............................. 100 Leperditelia ornata $\mathbf{n}$. sp..........43, 209, XVII. Leperditia sp. undet .......................22, 70, 76 Leperditia ? sp. undet .......................... 95 Leperditia alta (Con) )......................77, 78, 79, 259,265, XXIV. altoides $\mathrm{n} . \mathrm{sp}$............. 252, XXIII. elongata n. sp. .......76, 259, XXIII. fabulites (Con.).........18, 19, 20, 21, 22, $41,43,46,47,208$, XIII. gigantea n. sp..........76, 260, XXIII.

Leptæna bipartita Hall........................ $\mathbf{2 2 6}$ indenta Con.......................... 276 rhomboidalis (Wilck.)...........64, 65, $66,81,85,86,87,88,89$, $90,92,91,95, \quad 104,228$, 278, 302, 325, 366, XX., XXVII., XXXIII, XLI, LI. rhomboidalis Wilck. var, ven. tricosa $(\mathrm{H})$

Ihomboidalis var. ventricosa

(Hall)..................101, 346, XLVI. sericea Meek............................. 149

sp. — Hall.............................. 226

Leptana ? nulceata Hall:.......................... 349

Leptocolia acutiplicata Hall........................ $\mathbf{3 7 0}$ concava Hall........................... 316

dichotoma Hall...................... 3 ระ

flabellites Ifall..................... 35 7
Leptocolia imbricata Hall.

312 Lichas pustulosus Hall................92, 320, XL. Lichenalia sp. undet........................... 64 Lichenalia? sp. undet.......................... 64 Lichenalia torta Hall....82, 83, 85, 273, XXVI. Lingula sp. undet..............19, 21, 23, 27, 29, 30 , $31,42,45,47,94,104,365$ Philomela Bill?.. $145, I X$. progue Bill?............................ 38 riciniformis Hall............25, 144, IX. spatiosa Hall............................. 300

Lingula? sp, undet................................ . 324 Lingulasma galenænsis U. \& $\mathrm{S}$.....42, 145, IX, Lingulella stoneana Whitf............12, 112, I. Liospira sp. undet.

15,128 micula (Hall)............25, 26, 27, 28, 30, $32,33,31,182$, XII.

Liostracus? jerseyensis Weller.................. 119 Longwood sandstone............................ 55 Lophospira sp. undet...........................18, 19 medialis U. \& $\mathrm{S} . . . \ldots . . .28,30,32,33$, $31,35,36,181$, XII. oweni U. \& S.......... 21, 181, XIY. Lower Oriskany fauna, description of.... 322 Loxonema sp. undet...............63, 103, 371, LI. Loxonema ? sp. undet..................... 83, $\mathbf{2 4 7}$, 294, XXII., XXXII.

Loxonema attenuata Hall....89, 319, XXXIX. jerseyensis n. sp .....95, 335, XLIII.

\section{MT.}

Manlius limestone................................ 58, 78 Manlius limestone fauna, description of.. $\mathbf{2 6 0}$ Medina sandstone.................................. 55 Megambonia ? sp. undet..................... 95, 333 Megambonia aviculoidea Hall.... ..............79, 263, XXIV. bellistriata Hall.......101, 360, L. parva n. sp.................... 95, 96, 333, XLIII.

Merista lata Hall................................. 359

lievis Hall.................................. 31 z

princeps Hall..... ........................ 331

Meristella lævis (Van.)..82, 83, 84, 85, 87, 88, 89, $90,92,290,31 \%$, XXXI. XXXVIII.

lata.........98, 100, 101, 359, XLVII. princeps...............95, 331, XLII. Metaplasia plicata n. sp............... 98, 100, 101, 102, 356, XLVIII. pyxidata (Hall)..100, 355, XLVII. Microdiscus ? 8p. undet..............12, 114, III. Modiolopsis sp. undet..........18, 19, 20, 33, 34, 40 carinatus Hall................... 173 depressa $\mathbf{x}$. sp ..........38, 171, XI. faba (Con.)..........25, 26, 27, 28, 30, $32,33,34,36,168, \mathrm{XI}$. jerseyensis $\mathrm{n}$. sp........19, 170, XI.

Monotrypa sp. undet....................... 39, $\mathbf{4 3}, \mathbf{4 1}$ corrugata n. 8 p......63, 64, 66, 67, 68, $69,70,71,72,223$, XVIII. 
Monotrypa globosa n, sp...........38, 142, VIII. sphærica (Hall).....82, 274, XXVI.

Monroe shales. faunas of descriptions of. $3 \% 9$

Mud pond, fossils near..

Mytilarca sp. undet. obliqua n. sp..........63, 245, XXII.

Mytilarca? sp. undet... 318, XXXIX.

\section{N.}

Nearpass quarry, fossils at......63, 76, 78, 82, 92 section.. fossils in..........86, 87, 94, 97, 99 Newfoundland, fossils at and near.......71, 105,

Newfoundland grit 106,107

New foundland grit fauna, description of.. $3 \% 2$ New Scotland beds.

New Scotland-Becraft fauna, descriptions

of. $.59,86$

Newton, fossils near..................12, 13, 41, 42, 45 Nucleospira ventricosa Hall...........83, 87, 290, 316, XXX., XXXVII. Nucula ? sp. undet.................. 68, $\mathbf{2 4 2 ,}$ XXII. Nucula levata Hall................................. 165 Nyctopora billingsi Nich...................23, 39, 42, $46,13 \%$, VII.

o.

Odontopleura parvula Walc. ?......... 201, XV. Olenellus ? sp. undet...................12, 115, III. Olenellus thompsoni (Hali) ................114, II. Olenus thompsoni .................................. 114 Onondaga limestone............................... 103 Onondaga limestone fauna, descriptions of .... 365 Ophileta? sp. undet. .15, 129 Orbiculoidea ? sp. undet.......... ............... 39 Orbiculoider sp. undet.....................14\%, IX. ampla (Hall).........94, 324, XLI. jervensis (Barrett)............97, 98, 343 , XLV. jervensis zone, The.......... 97 lamellosa (Hall)...............26, 30,

$39,14 \%$, IX

Ordovician faunas. 123

Ordovician formations.......................... 15-53 Oriskany faunas, descriptions of.............. 341 Oriskany formation...................................60, 93 Orthis bicostatus Van. ............................... 239 electra Billings................................ 125 eminens Hall................................. 304 flabellites Foerste.........65, 72, 231, XX. hipparionyx Hall........................... 346 insignis Hall.................................. 308 interstriata Hall.............................. 229 multistriata Hall.............................. 30 musculosa Hall.............................. 349 newtonensis n. sp................12, 113, I. oblata Ha]l. 304 (Dinorthis) pectinella Hall \& Clarke.. 154
Orthis perelegans $\mathbf{H a l l}$............................. 305 plicatella Hall............................... 152 strophomenoides Hall...................... 303 subæquata Courad.......................... 156 subcarinata Hall ......................306, 326 (Dalmanella) testudinaria W. \& S...... 155 tricenaria Con........................ 22, 38, $40,42,43,151, I X$.

vanuxemi Hall ............................... 368 v'arica Hall.................................. 306

Orthoceras sp. undet..........19, 26, 27, 28, 30, 31, $32,31,35,36,40,43,63$, $79,89,95,95,98,190$, 265, 319, 33\%, 364, XIII., XXV., XlLIII. tenuitextum (Hall).........189, XIII. tenuistriatum $(\mathrm{H}) \ldots \ldots \ldots \ldots \ldots \ldots . . . . . . . .24$, 25, 188, XIII.

Orthodesma sp. undet......................... 32 canaliculatum Ulrich......... 30 , $1 \% 1, \mathrm{XI}$. Orthostrophia strophomenoides (Hall) .........89, 9), 303, XXXIV. Orthothetes sp. undet...............97, 34\%, XLV. chemungensis (Con.)........... 106 deckerensis $\mathrm{n}$, sp........63, 64, 65, 68, $69,70,71,229, \mathrm{XX}$. interstriatus (Hall) .............65, 66, $70,229, \mathrm{XX}$. pandora (Bill)........ 104, 105, $\mathbf{3 6 7}$, 373, 880, LII, LIII. woolworthanus (Hall)..........85, 88, 278, 303, XXVII., XXXIV.

Oxford Furnace, fossils near................... 11 Oxydiscus, sp. undet............................ $\quad \mathbf{4 6}$ subacutus Uirich...........179, XII.

\section{$\mathbf{P}$.}

Palæoneilo emarginata (Con.) .............. 107 Paleozoic formations, general relations... $\quad 7$ table of ............... 9

Paracyclus elliptica Hall ? ..................... 107 Parastrophia hemiplicata (Hall)........23, 26, 38, $40,41,42,43,44,158, X$. Pentamerus circularis $\mathrm{n}, \mathrm{sp} . . . . . . .65,233, \mathrm{XX}$. galeatus Hall.. ................... 279

Peter's Valley, fossils near...................69, 83, $89,95,101,103$ Stormville sandstone near.. 91

"Peth stone" "......................................... 77 Phacops sp. undet.........................85, 98, 100 callicephalus Hall..................... 206 logani Hall..........87, 89, 92, 321, XL. rana (Green).......................... 106 Phacops ? sp. undet............................364, I. Pholidops sp. undet............................. 95 arenaria Hall ?..100, 101, 344, XLV. ovata Hall...........63, 66, 86, 101, 102, 226, 300, 345, XX. ovatus Hall ............................., $\mathbf{2} \mathbf{2 6}$

Phragmolites sp. undet........................ 19 
Phragmolites compressus Con........ 178, XII. Phylloporina fenestrata $H_{.} . . . . .20,38,143$, VII. Platyceras sp. undet......... 64, 63, 82, 95, 98, 104, 247, 335, 371, XXII., XLIII. gebhardi Hall. 318 gibbosum Hall.....83, 294, XXXII. tortuosum Hall.....101, 362, XLIX.

Platyceras ? columbiana n. sp.........16, 131, IV. Platymetopus trentonensis $\left(\mathbf{H}_{.}\right) \ldots . . .24,31,32,35$, $36,38,42,44,46,200, x V$.

Platynotus trentonensis $\mathrm{Hall}$. 200

Platyostoma desmatum (Clarke).................. 98,

362, XLIX. nearpassi $\mathrm{n}, \mathrm{sp} . . . .95, \mathbf{3 3 4}$, XLIII. ventricosa Con.................100, 101, 102, 361, XLIX.

Platystrophia biforata (Schl )............32, 38, 40, $42,43,45,153, I X$.

Plectambonites sericeus (Eow.)......22, 23, 25, 26, $27.28,29,30,31,32,35,34,35,36$, $38,39,41,42,43,44,45,46,47$, $48,51,149,216, I_{0}$, XVI.

Plectorthis plicatella (Hall).....22, 23, 24, 25, 26, $28,29,30,31,38,41,44,45,51$, $152, \approx 16, I X .$, XVI.

Pleurotomaria micula Hall. 182

Polygyrata n, gen. 130 sinjstra n. sp...............16, 130, IV.

Poxino Island shale. 57,61

Prasopora simulatrix Ulr....22, 24, 25, 26, 27, 29, $30,32,38,39,41,42,43$, $44,45,46,47,48,140$, VIII.

Prismatophyllum inequalis (Hall)... 65 , $219, \mathrm{XYI}$.

Proetus brevimarginatus n. sp.................. 22, $23,24,27,32,31,19 \%, X V$. latimarginatus $\mathrm{n}$. $\mathrm{sp} . \ldots \ldots \ldots . . .23,24,25,26$ $27,28,29,30,51,32,33,31$, $35,36,43,45,195$, XIV. pachydermatus Barrett. 65 66, 248, XXII. protuberans Hall........82, 296, XXXII.

Proetus ? depressus n. sp........... 63, 249, XXII. Proetus ? spinosus n. sp.............68, 250, XXII. Protowarth:a cancellata (Hall).....25, 27, 31, 32, $33,34,35,36.175$, XII.

Pseudosphærexochus trentonensis................21, $205, \mathrm{XV}$.

Pterinea sp. undet. 63 emacerata (Con.) ?......65, 242, XXII. flabella (Con.)................1 5, 378, LII.

Pterinea? sp, undet. 98,243

Pteronites? subplana Hall.. 243, XXII. Pterotheca expansa (Emm.) ?..........179, XII. Pterygometopus sp. undet.....................21, 22 callicepbalus (H.).......22, 24, $25,27,28,29,30,31,32$, $33,34,35,36,38,41,42$, $44,45,47,206, \mathrm{XV}$.
Pterygometopus intermedius Walc.............19,

$20,208, X V$.

Ptilodictya sp. undet.......................... 64

frondosa n. sp....61, 68, 224, XIX. lobata n. sp......... 82, 272, XXVI. Ptychoparia sp. undet...............12, 118, III. Ptychoparia ? sp. undet.................. 118, III. Ptychoparia blairi n. sp................ 13, 116, I, calcifera Walc. ?..........13, 117, I. newtonensis n. sp......12, 117, III. Ptychopteria ? subquadrata n. 8p .............. 68, 244, XXII. Ptychopyge jerseyensis n. sp......20, 193, XIV.

12.

Ratinesquina alternata (Emm.)......18, 19, 20, 21, $22,23,24,25,26,27,28,29$, $30,31,32,33,34,35,36,38,89$,

$40,42,43,44,45,46,47,48,148, I X$. Raphistoma columbiana n. sp.......15, 128, IV. peracutum U. \& S..20, 180, XII.

Receptaculites occidentalis Salter.........40, 45, $46,47,135, \mathrm{VI}$.

Rensselæria subglobosa $\mathrm{n}$. sp.............. 94, 95, 96, 329, XLII.

sucsana Hall.......................... 35:3

Reteograptus geinitzianus Hall...53, $\mathbf{2 1 5}$, XVI. Retepora fenestrata Hall........................... 143 Reticularia bicostata (Van.)............63, 64, 68, $69,71,239$, XXI.

fimbriata (Con.).........103, 369, LI. Rhinidictya sp. undet.......20, 21, 22, 32, 35, 38, $40,41,42,43,45,143$, VIII. Rh!pidomella eminens (Hall)............. 86, 88 , 304, XXXIV. sp. cf. R. musculosa (Hall)..100, 349

oblata (Hal1)..86, 87, 88, 89, 90, 92, 98, 304, 350, XXXV., XLVI. preoblata $\mathrm{n}$. sp......6 $20,232, \mathrm{XX}$. vanuxemi (Hall)................103, 104, $368, \mathrm{LI}$

Rhombopteria clathratus n. sp...............83, 84 , 291, XXXI. clathratus var.......292, XXXI.

Rhynchonella sp undet........................ 79 'agglomerata n. sp........63, 64, 65 ,

$66,68,69,70,71,72,934$, XXI. altiplicata Hall..............83, 81, $85,38 \%$, XXIX. bialveata Hall...94, 327, XLI1. breviplicuta n. sp ...........98, 350, XLVI. deckerensis $\mathrm{n}$. S1.......63, 64, 65, $68,70,71,72,234$, XXI. formosa Hall.............309, 328 semiplicata (Con.)...........82, 84, 281, XXIX. transversa Hall.................. 82, 283, XXIX. 
Rhynchonella mutabitis Hall.................... 283 rucleolata Hall................... 284 pyramidata Hall................. 285 vellicata Hall....................... 308

Rhynchonella ? bialveata Hall.................... 32y

lamellata Schuchert............ $\mathbf{2 3}$ '

Rhynchospira formosa (Hall).......66, 83, 84, 85, 240, 289, XXI., XXXI.

Rhynchotrems dentata (Hall)..............159, X. formosฉ (Hall) ? ........ 92, 94, 95, 309,328, XXXVI. inæquivalvis (Castel.)......22, 23, $40,43,46,47,159, X$. Rhynchotreta transversa n. sp...83, 286, XXIX. Romingeria ? trentonensis $\mathrm{n} . \mathrm{sp} . . . . . . . . . .21,46$, $47,138, \mathrm{VI}$

Rondout formation. 58,76

Rondout fauna, description of. $25 \%$

\section{s.}

Scenidium anthonensis Sard.

$.19,21$ $43,15 \%, X$. insigne (Hall)....87, 308, XXXVI. Schizocrania filosa (H).......22, 28, 38, 146, IX. superincreta Barrett.............95, 323, XLI

Schizophoria bisinuata $\mathrm{n}$. sp. 84,85 , $2 \% 8$, XXXI. $30 \%, \mathrm{XXXV}$ sp. ef. S. striatula (Bchl.)........105, 374, LII.

Shawangunk conglomerate................... 54

Silurian faungs.

Silurian formations............................. 54-80

Skunnemunk conglomerate.................. 108

Solenopleura jerseyensis Weller....... 119, II.

Spirifer sp. undet.........65, 105, 369, 376, LII. arenosus (Con.)..100, 101, 353, XLVIII. arrectus Hall.. 354 audaculus (Con.) ?........107, 382, LIII. bicostatus Hall........................... 239 concinnus Hall...........83, 289, XXX. cyclopterus Hall......................82, 84,

$8587,88,89,90,92, \mathbf{2 8}$,

314, XXX., XXXVIII macropleurus (Con.)....85, 87, 88, 89, 90, 288, 313, XXX., XXXVII. macrothyris Hall......... 105, 375 , LII. medialis Hall. 382 murchisoni Castel................94, 95, 97, $98,99,100,101,102,329$, 354, XLII, XLVIII. murchisoni zone, The

99 nearpassi n. sp...........94, 330, XLII. octocostatus Hall.........83, $288, \mathrm{XXX}$. perlamellosus Hall......... 87, 88, 89, 90, 313, XXXVII, XXXVIII. pyxidatus Hall. 355 vanuxemi Hall.
Spirifer vanuxemi, Hall, var. minor, $\mathrm{n}$. var........65, 238 , XXI. sp. cf. S. varicosus Hall.............. 104 Spirifera fimbriata Hall............................ 369 Spirorbis sp. undet............................... 66 Stillwater, fossils near........................... 46 Stormville sandstone........................... 91 Straparollus sp. undet..............63, 246, XXII. Streptelasma corniculum H...............21, 22, 23 , $35,36,39,40,42,44$ $45,46,47,136$, VI strictum Hall..............86, 87, 90 92, 298, XXXIII

Streptorhynchus chemungensis var, pandora

Hall. $3 \% 3$

Streptorhynchus pandora Hall........ ........ 367 Stromatopora concentrica Goldf............66, 82, 223,271

Strophecdontr sp. undet..........92, 91, 95, $\mathbf{2 6 0}$ 301,325, XLI beckei Hall......... 86, 87, 88, 89 $91,92,300$, XXXIII. bipartita (Hall)..63, 64, 65, 66, 68, $69,70,71,72,226, X X$ indenta (Con.)..85, 276 , XXVI. inequiradiata Hall............105, 372, LI. levenworthana Hall....... 302 magnifica (Hall).....94, 95, 97, 98, $99,100,101,102,324$, 345, XLI., XLV. perplana (Con.).....103, 366, LI. planulata Hall..........82, 84, 85, 276, XXVII. (Leptostrophia) textilis $\mathbf{H}$. \& $\mathbf{C}$ 226 textilis Schuchert............. 227 varistriata (Con.).............79, 82, 83, 84, 85, 261, 274, XXIV, XXVII. varistriata var. arata Hall 85, 275, XXVII.

Etrophodonta beckii Hall ................... 300

magnifica Hall..................... 345

néarpassi Barrett................ 226

perplana Hall...................... 366

punctulifera Hall................... ₹7y

textilis Hall.................... 226

varistriata Hall................... 261

Strophomena sp. undet.........................18, 19

alternatx Meek................. 148

bipartita Hall.................... 226 filitexta Hall \& Clarke........ 150 incurvata (Shep.)...21, 22, 23, 24, $25,26,27,28,29,30,31,32,35,38$, $39,40,42,43,44,45,46,150$, IX. rugosa var. ventricosa Hall... $\mathbf{3 4 6}$ woolworthana Hall............. 278

Strophomena? bipartita Schuchert............ 227 Strophonella levenworthana (Hall).......86, 88, 302, XXXIV. 
Strophonella punctulifera (Con.)...........82, 84 , $85,86,87,85,89,92$, 27\%. 301, XXYI., X.XIII.

Strophostylus sp. undet ....................166, 107 gebhardi (Con.)...............87, 89, 318, IXXT.

Sussex, fossils at 51

Swartswood, fossils near.

40

Syntrophia lateralis (Whitf.)........15, 126, IV.

\section{T.}

Table of Paleozoic formations...

Tentaculites acula Hall? $95,336, X I I I$ elongatus Hal $82,81,85$, 57, 9S, 100, 101, 102, 295, 319,363 , XXXII., L. grracanthus (Eaton) ........... 79, 264, XXIV. (i) $\cos _{2}: i^{2}$ .......... 264

Tetranota bidorsata (Hall) $25,26,28,31$ $32,41,178$, XII. Trachypora oriskania n. sp.......97, 341, XLV. Tranquility, fossils near.

Trematis (Echizocrania) superincreta Barrett.

Trematospira formosa $\mathrm{Hall}$. 240

Trematospira maltistriata Hall.........87, 89, 90, 315, XITVIIL.

Trenton fauns, described 135

Trenton limesione. .. 16-19

Trinucleus concentricus (Eaton)......25, 30, 31, $32,192, \mathrm{XIV}$.

Triplesia lateralis Whitfield. 126

Tri-States, N. Y., fossils near. 63,103

Tropidoleptus carnatus (Con)? 106,107 ,

Tubipora catenularia Lín
U.

Uncinulus mutabilis (Hall) $82,84,85$ 283, XXIX. nucleolatus (Hall) ................ 85, 284, XXIX. prramidatus (Hall) ...... 83, 87, 285, 309, XXIX, XXXVI. vellicatus (Hall).........87, 88, 89, 92, 308 , XXXVI.

Upper Longrood, fossils at $\% 2$ 2ensas

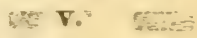
Cast Vermipora sp. undet............................... I' 64 serpuloides Hall .....94, 322,!XLI.

w.

Wallpack Center, fossils/near......70, 81, 95, 101 Wallpack ridge, fossils near............. 88, 97 Wasbington, fossils near....................... 11 West Milford, fossils near...................... 106 Whitella? sp. andet............................ 28 Whitella suborbicularis n. sp.......... 168, XI. subtruncata (H811).........30, 169, XI. Whitfieldella nucleolata (Hall)............ 66, 70, 241, XXI.

Whitfieldells ? sp. undet........................65, 71 Whitfieldella (?) nucleolata Schuchert.... 241 Wilsonia globos\& n. sp.............66, 235, XXI. Woodstock, fossils near........................ 107

\section{Z.}

Zaphrentis sp. undet........63, 65, 70, 71, 83, 104 105, 223, 365, 372, XVII. roemeri E. \& H ?...82, 2z0, XXVI. Zrgospira nicoletti U.\& S..............38, 161, Х recurvirostris (H)..............22, 25, 26 , $27,28,29,30,31,32,33,34,35$, $36,41,43,41,45,161, \mathrm{X}$. 





\section{Date Dr SERTAL-DOINOT REMOVE FROM BUILDING}

\section{CIRCULATES ONLY. TO DEPT. OFFICES}


